\title{
EXPERIMENT DATA REPORT FOR LOFT NONNUCLEAR TEST L1-4
}

\author{
DOYLE L. BATT
}

July 1977

\section{MASTER}

\section{EG\&G Idaho, Inc.}

IDAHO NATIONAL ENGINEERING LABORATORY

\section{ENERGY RESEARCH AND DEVELOPMENT ADMINISTRATION}




\section{DISCLAIMER}

This report was prepared as an account of work sponsored by an agency of the United States Government. Neither the United States Government nor any agency Thereof, nor any of their employees, makes any warranty, express or implied, or assumes any legal liability or responsibility for the accuracy, completeness, or usefulness of any information, apparatus, product, or process disclosed, or represents that its use would not infringe privately owned rights. Reference herein to any specific commercial product, process, or service by trade name, trademark, manufacturer, or otherwise does not necessarily constitute or imply its endorsement, recommendation, or favoring by the United States Government or any agency thereof. The views and opinions of authors expressed herein do not necessarily state or reflect those of the United States Government or any agency thereof. 


\section{DISCLAIMER}

Portions of this document may be illegible in electronic image products. Images are produced from the best available original document. 
Printed in the United States of America Available from

National Technical Information Service

U.S. Department of Commerce

5285 Port Royal Road

Springfield, Virginia 22161

Price: Printed Copy $\$ 9.00$; Microfiche $\$ 3.00$

"The NRC will make available data tapes and operational computer codes on research programs dealing with postulated loss-of-coolant accidents in light water reactors. Persons requesting this information must reimburse the NRC contractors for their expenses in preparing copies of the data tapes and the operational computer codes. Requests should be submitted to the Research Applications Branch, Office of Nuclear Regulatory Research, Nuclear Regulatory Commission, Washington, D.C. 20555."

\section{NOTICE}

This report was prepared as an account of work sponsored by the United States Government. Neither the United States nor the Energy Research and Development Administration, nor the Nuclear Regulatory Commission, nor any of their employees, nor any of their contractors, subcontractors, or their employees, makes any warranty, express or implied, or assumes any legal liability or responsibility for the accuracy, completeness or usefulness of any information, apparatus, product or process disclosed, or represents that its use would not infringe privately owned rights. 


\section{EXPERIMENT DATA REPORT FOR LOFT NONNUCLEAR TEST L1-4}

Approved:

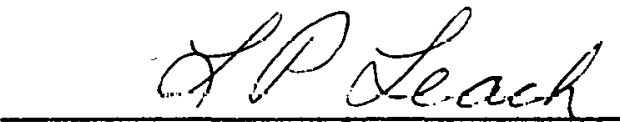

L. P. Leach, Acting Manager LOFT Experimental Program Division
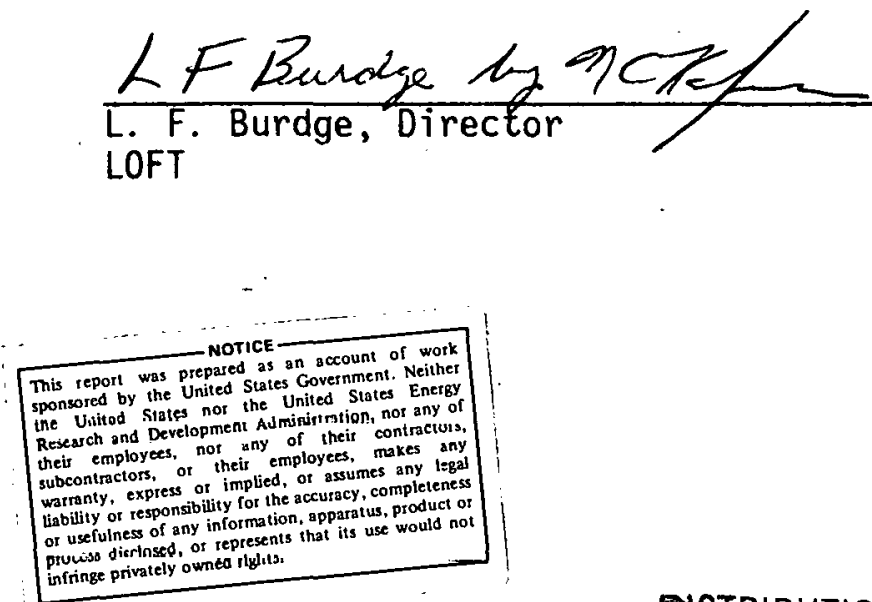


\section{EXPERIMENT DATA REPORT FOR LOFT \\ NONNUCLEAR TEST LI-4}

by

Doyle L. Battt

EG\&G Idaho, Inc.

July 1977

PREPARED FOR THE

U.S. NUCLEAR REGULATORY COMMISSION AND

ENERGY RESEARCH AND DEVELOPMENT ADMINISTRATION

IDAHO OPERATIONS OFFICE

UNDER CONTRACT NO. EY-76-C-07-1570 


\section{ACKNOWLEDGMENTS}

Appreciation is expressed to J. R. Chappell, L. D. Goodrich, G. Hammer, H. C. Robinson, EDR task group members, and the personnel of the LOFT Data Systems Branch for their special help in preparing this. document. 


\section{ABSTRACT}

Test L1-4 was the fourth in a series of five nonnuclear isothermal blowdown tests conducted by the Loss of Fluid Test (LOFT) Program. Test L1-4 was the first Nuclear Regulatory Commission standard problem (International Problem No. 5 and U. S. Problem No. 7) experiment conducted at LOFT. Data from this test will be compared with predictions generated by the standard problem participants. For this test the LOFT Facility was configured to simulate, a loss-of-coolant accident in a large pressurized water reactor resulting from a $200 \%$ double-ended offset shear break in a cold leg of the primary coolant system. A hydraulic core simulator assembly was installed in place of the nuclear core. The initial conditions in the primary coolant system intact loop were: temperature at $279^{\circ} \mathrm{C}$, gauge pressure at $15.65 \mathrm{MPa}$, and intact loop flow at $268.4 \mathrm{~kg} / \mathrm{s}$. During system depressurization into a simulated containment, emergency core cooling water was injected into the primary coolant system cold leg to provide data on the effects of emergency core cooling on system thermalhydraulic response. The experiment was successful in accomplishing all of the objectives outlined in the experiment operating specification for this test. 
SUMMARY

The intent of this report is to present selected data from LOFT Test LI-4, which was performed as a part of the LI (nonnuclear) series of LOFT Program tests. The data are presented in the form of graphs in SI units: In conjunction with the data obtained from direct measurement, chosen computed parameters are included to facilitate in the analysis of the system thermal-hydraulic behavior. Plots of representative instrument types and ranges and their associated error bands are also presented.

The Ll test series consists of five nonnuclear blowdown experiments which are initiated with isothermal conditions established in the reactor intact coolant loop and vessel. Test $11-4$, the fourth test in the Ll series, was successfully conducted on May 3, 1977. This test was designated as a standard problem (International Problem No. 5 and $U$. S. Problem No. 7) by the Nuclear Regulatory Commission. The data were released for review by all participants on June 21, 1977.

The LOFT Integral Test Facility is a highly instrumented, pressurized water reactor test system designed to be representative of large pressurized water reactors (LPWR) for the simulation of loss-ofcoolant accidents (LOCA). The test assembly consists of;

(1) A reactor vessel with a hydraulic core simulator installed in place of a nuclear core.

(2) An intact loop with active steam generator, pressurizer, and two primary coolant pumps connected in parallel.

(3) A broken loop with a simulated pump, a simulated steam generator, and the two quick-opening blowdown valve assemblies. 
(4) A blowdown suppression system consisting of a blowdown header, blowdown suppression tank, and a blowdown suppression tank spray system.

(5) An emergency core coolant (ECC) injection system consisting of a low-pressure injection system (LPIS) pump, a high-pressure injection system (HPIS) pump, and an accumulator. For the performance of the L1-4 loss-of-coolant experiment (LOCE), the test assembly was configured to represent a $200 \%$ double-ended offset shear in a cold leg of a LPWR.

The areas of interest specific to Test $\mathrm{LI}-4$ were to (a) provide comparison of delayed HPIS and LPIS injection to the cold leg and the lower plenum and (b) obtain data for evaluating downcomer bypass and mixing of the ECC with the primary coolant. To determine system thermal-hydraulic response, ECC was directed to the primary coolant system cold leg injection line using accumulator ACC-A, HPIS pump $A$, and LPIS pump A. The accumulator initiated injection at. 22 seconds, and HPIS flow and LPIS flow were initiated at 23 and 39 seconds after rupture, respectively.

Test L1-4 was initiated from primary coolant system initial conditions of $15.65 \mathrm{MPa}$ gauge pressure and $279^{\circ} \mathrm{C}$ with an intact loop flow rate of $268.4 \mathrm{~kg} / \mathrm{s}$. The complete set of initial test conditions is specified in Reference $I$ and is summarized in Table IV of this report.

Data were successfully collected and processed from 526 of the 551 data channels utilized during Test LI-4. Instrument malfunctions pertinent to a particular data channel are specified in Table VII. Of the ${ }^{-}$instruments which malfunctioned, none impacted the success of the experiment.

Test L1-4 was successful in accomplishing the objectives as presented in Reference 1 and summarized in Section $I$ of this report. 
ACKNOWLEDGMENTS ........................

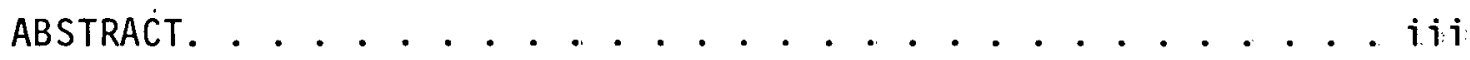

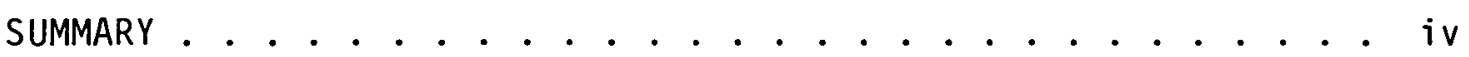

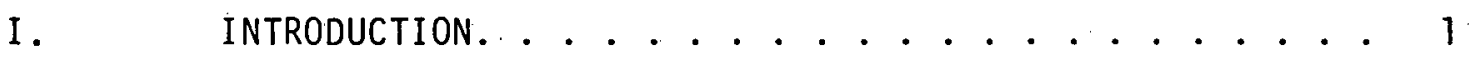

II. SYSTEM CONFIGURATION. . . . . . . . . . . . . 6

III. MEASUREMENTS AND INSTRUMENTATION . . . . . . 12

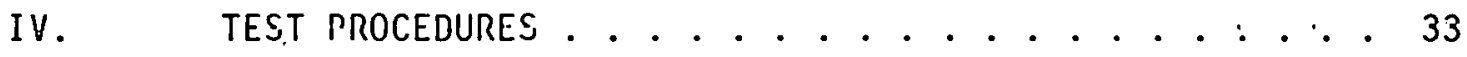

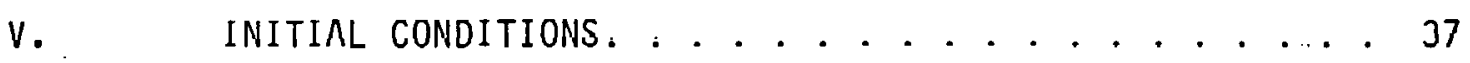

VI. DATA CONSISTENCY CHECKS ............... 42

VII. DATA PRESENTATION ................... 48

1. TEST LI-4 MEASURED PARAMETERS -- SHORT-TERM

PLOTS (2 Seconds or Less). . . . . . . . . . 97

2. TEST LI-4 MEASURED PARAMETERS -- MEDIUM-TERM

PLOTS $(-10$ to 70 seconds $)$. . . . . . . 105

3. TEST LI-4 MEASURED PARAMETERS -- LONG-TERM PLOTS

(190 and 600 seconds).............. 163

4. TEST LI-A COMPUTED PARAMETERŚ. . . . . . . . . 183

5. ERROR BAND PLOTS ........................ 215

VIII. REFERENCES. . . . . . . . . . . . 229

IX. LIST OF ABBREVIATIONS AND ACRONYMS. . . . . . . . 231

FIGURES

1. LOFT major components............ 9

2. LOFT piping schematic (with instrumentation) ... 10

3. Gamma densitometer beam configuration. ..... 13

4. Gamma densitometer flow regime logic...... 15 
5. LOFT thermo-fluids measurements instrumentation. . 19

6. LOFT reactor vessel instrumentation. . . . . 20

7. LOFT pressurizer instrumentation . . . . . . 21

8. LOFT steam generator instrumentation . . . . 22

9. LOFT intact loop pump instrumentation. ..... 23

10. LOFT accumulator instrumentation . . . . . 24

11. LOFT ECCS instrumentation--1eft side . . . . 25

12. LOFT blowdown suppression tank instrumentation . . 26

13. New instrumentation in the intact loop .... 28

14. New instrumentation in the broken loop.... 29

15. New DTT locations in the broken loop cold leg

(BL-1).............. 30

TEST LI-4 MEASURED PARAMETERS

SHORT-TERM PLOTS (2 SECONDS OR LESS)

16. Valve opening (\%) for broken loop QOBV cold leg valve (CV-PI38-1) and hot leg valve (CV-P138-15) . . . . . . . . . 98

17. Valve opening (\%) for broken loop cold leg QOBV (CV-P138-1) and cold leg QOBV inlet pressure (PT-P138-111). . . . . . . . . . . 98

18. Pressure in broken loop cold leg (PE-BL-1 and -8$)($ filtered to $250 \mathrm{~Hz}) \ldots 99$

19. Pressure in broken loop hot leg (PE-BL-2, -3, and -6$)$ (filtered to $250 \mathrm{~Hz}) \ldots 99$

20. Pressure in intact loop hot leg, steam generator outlet, and pressurizer (PE-PC-2, $-3 A$, and -4 ) (filtered to $250 \mathrm{~Hz}$ ) ........... 100

21. Pressure in reactor vessel core simulator ins trument stalk (PE-CS-1.FF and - $2 F F$ ) (filtered to $250 \mathrm{~Hz}) \ldots . . . . . . .200$

22. Pressure in reactor vessel downcomer instrument stalks 1 and 2 (PE-1ST-1FF and -3FF and PE-2ST-1FF and -3FF) (filtered to $250 \mathrm{~Hz}$ ). . . . 101 
23: Pressure in blowdown suppression tank bottom under downcomer $4,180^{\circ}(P E-S V-01)$ and under downcomer $1,157.5^{\circ}(\mathrm{PE}-\mathrm{SV}-03)$. . . . . . . 101

24. Pressure in blowdown suppression tank header above downcomer 1 (PE-SV-18) and tank bottom, $1.38 \mathrm{~m}$ north of downcomer $3,180^{\circ}(\mathrm{PE}-\mathrm{SV}-22) . .102$

25. Pressure in blowdown suppression tank bottom, $1.379 \mathrm{~m}$ south of downcomer $2,180^{\circ}$ (PE-SV-26); under downcomer $2,180^{\circ}(P E-S V-43)$; and under downcomer $3,180^{\circ}(\mathrm{PE}-\mathrm{SV}-44)$. . . . . . . 102

26. Pressure in bellows between broken 10op and blowdown suppression tank header (hot 1 eg PE-SV-70 and coid leg PE-SV-75)....... 103

$$
\begin{gathered}
\text { TEST L } 1-4 \text { MEASURED PARAMETERS } \\
\text { MEDIUM-TERM PLOTS (-10 T0 } 70 \text { SECONDS) }
\end{gathered}
$$

27. Density in broken loop cold leg, chordal density $(D E-B L-1 A,-1 B$, and $-1 C) . . . . . .106$

28. Density in broken loop hot leg, chordal density $(\mathrm{DE}-\mathrm{BL}-2 \mathrm{~A},-2 \mathrm{~B}$, and $-2 \mathrm{C}) . . . . .106$

29. Density in broken loop, average fluid densities $(\mathrm{nE}-\mathrm{BI}-1$ and -?):................. 107

30. Density in intact loop cold leg, chordal density (DE-PC-1A. - TB, and $-1 C$. . . . . . . . 107

31. Density in intact loop hot leg, chordal density $(D E-P C-2 A,-2 B$, and $-2 C)$........ 108

32. Density in intact loop at steam generator. outlet, chordal density (DE-PC-3A, $-3 B$, and $-3 C$ ).................... 108

33. Density in intact loop, average fluid densities $(D E-P C-1,-2$, and -3) ......... 109

34. Tluid velocity in broken louj culd leg at DTT flange (FE-BL-1A, $-1 B$, and $-1 C$ ) (filtered to

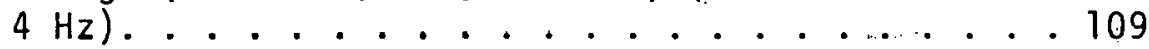

35. Fluid velocity in broken loop hot and cold legs at DTT flanges ( $\bar{F} \bar{E}-\overline{B L}-1$ and -2$). . . . . . .110$

36. Fluid velocity in reactor vessel core simulator instrument stalk (FE-CS-1) ......... 110 
37. Fluid velocity in intact loop cold leg, hot leg, and steam generator outlet at DTT flanges

(FE-PC-1, -2, and -3).............111

38. Flow rate in ECCS accumulator $A$ discharge,

high range (FT-P120-36-1). . . . . . . 117

39. Flow rate in ECCS accumulator $A$ discharge,

low range (FT-P120-36-5) ........ 112

40. Flow rate in ECCS LPIS pump A discharge

(FT-P120-85) . . . . . . . . 112

41. Flow rate in ECCS HPIS pump A discharge

(FT-P128-104). . . . . . . . . 1.13

42. Flow rate in intact loop hot leg venturi

(FT-P139-27-1) ........... . 113

43. Flow rate in intact loop hot leg venturi

(FT-P139-27-3) ............ 114

44. Liquid level in reactor vessel downcomer instrument stalk 1 , bubble plot (LE-1ST-1

and -2)................... 115

45. Liquid level in reactor vessel downcomer

instrument stalk 2, bubble plot (LE-2ST-1

and -2).................... 116

46. Liquid level in ECCS accumulator $A$

(LIT-P120-44). . . . . . . . . . 117

47. Liquid level in blowdown suppression tank

(LT-PT38-33 and -58) ........... 117

48. Liquid level in pressurizer (LT-P13.9-6,

-7 , and -8)............... 118

49. Liquid level in steam generator secondary

side $(L T-P 4-8 B)$. . . . . . . . . 118

50. Momentum flux in broken loop cold leg at DTT

flange (ME-BL-1A and $-1 \mathrm{C}$ ) (filtered to $4 \mathrm{~Hz}$ ) . . 119

51. Momentum flux in broken loop cold and hot legs

(ME-BL- 1 and -2 ) (filtered to $4 \mathrm{~Hz}$ )..... 119

52. Momentum flux in reactor vessel core simulator stalk (ME-CS-1) (filtered to $4 \mathrm{~Hz}$ ) . . . . 120

53. Momentum flux in intact loop cold leg and hot leg (ME-PC-1 and -2) (filtered to $4 \mathrm{~Hz}$ )..... 120 
54. Momentum flux in reactor vessel downcomer stalk 1, $1.13 \mathrm{~m}$ above reactor vessel bottom $(\mathrm{ME}-\mathrm{IST}-1)$ (filtered to $4 \mathrm{~Hz}$ )......... 121

55. Momentum flux in reactor vessel downcomer stalk 2, $1.13 \mathrm{~m}$ above reactor vessel bottom (ME-2ST-1) (filtered to $4 \mathrm{~Hz}$ )........ 121

56. Differential pressure in broken loop hot leg across 14-to-5-in. contraction (PdE-BL-1). . . . 122

57. Differential pressure in broken loop cold leg across 14-to-5-in. contraction (PdE-BL-2). . . 122

50. Differential pressure in broken loop across brcak plànés (PdE-BL-3 and -4 ).......... 123

59. Differential pressure in broken loop hot leg across pump simulator (PdE-BL-5) . . . . . . 123

60. Differential pressure in broken loop hot leg across steam generator simulator outlet flange $($ PdE-BL-6) ................. . 124

61. Differential pressure in broken loop hot leg across the steam generator simulator $(P d E-B L-7) . .124$

62. Differential pressure in broken loop hot leg across steam generator simulator inlet flange $(\mathrm{PdE}-\mathrm{BL}-8)$ (filtered to $4 \mathrm{~Hz}$ ). . . . . . . 125

63. Differential pressure in broken loop from 14-to-5-in. contraction to first tap $(0.127 \mathrm{~m}$ downstream) (PdE-BL-9) .......... . . 125

64. Differential pressure in broken loop from 14-to-5-in. contraction inlet to break plane $(\mathrm{PdE}-\mathrm{BL}-10) . . . . . . . . . . .126$

65. Differential pressure in reactor vessel core simulator to downcomer instrument stalk 2, $0.62 \mathrm{~m}$ from reactor vessei bottom (PdE-CS-1). . 126

66. Differential pressure in intact loop cold leg across primary coolant pumps 1 and $2(\mathrm{PdE}-\mathrm{PC}-1) . .127$

67. Differential pressure in. intact loop across the steam generator $(P d E-P C-2) \ldots . . . . . . .127$

68. Differential pressure in intact loop hot leg piping from reactor vessel outlet to the flow venturi $(\mathrm{PdE}-\mathrm{PC}-3)$ (filtered to $4 \mathrm{~Hz})$. . . . . 128 
69. Differential pressure in intact loop hot leg piping from flow venturi to steam generator inlet $(\mathrm{PdE}-\mathrm{PC}-4)$. . . . . . . . . . . 128

70. Differential pressure in intact loop cold leg primary coolant pump discharge to reactor vessel. inlet nozzle (PdE-PC-5) (filtered to $4 \mathrm{~Hz}$ ). . . . . . . . . . . . . 129

71. Differential pressure in intact loop cold leg reactor vessel inlet to broken loop cold leg reactor vessel inlet ( $\mathrm{PdE}-\mathrm{PC}-7)$ (filtered to $4 \mathrm{~Hz}$ ). . . . . . . . . . . . . 129

72. Differential pressure in intact loop across surge line (PdE-PC-8)............ 130

73. Differential pressure in intact loop across primary coolant pumps 1 and 2 (PdE-PC-9 and -10).................. 130

74. Differential pressure in reactor vessel intact loop cold leg inlet to downcomer stalk 2 (PdE-RV-3) (filtered to $4 \mathrm{~Hz}$ ). . . . . 131

75. Differential pressure in reactor vessel upper plenum to the intact loop hot leg reactor vessel outlet nozzle (PdE-RV-4). . . . 131

76. Differential pressure in blowdown suppression tank across vacuum breaker line $(P d E-S V-9) . . .132$

77. Differential pressure in reactor vessel downcomer stalk 2, between 5.32 and $0.62 \mathrm{~m}$ above reactor vessel bottom ( $\mathrm{PdE}-2 \mathrm{ST}-2)$ (filtered to $4 \mathrm{~Hz}$. . . . . . . . . . . . 132

78. Differential pressure in intact loop across reactor vessel inlet and outlet nozzles (PdT-P139-30)............. 133

79. Pressure in broken loop cold and hot legs $($ PE-BL-1 and -2)............. 133

80. Pressure in broken loop hot leg downstream of pump simulator and cold leg upstream of break plane (PE-BL-3 and -4)........ 134

81. Pressure in broken. 10op cold leg (PE-BL-1, -4 , and -8 )................... 134

82. Pressure in broken loop hot leg (PE-BL-2, -3 , and -6 ).............. 135 
83. Pressure in reactor vessel core simulator instrument stalk, wide range (PE-CS-1A). . . 135

84. Pressure in reactor vessel core simulator instrument stalk, narrow range (PE-CS-1B). . . 136

85. Pressure in intact loop cold leg, hot leg, and steam generator outlet (PE-PC-1, -2, and -3A). . 136

86. Pressure in intact loop steam generator outlet, narrow range (PE-PC-3B)........ 137

87. Pressure in intact loop cold leg, hot leg, and pressurizer (PE-PC-1, -2, and -4). . . . . 137

88. Pressure in reactor vessel downcomer instrument stalk 1 and core simulator (PE-CS- $1 A$ and

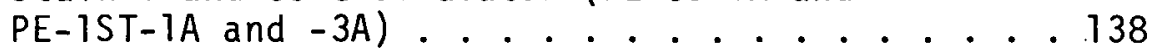

89. Pressure in reactor vessel downcomer instrument stalk $1,0.62$ and $5.32 \mathrm{~m}$ above reactor vessel bottom, narrow range (PE-1ST-1B and -3B) . . 138

90. Pressure in reactor vessel downcomer instrument stalk 2 and core simulator (PE-CS-1A and PE-2ST-1A) . . . . . . . . . . . 139

91. Pressure in blowdown suppresssion tank bottom under downcomer $4,180^{\circ} ; 1.384 \mathrm{~m}$ north of downcomer $3,180^{\circ}$; under downrnmer 3 ; under down-

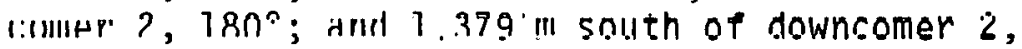
$180^{\circ}$ (PE-SV-1, $-22,-26,-43$, and -44$) \ldots 139$

92. Pressure in blowdown suppression tank bottom under downcomer $4,67.5^{\circ}$; between downcomers 3 and $4,67.5^{\circ}$; and under downcomer $1,67.5^{\circ}$ $(P E=S V=2,=4$, and -23$) \ldots 110$

93. Fressure in blowdown suppréssiun länk subiileryed at A-end and tank bottom north of downcomer 4 (PE SV - 10, -12, and -24) ......... 140

94. Pressure in blowdown suppression tank bottom south of dowmcomer 1 (PE-SV-13)....... 141

95. Pressure in blowdown suppression tank header above downcomer $4,321^{\circ}$, and above downcomer 1 (PE-SV-14 and -18) .............. 141

96. Pressure in blowdown suppression tank submerged near downcomers 4 and 1 (PE-SV-15 and -16) .. 142 
97. Pressure in blowdown suppression tank gas space near downcomers 4 and 1 (PE-SV-58 and -61) . . 142

98. Pressure in ECCS accumulator A (PT-P120-43). . . 143

99. Pressure in ECCS cold leg injection line $($ PT-P120-61).............. 143

100. Pressure in ECCS injection from accumulator $A$ to the cold leg (PE-1ST-1A and PT-P120-43

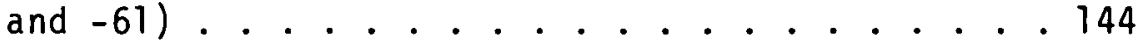

101. Pressure in ECCS LPIS pump A discharge (PT-P120-83)............... 144

102. Pressure in blowdown suppression tank top (PT-P138-55, -56, and -57) ......... 145

103. Pressure in intact loop hot leg venturi (PT-P139-2, -3, and -4)........... 145

104. Pump speed for intact loop pumps 1 and 2 (RPE-PC-1 and -2).............. 146

105. Pump speed (normalized) for intact loop pumps 1 and 2 (RPE-PC-1 and -2)....... 146

106. Pump power for intact loop pumps 1 and 2 (PCP-1-P and PCP-2-P)........... 147

107. Temperature in broken loop cold leg, hot leg, and reflood assist bypass system (TE-BL-1, -2 , and -3 )................. 147

108. Temperature in broken loop cold leg bottom, middle, and top at DTT flange (TE-BL-1A, $-T B$, and $-1 C) . . . . . . . . . . . . .148$

109. Temperature in reactor vessel core simulator instrument stalk (TE-CS-1)........ 148

110. Temperature in intact loop cold leg, hot leg, and steam generator outlet (TE-PC-1, -2, and -3) 149

111. Temperature in ECCS accumulator A (TE-P120-41). . 149

112. Temperature in blowdown suppression tank liquid at tank bottom and vapor at tank top (TE-PI38-22 and -34)................ 150

113. Temperature in broken loop cold leg QOBV inlet and isolation valve inlet (TE-P138=62 and -63 ).............. 150 
114. Temperature in broken loop hot leg QOBV inlet and isolation valve inlet (TE-P138-66 and -65) . . 151

115. Temperature in intact loop pressurizer vapor and 1iquid (TE-P139-19 and -20). ....... 151

116. Temperature in intact loop cold leg upstream of DTT flange (TE-P139-29) . ....... 152

117. Temperature in steam generator intact loop cold leg, hot leg, and secondary side. (TE-SG-1, -2, and -3)........ 152

118. Temperature in blowdown suppression tank B-end thermocouple stalk (TE-SV-1, -2 , and -3 ) ... 153

119. Temperature in blowdown suppression tank B-end thermocouple stalk (TE-SV-5 and -6 ). ..... 153

120. Temperature in blowdown suppression tank A-end thermocouple stalk (TE-SV-7, -8, and -9) .... 154

121. Temperature in blowdown suppression tank A-end thermocouple stalk (TE-SV-10,-11, and -12). . . 154

122. Temperature in blowdown suppression tank $2.72 \mathrm{~m}$ from tank bottom (TE-SV-1 and -7)...... 155

123. Temperature in blowdown suppression tank $2.36 \mathrm{~m}$ from tank bottom (TE-SV-2 and -8)...... 155

1.24. Temperature in blowdown suppression tank $1.90 \mathrm{~m}$ from tank bottom (TE-SV-3 and -9). ..... 156

125. Temperature in blowdown suppression tank $0.99 \mathrm{~m}$ from tank bottom (TE-SV-5 and -11).... 156

126. Temperature in blowdown suppression tank $0.374 \mathrm{~m}$ from tank bottom (TE-SV-6 and -12) . . 157

127. Temperature in blowdown suppression tank $1.45 \mathrm{~m}$ from tank bottom ..(TE-SV-10). . . ..... 157

128. Temperature in reactor vessel downcomer ins trument sta $1 \mathrm{k} \cdot 1$ (TE-1ST-1, $-2,-3$, and -4$). .158$

129. Temperature in reactor vessel downcomer ins trument stalk 1 (TE-1ST-6, $-8,-9$, and -10$): .158$

130. Temperature in reactor vessel downcomer instrument stalk 1 (TE-1ST-11, -12, -13, and -14). . . 159 
131. Temperature in reactor vessel downcomer instrument stalk 2 (TE-2ST-2). ........ 159

132. Temperature in reactor vessel downcomer instrument stalk $2(\mathrm{TE}-2 \mathrm{ST}-14) \ldots 160$

133. Temperature in reactor vessel downcomer instrument stalks 1 and $2,4.2 \mathrm{~m}$ above reactor vessel bottom (TE-1ST-2 and TE-2ST-2) ....... 160

134. Temperature in reactor vessel downcomer instrument stalks 1 and $2,1.17 \mathrm{~m}$ above reactor vessel bottom in DTTS (TE-1ST-14 and TE-2ST-14) ... 161

135. Temperature in ECCS cold leg injection line (TT-P120-62) ................... 161

136. Temperature in intact loop hot leg in elbow near venturi (TT-P139-32 and -33). ..... 162

$$
\begin{gathered}
\text { TEST LI-4 MEASURED PARAMETERS } \\
\text { LONG-TERM PLOTS ( } 190 \text { AND } 600 \text { SECONDS) }
\end{gathered}
$$

137. Density in broken loop cold leg, chordal density (DE-BL-1A, $-1 B$, and $-1 C) \ldots 164$

138. Density in broken loop hot leg, chordal density (DE-BL-2A, $-2 B$, and $-2 C) \ldots 164$

139. Fluid velocity in broken loop cold leg at DTT flanges $(F E-B L-1) \ldots . . . . . .165$

140. Flow rate in ECCS accumulator A discharge, high range (FT-PT20-36-1). . . . . . . 165

141. Flow rate in ECCS accumulator A discharge, low range (FT-P120-36-5) .......... 160

142. Flow rate in ECCS LPIS pump A discharge (FT-P120-85) . . . . . . . . 166

143. Flow rate in ÉCCS HPIS pump A discharge (FT-P128-104).............. 167

144. Flow rate in ECC lines to intact loop cold leg (FT-P128-104, FT-P120-36-5, and FT-P120-85). . 167

145. Liquid level in blowdown suppression tank (LT-P138-33 and -58) ............. 168

146. Momentum flux in reactor vessel downcomer instrument stalk $1,1.13 \mathrm{~m}$ above reactor

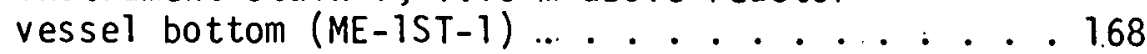


147. Momentum flux in reactor vessel downcomer instrument stalk,2, $1.13 \mathrm{~m}$ above reactor vessel bottom (ME-2ST-1)......... 169

148. Pressure in reactor vessel core simulator instrument stalk, narrow range, and intact loop steam generator outlet (PE-CS-1B and

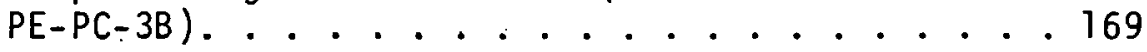

149. Pressure in ECCS cold leg injection line (PT-P120-61).............. 170

150. Pressure in ECCS LPIS pump A discharge (PT-P120-83) . . . . . . . . . . . . . . 170

151. Pressure in blowdown suppression tank spray system pump discharge and cooldown heat exchanger outlet (PT-PI38-136 and.-151). . . . . 171

152. Temperature in broken loop cold leg and hot leg $(T E-B L-1$ and -2$)$. . . . . . . . . . 171

153. Temperature in reactor vessel core simulator instrument stalk $(T E-S C-1)$. . . . . . . 172

154. Temperature in intact loop cold leg, hot leg; and steam generator outlet (TE-PC-1, -2, and -3) 172

155. Temperature in blowdown suppression tank spray sys tem pump discharge (TE-P138-142). . . . . 173

156. Temperature in blowdown suppression tank spray sys tem $3.79 \mathrm{l} / \mathrm{s}$ header and $13.88 \mathrm{l} / \mathrm{s}$ spray header (TE-P138-141 and -143) ........... . 173

157. Temperature in blowdown suppression tank B-end thermocouple stalk (TE-SV-1, -2, and -3) . . . 174

158 Temperature in blowdown suppression tank. B-end thermocouple stalk (TE-SV-5 and -6). . . . . 174

159. Temperature in blowdown suppression tank A-end thermucouple stalk (TE-SV-7, -8, and -9).... 175

160. Temperature in blowdown suppression tank A-end thermocouple s.talk (TE-SV-10,-11, and -12). . . 175

161. Flow rate in blowdown suppression tank system pump discharge (FE-P138-139 and -140). . . . . 176

162. Liquid level in blowdown suppression tank north and south ends (LT-P138-33 and -58). . . . . 176 
163.

Pressure in blowdown suppression tank bottom under downcomers 4,3 , and 2 (PE-SV-1, -22, and -26)................. . . 177

164. Pressure in blowdown suppression tank header above downcomer 1 (PE-SV-18) ....... . . 177

165. Pressure in blowdown suppression tank bellows at header to test assembiy $($ PE-SV-70). . . . . 178

166. Pressure in blowdown suppression tank header $($ PE-SV-75) ............... . 178

167. Pressure in blowdown suppression tank top (PT-P138-55, -56, and -57) . . . . . . . 179

168. Pressure in blowdown suppression tank spray pump BS-P-83 discharge and at heat exchanger BS-H-32 tube side (PT-P138-136 and -151) .... 179

169. Temperature in blowdown suppression tank. spray pump discharge (TE-P138-142) . . . . . 180

170. Temperature of liquid at $3.79 \mathrm{l} / \mathrm{s}$ and $13.881 / \mathrm{s}$ spray headers (TE-P138-141 and -143 )................. 180

171. Temperature in blowdown suppression tank B-end thermocouple stalk (TE-SV-1, -2, and -3) .... 181

172. Temperature in blowdown suppression tank B-end thermocouple stalk 1 (TE-SV-5 and -6)...... 181

173. Temperature in blowdown suppression tank. A-end thermocouple stalk 2 (TE-SV-7 and -9)...... 182

174. Temperature in blowdown suppression tank A-end thermocouple stalk 2 (TE-SV-10,-11, and -12). . 182

\section{TEST LI-4 COMPUTED PARAMETERS}

175. Flow regime and average density in broken

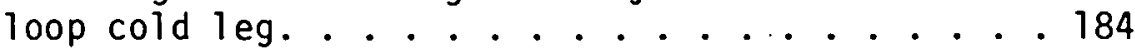

176. Flow regime and average density in broken loop hot leg.................... 185

177. Flow regime and average density in intact loop cold. leg. . . . . . . . . . . . . 186

178. Flow regime and average density in intact

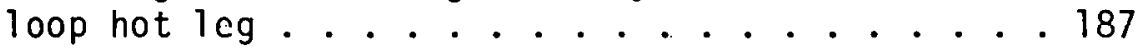


179. Enthalpy in broken loop cold leg ...... 188

180. Enthalpy in broken loop hot leg. . . . . . 188

181. Enthalpy in intact loop cold leg ....... 189

182. Enthalpy in intact loop hot leg....... 189

183. Enthalpy in intact loop at steam generator outlet................. 190

184. Enthalpy in broken loop cold and hot legs. . . 190

185. Mass flow rate per system volume in intact loop cold leg calculated from FE-PC-l and

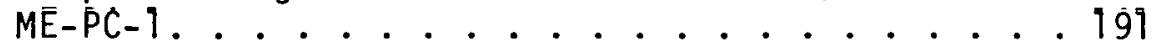

186. Mass flow rate per system volume in intact loop hot leg calculated from FE-PC-2 and ME-PC-2. . . . . . . ........ 191

187. Mass flow rate per system volume in intact loop cold and hot legs calculated from

FE and ME............... 192

188. Mass flow rate per system volume in broken 1oop cold leg calculated from DE-BL-1 and

ME-BL-1................ 192

189. Mass flow rate per system volume in broken loop hot leg calculated from DE BL $\cdots$ ? and ME-BL-2. . ................ 193

190. Mass flow rate per system volume in broken loop hot and cold legs calculated from $D E$ and $\mathrm{ME}$................... 193

191. Mass flow rate per system volume in intact loop cold leg calculated from DE-PC- 1 and ME-PC-1................ 194

192. Mass flow rate per system volume in intact loop hot leg calculated from DE-PC-2 and ME-PC-2.................. 194

193. Mass flow rate per system volume in intact loop cold and hot legs calculated from

DE and ME................ 195

194. Mass flow rate per system volume in broken loop cold leg calculated from $\mathrm{FE}-\mathrm{BL}-1$ and DE-BL-1................ . . 195 
195. Mass flow rate per system volume in broken loop hot leg calculated from FE-BL-2 and

$\mathrm{DE}-\mathrm{BL}-2$. . . . . . . . . . . . . . . 196

196. Mass flow rate per system volume in broken loop hot and cold legs calculated from FE and DE . . . . . . . . . . . . . 196

197. Mass flow rate per system volume in intact loop cold leg.calculated from FE-PC-1 and DE-PC-1............... . 197

198. Mass filow rate per system volume in intact loop hot leg calculated from FE-PC-2 and DE-PC-2. . . . . . . . . . . . . 197

199. Mass flow rate per system volume in intact loop steam generator outlet calculated from FE-PC-3 and DE-PC-3. . . . . . . . . . 198

200. Mass flow rate per system volume in intact loop cold $\mathrm{leg}$, hot leg, and steam generator outlet calculated from FE and DE ...... 198

201. Mass flow rate per system volume in broken loop cold leg calculated from PdE-BL-2 and DE-BL-1. . . . . . . . . . . . . . 199

202. Mass flow rate per. system volume in broken loop hot leg.calculated from PdE-BL-1 and DE-BL-2. . . . . . . . . . . . . . . 199

203. Mass flow rate per system volume in broken loop hot and cold legs calculated from $\mathrm{PdE}$ and $\mathrm{DE}$................. . 200

204. Mass flow rate per system volume in pressurizer calculated from LT-Pl39-6, -7, and -8 and PE-PC-4............... 200

205. Pump speed, electrica1, in intact loop primary coolant pumps 1 and 2.................201

206. Pump motor slip in intact loop .primary coolant

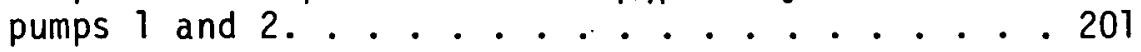

207. Pump water horsepower (normalized for PCP-1 and $P(P-2)$..................... 202

208. Pressure, closure, in intact loop. . . . . . 202

209. Static quality in broken loop cold leg.... . 203 
210. Static quality in broken loop hot leg. ... 203

211. Static quality in intact loop cold leg .... 204

212. Static quality in intact loop hot leg. . . . 204

213. Static quality in intact loop at steam.

generator outlet ......... 205

214. Flow quality in broken loop cold leg ..... 205

215. Flow quality in broken loop hot leg. . . . 206

216. Flow quality in broken loop cold and hot legs. . . 206

217. एlow quality in intact loop cold leg ..... 207

218. Flow quality in intact loop hot leg. ..... 207

219. Flow quality in intact loop at steam

generator outlet . . . . . . . 208

220. Flow quality in intact loop cold. leg, hot leg, and steam generator outlet ........ 208

221. Saturation temperature in broken loop cold leg overlaid with TE-BL-1......... 209

222. Saturation temperature in broken loop hot

leg overlaid with TE-BL-2. . . . . . . 209

223. Saturation temperature in intact loop cold

leg overlaid with lt-PC-1........ 210

224. Saturation temperature in intact loop hot

leg overlaid with TE-PC-2. . . . . . 210

225. Saturation temperature in intact loop steam generator outlet overlaid with TE-PC-3 ... . 271

226. Saturation temperature in reactor vessel core simulator instrument stalk overlaid with TE-CS-1 . 211

227. Saturation temperature in reactor vessel downcomer instrument stalk 1 overlaid with TE-1ST-1A. . . . . . . . . . . 212

228. Saturation temperature in reactor vessel downcomer instrument stalk 2 overlaid with TE-2ST-1A. . . . . . . . . 212

229. Void fraction in broken loop cold and hot legs . . 213 
230. Void fraction in intact loop cold leg; hot leg; and steam generator outlet.......... 213

231. Volumetric flow rate of ECC into cold leg injection. 1 ine calculated from FT-P120-36-1, FT-P120-85, and FT-P128-104......... 214

\section{ERROR BAND PLOTS}

232. Valve opening (\%) in broken loop hot leg QOBV with error bands (CV-P138-15)........ . 216

233. Chordal density in broken loop cold leg with error bands $(D E-B L-1 A)$ (filtered to $4 \mathrm{~Hz})$. . . . 216

234. Average velocity in broken loop cold leg at DTT flange with error bands (FE-BL-1) (filtered to $4 \mathrm{~Hz}$ ).............. . 217

235. Average velocity in reactor vessel downcomer instrument stalk 1 with error bands (FE-1ST-1) (filtered to $4 \mathrm{~Hz}$ ) . . . . . . . . . 217\%

236. Flow rate in ECCS HPIS pump A discharge with error bands (FT-P128-104).......... 218

237. Liquid level in blowdown suppression tank south end with error bands (LT-PT38-58)....... 218

238. Liquid level in pressurizer north side with error bands (LT-P139-8)........... 219

239. Momentum flux in broken loop cold leg at DTT flange with error bands (ME-BL-1) (filtered to $4 \mathrm{~Hz}$ )................ 219

240. Momentum flux in reactor vessel downcomer instrument stalk 7 with error bands (ME-1ST- 1 ) (filtered to $4 \mathrm{~Hz}$.............. 220

241. Differential pressure in broken loop hot leg at 14-to-5-in. reduction with error bands (PdE-BL-1) (filtered to $4 \mathrm{~Hz}$ ) ........... 220

242. Differential pressure in broken loop cold leg at 14-to-5-in. reduction with error bands (PdE-BL-2) (filtered to $4 \mathrm{~Hz}$ )............ . 221

243. Differential pressure in broken loop cold leg across break plane with error bands $(P \mathrm{dE}-\mathrm{BL}-3) .221$ 
244.

Differential pressure in broken loop hot leg across steam generator simulator outlet flange

with error bands (PdE-BL-6) (filtered to $4 \mathrm{~Hz}$ ) . . 222

245. Differential pressure in intact loop cold leg across primary coolant pumps 1 and 2 with error bands $(\mathrm{PdE}-\mathrm{PC}-1)$. . . . . . . . . . 222

246. Differential pressure in intact loop hot leg reactor vessel outlet to flow venturi with error bands $(P d E-P C-3)$. . . . . . . . 223

247. Differential pressure in intact loop across the reactor vessel inlet and outlet nozzles with error bands (PdT-P139-30)......... 223

248. Pressure in broken loop hot leg with error bands (PE-BL-2).............. . 224

249. Pressure in reactor vessel core simulator instrument stalk, wide range, with error bands $(P E-C S-1 A) . . . . . . . . .224$

250. Pressure in reactor vessel core simulator instrument stalk, narrow range, with error bands $(P E-C S-1 B) . . . . . . . . .225$

251. Pressure in reactor vessel core simulator instrument stalk, short-term plot, with error bands (PE-CS-2FF)............ 225

252. Pressure in blowdown suppresston tank hedrler above downcomer 4, short-term plot, with error bands (PE-SV-14)............ 226

253. Pressure in blowdown suppression tank header above downcomer 4,70-second plot, with error bands $(P E-S V-11) . . . . . . . .226$

254. Pump speed in inlacl luup optraling puimp 2 with error bands (RPE-PC-2). . . . . . . 227

255. Temperature in broken loop hot leg with error bands $(\mathrm{TE}-\mathrm{BL}-2) . . . . . . . .227$

256. Temperature in blowdown suppression tank B-end thermocouple stalk with error bands $(T E-S V-6) . .228$ 


\section{-TABLES}

I. Nomenclature for LOFT Instrumentation. . ... . 18

II. New Instrumentation for Nonnuclear Test L]-4 . . 27

III. Chronology of Events for Test LI-4 . . . . . 36

IV. Initial Conditions for Nonnuclear Test LI-4. . . 37

V. Primary Coolant Temperature Distribution at Blowdown Initiation......... 40

VI. Water Chemistry Results for Nonnuclear Test L1-4 . 41

VII. Measured Parameters for LOFT Nonnuclear Test L1-4.............. . . 51

VIII. Computed Parameters for LOFT Nonnuclear Test LI-4................. . . 83

IX. Typical Error Bands. . . . . . . . . . 215, 


\section{EXPERIMENT DATA REPORT FOR LOFT \\ NONNUCLEAR TEST LI-4}

\section{INTRODUCTION}

The intent of this report is to present the LI-4 test data in an uninterpreted but readily usable form for use by the nuclear community in advance of detailed analysis and interpretation. The data, presented herein in the form of graphs in International System of Units (SI units), have been analyzed and qualified to the extent necessary to ensure that they are reasonable and consistent. Initial assessment of the data from this test and comparison with the experiment prediction [2] were performed in the quick look report for nonnuclear experiment $\mathrm{L} 1-4^{[3]}$. Test $\mathrm{Ll}-4$ was designated as a Nuclear Regulatory Commission (NRC) standard problem (International Problem No. 5 and U. S. Problem No. 7). Data from the test will be compared with Test LI-4 predictions performed by the standard problem participants and with the LOFT experiment prediction. Test L1-4 was performed on May 3, 1977, and the data were released for analysis on June $21,1977$.

The Loss of Fluid Test (LOFT) Program is part of the Water Reactor Safety Research Program sponsored by the Nuclear Regulatory Commission and is administered by the Energy Research and Development Administration. The tests are conducted at the Idaho National Engineering Laboratory (INEL), Test Area North (TAN). The objectives of the program are:

(1) To provide data required to evaluate the adequacy and improve the analytical methods currently used to predict the loss-ofcoolant accident (LOCA) response of large pressurized water reactors (LPWRs): The performance of engineered safety features (ESF) with particular emphasis on emergency core cooling system (ECCS) and the quantitative margins of safety inherent in the performance of ESF is of primary interest. 
(2) To identify and investigate any unexpected event(s) or threshold(s) in the response of either the plant or the ESF, and develop analytical techniques that adequately describe and account for such unexpected behavior.

In order to meet these objectives, the LOFT Integral Test Facility ${ }^{[a]}$ has been designed to simulate the major components of a LPWR, and several series of the experiments have been planned to produce data on the combined thermal, hydraulic, nuclear, and structural processes expected to occur during a LOCA.

The first LOFT test series (designate. 1.1) is the nonnuclear test series which consists of five isothermal blowdown tests. This test series has been designed to make available large scale isothermal blowdown system data as a first phase of the LOFT Experimental Program. Varied parameters include break size, break location, break opening time, primary coolant system (PCS) flow resistance, emergency core coolant (ECC) injection location, and PCS pressure. Specifically, the purposes of this test series are:

(1) To determine that the equipment/systems function properly

(2) To demonstrate that the entire test facility can withstand the structural loads of blowdown

(3) To determine that the blowdown test procedures are adequate

[a] The term "integral" is used to describe an experiment combining the nuclear, thermal, hydraulic, and structural processes occurring during a LOCA and differentiates it from the separate effects, nonnuclear, small-scale, thermal-hydraulic experiments conducted for loss-of-coolant analysis. 
(4) To provide experience to operators prior to nuclear tests

(5) To obtain isothermal loss-of-coolant experiment (LOCE) data for comparison with similar data from other experimental programs, and to experimentally, determine thermal-hydraulic system behavior prior to nuclear blowdown.

A detailed description of the LOFT Facility and the LI test series can be found in Reference 4 .

Tests in the $\mathrm{L} 1$ test series conducted prior to Test $\mathrm{LI}-4$ consist of:

(1) Test $\mathrm{LI}_{-1}^{[5]}$, which was conducted from initial conditions of $282.2^{\circ} \mathrm{C}$ and $9.11 \mathrm{MPa}$ (gauge pressure) and was a $100 \%$ hot leg break simulation. ECC injection was directed to the cold leg.

(2) Test $4.2^{[6]}$, which was conducted from initial conditions of $282^{\circ} \mathrm{C}$ and $15.55 \mathrm{MPa}$ (gauge pressure) and was a $200 \%$ cold leg break simulation without ECC injection. ECC was injected into the intact loop cold leg 13.3 minutes after. Test LI-2 initiation for a "hot wall delay". experiment.

(3) Test $L 1-3^{[7]}$, which was conducted from initial conditions of $282^{\circ} \mathrm{C}$ and $15.55 \mathrm{MPa}$ (gauge pressure) and was a $200 \%$ cold leg break simulation. ECC injection was directed to the lower plenum of the reactor vessel using low-pressure injection system (LPIS) pump $A$ and high-pressure injection system (HPIS) pump A. Accumulators $A C C-A$ and $A C C-B$, however, failed to inject ECC into the lower plenum during this test. The original Test LI-3 was conducted again as Test LI-3A to obtain accumulator ACC-A injection.

(4) Test $L 1-3 A^{[8]}$, which was conducted from initial conditions of $283.3^{\circ} \mathrm{C}$ and $15.46 \mathrm{MPa}$ (gauge pressure) and was a $200 \%$ cold leg 
break simulation. ECC injection was directed to the lower plenum of the reactor vessel.

Test LI-4 was conducted from initial conditions of $279^{\circ} \mathrm{C}$ and 15.65 $\mathrm{MPa}$ (gauge pressure) and was a 200\% (100\% of the break area in each leg) double-ended offset shear in the cold leg of a four-loop LPWR. The specific purposes of Test L1-4 were to:

(1) Provide comparison of delayed HPIS and LPIS injection to the cold leg and the lower plenum

(2) Provide data reproducibility information by comparing with other related tests

(3) Obtain data for evaluating downcomer bypass and mixing of the ECC with the primary coolant

(4) Determine the effects of PCS operation and rapid depressurization with boric acid coolant

(5) Test system performance with plant protection system (PPS) backup under operating procedures as similar as possible to those planned for nuclear operation

(6) Provide system thermal-hydraulic data to compare with predictions and other experimental data for code verification purposes.

Section II of this report briefly describes the LOFT system and the facility configuration specific to this test. Section III discusses the LOFT instrumentation system including the basic types of detectors utilized, the methods of obtaining certain measurements, and the LOFT data reduction process. Section IV summarizes the test procedures used to conduct Test $\mathrm{LI}-4$ and presents a chronology of events that occurred during the test. Section $V$ presents the initial conditions of the test, both specified and as measured. Section VI discusses numerous methods 
employed to verify the consistency and accuracy of the data presented. Finally, Section VII presents the data graphs and provides tables of comments and supporting information necessary for the interpretation of the data. 


\section{SYSTEM CONFIGURATION}

The LOFT Facility has been designed to simulate the major components and system responses of a LPWR during a LOCA. The test assembly is comprised of five major subsystems which have been instrumented such that desirable system parameters can be measured and recorded during a LOCE. The subsystems include: (a) the reactor vessel, (b) the intact loop, (c) the broken loop, (d) the blowdown suppression system, and (e) the ECCS. System instrumentation is discussed in section III.

The LOFT reactor vessel simulates the reactor vessel of a LPWR. It has an annular downcomer, a lower plenum, lower core support plates, a core simulator, and an upper plenum. The downcomer connects with the cold leg of both the intact loop and the broken loop and contains two instrument stalks; the upper plenum connects the hot leg of both the intact loop and the broken loop. The core simulator contains an instrument stalk and a hydraulic orifice plate assembly to simulate the flow resistance of a nuclear core which will be installed for nonnuclear LOCE LI-5.

The intact loop simulates the unbroken loops of a LPWR. This loop contains a steam generatior, two circulating coolant pumps connected in parallel, a pressurizer, a venturi flowmeter, and connecting piping. For this experiment, the primary side steam generator inlet and outlet plenums contained square edged orifice plates sized for a low resistance or core flow area scaling. Thus, these orifices provided a similar pressure drop at scaled flow rates around the LOFT intact loop (excluding the reactor vessel) as exists in a LPWR operating loop. The secondary side of the steam generator was filled to a predetermined level and isolated from the remainder of the secondary coolant system (SCS). The intact loop circulating coolant pumps were used to bring the system to the initial test temperature of $279^{\circ} \mathrm{C}$. For Test $\mathrm{Ll}-4$, the electrical power to the primary system motor generator (PSMG) sets was terminated within 1 second after blowdown initiation. This action left 
the PSMG sets electrically connected to their respective intact loop pumps such that pump coastdown characteristics were under the influence of the $316 \mathrm{~kg} / \mathrm{m}^{2}$ (effective) inertia flywheels on the generators. This electrically coupled system represented the inertia and the subsequent coastdown of the circulating coolant pumps in a LPWR. When the intact loop pumps reached a speed of approximately $750 \mathrm{rpm}$, the electrical power to the pump motors was terminated by opening the generator field breakers.

The broken loop simulates the broken loop of a LPWR. It consists basically of a hot leg and cold leg that are connected to the reactor vessel and the blowdown suppression tank header. Each leg consists of a break plane orifice which determines the break size to be simulated, a quick-opening blowdown valve (QOBV) which simulates a pipe break, a recirculation line, an isolation valve, and connecting piping. The recirculation lines established a small flow from the broken loop to the intact loop to maintain these loop temperatures approximately equal prior to the blowdown. These recirculation paths are secured just prior to blowdown initiation.

Test L1-4 simulated a $200 \%$ double-ended shear break in a cold leg of a LPWR operating loop. In this configuration, the broken loop hot leg contained, in addition to the above mentioned components, a steam generator simulator and a pump simulator. These simulators have hydraulic orifice plate assemblies installed which have similar (passive) resistances to flow as a real steam generator and a locked rotor pump. The break flow area (break plane orifice area) in this configuration is $0.0084 \mathrm{~m}^{2}$ in each line; this is $100 \%$ of the possible break flow area.

The blowdown suppression system simulates the containment back pressure of a LPWR. This system is comprised of the blowdown suppression tank header, the blowdown suppression tank (BDST), the nitrogen pressurization system, and the blowdown suppression tank spray system (BDSTSS). The blowdown header is connected to the suppression tank by four suppression tank downcomers that extend inside the tank and 
discharge below the water level established as a Test L1-4 initial condition. The nitrogen pressurization system is supplied by the LOFT inert gas system and utilizes a remote controlled pressure regulator to establish and maintain the specified BDST initial pressure. The spray system consists of a centrifugal pump which discharges through a heatup heat exchanger and either three spray headers or a pump recirculation line that contains a cooldown heat exchanger. The spray pump suction can be aligned to either the BDST or the borated water storage tank (BWST). The three spray headers have a $1.31 / \mathrm{s}, \mathrm{a} 3.8 \mathrm{l} / \mathrm{s}$, and a $13.9 \mathrm{l} / \mathrm{s}$ flow rate capacity and are located in the BDST along the upper centerline. To model the containment. hark pressure of a LPWR, predetermined initial conditions are established in the BDST. For Test $\mathrm{L} 1-4$, suppression tank spray was automatically initiated and adjusted to follow a predetermined pressure trace after accumulator nitrogen entered the tank. Therefore, the blowdown effluent was contained within the BDST while obtaining the same peak pressure and predetermined pressure trace as if the break was in a LPWR which was discharging into its containment vessel.

The LOFT ECCS simulates the ECCS of a LPWR. The accumulator, the HPIS, and the LPIS were used during this experiment. Each system was configured to inject scaled ${ }^{[2]}$ flow rates of ECC directly into the PCS cold leg. To provide these scaled flow rates, accumulator ACC-A, HPIS pump $A$, and LPIS pump $A$ were utilized. Accumulator ACC-A was preset to inject $E C C$ at a system pressure of $4.14 \mathrm{MPa}$ (gauge pressure). HPIS pump $A$ was preset to inject at $1.085 \mathrm{l} / \mathrm{s}$ and to initiate by LOCE control at 22 seconds after the initiation of blowdown; LPIS pump $A$ was adjusted to initiate by LOCE control no sooner than 35.5 seconds after the initiation of blowdown. While the above ECCS injection times and pressure represent those, preset test conditions specified in the EOS, the actual recorded parameters are presented in the test summary and in Section IV.

The LOFT major components are shown pictorially in Figure 1, and a LOFT piping schematic, with instrumentation, is shown in Figure 2 . 


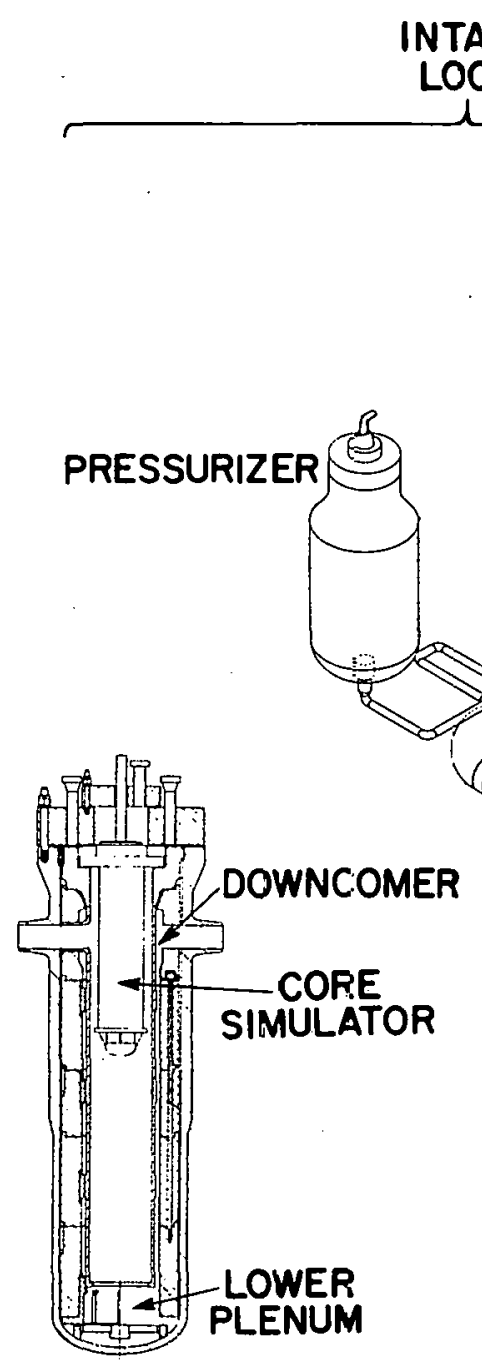

INTACT

STEAM

GENERATOR

\section{REACTOR}

VESSEL

Fig. 1 LOFT major components. 


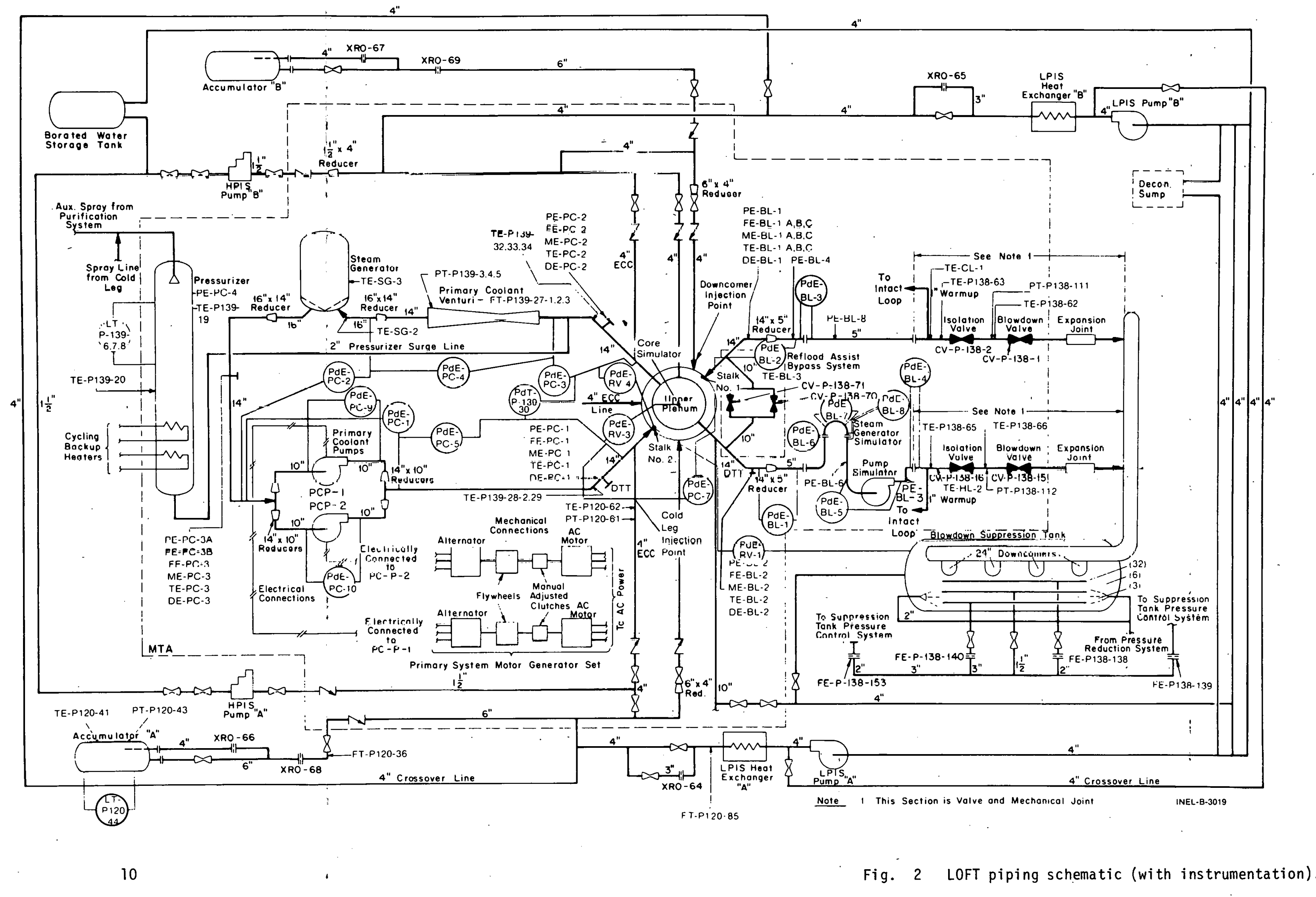


Reference 1 gives details of the experiment configuration and operation; Reference 4 gives a detailed description of the LOFT system. 


\section{MEASUREMENTS AND INSTRUMENTATION}

The 'LOFT instrumentation system was designed to measure and record the important events that occur during a LOCE. For Test L1-4, 551 channels of data were recorded. Data from the thermal-hydraulic measurements (i.e., temperatures, pressures, flow rates, liquid levels, densities, pump speeds, and QOBV positions as functions of time) are of primary importance and are included in this report. Mechanical measurement data such as acceleration and strain.are essential for mnnitoring structural loads on the LOFT system but are not of primary interest as the results are specific to the LOFT mechanical arrangement and therefore are not included.

Thermocouples and resistance temperature devices were used to sense the fluid temperatures at all major locations in the system.

Pressure measurements were generally obtained with strain-gage-type transducers with pressure transmission lines connerting the transducers to the measurement points. A few piezoelectric-type transducers were used where high-frequency response was desired rather than absolute accuracy. Free-field pressure transducers, in which the sensing elements were inside a bellows arrangement, were also used to eliminate connecting transmission lines and thereby produce higher frequency response without the distortion caused by the lines.

Differential pressures were measured by strain-gage-type transducers with double chamhers. The transduccrs were comiected lo the two measurement. points with pressure transmission lines.

Flow velocities were generally obtained directly by use of turbine flowmeters.

Density was measured by means of gamma densitometers (shown in Figure 3 ), which use the attenuation of gamma rays from a cesium-137 source to sense the mass of fluid within a pipe. The densitometers used 


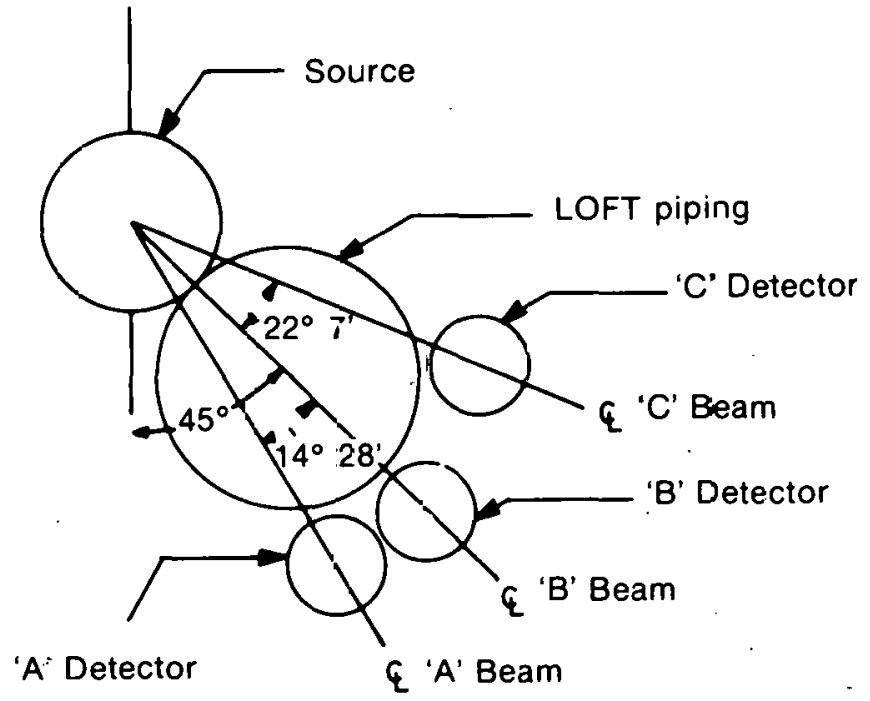

Relation of source and detector to pipe in $\mathrm{DE}-\mathrm{BL}-1$ and $\mathrm{DE}-\mathrm{PC}-1$ (view looking toward reactor vessel).

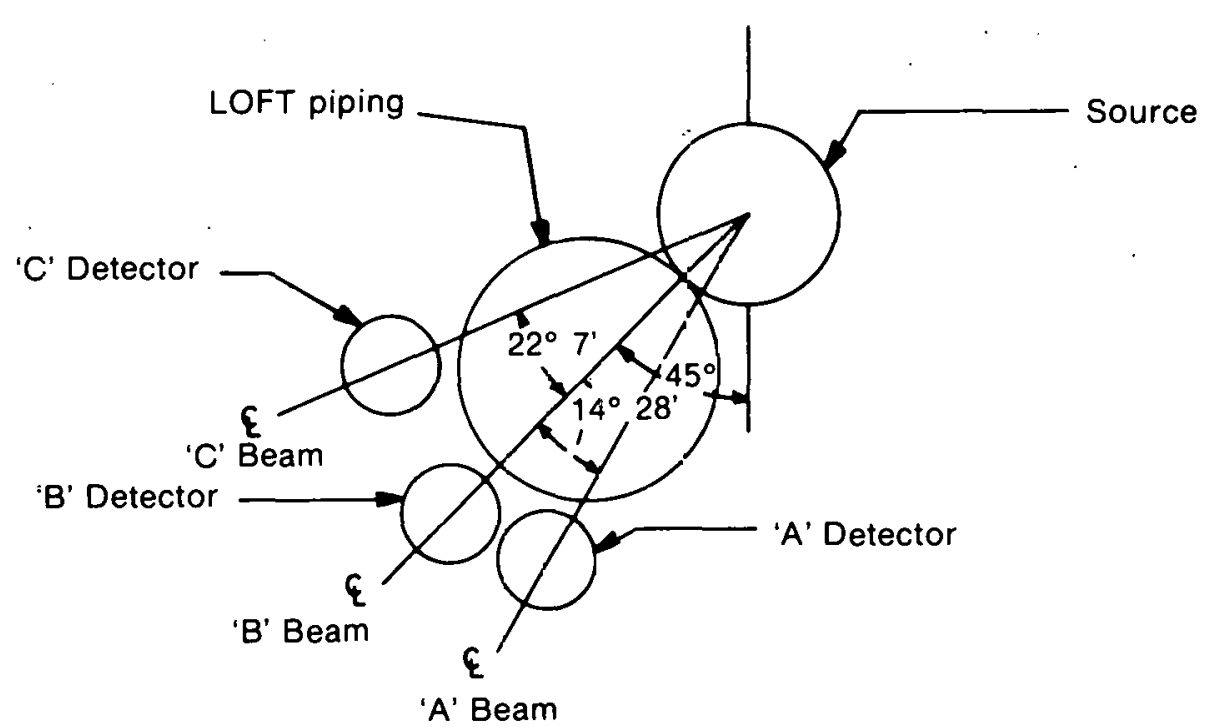

Relation of source and detector to pipe in $D E-B L-2$ and $D E-P C-2$ (view looking towàrd reactor vesse 1).

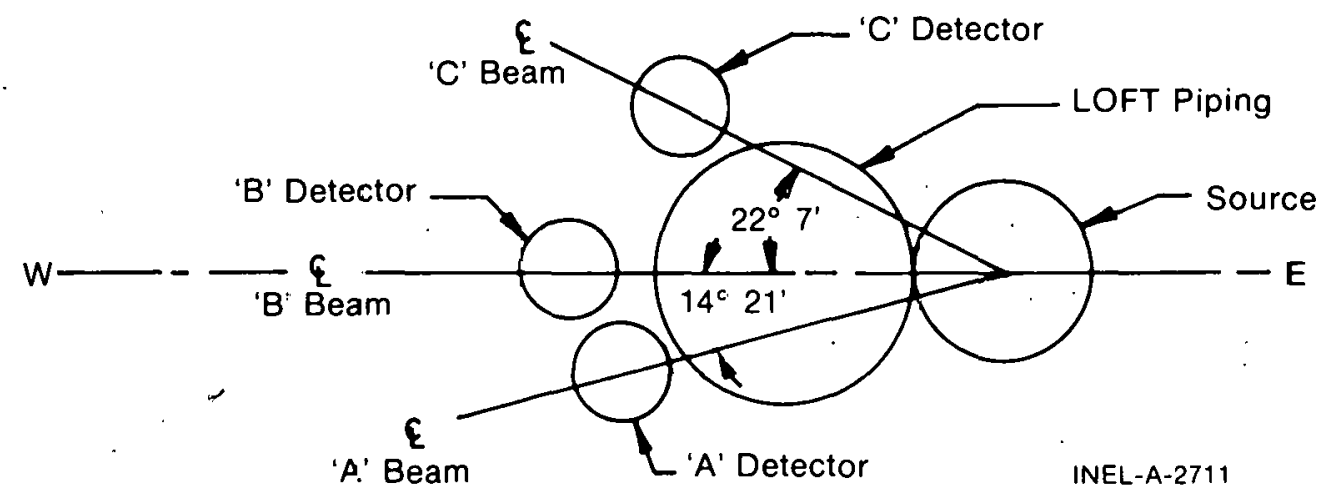

Relation of source and detector to pipe in DE-PC-3 (view looking down).

Fig. 3 Gamma denstiometer beam configuration. 
in LOFT each have three beams (designated $A, B$, and $C$ ) which traverse the lower, middle, and upper parts of the pipe, respectively, for the horizontal pipe densitometers. For the steam generator discharge densitometer, where the pipe is vertical, the densitometer ' $B$ ' beam is in the plane of the adjacent pipe bends. By using the logic table given in Figure 4 and special calibrations, the average density and the flow regime can be obtained. The special calibrations mentioned were obtained from testing with lucite and wood representations of various fluid density distributions in an actual piece of LOFT piping. These calibrations were then used to produce weighting factors to be used on each beam in combining the individual beam outputs to obtain the average derisity. Experimentation showed the use of simple weighting factors to be as accurate for average density and several more complex methods of determining the fluid distribution in the pipe. The resultant weighting factors were changed as a function of the flow regime. The weighting factors used in this report were as shown in the following equations:

$$
\bar{\rho}=0.437 \rho_{A}+0.417 \rho_{B}+0.146 \rho_{C}
$$

for stratified flow, and

$$
\bar{\rho}=0.345 \mu_{A}+0.401 \rho_{B}+0.254 \rho_{C}
$$

for other flow regimes.

Liquid levels. were obtained by means of (a) differential pressure transducers in the pressurizer, accumulators, and suppression tank, and (b) liquiuid delectors, which sense the conductivity of the fluid near each of a series of electrical contacts, in the reactor vessel.

Valve positions (analog indication from 0 to $100 \%$ of opening) were measured by either resistance potentiometers or differential transformers.

Mechanical pump speed was measured by an eddy current displacement transducer which used a slotted metallic target attached to the top of 


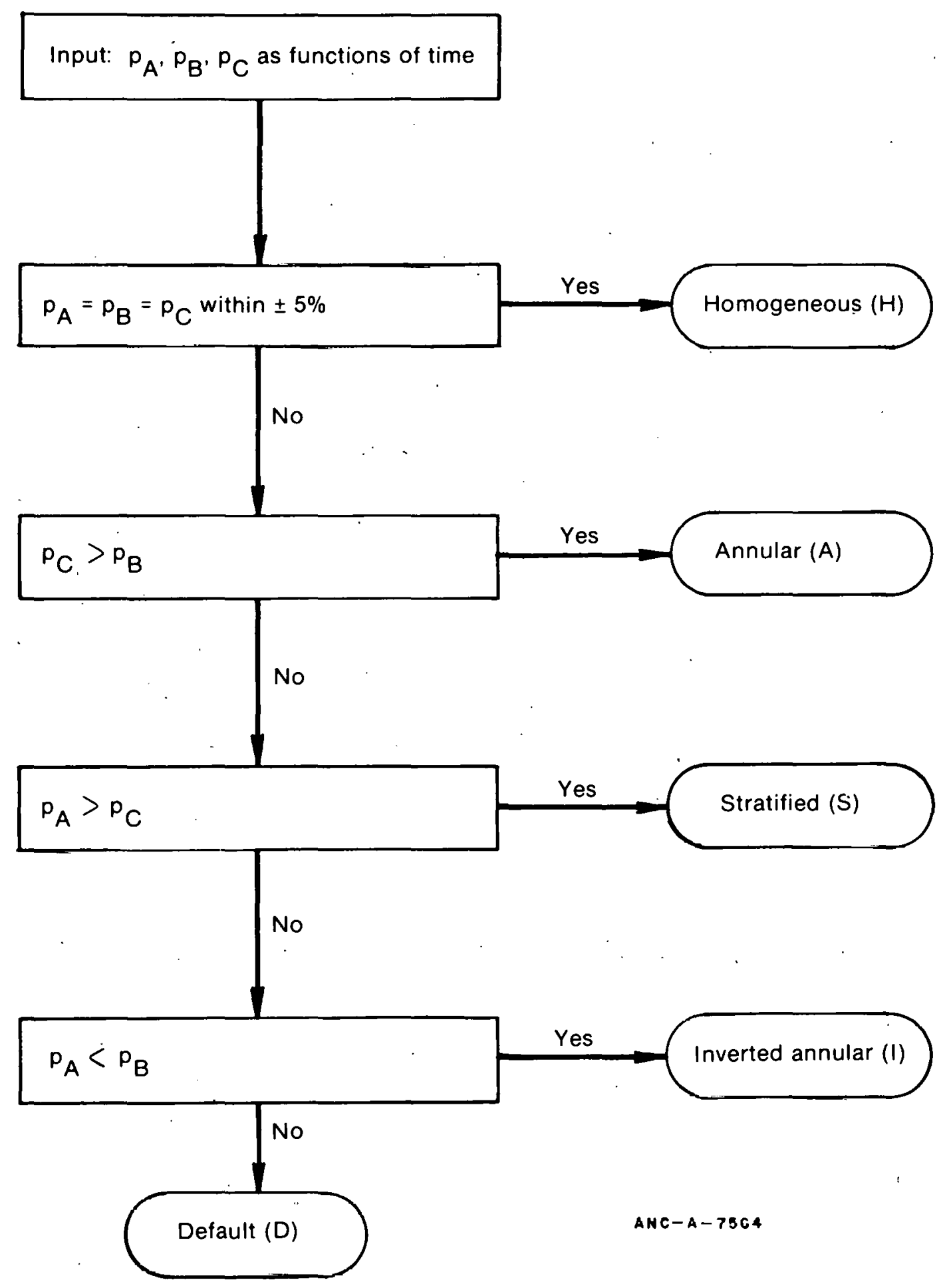

Fig. 4 Gamma densitometer flow regime logic. 
the pump motor shaft. The target contains six asymmetrical slots such that pump speed and direction of rotation. can be determined. Pump speed was also calculated from the PSMG set frequency. No allowance for slip between the electrical field and the rotor was used in this latter calculation. Electrical pump power was measured by a wattmeter.

Acceleration, displacement, mechanical strain, and valve off-on indicators were sensed by accelerometers, linear variable differential transformers, bonded strain gages, and micrnswitches, respectivcly. since these are not considered of prime importance in understanding this experiment, they are not included here. This information will be reported in an addendum to this report if sufficient requests for the information are received.

Many quantities such as mass flow rates can be computed by combining measured parameters. The calculated quantities, termed. "computed parameters", that appear in this report are identified in Table VIII in Section VII.

The data acquisition and visual display system (DAVDS) was used to record the measurement data from the various instrumentation systems on a combination of digital recorders, medium- and wide-band frequency modulation (FM) tape recorders, and oscillographic recorders. Redundant records were made where different uses dictated more than one recording mode or extra safety measures were desired for critical measurements.

A digital computer was used to collect the LOCE data in a multiplex format at the LOFT Facility and to perform equipment calibrations and post-test data reduction and plotting. Immediately following the test, the computer was used to reduce critical channels of the data so that a decision could be made quickly as to the success of the experiment. The recorded analog data were converted into digital form, and the digital data were demultiplexed to be compatible with the CDC CYBER 76/173 computer. 
The CDC CYBER 76/173 computer was used to further reduce the data. Calibration factors were first applied to produce engineering units data plots so that engineering specialists could examine each channel for discrepancies or unexpected events. After the data graphs were examined and qualified, they were then used to generate graphs and compute variables. Specifics of these topics are given in Section VII and a complete description of the data acquisition system and data reduction is given in References 9 and 10.

Figure 2 shows a piping schematic with instrument locations indicated. Table I gives the nomenclature for LOFT instrumentation designations, Figure 5 shows an isometric view of the major system components with instrument locations indicated, and Figures 6 through 12 give more specific locations for instruments located on individual components. Reference 4 should be consulted for details of instrument design and locations. (Locations, ranges, and frequency responses for instruments used in obtaining data presented in this report may also be obtained from Table VII which is presented in Section VII.) Various new instruments were added for Test LI-4. The new instruments are given, with their locations, in Table II. Figures 13, 14, and 15 show the locations of the new instrumentation. 
TABLE I

NOMENCLATURE FOR LOFT INSTRUMENTATION

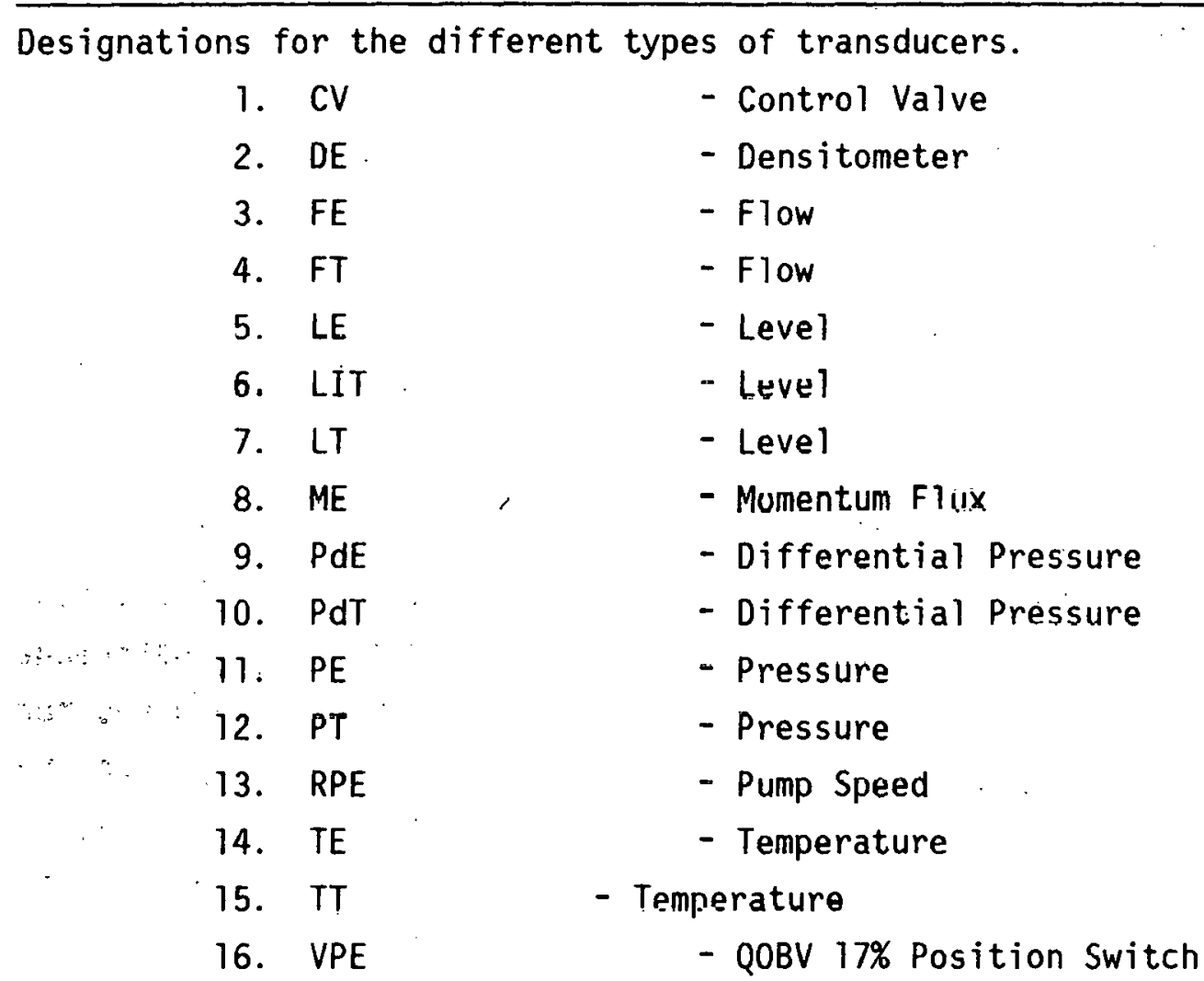

Designations for the different systems, exropt for the nuclear core which has not been installed.

1. BL

2. CS

3. $\mathrm{PC}$

4. RV

5. SG

6. ST

7. SV
- Broken Loop

- Core Simulator

- Intact Loop

- Reactor Vessel

- Steam Generator

- Downcuilier Ins lrument Stālk

- Blowdown Suppression Tank 


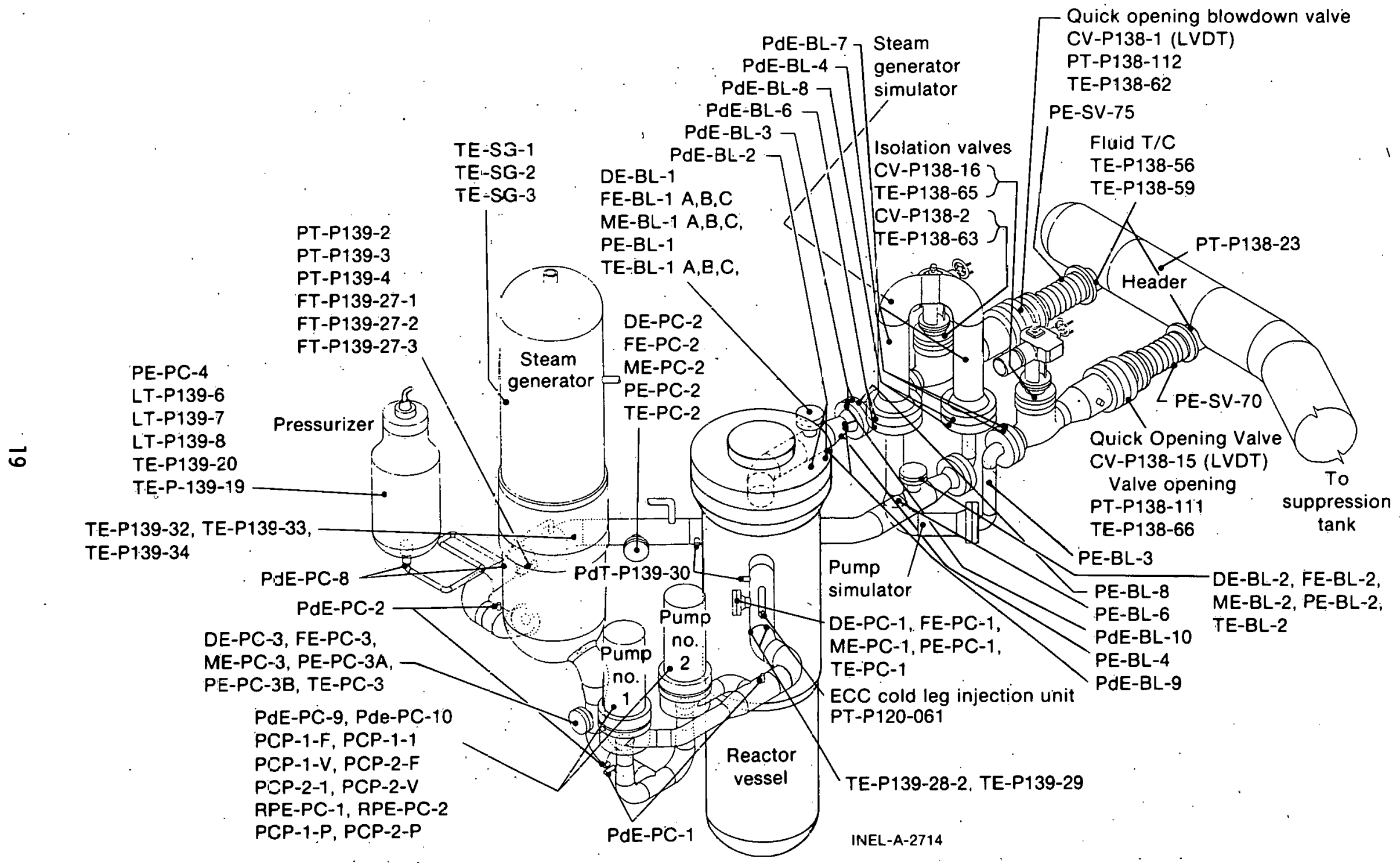

Fig. 5 LOFT thermo-fluid measurements instrumentation. 

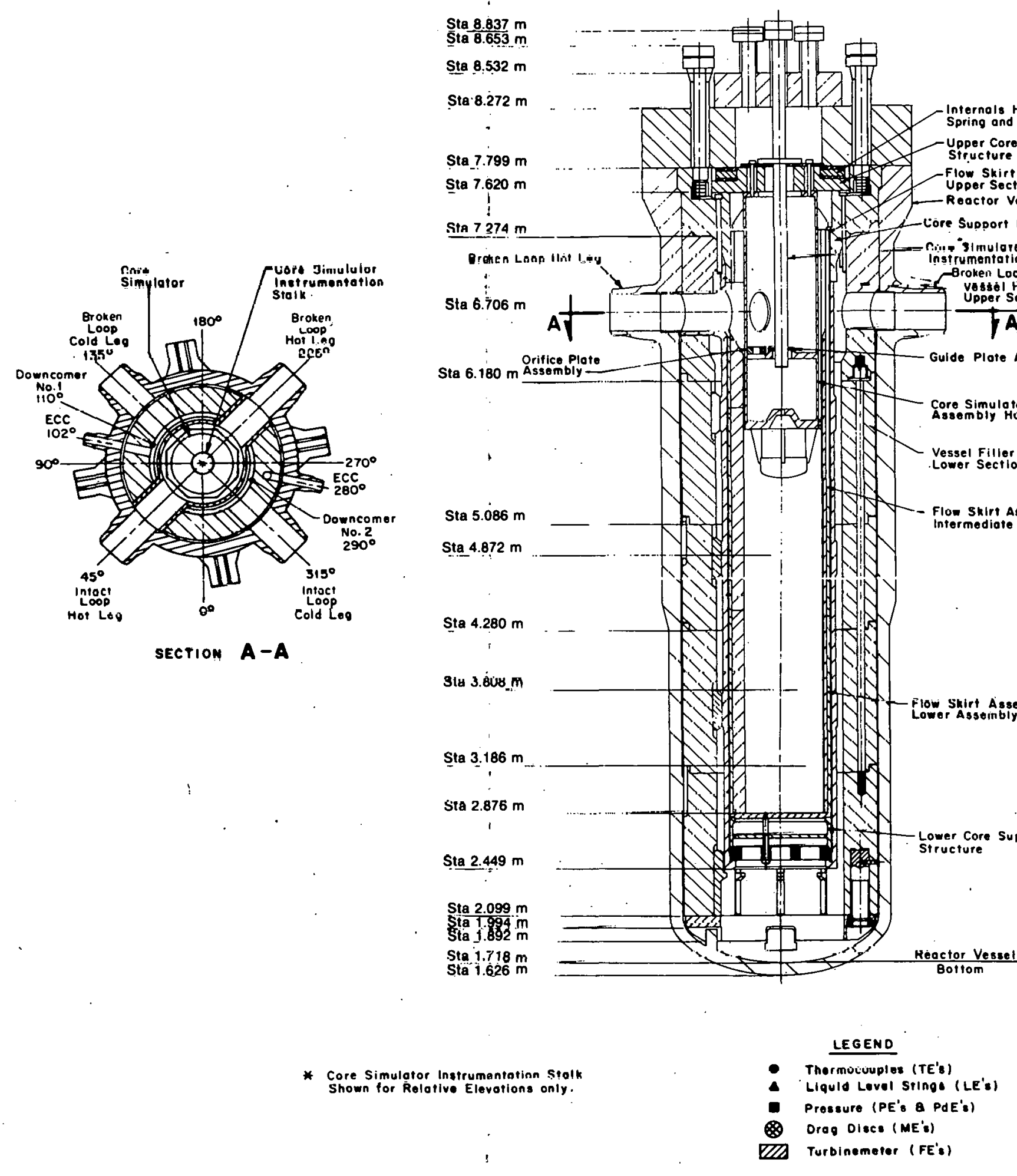

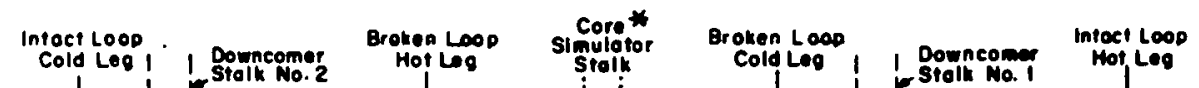

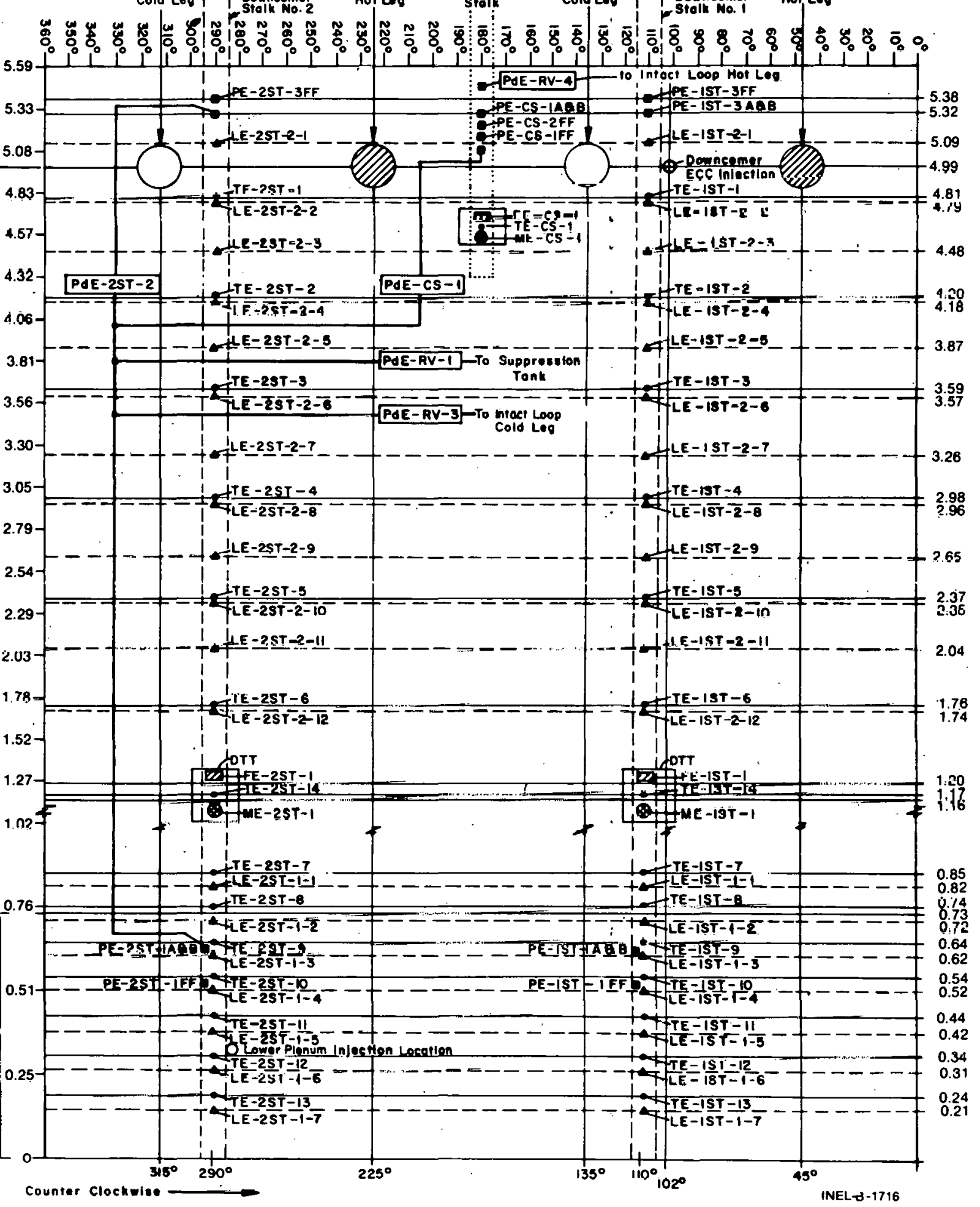

Fig. 6 LOFT reactor vessel instrumentation. 


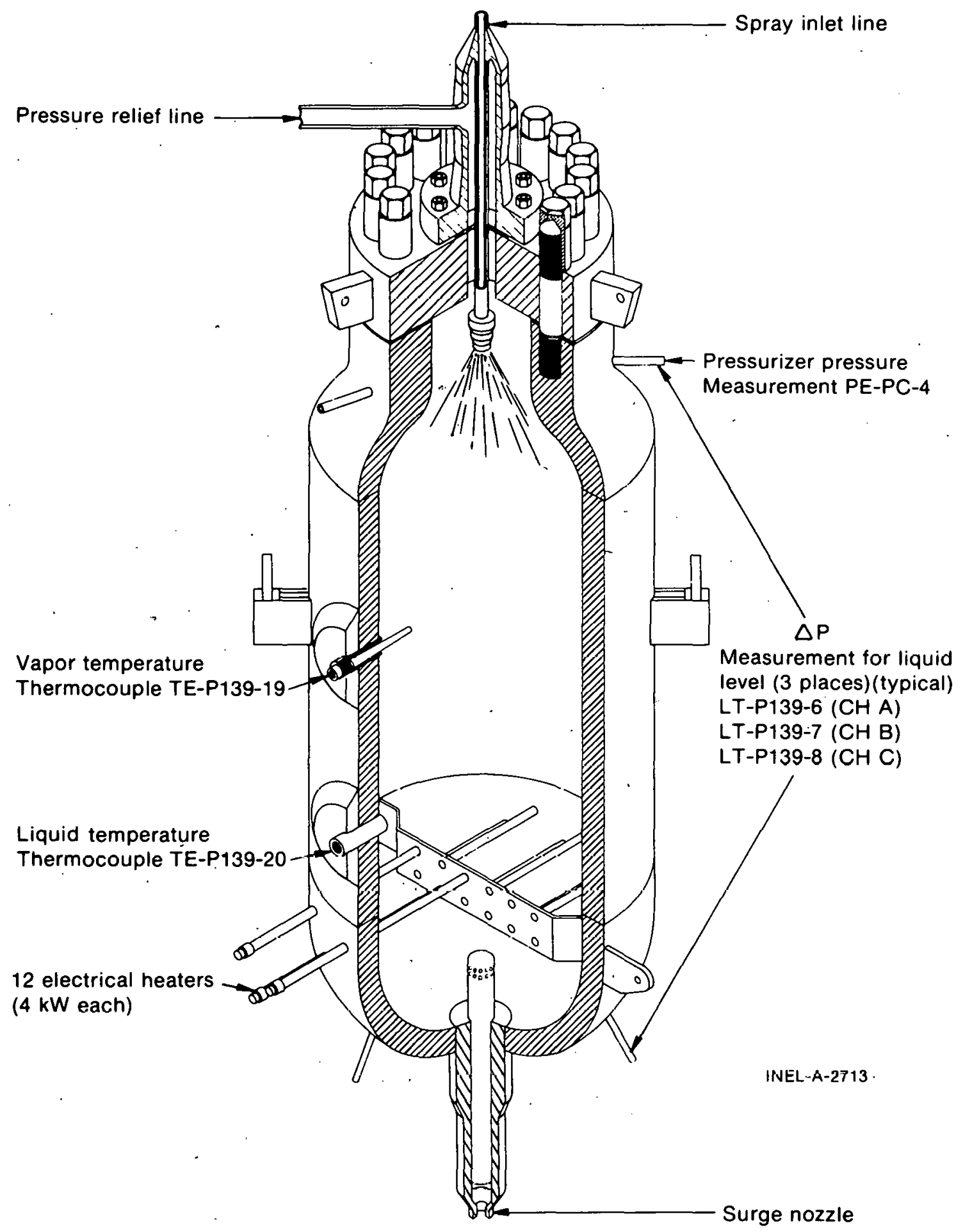

Fig. 7 LOFT pressurizer instrumentation. 


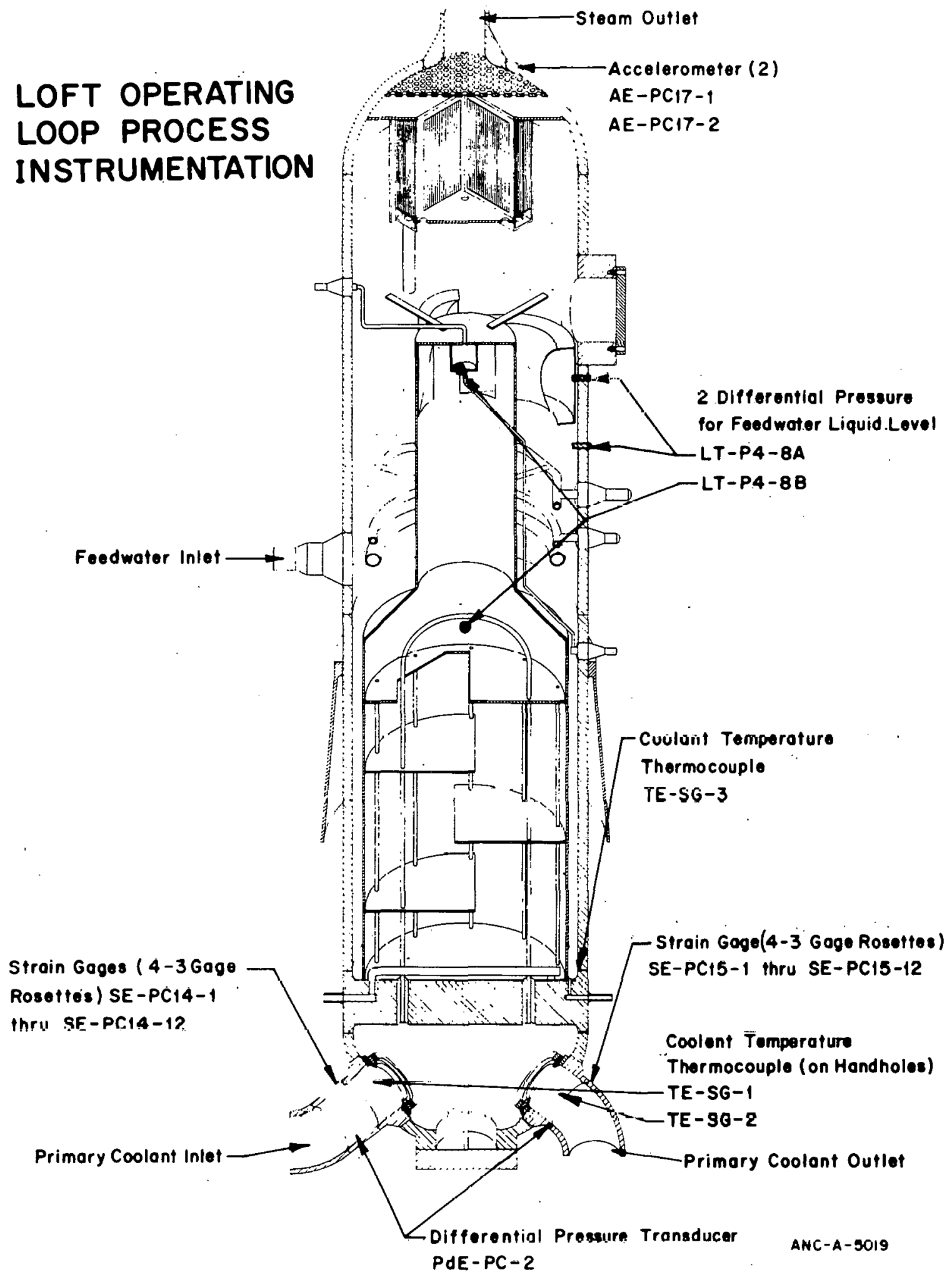

Fig. 8 LOFT steam generator instrumentation. 


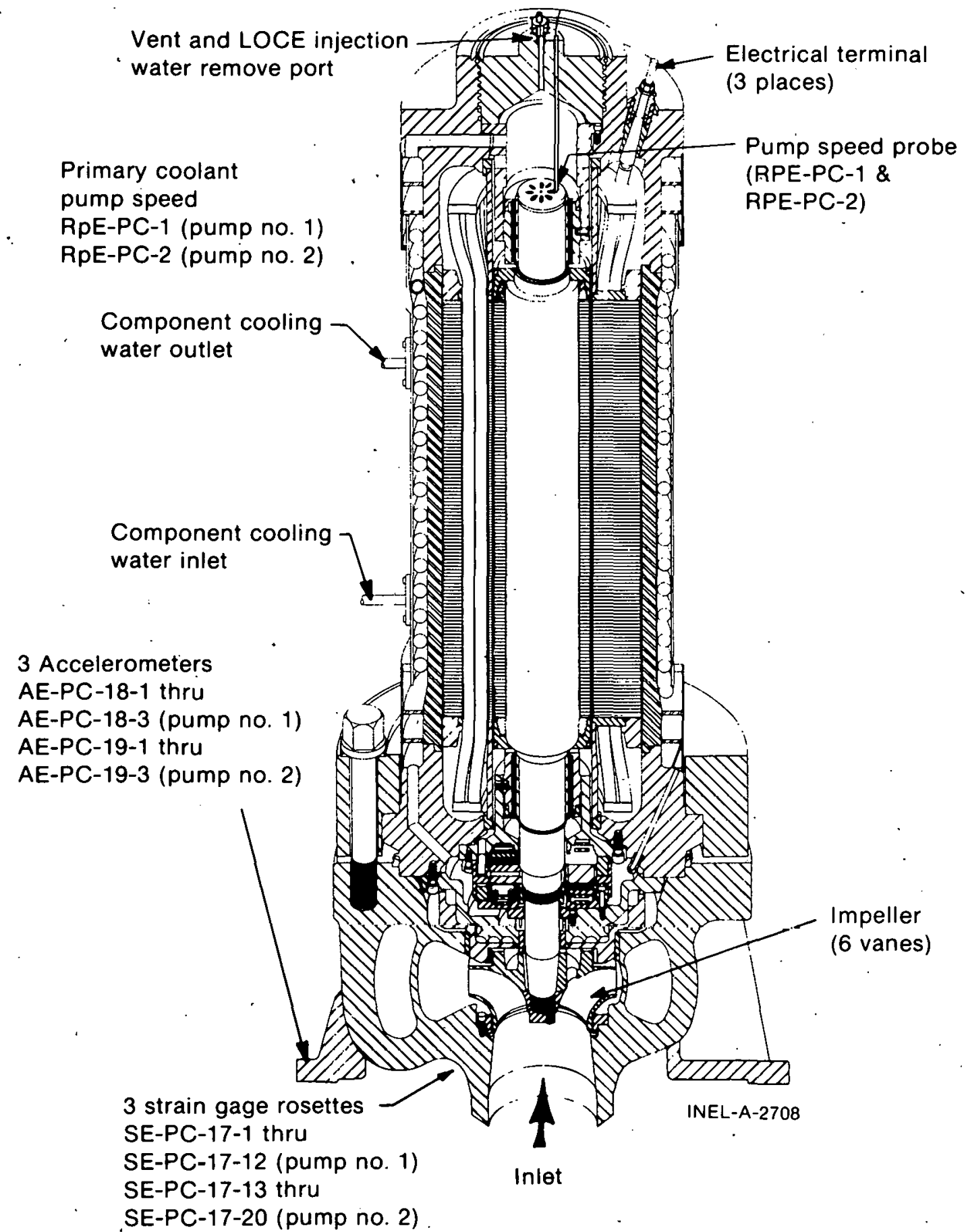

Fig. 9 LOFT intact loop pump instrumentation. 


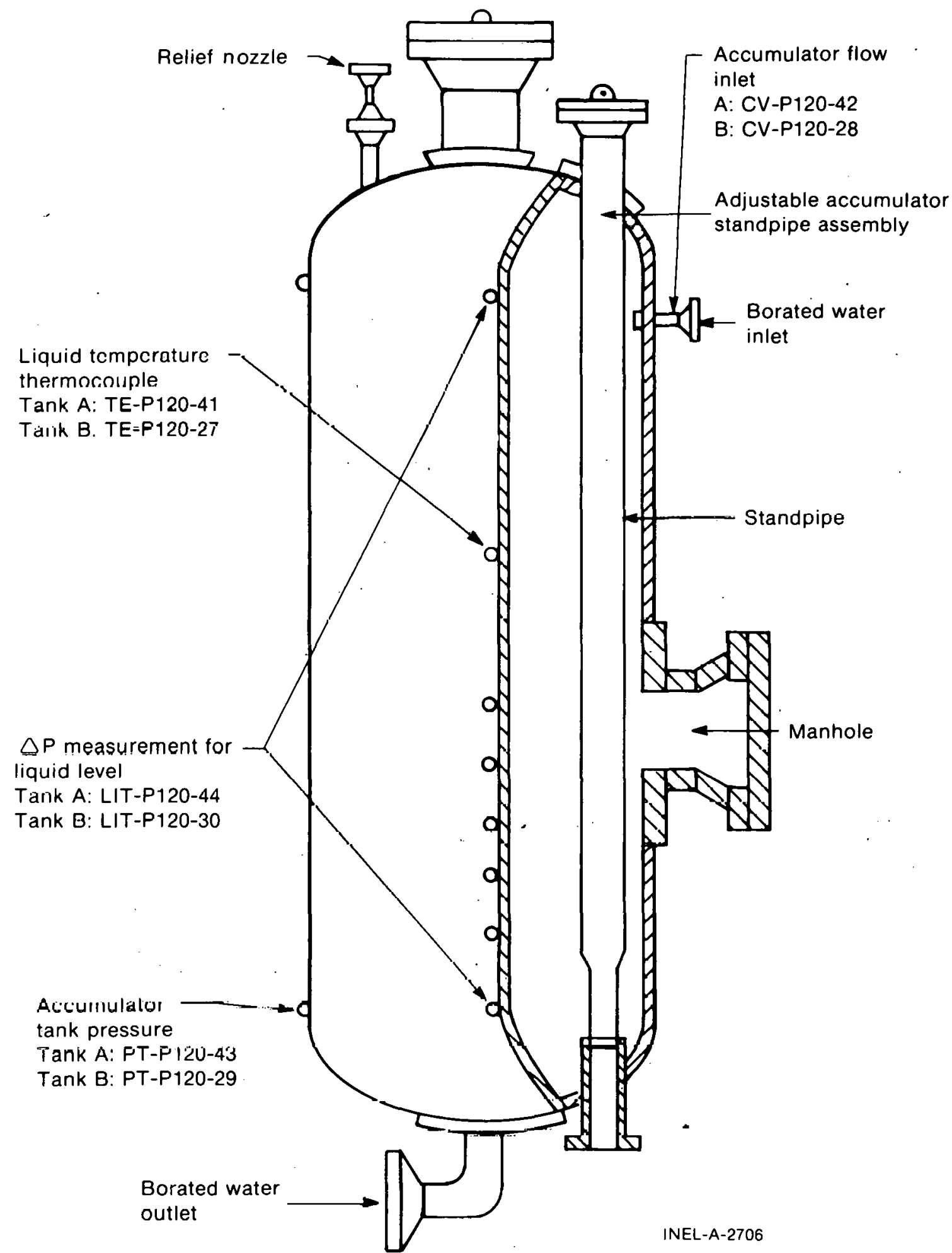

Fig. 10 LOFT accumulator instrumentation. 


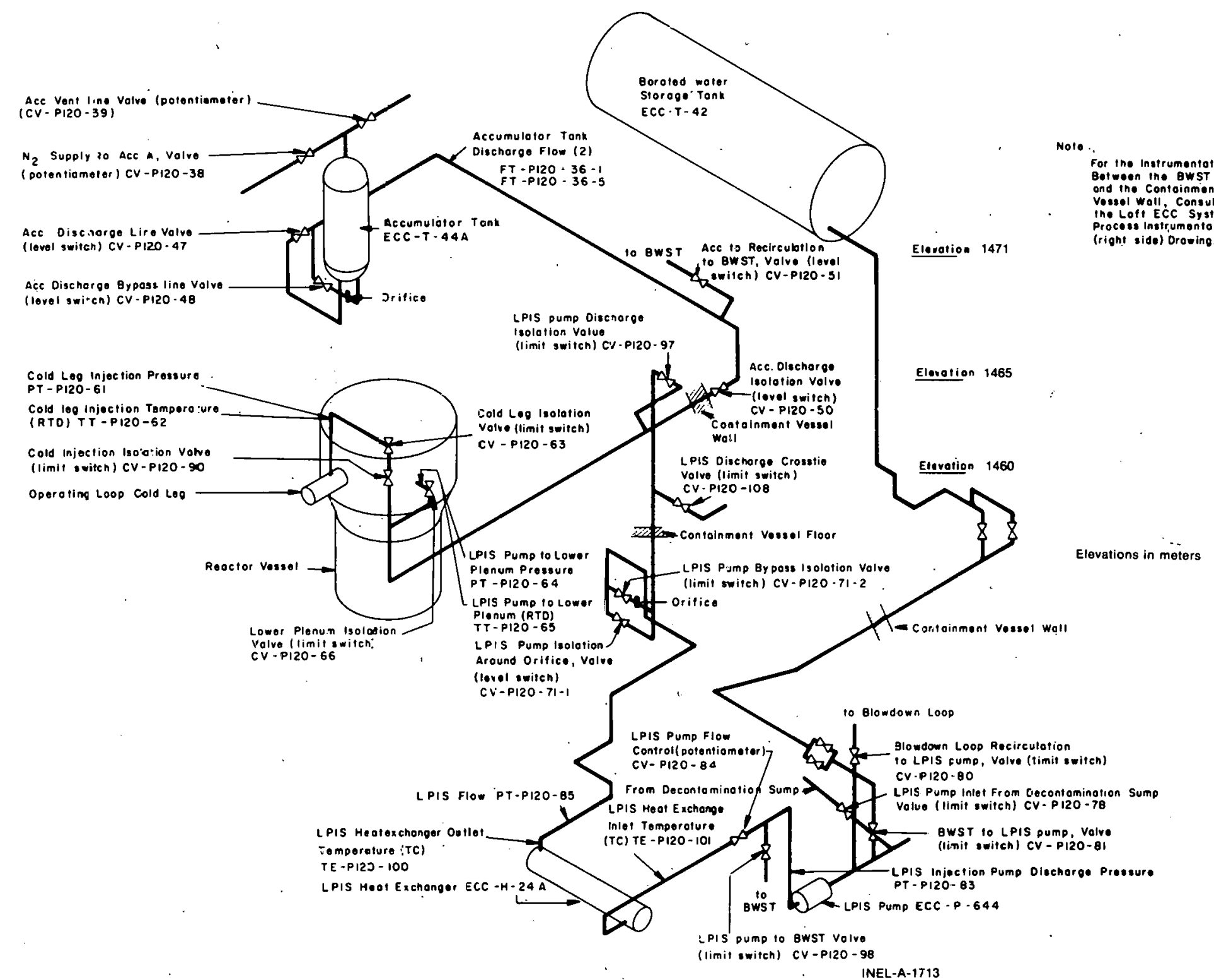

Fig. il LOFT ECCS instrumentation -- left side. 

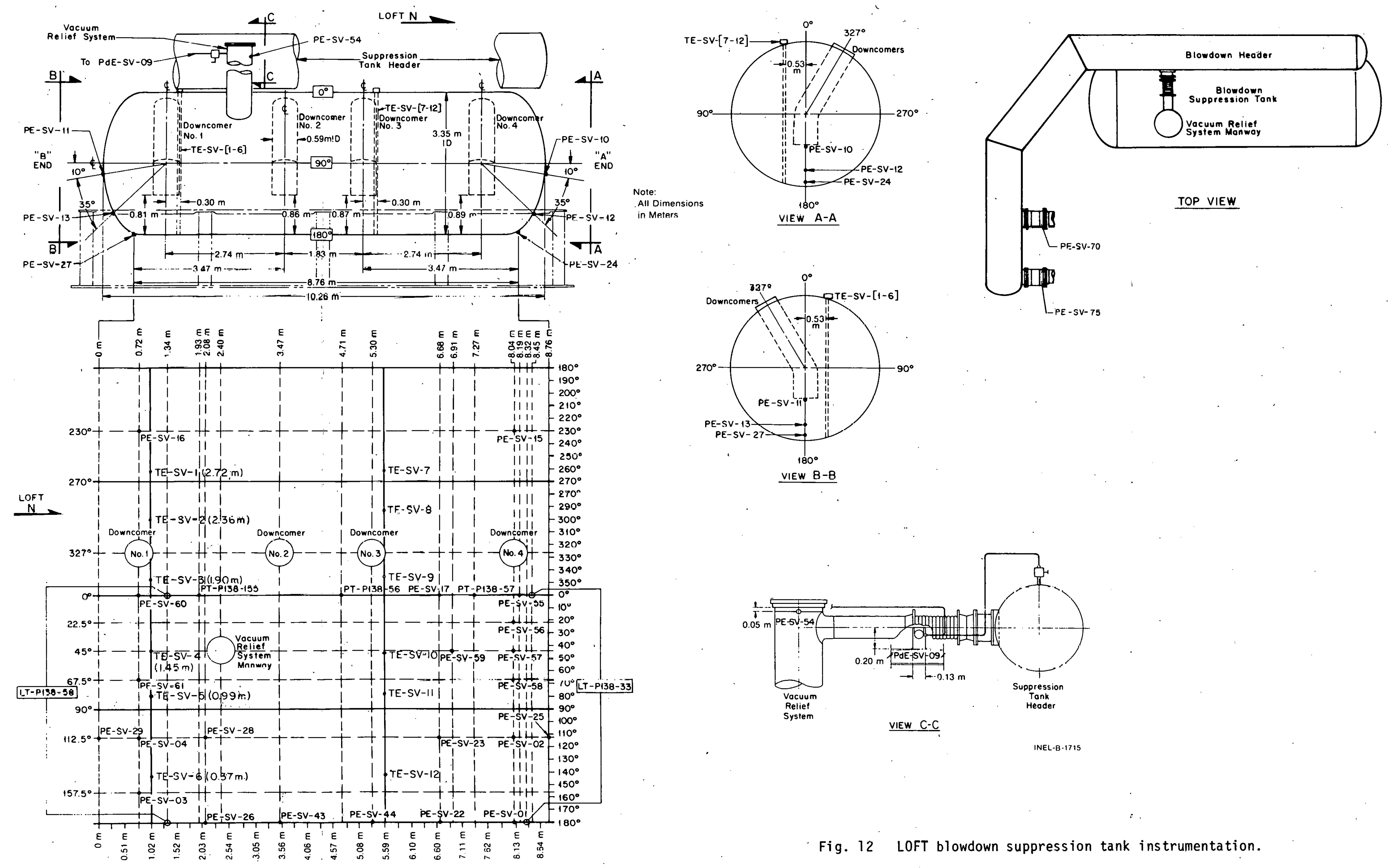


\section{TABLE II}

NEW INSTRUMENTATION FOR NONNUCLEAR TEST LI-4

\begin{tabular}{|c|c|}
\hline $\begin{array}{l}\text { Measurement } \\
\text { Identification }\end{array}$ & Description \\
\hline$P d E-P C-8$ & $\begin{array}{l}\text { Differential pressure across the pressurizer } \\
\text { surge line }\end{array}$ \\
\hline$P d E-P C-9$ & $\begin{array}{l}\text { Differential pressure across intact loop } \\
\text { pump } 1\end{array}$ \\
\hline$P d E-P C-10$ & $\begin{array}{l}\text { Differential pressure across intact loop } \\
\text { pump } 2\end{array}$ \\
\hline$P d E-B L-9$ & $\begin{array}{l}\text { Broken loop cold leg differential pressure } \\
\text { from end of } 14-t 0-5-i n \text {. contraction to } \\
\text { middle of } 5 \text {-in.-diameter pipe }\end{array}$ \\
\hline$P d E-B L-10$ & $\begin{array}{l}\text { Broken loop cold leg differential pressure } \\
\text { from middle of } 5 \text {-in.-diameter pipe to break plane }\end{array}$ \\
\hline $\begin{array}{l}F E-B L-1 A \\
M E-B L-1 A \\
T E-B L-1 A\end{array}$ & $\begin{array}{l}\text { Broken loop cold leg fluid velocity, momentum } \\
\text { flux, and fluid temperature at DTT flange on } \\
\text { bottom DTT. }\end{array}$ \\
\hline $\begin{array}{l}F E-B L-1 B \\
M E-B L-1 B \\
T E-B L-1 B\end{array}$ & $\begin{array}{l}\text { Broken loop cold leg fluid velocity, momentum } \\
\text { flux, and fluid temperature at DTT flange on } \\
\text { middle DTT }\end{array}$ \\
\hline $\begin{array}{l}F E-B L-1 C \\
M E-B L-1 C \\
T E-B L-1 C\end{array}$ & $\begin{array}{l}\text { Broken loop cold leg fluid velocity, momentum } \\
\text { flux, and fluid temperature at DTT flange on } \\
\text { top DTT }\end{array}$ \\
\hline PE-SV-75 & Pressure at broken loop cold leg expansion joint \\
\hline PCP-1-P & Pump power, intact loop pump 1 \\
\hline$P C P-2-P$ & Pump power, intact loop pump 2 \\
\hline
\end{tabular}

Instruments were calibrated before installation either by the instrument vendor or at the INEL. Calibration data were then correlated with other parameters to determine the functional relationships between errors and variables other than those the instrument was designed to measure. These error functions were then represented by mathematical equations (usually in the form of polynomials of degree five or less) and incorporated in the data reduction program. 


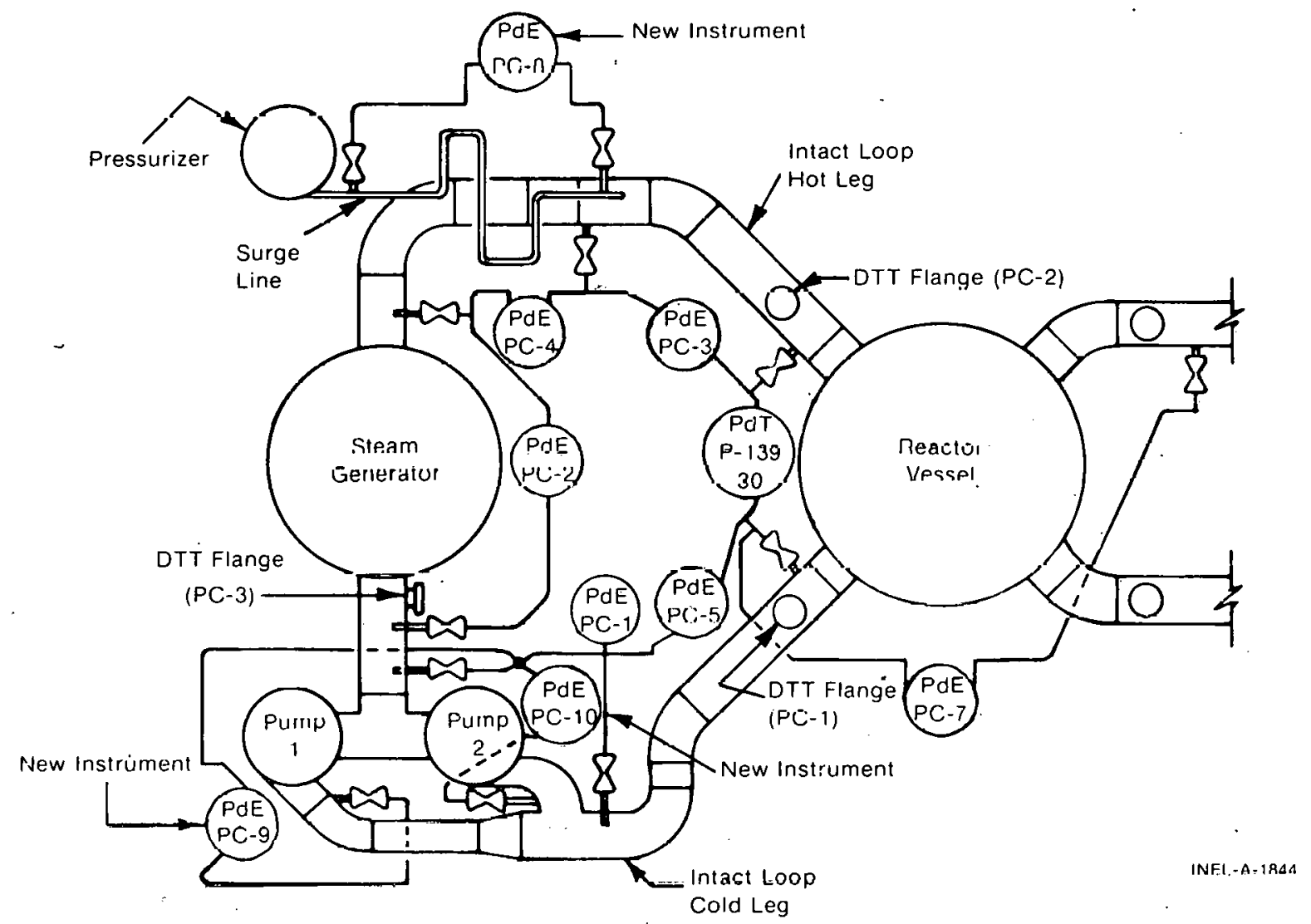

Fig. 13 New instrumentation in the intact loop. 


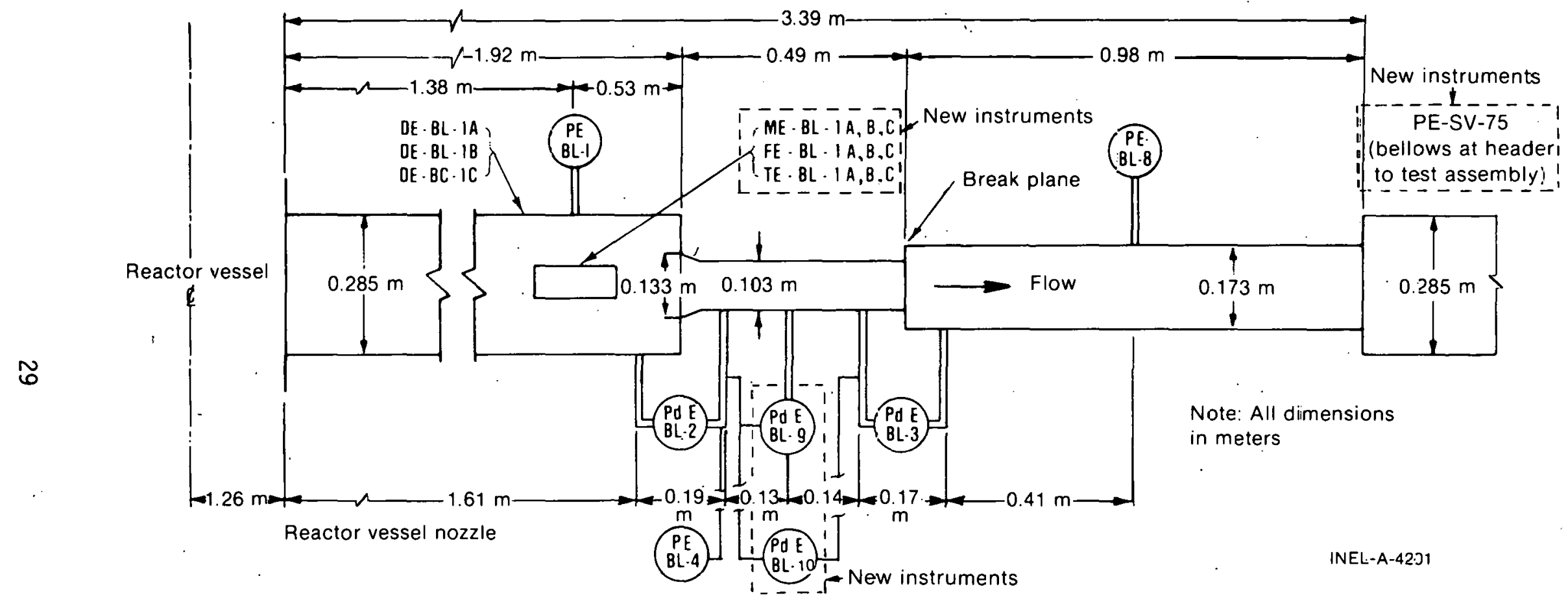

Fig. 14 New instrumentation in the broken loop. 


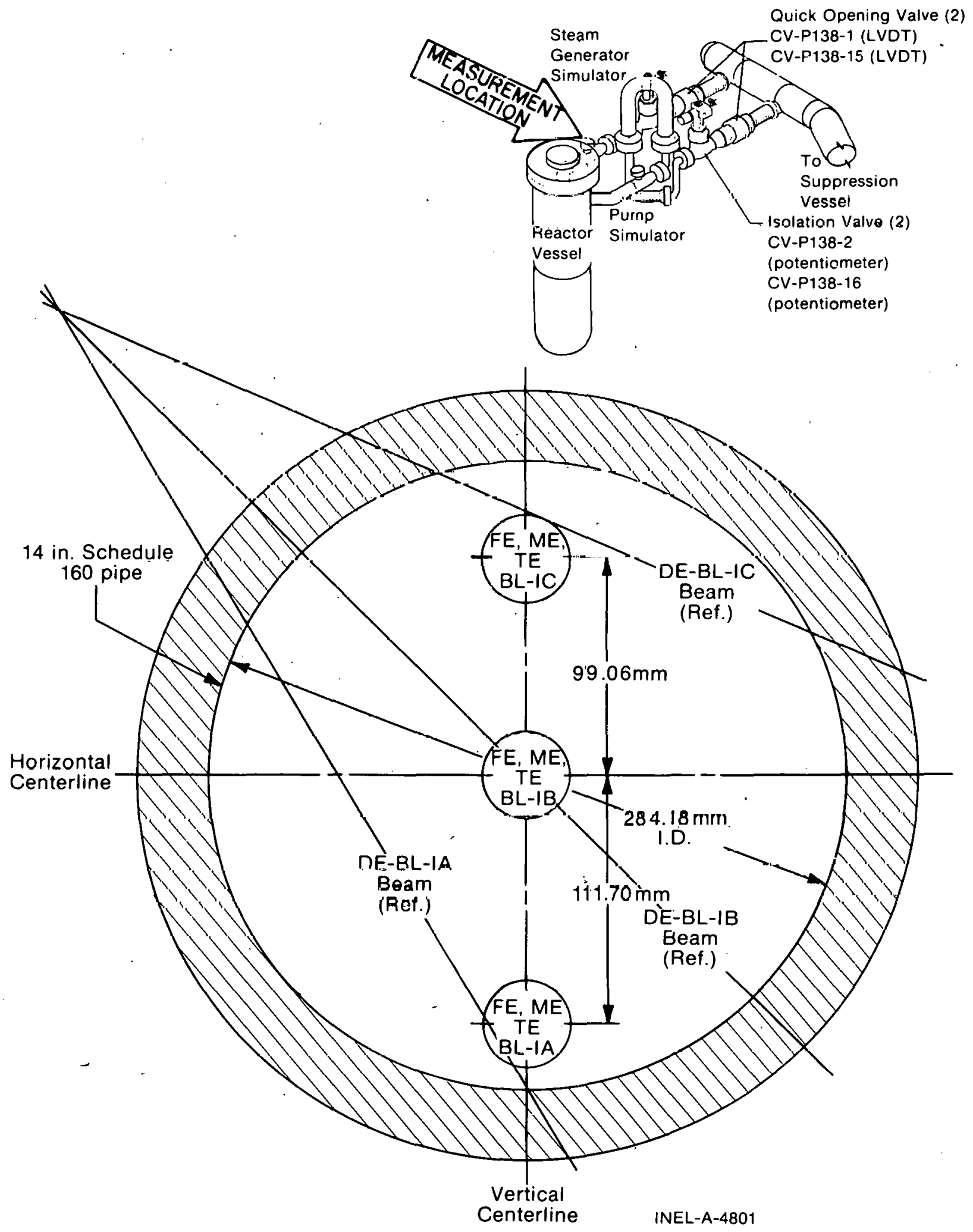

Fig.-15 New DTT locations in the broken loop cold leg (BL-1). 
The turbine meters and the drag discs in the intact loop were calibrated to convert the point measurement values to the mean values across the entire flow area. These calibrations were performed using the data from the single-phase variable frequency pump tests conducted prior to blowdown initiation. Least squares curve fits were calculated for the square root of the intact loop differential pressures plotted against the pump speed to confirm the adequacy of the differential pressure offset corrections. Similarly, the intact loop venturi meter data were plotted against the square root of the corrected differential pressure measurements to confirm or adjust the venturi meter offset corrections. The corrected venturi meter data were then used to calculate average velocities and momentum fluxes in the intact loop and the reactor vessel. These calculated quantities were subsequently compared to the measured turbine meter velocities and drag disc momentum fluxes to verify or to provide changes to the respective instrument calibration equations.

Additional calibrations were performed on specified turbine meters and drag discs to convert the point measurements to average measurements. These instruments included broken loop turbine meters and drag discs in the intact loop and reactor vessel which were overranged during the pump frequency tests. In the intact loop and reactor vessel, the flow rates calculated using the turbine meters and their associated areas were normalized with the intact loop venturi during steady-state (initial) conditions to determine the calibration factors for the turbine flowmeters. These calibration factors were squared and applied to the drag discs. To determine the calibration factors for the drag disc in the core simulator, the flow rate was calculated using the flow area of the LOFT nuclear core and normalized with the venturi flow rate. Similar calibration factors were developed for the broken loop drag discs using the results of accumulator blowdown tests (where the accumulator flow was directed through the broken loop).

The differential pressures were calibrated to read zero at zero flow regardless of the elevation differences between taps. 
The presented data for average velocity and average momentum flux are based on the following flow areas at the instrument locations:

\section{Ins trument}

FE-BL-1A, $-1 B,-1 C$, and -2

$M E-B L-1 A,-1 B,-1 C$, and -2

$F E-P C-1,-2$, and -3

$M E-P C-1,-2$, and -3

FE-CS-

ME-CS-1

FE-1ST-1 and FE-2ST-1

ME-1ST-1 and ME-2ST-1

\section{Flow Area}

$0.0634 \mathrm{~m}^{2}$

$0.0634 \mathrm{~m}^{2}$

$0.165 \mathrm{~m}^{2}$

$0.141 \mathrm{~m}^{2}$

Error bands (upper and lower) were added as overlays to the plots of certain representative instruments from Test L1-3. These plots can be found in Section 5 of the presented data.

Information on the calibration factors, accuracy, and response of specific instruments is given in the LOFT Experimental Measurements Uncertainty Analysis [11]. Instrument calibrations and system testing conducted subsequent to completing the uncertainty analysis have been used to update the information presented and to process the data contained herein. Reference 11 is currently being revised to reflect the improved information and the observed instrument performances obtained to datc. 


\section{TEST PROCEDURES}

In preparation for Test $17-4$, the PCS was filled and vented and the system water chemistry was established to the specifications listed in lable VI. Ihe SCS, ECCS, the blowdown suppression system, and supporting plant systems were configured as specified in the experiment operating specification (EOS) $[1]$.

Prior to the heatup of the plant, several tests were performed on the LOFT system. These tests included plant requalification tests, QOBV operation and seat leakage checks, pump coastdown runs, LOCE control system checks, and operational verification of newly installed instrumentation. Selected system process instrumentation was calibrated and an electrical calibration was performed on the DAVDS.

The PCS pressure was hydrostatically increased to $1.38,3.45,6.90$, $10.35,13.8$, and $15.5 \mathrm{MPa}$ (gauge pressure) at cold plant temperature and zero flow conditions. The DAVDS recorded 20 seconds of data at each pressure plateau to provide information to determine the degree of sensitivity of the pressure sensing instruments. The system was concurrently inspected for leakage at the various test pressures.

The plant was brought, to the initial temperature of $279^{\circ} \mathrm{C}$ in a stepwise manner using the work energy addition of the primary coolant pumps. During the warmup, the purification and sampling systems were valved into the PCS to maintain water chemistry requirements and to provide a water sample at system conditions for subsequent analysis. Isothermal conditions were obtained in the nonflowing broken loop by means of the recirculation lines back to the intact loop. Before plant temperature exceeded $93.3^{\circ} \mathrm{C}$, the secondary side of the steam generator was drained to the $0 \%$ power program reference level $(2.59 \mathrm{~m}$ from the top of the tube sheet), water chemistry: was established, and the steam generator secondary side was valved out. Prior to LOCE initiation, the BDST was heated up and pressurized with nitrogen to its specified initial conditions. 
The plant was stabilized at three points during heatup: $121^{\circ} \mathrm{C}-$ $3.45 \mathrm{MPa}$ (gauge pressure), $238^{\circ} \mathrm{C}-15.5 \mathrm{MPa}$ (gauge pressure), and $279^{\circ} \mathrm{C}$ - $15.45 \mathrm{MPa}$ (gauge pressure). At each stabilization point a burst (20 to 30 seconds) of data was recorded for calibration checks and to determine the degree of instrument temperature sensitivity. At the 121 , 238 , and $279^{\circ} \mathrm{C}$ stabilization points, frequency tests were performed by varying primary coolant pump frequency from 20 to $60 \mathrm{~Hz}$ in $10 \mathrm{~Hz}$ increments. Following the frequency tests, single-phase pump coastdown tests were conducted at the $9.2 \mathrm{MPa}$ and $211.5^{\circ} \mathrm{C}$ points with an initial flow of $475 \mathrm{~kg} / \mathrm{s}$. At the $282^{\circ} \mathrm{C}$ stabilization point, single-phase pump coastdown tests were performed with initial flows of $269 \mathrm{~kg} / \mathrm{s}$. Data were recorded for about 60 seconds for each of the four pump coastdowns and the data were used for calibration checks. Following each pump coastdown, data were recorded for zero flow conditions. When plant conditions were stabilized at $283^{\circ} \mathrm{C}$ and $15.6 \mathrm{MPa}$, the $\mathrm{plant}$ was allowed to soak for more than 40 hours to assure isothermal conditions for the blowdown. During this 40-hour soak, an electrical calibration of the DAVDS was performed. Additionally, ECCS accumulator ACC-A was filled and pressurized to its specified values.

Prior to blowdown initiation, the system parameters were checked to insure that they were within specified bands and last-minute instrument checks and valve lineup checks were performed. During this period, the initial-condition water samples were taken from the primary coolant system, the secondary coolant system, and the BDST. The pressurizer, steam generator, and BDST water levels were established: 'The purification system, which was the primary mode of plant temperature control, was valved out. The conditions in the intact loop were established to provide $268.4 \mathrm{~kg} / \mathrm{s}$ flow with temperature and pressure at $279^{\circ} \mathrm{C}$ and $15.65 \mathrm{MPa}$ (gauge), respectively, at the time of blowdown initiation. Primary coolant pump injection flow was initiated and the broken loop recirculation lines to the intact loop were closed.

Immediately prior to blowdown (within 60 seconds), the DAVDS was activated and data recording was started, the QOBV isolation valves were opened, and the pressurizer heaters were secured. Test Li-4 blowdown 
was initiated. QOBV-2 (CV-P138-15) commenced opening $1.3 \mathrm{~ms}$ before QOBV-1 (CV-P138-1) and opened to a 12-inch Schedule 160 (0.30-m OD) pipe area in 22 IIIS; QOBV-1 opened to the same flow area in $17.9 \mathrm{~ms}$. Thus Test LI-4 successfully simulated a simultaneous $200 \%$ offset cold leg shear.

Electrical power to the PSMG sets was terminated within 1 second after blowdown initiation which allowed the pumps to coastdown under the influence of the flywheels and the fluid dynamic forces on the pump impellers. The PSMG set field breakers were tripped at 24.5 seconds before the primary coolant pumps coasted down below $12.5 \mathrm{~Hz}$.

ECC injection was directed to the intact loop cold leg during blowdown. Injection from accumulator $A C C-A$ at a system pressure of $4.14 \mathrm{MPa}$ began approximately 23 seconds after initiation of blowdown and continued for 42 seconds. HPIS pump A was initiated by LOCE control 23 seconds after the initiation of blowdown and injected at a flow rate of $1.1 \mathrm{l} / \mathrm{s}$. LPIS pump A was initiated by LOCE control 39 seconds after the initiation of blowdown. Nitrogen gas from accumulator ACC-A entered the system at 65 seconds and continued to flow for about 35 seconds.

After accumulator nitrogen entered the BDST, the BDST spray was automatically initiated. This spray was continued for approximately 5 minutes and then secured.

The DAVDS digital recording system obtained approximately 6 minutes of data after simulated rupture and was secured. The DAVDS analog system continued recording blowdown suppression tank parameters for 10 minutes after blowdown initiation and was then secured. An electrical calibration of the DAVDS was performed following the test completion.

A sequence of events for Test LI-4 is provided in Table III. 
TABLE III

CHRONOLOGY OF EVENTS FOR NONNUCLEAR TEST LI-4

\begin{tabular}{|c|c|}
\hline Event & $\begin{array}{c}\text { Time } \\
\text { (Seconds After } \\
\text { Blowdown Initiation) }\end{array}$ \\
\hline 1.1-4 initiation & 0 \\
\hline End of subronled hlowdown & $\sim 0.08$ \\
\hline PCS pump trip & $\sim 1.0$ \\
\hline Pressurizer empty & 14 \\
\hline Accumulator $A$ injection initiated & 23 \\
\hline HPIS injection initiated & $\left(2 \ddot{2} \pm 2^{23}\right.$ specteled $\left.[1]\right)$ \\
\hline LPIS injecrion initiated & $\left(35 \pm 2^{39}\right.$ specified $\left.[1]\right)$ \\
\hline End of saturated blowdown & $\sim 50$ \\
\hline Accumulator A empty of liquid & 58 \\
\hline Accumulator liquid line flow ends ${ }^{[a]}$ & 65 \\
\hline BDST spray flow initiated & 84 \\
\hline $\begin{array}{l}\text { [a] Flow measuring point is downstream } \\
\text { indicators. }\end{array}$ & frnm arroumulat.nr level \\
\hline
\end{tabular}




\section{INITIAL CONDITIONS}

The initial conditions and tolerance bands for Test L1-4 are presented in Table IV along with the values measured immediately prior to the blowdown initiation. These pretest requirements and the justification for their selection are specified in EOS Volume $2^{[1]}$.

Six initial conditions were slightly out of tolerance for this test: The measured PCS pressure was $15.65 \mathrm{MPa}$ (gauge) instead of the $15.60 \mathrm{MPa}$ (gauge) maximum pressure as specified in EOS Volume 2. The PCS temperature was $279^{\circ} \mathrm{C}$ instead of the specified $282^{\circ} \mathrm{C}$. The ECC accumulator injected water volume was $2.05 \mathrm{~m}^{3}$ instead of the maximum specified of $2.04 \mathrm{~m}^{3}$. The pressurizer pressure like the PCS pressure was $15.65 \mathrm{MPa}$ (gauge) instead of the $15.60 \mathrm{MPa}$ (gauge) maximum pressure specified. The steam generator secondary side water level was $3.02 \mathrm{~m}$ instead of the maximum specified value of $2.97 \mathrm{~m}$. The suppression tank level was $1.41 \mathrm{~m}$ instead of the maximum specified level of $1.40 \mathrm{~m}$.

These discrepancies did not have any adverse effect on the experiment.

\section{TABLE IV}

INITIAL CONDITIONS FOR NONNUCLEAR TEST L1-4

\begin{tabular}{|c|c|c|}
\hline Parameter & EOS Specified Value ${ }^{[1]}$ & Measured Value \\
\hline$\frac{\text { Primary Coolant }}{\text { System }}$ & & \\
\hline Mass flow rate $(\mathrm{kg} / \mathrm{s})$ & $270.9 \pm 6.3$ & 268.4 \\
\hline Pressure (gauge) (MPa) & $15.5 \pm 0.10$ & 15.65 \\
\hline Temperature $\left({ }^{\circ} \mathrm{C}\right)$ & 282 & 279 \\
\hline $\begin{array}{l}\text { Boron concentration } \\
(P C \text { and } E C C)(p p m)\end{array}$ & $0-3600$ & 1494 \\
\hline
\end{tabular}


TABLE IV (contd.)

Parameter

ECC Accumulator

Cas volume $\left(\mathrm{m}^{3}\right)$

$1.7+0.07$

1.16

Water volume injected $\left(\mathrm{m}^{3}\right)$

$1.97 \pm 0.07$

2.05

Pressure (gauge) (MPa)

$4.14 \pm 0.172$

$32 \leq 3$

4.14

Temperature $\left({ }^{\circ} \mathrm{C}\right)$

$0.86 \pm 0.05$

Standpipe gate height (m)

Pressurizer

Steam volume $\left(\mathrm{m}^{3}\right)$

$0.33 \pm 0.1$

0. 30

Water volume $\left(\mathrm{m}^{3}\right)$

$0.63 \pm 0.1$

Not specified

$15.5 \pm 0.10$

33

0.86

Water temperature $\left({ }^{\circ} \mathrm{C}\right)$

Pressure (MPa)

Steam Generator

Secondary Side

Water volume $\left(\mathrm{m}^{3}\right)$

Not specified .

3.46

Water level (m)

$2.916 \pm 0.025$

3.02

Water temperature $\left({ }^{\circ} \mathrm{C}\right)$

Not specified

279

Pressure (gauge) (MPa)

Not specified

6.55

Suppression Tank

Liquid level (m)

Gas volume $\left(\mathrm{m}^{3}\right)$

Liquid volume $\left(\mathrm{m}^{3}\right)$

Downcomer ${ }^{[a]}$ submergence $(m)$

Water temperature $\left({ }^{\circ} \mathrm{C}\right)$

Pressure (gas space)

(gauge) (KPa)
$1.37 \pm 0.03$

Not specified

33.79

Not specified

41.26

0.55

85

$84 \pm 3.6$

$9.65 \pm 6.89$
7.85 
TABLE IV (contd.)

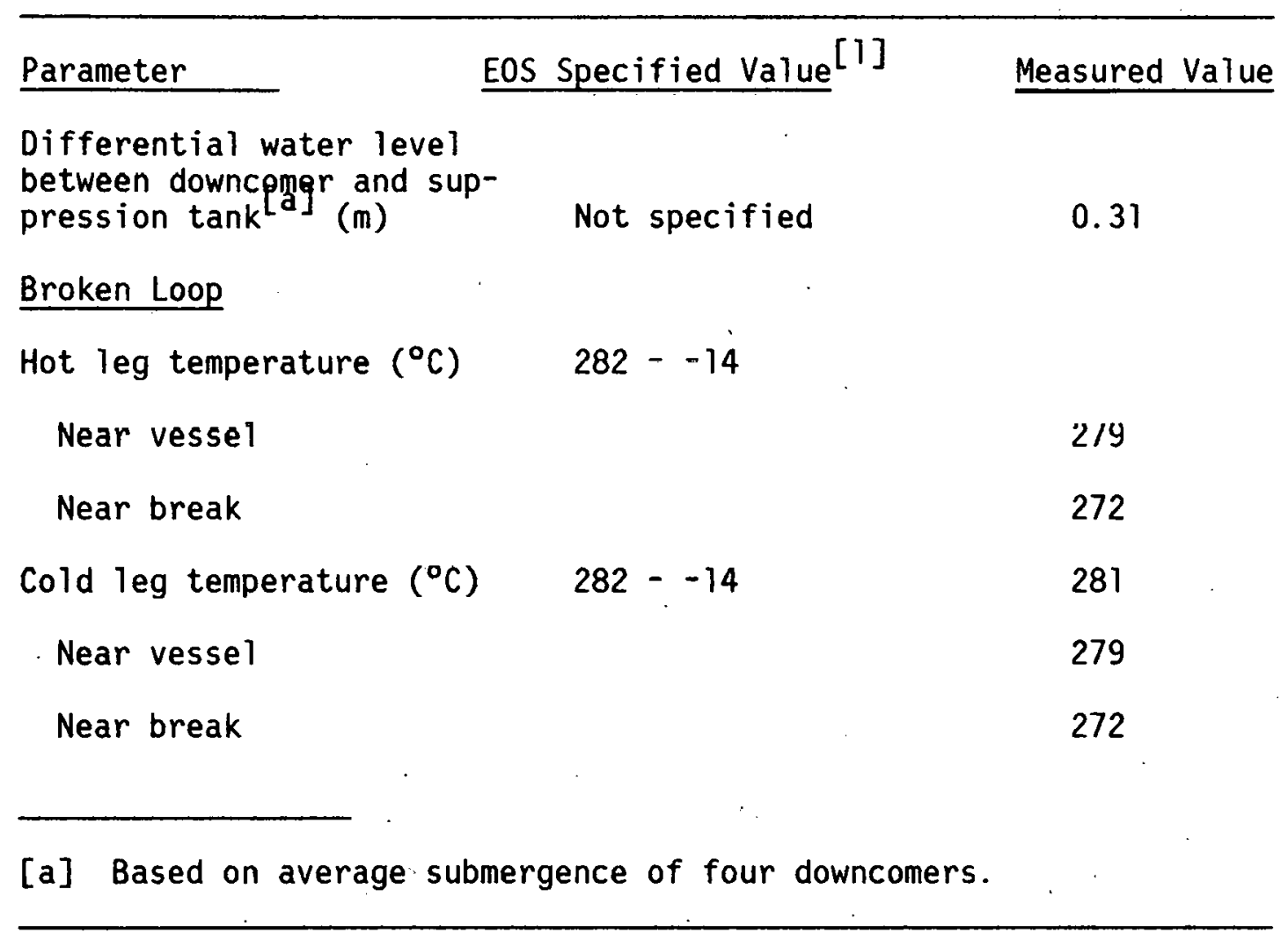

Table $V$ gives the fluid temperature distribution of the PCS immediately prior to blowdown initiation. As can be seen, the system temperature distribution was nearly constant, except for the pressurizer liquid and vapor space. This essentially isothermal condition was due to the greater than 40-hour soak at the initial condition temperature and pressure before the commencement of blowdown.

Table VI specifies the required water chemistry for the PCS, the blowdown suppression tank, and the SCS. In addition, the results of the water chemistry analysis for these systems are presented for pre-LOCE and post-LOCE conditions. The pre-LOCE accumulator A boron concentration was 3307 ppm and the BWST boron concentration was 3258 ppm. After blowdown, the boron concentration in the PCS was $4941 \mathrm{ppm}$. These analyses were required to utilize the data from the reactor vessel downcomer liquid level probes. 


\section{TABLE V}

PRIMARY COOLANT TEMPERATURE DISTRIBUTION AT BLOWDOWN INITIATION

\begin{tabular}{|c|c|c|}
\hline Location & Detector & $\begin{array}{c}\text { Temperature } \\
\left({ }^{\circ} \mathrm{C}\right)\end{array}$ \\
\hline Intact loop hot leg (near vessel) & $T E-P C-2$ & 279 \\
\hline Intact loop steam generator inlet & $T E-S G-1$ & 281 \\
\hline Int.act. loop steam generator outlet & $T E-S G-2$ & 279 \\
\hline $\begin{array}{l}\text { Intact loop cold leg (near steam generator } \\
\text { outlet) }\end{array}$ & $T E-P C-3$ & 281 \\
\hline Intact loop cold leg (near vesse 1 ) & $T E-P C-1$ & 279 \\
\hline $\begin{array}{l}\text { Reactor vessel downcomer: } \\
\text { Instrument stalk } 1 \\
\text { Instrument stalk } 2\end{array}$ & $\begin{array}{l}\text { TE-1ST-2 } \\
\text { TE-2ST-2 }\end{array}$ & $\begin{array}{l}282 \\
279\end{array}$ \\
\hline $\begin{array}{l}\text { Reactor vessel lower plenum: } \\
\text { Instrument stalk } 1 \\
\text { Instrument. stalk } 2\end{array}$ & $\begin{array}{l}\text { TE-1ST-9 } \\
\text { TE-1ST-14 }\end{array}$ & $\begin{array}{l}282 \\
279\end{array}$ \\
\hline Reactor vessel core simulator & TE-CS-1 & 279 \\
\hline Broken loop hot leg (near vessel) & TE-BL-2 & 281 \\
\hline Broken loop hot leg (near break) & TE-P138-171 & 272 \\
\hline Broken loop cold leg (near vessel) & $T E-B L-1$ & 279 \\
\hline Broken loop cold leg (near break) & $T E-P 138-170$ & 272 \\
\hline $\begin{array}{l}\text { Intact loop pressurizer: } \\
\text { Liquid space } \\
\text { Vapor space }\end{array}$ & $\begin{array}{l}\text { TE-P139-20 } \\
\text { TE-P139-19 }\end{array}$ & $\begin{array}{l}349 \\
346\end{array}$ \\
\hline
\end{tabular}




\section{TABLE VI}

WATER CHEMISTRY RESULTS FOR NONNUCLEAR TEST L I-4

\begin{tabular}{|c|c|c|c|c|c|c|c|c|}
\hline \multirow[b]{2}{*}{ Parameter } & \multicolumn{3}{|c|}{ Primary Coolant Intact Loop } & \multicolumn{3}{|c|}{ Blowdown Suppression Tank } & \multicolumn{2}{|c|}{ Secondary Coolant System } \\
\hline & Specified $^{[\mathrm{a}]}$ & Pre-LOCE $^{[\mathrm{b}]}$ & Post-LOCE ${ }^{[\mathrm{c}]}$ & Specified & Pre-LOCE & Post-LOCE & Specified & Pre-LOCE \\
\hline $\mathrm{PH}\left(\right.$ ( $\left.25^{\circ} \mathrm{C}\right)$ & $4.2-10.5$ & 6.3 & 4.88 & $4.2-10.5$ & 5.88 & 5.76 & $9.0-10.2$ & 9.72 \\
\hline $\begin{array}{l}\text { Conductivity }\left(\frac{\text { umho }}{\mathrm{cm}}\right) \\
\left(025^{\circ} \mathrm{C}\right)\end{array}$ & $60 \max$ & 27 & 54 & $60 \max$ & 45 & 37 & $700 \max$ & 71 . \\
\hline Total solids (ppm) & $\therefore-$ & 5414.9 & $19,509.8$ & -- & $10,955.7$ & 10,352 & --- & -- \\
\hline Total gas $(\mathrm{cc} / \mathrm{kg})$ & $100 \max$ & 28.4 & -- & --- & none & 8.2 & --- & none \\
\hline Dissolved oxygen (ppm) & $0.10 \max$ & 0.01 & 0.05 & -.- & --- & -- & $0.10 \max$ & 0.005 \\
\hline Lithium (ppm) & $0.2-2.2$ & 2.3 & 2.4 & --- & -- & -- & -- & --- \\
\hline $\begin{array}{l}\text { Hydrazine (ppm) } \\
\left(0<250^{\circ} \mathrm{F}\right)\end{array}$ & $1.0 \min -10$ & $<0.2$ & $<0.2$ & --- & --- & --- & $1.0 \mathrm{~min}$ & $<0.2$ \\
\hline Chloride (ppm) & $0.15 \max$ & $<0.1$ & $<0.1$ & $0.15 \max$ & $<0.1$ & $<0.1$ & $0.5 \max$ & $<0.1$ \\
\hline Dissolved solids (ppm) & --- & 5413 & 19,508 & --- & 10,955 . & 10,350 & $500 \max$ & 45.5 \\
\hline Undissolved solids (ppm & pm) $1.0 \max$ & 1.925 & 1.8 & $1.0 \max$ & 0.7 & 1.575 & $50 \max$ & $<0.1$ \\
\hline Hardness (ppm) & --- & -- & --- & --- & --- & $\cdots$ & --- & $<0.1$ \\
\hline Phosphate (ppm) & -- & --- & --- & --- & -- & --- & $15-75$ & 26 \\
\hline Gas $0_{2}$ content (q) & --- & -- & -- & $\therefore$ & $\cdots$ & $\cdots$ & -- & -- \\
\hline Boron (ppm) & $0-3600$ & 1494 & 4941 & $3000-3600$ & 2514 & 2557. & $1000 \max$ & --- \\
\hline $\begin{array}{l}\text { [a] Specified values } r \\
\text { [b] Sample taken upstr } \\
{[c] \text { Sample taken from }}\end{array}$ & $\begin{array}{l}\text { revised Febr } \\
\text { tream of the } \\
m \text { the pressur }\end{array}$ & $\begin{array}{l}\text { lary } 7,1977 \\
\text { CS ion exch } \\
\text { zer. }\end{array}$ & $\begin{array}{l}\text { n LOFT Pla } \\
\text { er. }\end{array}$ & t Operating $M$ & anual ${ }^{[12]}$. & & & \\
\hline
\end{tabular}




\section{DATA CONSISTENCY CHECKS}

As a subsequent step in the data reduction process described in Section III, all data presented in this report were subjected to a thorough review to verify that. they were ronsist.ent. and reasnnahte Where possible, instrument channel outputs and computed parameters were compared to test predictions, previous tests, corresponding parameter channels, and calculated quantities. In many instances, these consistency checks were performed as data plot overlays and, therefore, the respective figure numbers are specified below as the individual topics are discussed. For other measurements, the comparisons and resulting calculations were performed within the company and are not included in this report. Those measurement comparisons that were determined to be within the accuracy of the particular instrument, as specified in Reference 11 were labeled as qualified engineering units data (QEUD). Specifically, several techniques have been developed and employed to perform data consistency checks on the presented data; these techniques are discussed below and results of these checks are reflected in Table VII.

Measured system temperatures were qualified where possible by reviewing the isothermal temperature distributions just prior to blowdown initiation and during the blowdown transient. When temperatures measuring a similar condition were within the specified accuracy of the detectors, the detector output was considered reasonable and was qualified. All PCS channels were reviewed in this manner, and selected initial temperature measurements are summarized in Table $V$. The pressurizer liquid and vapor space temperatures were checked for consistency by comparing these values with the saturation temperature for the corresponding pressurizer pressure at various points in time. This check was valid prior to and during the system blowdown until the pressurizer emptied at 14 seconds. Similarly, steam generator secondary side temperature was examined throughout the test by comparing the measured temperature with the saturation temperature for the respective SCS pressure. BDST temperature elements TE-SV-1-6 and TE-SV-7-12 were 
evaluated by comparing the pretest measurements of the thermocouples in the same horizontal stratum. Overlays of these parameters are presented in Figures 118 through 121. BDST temperature comparison after the initiation of blowdown was not meaningful for data consistency checks due to uneven mixing and condensation producing temperature stratification in the tank.

Pressure data were reviewed in a similar manner. During the approach to Test $\mathrm{LI}-4$ initial conditions at zero-flow conditions, the PCS was raised to various specified temperatures and pressures as described in section $V$. At each data point, PCS pressure measurement detectors were compared to a $0.1 \%$ accuracy, 0 to $34.5 \mathrm{MPa}$ (gauge pressure) pressure test gauge to verify that the slope had not statistically changed and to establish the offset of the instrument. Immediately prior to blowdown, PCS pressures were again compared to the test gauge standards (Heise, PE-PC-5, and PE-PC-6) to ensure that all detectors were measuring within their specified accuracy bands. During the blowdown transient, pressure data from corresponding measurement locations were compared by overlaying the data plots. These plots are presented in Figures 79 through 90. Pressurizer. pressure was qualified by comparison with PCS pressure channels and by saturation temperature as discussed above; SCS pressure was qualified by comparison of saturation temperature to the measured temperature as presented in the paragraph on temperature techniques. The BDST pressure instruments were evaluated by comparing process and experimental pressure measurements prior to and during the blowdown transient. Representative instrument plots are presented for this comparison in Figures 91 through 97.

Comparison of measured temperature with the saturation temperature of the pressure measurement at the same location provided another method to verify PCS data consistency. This technique, however, was valid only during the saturated blowdown transient up till the time the measurement location voided of fluid. After voiding occurred, the measured temperature increased above the corresponding saturation temperature due to radiant heating of the detector element by the structural system components and detector element stem conduction. Temperature detectors 
in the reactor vessel which became wetted by the ECCS lower plenum injection displayed a measured temperature which decreased below the corresponding saturation temperature as the detector became immersed in the cooler fluid. Comparisons of saturated temperature and measured temperature are presented in Figures 221 through 228.

Data consistency checks for the differential pressure measurements were provided by several basic methods. Prior to blowdown initiation, no flow data were recorded to determine instrument offsets. PCS operating conditions were then established as specified in EOS Volume 2, and selected PCS pressure drops were compared with predicted values. At various PCS operating conditions, intact loop flow resistance coefficients were calculated and verified to remain essentially constant and to agree with previously tabulated data. Further consistency checks were performed on the intact loop differential pressure instruments by plotting the square root of the differential pressure against pump speed using data from the pump frequency tests conducted prior to blowdown. The results of least'squares curve fits performed on these plots were then used to confirm instrument zero offsets. Both prior to and during the blowdown transient, differential pressure measurements were compared with the differential pressure computed by subtracting appropriate absolute pressure measurements. Finally, pressure closure was calculated for three flow loops: (a) the PCS Intact loop, (b) the broken loop hot leg to the BDST, and (c) the broken loop cold leg to the BDST. The presssurè closure for thẻse three loops is defined in Table VIII and presented for loop (a) in Figure 208.

Four system level measurements were important for Test LI-4: (a) accumulator ACC-A liquid level, (b) BDST liquid level, (c) pressurizer coolant level, and (d) reactor vessel coolant level. The accumulator level was qualified by comparing the pre-LOCE and post-LOCE liquid levels as measured with the level detector to the level measured by an external sightglass. Further post-test data consistency checks were performed by comparing the injected accumulator volume as determined by the external sightglass with the accumulator volumetric flow rate integrated with respect to time. BDST liquid level was 
evaluated by comparing two incependent level measurements which are plotted as an overlay in Figure 162. Similarly, pressurizer level was reviewed by redundant level measurements. The three independent level measurements are plotted as an overlay in Figure 48 . The reactor vessel liquid level probes were verified to be indicating satisfactorily by performing a pretest conductivity calibration with the vessel liquid full and under cold and hot plant conditions.

Primary coolant pump speed measurements were checked for consistency by comparison with pump speed as calculated from the PSMG frequencies. This check was valid prior to and during the blowdown transient until the PSMG field breakers were opened at 24.5 seconds. Prior to test initiation, the pump speed was further checked, along with the intact loop flow rate and pump differential pressure, by reviewing the agreement with the manufacturer's pump performance curves. Pump run voltages and currents were evaluated prior to the initiation of blowdown by calculating. the pump electrical horsepower input, the pump water horsepower, and finally the combined pump efficiency. These calculated efficiencies were then compared to previously recorded efficiencies determined during pump requalification tests.

To evaluate the PCS average fluid densities, calculations were performed by using the gamma densitometer. To ensure that the gamme densitometer measurements were accurate for these calculations, the individual beam densities were compared to the known density of the PCS just prior to blowdown initiation. Additionally each densitometer gamme source was stowed in its lead cask to obtain an essentially infinito density data point for each densitometer calibration curve. These known density values were then used to adjust the instrument electronics to give the correct readings from the gamma densitometers. As a final pretest check on the densitometer calibrations, a high and low calibration tungsten shim of known density was inserted in each individual densitometer beam. DAVDS data were then taken and reviewed for these measurement channels in each shim position. 
Several techniques were employed to verify the validity of the measured data from the turbine meters, the drag discs, and the intact loop mass flow rate venturi meters. In particular, the broken loop turbine meters and drag discs were calibrated as discussed in Section III. The intact loop venturi meter data were examined by performing least squares curve fits for the computed venturi meler velocities plotted against the corrected average pump speed. The results of these data consistency checks for this test indicated discrepancies in the intact loop mass flow rates measured by the venturi meters. New venturi meter calibration equation offsets were therefore derived by using the above curve fitting technique with the variablefrequency single-phase test data obtained prior to blowdown initiation. These corrected venturi meter mass flow rates were then used to calculate average velocities and momentum fluxes in the intact loop and the reactor vessel. These values were subsequently used to correlate the output of the turbine meters and drag discs. Finally, the measured average turbine meter velocities and drag disc momentum fluxes were confirmed or adjusted to produce consistent data in the pump frequency tests. As an independent check, the turbine meter and drag disc data were used to calculate fluid density as specified in Section III. These values were then compared to the known single-phase density prior to blowdown. This analysis was performed on all the turbine meters and drag discs in the intact loop and the reactor vessel with the exceptions of thuse instrumenls lhal failed ds lisled in Table VII.

The computed parameter, mass flow rate per system volume, was calculated by five different methods at various locations in the intact loop, broken loop, and the reactor vessel. A list of the measurement parameters, measurement locations, and the calculation methods used are summarized in Table VIII. Comparison of the calculated results obtained by each method at a particular measurement location was utilized to provide the data consistency checks for this computed parameter. It should also be noted that these comparisons provided a redundant check of the individual instruments used for each computation. The mass flow rates per system volume were also calculated for the pressurizer and the BDST as defined in Table VIII. Consistency for the pressurizer was 
verified by integrating the mass flow rate with time and comparing the total mass ejected with the known mass in the pressurizer prior to blowdown initiation. The results are presented in Figure 204. The mass flow rate into the BOST by the method of instantaneous level change with time produced unreliable transient results due to the erratic BDST level measurement during the blowdown. This method, therefore, did not produce a reliable data consistency check.

System fluid velocities were evaluated during the blowdown transient by utilizing two independent methods. Velocities were measured directly by the turbine meters. Data consistency checks were performed by comparing the turbine flowmeter velocities for representative system locations with the respective calculated fluid velocities. To provide reliable data for these velocity checks, the gamma densitometers, the drag discs, and the turbine flowmeters were calibrated prior to test initiation as discussed in Section III and in this section.

As a redundant approach to verify the validity of Test LI-4 data, selected instrument parameters were overlaid with plots from (a) the experiment prediction for Test $\mathrm{LT}_{-4}^{[2]}$, (b) the Semiscale counterpart test $(S-01-4 A)^{[13]}$, and (c) the LOFT nonnuclear Test $L 1-3 A^{[8]}$. Parameters of interest in these comparisons included broken and intact loop average densities, pressures, temperatures, fluid velocities, and computed mass flow rates per system volume. The differential pressure measurements across selected PCS components were also examined. The results of these comparisons are not included in this report.

A number of additional techniques are being developed to reconcile inconsistancies in the mass flow rates through the break planes. As of yet, the analysis has not been completed for Test LI-4 and thus will not be presented here. 


\section{DATA PRESENTATION}

The data presented in this report include selected pertinent thermal-hydraulic data from LOFT Test LI-4. The data have been divided into four calegories: qualified enginecring units data (QEUD), restrained, trend, and channel failed. Ihe "QEUD" designation was applied to measurements that have hepn rompared to other measurements and have been found to be within the accuracy of the instrument. These dat.a rher.ks are discussed in detail in Section VI. The "restrained" designation was applied to measurements in which the instruments did not fail but the data have some restrictions. The "trend" designation was applied to measurements that appeared to be reasonable but no comparable measurement for cross-checking was recorded.

The data were processed to the extent of converting the data to SI units, combining measurements to produce computed parameters, and overlaying graphs of corresponding parameters at several locations to facilitate comparison. Point values of momentum flux from the drag discs and velocity from the turbine flowmeters have been converted to average values by using the intact loop venturi meter as discussed in Section III. Data from the drag discs, the turbine flowmeters, specified differential pressure instruments, and the gamma densitometers were rillered with a $4 \cdot \mathrm{llz}$ low pass filter prior to presentation. Measurement uncertainties for each instrument were reported in Reference 11 and are subsequently being revised as dictaled by ill situ testing and calibrations. These uncertainties have been used to produce error band plots of Test L7-3 data [p] ots of data with upper and lower bounds of the $95 \%(2 \sigma)$ confidence levels overlaid]. For the drag discs and gamma densitometers, uncertainty analyses have been performed for the point measurements only. Further analyses will be required before average value uncertainties can be reported.

For LOFT Test L1-4, the instrumentation system performed well. of 551 instrument channels recorded during this experiment, only 25 instrument channels failed. 
Table VII lists the sensors that were intended to be reported for Test. L1-4. It gives the detector location, range, and frequency response along with the figure number where the data can be found. This table also contains a "Comments" column which gives information relative to the usability of the data.

Table VIII lists the parameters that were computed from the sensor outputs and other factors, such as geometrical constants. This table also gives the equations used to compute these parameters, the figure number on which the data can be found, and comments which may reflect on the usefuiness of the data.

The data are presented in graphical form, and are arranged two plots per page. The data plots are further divided into five major sections with the individual plots in each section being presented in alphanumeric order to facilitate comparison and location of desired parameters. These data sections include:

1. TEST LI-4 MEASURED PARAMETERS -- SHORT-TERM PLOTS (2 SECONDS $O R$ LESS) - Figures 16 through 26. This section contains the detector outputs, including overlays, which were specifically designed for the short-term transient and, therefore, do not exceed 2-second duration.

2. TEST L $1-4$ MEASURED PARAMETERS - - MEDIUM-TERM PLOTS ( -10 TO 70 SECONDS) - Figures 27 through 136.

3. TEST L $1-4$ MEASURED PARAMETERS -- LONG-TERM PLOTS (190 AND 600 SECONDS) - Figures 137 through 174 . This section contains selected detector outputs, including overlays of 190- and $600-$ second duration.

4. TEST $L 1-4$ COMPUTED PARAMETERS - Figures 175 through 231. 
5. ERROR BAND PLOTS - Figures 232 through 256. This section contains error band plots for several representative instrument types, ranges, and frequency responses.

Time zero for each plot is the average of the times at which each of lile two QOBV sleeves opened to $17 \%$ of full travel. This definition for time of blowdown initiation $\left(T_{0}\right)$ was used since (a) a flow area does not exist through each QOBV until the valve. sleeve clears the huddle chamber at $17 \%$ of its full travel and (b) QOBV-2 (CV-P138-15) commenced opening $1.3 \mathrm{~ms}$ sooner than QOBV-1 (CV-P138-1). It should be noted that, while this definition of time zero is adequate. for measurement comparisons using time scales on the order of several seconds, the user may wish to utilize a different time zero definition for evaluation of shorter time phenomena. The data are presented prior to the defined time zero to allow for such a comparison.

The scales selected for the graphs were chosen to provide an overview of the test and do not reflect the obtainable resolution of the data.

It should be noted that the instrument uncertainties presented in Section 5, "Error Band Plots", apply to data that are tabulated. The printing error and error from individuals reading these plots cannot be quantified, thereby necessitating the application of uncertainties to only tabulated data.

The volume of data contained in this report is large, and although every effort was made to prevent it, an error may have found its way into the report. In the event a user detects an error, prompt notification would be appreciated so that other users may be notified. 


\section{TABLE VII}

MEASURED PARAMETERS FOR LOFT NONNUCLEAR TEST L $1-4$

\begin{tabular}{|c|c|c|c|c|c|c|c|}
\hline \multirow[b]{2}{*}{$\begin{array}{l}\text { PARAMETER } \\
\text { Syster } \\
\text { Detector }\end{array}$} & \multirow[b]{2}{*}{ Location } & \multicolumn{2}{|c|}{ Range } & \multicolumn{2}{|c|}{ Frequency Response } & \multirow[b]{2}{*}{$\begin{array}{l}\text { Rata } \\
\text { Pig. } \\
\text { No. }\end{array}$} & \multirow[b]{2}{*}{ Measurement Coments } \\
\hline & & Detector & $\begin{array}{l}\text { Data } \\
\text { Acquisition } \\
\text { System }\end{array}$ & Detector & $\begin{array}{l}\text { Data } \\
\text { Systea] }\end{array}$ & & \\
\hline \multicolumn{8}{|l|}{ VALVE OPENING } \\
\hline $\begin{array}{l}\text { Broken Loop } \\
\text { CV-P138- } 1\end{array}$ & $\begin{array}{l}\text { Broken loop cold leg between } \\
\text { break plane and suppression tank. }\end{array}$ & $0-100 \%$ & $0-1008$ & $35 \mathrm{~Hz}$ & 500 pps & $\begin{array}{l}16 \\
17\end{array}$ & Trend $d a=a^{[b]}$. \\
\hline $\begin{array}{l}\text { Broken Loop } \\
\text { CV-P138-15 }\end{array}$ & $\begin{array}{l}\text { Broken loop hot leg between } \\
\text { break plane and suppression tank. }\end{array}$ & $0-1008$ & $0-100 \%$ & $35 \mathrm{~Hz}$ & 500 pps & 16 & Trend da:a. \\
\hline \multicolumn{8}{|l|}{ CHORDAL DENSITY } \\
\hline $\begin{array}{l}\text { Broken Loop } \\
\text { DE-BL-IA }\end{array}$ & $\begin{array}{l}\text { Broken loop cold leg at oTT } \\
\text { flange. Beam line } 14^{\circ} 21 \text { nin } \\
\text { from - iB line [CW looking } \\
\text { toward reactor vessel (RV)]. }\end{array}$ & $\begin{array}{l}8.0 \times 10^{-3} \\
-1.0 \mathrm{mg} / \mathrm{m}^{3}\end{array}$ & $\begin{array}{l}8.0 \times 10^{-3} \\
-1.0 \mathrm{mg} / \mathrm{m}^{3}\end{array}$ & $1,000 \mathrm{~Hz}$ & $\begin{array}{l}1,000 \mathrm{~Hz} \\
50 \mathrm{pps}\end{array}$ & $\begin{array}{r}27 \\
137\end{array}$ & $\begin{array}{l}\text { QEUD }{ }^{[\mathrm{C}]} \text { Filtered to } 4 \mathrm{~Hz} \\
\text { for } 0 \text { to } 70 \text { s plots anly. }\end{array}$ \\
\hline $\begin{array}{l}\text { Broken Loop } \\
\text { DE-BL-IB }\end{array}$ & $\begin{array}{l}\text { Broken loop cold leg at oTT } \\
\text { flange. Beas line through } \mathcal{E} \\
\text { of pipe } 45^{\circ} \text { from vertical } \\
\text { (CCW looking toward RV). }\end{array}$ & $\begin{array}{l}8.0 \times 10^{-3} \\
-1.0 \mathrm{mg} / \mathrm{m}^{3}\end{array}$ & $\begin{array}{l}8.0 \times 10^{-3} \\
-1.0 \mathrm{mg} / \mathrm{m}^{3}\end{array}$ & $\begin{array}{l}1,000 \mathrm{~Hz} \\
10 \mathrm{~Hz}\end{array}$ & $\begin{array}{l}1,000 \mathrm{~Hz} \\
50 \mathrm{pps}\end{array}$ & $\begin{array}{r}27 \\
137\end{array}$ & $\begin{array}{l}\text { QEUD. Filtered to } 4 \mathrm{~Hz} \text { for } \\
0 \text { to } 70 \text { s plots only. }\end{array}$ \\
\hline $\begin{array}{l}\text { Broken Loop } \\
\text { DE-BL-IC }\end{array}$ & $\begin{array}{l}\text { Broken loop cold leg at } D T \\
\text { flange. Beam line } 22^{\circ} 7 \mathrm{~min} \\
\text { from-lB line (CCW looking ' } \\
\text { toward RV). }\end{array}$ & $\begin{array}{l}8.0 \times 10^{-3} \\
-1.0 \mathrm{mg} / \mathrm{m}^{3}\end{array}$ & $\begin{array}{l}8.0 \times 10^{-3} \\
-1.0 \mathrm{mg} / \mathrm{m}^{3}\end{array}$ & $\begin{array}{l}1,000 \mathrm{~Hz} \\
10 \mathrm{~Hz}\end{array}$ & $\begin{array}{l}1,00 \mathrm{CHz} \\
50 \mathrm{pFs}\end{array}$ & $\begin{array}{r}27 \\
137\end{array}$ & $\begin{array}{l}\text { QEUD. Filtered to } 4 \mathrm{~Hz} \text { for } \\
0 \text { to } 70 \leq \text { plots only. }\end{array}$ \\
\hline $\begin{array}{l}\text { Broken Loop } \\
\text { OE-BL-2A }\end{array}$ & $\begin{array}{l}\text { Broken loop hot leg at } D T T \text { flange. } \\
\text { Beat line } 14^{\circ} 21 \text { min from }-2 B \\
\text { line (CCW looking toward RV). }\end{array}$ & $\begin{array}{l}8.0 \times 10^{-3} \\
-1.0 \mathrm{mg} / \mathrm{m}^{3}\end{array}$ & $\begin{array}{l}8.0 \times 10^{-3} \\
-1.0 \mathrm{mg} / \mathrm{m}^{3}\end{array}$ & $\begin{array}{l}1,000 \mathrm{~Hz} \\
10 \mathrm{~Hz}\end{array}$ & $\begin{array}{l}1,00 \mathrm{CHz} \\
50 \mathrm{pFs}\end{array}$ & $\begin{array}{r}28 \\
138\end{array}$ & $\begin{array}{l}\text { QEUD. Filterec to } 4 \mathrm{~Hz} \text { for } \\
0 \text { to } 70 \mathrm{~s} \text { plots only: }\end{array}$ \\
\hline $\begin{array}{l}\text { Broken Loop } \\
\text { DE-BL-2B }\end{array}$ & $\begin{array}{l}\text { Broken loop hot leg at } D T \text { flange. } \\
\text { Beam line through } \text { of pipe } 45^{\circ} \\
\text { from vertical (CW fooking toward } \\
\text { RV). }\end{array}$ & $\begin{array}{l}8.0 \times 10^{-3} \\
-1.0 \mathrm{mg} / \mathrm{m}^{3}\end{array}$ & $\begin{array}{l}8.0 \times 10^{-3} \\
-1.0 \mathrm{mg} / \mathrm{m}^{3}\end{array}$ & $\begin{array}{l}1,000 \mathrm{~Hz} \\
10 \mathrm{~Hz}\end{array}$ & $\begin{array}{l}1,000 \mathrm{~Hz} \\
50 \mathrm{pps}\end{array}$ & $\begin{array}{r}28 \\
1388\end{array}$ & $\begin{array}{l}\text { QEUD. Fintered to } 4 \mathrm{~Hz} \text { for } \\
0 \text { to } 70 \mathrm{~s} \text { plots only. }\end{array}$ \\
\hline
\end{tabular}


IABLE VII (contd.)

\begin{tabular}{|c|c|c|c|c|c|c|c|}
\hline \multirow[b]{2}{*}{$\begin{array}{l}\text { PARAGETER } \\
\text { Syscem } \\
\text { Detector }\end{array}$} & \multirow[b]{2}{*}{ Location } & \multicolumn{2}{|c|}{ Range } & \multicolumn{2}{|c|}{ Frequency Response } & \multirow[b]{2}{*}{$\begin{array}{l}\text { Data } \\
\text { Fig. } \\
\text { No. }\end{array}$} & \multirow[b]{2}{*}{ Messurement Coments } \\
\hline & & Detector & $\begin{array}{l}\text { Data } \\
\text { Acquisition } \\
\text { System }\end{array}$ & Detector & $\begin{array}{l}\text { Data } \\
\text { Systea }\end{array}$ & & \\
\hline $\begin{array}{l}\text { Broken Loop } \\
\text { DE-BL-2C }\end{array}$ & $\begin{array}{l}\text { Broken loop hot leg at } 0 T T \\
\text { flange. Beam line } 22^{\circ} 7 \mathrm{~min} \\
\text { from }-2 \mathrm{~B} \text { line (CW looting } \\
\text { toward RV). }\end{array}$ & $\begin{array}{l}8.0 \times 10^{-3} \\
-1.0 \mathrm{mg} / \mathrm{m}^{3}\end{array}$ & $\begin{array}{l}8.0 \times 10^{-3} \\
-1.0 \mathrm{mg} / \mathrm{m}^{3}\end{array}$ & $\begin{array}{l}1,000 \mathrm{~Hz} \\
10 \mathrm{~Hz}\end{array}$ & $\begin{array}{l}1,000 \cdot \mathrm{Hz} \\
50 \mathrm{pps}\end{array}$ & $\begin{array}{r}28 \\
138\end{array}$ & $\begin{array}{l}\text { QEUD. Filtered to } 4 \mathrm{~Hz} \text { for } \\
0 \text { to } 70 \text { s plots only. }\end{array}$ \\
\hline $\begin{array}{l}\text { Intact Loop } \\
\text { DE-PC-TA }\end{array}$ & $\begin{array}{l}\text { Intact loop cold leg at DTT } \\
\text { flange. Beam line } 14^{\circ} 21 \text { min } \\
\text { from - iB line (CW looking away } \\
\text { from RV). }\end{array}$ & $\begin{array}{l}8.0 \times 10^{-3} \\
-1.0 \mathrm{mg} / \mathrm{m}^{3}\end{array}$ & $\begin{array}{l}8.0 \times 10^{-3} \\
-1.0 \mathrm{mg} / \mathrm{m}^{3}\end{array}$ & $\begin{array}{l}1,000 \mathrm{~Hz} \\
10 \mathrm{~Hz}\end{array}$ & $\begin{array}{l}1,000 \mathrm{~Hz} \\
50 \mathrm{pps}\end{array}$ & 30 & $\begin{array}{l}\text { QEUD. Filtered to } 4 \mathrm{~Hz} \text { for } \\
0 \text { to io s plots only. }\end{array}$ \\
\hline $\begin{array}{l}\text { Intact Loop } \\
\text { DE-PC-1B }\end{array}$ & $\begin{array}{l}\text { Intact loop cold leg at DTr } \\
\text { flange. Beam line through } f \text { of } \\
\text { pipe } 45^{\circ} \text { from vertical (CCh } \\
\text { looking away from RV) }\end{array}$ & $\begin{array}{l}8.0 \times 10^{-3} \\
-1.0 \mathrm{gg} / \mathrm{m}^{3}\end{array}$ & $\begin{array}{l}8.0 \times 10^{-3} \\
-1.0 \mathrm{mg} / \mathrm{m}^{3}\end{array}$ & $\begin{array}{l}1,0100 \mathrm{tz} \\
10 \mathrm{~Hz}\end{array}$ & $\begin{array}{l}1,0.20 \mathrm{~Hz} \\
50 \text { pps }\end{array}$ & 30 & $\begin{array}{l}\text { QEUD. Filtered to } 4 \mathrm{~Hz} \text { for } \\
0=0 \text {;0 s plots only. }\end{array}$ \\
\hline $\begin{array}{l}\text { Intact Loop } \\
\text { DE-PC-1C }\end{array}$ & $\begin{array}{l}\text { Intact loop cold leg at DTT } \\
\text { flange. Beam line } 22^{\circ} 7 \text { min } \\
\text { from-iB line (CCW looking } \\
\text { away from RV). }\end{array}$ & $\begin{array}{l}8.0 \times 10^{-3} \\
-1.0 \mathrm{mg} / \mathrm{m}^{3}\end{array}$ & $\begin{array}{l}8.0 \times 10^{-3} \\
-1.0 \mathrm{mg} / \mathrm{m}^{3}\end{array}$ & $\begin{array}{l}1,030+1 z \\
10+z\end{array}$ & $\begin{array}{l}1,00 \mathrm{OHz} \\
50 \mathrm{pps}\end{array}$ & 30 & $\begin{array}{l}\text { QEUD. Filtered to } 4 \mathrm{~Hz} \text { for } \\
0 \text { to } 5 \text { plats only. }\end{array}$ \\
\hline $\begin{array}{l}\text { Intact Loop } \\
\text { DE-PC-2A }\end{array}$ & $\begin{array}{l}\text { Intact loop hot leg at DT } \\
\text { flange. Beam line } 14^{\circ} 21 \text { mir. } \\
\text { from }-2 B \text { line (CW looxing aivay } \\
\text { from } R V \text { ). }\end{array}$ & $\begin{array}{l}8.0 \times 10^{-3} \\
-1.0 \mathrm{mg} / \mathrm{m}^{3}\end{array}$ & $\begin{array}{l}\text { B. } 0 \times 10^{-3} \\
-1.0 \mathrm{mg} / \mathrm{m}^{3}\end{array}$ & $\begin{array}{l}1,030 \mathrm{~Hz} \\
10 \mathrm{tz}\end{array}$ & $\begin{array}{l}1,00 \mathrm{OHz} \\
50 \mathrm{pps}\end{array}$ & 31 & $\begin{array}{l}\text { QEIJD. Filtered to } 4 \mathrm{kiz} \text { for } \\
0 \text { to iJ } 5 \text { plots only. }\end{array}$ \\
\hline $\begin{array}{l}\text { Intact Loop } \\
\text { DE-PC-2B }\end{array}$ & $\begin{array}{l}\text { Intact loop hot leg at DTT } \\
\text { flange. Beam line through } \mathcal{E} \text { of } \\
\text { pipe } 45^{\circ} \text { from vessel (CCW } \\
\text { looking away from RV). }\end{array}$ & $\begin{array}{l}8.0 \times 10^{-3} \\
-1.0 \mathrm{mg} / \mathrm{m}^{3}\end{array}$ & $\begin{array}{l}8.0 \times 10^{-3} \\
-1.0 \mathrm{mg} / \mathrm{m}^{3}\end{array}$ & $\begin{array}{l}1,0 \mathrm{OG} \mathrm{Hz} \\
10 \mathrm{~Hz}\end{array}$ & $\begin{array}{l}1,000 \text { He } \\
50 \text { pes }\end{array}$ & 31 & $\begin{array}{l}\text { QEJD. Filtered to } 4 \mathrm{~Hz} \text { for } \\
0 \text { to } 3 \text { s plots only. }\end{array}$ \\
\hline
\end{tabular}


TABLE VII (contd.)

\begin{tabular}{|c|c|c|c|c|c|c|c|}
\hline \multirow[b]{2}{*}{$\begin{array}{l}\text { PARAMETER } \\
\text { System } \\
\text { Detector }\end{array}$} & \multirow[b]{2}{*}{ Location } & \multicolumn{2}{|c|}{ Range } & \multicolumn{2}{|c|}{ Frequency Response } & \multirow[b]{2}{*}{$\begin{array}{l}\text { Data } \\
\text { Ftg. } \\
\text { No. }\end{array}$} & \multirow[b]{2}{*}{ Measurement Couments } \\
\hline & & Detector & $\begin{array}{l}\text { Data } \\
\text { Acquisition } \\
\text { Systea }\end{array}$ & Detector & $\underset{\text { System }}{\text { Data }}$ & & \\
\hline $\begin{array}{l}\text { Intact Loop } \\
D E-P C-2 C\end{array}$ & $\begin{array}{l}\text { Intact loop hot leg at orT } \\
\text { flange. Beam line } 22^{\circ} 7 \mathrm{~min} \\
\text { from }-2 B \text { line (CCW looking away } \\
\text { from RV). }\end{array}$ & $\begin{array}{l}8.0 \times 10^{-3} \\
-1.0 \mathrm{mg} / \mathrm{m}^{3}\end{array}$ & $\begin{array}{l}8.0 \times 10^{-3} \\
-1.0 \mathrm{mg} / \mathrm{m}^{3}\end{array}$ & $1,000 \mathrm{~Hz}$ & $\begin{array}{l}1,000 \mathrm{~Hz} \\
50 \mathrm{pps}\end{array}$ & 31 & $\begin{array}{l}\text { QEUD. Filtered to } 4 \mathrm{~Hz} \text { for } \\
0 \text { to } 70 \text { s plots only. }\end{array}$ \\
\hline $\begin{array}{l}\text { Intact Loop } \\
\text { DE-PC-3A }\end{array}$ & $\begin{array}{l}\text { Steam generator (SG) outlet at } \\
\text { on flange. Bean } 1 \text { ine } 14^{\circ} 21 \text { min } \\
\text { from -3B line (CCW looking down). }\end{array}$ & $\begin{array}{l}8.0 \times 10^{-3} \\
-1.0 \mathrm{mg} / \mathrm{m}^{3}\end{array}$ & $\begin{array}{l}8.0 \times 10^{-3} \\
-1.0 \mathrm{mg} / \mathrm{m}^{3}\end{array}$ & $1,000 \mathrm{~Hz}$ & $\begin{array}{l}1,00: 3 \mathrm{~Hz} \\
50 \text { pos }\end{array}$ & 32 & $\begin{array}{l}\text { QEUD. Filtered to } 4 \mathrm{~Hz} \text { for } \\
0 \text { to } 70 \text { s plots only. }\end{array}$ \\
\hline $\begin{array}{l}\text { Intact Loop } \\
\text { DE-PC-3B }\end{array}$ & $\begin{array}{l}\text { SG out let at DTT flange. } \\
\text { Beam line } 65^{\circ} \text { from flange } E \\
\text { (CW looking down). }\end{array}$ & $\begin{array}{l}8.0 \times 10^{-3} \\
-1.0 \mathrm{mg} / \mathrm{m}^{3}\end{array}$ & $\begin{array}{l}8.0 \times 10^{-3} \\
-1.0 \mathrm{mg} / \mathrm{m}^{3}\end{array}$ & $\begin{array}{l}1,000 \mathrm{~Hz} \\
10 \cdot \mathrm{Hz}\end{array}$ & $\begin{array}{l}\mathrm{l}, 003 \mathrm{~Hz} \\
50 \mathrm{p} 2 \mathrm{~s}\end{array}$ & 32 & $\begin{array}{l}\text { QEUD. Filtered to } 4 \mathrm{~Hz} \text { for } \\
0 \text { to } 70 \text { p plots only. }\end{array}$ \\
\hline $\begin{array}{l}\text { Intact Loop } \\
\text { DE-PC-3C }\end{array}$ & $\begin{array}{l}\text { SG out iet at } D T \text { flange. } \\
\text { Beam line } 22^{\circ} 7 \text { min from }-2 B E \\
\text { (CW looking down). }\end{array}$ & $\begin{array}{l}8.0 \times 10^{-3} \\
-1.0 \mathrm{mg} / \mathrm{⿴囗}^{3}\end{array}$ & $\begin{array}{l}8.0 \times 10^{-3} \\
-1.0 \mathrm{mg} / \mathrm{m}^{3}\end{array}$ & $\begin{array}{l}1,000 \mathrm{~Hz} \\
10 \mathrm{~Hz}\end{array}$ & $\begin{array}{l}7,000 \mathrm{~Hz} \\
50 \mathrm{pPs}\end{array}$ & 32 & $\begin{array}{l}\text { QEUD. Filtered to } 4 \mathrm{~Hz} \text { for } \\
\text { o to } 70.5 \text { plots only. }\end{array}$ \\
\hline $\begin{array}{l}\text { FLUID VELOCITY, } \\
\text { AVERAGED }\end{array}$ & & & & & & & $\begin{array}{l}\text { All turbine meter measure- } \\
\text { ments are unidirectional. }\end{array}$ \\
\hline $\begin{array}{l}\text { Broken Loop } \\
\text { FE-BL-1A }\end{array}$ & $\begin{array}{l}\text { Broken loop cold leg at orT rake } \\
\text { bottom. }\end{array}$ & $2.3-45.7 \mathrm{~m} / \mathrm{s}$ & $0-57.9 \mathrm{~m} / \mathrm{s}$ & $9 \mathrm{~Hz}$ & $\begin{array}{l}1,001) \mathrm{Hz} \\
50 \mathrm{pps}\end{array}$ & $\begin{array}{r}34 \\
139\end{array}$ & $\begin{array}{l}\text { Restrained dat. }{ }^{[\mathrm{d}]} \text {. Filtered } \\
\text { to } 4 \mathrm{~Hz} \text { for } 0 \text { to } 70 \mathrm{~s} \text { plot } \\
\text { only. Q Q } \\
\text { ondy above } 1.0 \mathrm{~m} / \mathrm{s} \text {. }\end{array}$ \\
\hline $\begin{array}{l}\text { Broken loop } \\
\text { FE-BL-1B }\end{array}$ & $\begin{array}{l}\text { Broken loop cold leg at orT rake } \\
\text { center. }\end{array}$ & $2.3-45.7 \mathrm{~m} / \mathrm{s}$ & $0-57.9 \mathrm{~m} / \mathrm{s}$ & $9 \mathrm{~Hz}$ & $\begin{array}{l}1,001) \mathrm{Hz} \\
50 \mathrm{pps}\end{array}$ & $\begin{array}{r}34 \\
139\end{array}$ & $\begin{array}{l}\text { Restrained data. Filtered } \\
\text { to } 4 \mathrm{~Hz} \text { for } 0 \text { to } 70 \mathrm{~s} \text { plot } \\
\text { only. QEUD only above } 1.0 \mathrm{~m} / \mathrm{s}\end{array}$ \\
\hline $\begin{array}{l}\text { Broken loop } \\
\text { FE-BL-iC }\end{array}$ & $\begin{array}{l}\text { 8roken loop cold leg at } 0 \pi \text { rake } \\
\text { top. }\end{array}$ & $2.3-45.7 \mathrm{~m} / \mathrm{s}$ & $0-57.9 \mathrm{~m} / \mathrm{s}$ & $9 \mathrm{~Hz}$ & $\begin{array}{l}1,000 \mathrm{~Hz} \\
50 \mathrm{pps}\end{array}$ & $\begin{array}{r}34 \\
139\end{array}$ & 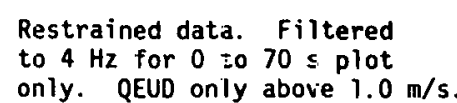 \\
\hline
\end{tabular}


TABLE VII (contd.!

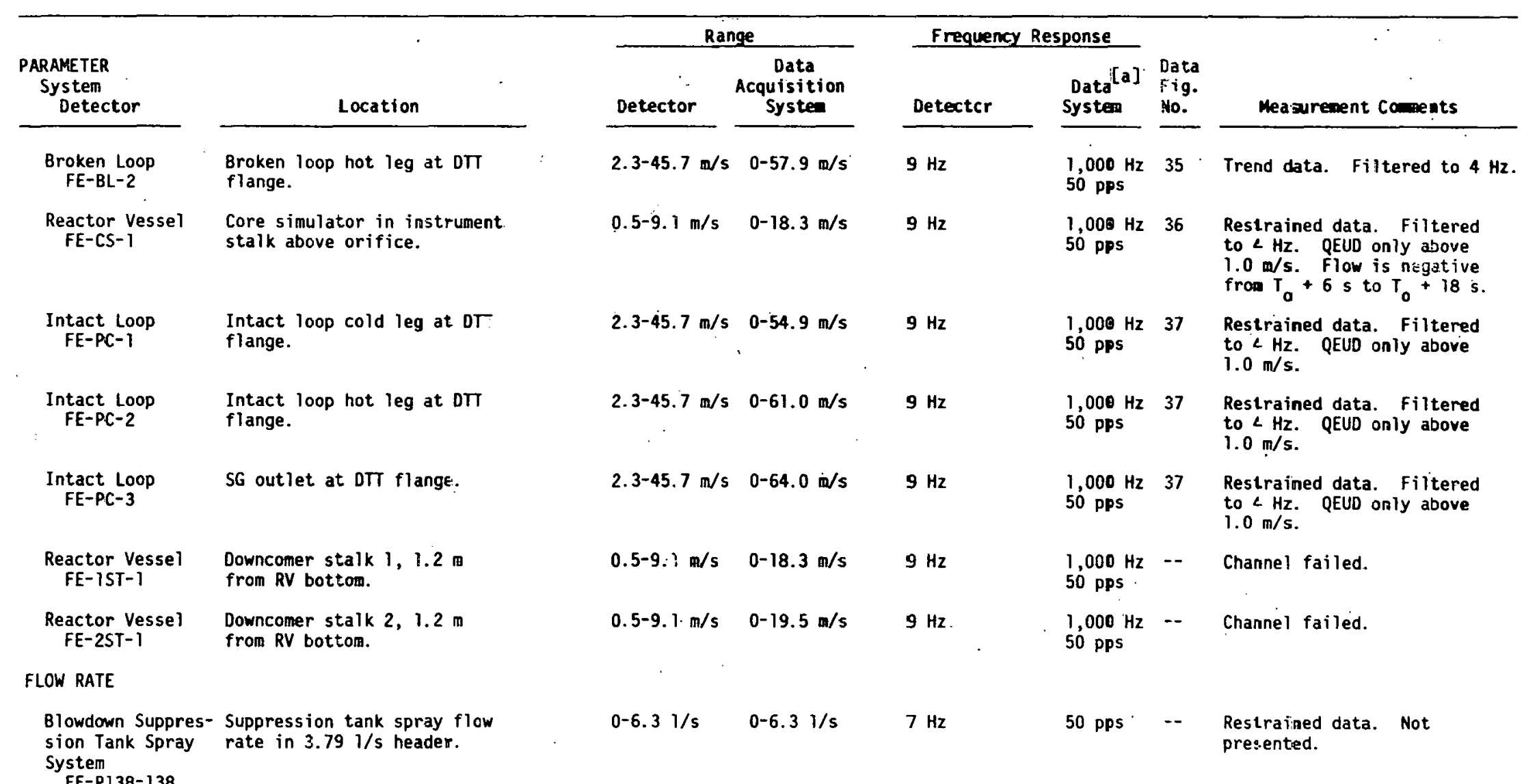


TABLE VII (contd.)

\begin{tabular}{|c|c|c|c|c|c|c|c|}
\hline \multirow[b]{2}{*}{$\begin{array}{l}\text { PARAMETER } \\
\text { System } \\
\text { Detector }\end{array}$} & \multirow[b]{2}{*}{ Location } & \multicolumn{2}{|c|}{ Range } & \multicolumn{2}{|c|}{ Frequency Response } & \multirow[b]{2}{*}{$\begin{array}{l}\text { Data } \\
\text { Fig. } \\
\text { Ho. }\end{array}$} & \multirow[b]{2}{*}{ Measurement Compents } \\
\hline & & Detector & $\begin{array}{l}\text { Data } \\
\text { Acquisition } \\
\text { Systea }\end{array}$ & Detector & $\begin{array}{l}\text { Data: } \\
\text { Systed }\end{array}$ & & \\
\hline $\begin{array}{l}\text { Blowdown Suppres- } \\
\text { sion Tank Spray } \\
\text { System } \\
\text { FE-P138-139 }\end{array}$ & $\begin{array}{l}\text { Suppression tank spray flow } \\
\text { rate from pump discharge. }\end{array}$ & $0-25.2 \mathrm{l} / \mathrm{s}$ & $0-25.2 \mathrm{l} / \mathrm{s}$ & $7 \mathrm{~Hz}$ & 50 pFs & 161 & QEUD. \\
\hline $\begin{array}{l}\text { Blowdown Suppres- } \\
\text { sion Tank Spray } \\
\text { System } \\
\text { FE-P138-140 }\end{array}$ & $\begin{array}{l}\text { Suppression tank spray flow } \\
\text { rate in the } 13.91 / 5 \text { header. }\end{array}$ & $0-18.9 \mathrm{l} / \mathrm{s}$ & $0-18.9 \mathrm{l} / \mathrm{s}$ & $7 \mathrm{~Hz}$ & 50 pps & -- & $\begin{array}{l}\text { Restrained data. Not } \\
\text { presented. }\end{array}$ \\
\hline $\begin{array}{l}\text { Blowdown Suppres- } \\
\text { sion Tank Spray } \\
\text { System } \\
\text { FE-P138-153 }\end{array}$ & $\begin{array}{l}\text { Suppression tank spray flow } \\
\text { rate in the spray pump } \\
\text { recirculation line. }\end{array}$ & $0-9.5 \mathrm{l} / \mathrm{s}$ & $0-9.5 \mathrm{l} / \mathrm{s}$ & $7 \mathrm{~Hz}$ & $50 \mathrm{pF} \cdot \mathrm{s}$ & -- & $\begin{array}{l}\text { Restrained data. Valid to } \\
85 \mathrm{~s} \text {. Nat presented. }\end{array}$ \\
\hline $\begin{array}{l}\text { Emergency core } \\
\text { Cooling System } \\
\text { FT-P120-36-1 }\end{array}$ & $\begin{array}{l}\text { Accumulator } A \text { in } 6-i n \text {. line } \\
\text { downstream of orifice. }\end{array}$ & $0-1.5 \mathrm{~m}$ & $0-126.2 \mathrm{l} / \mathrm{s}$ & $5 \mathrm{~Hz}$ & $50 \mathrm{pps}$ & $\begin{array}{r}38 \\
140\end{array}$ & QEUD. \\
\hline $\begin{array}{l}\text { Emergency Core } \\
\text { Cooling System } \\
\text { FT-PI20-36-5 }\end{array}$ & $\begin{array}{l}\text { Accumulator } A \text { in } 6-i n . \text { line } \\
\text { downstrean of orifice. }\end{array}$ & $0-15.2 \mathrm{~m}$ & $0-37.91 / 5$ & $5 \mathrm{~Hz}$ & 50 pps & $\begin{array}{r}39 \\
141 \\
144\end{array}$ & $\begin{array}{l}\text { Restrained data. Overranged } \\
\text { from } T_{0}+228 \text { s to } T_{0}+262 \mathrm{~s}\end{array}$ \\
\hline $\begin{array}{l}\text { Emergency Core } \\
\text { Cooling System } \\
\text { FT-P120-85 }\end{array}$ & $\begin{array}{l}\text { LPIS pump } A \text { in } 4-\text { in. line } \\
\text { between heat exchanger and } \\
\text { orifice. }\end{array}$ & $2.5-50.5 \mathrm{l} / \mathrm{s}$ & $0-25.2 \mathrm{l} / \mathrm{s}$ & $5 \mathrm{~Hz}$ & $50 \mathrm{pps}$ & $\begin{array}{r}40 \\
142 \\
144\end{array}$ & QEUD. \\
\hline $\begin{array}{l}\text { Emergency Core } \\
\text { Cooling System } \\
\text { FT-P128-104 }\end{array}$ & HPIS pump A discharge. & $0.1-1.9 \mathrm{l} / \mathrm{s}$ & $0-1.9 \mathrm{l} / \mathrm{s}$ & $5 \mathrm{~Hz}$ & 50 pps & $\begin{array}{r}41 \\
144 \\
143\end{array}$ & QEUD. \\
\hline
\end{tabular}


TABLE VII (contd.)

\begin{tabular}{|c|c|c|c|c|c|c|c|}
\hline \multirow[b]{2}{*}{$\begin{array}{l}\text { PARAMETER } \\
\text { Systen } \\
\text { Detector }\end{array}$} & \multirow[b]{2}{*}{ Location } & \multicolumn{2}{|c|}{ Range } & \multicolumn{2}{|c|}{ Irequency Response } & \multirow[b]{2}{*}{$\begin{array}{l}\text { Data } \\
\text { Fig. } \\
\text { No. } \\
\end{array}$} & \multirow[b]{2}{*}{ Measurement Comients } \\
\hline & & Detector & $\begin{array}{c}\text { Data } \\
\text { Acquisition } \\
\text { System } \\
\end{array}$ & De-ector & $\begin{array}{l}\text { Data:-a] } \\
\text { Systea }\end{array}$ & & \\
\hline $\begin{array}{l}\text { Intact Loop } \\
\text { FT-P139-27-1 }\end{array}$ & $\begin{array}{l}\text { Intact loop hot leg venturi } \\
\text { flowmeter (right side } \\
\text { facing } 56 \text { ). }\end{array}$ & $\begin{array}{l}63.0-630.0 \\
\mathrm{~kg} / \mathrm{s}\end{array}$ & $\begin{array}{l}0-630.0 \\
\mathrm{~kg} / \mathrm{s}\end{array}$ & $5 \mathrm{~Hz}$ & $\begin{array}{l}1,00 C \text { W } \\
50 \text { PFS }\end{array}$ & 42 & $\begin{array}{l}\text { Restrained data. Gcod for } \\
\text { initial conditions cnly; data } \\
\text { not corrected for density } \\
\text { changes after } T_{0} \text {. }\end{array}$ \\
\hline $\begin{array}{l}\text { Intact Loop } \\
\text { FT-P139-27-2 }\end{array}$ & $\begin{array}{l}\text { Intact loop hot leg venta-i } \\
\text { flowmeter (left side } \\
\text { facing } 5 G \text { ). }\end{array}$ & $\begin{array}{l}\mathrm{O}=-19.3 \\
\text { in } \mathrm{H}_{2} \mathrm{O}^{\mathrm{O}}\end{array}$ & $\begin{array}{l}\mathrm{O}-19.3 \\
\mathrm{~m} \mathrm{H}_{2} \mathrm{O}\end{array}$ & $5 \mathrm{~Hz}$ & $\begin{array}{l}1,000 \mathrm{~Hz} \\
50 \mathrm{PPS}\end{array}$ & $\because-$ & Channel failed. \\
\hline $\begin{array}{l}\text { Intact Loop } \\
\text { FT-P139-27-3 }\end{array}$ & $\begin{array}{l}\text { Intact loop hot leg } \\
\text { venturi flowmeter, (boitomo. }\end{array}$ & $\begin{array}{l}63.0-630.0 \\
\mathrm{~kg} / \mathrm{s}\end{array}$ & $\begin{array}{l}0-630.0 \\
\mathrm{~kg} / \mathrm{s}\end{array}$ & $5 \mathrm{~Hz}$ & $50 \mathrm{pps}$ & 43 & $\begin{array}{l}\text { Restrained data. Good for } \\
\text { initial conditions only; data } \\
\text { not corrected for density } \\
\text { changes after } T_{0} \text {. }\end{array}$ \\
\hline \multicolumn{8}{|l|}{ LIQUID LEVEL } \\
\hline $\begin{array}{l}\text { Reactor Vessel } \\
\text { LE-IST-1 } \\
\text { and }-2\end{array}$ & $\begin{array}{l}\text { Downcomer } 1 \text { with stings } \\
\text { between } 5.1 \mathrm{~m} \text { and } 0.21 \mathrm{~m} \\
\text { above RV bottom. }\end{array}$ & $0-4.1 \mathrm{~m}$ & $-1-+1 v$ & $0.7 \mathrm{kz}$ & $1,000 \mathrm{~Hz}$ & 44 & QEUD. \\
\hline $\begin{array}{l}\text { Reactor Vesse] } \\
\text { LE-2ST-1 } \\
\text { and }-2\end{array}$ & $\begin{array}{l}\text { Downcomer } 2 \text { with stings } \\
\text { between } 5.1 \mathrm{~m} \text { and } 0.21 \mathrm{~m} \\
\text { above } R V \text { bottom. }\end{array}$ & $3-4.1 \mathrm{~m}$ & $-7-+1 \mathrm{~V}$ & $0.7 \mathrm{~Hz}$ & $1,0.30 \mathrm{~Hz}$ & 45 & QEUD. LE-2ST-2-2 channel failec \\
\hline $\begin{array}{l}\text { Emergency Core } \\
\text { Cooling System } \\
\text { LIT-P 120-44 }\end{array}$ & Accumulator $A$. & $3-3 m$ & $0-3 \mathrm{~m}$ & $5 \mathrm{~Hz}$ & $\begin{array}{l}50 \mathrm{pps} \\
.\end{array}$ & 46 & QEUD. \\
\hline $\begin{array}{l}\text { Secondary coolant } \\
\text { System } \\
\text { LT-P4-8B }\end{array}$ & SG secondary level. & $\begin{array}{l}-3.6-+1.4 \mathrm{~m} \\
\mathrm{H}_{2} \mathrm{O}\end{array}$ & $\begin{array}{l}-3.6-+1.4 \mathrm{~m} \\
\mathrm{H}_{2} \mathrm{O}^{-}\end{array}$ & $5 \mathrm{~Hz}$ & $\begin{array}{l}50, \mathrm{pps} \\
1,000 \mathrm{~Hz}\end{array}$ & 49 & $\begin{array}{l}\text { QEed. Data display instru- } \\
\text { ment ringing from } \mathrm{T}_{0} \text { to } 25 \mathrm{~s} \text {. }\end{array}$ \\
\hline
\end{tabular}


TABLE VII (contd.)

\begin{tabular}{|c|c|c|c|c|c|c|c|}
\hline \multirow[b]{2}{*}{$\begin{array}{l}\text { PARAMETER } \\
\text { System } \\
\text { Detector }\end{array}$} & \multirow[b]{2}{*}{ Location } & \multicolumn{2}{|c|}{ Range } & \multicolumn{2}{|c|}{ Frequency Response } & \multirow[b]{2}{*}{$\begin{array}{l}\text { Data } \\
\text { Fig. } \\
\text { Ho. } \\
\end{array}$} & \multirow[b]{2}{*}{ Measurement Coments } \\
\hline & & Detector & $\begin{array}{l}\text { Data } \\
\text { Acquisition } \\
\text { Systew }\end{array}$ & Detector & $\underset{\substack{\text { Data } \\
\text { System }}}{[a]}$ & & \\
\hline $\begin{array}{l}\text { Blowdown Suppres- } \\
\text { sion Tank } \\
\text { LT-P138-33 }\end{array}$ & $\begin{array}{l}\text { Blowdown suppression tank level } \\
\text { on north end of tank. }\end{array}$ & $0-3.3 \mathrm{~m}$ & $0-3.4 \square$ & $5 \mathrm{~Hz}$ & $\begin{array}{l}1,0610 \mathrm{~Hz} \\
50 \mathrm{FPS}\end{array}$ & $\begin{array}{r}47 \\
145 \\
162\end{array}$ & $\begin{array}{l}\text { QEUD. [iata display instrument } \\
\text { saturation from } T_{0} \text { to } \sim T_{0} \\
+1.5 \text { s. }\end{array}$ \\
\hline $\begin{array}{l}\text { Blowdown Suppres- } \\
\text { sion Tank } \\
\text { LT-P138-58 }\end{array}$ & $\begin{array}{l}\text { Blowdown suppression tank level } \\
\text { on south end of tank. }\end{array}$ & $0-3.4 \mathrm{~m}$ & $0-3.4 \mathrm{~m}$ & $5 \mathrm{~Hz}$ & $\begin{array}{l}1,0 \mathrm{CO} \mathrm{Hz} \\
50 \mathrm{Fps}\end{array}$ & $\begin{array}{r}47 \\
145 \\
162\end{array}$ & $\begin{array}{l}\text { QEUD. Cata display instrument } \\
\text { saturation from } T_{0} \text { to } 2 T_{0} \\
+1.5 \mathrm{~s} \text {. }\end{array}$ \\
\hline $\begin{array}{l}\text { Intact Loop } \\
\text { LT-P139-6 }\end{array}$ & $\begin{array}{l}\text { Pressurizer level on southeast } \\
\text { side. }\end{array}$ & $0-1.9 \mathrm{~m}$ & $0-1.9 \mathrm{~m}$ & $5 \mathrm{~Hz}$ & $\begin{array}{l}1,0 \mathrm{COOHz} \\
50 \mathrm{FPs}\end{array}$ & 48 & QEUD frem $T_{0}$ to $T_{0}+13 \mathrm{~s}$ \\
\hline $\begin{array}{l}\text { Intact Loop } \\
\text { LT-P139-7 }\end{array}$ & $\begin{array}{l}\text { Pressurizer level on southwest } \\
\text { side. }\end{array}$ & $0-1.9 \mathrm{~m}$ & $0-1.9$ व & $5 \mathrm{~Hz}$ & $\begin{array}{l}1,0 \mathrm{COOHz} \\
50 \mathrm{FPs}\end{array}$ & 48 & QEUD frest $T_{0}$ to $T_{0}+13 \mathrm{~s}$ \\
\hline $\begin{array}{l}\text { Intact Loop } \\
\text { LT-P139-8 }\end{array}$ & $\begin{array}{l}\text { Pressurizer level on north } \\
\text { side. }\end{array}$ & $0-1.9 \mathrm{~m}$ & $0-1: 9$ m & $5 \mathrm{~Hz}$ & $50 \mathrm{Fps}$ & 48 & QEUD frem $T_{0}$ to $T_{0}+13 \mathrm{~s}$ \\
\hline $\begin{array}{l}\text { MOMENTUM FLUX, } \\
\text { AVERAGED }\end{array}$ & & & & & & & \\
\hline $\begin{array}{l}\text { Broken Loop } \\
\text { ME-BL-IA }\end{array}$ & $\begin{array}{l}\text { Broken loop cold leg at } D T \text { rake } \\
\text { bottom. }\end{array}$ & $\begin{array}{l}2.98-74.4 \\
\mathrm{mg} / \mathrm{m}-\mathrm{s}^{2}\end{array}$ & $\begin{array}{l}-684.5 \\
\mathrm{mg} / \mathrm{m} \mathrm{s}^{2}\end{array}$ & $35 \mathrm{~Hz}$ & $\begin{array}{l}1,0 \mathrm{CCO} \mathrm{Hz} \\
50 \mathrm{FPs}\end{array}$ & 50 & $\begin{array}{l}\text { Trend data. Filtered to } 4 \mathrm{~Hz} \\
\text { for } 0 \mathrm{tc} 70 \mathrm{~s} \text { plot. Unfiltered } \\
\text { for } 0 \mathrm{tc} 175 \mathrm{~s} \text { plot. Data tem- } \\
\text { perature sensitive after } \sim \mathrm{T}_{0} \\
+50 \mathrm{~s} \text {. }\end{array}$ \\
\hline $\begin{array}{l}\text { Broken Loop } \\
\text { ME-BL-1B }\end{array}$ & $\begin{array}{l}\text { Broken loop cold leg at } 0 \pi \text { rake } \\
\text { center. }\end{array}$ & $\frac{2.98-74.4}{\mathrm{mg} / \mathrm{m}-\mathrm{s}^{2}}$ & $\begin{array}{l}-684.5 \\
\mathrm{mg} / \mathrm{m}-\mathrm{s}^{+684.5}\end{array}$ & $35 \mathrm{~Hz}$ & $\begin{array}{l}1,0 \mathrm{COOHz} \\
50 \mathrm{Fps}\end{array}$ & -- & Channel failed. \\
\hline $\begin{array}{l}\text { Broken loop } \\
\text { ME-BL-IC }\end{array}$ & $\begin{array}{l}\text { Broken loop cold leg at } D T \text { rake } \\
\text { top. }\end{array}$ & $\frac{2.98-74.4}{\mathrm{mg} / \mathrm{m}-\mathrm{s}^{2}}$ & $\begin{array}{l}-684.5-584.5 \\
\mathrm{mg} / \mathrm{m}^{-\mathrm{s}}\end{array}$ & $35 \mathrm{~Hz}$ & $\begin{array}{l}1,060 \mathrm{~Hz} \\
50 \mathrm{FPs}\end{array}$ & 50 & $\begin{array}{l}\text { Trend dzta. Filtered to } 4 \mathrm{~Hz} \\
\text { for } 0 \text { tc } 70 \mathrm{~s} \text { plot. Unfiltered } \\
\text { for } 0 \text { tc } 175 \mathrm{~s} \text { plot. Oata tem- } \\
\text { perature sensitive after } \sim T_{0} \\
+50 \mathrm{~s} \text {. }\end{array}$ \\
\hline
\end{tabular}




\section{TABLE VII (contd.)}

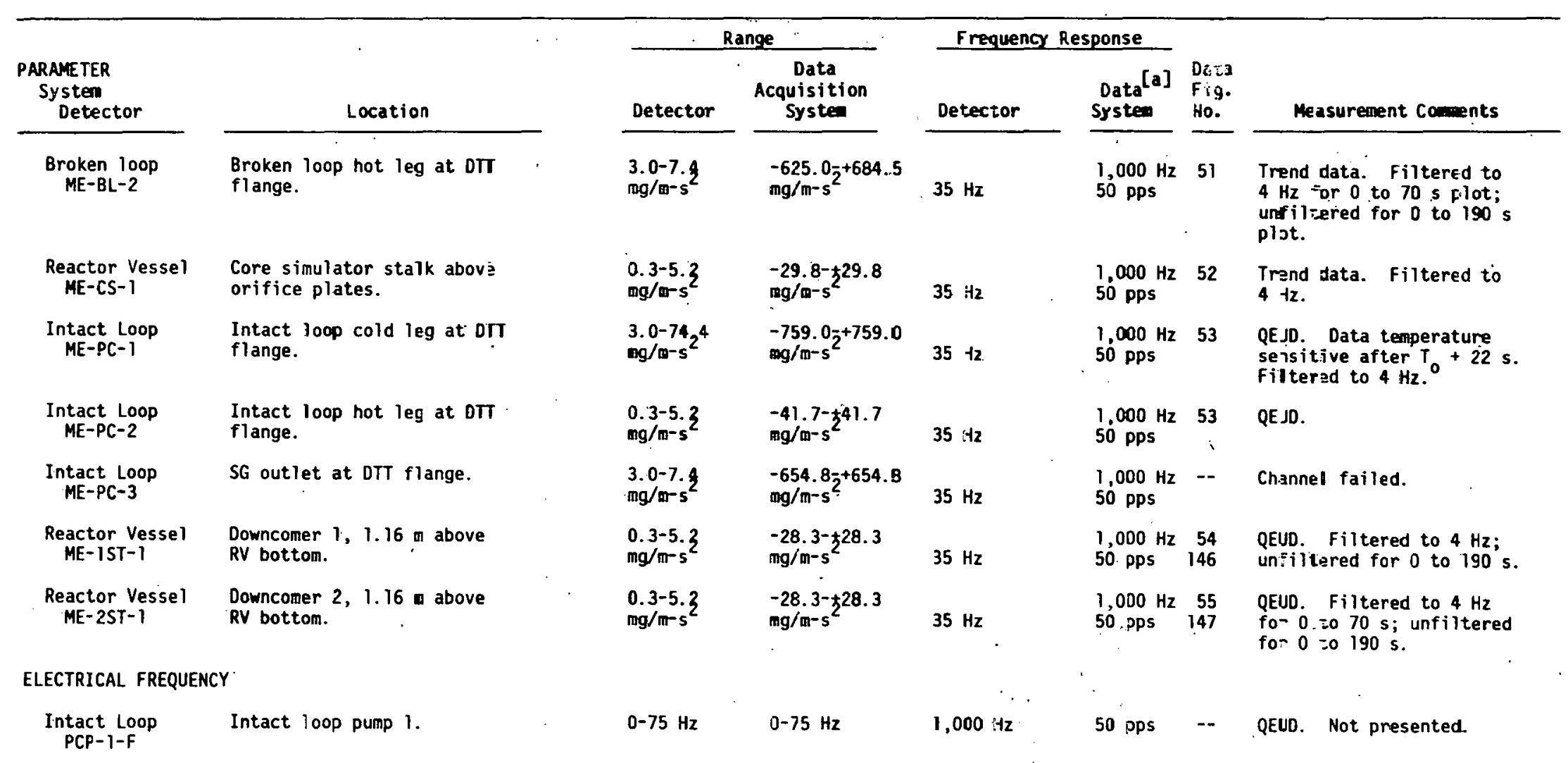


TABLE VII (contd.)

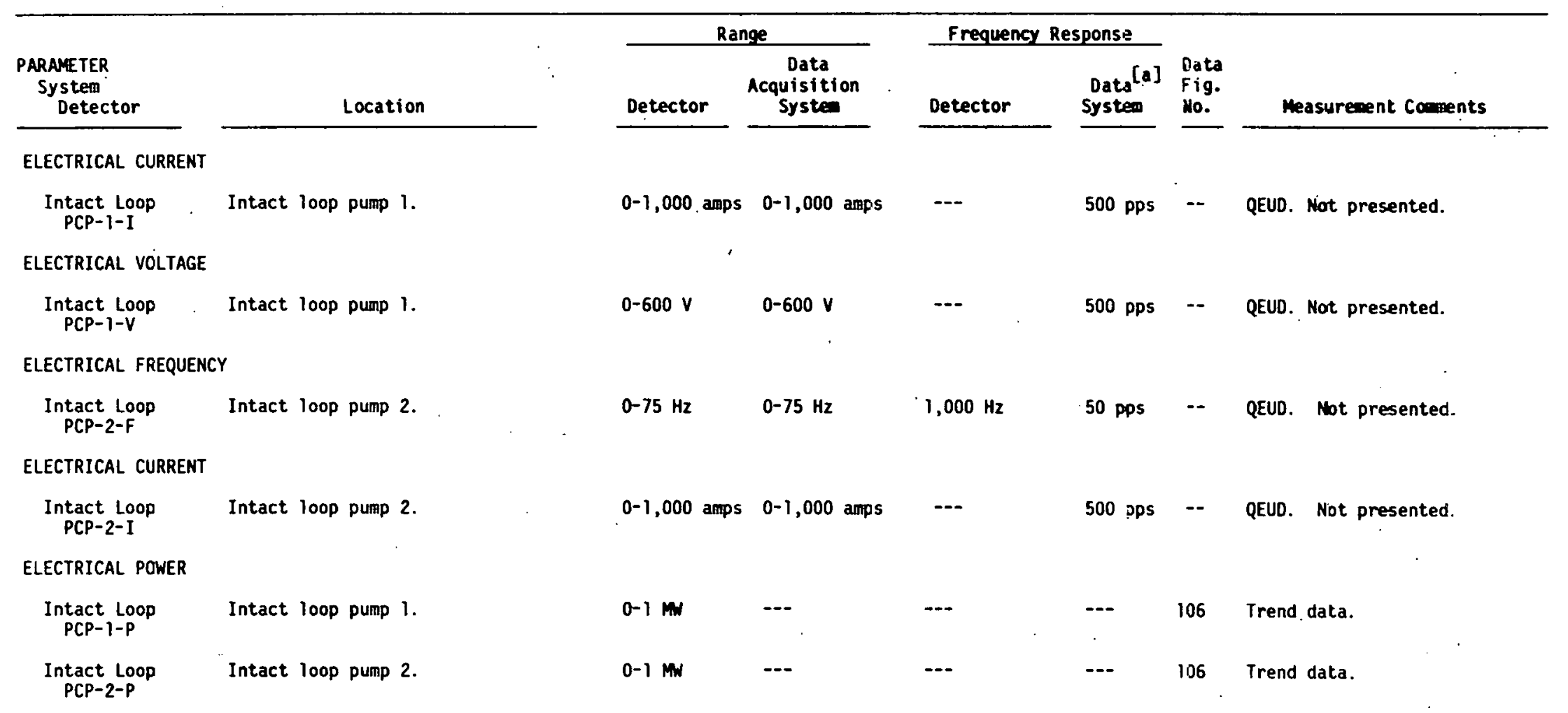


TABLE VII (contd.)

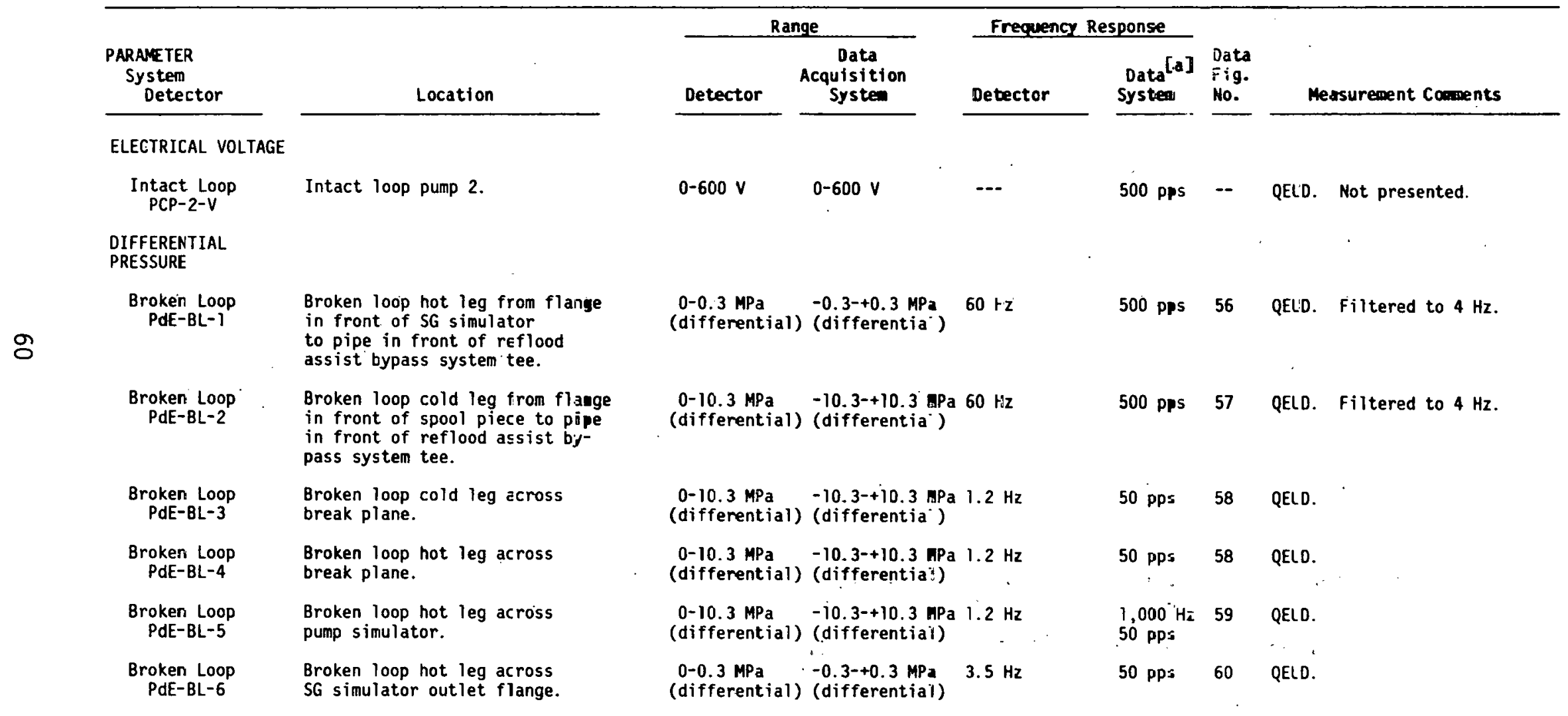


TABLE VII (contd.)

\begin{tabular}{|c|c|c|c|c|c|c|c|}
\hline \multirow{3}{*}{$\begin{array}{c}\text { PARAMETER } \\
\text { System } \\
\text { Detector }\end{array}$} & \multirow[b]{2}{*}{ Location } & \multicolumn{2}{|c|}{ Range } & \multicolumn{2}{|c|}{ Frequency Response } & \multirow[b]{2}{*}{$\begin{array}{l}\text { Data } \\
\text { Fig. } \\
\text { Na. } \\
\end{array}$} & \multirow[b]{2}{*}{ Measurement Comments } \\
\hline & & Detector & $\begin{array}{c}\text { Data } \\
\text { Acquisition } \\
\text { System } \\
\end{array}$ & Detector & $\begin{array}{c}\text { Data }[a] \\
\text { System }\end{array}$ & & \\
\hline & $\begin{array}{l}\text { Broken loop hot leg across } \\
\text { SG simulator. }\end{array}$ & $\begin{array}{l}0-0.7 \mathrm{MPa} \\
\text { (differential) }\end{array}$ & $\begin{array}{l}-0.3-+0.3 \mathrm{MPa} \\
(\text { differential) }\end{array}$ & $3: 5 \mathrm{~Hz}$ & $\begin{array}{l}1,000 \mathrm{~Hz} \\
50 \mathrm{pps}\end{array}$ & 6 & QEUD. \\
\hline $\begin{array}{l}\text { Broken Loop } \\
\text { PdE-BL-8 }\end{array}$ & $\begin{array}{l}\text { Broken loop hot leg across } \\
\text { SG simulator inlet flange. }\end{array}$ & $\begin{array}{l}0-0.3 \mathrm{MPa} \\
\text { (differential) }\end{array}$ & $\begin{array}{l}-0.3-+0.3 \mathrm{MPa} \\
(\text { differential })\end{array}$ & $3.5 \mathrm{~Hz}$ & 50 pps & 62 & QEUD. Fil tered $=04 \mathrm{~Hz}$. \\
\hline $\begin{array}{l}\text { Broken Loop } \\
\text { PdE-BL-9 }\end{array}$ & $\begin{array}{l}\text { Broken loop across } 14-\text { to-5-in. } \\
\text { contraction to middle of } 5 \text {-in. } \\
\text { pipe. }\end{array}$ & $\begin{array}{l}0-1.37 \mathrm{MPa} \\
\text { (differential) }\end{array}$ & ) $\begin{array}{l}0-1.38 \mathrm{MPa} \\
\text { (differentia })\end{array}$ & $194 \mathrm{~Hz}$ & -- & 63 & Trend data: \\
\hline $\begin{array}{l}\text { Broken Loop } \\
\text { PdE-BL-10 }\end{array}$ & $\begin{array}{l}\text { Broken loop from middle of } 5 \text {-in. } \\
\text { pipe to break plane. }\end{array}$ & $\begin{array}{l}0-1.37 \mathrm{MPa} \\
\text { (differential) }\end{array}$ & ) $\begin{array}{l}0-1.38 \mathrm{MPa} \\
\text { (differential) }\end{array}$ & $194 \mathrm{~Hz}$ & $\ldots$ & 64 & Trend data. \\
\hline $\begin{array}{l}\text { Reactor Vessel } \\
\text { PdE-CS-1 }\end{array}$ & $\begin{array}{l}\text { RV between core simulator } \\
\text { instrument stalk and down- } \\
\text { comer } 2,0.62 \mathrm{~m} \text { from } \\
\text { RV bottom. }\end{array}$ & 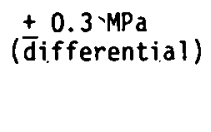 & $\stackrel{+0.2 \mathrm{MPa}}{\text { Tdifferential) }}$ & $2.3 \mathrm{~Hz}$ & $50 \mathrm{pps}$ & 65 & $\begin{array}{l}\text { Restrained data. Valid prior } \\
\text { to } T_{0} \text {. Filtered to } 4 \mathrm{~Hz} \text {. }\end{array}$ \\
\hline $\begin{array}{l}\text { Intact Loop } \\
\text { PdE-PC-T }\end{array}$ & $\begin{array}{l}\text { Intact loop cold leg across } \\
\text { primary coolant pumps. }\end{array}$ & $\begin{array}{l}0.0 .7 \mathrm{MPa} \\
\text { (differential) }\end{array}$ & $\begin{array}{l}-0.7-+0.7 \mathrm{MPa} \\
(\text { differential) }\end{array}$ & $0.7 \mathrm{~Hz}$ & $\begin{array}{l}1,000 \mathrm{~Hz} \\
50 \mathrm{pps}\end{array}$ & €6 & QEUD. \\
\hline $\begin{array}{l}\text { Intact Loop } \\
\text { PdE-PC-2 }\end{array}$ & Intact loop across SG. & $\begin{array}{l}0-0.7 \mathrm{MPa} \\
\text { (differential) }\end{array}$ & $\begin{array}{l}-0.7-+0.7 \mathrm{MPa} \\
(\text { differenti.al })\end{array}$ & $3.5 \mathrm{~Hz}$ & $50 \mathrm{pps}$ & 67 & QEUD. \\
\hline $\begin{array}{l}\text { Intact Loop } \\
\text { PdE-PC-3 }\end{array}$ & $\begin{array}{l}\text { Intact loop hot leg fiping, } \\
\text { RV to venturi. }\end{array}$ & $\begin{array}{l} \pm 0.1 \mathrm{MPa} \\
(\text { (differential) }\end{array}$ & $\begin{array}{l}+0.1 \mathrm{MPa} \\
\text { (differential) }\end{array}$ & $2.3 \mathrm{~Hz}$ & $50 \mathrm{pps}$ & 68 & $\begin{array}{l}\text { Trend data. Tap relocated prior } \\
\text { to } L 1-4 \text { at } 90^{\circ} \text { from pressurizer } \\
\text { surge line inlet and if olane of }\end{array}$ \\
\hline $\begin{array}{l}\text { Intact Loop } \\
\text { PdE-PC-4 }\end{array}$ & $\begin{array}{l}\text { Intact loop hot leg fiping, } \\
\text { venturi to } S G \text {. }\end{array}$ & $\stackrel{+0.1 \mathrm{MPa}}{\text { (differential) }}$ & $\begin{array}{l}+ \text { G.1 MPa } \\
\text { Tdifferential) }\end{array}$ & $2.3 \mathrm{~Hz}$ & $50 \mathrm{pps}$ & 69 & $\begin{array}{l}\text { inlet. Differential pressures in- } \\
\text { fluenced by velocity effects from } \\
\text { pressurizer flow. Filtered to } 4 \mathrm{~Hz}\end{array}$ \\
\hline
\end{tabular}


TABLE VII (contd.)

\begin{tabular}{|c|c|c|c|c|c|c|c|}
\hline \multirow[b]{2}{*}{$\begin{array}{l}\text { PARAME TER } \\
\text { System } \\
\text { Detector } \\
\end{array}$} & \multirow[b]{2}{*}{ Location } & \multicolumn{2}{|c|}{ Range } & \multicolumn{2}{|c|}{ Frequency Response } & \multirow[b]{2}{*}{$\begin{array}{l}\text { Deta } \\
\text { Fig. } \\
\text { Ho. }\end{array}$} & \multirow[b]{2}{*}{ Weasurenent Comsents } \\
\hline & & Detector & $\begin{array}{l}\text { Data } \\
\text { Acquisition } \\
\text { System }\end{array}$ & Detector & $\begin{array}{l}\text { Data[a] } \\
\text { Systea }\end{array}$ & & \\
\hline $\begin{array}{l}\text { Intact Loop } \\
\text { PdE-PC-5 }\end{array}$ & $\begin{array}{l}\text { Intact loop cold leg priaary } \\
\text { coolant pumps to RV nozzie. }\end{array}$ & $\stackrel{ \pm 0.1 \mathrm{MPa}}{(\overline{d i f f e r e n t i a l)})}$ & $\begin{array}{l}+0.1 \mathrm{MPa} \\
\text { (differential) }\end{array}$ & $2.3 \mathrm{~Hz}$ & 50 pos & 70 & QEUD. Filtered to $\& \mathrm{~Hz}$. \\
\hline $\begin{array}{l}\text { Intact Loop } \\
\text { PdE-PC-7 }\end{array}$ & $\begin{array}{l}\text { Intact loop coid leg RV : nle } \\
\text { to broken loop cold } \\
\text { leg RV inlet. }\end{array}$ & $\stackrel{+0.1 \mathrm{MPa}}{\stackrel{+0.10}{(d i f f e r e n t i a l)}}$ & $\begin{array}{l}+0.1 \mathrm{MPa} \\
\text { (differential) }\end{array}$ & $2.3 \mathrm{~Hz}$ & 50 pJs & 71 & QEUD. Filtered to $7 \mathrm{~Hz}$. \\
\hline $\begin{array}{l}\text { Intact Loop } \\
\text { PdE-PC-8 }\end{array}$ & $\begin{array}{l}\text { Intact loop across presstrizer } \\
\text { surge line. }\end{array}$ & $\begin{array}{l}0-10.34 \mathrm{mPa} \\
\text { (differential) }\end{array}$ & $\begin{array}{l}0-10.34 \mathrm{MPa} \\
\text { (differential) }\end{array}$ & -- & --- & 72 & QEUD. \\
\hline $\begin{array}{l}\text { Intact Loop } \\
\text { PdE-PC-9 }\end{array}$ & Intact loop across pump 1. & $\begin{array}{l}0-0.689 \mathrm{MPa} \\
(\text { differential) }\end{array}$ & $\begin{array}{l}0-0.689 \mathrm{MPa} \\
\text { (differential) }\end{array}$ & --- &.-- & 73 & QEUD. \\
\hline $\begin{array}{l}\text { Intact Loop } \\
\text { PdE-PC-10 }\end{array}$ & Intact loop across pump $\bar{c}$. & $\begin{array}{l}0-0.689 \mathrm{MPa} \\
\text { (differential) }\end{array}$ & $\begin{array}{l}0-0.689 \mathrm{MPa} \\
\text { (differential) }\end{array}$ & $--\cdot$ & $--:$ & 73 & QEUD. \\
\hline $\begin{array}{l}\text { Reactor Vessel } \\
\text { PdE-RV-1 }\end{array}$ & $\begin{array}{l}\text { Between downcomer staik } 1 \\
\text { and blowdown suppression ta.jk. }\end{array}$ & $\begin{array}{l}0-10.3 \mathrm{MPa} \\
\text { (differential) }\end{array}$ & $\begin{array}{l}-10.3-+10.3 \mathrm{MPa} \\
\text { (differential) }\end{array}$ & $1.2 \hat{z}$ & $50 \mathrm{pps}$ &.-- & Crannel failed. \\
\hline $\begin{array}{l}\text { Reactor Vessel } \\
\text { PdF-RV-3, }\end{array}$ & $\begin{array}{l}\text { Intact loop cold leg inlet to } \\
\text { bottom of downcomer. }\end{array}$ & $\stackrel{+0.1 \mathrm{MPa}}{(\mathrm{d} i f f e r e n t i a l)}$ & $\begin{array}{l}+0.1 \mathrm{MPa} \\
\text { (differential) }\end{array}$ & $2 . \Xi: t z$ & $50 \mathrm{pps}$ & 74 & QEUD. Filtered to $\& \mathrm{~Hz}$. \\
\hline $\begin{array}{l}\text { Reactor Vessel } \\
\text { PdE-RV-4 }\end{array}$ & $\begin{array}{l}\text { Upper plenum to the FV outure } \\
\text { nozzle in the intact loof } \\
\text { hot leg. }\end{array}$ & $\begin{array}{l}+0.1 \mathrm{MPa} \\
\text { (differential) }\end{array}$ & $\stackrel{+0.1 \mathrm{MPa}}{\text { (differential) }}$ & $2 . \equiv H z$ & $50 \mathrm{pps}$ & 75 & $\begin{array}{l}\text { Trend data. Uninte mpreted } \\
\text { data Efter } T_{0}\end{array}$ \\
\hline $\begin{array}{l}\text { Blowdown Suppres- } \\
\text { sion Tank } \\
\text { PdE-SV-9 }\end{array}$ & $\begin{array}{l}\text { Suppression tank acrcss the } \\
\text { vacuum breaker line. }\end{array}$ & $\begin{array}{l}0-5.1 \mathrm{~m} \\
\mathrm{H}_{2} \mathrm{O}^{-}\end{array}$ & $\begin{array}{l}-2.5-+2.5 \mathrm{~m} \\
\mathrm{H}_{2} \mathrm{O}\end{array}$ & $5+2$ & 50 pps & 76 & $\begin{array}{l}\text { Trendl data. Good data - not } \\
\text { qLalified. }\end{array}$ \\
\hline $\begin{array}{l}\text { Reactor Vessel } \\
\text { PdE-2ST-2 }\end{array}$ & $\begin{array}{l}\text { Downcomer } 2 \text { between } 5.32 \text { and } \\
0.62 \mathrm{~m} \text { above RV bottcm. }\end{array}$ & $\begin{array}{l}0-0.2 \mathrm{MPa} \\
\text { (differential) }\end{array}$ & $\begin{array}{l}-0.2-+0.2 \mathrm{MPa} \\
\text { (differential) }\end{array}$ & $60 \mathrm{~Hz}$ & 50 pps & 77 & $\begin{array}{l}\text { Trend data. Uninterpreted } \\
\text { deta =fter } T_{0} \text {. ' Fii Fered to } \\
4 \mathrm{Hzz} .\end{array}$ \\
\hline
\end{tabular}


TABLE VII (contd.)

\begin{tabular}{|c|c|c|c|c|c|c|c|}
\hline \multirow[b]{2}{*}{$\begin{array}{l}\text { PARAMETER } \\
\text { System } \\
\text { Detector }\end{array}$} & \multirow[b]{2}{*}{ Location } & \multicolumn{2}{|c|}{ Range } & \multicolumn{2}{|c|}{ Frequency Response } & \multirow[b]{2}{*}{$\begin{array}{l}\text { Caca } \\
\text { fig. } \\
\text { No. }\end{array}$} & \multirow[b]{2}{*}{ Measurement Coments } \\
\hline & & Detector & $\begin{array}{l}\text { Data } \\
\text { Acquisition } \\
\text { System }\end{array}$ & Detector & $\begin{array}{l}\text { Data[a] } \\
\text { System }\end{array}$ & & \\
\hline $\begin{array}{l}\text { Intact Loop } \\
\text { PdT-P139-27-1 }\end{array}$ & Primary coolant flow, Channel A. & $\begin{array}{c}0-0.199 \mathrm{MPa} \\
\text { (differential) }\end{array}$ & $\begin{array}{l}0-0.199 \mathrm{MPa} \\
\text { (differential) }\end{array}$ & --- & --- & -- & $\begin{array}{l}\text { Restrained data. Good for } \\
\text { initial conditions only. Plot } \\
\text { not presented. }\end{array}$ \\
\hline $\begin{array}{l}\text { Intact Loop } \\
\text { PdT-P139-27-2 }\end{array}$ & Primary coolant flow, Channel B. & $\begin{array}{c}0-0.189 \mathrm{MPa} \\
\text { (differential) }\end{array}$ & $\begin{array}{l}0-0.189 \mathrm{MPa} \\
\text { (differential) }\end{array}$ & --- & --- & -- & $\begin{array}{l}\text { Restrained data. Good for } \\
\text { initial conditions cnly. Plot } \\
\text { not presented. }\end{array}$ \\
\hline $\begin{array}{l}\text { Intact Loop } \\
\text { PdT-P139-27-3 }\end{array}$ & Primary coolant flow, Channel $\mathrm{C}$. & $\begin{array}{c}0-0.195 \mathrm{MPa} \\
\text { (differential) }\end{array}$ & - & --- & --- & -- & $\begin{array}{l}\text { Restrained data. Good for. } \\
\text { initial conditions only. Plot } \\
\text { not presented. }\end{array}$ \\
\hline $\begin{array}{l}\text { Intact Loop } \\
\text { PdT-P139-30 }\end{array}$ & $\begin{array}{l}\text { Across RV just beyond intact } \\
\text { loop inlet and out let nozzles. }\end{array}$ & $\begin{array}{l}0-0.3 \mathrm{mPa} \\
\text { (differential) }\end{array}$ & $\begin{array}{l}0-0.3 \mathrm{MPa} \\
\text { (differential) }\end{array}$ & $5 \mathrm{~Hz}$ & $50 \mathrm{pps}$ & 78 & $\begin{array}{l}\text { Restrained data. Valid for } \\
\text { initial conditions only. }\end{array}$ \\
\hline PRESSURE & & & & & & & \\
\hline $\begin{array}{l}\text { Broken Loop } \\
\text { PE-BL-1 }\end{array}$ & $\begin{array}{l}\text { Broken loop cold leg at: DTT } \\
\text { flange. }\end{array}$ & $\begin{array}{l}0-20.7 \mathrm{MPa} \\
\text { (gauge) }\end{array}$ & $\begin{array}{l}0-20.7 \mathrm{MPa} \\
\text { (gauge) }\end{array}$ & $>500 \mathrm{~Hz}$ & $\begin{array}{l}1,000 \mathrm{~Hz} \\
50 \mathrm{pps}\end{array}$ & $\begin{array}{l}18 \\
79 \\
81\end{array}$ & QEUD. \\
\hline $\begin{array}{l}\text { Broken Loop } \\
\text { PE-BL-2 }\end{array}$ & $\begin{array}{l}\text { Broken loop hot.leg at } 0 T T \\
\text { flange. }\end{array}$ & $\begin{array}{l}0-20.7 \mathrm{MPa} \\
\text { (gauge) }\end{array}$ & $\begin{array}{l}0-20.7 \mathrm{MPa} \\
\text { (gauge) }\end{array}$ & $>500 \mathrm{~Hz}$ & $\begin{array}{l}1,000 \mathrm{~Hz} \\
50 \mathrm{pps}\end{array}$ & $\begin{array}{l}19 \\
79 \\
82\end{array}$ & QEUD. \\
\hline $\begin{array}{l}\text { Broken Loop } \\
\text { PE-BL-3 }\end{array}$ & $\begin{array}{l}\text { Broken loop hot leg downstrean } \\
\text { of pump simulator. }\end{array}$ & $\begin{array}{l}0-20.7 \mathrm{MPa} \\
\text { (gauge) }\end{array}$ & $\begin{array}{l}0-20.7 \mathrm{MPa} \\
\text { (gauge) }\end{array}$ & $>500 \mathrm{~Hz}$ & $\begin{array}{l}1,000 \mathrm{~Hz} \\
50 \mathrm{pps}\end{array}$ & $\begin{array}{l}19 \\
80 \\
82\end{array}$ & QEUD. \\
\hline
\end{tabular}


TABLE VII (contd.)

\begin{tabular}{|c|c|c|c|c|c|c|c|c|}
\hline & \multirow[b]{2}{*}{$\begin{array}{l}\text { PARAMETER } \\
\text { Systen } \\
\text { Detector }\end{array}$} & \multirow[b]{2}{*}{ Location } & \multicolumn{2}{|c|}{ Range } & \multicolumn{2}{|c|}{ Frequency Response } & \multirow[b]{2}{*}{$\begin{array}{l}\text { Data } \\
\text { Yig. } \\
\text { Ho. }\end{array}$} & \multirow[b]{2}{*}{ Measurement Coments } \\
\hline & & & Detector & $\begin{array}{l}\text { Data } \\
\text { Acquisition } \\
\text { System }\end{array}$ & Detector & $\begin{array}{l}\text { Data[a] } \\
\text { System }\end{array}$ & & \\
\hline & $\begin{array}{l}\text { Broken Loop } \\
\text { PE-BL-4 }\end{array}$ & $\begin{array}{l}\text { Broken loop cold leg at inlet } \\
\text { of spool piece. }\end{array}$ & $\begin{array}{l}0-20.7 \mathrm{MPa} \\
\text { (gauge) }\end{array}$ & $\begin{array}{l}0-20.7 \mathrm{MPa} \\
\text { (gauge) }\end{array}$ & $>500 \mathrm{~Hz}$ & $\begin{array}{l}1,000 \mathrm{~Hz} \\
50 \mathrm{pps}\end{array}$ & $\begin{array}{l}80 \\
81\end{array}$ & $\begin{array}{l}\text { Restr.jined data. F } 1 \text { tered at } \\
500 \mathrm{~Hz} \text {. QEUD below } 500 \mathrm{~Hz} \text {. }\end{array}$ \\
\hline & $\begin{array}{l}\text { Broken Loop } \\
\text { PE-BL-6 }\end{array}$ & $\begin{array}{l}\text { Broken loop hot leg at outlet } \\
\text { of SG simulator. }\end{array}$ & $\begin{array}{l}0-20.7 \mathrm{MPa} \\
\text { (gauge) }\end{array}$ & $\begin{array}{l}0-20.7 \mathrm{MPa} \\
\text { (gauge) }\end{array}$ & $>500 \mathrm{rz}$ & $\begin{array}{l}1,000 \mathrm{~Hz} \\
50 \mathrm{pps}\end{array}$ & $\begin{array}{l}19 \\
82\end{array}$ & QQUD. \\
\hline & $\begin{array}{l}\text { Broken Loop } \\
\text { PE-BL-8 }\end{array}$ & $\begin{array}{l}\text { Broken loop cold leg at center } \\
\text { of spool piece. }\end{array}$ & $\begin{array}{l}0-20.7 \mathrm{MPa} \\
\text { (gauge) }\end{array}$ & $\begin{array}{l}0-20.7 \mathrm{MPa} \\
\text { (gauge) }\end{array}$ & $>500+2$ & $\begin{array}{l}1, \mathrm{COOOHz} \\
50 \mathrm{pps}\end{array}$ & $\begin{array}{l}18 \\
81\end{array}$ & QEUD. \\
\hline & $\begin{array}{l}\text { Reactor Vesse } 1 \\
\text { PE-CS-IA }\end{array}$ & $\begin{array}{l}\text { Core simulator stalk above } \\
\text { orifice plate, wide range } \\
(20.7 \mathrm{MPa}) \text {. }\end{array}$ & $\begin{array}{l}0-20.7 \mathrm{MPa} \\
\text { (gauge) }\end{array}$ & $\begin{array}{l}0-20.7 \mathrm{MPa} \\
\text { (gauge) }\end{array}$ & $45 \mathrm{~Hz}$ & $\begin{array}{l}1,000 \mathrm{~Hz} \\
50 \mathrm{pps}\end{array}$ & $\begin{array}{l}83 \\
88 \\
90\end{array}$ & QQUN. \\
\hline & $\begin{array}{l}\text { Reactor Vessel } \\
\text { PE-CS-18 }\end{array}$ & $\begin{array}{l}\text { Core simulator stalk above } \\
\text { orifice plate, narrow range } \\
(1.4 \mathrm{MPa}) \text {. }\end{array}$ & $\begin{array}{l}0-1.4 \mathrm{MPa} \\
\text { (gauge) }\end{array}$ & $\begin{array}{l}0-1.4 \mathrm{MPa} \\
\text { (gauge) }\end{array}$ & $45 \mathrm{~Hz}$ & $\begin{array}{l}1,600 \mathrm{~Hz} \\
50 \mathrm{pps}\end{array}$ & $\begin{array}{r}84 \\
148\end{array}$ & $\begin{array}{l}\text { Restrained data. Pressure } \\
\text { beyond instrunent range until } \\
T_{\dot{a}}+31 \text { s. }\end{array}$ \\
\hline \multirow[t]{4}{*}{. } & $\begin{array}{l}\text { Reactor Vessel } \\
\text { PE-CS-IFF }\end{array}$ & $\begin{array}{l}\text { Core simulator stalk above } \\
\text { orifice plate. }\end{array}$ & $\begin{array}{l}0-20.7 \mathrm{mPa} \\
\text { (gauge) }\end{array}$ & $\begin{array}{l}0-17.2 \mathrm{MPa} \\
\text { (gauge) }\end{array}$ & $4,100 \mathrm{~Hz}$ & $\begin{array}{l}1,000 \mathrm{~Hz} \\
50 \mathrm{pps}\end{array}$ & 21 & $\begin{array}{l}\text { Restrained data. Instrument } \\
\text { tempe-ature sensitive after } \\
\sim T_{0}+10 \mathrm{~s} \text {. }\end{array}$ \\
\hline & $\begin{array}{l}\text { Reactor Vessel } \\
\text { PE-CS-2FF }\end{array}$ & $\begin{array}{l}\text { Core simulator stalk above } \\
\text { orifice plate. }\end{array}$ & $\begin{array}{l}0-20.7 \mathrm{MPa} \\
\text { (gauge) }\end{array}$ & $\begin{array}{l}0-17.2 \mathrm{MPa} \\
\text { (gauge) }\end{array}$ & 4, $100 \mathrm{~Hz}$ & $\begin{array}{l}1,000 \mathrm{~Hz} \\
50 \mathrm{pps}\end{array}$ & 21 & $\begin{array}{l}\text { Restrained data. Instrument } \\
\text { temperature sensitive after } \\
\sim T_{0}+10 \mathrm{~s} \text {. }\end{array}$ \\
\hline & $\begin{array}{l}\text { Intact Loop } \\
\text { PE-PC-1 }\end{array}$ & $\begin{array}{l}\text { Intact loop cold leg at oT } \\
\text { flange. }\end{array}$ & $\begin{array}{l}0-20.7 \mathrm{MPa} \\
\text { (gauge) }\end{array}$ & $\begin{array}{l}0-20.7 \mathrm{MPa} \\
\text { (gauge) }\end{array}$ & $>500+z$ & $\begin{array}{l}1,000 \mathrm{~Hz} \\
50 \mathrm{pps}\end{array}$ & $\begin{array}{l}85 \\
87\end{array}$ & QEDD. Analog channel failed. \\
\hline & $\begin{array}{l}\text { Intact Loop } \\
\text { PE-PC-2 }\end{array}$ & $\begin{array}{l}\text { Intact loop hot leg at } 0 \pi T \\
\text { flange. }\end{array}$ & $\begin{array}{l}0-20.7 \mathrm{MPa} \\
\text { (gauge) }\end{array}$ & $\begin{array}{l}0-20.7 \mathrm{MPa} \\
\text { (gauge) }\end{array}$ & $>500 \mathrm{rz}$ & $\begin{array}{l}1,000 \mathrm{~Hz} \\
50 \mathrm{pps}\end{array}$ & $\begin{array}{l}20 \\
85 \\
87\end{array}$ & QEUD. \\
\hline
\end{tabular}


TABLE VII (contd.)

\begin{tabular}{|c|c|c|c|c|c|c|c|}
\hline \multirow[b]{2}{*}{$\begin{array}{l}\text { PARAMETER } \\
\text { System } \\
\text { Detector }\end{array}$} & \multirow[b]{2}{*}{ Location } & \multicolumn{2}{|c|}{ Range } & \multicolumn{2}{|c|}{ Frequency Response } & \multirow[b]{2}{*}{$\begin{array}{l}\text { Data } \\
\text { Fig. } \\
\text { No. }\end{array}$} & \multirow[b]{2}{*}{ Measurement Couments } \\
\hline & & Detector & $\begin{array}{l}\text { Data } \\
\text { Acquisition } \\
\text { Systea }\end{array}$ & Detectór & $\begin{array}{l}\text { Data[a] } \\
\text { Systead }\end{array}$ & & \\
\hline $\begin{array}{l}\text { Intact Loop } \\
\text { PE-PC-3A }\end{array}$ & $\begin{array}{l}\text { SG out let at } 0 \pi \text { flange, } \\
\text { wide range }(0-20.7 \mathrm{MPa}) \text {. }\end{array}$ & $\begin{array}{l}0-20.7 \mathrm{MPa} \\
\text { (gauge) }\end{array}$ & $\begin{array}{l}0-20.7 \mathrm{MPa} \\
\text { (gauge) }\end{array}$ & $>500 \mathrm{~Hz}$ & $\begin{array}{l}1,000 \mathrm{~Hz} \\
50 \mathrm{pps}\end{array}$ & $\begin{array}{l}20 \\
85\end{array}$ & QEUD. \\
\hline $\begin{array}{c}\text { Intact Loop } \\
\text { PE-PC-3B }\end{array}$ & $\begin{array}{c}\text { SG outlet at } \text { OTT flange, } \\
\text { narrow range }(0-1.4 \mathrm{MPa}) \\
-\end{array}$ & $\begin{array}{l}0-1.4 \mathrm{MPa} \\
\text { (gauge) }\end{array}$ & $\begin{array}{l}0-1.4 \mathrm{MPa} . \\
\text { (gauge) }\end{array}$ & $>500 \mathrm{~Hz}$ & 50 pps & $\begin{array}{r}86 \\
148\end{array}$ & $\begin{array}{l}\text { Restrained data. Pressure } \\
\text { beyond instrument range until } \\
\mathrm{T}_{0}+31 \mathrm{~s} .\end{array}$ \\
\hline $\begin{array}{l}\text { Intact Loop } \\
\text { PE-PC-4 }\end{array}$ & $\begin{array}{l}\text { Intact loop pressurizer } \\
\text { vapor space. }\end{array}$ & $\begin{array}{l}0-20.7 \mathrm{MPa} \\
\text { (gauge) }\end{array}$ & $\begin{array}{l}0-20.7 \mathrm{MPa} \\
\text { (gauge) }\end{array}$ & $>500 \mathrm{~Hz}$ & $\begin{array}{l}1,000 \mathrm{~Hz} \\
50 \mathrm{pps}\end{array}$ & $\begin{array}{l}20 \\
87\end{array}$ & QEUD. \\
\hline $\begin{array}{l}\text { Intact Loop } \\
\text { PE-PC-5 }\end{array}$ & Intact loop reference pressure. & $\begin{array}{l}0-20.68 \mathrm{MPa} \\
\text { (gauge) }\end{array}$ & $\begin{array}{l}0-20.68 \mathrm{MPa} \\
\text { (gauge) }\end{array}$ & -- & -- & -- & QEUD. Not presented. \\
\hline $\begin{array}{l}\text { Intact Loop } \\
\text { PE-PC-6 }\end{array}$ & Intact loop reference pressure. & $\begin{array}{l}0-20.68 \mathrm{MPa} \\
\text { (gauge) }\end{array}$ & $\begin{array}{l}0-20.68 \mathrm{MPa} \\
\text { (gauge) }\end{array}$ & -- & -- & -- & QEUD. Not presented. \\
\hline $\begin{array}{l}\text { Blowdown Suppres- } \\
\text { sion System } \\
\text { PE-SV-1 }\end{array}$ & $\begin{array}{l}\text { Blowdown suppression tank botton } \\
\text { under downcomer } 4 \text { (north end), } \\
180^{\circ} \text { fron top vertical (CW looking } \\
\text { north). }\end{array}$ & $\begin{array}{l}0-0.7 \mathrm{MPa} \\
\text { (gauge) }\end{array}$ & $\begin{array}{l}0-0.7 \mathrm{MPa} \\
\text { (gauge) }\end{array}$ & $500 \mathrm{~Hz}$ & $\begin{array}{l}1,000 \mathrm{~Hz} \\
500 \mathrm{pFS}\end{array}$ & $\begin{array}{r}23 \\
91 \\
163\end{array}$ & $\begin{array}{l}\text { QEUD. Filtered to } 60 . \mathrm{Hz} \text {. } \\
\text { All BDST Fressure instrument } \\
\text { initial values are adjusted } \\
\text { to } 0.01 \text { MFa. Use PT-P138-56 } \\
\text { and }-57 \text { ta. obtain the initial } \\
\text { pressure for all [PE-SV-]. }\end{array}$ \\
\hline $\begin{array}{l}\text { Blowdown Suppres- } \\
\text { sion System } \\
\text { PE-SV-2 }\end{array}$ & $\begin{array}{l}\text { Blowdown suppression tank across } \\
\text { from downcomer } 4 \text { (north end), } \\
112.5^{\circ} \text { from top vertical (CW } \\
\text { looking north). }\end{array}$ & $\begin{array}{l}0-0.7 \mathrm{MPa} \\
\text { (gauge) }\end{array}$ & $\begin{array}{l}0-0.7 \mathrm{MPa} \\
\text { (gauge) }\end{array}$ & $500 \mathrm{~Hz}$ & $500 \mathrm{pF} \cdot \mathrm{s}$ & 92 & QEUD. \\
\hline $\begin{array}{l}\text { Blowdown Suppres- } \\
\text { sion System } \\
\text { PE-SV-3 }\end{array}$ & $\begin{array}{l}\text { Blowdown suppression tank across } \\
\text { from downcomer } 1 \text { (south end), } \\
157.5^{\circ} \text { from top vertical (CW } \\
\text { looking north). }\end{array}$ & $\begin{array}{l}0-0.7 \mathrm{MPa} \\
\text { (gauge) }\end{array}$ & $\begin{array}{l}0-0.7 \mathrm{MPa} \\
\text { (gauge) }\end{array}$ & $500 \mathrm{~Hz}$ & $\begin{array}{l}1,000 \mathrm{~Hz} \\
500 \mathrm{pF} \cdot \mathrm{s}\end{array}$ & 23 & QEUD. \\
\hline
\end{tabular}


TABLE VII (contd.)

\begin{tabular}{|c|c|c|c|c|c|c|c|c|}
\hline \multirow[b]{2}{*}{$\begin{array}{l}\text { PARAMETER } \\
\text { System } \\
\text { Detector }\end{array}$} & \multirow[b]{2}{*}{ Location } & \multicolumn{2}{|c|}{ Range } & \multicolumn{3}{|c|}{ Frequency Response } & \multirow[b]{2}{*}{$\begin{array}{l}\text { Deta } \\
\text { Fig. } \\
\text { No. }\end{array}$} & \multirow[b]{2}{*}{ Measurement Coments } \\
\hline & & Detector & $\begin{array}{c}\text { Data } \\
\text { Acquisition } \\
\text { Syste }\end{array}$ & Detector & & $\begin{array}{l}\text { Data[a] } \\
\text { System }\end{array}$ & & \\
\hline $\begin{array}{l}\text { Blowdiown Suppres- } \\
\text { sion System } \\
\text { PE-SV-4 }\end{array}$ & $\begin{array}{l}\text { Blowdown suppression tank across } \\
\text { from downcomer } 1 \text { (solth end). } \\
112.5^{\circ} \text { from top vertical (CW } \\
\text { looking north). }\end{array}$ & $\begin{array}{l}0-0.7 \mathrm{MPa} \\
\text { (gauge) }\end{array}$ & $\begin{array}{l}0-0.7 \mathrm{MPa} \\
\text { (gauge) }\end{array}$ & $500: 12$ & & 500 pps & 92 & $\begin{array}{l}\text { QEUD. All BDST pressure instru- } \\
\text { ment initial values are adjusted } \\
\text { te } 0 .[1 \text { MPa. Use PT-PI38-56 and } \\
\text {-57 t: obtain the initial pres- } \\
\text { sLre for all [PE-SV-]. }\end{array}$ \\
\hline $\begin{array}{l}\text { Blowdown Suppres- } \\
\text { sion System } \\
\text { PE-SV-10 } \\
\end{array}$ & $\begin{array}{l}\text { Blowdown suppression tank A-end } \\
\text { (north end), } 10^{\circ} \text { from tank } \\
\text { horizontal } \mathcal{E}(\mathrm{CW} \text { looking west) } \\
\text { (vertex of dngle at intersection } \\
\text { of downcomer } 4 \mathrm{E} \text { and tank hori- } \\
\text { horizontal } \mathcal{E} \text { ). }\end{array}$ & $\begin{array}{l}0-0.7 \mathrm{MPa} \\
\text { (gauge) }\end{array}$ & $\begin{array}{l}0-0.7 \text { MPa } \\
\text { (gauge) }\end{array}$ & $50 \mathrm{CHz}$ & & 500 pps & 93 & QEUD. \\
\hline $\begin{array}{l}\text { Blowdown Suppres- } \\
\text { sion System } \\
\text { PE-SV-11 }\end{array}$ & $\begin{array}{l}\text { Blowdown suppression tank B-end } \\
\text { (south end), } 10^{\circ} \text { from tank } \\
\text { horizontal } \mathcal{E}(\mathrm{CCW} \text { looking west) } \\
\text { (vertex of angle at intersect ion } \\
\text { of downcomer } 1 \mathcal{E} \text { and tank } \mathcal{E} \text { ). }\end{array}$ & $\begin{array}{l}0-0.7 \mathrm{MPa} \\
\text { (gauge) }\end{array}$ & $\begin{array}{l}0-0.7 \mathrm{MPa} \\
\text { (gauge) }\end{array}$ & $500 \mathrm{Az}$ & & 50C pps & -- & Channel failed. \\
\hline $\begin{array}{l}\text { Blowdown Suppres- } \\
\text { sion System } \\
\text { PE-SV-12 }\end{array}$ & $\begin{array}{l}\text { B lowdown suppression tank A-End } \\
\text { (north end), } 45^{\circ} \text { from tank } \\
\text { horizontal } \mathrm{E} \text { (CW looking west) } \\
\text { (vertex of angle at intersection } \\
\text { of downcomer } 4 \mathrm{E} \text { and tank hori- } \\
\text { zontal } \mathrm{C} \text { ). }\end{array}$ & $\begin{array}{l}0-0.7 \mathrm{MPa} \\
\text { (gauge) }\end{array}$ & $\begin{array}{l}0-0.7 \mathrm{MPa} \\
\text { (gauge) }\end{array}$ & $500 \mathrm{~Hz}$ & & $500 \mathrm{pps}$ & 93 & QEJD. \\
\hline $\begin{array}{l}\text { Blowdown Suppres- } \\
\text { sion System } \\
\text { PE-5V-13 }\end{array}$ & $\begin{array}{l}\text { Blowdown suppression tank B-end } \\
\text { (south end), } 45^{\circ} \text { from tank } \\
\text { horizontal } \mathrm{E} \text { (CCW looxing west) } \\
\text { (vertex of angle at i itersection } \\
\text { of downcomer i } E \text { and tank hori- } \\
\text { zontal } E \text { ). }\end{array}$ & $\begin{array}{l}0-0.7 \mathrm{MPa} \\
\text { (gauge) }\end{array}$ & $\begin{array}{l}0-0.7 \mathrm{MPa} \\
\text { (gauge) }\end{array}$ & $500 \mathrm{rz}$ & & $500 \mathrm{pps}$ & 94 & QE JD. \\
\hline
\end{tabular}


TABLE VII (contd.)

\begin{tabular}{|c|c|c|c|c|c|c|c|}
\hline \multirow[b]{2}{*}{$\begin{array}{l}\text { PARAMETER } \\
\text { System } \\
\text { Detector }\end{array}$} & \multirow[b]{2}{*}{ Location } & \multicolumn{2}{|c|}{ Range } & \multicolumn{2}{|c|}{ Frequency Response } & \multirow[b]{2}{*}{$\begin{array}{l}\text { Data } \\
\text { Fig. } \\
\text { Ho. }\end{array}$} & \multirow[b]{2}{*}{ Measurement coments } \\
\hline & & Detector & $\begin{array}{l}\text { Data } \\
\text { Acquisition } \\
\text { Systea }\end{array}$ & Detector & $\underset{\substack{\text { Datad } \\
\text { Systea }}}{[a]}$ & & \\
\hline $\begin{array}{l}\text { Blowdown. Suppres- } \\
\text { sion System } \\
\text { PE-SV-14 }\end{array}$ & $\begin{array}{l}\text { Blowdown suppression tank header } \\
\text { above downcomer } 4,327^{\circ} \text { from top } \\
\text { vertical (CW looking north). }\end{array}$ & $\begin{array}{l}0-0.7 \mathrm{MPa} \\
\text { (gauge) }\end{array}$ & $\begin{array}{l}0-0.7 \mathrm{MPa} \\
\text { (gauge) }\end{array}$ & $500 \mathrm{~Hz}$ & $500 \mathrm{pps}$ & 95 & $\begin{array}{l}\text { QEUD. All BDST pressure instru- } \\
\text { ment initial values are adjusted } \\
\text { to } 0.01 \mathrm{mPa} \text { Use PT-P138-56 and } \\
-57 \text { to obtain the Initial pres- } \\
\text { sure for all [PE-SV-]. }\end{array}$ \\
\hline $\begin{array}{l}\text { Blowdown Suppres- } \\
\text { sion System } \\
\text { PE-sV-15 }\end{array}$ & $\begin{array}{l}\text { Blowdown suppression tank across } \\
\text { from downcomer } 4,230^{\circ} \text { from } \\
\text { top vertical (CW looking north). }\end{array}$ & $\begin{array}{l}0-0.7 \mathrm{MPa} \\
\text { (gauge) }\end{array}$ & $\begin{array}{l}0-0.7 \mathrm{MPa} \\
\text { (gauge) }\end{array}$ & $500 \mathrm{~Hz}$ & 500 pps & 96 & QEUD. \\
\hline $\begin{array}{l}\text { Blowdown Suppres- } \\
\text { sion System } \\
\text { PE-SV-16 }\end{array}$ & $\begin{array}{l}\text { Blowdown suppression tank across } \\
\text { from downcomer } 1,230^{\circ} \text { from } \\
\text { top vertical (CW looking north). }\end{array}$ & $\begin{array}{l}0-0.7 \mathrm{MPa} \\
\text { (gauge) }\end{array}$ & $\begin{array}{l}0-0.7 \mathrm{MPa} \\
\text { (gauge) }\end{array}$ & $500 \mathrm{~Hz}$ & $500 \mathrm{pps}$ & 96 & QEUD. \\
\hline $\begin{array}{l}\text { Blowdown Suppres- } \\
\text { sion System } \\
\text { PE-SV-17. }\end{array}$ & $\begin{array}{l}\text { Blowdown suppression tank, } \\
1.38 \text { m north of downcomer } 3 \text {. E } \\
327^{\circ} \text { from top vertical (Cw loking } \\
\text { north). }\end{array}$ & $\begin{array}{l}0-0.7 \mathrm{MPa} \\
\text { (gauge) }\end{array}$ & $\begin{array}{l}0-0.7 \mathrm{MPa} \\
\text { (gauge) }\end{array}$ & $500 \mathrm{~Hz}$ & 500 pps & - & QEUD. Nat presented. \\
\hline $\begin{array}{l}\text { Blowdown Suppres- } \\
\text { sion System } \\
\text { PE-SV-18 }\end{array}$ & $\begin{array}{l}\text { Blowdown suppression tank header } \\
\text { above downcomer } 1 \text {. }\end{array}$ & $\begin{array}{l}0-0.7 \mathrm{MPa} \\
\text { (gauge) }\end{array}$ & $\begin{array}{l}0-0.7 \mathrm{MPa} \\
\text { (gauge) }\end{array}$ & $500 \mathrm{~Hz}$ & 500 Fps & $\begin{array}{r}24 \\
95 \\
164\end{array}$ & QEUD. \\
\hline $\begin{array}{l}\text { Blowdown Suppres- } \\
\text { sion System } \\
\text { PE-sV-22 }\end{array}$ & $\begin{array}{l}\text { Blowdown suppression tank bottom, } \\
1.38 \mathrm{~m} \text { north of downcomer } 3 \mathrm{E} \text {. }\end{array}$ & $\begin{array}{l}0-0.7 \mathrm{MPa} \\
\text { (gauge) }\end{array}$ & $\begin{array}{l}0-0.7 \mathrm{MPa} \\
\text { (gauge) }\end{array}$ & $500 \mathrm{~Hz}$ & $\begin{array}{l}1,00 \mathrm{CHz} \\
500 \mathrm{FPS}\end{array}$ & $\begin{array}{r}24 \\
91 \\
163\end{array}$ & QEUD. \\
\hline $\begin{array}{l}\text { Blowdown Suppres- } \\
\text { sion System } \\
\text { PE-SV-23 }\end{array}$ & $\begin{array}{l}\text { Blowdown suppression tank, } \\
1.38 \mathrm{~m} \text { north of downcomer } 3 \\
112.5^{\circ} \text { from top vertical ( } \mathrm{CW} \text {, } \\
\text { looking north). }\end{array}$ & $\begin{array}{l}0-0.7 \mathrm{MPa} \\
\text { (gauge) }\end{array}$ & $\begin{array}{l}0-0.7 \mathrm{MPa} \\
\text { (gauge) }\end{array}$ & $500 \mathrm{~Hz}$ & $500 \mathrm{FPS}$ & 92 & QEUD. \\
\hline
\end{tabular}


TABLE VII (contd.)

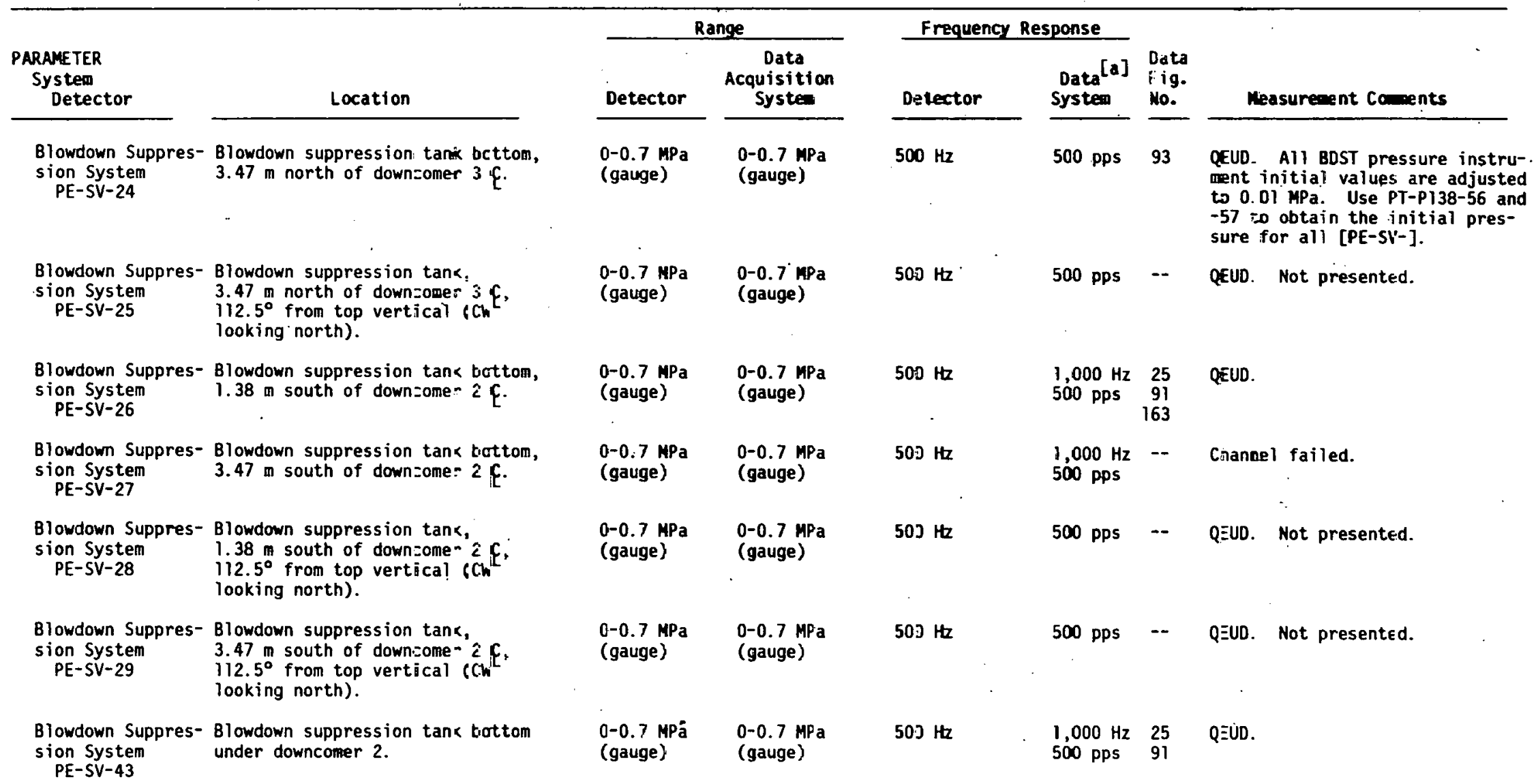


TABLE VII (contd.)

\begin{tabular}{|c|c|c|c|c|c|c|c|}
\hline \multirow[b]{2}{*}{$\begin{array}{l}\text { PARAMETER } \\
\text { System } \\
\text { Detector }\end{array}$} & \multirow[b]{2}{*}{ Location } & \multicolumn{2}{|c|}{ Range } & \multicolumn{2}{|c|}{ Frequency Response } & \multirow[b]{2}{*}{$\begin{array}{l}\text { Data } \\
\text { Fig. } \\
\text { No. }\end{array}$} & \multirow[b]{2}{*}{ Measurement Coments } \\
\hline & & Detector & $\begin{array}{l}\text { Data } \\
\text { Acquisition } \\
\text { System }\end{array}$ & Detector & $\begin{array}{l}\text { Data[a] } \\
\text { Systea }\end{array}$ & & \\
\hline $\begin{array}{l}\text { Blowdown Suppres-. } \\
\text { sion System } \\
\text { PE-SV-44 }\end{array}$ & $\begin{array}{l}\text { 8) owdown suppression tank bottom } \\
\text { under downcomer } 3 \text {. }\end{array}$ & $\begin{array}{l}0-0.7 \mathrm{MPa} \\
\text { (gauge) }\end{array}$ & $\begin{array}{l}0-0.7 \mathrm{MPa} \\
\text { (gauge) }\end{array}$ & $500 \mathrm{~Hz}$ & $\begin{array}{l}1,000 \mathrm{~Hz} \\
500 \mathrm{pps}\end{array}$ & $\begin{array}{l}25 \\
91\end{array}$ & $\begin{array}{l}\text { QEUD. Al.1 BDST pressure instru- } \\
\text { ment initial values are adjusted } \\
\text { to } 0.01 \text { MPa. Use PT-P } 138-56 \text { and } \\
-57 \text { to obtain the initial pres- } \\
\text { sure for all [PE-SV-]. }\end{array}$ \\
\hline $\begin{array}{l}\text { Blowdown Suppres- } \\
\text { sion System } \\
\text { PE-SV-54 }\end{array}$ & $\begin{array}{l}\text { Blowdown yacuum relief system } \\
\text { rupture disc standpipe. }\end{array}$ & $\begin{array}{l}0-0.7 \mathrm{MPa} \\
\text { (gauge) }\end{array}$ & $\begin{array}{l}0-0.7 \mathrm{MPa} \\
\text { (gauge) }\end{array}$ & $500 \mathrm{~Hz}$ & 500 FPs & -- & QEUD. Hct presented. \\
\hline $\begin{array}{l}\text { Blowdown Suppres- } \\
\text { sion System } \\
\text { PE-SV-55 }\end{array}$ & $\begin{array}{l}\text { Blowdown suppression tank top, } \\
0.15 \mathrm{~m} \text { north of downcomer } 4 E \text {. }\end{array}$ & $\begin{array}{l}0-0.7 \mathrm{MPa} \\
\text { (gauge) }\end{array}$ & $\begin{array}{l}0-0.7 \mathrm{MPa} \\
\text { (gauge) }\end{array}$ & $500 \mathrm{~Hz}$ & 500 fPS & -- & Channel failed. \\
\hline $\begin{array}{l}\text { Blowdown Suppres- } \\
\text { sion System } \\
\text { PE-SV-57 }\end{array}$ & $\begin{array}{l}\text { Blowdown suppression tank across } \\
\text { from downconer } 4,45^{\circ} \text { from } \\
\text { top vertical (CW looking north). }\end{array}$ & $\begin{array}{l}0-0.7 \mathrm{MPa} \\
\text { (guage) }\end{array}$ & $\begin{array}{l}0-0.7 \mathrm{MPa} \\
\text { (gauge) }\end{array}$ & $500 \mathrm{~Hz}$ & 500 f.PS & -- & QEUD. Not presented. \\
\hline $\begin{array}{l}\text { Blowdown Suppres- } \\
\text { sion System } \\
\text { PE-SV-58 }\end{array}$ & $\begin{array}{l}\text { Blowdown suppression tank across } \\
\text { from downcomer } 4,67.5^{\circ} \text { from top } \\
\text { vertical (CW looking north). }\end{array}$ & $\begin{array}{l}0-0.7 \stackrel{\text { Ma }}{\text { (gauge) }} \\
\text { (a) }\end{array}$ & $\begin{array}{l}0-0.7 \mathrm{MPa} \\
\text { (gauge) }\end{array}$ & $500 \mathrm{~Hz}$ & 500 fps & 97 & QEUD. \\
\hline $\begin{array}{l}\text { Blowdown Suppres- } \\
\text { sion System. } \\
\text { PE-SV-59 }\end{array}$ & $\begin{array}{l}\text { Blowdown suppression tank, } \\
1.67 \text { n north of downcomer } 3 \text {, } \\
45^{\circ} \text { from top vertical (CW } \\
\text { looking north). }\end{array}$ & $\begin{array}{l}0-0.7 \mathrm{MPa} \\
\text { (gauge) }\end{array}$ & $\begin{array}{l}0-0.7 \mathrm{MPa} \\
\text { (gauge) }\end{array}$ & $500 \mathrm{~Hz}$ & 500 pps & -- & LnanNe \\
\hline $\begin{array}{l}\text { Blowdown Suppres- } \\
\text { sion System } \\
\text { PE-SV-60 }\end{array}$ & $\begin{array}{l}\text { Blowdown suppression tank top } \\
\text { above downcomer } 1 \text {. }\end{array}$ & $\begin{array}{l}0-0.7 \mathrm{MPa} \\
\text { (gauge) }\end{array}$ & $\begin{array}{l}0-0.7 \mathrm{MPa} \\
\text { (gauge) }\end{array}$ & $500 \mathrm{~Hz}$ & 500 pps & $\because$ & Channel failed. \\
\hline
\end{tabular}


TABLE VII (contd.)

\begin{tabular}{|c|c|c|c|c|c|c|c|}
\hline \multirow[b]{2}{*}{$\begin{array}{l}\text { PARAMETER } \\
\text { System } \\
\text { Detector }\end{array}$} & \multirow[b]{2}{*}{ Location: } & \multicolumn{2}{|c|}{ Range } & \multicolumn{2}{|c|}{ Erequency Response } & \multirow[b]{2}{*}{$\begin{array}{l}\text { Data } \\
\text { Fig. } \\
\text { Ho. }\end{array}$} & \multirow[b]{2}{*}{ Measurement Cocments } \\
\hline & & Detector & $\begin{array}{l}\text { Data } \\
\text { Acquisition } \\
\text { System }\end{array}$ & Detector & $\begin{array}{l}\text { Data[a] } \\
\text { Systed }\end{array}$ & & \\
\hline $\begin{array}{l}\text { Blowdown Suppres- } \\
\text { sion System } \\
\text { PE-SV-61 }\end{array}$ & $\begin{array}{l}\text { Blowdown suppression tank } \\
\text { across from downcomer } 1 \\
67.5^{\circ} \text { from top vertical } \\
\text { (CW looking north). }\end{array}$ & $\begin{array}{l}0-0.7 \mathrm{MPa} \\
\text { (gauge) }\end{array}$ & $\begin{array}{l}0-0.7 \mathrm{MPa} \\
\text { (gauge) }\end{array}$ & $50 \mathrm{C} \cdot \mathrm{Hz}$ & 520 pas & 97 & $\begin{array}{l}\text { QEUD. All BDST pressure instru- } \\
\text { nent initial values are adjusted } \\
=0 \text { ( } 1.01 \text { MPa. Use PT-P } 38-56 \text { and } \\
-57 \text { to obtain the initial pres- } \\
\text { sure for all [PE-SV-]. }\end{array}$ \\
\hline $\begin{array}{l}\text { Blowdown Suppres- } \\
\text { sion System } \\
\text { PE-SV-70 }\end{array}$ & $\begin{array}{l}\text { Bellows between broken loop } \\
\text { and blowdown suppression tank } \\
\text { header. }\end{array}$ & $\begin{array}{l}0-3.4 \mathrm{MPa} \\
\text { (gauge) }\end{array}$ & $\begin{array}{l}0-3.4 \mathrm{MPa} \\
\text { (gauge) }\end{array}$ & $30 \mathrm{~Hz}$ & 500 pps & $\begin{array}{r}26 \\
165\end{array}$ & QEUE: \\
\hline $\begin{array}{l}\text { Blowdown Suppres- } \\
\text { sion System } \\
\text { PE-sV-75 }\end{array}$ & Blowdown suppression ta.k həader. & $\begin{array}{l}0-3.4 \mathrm{MPa} \\
\text { (gauge) }\end{array}$ & $\begin{array}{l}0-3.4 \mathrm{MPa} \\
\text { (gauge) }\end{array}$ & --- & $-\cdots$ & $\begin{array}{r}26 \\
166\end{array}$ & QEUC. \\
\hline $\begin{array}{l}\text { Reactor Vessel } \\
\text { PE-TST-1A }\end{array}$ & $\begin{array}{l}\text { Downcomer stalk } 1,0.62 \mathrm{~m} \text { asove } \\
\text { RV bottom, wide range }(\mathrm{J}-20.7 \mathrm{MPa}) \text {. }\end{array}$ & $\begin{array}{l}0-20.7 \mathrm{MPa} \\
\text { (gauge) }\end{array}$ & $\begin{array}{l}0-20.7 \mathrm{MPa} \\
\text { (gauge) }\end{array}$ & $30 \mathrm{~Hz}$ & $\begin{array}{l}1,0 \mathrm{j0} \mathrm{Hz} \\
50 \mathrm{sps}\end{array}$ & $\begin{array}{r}88 \\
100\end{array}$ & OQEUC. \\
\hline $\begin{array}{l}\text { Reactor Vessel } \\
\text { PE-1ST-IB }\end{array}$ & $\begin{array}{l}\text { Downcomer stalk } 1,0.62 . \mathrm{m} \text { asove } \mathrm{RV} \\
\text { botton, narrow range }(0-1.4 \mathrm{MPa}) \text {. }\end{array}$ & $\begin{array}{l}0-1.4 \mathrm{MPa} \\
\text { (gauge) }\end{array}$ & $\begin{array}{l}0-1.4 \mathrm{MPa} \\
\text { (gauge) }\end{array}$ & $30 \mathrm{~Hz}$ & 50 sps & 89 & $\begin{array}{l}\text { Restrained data. Pressure } \\
\text { beyand instrument range until } \\
-T_{a}+31 \text { s. }\end{array}$ \\
\hline $\begin{array}{l}\text { Reactor Vessel } \\
\text { PE-TST-IFF }\end{array}$ & $\begin{array}{l}\text { Downcomer stalk } 1,0.55 \mathrm{~m} \text { above RV } \\
\text { botton. }\end{array}$ & $\begin{array}{l}0-20.7 \mathrm{MPa} \\
\text { (gauge) }\end{array}$ & $\begin{array}{l}0-17.2 \mathrm{MPa} \\
\text { (gauge) }\end{array}$ & 4. $100 \mathrm{~Hz}$ & $\begin{array}{l}1,030 \mathrm{~Hz} \\
50 \mathrm{Jps}\end{array}$ & 22 & $\begin{array}{l}\text { Restrained data. Instrument } \\
\text { temperature sensitive after } \\
\text { T }+10 \text { s. Channel failed } \\
\text { (ang-og). }\end{array}$ \\
\hline $\begin{array}{l}\text { Reactor Vessel } \\
\text { PE-1ST-3A }\end{array}$ & $\begin{array}{l}\text { Oowncomer stalk } 1,5.32 \mathrm{~m} \text { above } \\
\text { RV bottom, wide range }(0-20.7 \mathrm{MPa}) \text {. }\end{array}$ & $\begin{array}{l}0-20.7 \mathrm{MPa} \\
\text { (gauge) }\end{array}$ & $\begin{array}{l}0-20.7 \mathrm{MPa} \\
\text { (gauge) }\end{array}$ & 4: Hz & $\begin{array}{l}1,0.30 \mathrm{~Hz} \\
50 \mathrm{pps}\end{array}$ & 88 & GEUD. \\
\hline $\begin{array}{l}\text { Reactor Vessel } \\
\text { PE-1ST-3B }\end{array}$ & $\begin{array}{l}\text { Downcomer stalk } 1,5.32 \mathrm{~m} \text { above } \\
\text { RV bottom, narrow renge }(0-1.4 \mathrm{MPa}) \text {. }\end{array}$ & $\begin{array}{l}0-1.4 \mathrm{MPa} \\
\text { (gauge) }\end{array}$ & $\begin{array}{l}0-1.4 \mathrm{MPa} \\
\text { (gauge) }\end{array}$ & $4 i+z$ & 50 pps & 89 & $\begin{array}{l}\text { Festrained data. Pressure } \\
\text { teyond instrument range until } \\
T_{0}+30 \mathrm{~s} .\end{array}$ \\
\hline
\end{tabular}


TABLE VII (contd.)

\begin{tabular}{|c|c|c|c|c|c|c|c|}
\hline \multirow[b]{2}{*}{$\begin{array}{l}\text { PARAMETER } \\
\text { System } \\
\text { Detector }\end{array}$} & \multirow[b]{2}{*}{ Location } & \multicolumn{2}{|c|}{ Range } & \multicolumn{2}{|c|}{ Frequency Response } & \multirow[b]{2}{*}{$\begin{array}{l}\text { Data } \\
\text { Fig. } \\
\text { Mo. }\end{array}$} & \multirow[b]{2}{*}{ Measurement Comments } \\
\hline & & Detector & $\begin{array}{l}\text { Data } \\
\text { Acquisition } \\
\text { System }\end{array}$ & Detector & $\begin{array}{l}\text { Data[a] } \\
\text { System }\end{array}$ & & \\
\hline $\begin{array}{l}\text { Reactor Vessel } \\
\text { PE-IST-3FF }\end{array}$ & $\begin{array}{l}\text { Downcomer stalk } 1,5.39 \mathrm{~m} \text { above } \\
\text { RV bottom. }\end{array}$ & $\begin{array}{l}0-20.7 \mathrm{MPa} \\
\text { (gauge) }\end{array}$ & $\begin{array}{l}0-17.2 \mathrm{MPa} \\
\text { (gauge) }\end{array}$ & $4,100 \mathrm{~Hz}$ & $\begin{array}{l}1,000: \mathrm{iz} \\
50 \mathrm{pps}\end{array}$ & 22 & $\begin{array}{l}\text { Restrained data. Instrument } \\
\text { temperature sensitive after } \\
\sim T_{0}+10 \mathrm{~s} \text {. }\end{array}$ \\
\hline $\begin{array}{l}\text { Reactor Vessel } \\
\text { PE-2ST-1A }\end{array}$ & $\begin{array}{l}\text { Downcomer stalk } 2,0.62 \mathrm{~m} \text { above } \\
\text { RV botton, wide range }(0-20.7 \mathrm{MPa}) \text {. }\end{array}$ & $\begin{array}{l}0-20.7 \mathrm{MPa} \\
\text { (gauge) }\end{array}$ & $\begin{array}{l}0-20.7 \mathrm{MPa} \\
\text { (gauge) }\end{array}$ & $30 \mathrm{~Hz}$ & $\begin{array}{l}1,000 \mathrm{~Hz} \\
50 \mathrm{pps}\end{array}$ & 90 & QEUD. \\
\hline $\begin{array}{l}\text { Reactor Vessel } \\
\text { PE-2ST-1B }\end{array}$ & $\begin{array}{l}\text { Downcomer stalk } 2,0.62 \mathrm{~m} \text { above } \\
\text { RV bottom, narrow range }(0-1.4 \mathrm{MPa}) \text {. }\end{array}$ & $\begin{array}{l}0-1.4 \mathrm{MPa} \\
\text { (gauge) }\end{array}$ & $\begin{array}{l}0-1.4 \mathrm{MPa} \\
\text { (gauge) }\end{array}$ & $30 \mathrm{~Hz}$ & 50 pps. & -. & $\begin{array}{l}\text { Restrained data. Pressure } \\
\text { beyond instrument range until } \\
\sim \mathrm{T}_{0}+30 \mathrm{~s} \text {. }\end{array}$ \\
\hline $\begin{array}{l}\text { Reactor Vesse1 } \\
\text { PE-2ST-IFF }\end{array}$ & $\begin{array}{l}\text { Downconer stalk } 2,0.55 \mathrm{~m} \text { above } \\
\text { RV bottom. }\end{array}$ & $\begin{array}{l}0-20.7 \mathrm{MPa} \\
\text { (gauge) }\end{array}$ & $\begin{array}{l}0-17.2 \mathrm{MPa} \\
\text { (gauge) }\end{array}$ & $4,100 \mathrm{~Hz}$ & $\begin{array}{l}1,000 \mathrm{~Hz} \\
50 \mathrm{pps}\end{array}$ & 22 & $\begin{array}{l}\text { Restrained data. Instrument } \\
\text { temperature sensitive after } \\
\sim T_{0}+10 \mathrm{~s} \text {. }\end{array}$ \\
\hline $\begin{array}{l}\text { Reactor Vesse1 } \\
\text { PE-2ST-3FF }\end{array}$ & $\begin{array}{l}\text { Downcomer stalk 2, } 5.39 \text { a above } \\
\text { RV bottom. }\end{array}$ & $\begin{array}{l}0-20.7 \mathrm{MPa} \\
\text { (gauge) }\end{array}$ & $\begin{array}{l}0-17.2 \mathrm{MPa} \\
\text { (gauge) }\end{array}$ & $4,100 \mathrm{~Hz}$ & $\begin{array}{l}1,000 \mathrm{~Hz} \\
50 \mathrm{pps}\end{array}$ & 22 & $\begin{array}{l}\text { Restrained data. - Instrument } \\
\text { temperature sensitive after } \\
\sim T_{0}+10 \mathrm{~s} \text {. }\end{array}$ \\
\hline $\begin{array}{l}\text { Emergency Core } \\
\text { Cooling System } \\
\text { PT-PI 20-43 }\end{array}$ & $\begin{array}{l}\text { Accunulator } A, 0.69 \mathrm{~m} \text { above water } \\
\text { out let. }\end{array}$ & $\begin{array}{l}0-6.9 \mathrm{MPa} \\
\text { (gauge) }\end{array}$ & $\begin{array}{l}0-6.9 \mathrm{MPa} \\
\text { (gauge) }\end{array}$ & $5 \mathrm{~Hz}$ & 50 pps & $\begin{array}{r}98 \\
100\end{array}$ & QEUD. \\
\hline $\begin{array}{l}\text { Emergency Core } \\
\text { Cooling. Systen } \\
\text { PT-P120-61 }\end{array}$ & $\begin{array}{l}\text { Emergency core cooling injection } \\
\text { into cold leg. }\end{array}$ & $\begin{array}{l}0-20.7 \mathrm{MPa} \\
\text { (gauge) }\end{array}$ & $\begin{array}{l}0-20.7 \mathrm{MPa} \\
\text { (gauge) }\end{array}$ & $5 \mathrm{~Hz}$. & 50 pps & $\begin{array}{r}99 \\
100 \\
149\end{array}$ & QEUD. \\
\hline $\begin{array}{l}\text { Emergency Core } \\
\text { Cooling System } \\
\text { PT-P120-83 }\end{array}$ & LPIS pump A discharge line. & $\begin{array}{l}0-6.9 \mathrm{MPa} \\
\text { (gauge) }\end{array}$ & $\begin{array}{l}0-6.9 \mathrm{MPa} \\
\text { (gauge) }\end{array}$ & $5 \mathrm{~Hz}$ & $50 \mathrm{pps}$ & $\begin{array}{l}101 \\
150\end{array}$ & QEUD. \\
\hline
\end{tabular}


TABLE VII (contd.)

\begin{tabular}{|c|c|c|c|c|c|c|c|}
\hline \multirow[b]{2}{*}{$\begin{array}{l}\text { PARAMETER } \\
\text { System } \\
\text { Detector }\end{array}$} & \multirow[b]{2}{*}{ Location } & \multicolumn{2}{|c|}{ Range } & \multicolumn{2}{|c|}{ Frequency Response } & \multirow[b]{2}{*}{$\begin{array}{l}\text { Lata } \\
\text { Fig. } \\
\text { po. }\end{array}$} & \multirow[b]{2}{*}{ Measurement Coments } \\
\hline & & Detector & $\begin{array}{l}\text { Data } \\
\text { Acquisition } \\
\text { Systea }\end{array}$ & [ietector & $\underset{\text { Syszea }}{\operatorname{Da}_{y}[\mathrm{a}]}$ & & \\
\hline $\begin{array}{l}\text { Blowdown Suppres- } \\
\text { sion System } \\
\text { PT-P138-23 }\end{array}$ & $\begin{array}{l}\text { Blowdown header, } 0.89 \mathrm{~m} \text { south } \\
\text { of downcomer } 1,5^{\circ}=\text { rom bottiom } \\
\text { vertical (CCW looking south). }\end{array}$ & $\begin{array}{l}0-1.4 \mathrm{MPa} \\
\text { (gauge) }\end{array}$ & $\begin{array}{l}0-1.4 \mathrm{MPa} \\
\text { (gauge) }\end{array}$ & is tiz & 50 Jps & -- & QEULI. Not presented. \\
\hline $\begin{array}{l}\text { Blowdown Suppres- } \\
\text { sion System } \\
\text { PT- } 138-55\end{array}$ & $\begin{array}{l}\text { Blowdown suppressiod tank tup, } \\
1.22 \mathrm{~m} \text { north of downcomer } 1 \text {. }\end{array}$ & $\begin{array}{l}0-0.69 \mathrm{MPa} \\
\text { (gauge) }\end{array}$ & $\begin{array}{l}0-0.69-\mathrm{MPa} \\
\text { (gauge) }\end{array}$ & 5 Ht & $\begin{array}{l}1,0,00 \mathrm{~Hz} \\
50^{3 p s}\end{array}$ & 112 & $\begin{array}{l}\text { QEUC. Short-term analog not } \\
\text { reviewed. }\end{array}$ \\
\hline $\begin{array}{l}\text { Blowdown Suppres: } \\
\text { sion System } \\
\text { PT-P138-56 }\end{array}$ & $\begin{array}{l}\text { Blowdown suppression taink t.jp, } \\
1.24 \mathrm{~m} \text { north of downcomer } 2 \text {. }\end{array}$ & $\begin{array}{l}0-0.69 \mathrm{MPa} \\
\text { (gauge) }\end{array}$ & $\begin{array}{l}0-0.69 \mathrm{MPa} \\
\text { (gauge) }\end{array}$ & 5 Hb & $\begin{array}{l}1,0,00 \mathrm{~Hz} \\
50 \mathrm{pps}\end{array}$ & $\begin{array}{l}182 \\
157\end{array}$ & $\begin{array}{l}\text { qEUC. Short-term analog not } \\
\text { reviewed. }\end{array}$ \\
\hline $\begin{array}{l}\text { Blowdown Suppres- } \\
\text { sian System } \\
\text { PT-P138-57 }\end{array}$ & $\begin{array}{l}\text { Blowdown suppression tank vapor } \\
\text { space, Channel } \mathrm{C} \text {. }\end{array}$ & $\begin{array}{l}0-0.69 \mathrm{MPa} \\
\text { (gauge) }\end{array}$ & -.- & $-\cdots$ & -- & 167 & Q̣EUD. \\
\hline $\begin{array}{l}\text { Broken Loop } \\
\text { PT-P138-111 }\end{array}$ & $\begin{array}{l}\text { Broken loop cold leg QOBV inlet } \\
\text { between isolation velve and QDBV. }\end{array}$ & $\begin{array}{l}0-13.8 \mathrm{MPa} \\
\text { (gauge) }\end{array}$ & $\begin{array}{l}-13.8-+13.8 \\
\text { ipa (gauge) }\end{array}$ & $5 \mathrm{~Hz}$ & $\begin{array}{l}1,000 \mathrm{~Hz} \\
500 \mathrm{pPs}\end{array}$ & 17 & QEUD analog data only. \\
\hline $\begin{array}{l}\text { Broken Loop } \\
\text { PT-P138- } 112\end{array}$ & $\begin{array}{l}\text { Broken loop hot leg QOBV inlet } \\
\text { between isolation valive and QDBV. }\end{array}$ & $\begin{array}{l}0-13.8 \mathrm{MPa} \\
\text { (gauge) }\end{array}$ & $\begin{array}{l}-13.8-+13.8 \\
\text { ipa (gauge) }\end{array}$ & j $\mathrm{Hz}$ & $\begin{array}{l}1,000 \mathrm{~Hz} \\
500 \mathrm{pPs}\end{array}$ & -- & Channel failed. \\
\hline $\begin{array}{l}\text { Blowdown Suppres- } \\
\text { sion Tank Spray } \\
\text { System } \\
\text { PT-P138-136 }\end{array}$ & $\begin{array}{l}\text { Spray pump BS-P-83 cischarge } \\
\text { pressure. }\end{array}$ & $\begin{array}{l}0-3.4 \mathrm{MPa} \\
\text { (gauge) }\end{array}$ & $\begin{array}{l}0-3.4 \mathrm{MPa} \\
\text { (gauge) }\end{array}$ & j. $\mathrm{Hz}$ & 50 pps & $\begin{array}{l}151 \\
1 \in 8\end{array}$ & CEUD \\
\hline $\begin{array}{l}\text { Blowdown Suppres- } \\
\text { sion Tank Spray } \\
\text { System }\end{array}$ & $\begin{array}{l}\text { Spray systen cool down heat } \\
\text { exchanger outlet pressure. }\end{array}$ & $\begin{array}{l}0-3.4 \mathrm{MPa} \\
\text { (gauge) }\end{array}$ & $\begin{array}{l}0-3.4 \mathrm{MPa} \\
\text { (gauge) }\end{array}$ & j $\mathrm{Hz}$ & $50 . \mathrm{pps}$ & $\begin{array}{l}1 \leq 1 \\
1 \in 8\end{array}$ & CEUD: \\
\hline
\end{tabular}


TABLE VII (contd.)

\begin{tabular}{|c|c|c|c|c|c|c|c|}
\hline \multirow[b]{2}{*}{$\begin{array}{l}\text { PARAMETER } \\
\text { System } \\
\text { Detector }\end{array}$} & \multirow[b]{2}{*}{ Location } & \multicolumn{2}{|c|}{ Range } & \multicolumn{2}{|c|}{ Frequency Response } & \multirow[b]{2}{*}{$\begin{array}{l}\text { Data } \\
\text { Fig. } \\
\text { No. }\end{array}$} & \multirow[b]{2}{*}{ Measurement: Coments } \\
\hline & & Detector & $\begin{array}{l}\text { Data } \\
\text { Acquisition } \\
\text { System }\end{array}$ & Detector & $\begin{array}{l}\text { Data[a] } \\
\text { Systea }\end{array}$ & & \\
\hline $\begin{array}{l}\text { Intact Loop } \\
\text { PT-P139-2 }\end{array}$ & $\begin{array}{l}\text { Intact loop hot leg at venturi } \\
\text { on bottora. }\end{array}$ & $\begin{array}{l}0-20.7 \mathrm{MPa} \\
\text { (gauge) }\end{array}$ & $\begin{array}{l}0-20.7 \mathrm{MPa} \\
\text { (gauge) }\end{array}$ & $5 \mathrm{~Hz}$ & $\begin{array}{l}1,003 \mathrm{~Hz} \\
50 \mathrm{pos}\end{array}$ & 103 & QEUD. \\
\hline $\begin{array}{l}\text { Intact Loop } \\
\text { PT-P139-3 }\end{array}$ & $\begin{array}{l}\text { Intact loop hot leg at venturi } \\
\text { on left side when looking toward } \\
\text { SG. }\end{array}$ & $\begin{array}{l}0-20.7 \mathrm{mPa} \\
\text { (gauge) }\end{array}$ & $\begin{array}{l}0-20.7 \mathrm{MPa} \\
\text { (gauge) }\end{array}$ & $5 \mathrm{~Hz}$ & $\begin{array}{l}1,000 \mathrm{~Hz} \\
50 \mathrm{pps}\end{array}$ & 103 & QEUD. \\
\hline $\begin{array}{l}\text { Intact Loop } \\
\text { PT-P139-4 }\end{array}$ & $\begin{array}{l}\text { Intact loop hot leg at venturi } \\
\text { on right side when looking toward } \\
\text { SG. }\end{array}$ & $\begin{array}{l}0-20.7 \mathrm{MPa} \\
\text { (gauge) }\end{array}$ & $\begin{array}{l}0-20.7 \mathrm{MPa} \\
\text { (gauge) }\end{array}$ & $5 \mathrm{~Hz}$ & $\begin{array}{l}1,003 \mathrm{~Hz} \\
50 \mathrm{p} \text { ? }\end{array}$ & 103 & QEUD. \\
\hline \multicolumn{8}{|l|}{ PUMP SPEED } \\
\hline $\begin{array}{l}\text { Intact Loop } \\
\text { RPE-PC-1 }\end{array}$ & Intact loop punp 1 speed. & $0-4,500 \mathrm{rpm}$ & $0-10,000 \mathrm{rpq}$ & $3.5 \mathrm{~Hz}$ & 50 poss & $\begin{array}{l}104 \\
105\end{array}$ & QEUD. \\
\hline $\begin{array}{l}\text { Intact Loop } \\
\text { RPE-PC-2 }\end{array}$ & Intact loop pump 2 speed. & $0-4,500 \mathrm{rpm}$ & $0-10,000$ rp: & $3.5 \mathrm{~Hz}$ & 50 pos & $\begin{array}{l}104 \\
105\end{array}$ & $\begin{array}{l}\text { Restrained data. Unexplain- } \\
\text { able spikes. }\end{array}$ \\
\hline \multicolumn{8}{|l|}{ TEMPERATURE } \\
\hline $\begin{array}{l}\text { Broken Loop } \\
\text { TE-BL-IA }\end{array}$ & $\begin{array}{l}\text { Broken loop cold leg at } 0 \pi \text { rake } \\
\text { botton. }\end{array}$ & $0-1,260^{\circ} \mathrm{C}$ & $0-315.6^{\circ} \mathrm{C}$ & $1.8 \mathrm{~Hz}$ & 50 pगs & $\begin{array}{l}107 \\
108 \\
152\end{array}$ & QEUD. \\
\hline $\begin{array}{l}\text { Broken Loop } \\
\text { TE-BL-1B }\end{array}$ & $\begin{array}{l}\text { Broken loop cold leg at DTT rake } \\
\text { center. }\end{array}$ & $0-1,260^{\circ} \mathrm{C}$ & $0-315.6^{\circ} \mathrm{C}$ & $1.8 \mathrm{~Hz}$ & 50 pos & $\begin{array}{l}107 \\
108 \\
152\end{array}$ & QEUD. \\
\hline $\begin{array}{l}\text { Broken Loop } \\
\text { TE-BL-IC }\end{array}$ & $\begin{array}{l}\text { Broken loop cold leg at } 0 \pi T \text { rake } \\
\text { top. }\end{array}$ & $0-1,260^{\circ} \mathrm{C}$ & $0-315.6^{\circ} \mathrm{C}$ & $1.8 \mathrm{~Hz}$ & 50 pas & $\begin{array}{l}107 \\
108 \\
152\end{array}$ & QEUD. \\
\hline
\end{tabular}


TABLE VII (contd.)

\begin{tabular}{|c|c|c|c|c|c|c|c|}
\hline \multirow[b]{2}{*}{$\begin{array}{l}\text { PARAMETER } \\
\text { System } \\
\text { Detector }\end{array}$} & \multirow[b]{2}{*}{ Location } & \multicolumn{2}{|c|}{ Range } & \multicolumn{2}{|c|}{ Freque ncy Response } & \multirow[b]{2}{*}{$\begin{array}{l}\text { Data } \\
\text { Fig. } \\
\text { Mo. }\end{array}$} & \multirow[b]{2}{*}{ Masurement Coments } \\
\hline & & Detector & $\begin{array}{l}\text { Data } \\
\text { Acquisition } \\
\text { Systea }\end{array}$ & Detestor & $\begin{array}{l}\text { Data } \\
\text { Syste] }\end{array}$ & & \\
\hline $\begin{array}{l}\text { Broken Loop } \\
\text { TE-BL-2 }\end{array}$ & $\begin{array}{l}\text { Broken loop hot leg at DTI } \\
\text { flange. }\end{array}$ & $0-1,260^{\circ} \mathrm{C}$ & $0-315.6^{\circ} \mathrm{C}$ & $1.8+2$ & $50 \mathrm{pps}$ & $\begin{array}{l}107 \\
152\end{array}$ & $\begin{array}{l}\text { Restrained data. Data display } \\
\text { hot wall effects after } \sim T_{0} \\
+\$ 0 \mathrm{~s} .\end{array}$ \\
\hline $\begin{array}{l}\text { Broken Loop } \\
\text { TE-BL-3 }\end{array}$ & $\begin{array}{l}\text { Reflood assist bypass sys:en } \\
\text { near CV-P138-71. }\end{array}$ & $0-1,260^{\circ} \mathrm{C}$ & $0-315.6^{\circ} \mathrm{C}$ & 1.8: +.2 & 50 pps & 107 & Restrained data. \\
\hline $\begin{array}{l}\text { Broken Loop } \\
\text { TE-CL-1 }\end{array}$ & $\begin{array}{l}\text { Broken loop cold leg warm-up } \\
\text { line. }\end{array}$ & $0-1,260^{\circ} \mathrm{C}$ & $0-315.6^{\circ} \mathrm{C}$ & $1.8+.2$ & 50 pps & --- & $\begin{array}{l}\text { Instrument not connected for } \\
\text { test. }\end{array}$ \\
\hline $\begin{array}{l}\text { Reactor Vessel } \\
\text { TE-CS-1 }\end{array}$ & $\begin{array}{l}\text { Core simulator in instrumer.t } \\
\text { stalk above orifice plate. }\end{array}$ & $0-1,260^{\circ} \mathrm{C}$ & $0-315.6^{\circ} \mathrm{C}$ & 1.8. 1.2 & 50 pps & $\begin{array}{l}109 \\
153\end{array}$ & QEIJD. \\
\hline $\begin{array}{l}\text { Broken Loop } \\
\text { TE-HL-2 }\end{array}$ & $\begin{array}{l}\text { Broken loop hot leg warm- }\lrcorner \text {. } \\
\text { line. }\end{array}$ & $0-1,260^{\circ} \mathrm{C}$ & $0-315.6^{\circ} \mathrm{C}$ & $1.8+2$ & 50 pps & +- & $\begin{array}{l}\text { Instrument not connected for } \\
\text { test. }\end{array}$ \\
\hline $\begin{array}{l}\text { Intact Loop } \\
\text { TE-PC-1 }\end{array}$ & $\begin{array}{l}\text { Intact loop cold leg at } 0 \pi T \\
\text { flange. }\end{array}$ & $\mathrm{D}-1,260^{\circ} \mathrm{C}$ & $0-704.4^{\circ} \mathrm{C}$ & $1.8 \cdot+2$ & $\begin{array}{l}1,000 \mathrm{~Hz} \\
50 \mathrm{pps}\end{array}$ & $\begin{array}{l}110 \\
154\end{array}$ & $\begin{array}{l}\text { Restrained data. Displays hot } \\
\text { wall effects after } \& \mathrm{~T}_{0}+70 \mathrm{~s} .\end{array}$ \\
\hline $\begin{array}{l}\text { Intact Loop } \\
\text { TE-PC-2 }\end{array}$ & $\begin{array}{l}\text { Intact loop hot leg at DT } \\
\text { flange. }\end{array}$ & $\mathrm{D}-1,260^{\circ} \mathrm{C}$ & $0-704.4^{\circ} \mathrm{C}$ & $1.8+2$ & 50 pps & $\begin{array}{l}110 \\
154\end{array}$ & $\begin{array}{l}\text { Restrained data. Data display } \\
\text { ho: wall effects after } \sim T_{0} \\
+50 \mathrm{~s} .\end{array}$ \\
\hline $\begin{array}{l}\text { Intact Loop } \\
\text { TE-PC-3 }\end{array}$ & $\begin{array}{l}\text { Intact loop at SG outlet } \\
\text { DIT flange. }\end{array}$ & $0-1,260^{\circ} \mathrm{C}$ & $0-704.4^{\circ} \mathrm{C}$ & 1.8: $t z$ & 50 pps & $\begin{array}{l}110 \\
154\end{array}$ & $\begin{array}{l}\text { Restrained data. Display hot } \\
\text { wall effects after } \sim \mathrm{T}_{0}+45 \mathrm{~s} \text {. }\end{array}$ \\
\hline $\begin{array}{l}\text { Emergency Core } \\
\text { Cooling System } \\
\text { TE-P } 120-41\end{array}$ & Accumulator $A$ temperature. & $-17.8^{-+}+93.3^{\circ} \mathrm{C}$ & $C-17.8-+93.3^{\circ} \mathrm{C}$ & $7 \mathrm{~Hz}$ & 50 pps & 111 & Trend data. \\
\hline $\begin{array}{l}\text { Blowdown Suppres- } \\
\text { sion System } \\
\text { TE-P138-22 }\end{array}$ & $\begin{array}{l}\text { Blowdown suppression tank tottom, } \\
0.61 \text { morth of downc } 3 \text { mer } 1 \text {. }\end{array}$ & $10.0-148.9^{\circ} \mathrm{C}$ & $10.0-148.9^{\circ} \mathrm{C}$ & $7 \mathrm{~Hz}$ & 50 pps & 112 & $\begin{array}{l}\text { Trend Jata. Thermocouple } \\
\text { lo:ated in a stagnart fluid } \\
\text { zoce. }\end{array}$ \\
\hline
\end{tabular}




\section{TABLE VII (contd.)}

\begin{tabular}{|c|c|c|c|c|c|c|c|}
\hline \multirow[b]{2}{*}{$\begin{array}{l}\text { PARANETER } \\
\text { System } \\
\text { Detector }\end{array}$} & \multirow[b]{2}{*}{ Location } & \multicolumn{2}{|c|}{ Range } & \multicolumn{2}{|c|}{ Frequency Response } & \multirow[b]{2}{*}{$\begin{array}{l}\text { Data } \\
\text { Fig. } \\
\text { Mo. }\end{array}$} & \multirow[b]{2}{*}{ Measurement Coments } \\
\hline & & Detector & $\begin{array}{l}\text { Data } \\
\text { Acquisition } \\
\text { System }\end{array}$ & Detector & $\begin{array}{l}\text { Data } \\
\text { Systed }\end{array}$ & & \\
\hline $\begin{array}{l}\text { Blowdown Suppres- } \\
\text { sion System } \\
\text { TE-P138-34 }\end{array}$ & $\begin{array}{l}\text { Blowdown suppression tank top, } \\
1.30 \mathrm{~m} \text { south of downcomer } 4 .\end{array}$ & $10.0-204.4^{\circ} \mathrm{C}$ & $10.0-204.4^{\circ} \mathrm{C}$ & $1.8 \mathrm{~Hz}$ & 50 pps & 112 & QEUD. \\
\hline $\begin{array}{l}\text { Broken Loop } \\
\text { TE-P138-62 }\end{array}$ & Broken loop cold leg QOBV inlet. & $0-760.0^{\circ} \mathrm{C}$ & $10.0-343.3^{\circ} \mathrm{C}$ & $1: 8 \mathrm{~Hz}$ & 50 pps & 113 & Trend data. \\
\hline $\begin{array}{l}\text { Broken Loop } \\
\text { TE-P138-63 }\end{array}$ & $\begin{array}{l}\text { Broken loop cold leg isolation } \\
\text { valve inlet. }\end{array}$ & $10.0-343.3^{\circ} \mathrm{C}$ & $10.0-343.3^{\circ} \mathrm{C}$ & $0.06 \mathrm{~Hz}$ & 50 pps & 113 & Trend data. \\
\hline $\begin{array}{l}\text { Broken Loop } \\
\text { TE-P138-65 }\end{array}$ & $\begin{array}{l}\text { Broken loop hot leg isolation } \\
\text { valve inlet. }\end{array}$ & $10.0-343.3^{\circ} \mathrm{C}$ & $10.0-343.3^{\circ} \mathrm{C}$ & $0.06 \mathrm{~Hz}$ & 50 Pps & 114 & Trend data. \\
\hline $\begin{array}{l}\text { Broken Loop } \\
\text { TE-P1 38-66 }\end{array}$ & Broken loop hot leg QOBV inlet. & $0-760.0^{\circ} \mathrm{C}$ & $10.0-343.3^{\circ} \mathrm{C}$ & $1.8 \mathrm{~Hz}$ & 50 ग़ps & 114 & Trend data. \\
\hline $\begin{array}{l}\text { Blowdown Suppres- } \\
\text { sion Tank Spray } \\
\text { System } \\
\text { TE-P138-141 }\end{array}$ & $\begin{array}{l}\text { Temperature of spray in the } \\
3.79 \mathrm{l} / \mathrm{s} \text { header. }\end{array}$ & $-17.8-204.4^{\circ} \mathrm{C}$ & $\mathrm{C}-17.8-204.4^{\circ} \mathrm{C}$ & $7 \mathrm{~Hz}$ & 50 ग̣ps & $\begin{array}{l}156 \\
170\end{array}$ & Trend data. \\
\hline $\begin{array}{l}\text { Blowdown Suppres- } \\
\text { sion Tank Spray } \\
\text { System } \\
\text { TE-P138-142 }\end{array}$ & $\begin{array}{l}\text { Temperature of spray at spray } \\
\text { pump BS-P-83 discharge. }\end{array}$ & $-17.8-204.4^{\circ} \mathrm{C}$ & $\mathrm{C}-17.8-204.4^{\circ} \mathrm{C}$ & $7 \mathrm{~Hz}$ & 50 эps & $\begin{array}{l}155 \\
169\end{array}$ & Trend data. \\
\hline $\begin{array}{l}\text { B lowdown Suppres- } \\
\text { sion Tank Spray } \\
\text { System }\end{array}$ & $\begin{array}{l}\text { Temperature of spray in the } \\
13.88 \mathrm{l} / \mathrm{s} \text { header. }\end{array}$ & $-17.8-204.4^{\circ} \mathrm{C}$ & $\mathrm{C}-17.8-204.4^{\circ} \mathrm{C}$ & $7 \mathrm{~Hz}$ & 50 วps & $\begin{array}{l}156 \\
170\end{array}$ & Trend data. \\
\hline
\end{tabular}


TABLE VII (contd.)

\begin{tabular}{|c|c|c|c|c|c|c|c|}
\hline \multirow[b]{2}{*}{$\begin{array}{l}\text { PARAMETER } \\
\text { System } \\
\text { Detector }\end{array}$} & \multirow[b]{2}{*}{ Location } & \multicolumn{2}{|c|}{ Range } & \multicolumn{2}{|c|}{ Frequency Response } & \multirow[b]{2}{*}{$\begin{array}{l}\text { Data } \\
\text { Fig. } \\
\text { Mo. }\end{array}$} & \multirow[b]{2}{*}{ Measuremeat Coments } \\
\hline & & Detector & $\begin{array}{l}\text { Data } \\
\text { Acquisition } \\
\text { Systea }\end{array}$ & Detec:or & $\begin{array}{l}\text { Data[a] } \\
\text { System }\end{array}$ & & \\
\hline $\begin{array}{l}\text { Intact Loop } \\
\text { TE-P 139-19 }\end{array}$ & $\begin{array}{l}\text { Pressurizer vapor temperat ure, } \\
0.86 \mathrm{~m} \text { above the heater rods. }\end{array}$ & $\begin{array}{l}315.6- \\
371.1^{\circ} \mathrm{C}\end{array}$ & $\begin{array}{l}315.6- \\
371.1^{\circ} \mathrm{C}\end{array}$ & $7 \mathrm{~Hz}$ & 50 pps. & 115 & $\begin{array}{l}\text { Res:-rained data. Temperature } \\
\text { below instrument range after } \\
23 \mathrm{~s} \text {. }\end{array}$ \\
\hline $\begin{array}{l}\text { Intact Loop } \\
\text { TE-P } 139-20\end{array}$ & $\begin{array}{l}\text { Pressurizer liquid temperature, } \\
0.36 \mathrm{~m} \text { above heater rods. }\end{array}$ & $10.0-371.1^{\circ} \mathrm{C}$ & $10.0-371.1^{\circ} \mathrm{C}$ & $7 \mathrm{~Hz}$ & 50 pps. & 115 & Resiorained data. Valid to $70 \mathrm{~s}$. \\
\hline $\begin{array}{l}\text { Intact Loop } \\
\text { TE-P } 139-29\end{array}$ & $\begin{array}{l}\text { Intact loop cold leg just } \\
\text { upstream of DTI flange. }\end{array}$ & $10.0-343.3^{\circ} \mathrm{C}$ & $10.0-343.3^{\circ} \mathrm{C}$ & 0.06 比 & 50 pps. & 116 & $\begin{array}{l}\text { Restrained data. Good for } \\
\text { initial conditions only. }\end{array}$ \\
\hline $\begin{array}{l}\text { Intact Loop } \\
\text { TE-P.]39-32 }\end{array}$ & $\begin{array}{l}\text { Intact loop hot leg in elbow } \\
\text { near venturi. }\end{array}$ & $10.0-343.3^{\circ} \mathrm{C}$ & $10.0-343.3^{\circ} \mathrm{C}$ & $0.06 \mathrm{~Hz}$ & $\begin{array}{l}1,000 \text { tz } \\
50 \text { pps. }\end{array}$ & 136 & $\begin{array}{l}\text { QEUL fo- initial conditions } \\
\text { OnlE. }\end{array}$ \\
\hline $\begin{array}{l}\text { Intact Loop } \\
\text { TE-P } 139-33\end{array}$ & $\begin{array}{l}\text { Intact loop hot leg in elbaw } \\
\text { near venturi. }\end{array}$ & $10.0-343.3^{\circ} \mathrm{C}$ & $10.0-343.3^{\circ} \mathrm{C}$ & 0.06 Hb & $\begin{array}{l}1,000 \mathrm{tz} \\
50 \mathrm{pps}\end{array}$ & 136 & $\begin{array}{l}\text { QEUN fC- initial conditions } \\
\text { Onl:. }\end{array}$ \\
\hline $\begin{array}{l}\text { Intact Loop } \\
\text { TE-SG-1 }\end{array}$ & $\begin{array}{l}\text { Intact loop cold leg SG } \\
\text { outlet. }\end{array}$ & $0-1,260^{\circ} \mathrm{C}$ & $-17.8-+704.4^{\circ}=$ & $0.35 \mathrm{kt}$ & 50 pps. & 117 & $\begin{array}{l}\text { Res:rained data. Good for } \\
\text { inirial conditions only. }\end{array}$ \\
\hline $\begin{array}{l}\text { Intact Loop } \\
\text { TE-SG-2 }\end{array}$ & $\begin{array}{l}\text { Intact loop hot leg SG } \\
\text { inlet. }\end{array}$ & $0-1,260^{\circ} \mathrm{C}$ & $-17.8^{-}+704.4^{\circ}=$ & 0.35 比 & 50 pps. & 117 & $\begin{array}{l}\text { Restrained data. Good for } \\
\text { initial conditions only. }\end{array}$ \\
\hline $\begin{array}{l}\text { Secondary Coolant } \\
\text { System } \\
\text { TE-SG-3 }\end{array}$ & SG secondary side. & $\begin{array}{l}-201.1- \\
+610.0^{\circ} \mathrm{C}\end{array}$ & $\begin{array}{l}-17.8- \\
+315.6^{\circ} \mathrm{C}\end{array}$ & 0.07 tb & 50 pps. & 117 & $\begin{array}{l}\text { Res:rained data. Good for } \\
\text { initial conditions only. }\end{array}$ \\
\hline $\begin{array}{l}\text { Blowdown Suppres- } \\
\text { sion System } \\
\text { TE-SY-1 }\end{array}$ & $\begin{array}{l}\text { Blowdown suppression tank, } \\
0.3 \text { m north of downcomer } i, \\
0.53 \text { m east of tank } E, 2.72 \mathrm{~m} \\
\text { from tank bottom. }\end{array}$ & $\begin{array}{l}-101.1- \\
+371.1^{\circ} \mathrm{C}\end{array}$ & $\begin{array}{l}-17.8- \\
+204.4^{\circ} \mathrm{C}\end{array}$ & $1.8 \mathrm{~Hz}$ & $\begin{array}{l}1,000 \text { tz } \\
50 \mathrm{pps} ?\end{array}$ & $\begin{array}{l}118 \\
122 \\
157 \\
171\end{array}$ & $\begin{array}{l}\text { QEUU wtile instrument immersed. } \\
\text { Des gned to measure liquid } \\
\text { temperc =ure. }\end{array}$ \\
\hline
\end{tabular}


IABLE VII (contd.)

\begin{tabular}{|c|c|c|c|c|c|c|c|}
\hline \multirow[b]{2}{*}{$\begin{array}{l}\text { PARAMETER } \\
\text { Syster } \\
\text { Detector }\end{array}$} & \multirow[b]{2}{*}{ Location } & \multicolumn{2}{|c|}{ Range } & \multicolumn{2}{|c|}{ Frequency Response } & \multirow[b]{2}{*}{$\begin{array}{l}\text { Data } \\
\text { Fig. } \\
\text { Ho. }\end{array}$} & \multirow[b]{2}{*}{ Measurement coments } \\
\hline & & Detector & $\begin{array}{c}\text { Data } \\
\text { Acquisition } \\
\text { System }\end{array}$ & Detector & $\begin{array}{l}\text { Datd [a] } \\
\text { Systea }\end{array}$ & & \\
\hline $\begin{array}{l}\text { Blowdown Suppres- } \\
\text { sion System } \\
\text { TE-SV-2 }\end{array}$ & $\begin{array}{l}\text { Blowdown suppression tank, } 0.3 \mathrm{n} \\
\text { north of downcomer } 1,0.53 \mathrm{~m} \\
\text { east of tank } \mathrm{m}, 2.36 \mathrm{~m} \text { from } \\
\text { tank bottom. }\end{array}$ & $\begin{array}{l}-101.1- \\
+371.1^{\circ} \mathrm{C}\end{array}$ & $\begin{array}{l}-17.8- \\
+204.4^{\circ} \mathrm{C}\end{array}$ & $1.8 \mathrm{~Hz}$ & $\begin{array}{l}7,000 \mathrm{~Hz} \\
50 \mathrm{pps}\end{array}$ & $\begin{array}{l}118 \\
123 \\
157 \\
171\end{array}$ & $\begin{array}{l}\text { QEUD whi le instrument imaersed. } \\
\text { Designed to measure liquid } \\
\text { temperature. }\end{array}$ \\
\hline $\begin{array}{l}\text { Blowdown Suppres- } \\
\text { sion System } \\
\text { TE-SV-3 }\end{array}$ & $\begin{array}{l}\text { Blowdown suppression tank, } 0.3 \mathrm{~m} \\
\text { north of downcomer } 1,0.53 \mathrm{~m} \\
\text { east of tank } \mathrm{m}, 1.9 \mathrm{~m} \text { from } \\
\text { tank bottom. }\end{array}$ & $\begin{array}{l}-101.1- \\
+371.1^{\circ} \mathrm{C}\end{array}$ & $\begin{array}{l}-17.8- \\
+204.4^{\circ} \mathrm{C}\end{array}$ & $1.8 \mathrm{~Hz}$ & $\begin{array}{l}1,000 \mathrm{~Hz} \\
50 \mathrm{pps}\end{array}$ & $\begin{array}{l}118 \\
124 \\
157 \\
171\end{array}$ & $\begin{array}{l}\text { QEUD while instrument inmersed. } \\
\text { Designed to measure liquid } \\
\text { temperature. }\end{array}$ \\
\hline $\begin{array}{l}\text { Blowdown Suppres- } \\
\text { sion System } \\
\text { TE-SV-4 } \\
\text {. }\end{array}$ & $\begin{array}{l}\text { Blowdown suppression tank, } 0.3 \mathrm{~m} \\
\text { north of downcomer } 7 ; 0.53 \mathrm{~m} \\
\text { east of tank } E, 1.45 \mathrm{~m} \text { from } \\
\text { tank botton. }\end{array}$ & $\begin{array}{l}-101.1- \\
+371.10^{\circ} \mathrm{C}\end{array}$ & $\begin{array}{l}-17.8- \\
+204.4^{\circ} \mathrm{C}\end{array}$ & $1.8 \mathrm{~Hz}$ & $\begin{array}{l}1,000 \mathrm{~Hz} \\
50 \mathrm{pps}\end{array}$ & -- & Channel failed. \\
\hline $\begin{array}{l}\text { Blowdown Suppres- } \\
\text { sion System } \\
\text { TE-SV-5 }\end{array}$ & $\begin{array}{l}\text { Blowdown suppression tank, } 0.3 \mathrm{~m} \\
\text { north of downcomer } 1,0.53 \mathrm{~m} \\
\text { east of tank }\{, 0.99 \text { m from } \\
\text { tank bottom. }\end{array}$ & $\begin{array}{l}-101.1 \\
+371.1^{\circ} \mathrm{C}\end{array}$ & $\begin{array}{l}-17.8- \\
+204.4^{\circ} \mathrm{C}\end{array}$ & $1.8 \mathrm{~Hz}$ & $\begin{array}{l}1,000 \mathrm{~Hz} \\
50 \mathrm{pps}\end{array}$ & $\begin{array}{l}119 \\
125 \\
158 \\
172\end{array}$ & QEUD. \\
\hline $\begin{array}{l}\text { Blowdown Suppres- } \\
\text { sion System } \\
\text { TE-SV-6 }\end{array}$ & $\begin{array}{l}\text { Blowdown suppression tank, } 0.3 \mathrm{~m} \\
\text { north of downcomer } 1,0.53 \mathrm{~m} \\
\text { east of tank } \mathrm{E}, 0.37 \mathrm{~m} \text { froi } \\
\text { tank bottom. }\end{array}$ & $\begin{array}{l}-101.1- \\
+371.11^{\circ} \mathrm{C}\end{array}$ & $\begin{array}{l}-17.8- \\
+204.4^{\circ} \mathrm{C}\end{array}$ & $1.8 \mathrm{~Hz}$ & $\begin{array}{l}1,000 \mathrm{~Hz} \\
50 \text { pOS }\end{array}$ & $\begin{array}{l}119 \\
126 \\
158 \\
172\end{array}$ & QEUD. \\
\hline $\begin{array}{l}\text { Blowdown Suppres- } \\
\text { sion System } \\
\text { TE-SV-7 }\end{array}$ & $\begin{array}{l}\text { Blowdown suppression tank, } 0.3 \mathrm{~m} \\
\text { north of downcomer } 3,0.53 \mathrm{~m} \\
\text { east of tank }[, 2.72 \mathrm{~m} \text { from } \\
\text { tank bottom. }\end{array}$ & $\begin{array}{l}-101.1- \\
+371.1^{\circ} \mathrm{C}\end{array}$ & $\begin{array}{l}-17.8- \\
+204.4^{\circ} \mathrm{C}\end{array}$ & $1.8 \mathrm{~Hz}$ & 50 pps & $\begin{array}{l}120 \\
122 \\
159 \\
173\end{array}$ & $\begin{array}{l}\text { QEUD while instrument immersed. } \\
\text { Designed to measure liquid } \\
\text { temperature. }\end{array}$ \\
\hline $\begin{array}{l}\text { Blowdown Suppres- } \\
\text { sion System } \\
\text { TE-SV-8. }\end{array}$ & $\begin{array}{l}\text { Blowdown suppression tank, } 0.3 \text { m } \\
\text { north of downcomer } 3.0 .53 \mathrm{~m} \\
\text { east of tank } 2.2 .36 \mathrm{~m} \text { from } \\
\text { tank bottom. }\end{array}$ & $\begin{array}{l}-101.1{ }^{-1}-\bar{c} \\
+371.1^{\circ} \mathrm{C}\end{array}$ & $\begin{array}{l}-17.8^{-} \\
+204.4^{\circ} \mathrm{C}\end{array}$ & $1.8 \mathrm{~Hz}$ & $50 \mathrm{pps}$ & $\begin{array}{l}120 \\
123 \\
159\end{array}$ & $\begin{array}{l}\text { QEUD while instrument immersed. } \\
\text { Designed to measure liquid } \\
\text { temperature. }\end{array}$ \\
\hline
\end{tabular}


TABLE VII (contd.)

\begin{tabular}{|c|c|c|c|c|c|c|c|}
\hline \multirow[b]{2}{*}{$\begin{array}{l}\text { PARAMETER } \\
\text { Systema } \\
\text { Detector }\end{array}$} & \multirow[b]{2}{*}{ Location } & \multicolumn{2}{|c|}{ Range } & \multicolumn{2}{|c|}{ Frequency Response } & \multirow[b]{2}{*}{$\begin{array}{l}\text { Data } \\
\text { Fig. } \\
\text { No. }\end{array}$} & \multirow[b]{2}{*}{ Measurement Coments } \\
\hline & & Detector & $\begin{array}{l}\text { Data } \\
\text { Acquisition } \\
\text { Systea }\end{array}$ & Detector & $\underset{\substack{\text { Datad } \\
\text { Systea }}}{\text { [a] }}$ & & \\
\hline $\begin{array}{l}\text { Blowdown Suppres- } \\
\text { sion System } \\
\text { TE-SV-9 }\end{array}$ & $\begin{array}{l}\text { Blowdown suppression tank, } 0.3 \mathrm{~m} \\
\text { north of downcomer } 3,0.5 \mathrm{j} \mathrm{m} \\
\text { east of tank } \mathrm{E}, \mathrm{i}, 9 \mathrm{~m} \text { fran } \\
\text { tank bottom. }\end{array}$ & $\begin{array}{l}-101.1- \\
+371.1^{\circ} \mathrm{C}\end{array}$ & $\begin{array}{l}-17.8- \\
+204.4^{\circ} \mathrm{C}\end{array}$ & $1.8+z$ & $\begin{array}{l}1,0: 00 \mathrm{~Hz} \\
50 \text { गps }\end{array}$ & $\begin{array}{l}120 \\
124 \\
159 \\
173\end{array}$ & $\begin{array}{l}\text { QEiJD mile instrument iamersed. } \\
\text { Designad to measure liquid } \\
\text { temperature. }\end{array}$ \\
\hline $\begin{array}{l}\text { Blowdown Suppres- } \\
\text { sion System } \\
\text { TE-SV-10 }\end{array}$ & $\begin{array}{l}\text { Blowdown suppression tank } 0.3 \mathrm{~m} \\
\text { north of downcomer } 3,0.5 \mathrm{~m} \\
\text { east of tank } \mathrm{m}, 1.45 \mathrm{n} \text { from } \\
\text { tank bottom. }\end{array}$ & $\begin{array}{l}-101.1- \\
+371.1^{\circ} \mathrm{C}\end{array}$ & $\begin{array}{l}-17.8- \\
+204.4^{\circ} \mathrm{C}\end{array}$ & $1.8 \mathrm{~Hz}$ & $\begin{array}{l}1,0100 \mathrm{~Hz} \\
50 \mathrm{pps}\end{array}$ & $\begin{array}{l}121 \\
127 \\
160 \\
174\end{array}$ & $\begin{array}{l}\text { QEUD while instrument immersed. } \\
\text { Desigred to measure liquid } \\
\text { teaperature. }\end{array}$ \\
\hline $\begin{array}{l}\text { Blowdown Suppres- } \\
\text { sion System } \\
\text { TE-SV-11 }\end{array}$ & $\begin{array}{l}\text { Blowdown suppression tank: } 0.3 \mathrm{~m} \\
\text { north of downcomer } 3 ; 0.5, \mathrm{~m} \\
\text { east of tank }\{, 0.99 \mathrm{armem} \\
\text { tank bottom. }\end{array}$ & $\begin{array}{l}-101.1- \\
+371.1^{\circ} \mathrm{C}\end{array}$ & $\begin{array}{l}-17.8- \\
+204.4^{\circ} \mathrm{C}\end{array}$ & $1.8 \mathrm{kz}$ & $50 \mathrm{pps}$ & $\begin{array}{l}121 \\
125 \\
160 \\
174\end{array}$ & QEUD. \\
\hline $\begin{array}{l}\text { Blowdown Suppres- } \\
\text { si ion System } \\
\text { TE-SV-12 }\end{array}$ & $\begin{array}{l}\text { Blowdown suppression tank, } 0.3 \mathrm{~m} \\
\text { north of downcomer } 3,0.5 \mathrm{~m} \\
\text { east of tank }\{, 0.37 \mathrm{~m} \text { from } \\
\text { tank botton. }\end{array}$ & $\begin{array}{l}-101.11^{-} \\
+371.1^{\circ} \mathrm{C}\end{array}$ & $\begin{array}{l}-17.8- \\
+204.4^{\circ} \mathrm{C}\end{array}$ & $1.8 \mathrm{~Hz}$ & $50 \mathrm{pps}$ & $\begin{array}{l}121 \\
126 \\
160 \\
174\end{array}$ & QELID. \\
\hline $\begin{array}{l}\text { Reactor Vesse1 } \\
\text { TE-1ST-1 }\end{array}$ & Downcomer 1, $4.8 \mathrm{~m}$ fram RW bottom & $0-1,260^{\circ} \mathrm{C}$ & $-17.8-+704.4^{\circ} \mathrm{C}$ & $1.8 \mathrm{~Hz}$ & 50 fps & 128 & $\begin{array}{l}\text { Restrained data. Reading tem- } \\
\text { perature radiated from metal } \\
\text { after } .75 \mathrm{~s} .\end{array}$ \\
\hline $\begin{array}{l}\text { Reactor Vesse 1 } \\
\text { TE-IST-2 }\end{array}$ & Downcomer $1,4.2 \mathrm{~m}$ from RV bottom. & $0-1,260^{\circ} \mathrm{C}$ & $-17.8-+704.4^{\mathrm{c}} \mathrm{C}$ & $1.8 \mathrm{~Hz}$ & 50 Eps & $\begin{array}{l}128 \\
133\end{array}$ & $\begin{array}{l}\text { Restrained data. Reading tem- } \\
\text { perature radiated from metal } \\
\text { after } 75 \mathrm{~s} \text {. }\end{array}$ \\
\hline $\begin{array}{l}\text { Reactor Vesse I } \\
\text { TE-IST-3 }\end{array}$ & Downcomer $1,3.59 \mathrm{~m}$ from $R \mathrm{O}$ bottom. & $0-1,260^{\circ} \mathrm{C}$ & 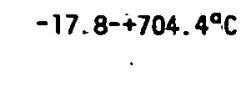 & $1.8 \mathrm{~Hz}$ & 50 pps & 128 & $\begin{array}{l}\text { Restrained data. Reading tem- } \\
\text { perature radiated from metal } \\
\text { after } \$ 5 \mathrm{~s} \text {. }\end{array}$ \\
\hline
\end{tabular}


TABLE VII (contd.)

\begin{tabular}{|c|c|c|c|c|c|c|c|c|}
\hline \multirow[b]{2}{*}{$\begin{array}{l}\text { PARAMETER } \\
\text { Systew } \\
\text { Detector }\end{array}$} & \multirow[b]{2}{*}{ Location. } & \multicolumn{2}{|c|}{ Range } & \multicolumn{2}{|c|}{ Frequency Response } & \multirow[b]{2}{*}{$\begin{array}{l}\text { Data } \\
\text { Fig. } \\
\text { Mo. }\end{array}$} & \multirow{2}{*}{\multicolumn{2}{|c|}{ Measurenent Coments }} \\
\hline & & Detector & $\begin{array}{c}\text { Data } \\
\text { Acquisition } \\
\text { System }\end{array}$ & Detector & $\underset{\text { Dystem }}{\text { Data] }}$ & & & \\
\hline $\begin{array}{l}\text { Reactor Vessel } \\
\text { TE-IST }-4\end{array}$ & Downcomer $1,2.98$ a from RV botton. & $0-1,260^{\circ} \mathrm{C}$ & $-17.8-+704.4^{\circ} \mathrm{C}$ & $1.8 \mathrm{~Hz}$ & 50 pps & 128 & $\begin{array}{l}\text { Restrained data. } \\
\text { perature radiated } f \\
\text { after } 75 \mathrm{~s} \text {. }\end{array}$ & $\begin{array}{l}\text { Reading tem- } \\
\text { from metal }\end{array}$ \\
\hline $\begin{array}{l}\text { Reactor Vessel } \\
\text { TE-1ST-5 }\end{array}$ & Downcoser $1,2.37$ m from RV bottom. & $0-1,260^{\circ} \mathrm{C}$ & $-17.8-+704.4^{\circ} \mathrm{C}$ & $1.8 \mathrm{~Hz}$ & 50 pps & -- & Channel failed (dig & gital). \\
\hline $\begin{array}{l}\text { Reactor Vessel } \\
\text { TE-1ST-6. }\end{array}$ & Downcomer $1,1.76 \mathrm{~m}$ from RV bottom. & $0-1,260^{\circ} \mathrm{C}$ & $-17.8-+704.4^{\circ} \mathrm{C}$ & $1.8 \mathrm{~Hz}$ & 50 pps & 129 & $\begin{array}{l}\text { Restrained data. } \\
\mathrm{T}_{0}+i 75 \mathrm{~s} .\end{array}$ & Good to \\
\hline $\begin{array}{l}\text { Reactor Vessel } \\
\text { TE-1ST-7 }\end{array}$ & Downcomer $1,0.85$ a from RV botton. & $0=1,260^{\circ} \mathrm{C}$ & 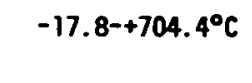 & $1.8 \mathrm{~Hz}$ & 50 pps & -- & Channel failed (dig & (gital). \\
\hline $\begin{array}{l}\text { Reactor Vessel } \\
\text { TE-1ST-8 }\end{array}$ & Downcomer $1,0.74$ in from RV bottom. & $0-1,260^{\circ} \mathrm{C}$ & 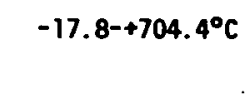 & $1.8 \mathrm{~Hz}$ & 50 pps & 129 & $\begin{array}{l}\text { Restrai ned data. } \\
\mathrm{T}_{0}+275 \mathrm{~s} .\end{array}$ & Good to \\
\hline $\begin{array}{l}\text { Reactor Vessel } \\
\text { TE-1ST-9 }\end{array}$ & Downcomer $1,0.64 \mathrm{~m}$ from RV botton. & $0-1,260^{\circ} \mathrm{C}$ & $-17.8-+704.4^{\circ} \mathrm{C}$ & $1.8 \mathrm{~Hz}$ & 50 pps & 129 & $\begin{array}{l}\text { Restrai.ned data. } \\
\mathrm{T}_{0}+275 \mathrm{~s}\end{array}$ & Good to \\
\hline $\begin{array}{l}\text { Reactor Vessel } \\
\text { TE-1ST-10 }\end{array}$ & Downcomer $1,0.54$ m from RV botton. & $0-1,260^{\circ} \mathrm{C}$ & 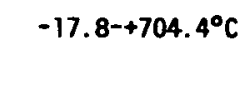 & $1.8 \mathrm{~Hz}$ & 50 pps & 129 & $\begin{array}{l}\text { Restrained data. } \\
\mathrm{T}_{0}+275 \mathrm{~s} .\end{array}$ & Good to \\
\hline $\begin{array}{c}\text { Reactor Vessel } \\
\text { TE- } 15 T-11\end{array}$ & Downcomer $1,0.44 \mathrm{~m}$ from RV bottom. & $0-1,260^{\circ} \mathrm{C}$ & $-17.8^{-+}+704.4^{\circ} \mathrm{C}$ & $1.8 \mathrm{~Hz}$ & 50 pps & 130 & $\begin{array}{l}\text { Restrained daza. G } \\
\mathrm{T}_{0}+275 \mathrm{~s} .\end{array}$ & Good to \\
\hline $\begin{array}{l}\text { Reactor Vessel } \\
\text { TE-1ST-12 }\end{array}$ & Downcomer $1,0.34$ m from RV bottom. & $0-1,260^{\circ} \mathrm{C}$ & $-17.8-+704.4^{\circ} \mathrm{C}$ & $1.8 \mathrm{~Hz}$ & 50 pps & 130 & $\begin{array}{l}\text { Restrained daza. } \\
\mathrm{T}_{0}+\sim 75 \mathrm{~s} .\end{array}$ & Good to \\
\hline $\begin{array}{l}\text { Reactor Vessel } \\
\text { TE-1ST-13 }\end{array}$ & Downcomer $1,0.24$ in from RV bottom. & $0-1,260^{\circ} \mathrm{C}$ & $-17.8^{-+}+704.4^{\circ} \mathrm{C}$ & $1.8 \mathrm{~Hz}$ & 50 pps & 130 & $\begin{array}{l}\text { Restrained dara. } \\
\mathrm{T}_{0}+275 \mathrm{~s} \text {. }\end{array}$ & Gciod to \\
\hline
\end{tabular}


TABLE VII (contd.)

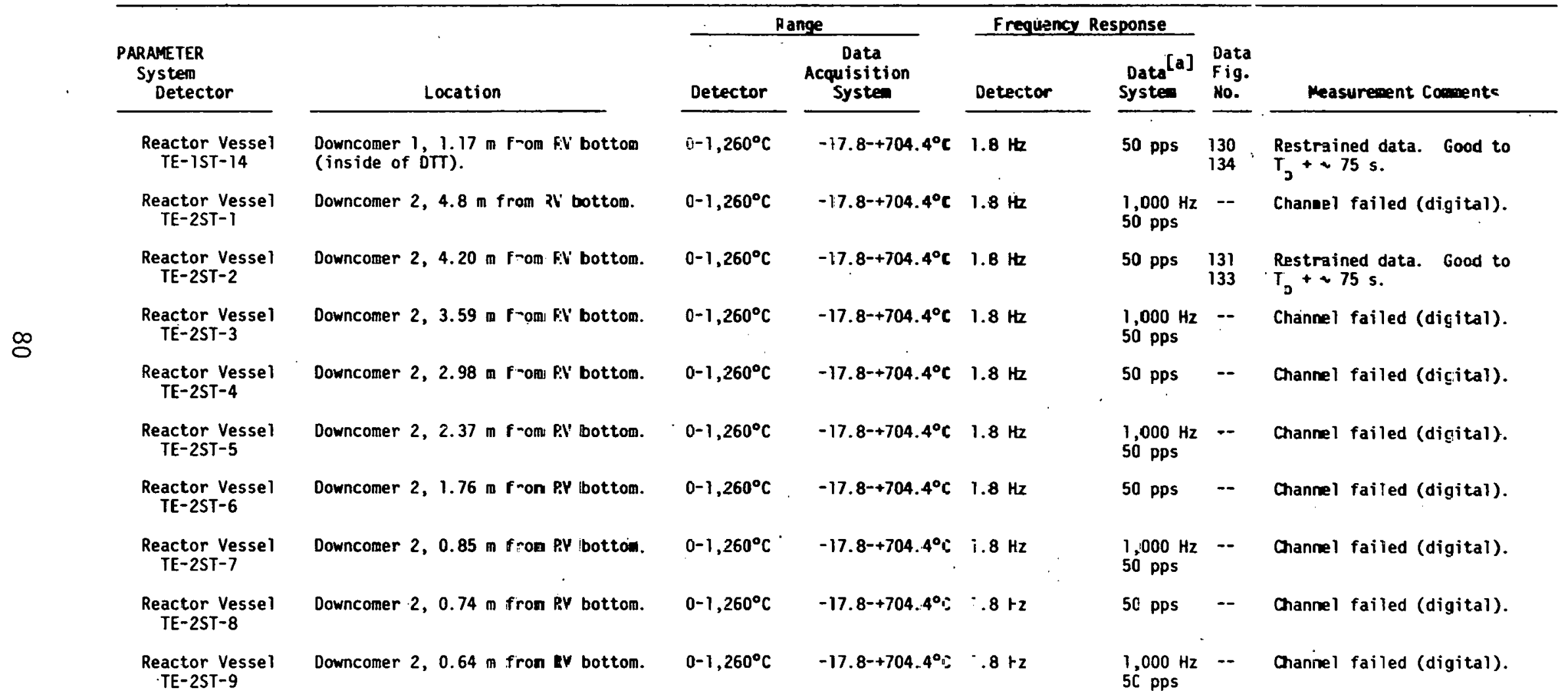


TABLE VII (contd.)

\begin{tabular}{|c|c|c|c|c|c|c|c|}
\hline \multirow[b]{2}{*}{$\begin{array}{l}\text { PARAMETER } \\
\text { System } \\
\text { Detector. }\end{array}$} & \multirow[b]{2}{*}{ Location } & \multicolumn{2}{|c|}{ Range } & \multicolumn{2}{|c|}{ Frequency Response } & \multirow[b]{2}{*}{$\begin{array}{l}\text { Data } \\
\text { Fig. } \\
\text { Mo. }\end{array}$} & \multirow[b]{2}{*}{ Measurement Coments } \\
\hline & & Detector & $\begin{array}{l}\text { Data } \\
\text { Acquisition } \\
\text { System }\end{array}$ & Detector & $\begin{array}{l}\text { Datada] } \\
\text { System }\end{array}$ & & \\
\hline $\begin{array}{l}\text { Reactor Vesse } 1 \\
\text { TE-2ST-10 }\end{array}$ & Downcomer 2, $0.54 \mathrm{~m}$ from RV bottom. & $0-1,260^{\circ} \mathrm{C}$ & $-17.8-+704.4^{\circ} \mathrm{C}$ & $1.8 \mathrm{~Hz}$ & 50 pps & -- & Channel failed (digital). \\
\hline $\begin{array}{l}\text { Reactor Vessel } \\
\text { TE-2ST-11 }\end{array}$ & Downcomer 2, $0.44 \mathrm{~m}$ from RV bottom. & $0-1,260^{\circ} \mathrm{C}$ & $-17.8-+704.4^{\circ} \mathrm{C}$. & $1.8 \mathrm{~Hz}$ & $\begin{array}{l}1,000 \mathrm{~Hz} \\
50 \mathrm{pps}\end{array}$ & - & Channel failed (digital). \\
\hline $\begin{array}{l}\text { Reactor Vesse } 1 \\
\text { TE-2ST-12 }\end{array}$ & Downcomer $2,0.34 \mathrm{~m}$ from RV bottom. & $0-1,260^{\circ} \mathrm{C}$ & $-17.8-+704.4^{\circ} \mathrm{C}$ & $1.8 \mathrm{~Hz}$ & 50 pps & -- & Channel failed (digital). \\
\hline $\begin{array}{l}\text { Reactor Vesse } 1 \\
\text { TE-2ST-13 }\end{array}$ & Downcomer 2, 0.24 is from RV bottom. & $0-1,260^{\circ} \mathrm{C}$ & $-17.8-+704.4^{\circ} \mathrm{C}$ & $1.8 \mathrm{~Hz}$ & 50 pps & -- & Channel failed (digital). \\
\hline $\begin{array}{l}\text { Reactor Vesse] } \\
\text { TE-2ST-14 }\end{array}$ & Downcomer $2, i .17 \mathrm{~m}$ from RV botton. & $0-1,260^{\circ} \mathrm{C}$ & $-17.8-+704.4^{\circ} \mathrm{C}$ & $1.8 \mathrm{~Hz}$ & 50 Fps & $\begin{array}{l}132 \\
134\end{array}$ & QEUD. \\
\hline $\begin{array}{l}\text { Emergency Core } \\
\text { Cooling System } \\
\text { TT-P120-62 }\end{array}$ & $\begin{array}{l}\text { Cold leg injection in } 4-\text { in. line } \\
\text { upstream of cold leg injection } \\
\text { point. }\end{array}$ & $10.0-343.3^{\circ} \mathrm{C}$ & $10.0-343.3^{\circ} \mathrm{C}$ & $0.07 \mathrm{~Hz}$ & 50 fps & 135 & $\begin{array}{l}\text { Restrained data. Good for } \\
\text { initial conditions only: }\end{array}$ \\
\hline $\begin{array}{l}\text { Intact Loop } \\
\text { TT-P } 139-32\end{array}$ & $\begin{array}{l}\text { Intact loop hot leg primary } \\
\text { coolant, Channel } \mathrm{A} \text {. }\end{array}$ & $260-343^{\circ} \mathrm{C}$ & -- & $\cdots$ & -- & 136 & Restrained data. \\
\hline
\end{tabular}




\section{TABLE VII (contd.)}

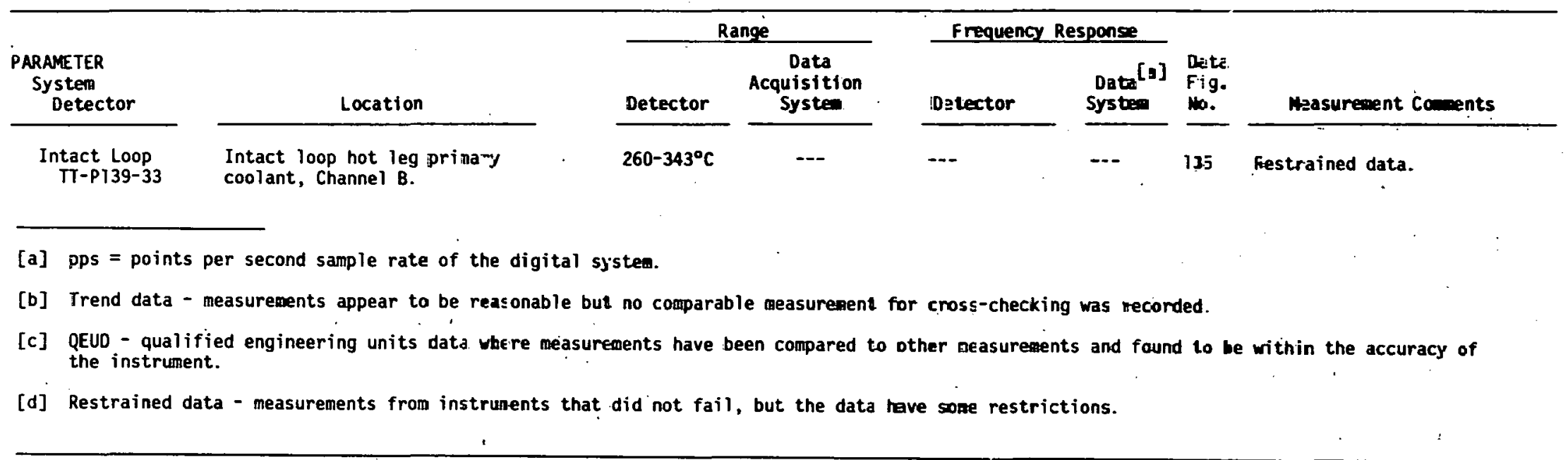




\section{TABLE VIII}

COMPUTED PARAMETERS FOR LOFT NONNUCLEAR TEST LI-4

\begin{tabular}{|c|c|c|c|c|}
\hline $\begin{array}{l}\text { PARAMETER } \\
\text { Location } \\
\text { Detectors } \\
\end{array}$ & Units & Calculation Method & $\begin{array}{l}\text { Fig. } \\
\text { No. }\end{array}$ & Remarks \\
\hline $\begin{array}{l}\text { DENSITY, AVERAGE } \\
\text { Broken LOOP Cold Leg } \\
\text { DE-BL-1A }\left(\rho_{A}\right) \\
\text { DE-BL-1B }\left(\rho_{B}\right) \\
\text { OE-BL-1C }\left(\rho_{C}\right)\end{array}$ & $\mathrm{Mg} / \mathrm{m}^{3}$ & $\begin{array}{l}\text { Density, Average } \\
\rho=K_{1} \rho_{A}+K_{2} \rho_{B}+K_{3} \rho_{C} \\
\text { where: }\end{array}$ & 29 & $\begin{array}{l}\text { The individual beam densities } \\
\text { were filtered with a } 4 \mathrm{~Hz} \text { fiT- } \\
\text { ter prior to being used in the } \\
\text { averaging calculation. }\end{array}$ \\
\hline $\begin{array}{l}\text { Broken Loop Hot Leg } \\
\text { DE-BL-2A }\left(\rho_{A}\right) \\
\left.\text { DE-BL-2B ( } \rho_{B}\right) \\
\left.\text { DE-BL-2C ( } \rho_{0}\right)\end{array}$ & $\mathrm{Mg} / \mathrm{m}^{3}$ & $\begin{array}{l}{ }_{A}, \rho_{B}, \rho_{C}=\text { average den- } \\
\text { sity along gamma densito- } \\
\text { meter beam lines } A, B \text {, } \\
\text { and } C \text {. }\end{array}$ & 29 & . \\
\hline $\begin{array}{l}\text { Intact Loop Cold Leg } \\
D E-P C-1 A\left(\rho_{A}\right) \\
D E-P C-1 B\left(\rho_{B}\right) \\
D E-P C-1 C\left(\rho_{C}\right)\end{array}$ & $\mathrm{Mg} / \mathrm{m}^{3}$ & $\begin{array}{l}\text { For stratified flow, } \\
\bar{\rho}=0.437 \rho_{A}+0.417 \rho_{B}+0.146 \rho_{C} \\
\text { For other flow regimes, } \\
\rho=0.345 \rho_{A}+0.401 \rho_{B}=0.254 \rho_{C} .\end{array}$ & 33 & . \\
\hline $\begin{array}{c}\text { Intact Loop Hot Leg } \\
\text { DE-PC-2A }\left(\rho_{A}\right) \\
D E-P C-2 B\left(\rho_{B}\right) \\
D E-P C-2 C\left(\rho_{C}\right)\end{array}$ & $\mathrm{Mg} / \mathrm{m}^{3}$ & & 33 & \\
\hline $\begin{array}{l}\text { Intact Loop Steam } \\
\text { Generator Outlet } \\
D E-P C-3 A\left(\rho_{A}\right) \\
D E-P C-3 B\left(\rho_{B}\right) \\
D E-P C-3 C\left(\rho_{C}\right)\end{array}$ & $\mathrm{Mg} / \mathrm{m}^{3}$ & & 33 & . \\
\hline
\end{tabular}


TABLE VIII (contd.)

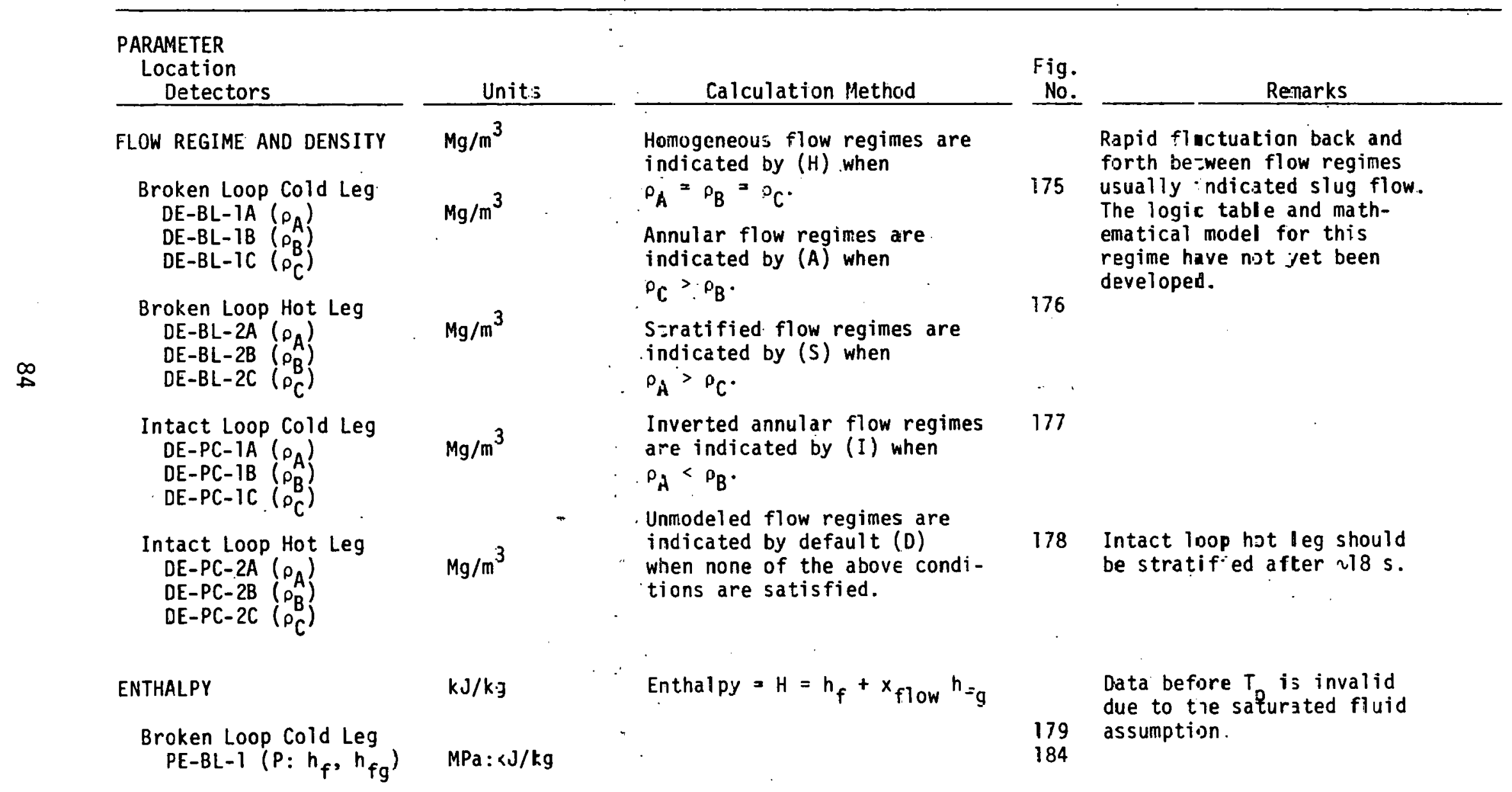


TABLE VIII (contd.)

\begin{tabular}{|c|c|c|c|c|}
\hline $\begin{array}{l}\text { PARAMETER } \\
\text { Location } \\
\text { Detectors } \\
\end{array}$ & Units & Calculation Method & $\begin{array}{l}\text { Fig. } \\
\text { No. }\end{array}$ & Remarks \\
\hline $\begin{array}{l}\text { ENTHALPY (contd.) } \\
\text { Broken Loop Hot Leg } \\
\left.\text { PE-BL-2 (P: } h_{f}, h_{f g}\right) \\
\text { Intact Loop Cold Leg } \\
\left.\text { PE-PC-1 (P: } h_{f}, h_{f g}\right) \\
\text { Intact Loop Hot Leg } \\
\left.\text { PE-PC-2 (P: } h_{f}, h_{f g}\right) \\
\text { Intact Loop, Steam } \\
\text { Generator Outlet } \\
\left.\text { PE-PC-3A (P: } h_{f}, h_{f g}\right)\end{array}$ & $\begin{array}{l}\mathrm{kJ} / \mathrm{kg} \\
\mathrm{MPa}: \mathrm{kJ} / \mathrm{kg} \\
\mathrm{MPa}: \mathrm{kJ} / \mathrm{kg}\end{array}$ & 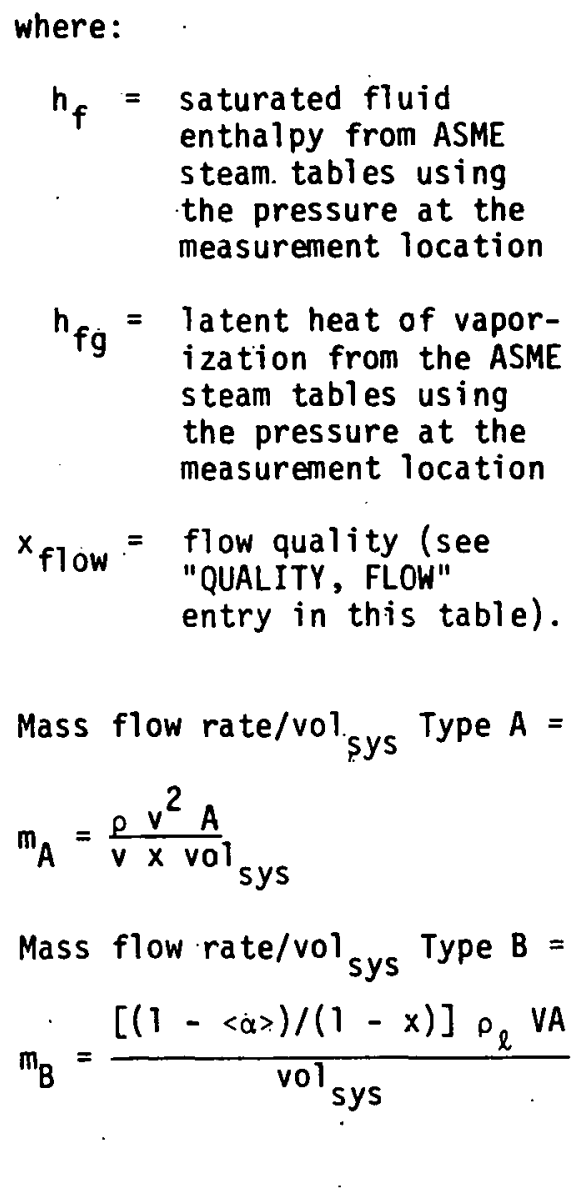 & $\begin{array}{l}182 \\
183\end{array}$ & $\begin{array}{l}\text { The output from the drag } \\
\text { discs, the turbine flow- } \\
\text { meters, and the gamma den- } \\
\text { sitometers were filtered to } \\
4 \mathrm{~Hz} \text { prior to performing } \\
\text { calculations. The measured } \\
\text { point values for the fluid } \\
\text { velocity and momentum flux } \\
\text { from the turbine flowmeters } \\
\text { and the drag discis, respec- } \\
\text { tively, were converted to } \\
\text { ayerage values prior to. per- } \\
\text { forming the calculations. }\end{array}$ \\
\hline
\end{tabular}




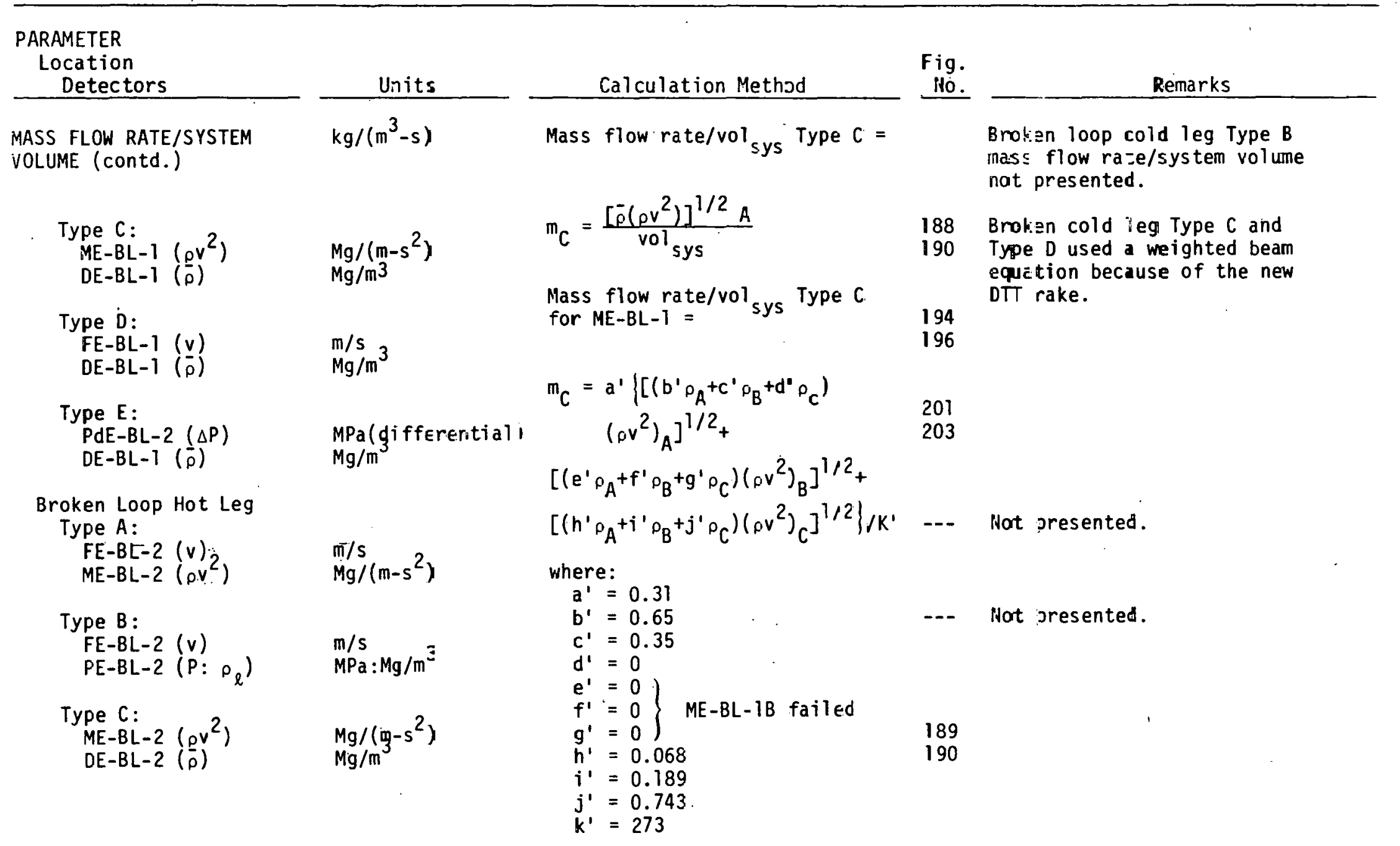


TABLE VIII (contd.)

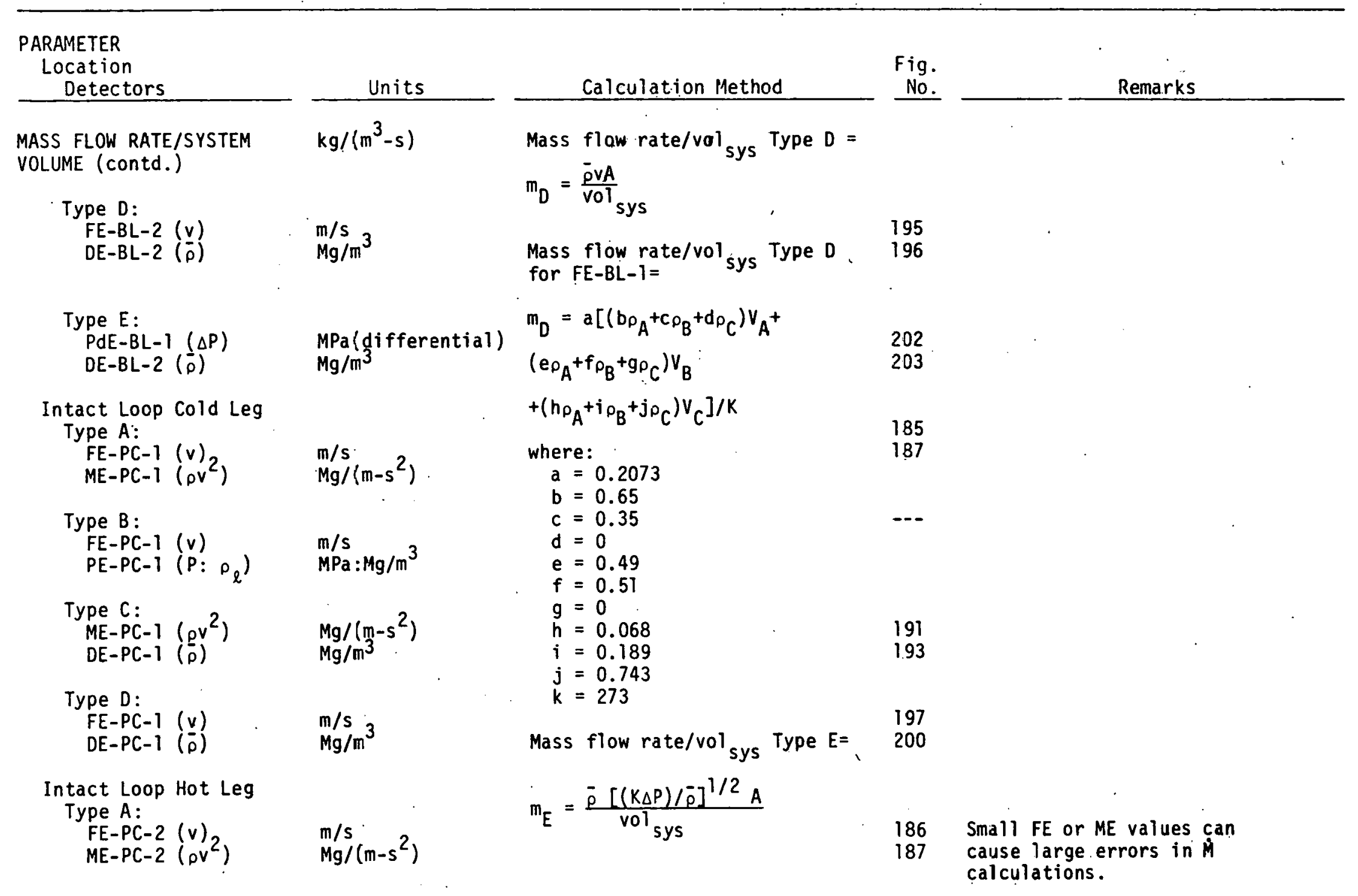




\begin{tabular}{|c|c|c|c|c|}
\hline $\begin{array}{l}\text { PARAMETER } \\
\text { Location } \\
\text { Detectors } \\
\end{array}$ & Units & Calculation Method & $\begin{array}{l}\text { Fig. } \\
\text { No. }\end{array}$ & Renarks \\
\hline $\begin{array}{l}\text { MASS FLOW RATE/SYSTEM } \\
\text { VOLUME (contd.) }\end{array}$ & $\mathrm{kg} /\left(\mathrm{m}^{3}-5\right)$ & $\begin{array}{l}\text { where: } \\
\qquad \bar{\rho}=\begin{array}{l}\text { average fluid density at } \\
\text { measurement location }\end{array}\end{array}$ & & \\
\hline $\begin{array}{l}\text { Type B: } \\
\text { FE-PC-2 (v) } \\
\left.\text { PE-PC-2 (P: } \rho_{\ell}\right)\end{array}$ & $\begin{array}{l}\mathrm{m} / \mathrm{s} \\
\mathrm{MPa}: \mathrm{Mg} / \mathrm{m}^{3}\end{array}$ & $\begin{aligned} \rho_{Q}= & \text { saturated liquid density } \\
& \text { from ASME steam tables }\end{aligned}$ & --- & \\
\hline $\begin{array}{l}\text { Type C: } \\
\text { ME-PC-2 }\left(\rho v^{2}\right) \\
\text { DE-PC-2 }\left(\frac{\rho}{\rho}\right)\end{array}$ & $\begin{array}{l}\mathrm{Mg} /\left(\mathrm{m}-\mathrm{s}^{2}\right) \\
\mathrm{Mg} / \mathrm{m}^{3}\end{array}$ & $\begin{aligned} \rho v^{2} & =\text { momentum flux [ME...] } \\
\langle\alpha\rangle= & \text { void fraction Isee } \\
& \text { "VOID FRACTION" entry }\end{aligned}$ & $\begin{array}{l}192 \\
193\end{array}$ & \\
\hline $\begin{array}{l}\text { Type D: } \\
\text { FE-PC-2 }(v) \\
\text { DE-PC-2 }\left(\frac{v}{p}\right)\end{array}$ & $\mathrm{m} / \mathrm{s}$ & $\begin{array}{l}\text { in this table) } \\
A=\text { flow area for the } \\
\text { measurement location }\end{array}$ & $\begin{array}{l}198 \\
200\end{array}$ & \\
\hline $\begin{array}{l}\text { Intact Loop, Steam } \\
\text { Generator Outlet } \\
\text { Type A: } \\
\text { FE-PC-3 }(v)^{2} \\
\text { ME-PC-3 }\left(\rho v^{2}\right)\end{array}$ & $\begin{array}{l}\mathrm{m} / \mathrm{s} \\
\mathrm{Mg} /\left(\mathrm{m}-\mathrm{s}^{2}\right)\end{array}$ & $\begin{array}{l}A_{\text {pipes }}=\begin{array}{l}0.0634 \mathrm{~m}^{2} \text { in the } \\
\text { plane of the DTTs }\end{array} \\
K=\text { conversion constant }\end{array}$ & --- & $\begin{array}{l}\text { Not presented; } \\
\text { ME- }{ }^{2} \mathrm{C}-3 \text { failec. }\end{array}$ \\
\hline $\begin{array}{l}\text { Type } B: \\
\text { FE-PC-3 (v) } \\
\text { PE-PC-3A }\left(P: \rho_{\ell}\right)\end{array}$ & $\begin{array}{l}\mathrm{m} / \mathrm{s} \\
\mathrm{MPa}: \mathrm{Mg} / \mathrm{m}^{3}\end{array}$ & $\begin{aligned} v= & \text { velocity of fluid at } \\
& \text { measurement locazion } \\
& {[\text { FE.....] }}\end{aligned}$ & & . \\
\hline $\begin{array}{l}\text { Type C: } \\
\text { ME-PC-3 }\left(\frac{\rho}{\rho} v^{2}\right) \\
\text { DE-PC-3 }\left(\frac{\rho}{\rho}\right)\end{array}$ & $\begin{array}{l}\mathrm{Mg} /\left(\mathrm{m}-\mathrm{s}^{2}\right) \\
\mathrm{Mg} / \mathrm{m}^{3}\end{array}$ & $\begin{aligned} s= & \text { flow quality (see } \\
& \text { "QUALITY, FLOW" =his } \\
& \text { table) }\end{aligned}$ & --- & $\begin{array}{l}\text { Not presented: } \\
\text { ME-PC-3 failec. }\end{array}$ \\
\hline $\begin{array}{l}\text { Type D: } \\
\text { FE-PC-3 (v) } \\
\text { DE-PC-3 }\left(\frac{p}{\rho}\right)\end{array}$ & $\begin{array}{l}\mathrm{m} / \mathrm{s} \\
\mathrm{Mg} / \mathrm{m}^{3}\end{array}$ & $\mathrm{Vol}_{\text {sys }}=7.73 \mathrm{~m}^{3}$. & $\begin{array}{l}199 \\
200\end{array}$ & \\
\hline
\end{tabular}


TABLE VIII (contd.)

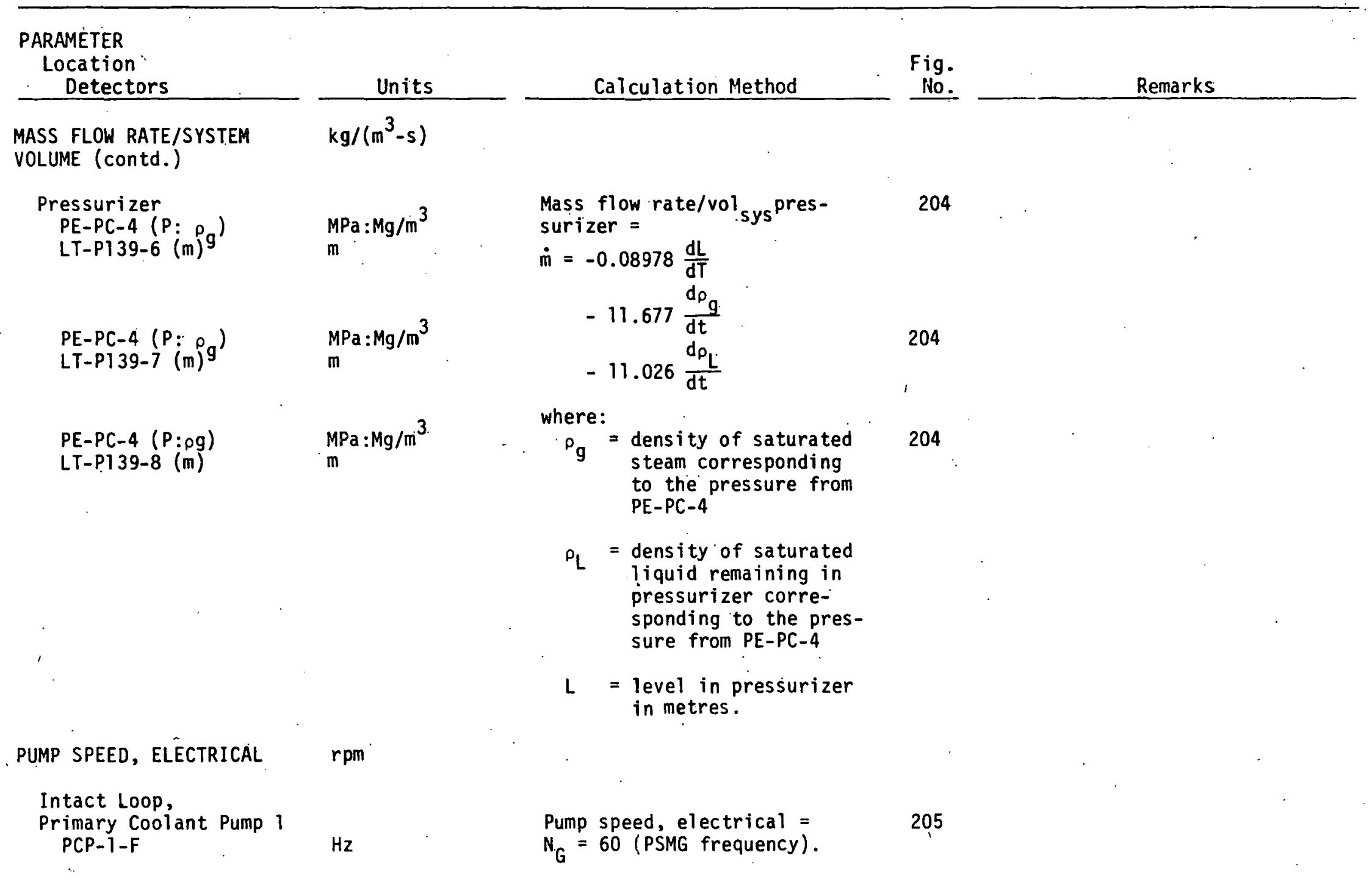


TABLE VIII (contd.)

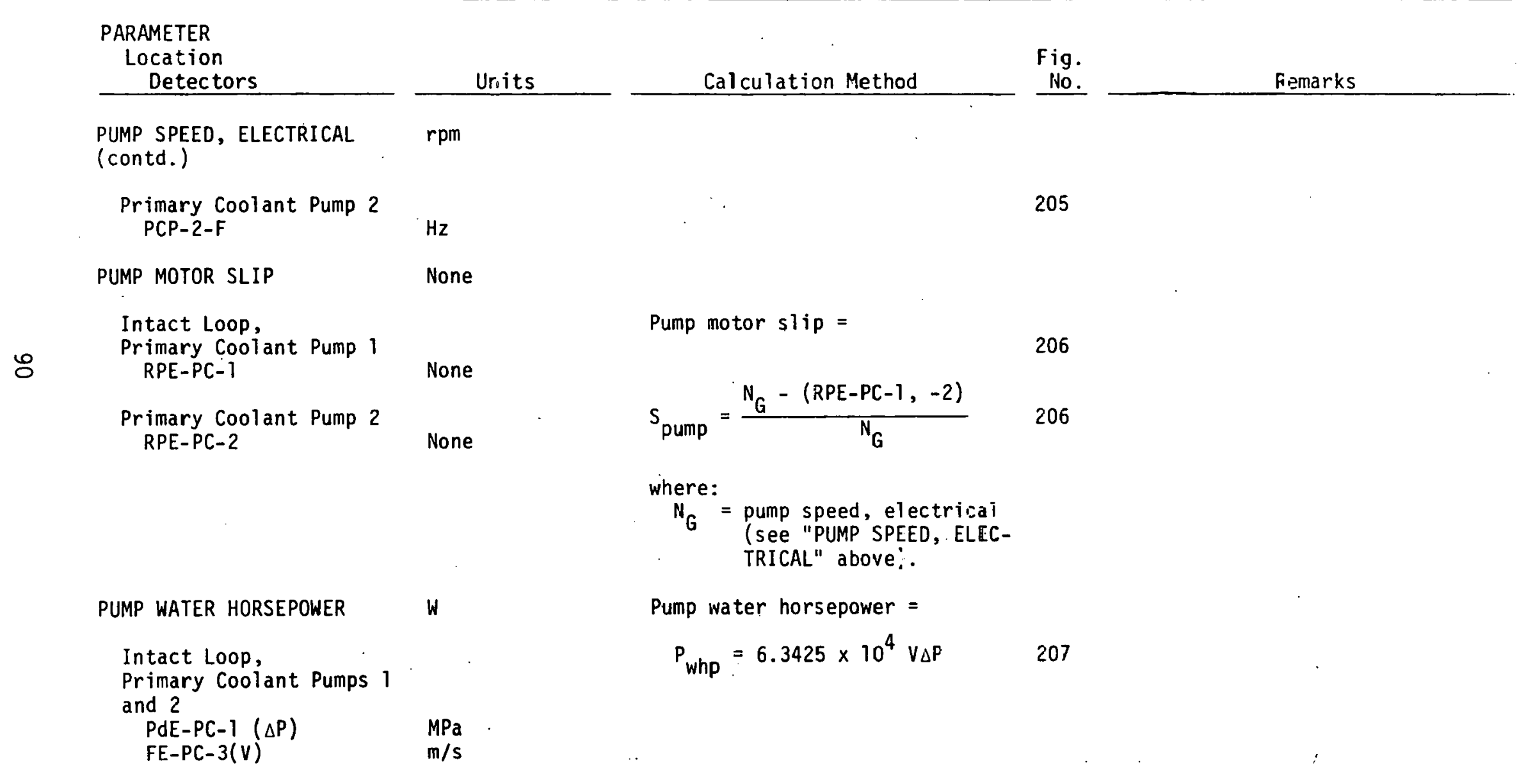


TABLE VIII (contd.)

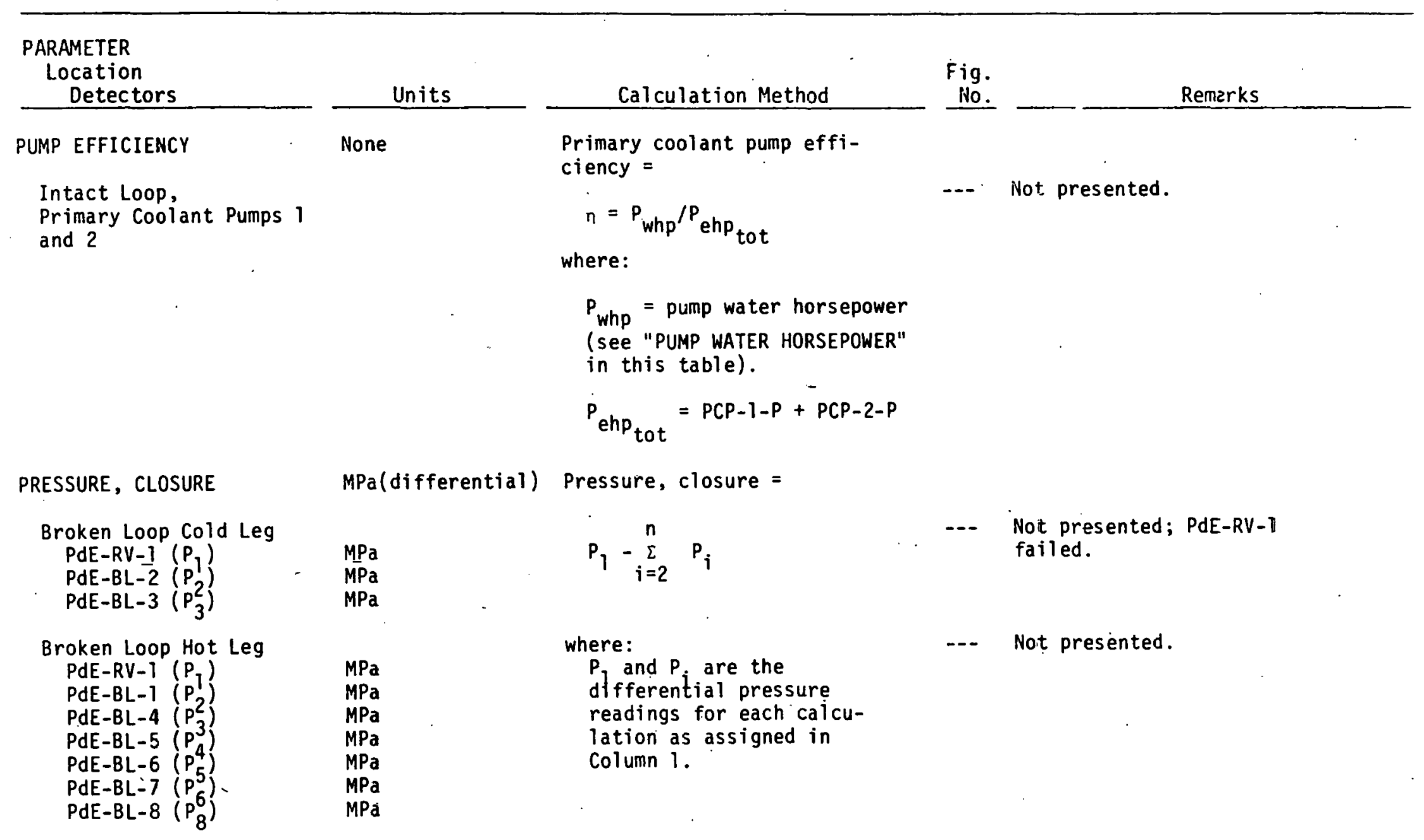


TABLE VIII (contd.)

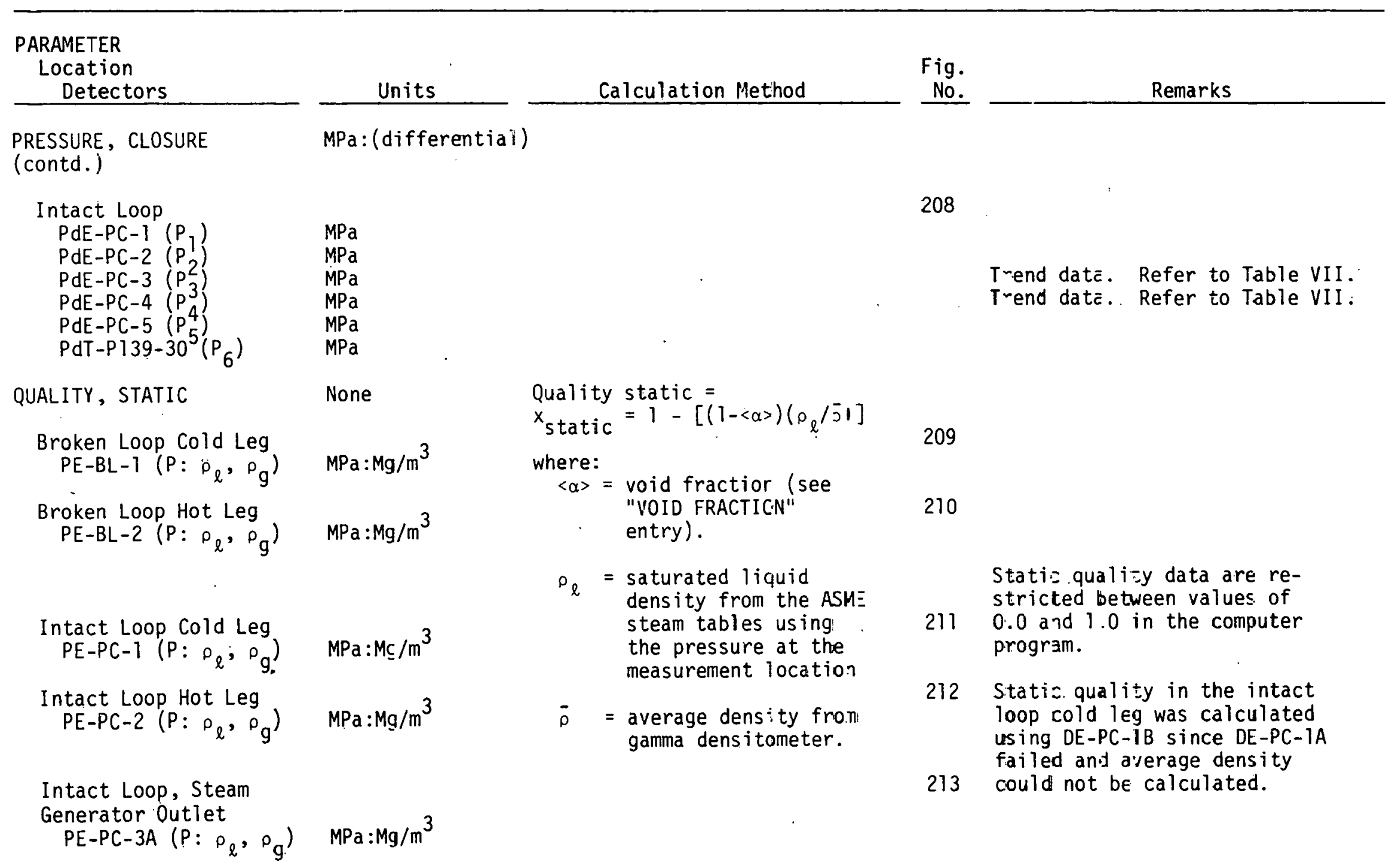


TABLE VIII (contd.)

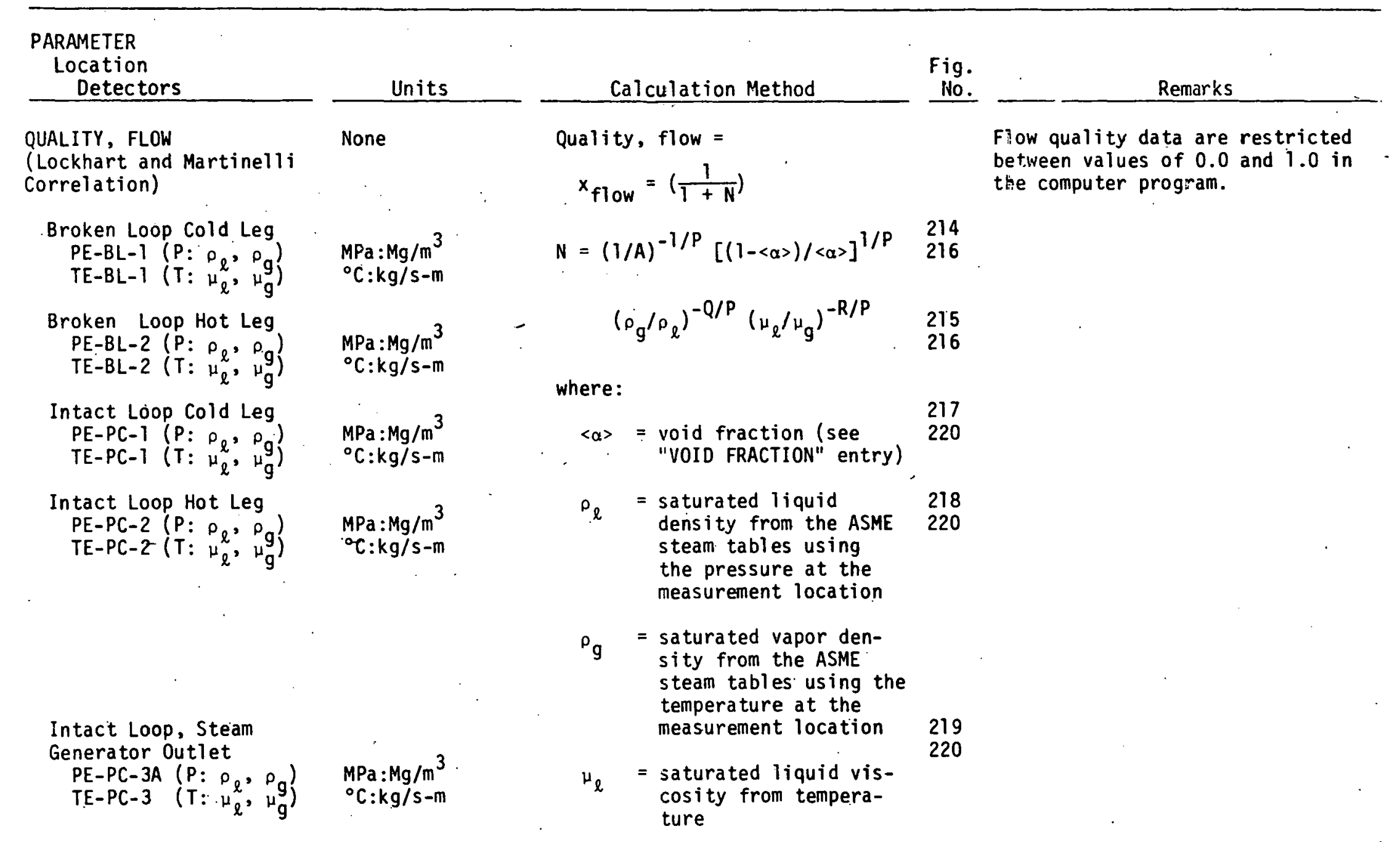


TABLE VIII (contd.)

\section{PARAMETER \\ Location \\ Detectors \\ QUALITY, FLOW \\ (Lockhart and Martinelli \\ Correlation) (contd.)}

Units

None

Calculation Method

$\mu_{g}=$ saturated vapor vis -

cosity from tempera-

ture.

Lockhart and Martinelli Coefficients [14]:
$A=0.28$
$P=0.64$
$Q=0.36$
$R=0.07$

Saturation temperatures

are taken from ASME steam

tables for measured pressures.

Temperatures are measured

by the detectors in

parentheses.

MPa

${ }^{\circ} \mathrm{C}$

$M P a$

${ }^{\circ} \mathrm{C}$

$\mathrm{MPa}$

${ }^{\circ} \mathrm{C}$

(TE-PC-2)

Intact Loop,

Steam Generator Outlet PE-PC- $3 A$

(TE-PC-3)
Fig.

No. Pemarks

Saturation temperature data

are not valid prior to $T$.

TE-E:-1 disp ays hot wal9

effe:ts after $253 \mathrm{~s}$.

222

TE-E_-2 disp:ays hot wall

effezts after $\prec 0 \mathrm{~s}$.

223

TE-PA-T displays hot wall effe:ts after $230 \mathrm{~s}$.

224

225 TE-PC-3 displays hot wall effects after $1.30 \mathrm{~s}$. 
TABLE VIII (contd.)

\begin{tabular}{l}
$\begin{array}{l}\text { PARAMETER } \\
\text { Location } \\
\text { Detectors }\end{array}$ \\
\cline { 1 - 2 } $\begin{array}{l}\text { TEMPERATURE, SATURATION } \\
\text { (contd.) }\end{array}$
\end{tabular}


TABLE VIII (contd.)

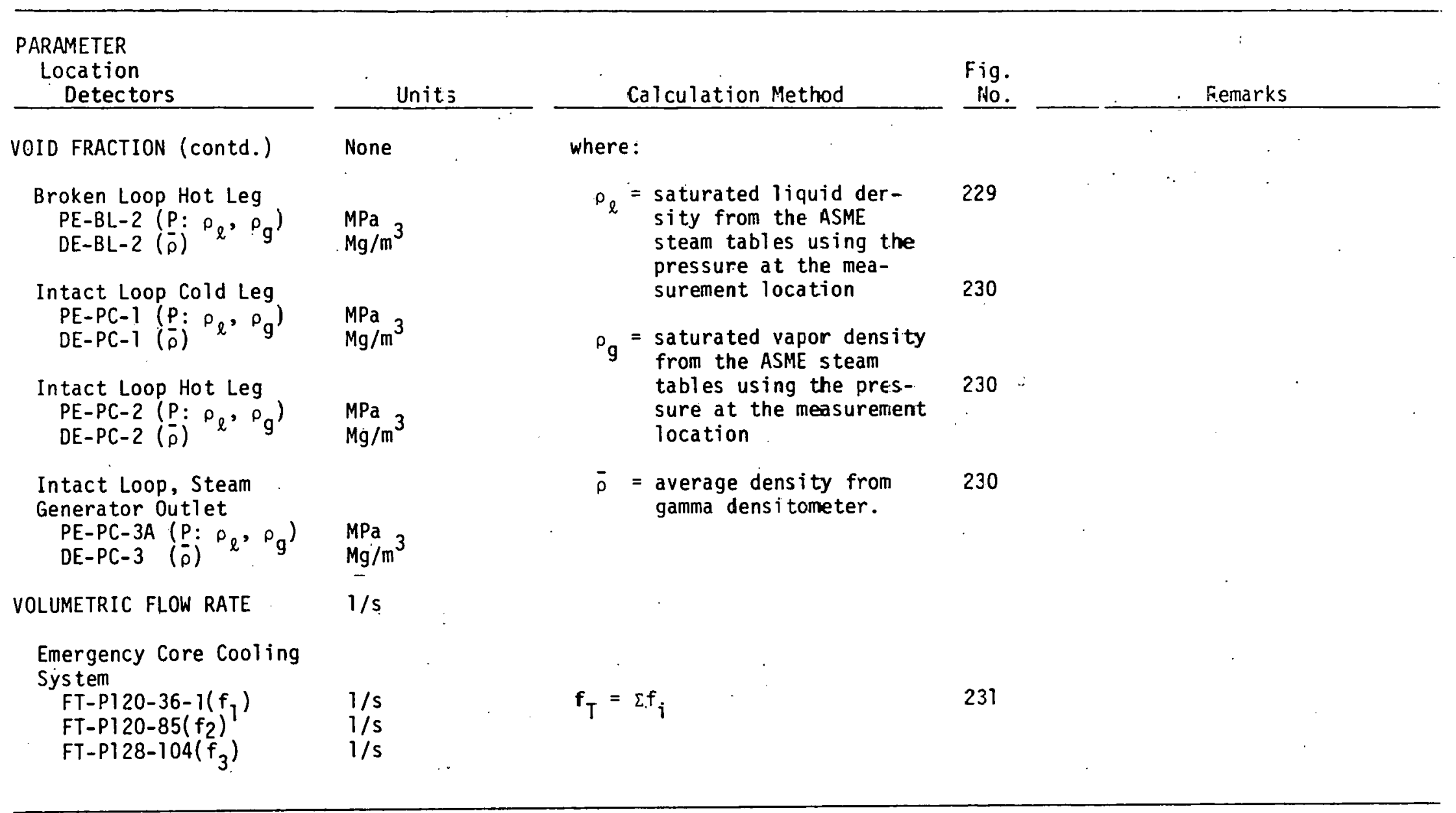




\section{TEST L1-4 MEASURED PARAMETERS -- \\ SHORT-TERM PLOTS (2 SECONDS OR LESS)}

This section of presented data consists of Figures 16 through 26. 


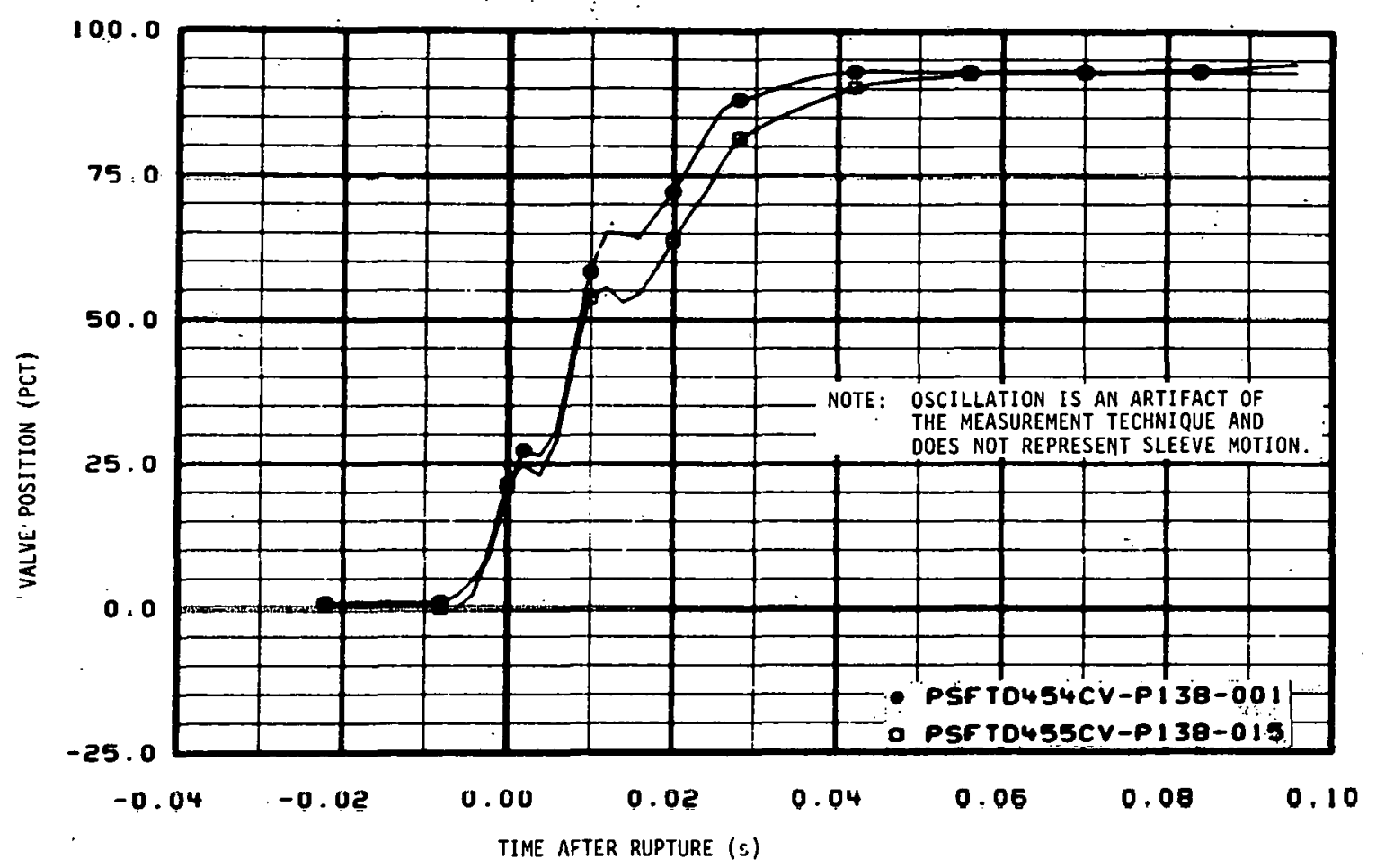

Fig. 16 Valve opening (\%) for broken loop QOBV cold leg valve (CV-P138-1) and hot leg valve (CV-P138-15).
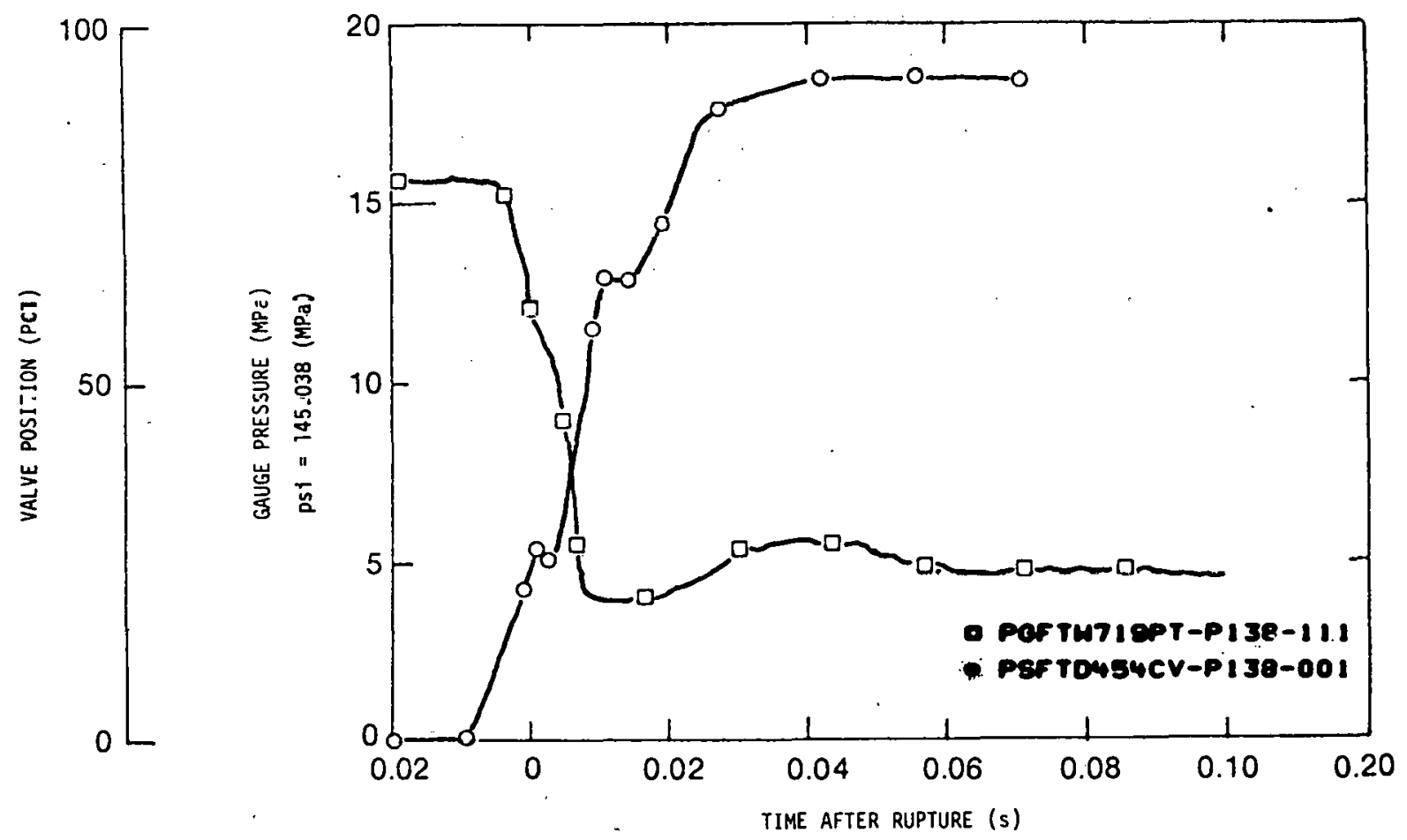

Fig. 17 Valve opening (\%) for broken loop cold leg QOBV (CV-P138-1) and cold leg QOBV inlet pressure (PT-P138-111). 


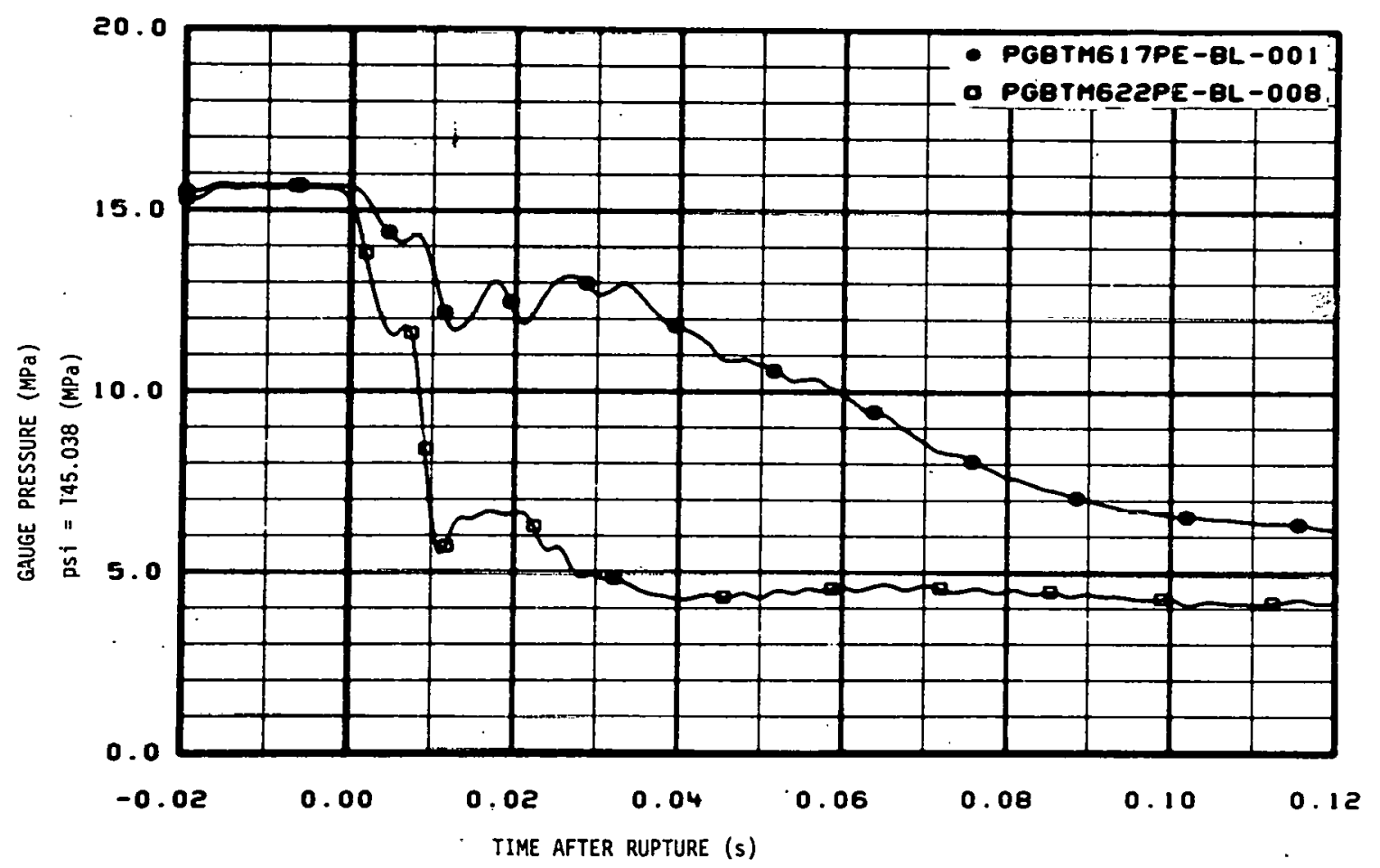

Fig. 18 Pressure in broken loop cold leg (PE-BL-1 and -8) (filtered to $250 \mathrm{~Hz}$ ).

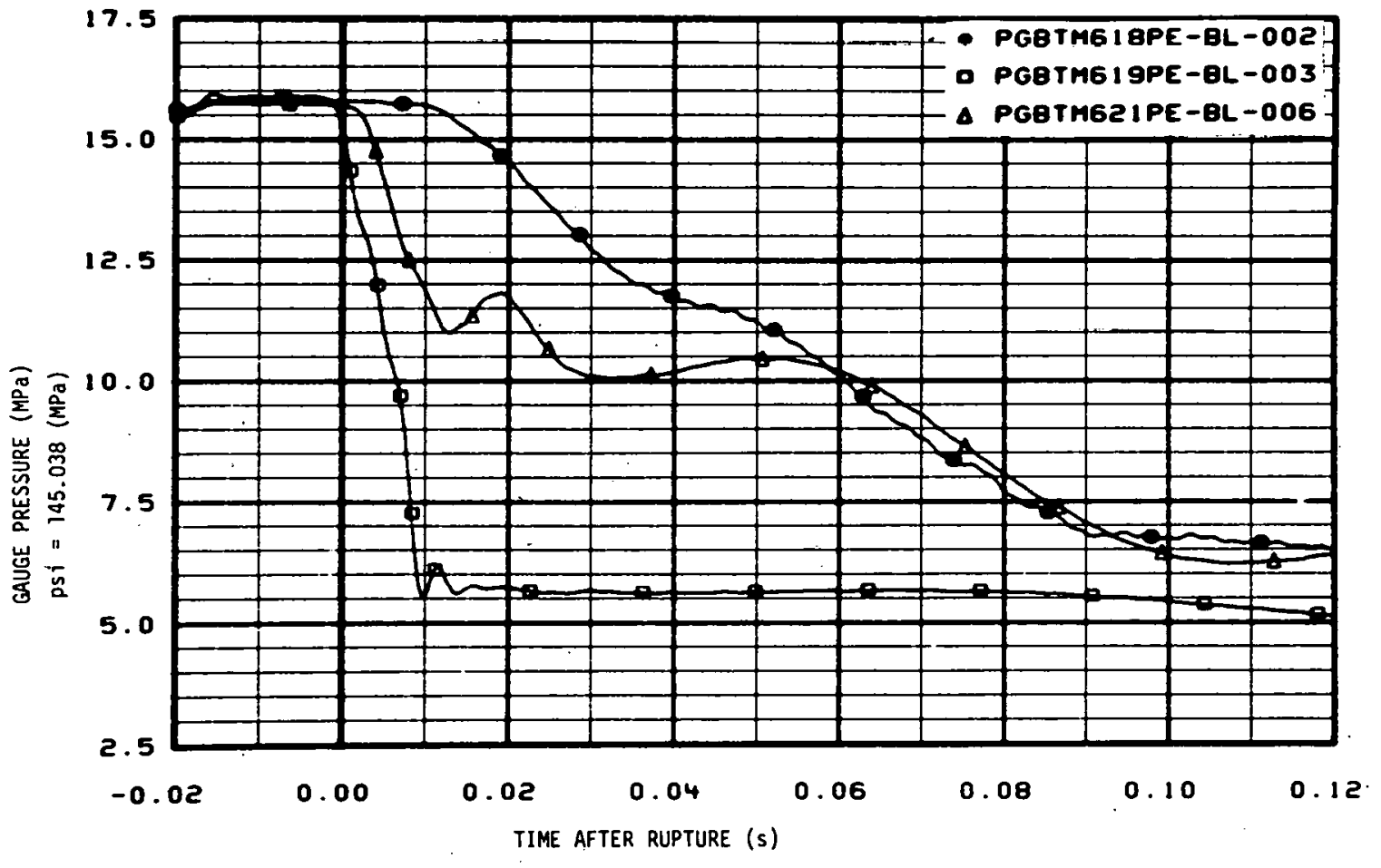

Fig. 19 Pressure in broken loop hot leg (PE-BL-2, -3, and -6) (filtered to $250 \mathrm{~Hz}$ ). 


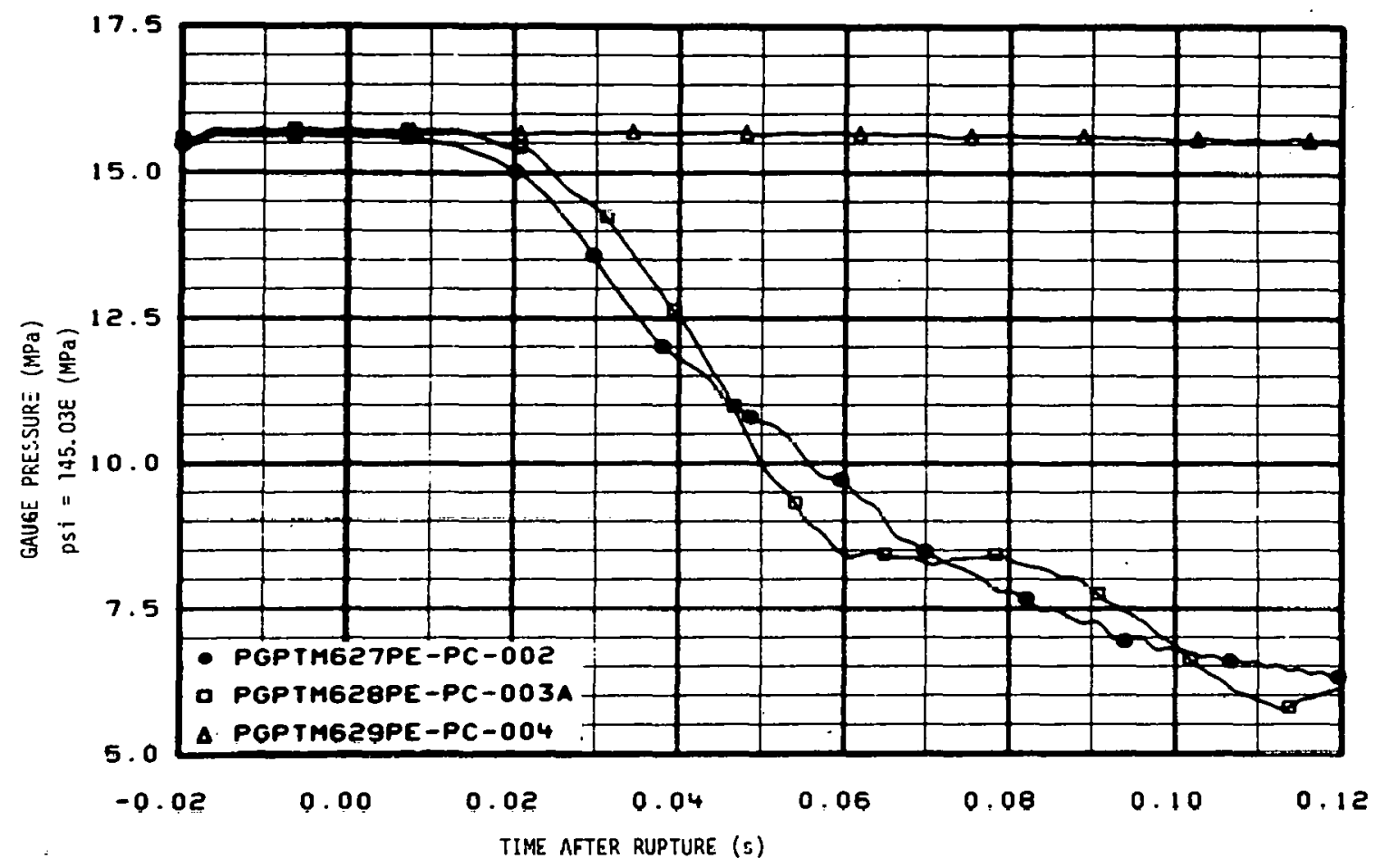

Fig. 20 Pressure in intact loop hot leg, steam generator outlet, and pressurizer ( $P E-P C-2,-3 A$, and -4 ) (filtered to $250 \mathrm{~Hz}$ ).

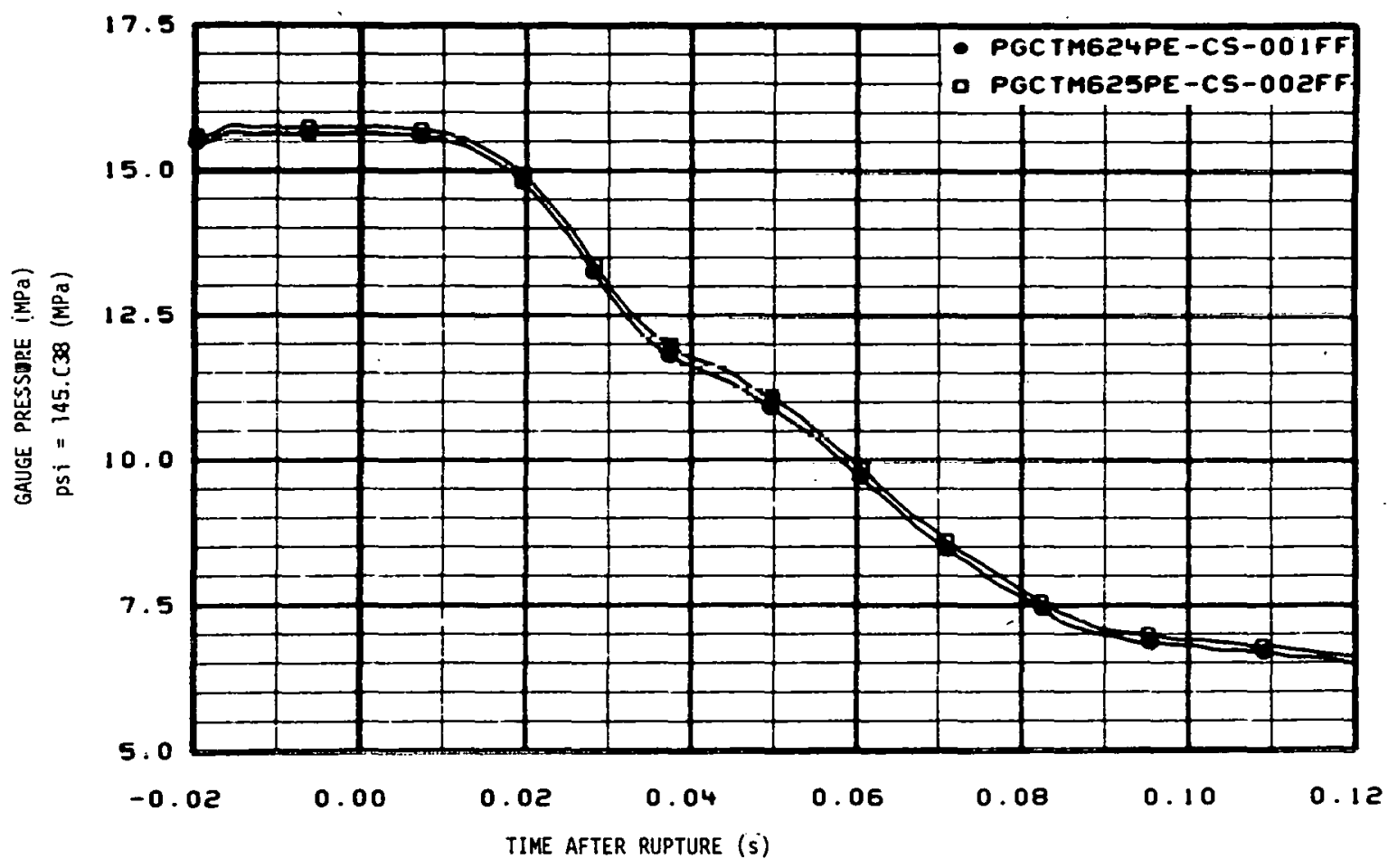

Fig. 21 Pressure in reactor vessel core simulator instrument stalk (PE-CS-1FF and -2FF) (filtered to $250 \mathrm{~Hz}$ ). 


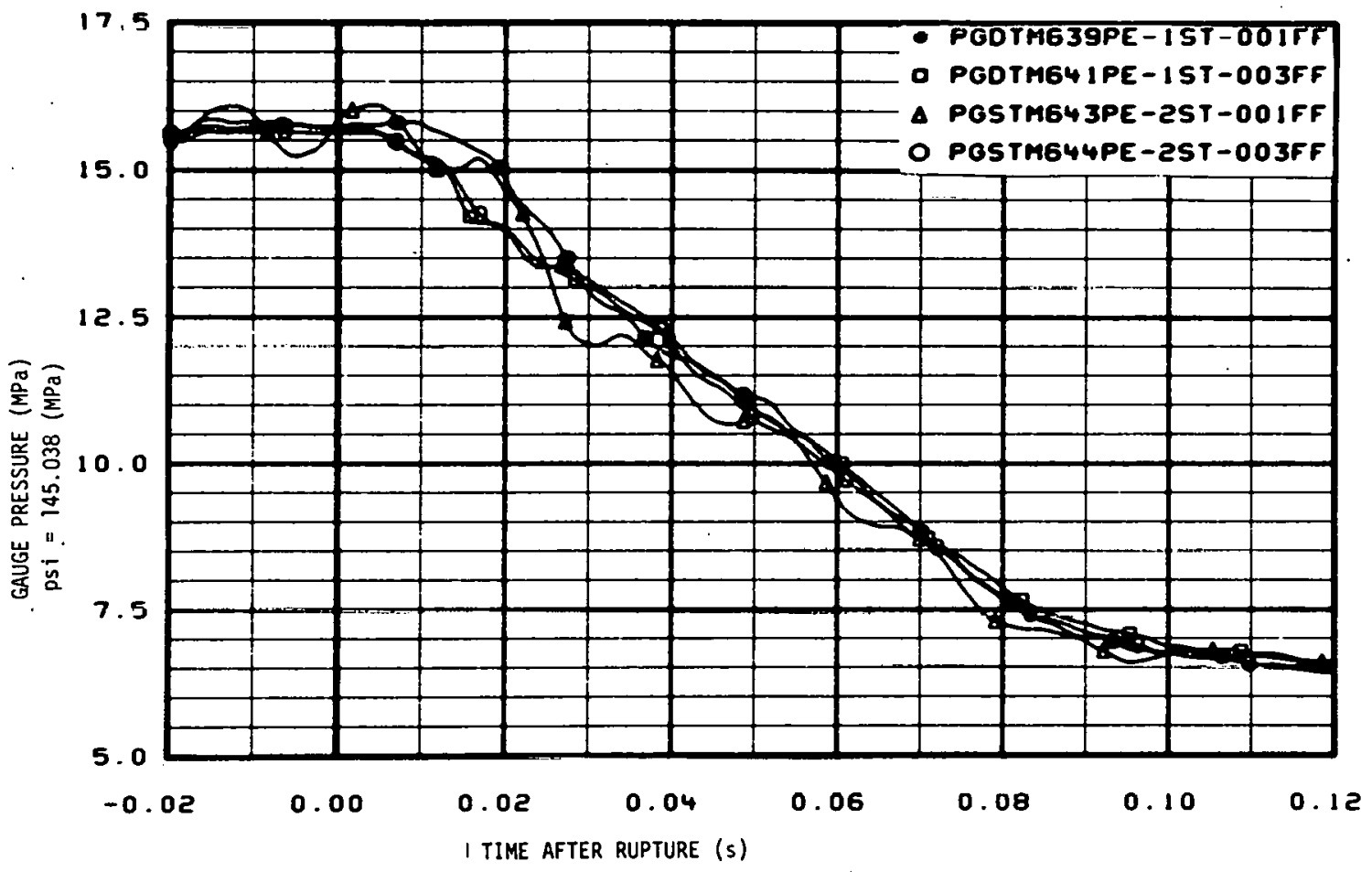

Fig. 22 Pressure in reactor vessel downcomer instrument stalks 1 and 2 (PE-1ST-IFF and -3FF and PE-2ST-IFF and -3FF) (filtered to $250 \mathrm{~Hz})$.

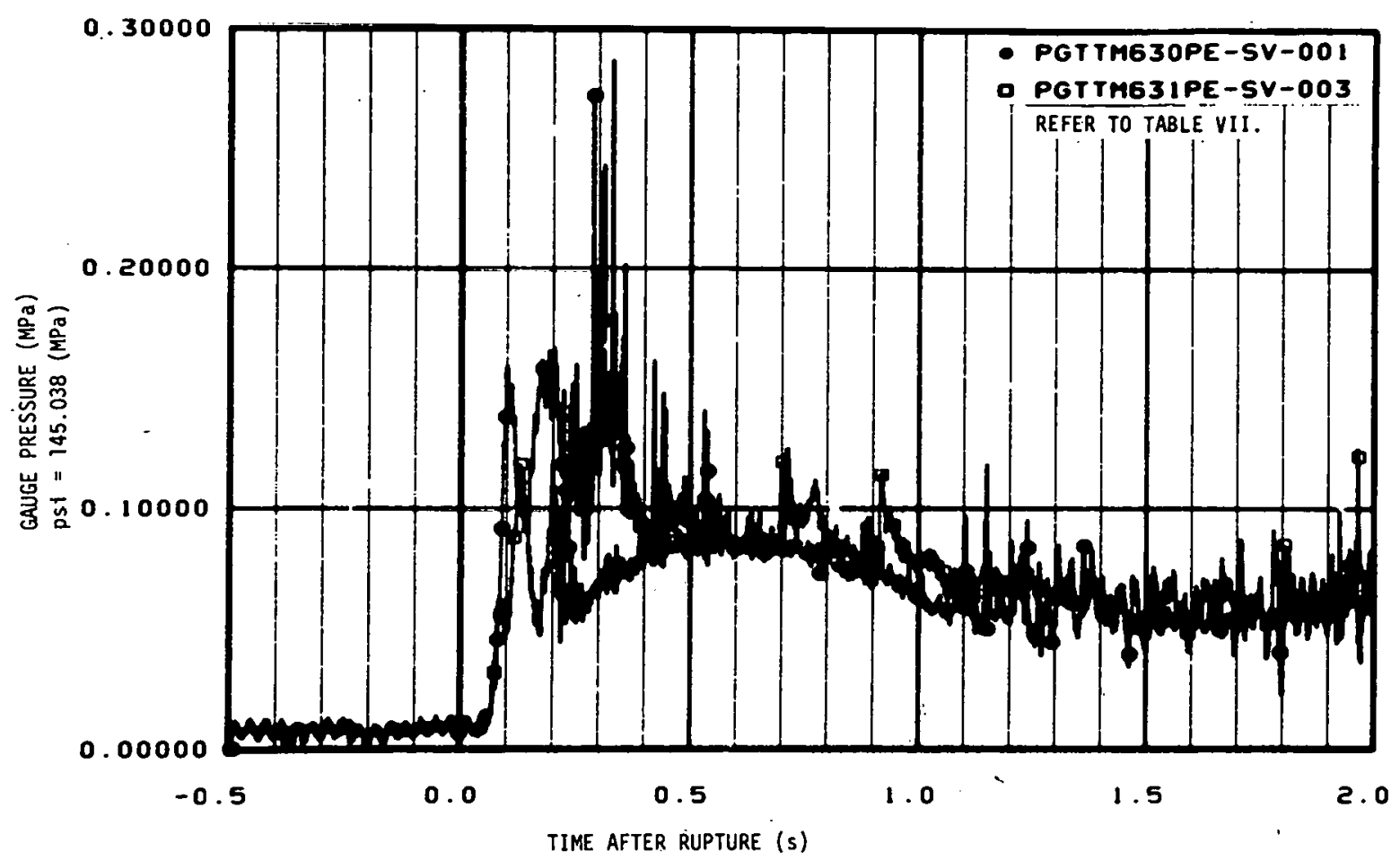

Fig. 23 Pressure in blowdown suppression tank bottom under downcomer $4,180^{\circ}$ (PE-SV-01) and under downcomer $1,157.5^{\circ}$ (PE-SV-03). 


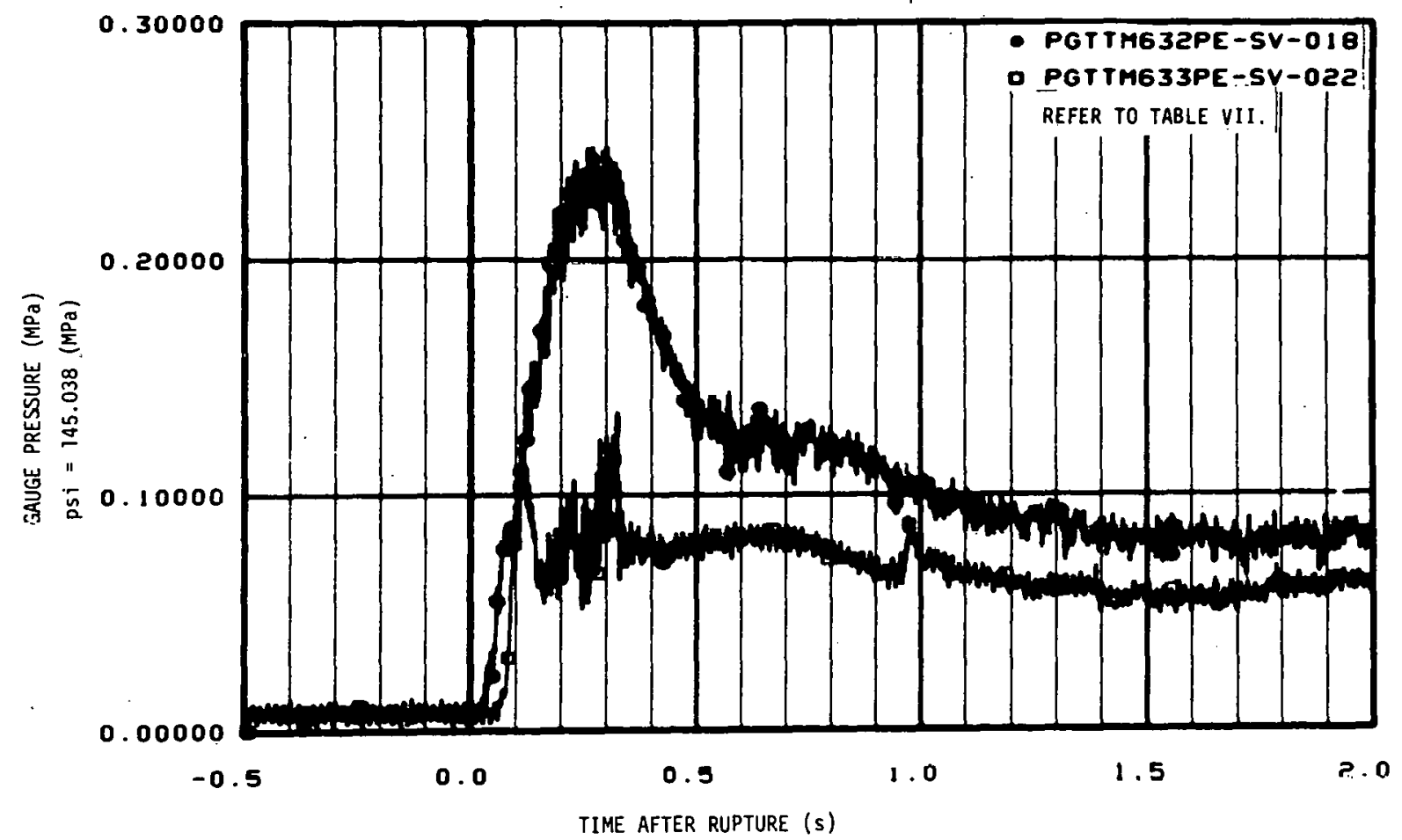

Fig. 24 Pressure in blowdown suppression tank header above downcoller 1 (PE-SV-18) and tank bottom, $1.38 \mathrm{~m}$ north of downcomer $3,180^{\circ}$ (PE-SV-22).

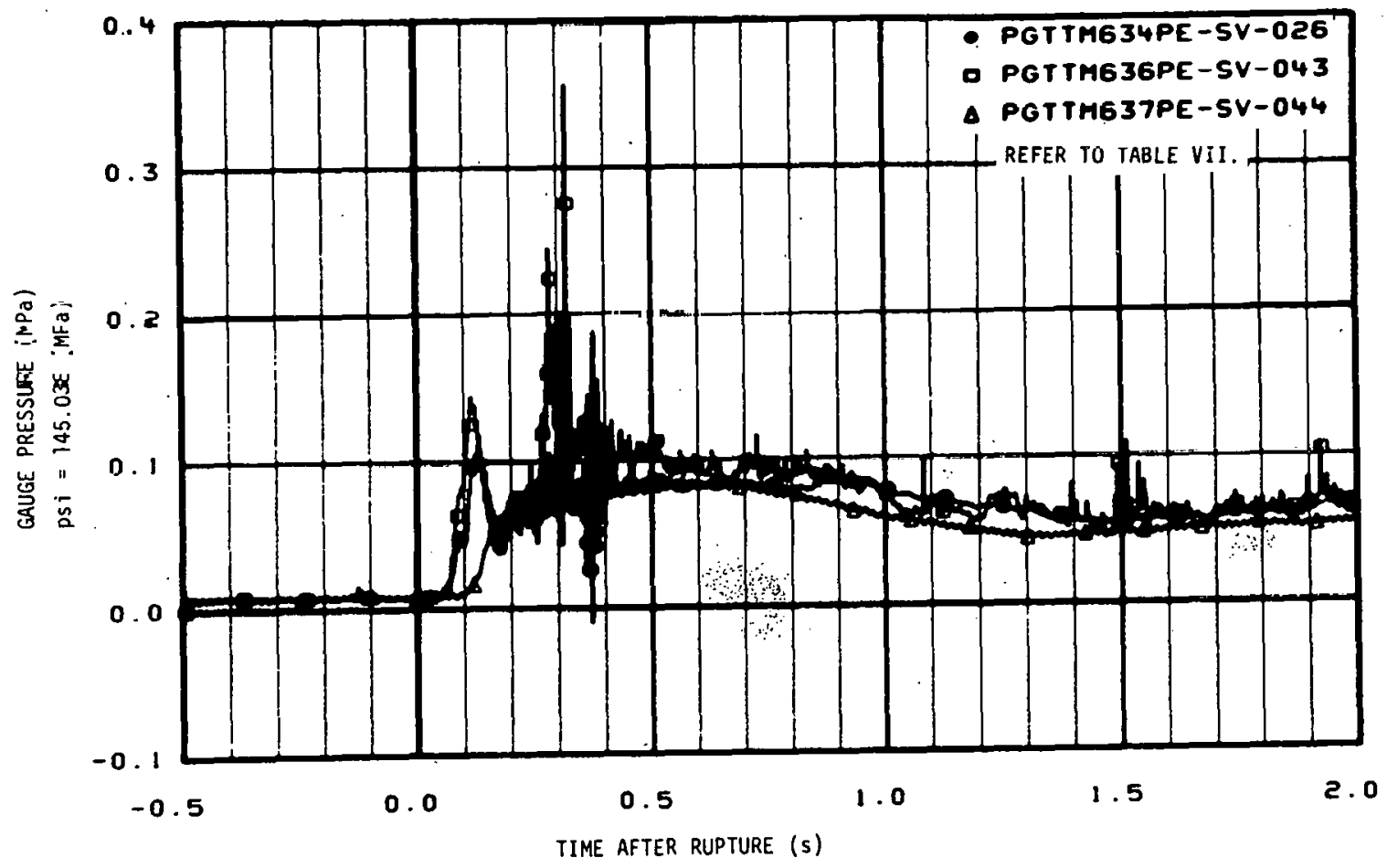

Fig. 25 Pressure in blowdown suppression tank bottom, $1.379 \mathrm{~m}$ south of

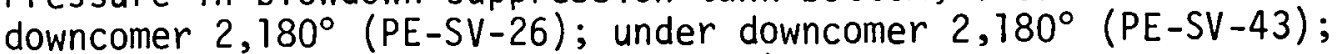
and under downcomer $3,180^{\circ}$ (PE-SV-44). 


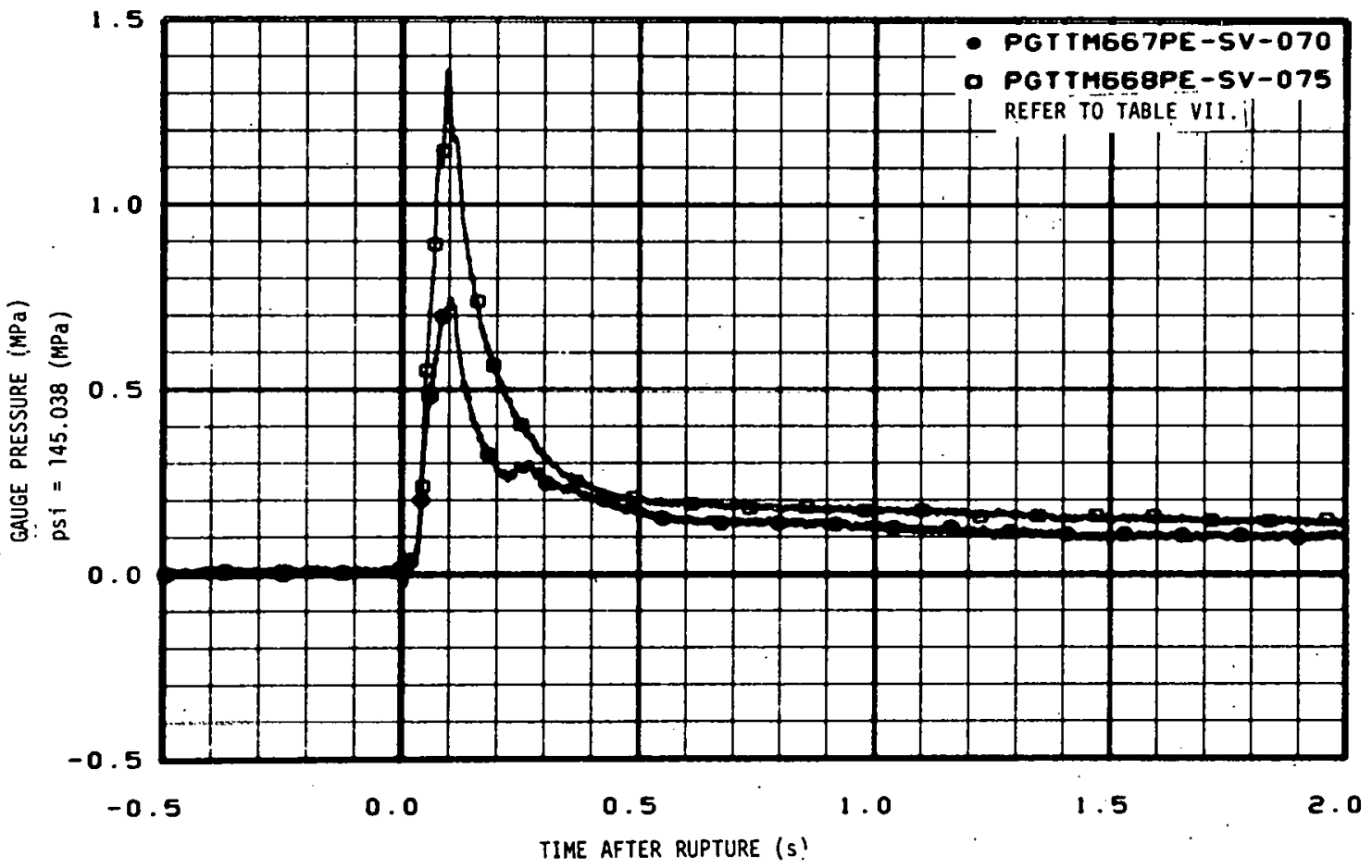

Fig. 26 . Pressure in bellows between broken loop and blowdown suppression tank header (hot leg PE-SV-70 and cold leg PE-SV-75). 


\section{THIS PAGE}

WAS INTENTIONALLY

LEFT BLANK 


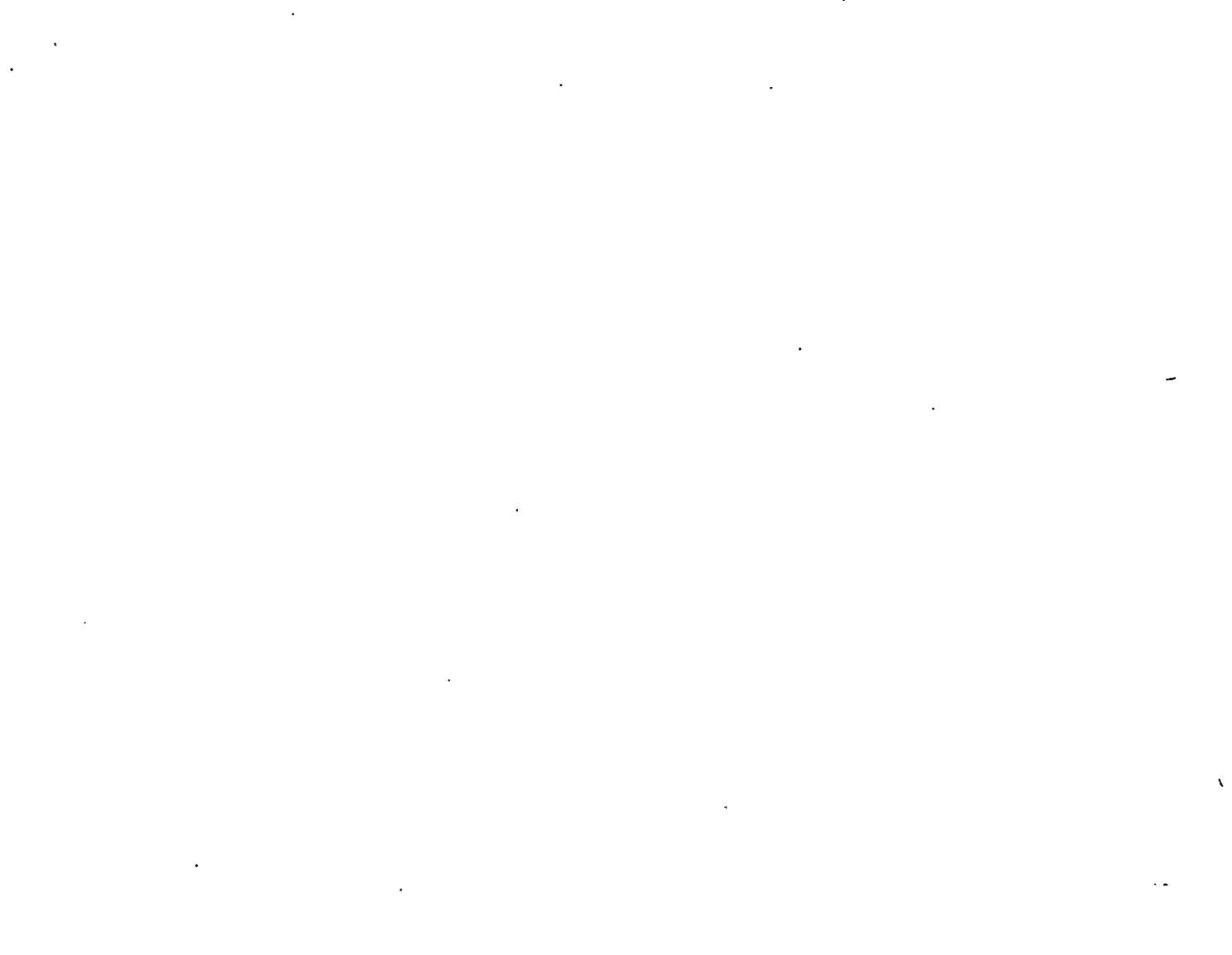


2. TEST L1-4 MEASURED PARAMETERS --

MEDIUM-TERM PLOTS ( -10 TO 70 SECONDS)

This section of presented data consists of Figures 27 through 136. 


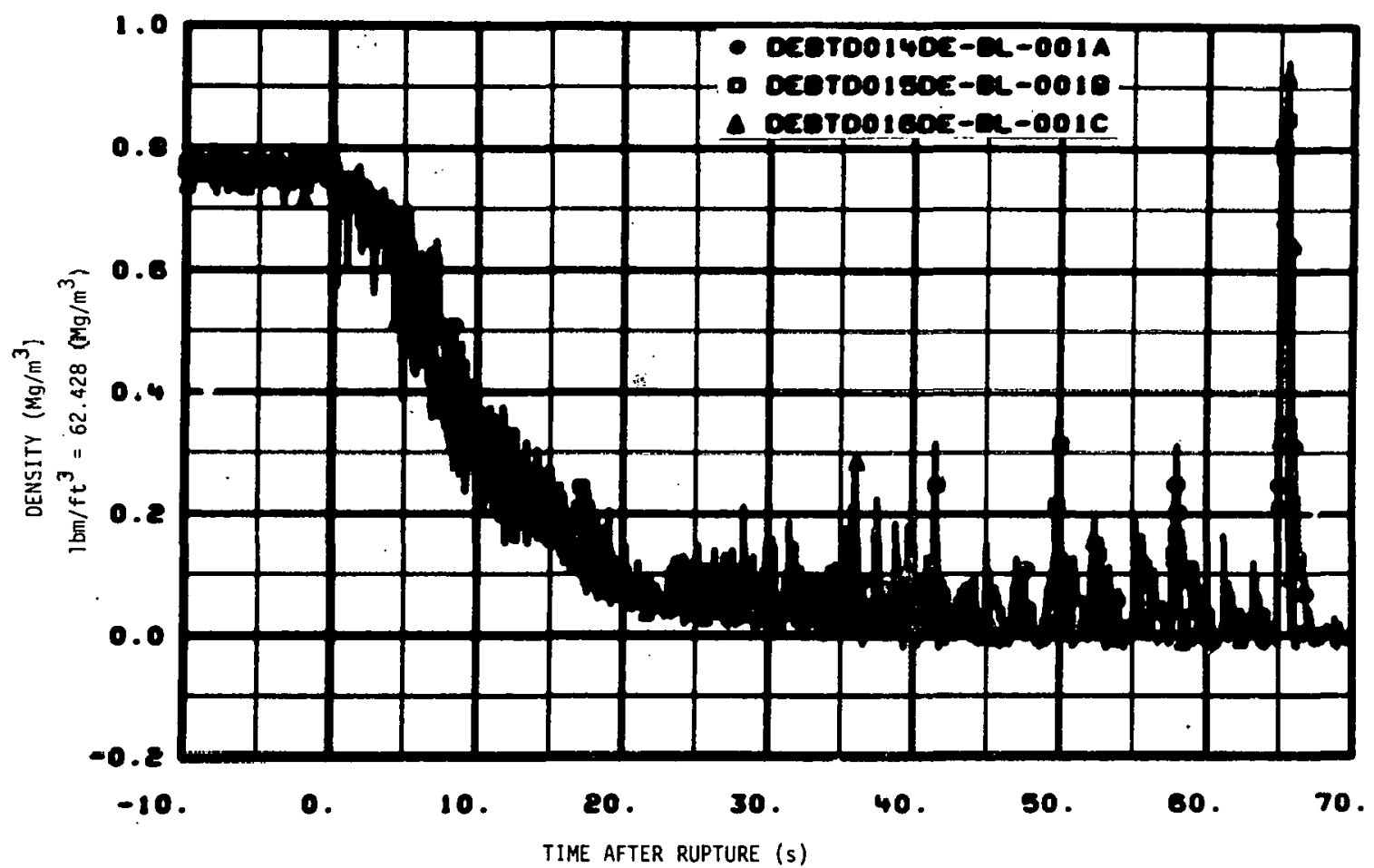

Fig. 27 Density in broken loop cold leg, chordal density (DE-BL-1A, -1B, and $-1 C$ ).

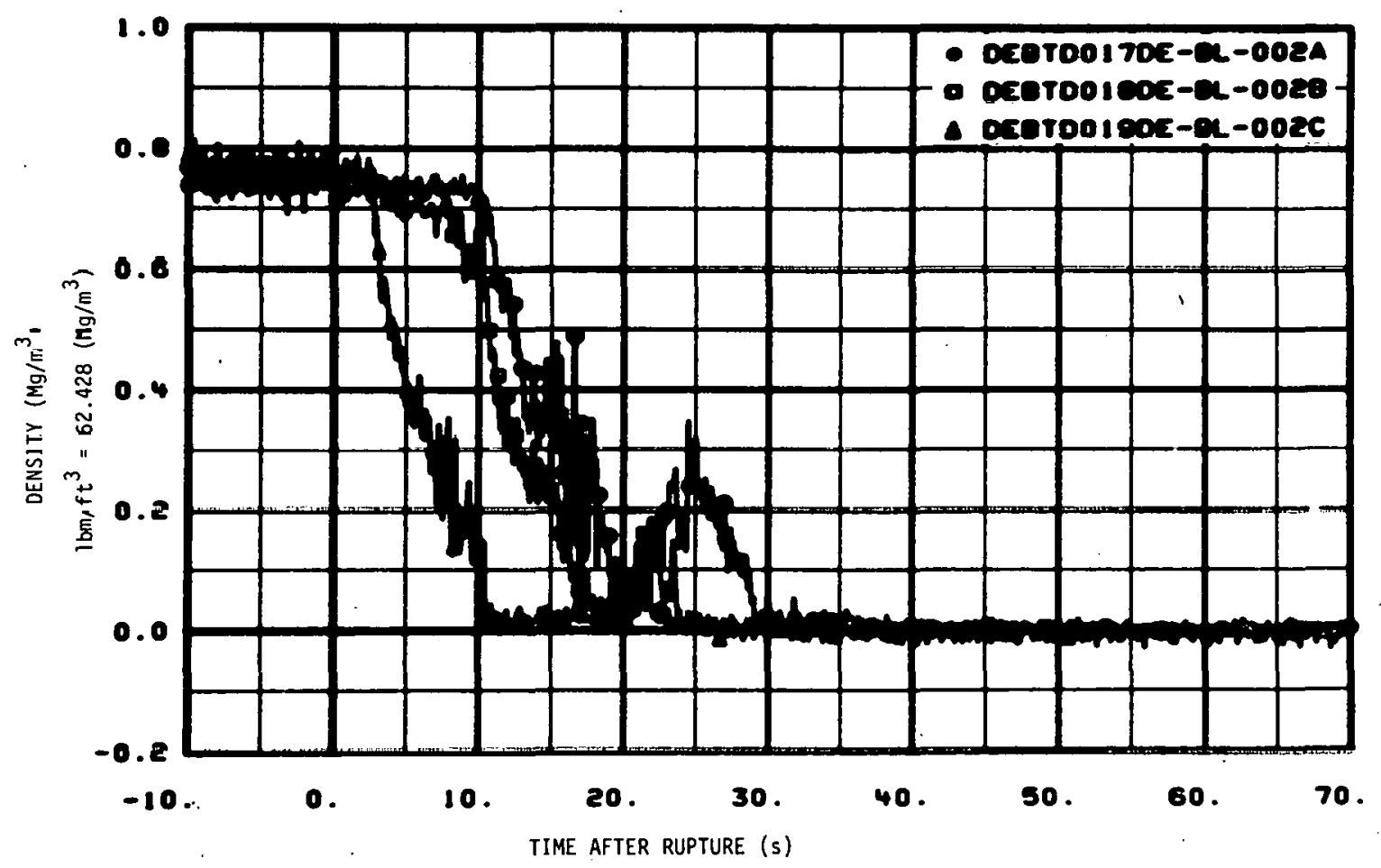

Fig. 28 Density in broken loop hot leg, chordal density ( $D E-B L-2 A,-2 B$, and $-2 C)$. 


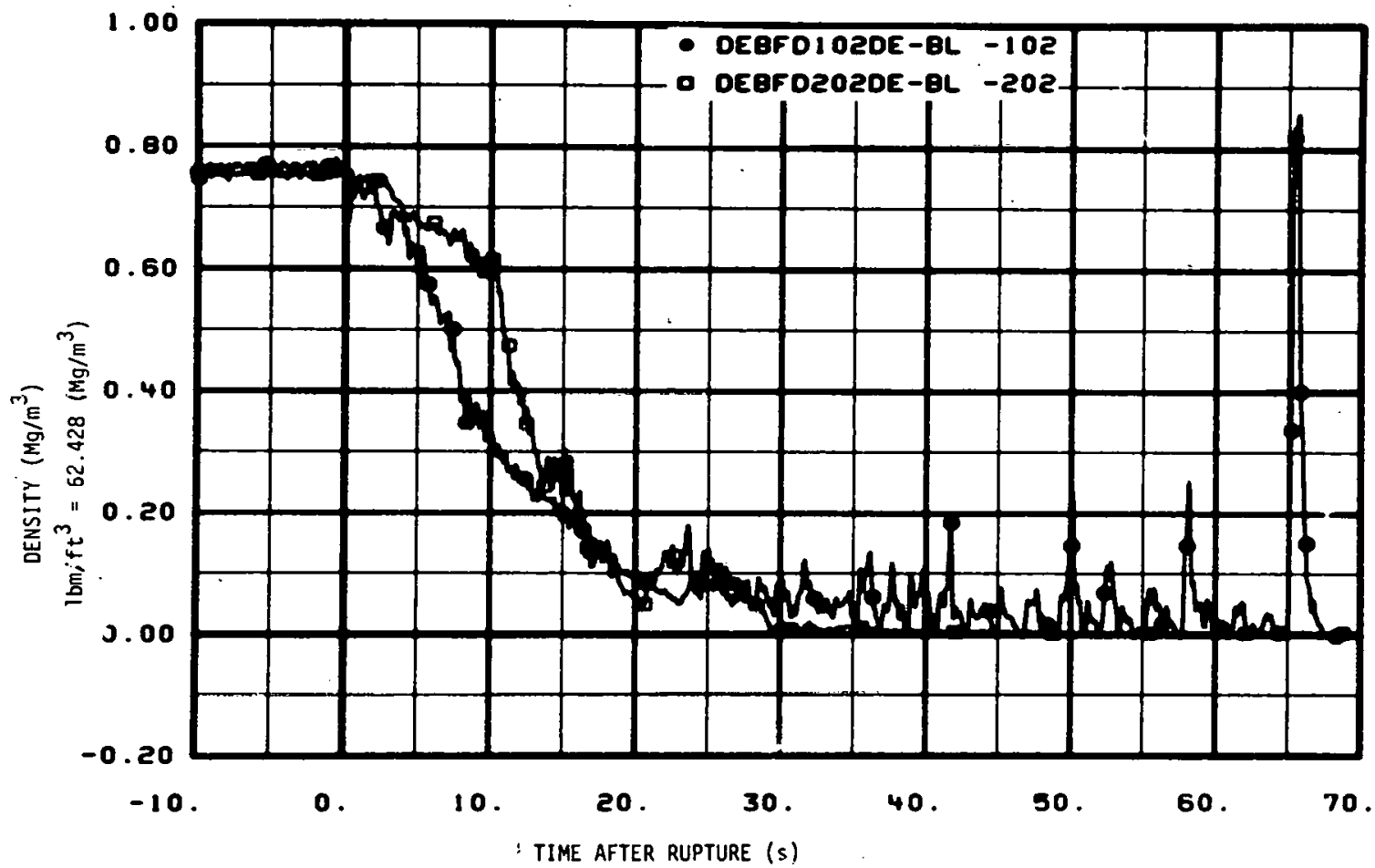

Fig. 29 Density in broken loop, average fluid densities (DE-BL-1 and -2 ).

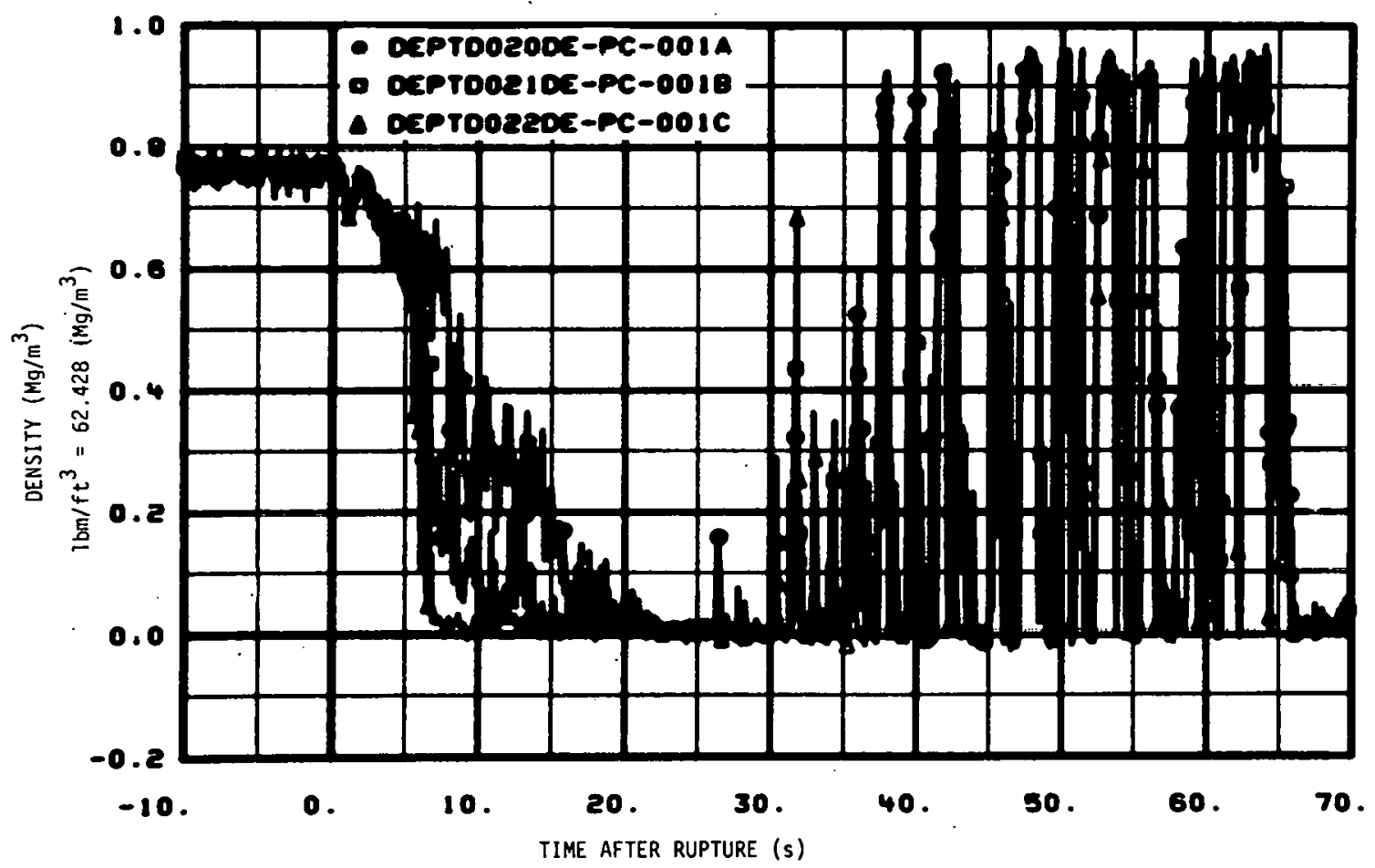

Fig. 30 Density in intact loop cold leg, chordal density (DE-PC-1A, -1B, and $-1 C$ ). 


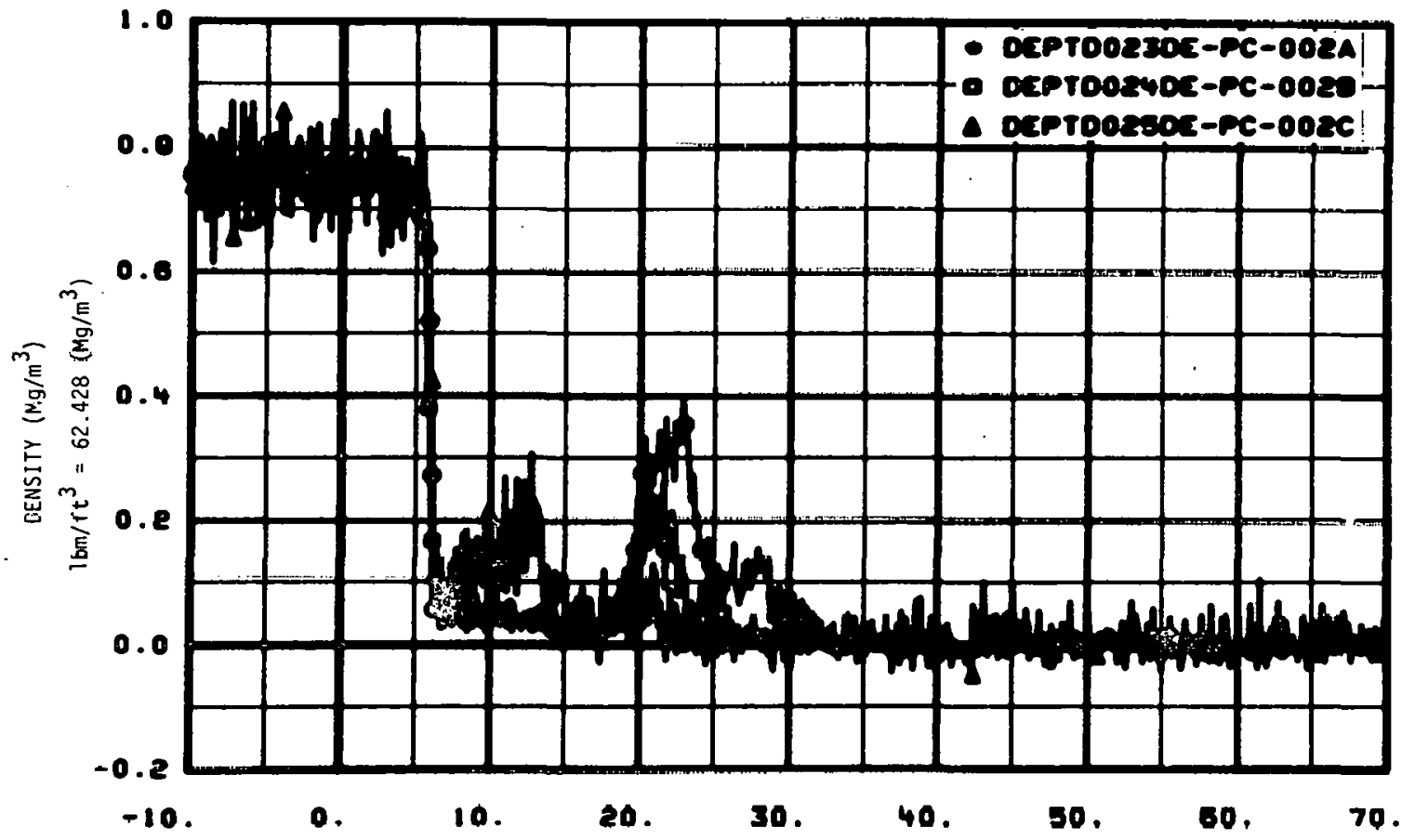

TIME AFTER RUPTURE ( $s$ )

Fig. 31 Density in intact loop hot leg, chordal density (DE-PC-2A, -2B, and $-2 \mathrm{C}$ ).

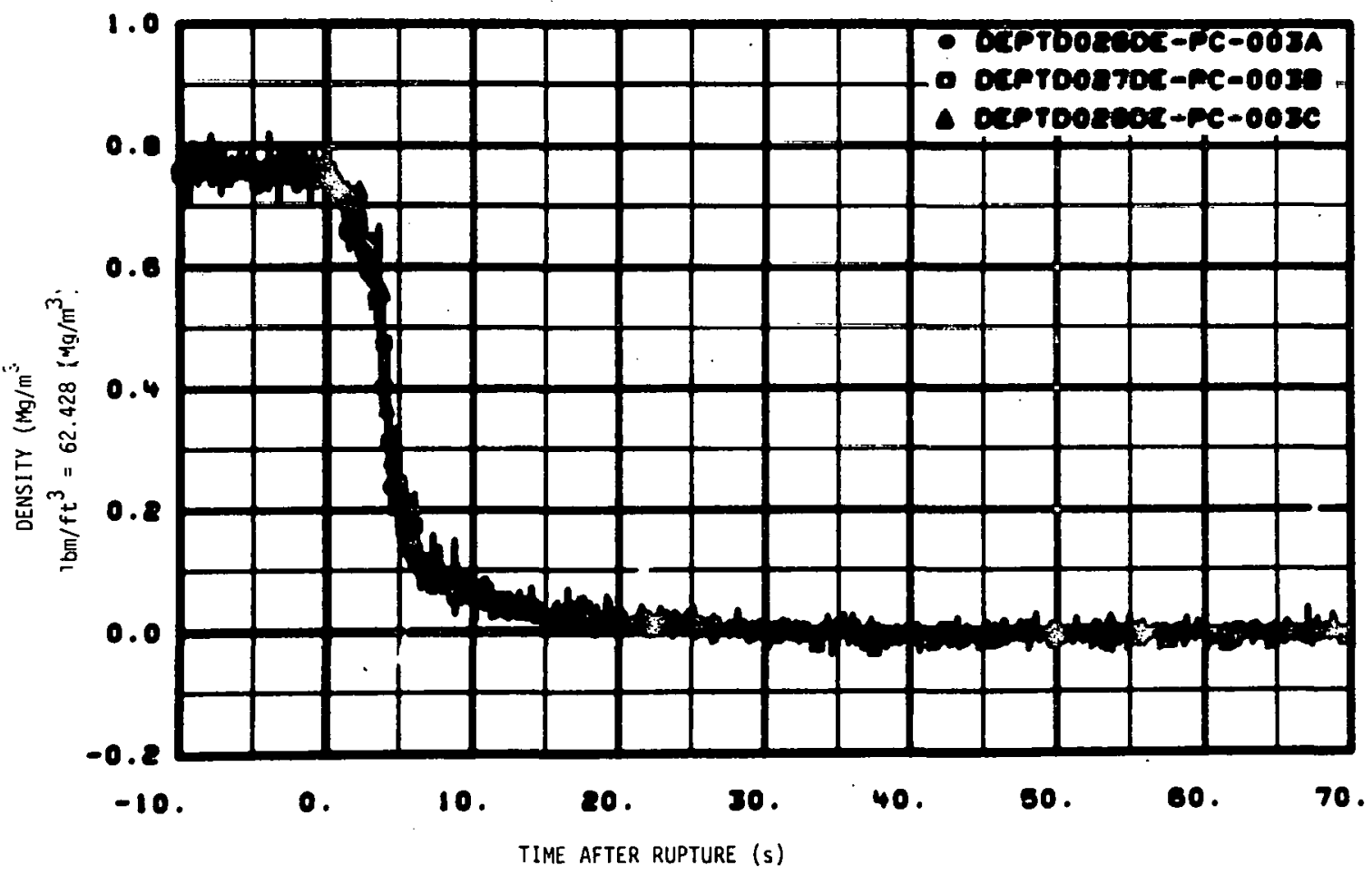

Fig. 32 Density in intact loop at steam generator outlet, chordal density ( $D E-P C-3 A,-3 B$, and $-3 C$ ). 


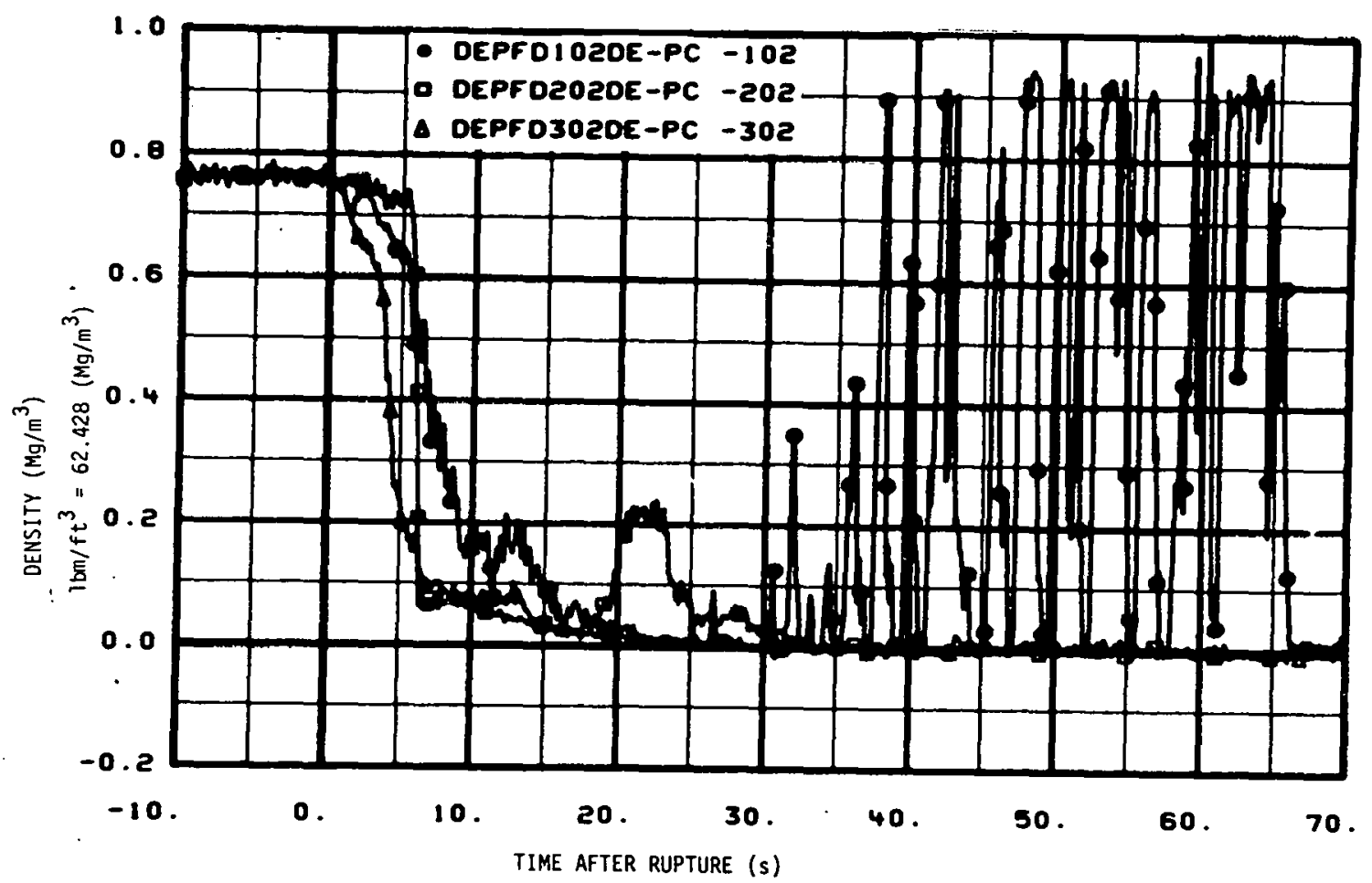
Fig. $33^{\circ} \begin{aligned} & \text { Density in intact loop, average fluid densities (DE-PC-1, }-2 \text {, } \\ & \text { and }-3 \text { ). }\end{aligned}$

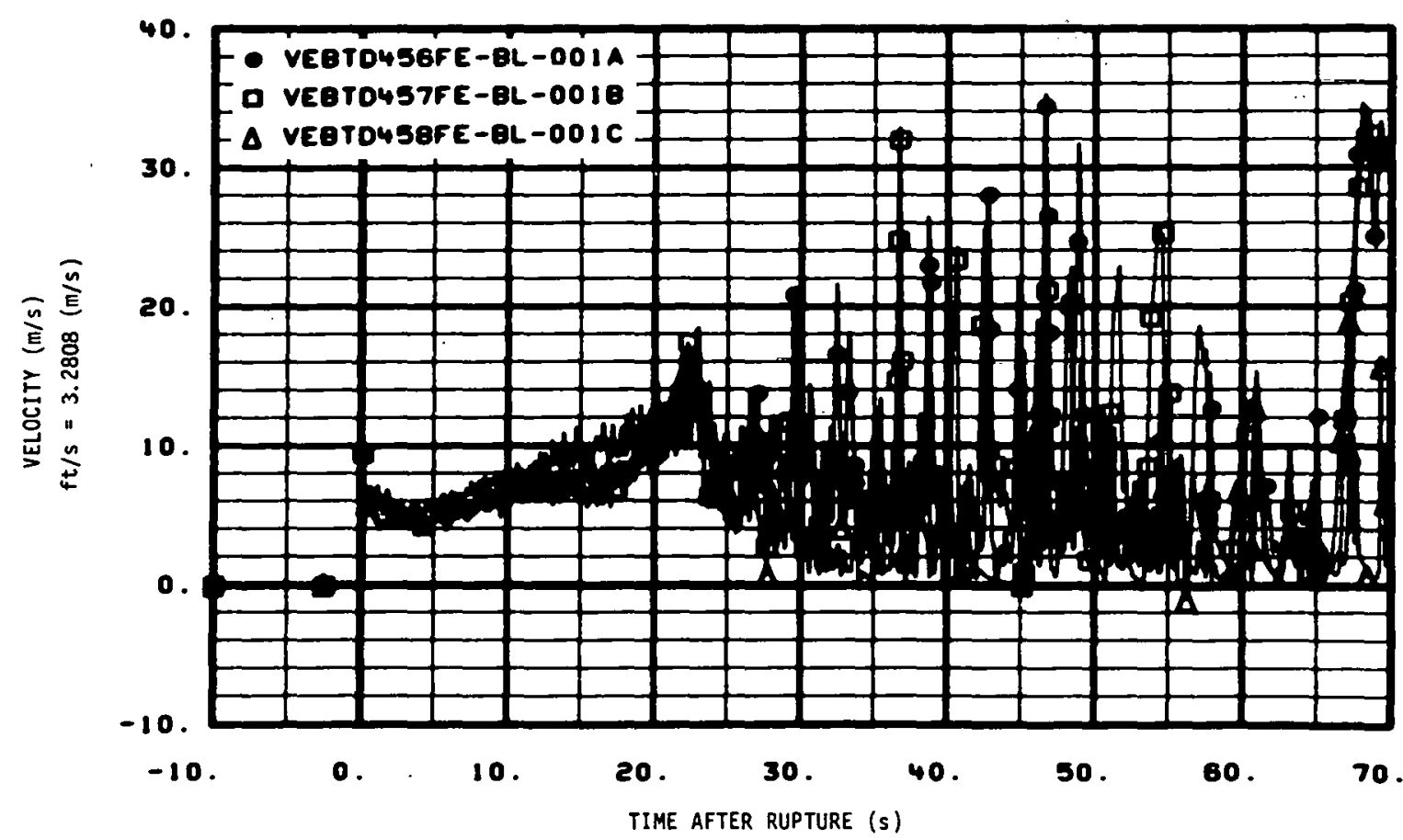

Fig. 34 Fluid velocity in broken loop cold leg at DTT flange (FE-BL-1A, - IB, and - IC) (filtered to $4 \mathrm{~Hz}$ ). 


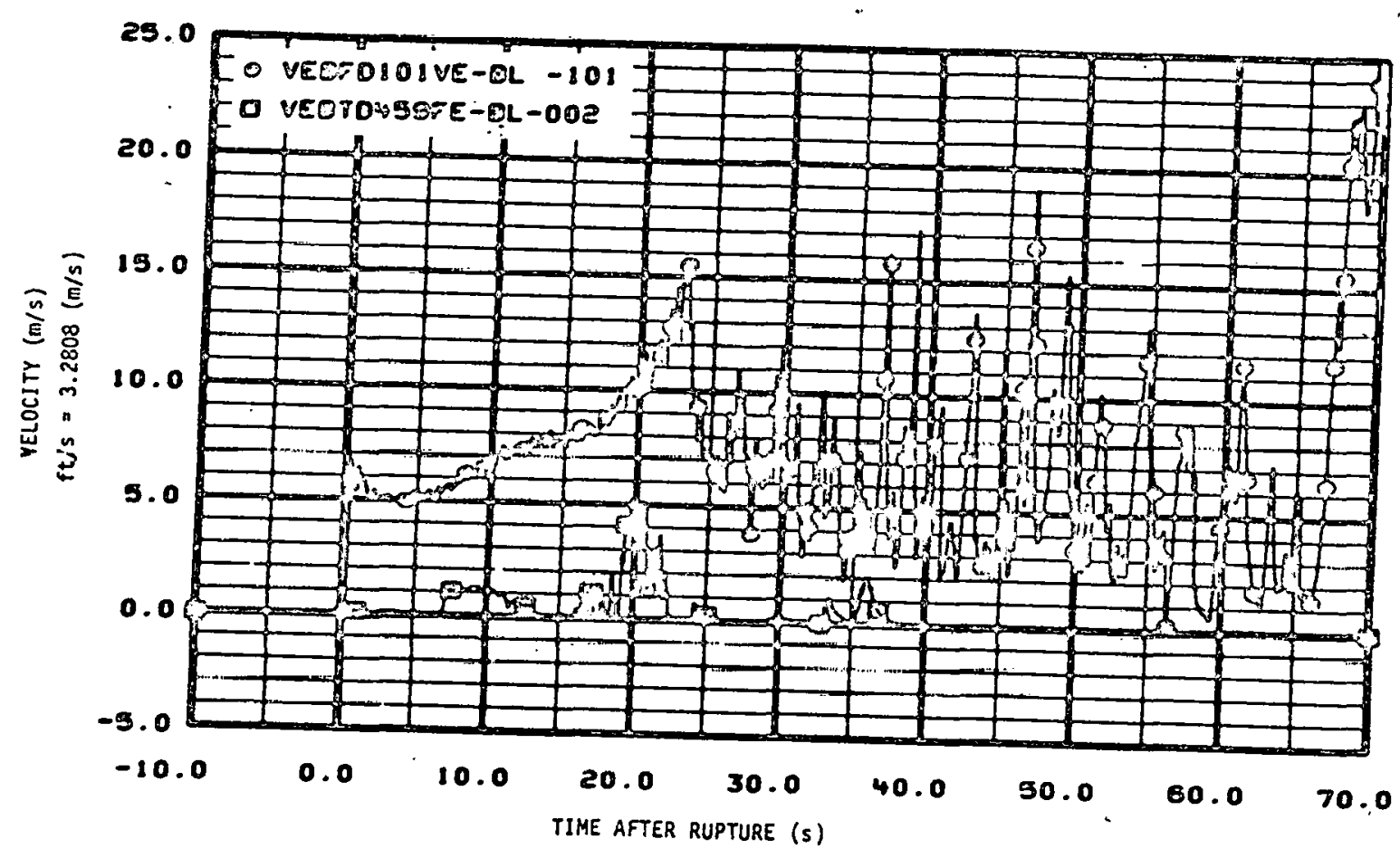

Fig. 35 Fluid velocity in broken loop hot and cold legs at DTT flanges (FE-BL-1 and -2 ).

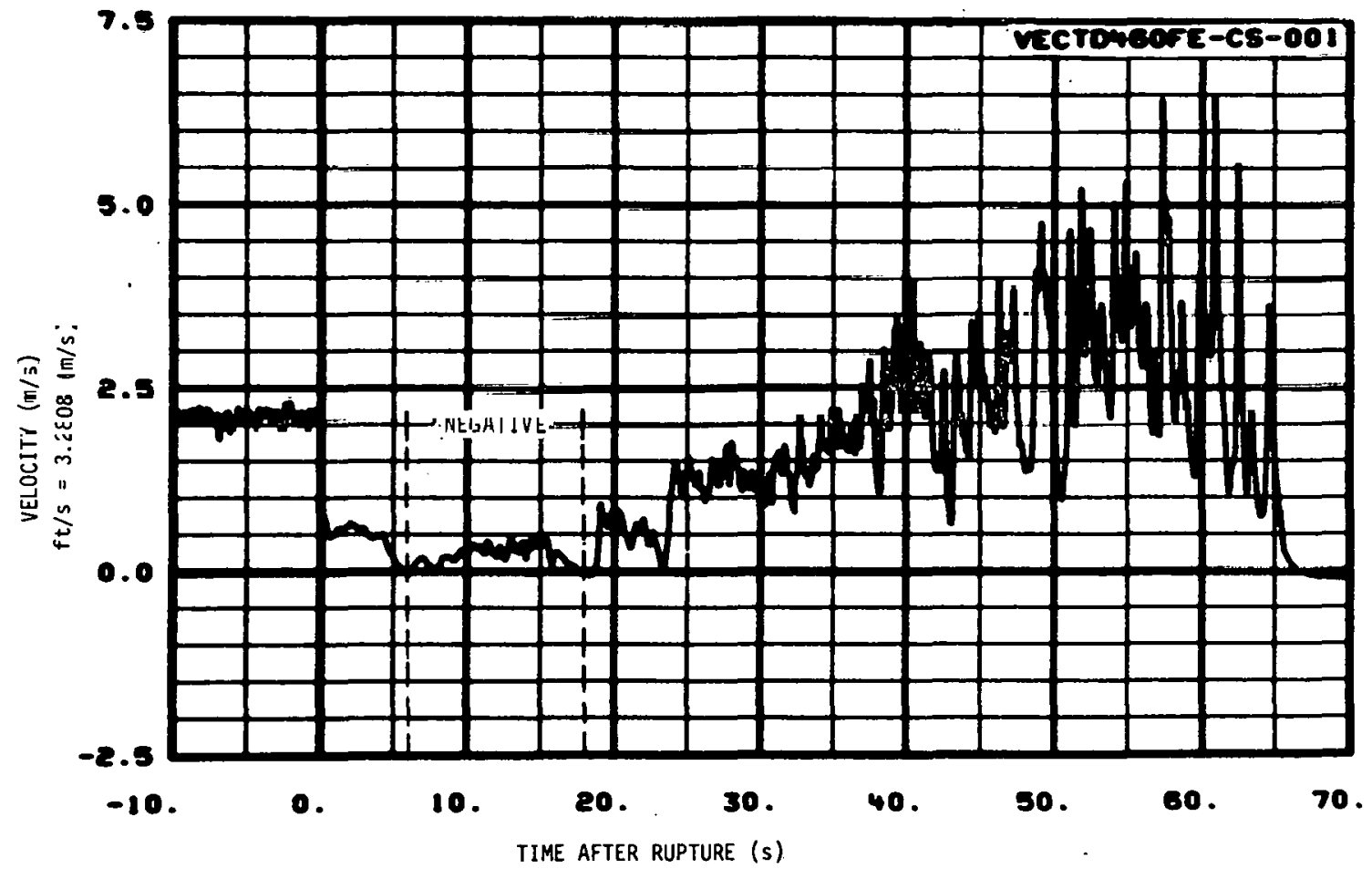

Fig. 36 Fluid velocity in reactor vessel core simulator instrument stalk (FE-CS-1). 


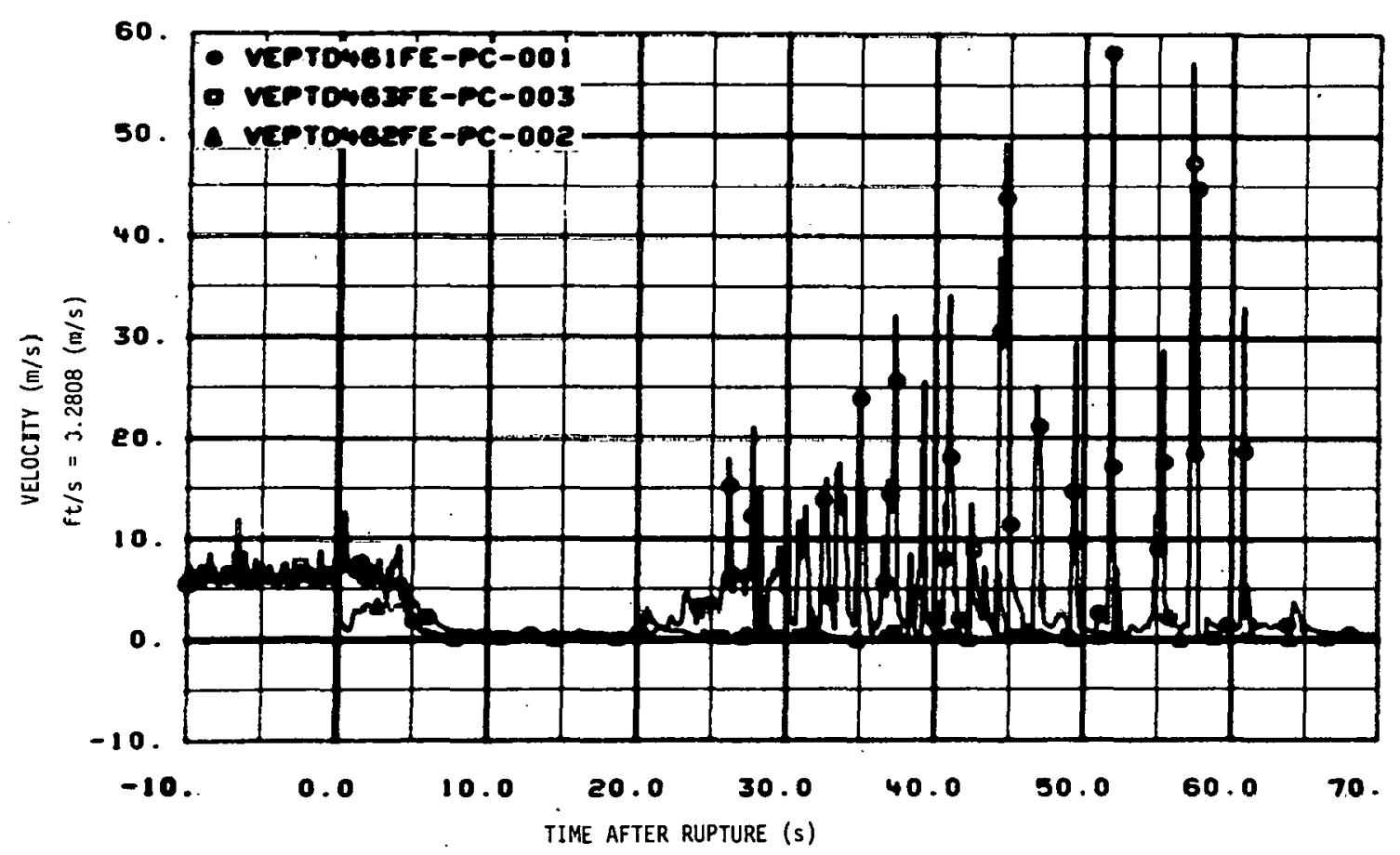

Fig. 37 Fluid velocity in intact loop cold leg, hot leg, and steam generator outlet at DTT flanges (FE-PC-1, -2, and -3).

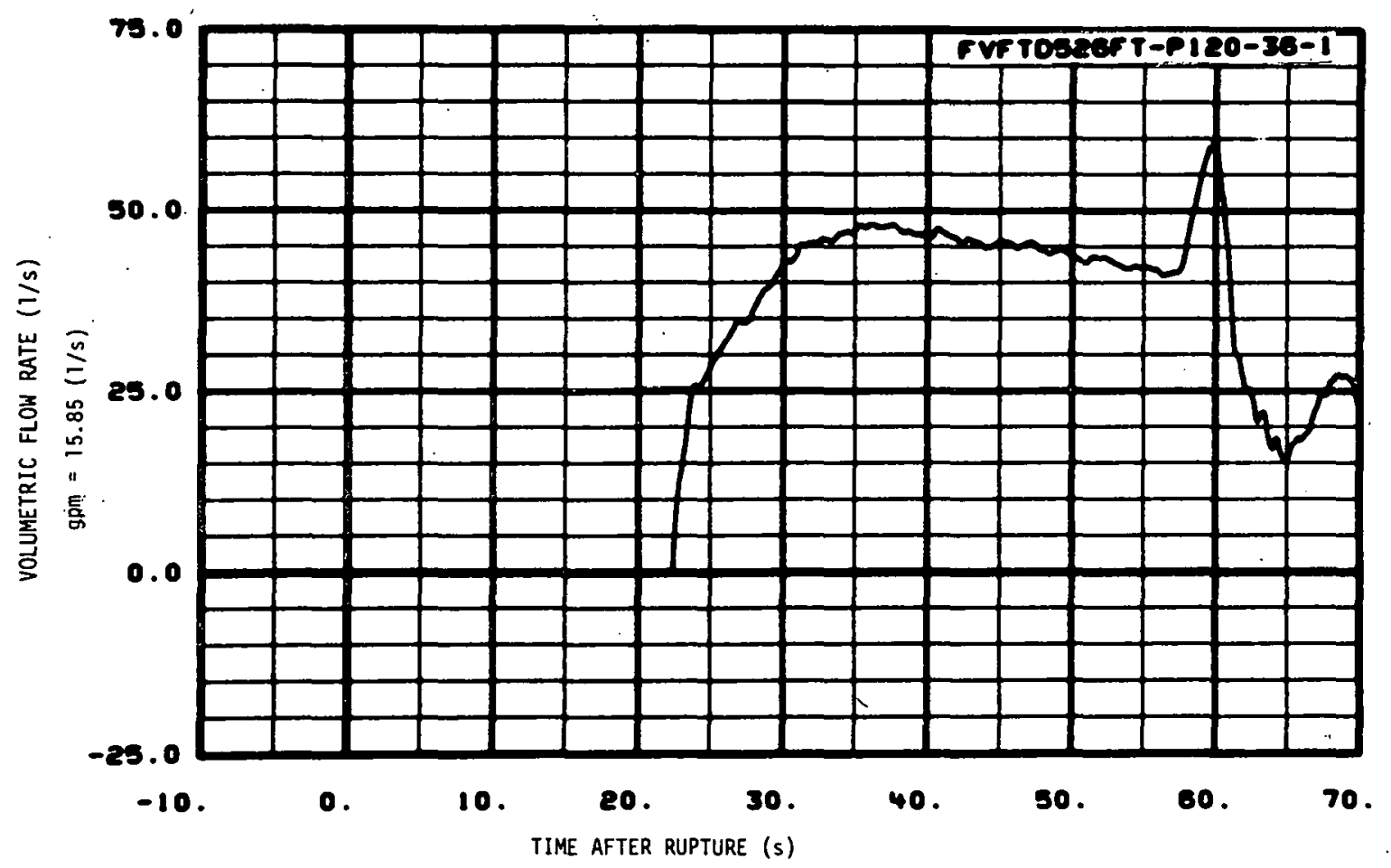

Fig. 38 Flow rate in ECCS accumulator A discharge, high range (FT-P120-36-1). 


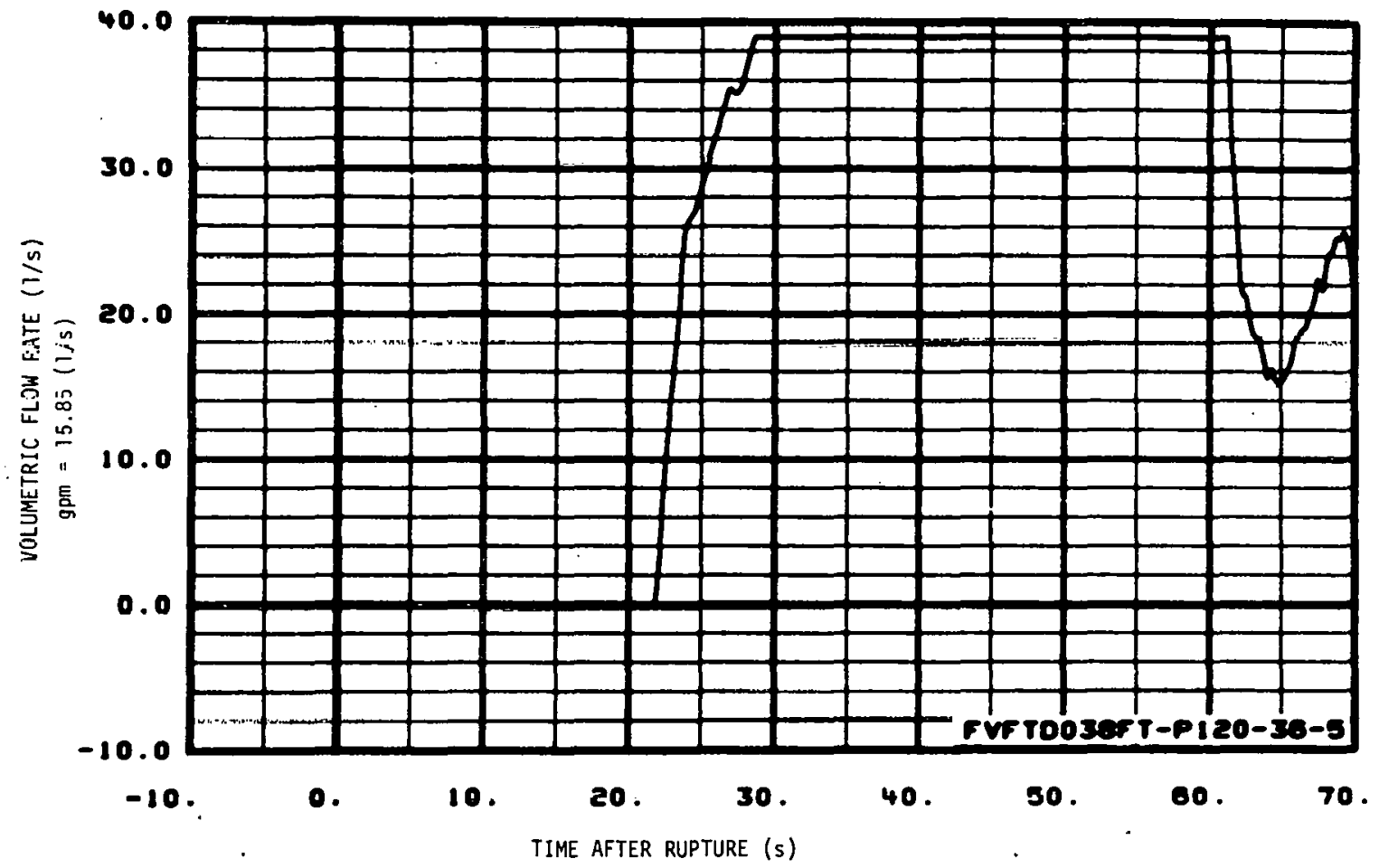

rig. 39 Flow rate in ECCS accumulatur A discharge, low range (FT-P120-36-5).

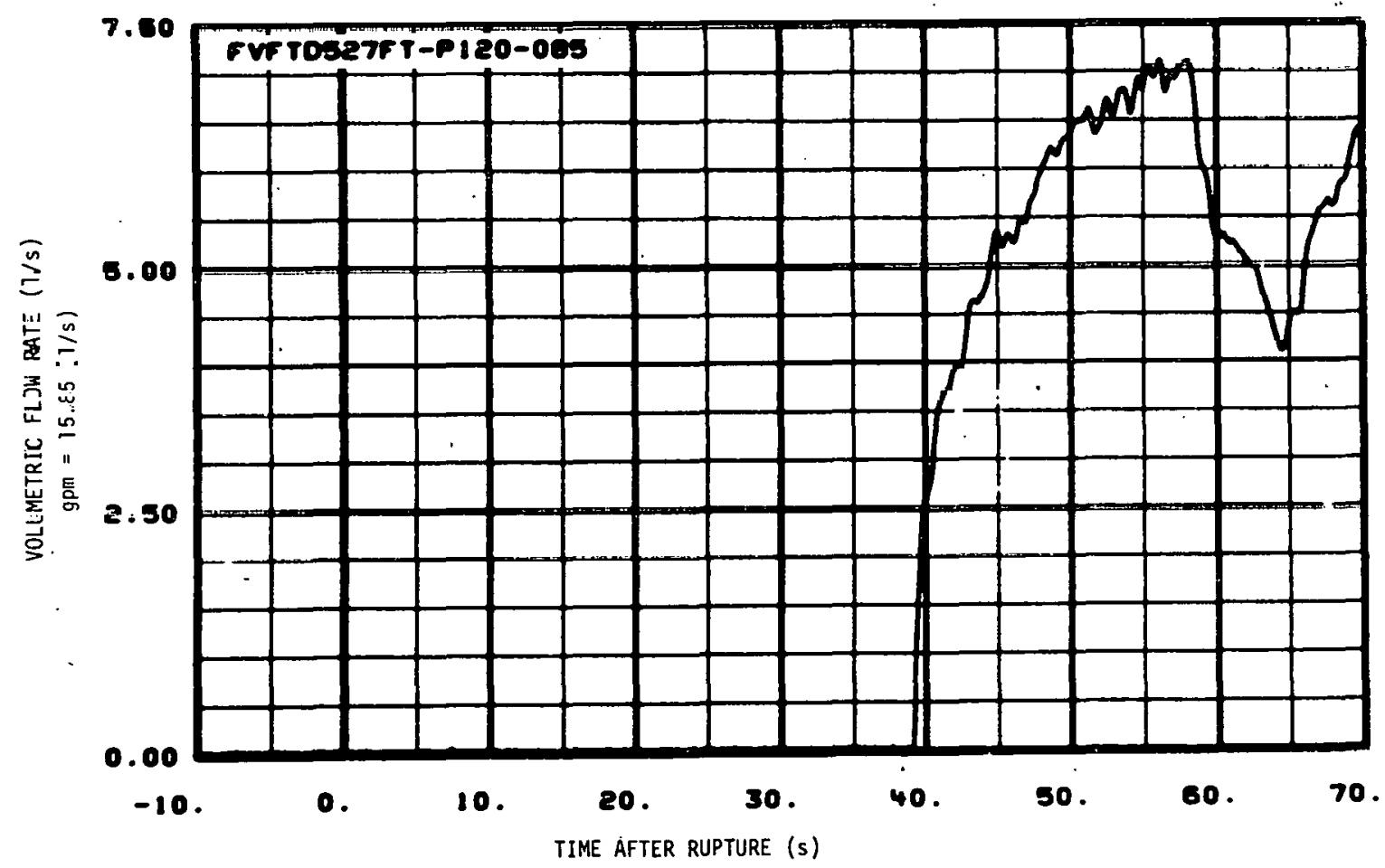

Fig. 40 Flow rate in ECCS LPIS pump A discharge (FT-P120-85). 


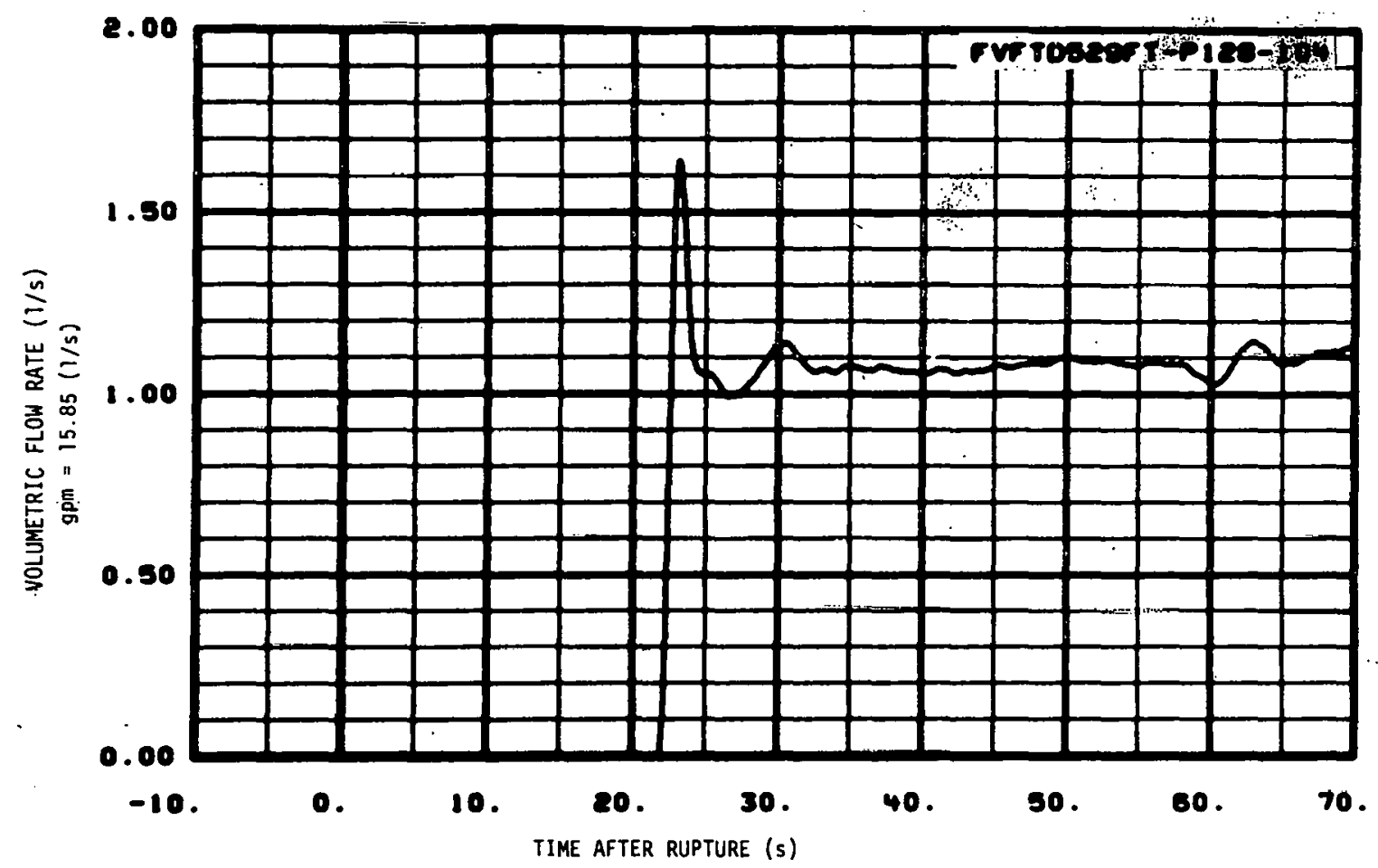

Fig. 41 Flow rate in ECCS HPIS pump A discharge (FT-P128-104).

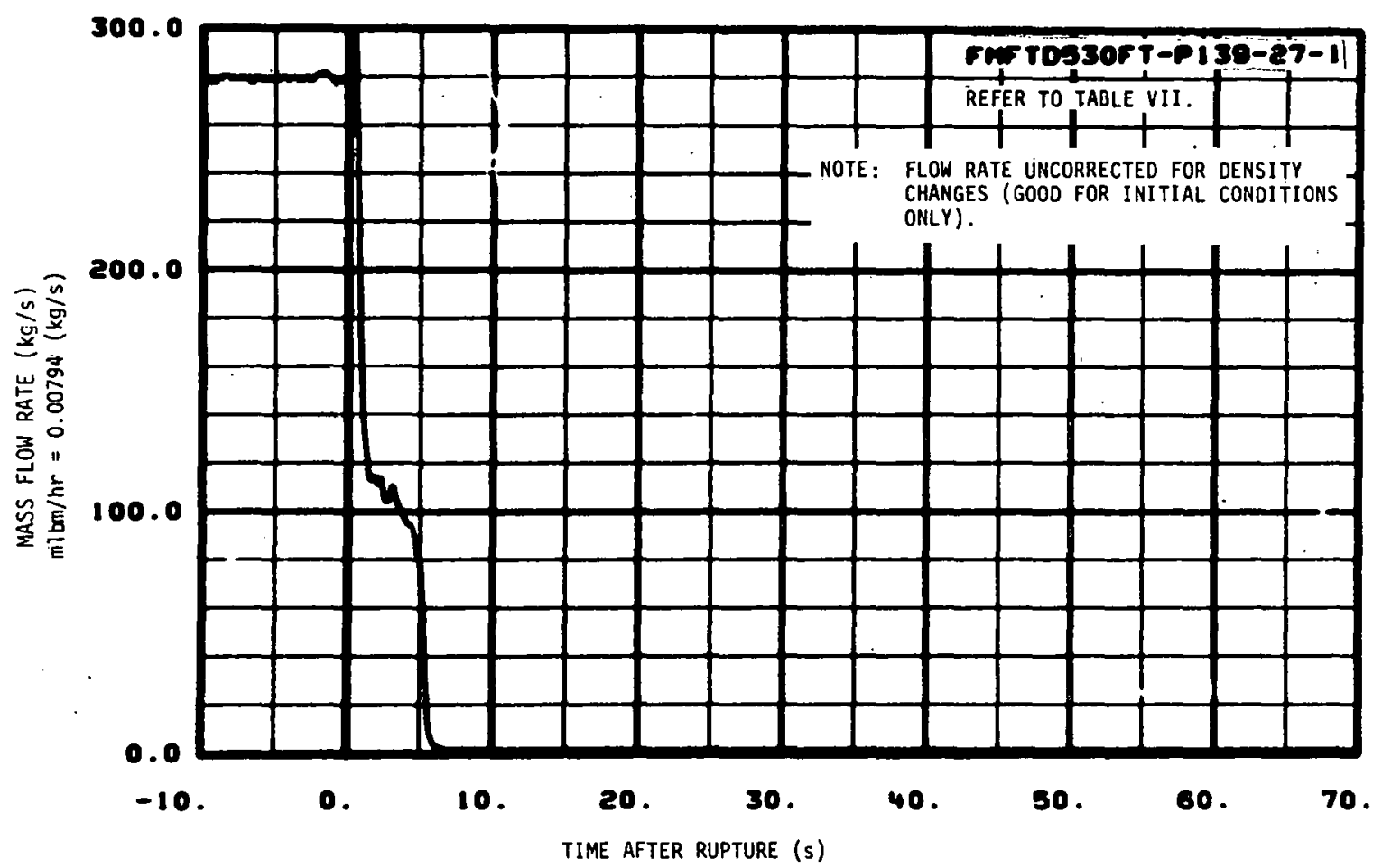

Fig. 42 Flow rate in intact loop hot leg venturi (FT-P139-27-1). 


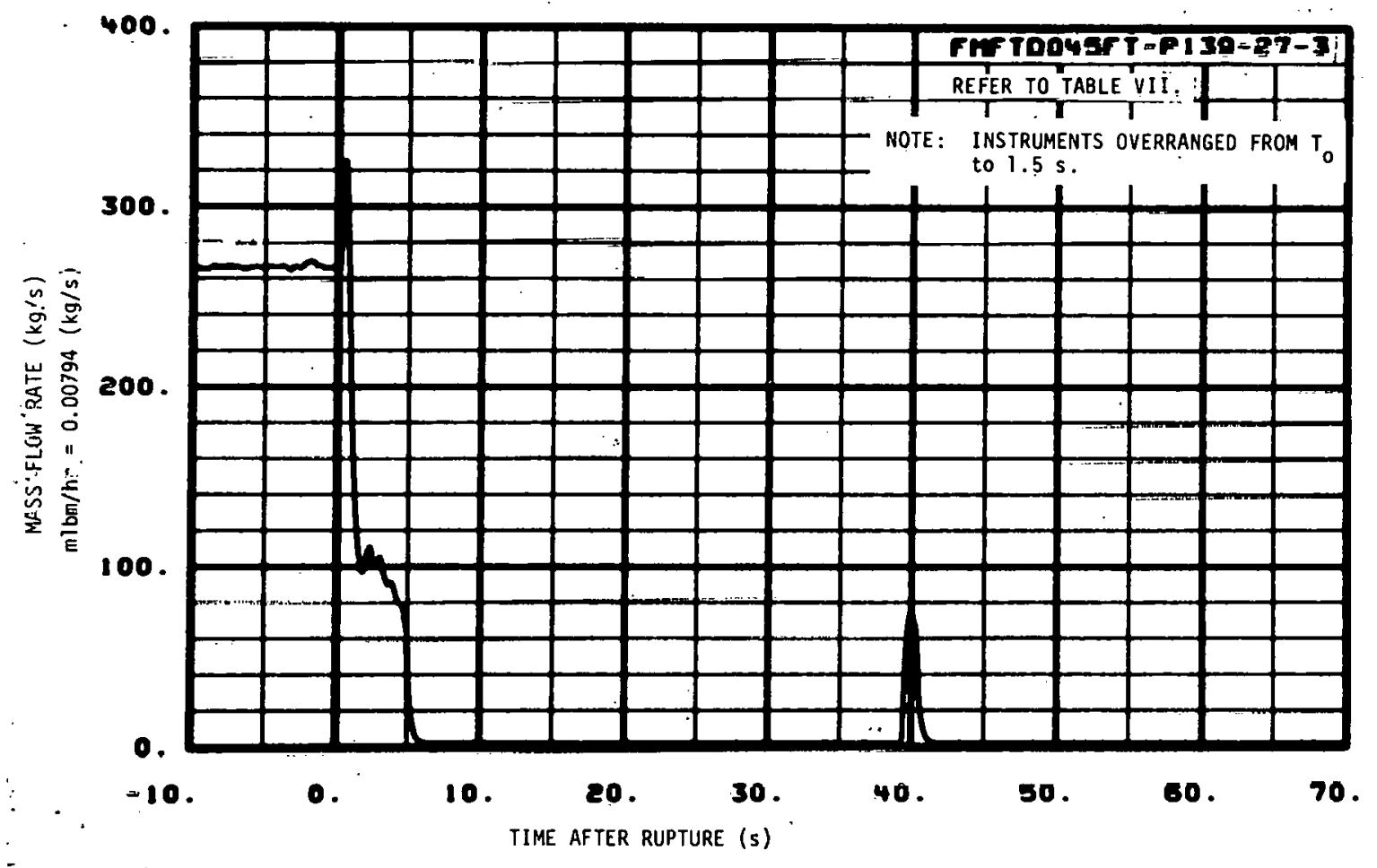

Fig. 43 Flow rate in intact loop hot leg venturi (FT-Pl39-27-3). 
LOFT LIQUID LEVEL LI-4 LE-1ST

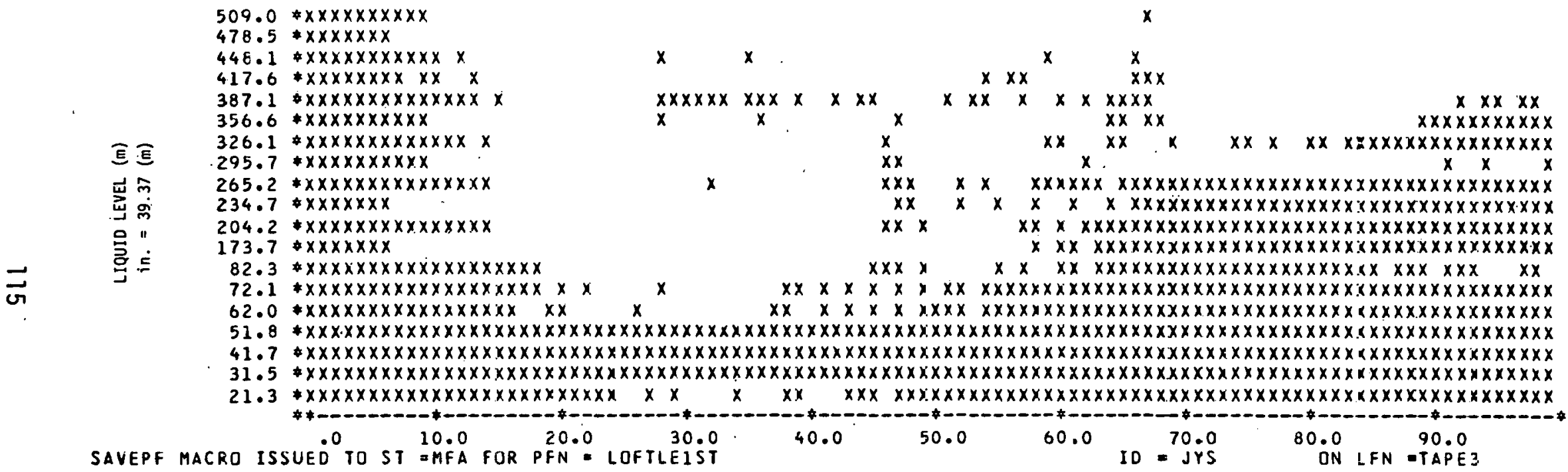

TIME AFTER RUPTURE ( $s$ )

Fig. 44 Liquid level in reactor vessel downcomer instrument stalk 1 , bubble plot (LE-1ST-1 and -2). 


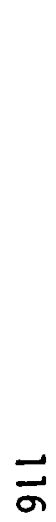

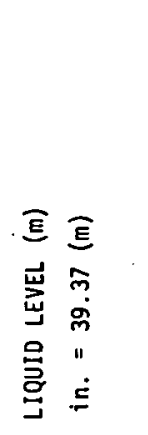

$509.0 * x \times x \times x \times x \times x$

$448.1+x \times x \times x \times x \times x$

$417.6 * x \times x \times x \times x \times x$

$387.1 \neq x \times x \times x x x x \quad x x \quad x x$

$356.6 * x \times x \times x x x x x$

$326.1+x \times x \times x \times x \times x \quad x x \times$

$295.7 * x \times x \times x \times x \times x$

$265.2 \notin x \times x \times x \times x \times x \times x x$

$234.7 * x \times x \times x \times x$

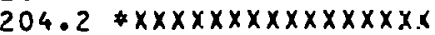

$173.7 * x \times x \times x \times x$

$82.3 * x \times x \times x \times x \times x \times x \times x \times x \times x \times 1 x x$

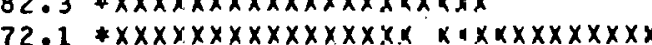

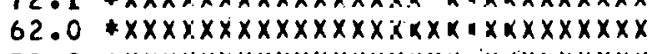

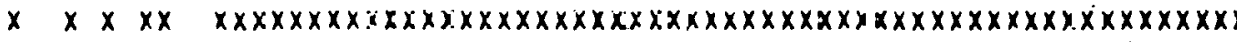

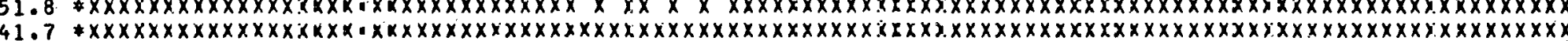

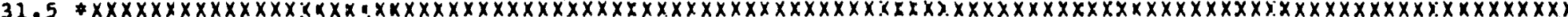

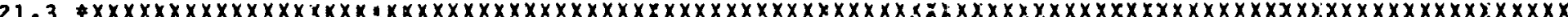
*\# 00.0 23.0 30.0 40.0 50.0 0.0 $I 0=J Y S$ 90.0 SAVEPF MACRO ISSUED TO ST $=$ MFA $=J R$. $: F V=L O F T L E 2 S T$

TIME AFTER RUPTURE (s)

Fig. 45 Liquid level in reactor vessel downcomer instrument stalk 2 , bubble plot (LE-2ST-1 and -2). 


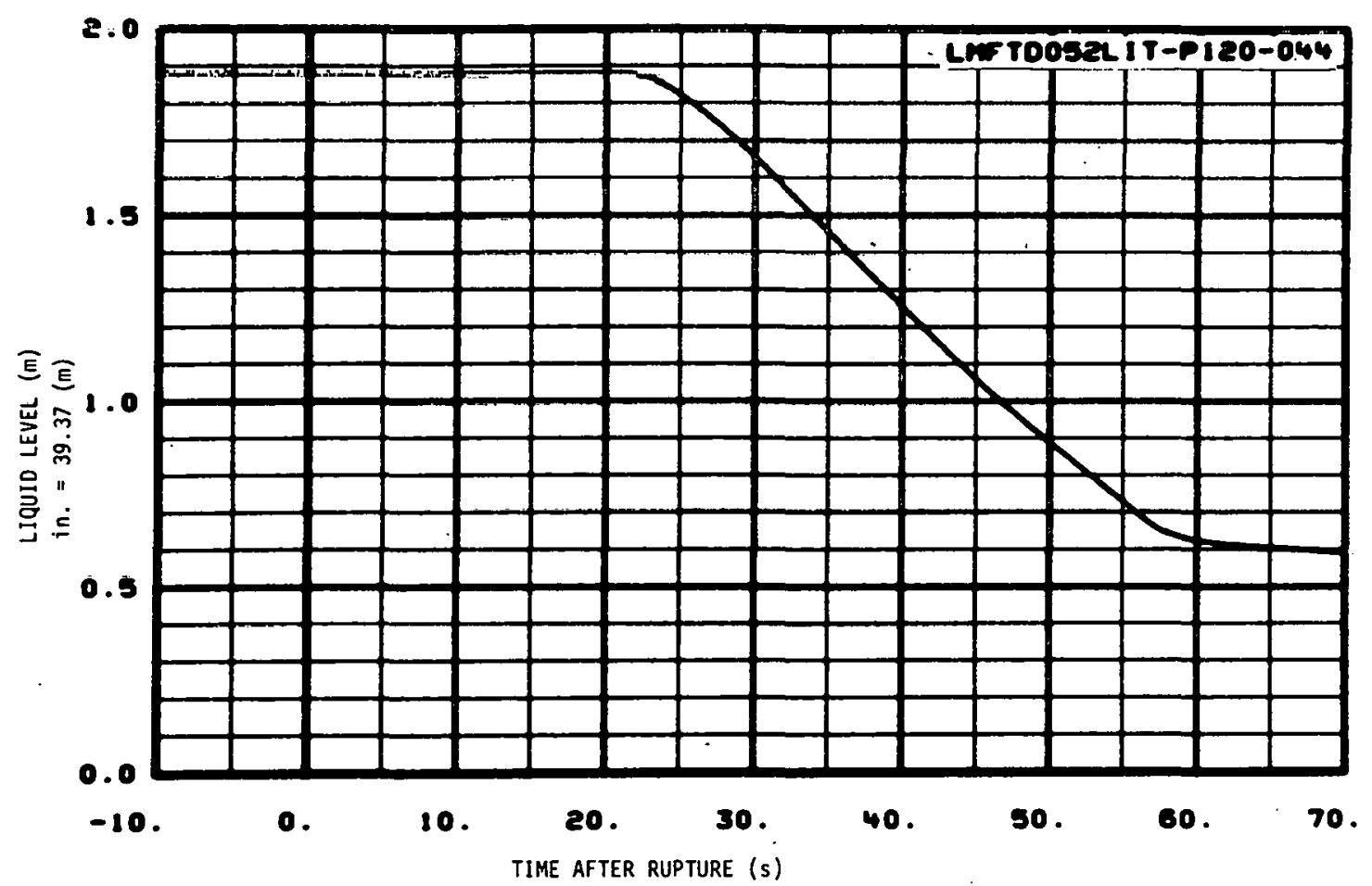

Fig. 46 Liquid level in ECCS accumulator A (LIT-P120-44).

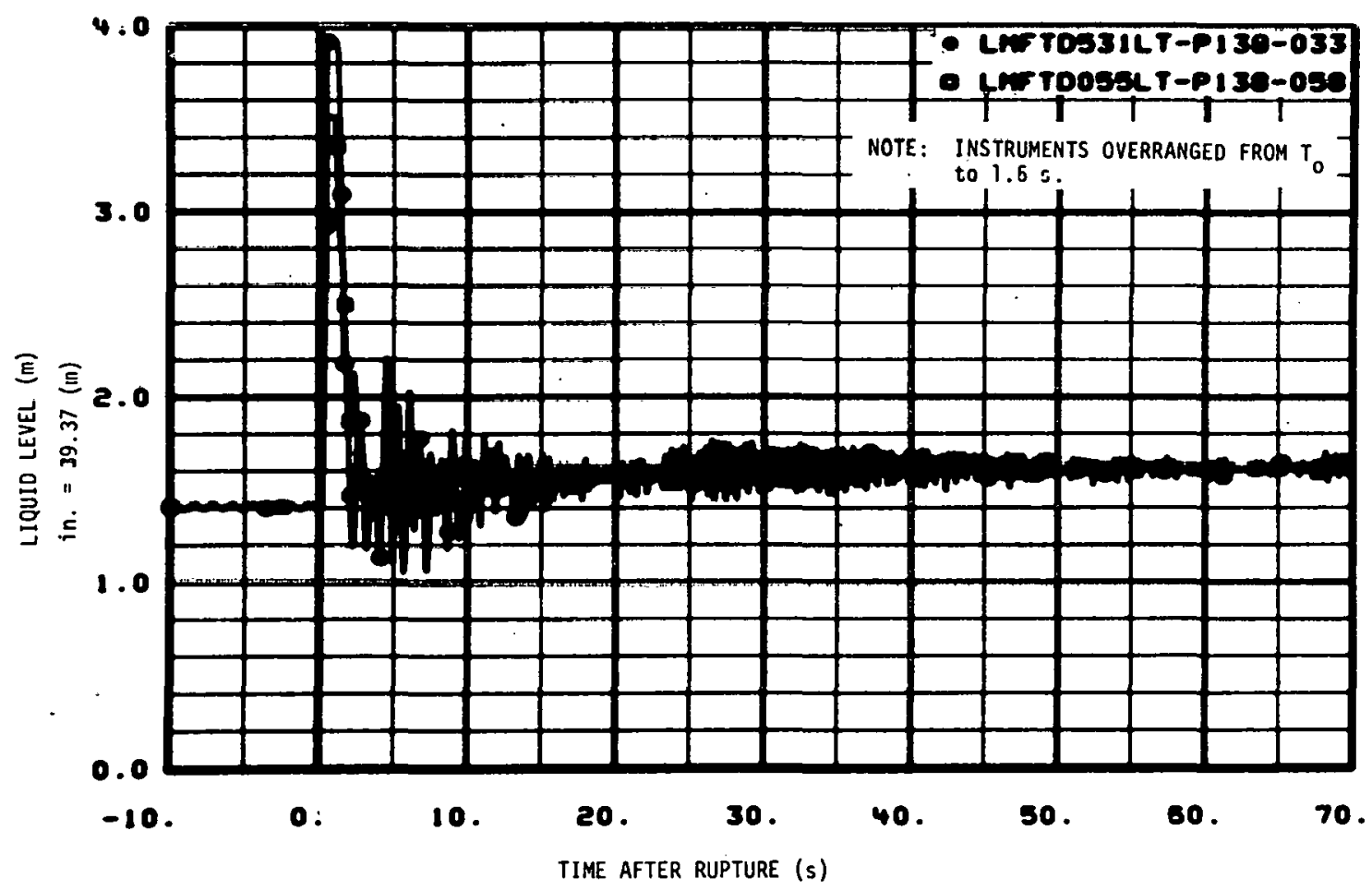

Fig. 47 Liquid level in blowdown suppression tank (LT-P138-33. and -58). 


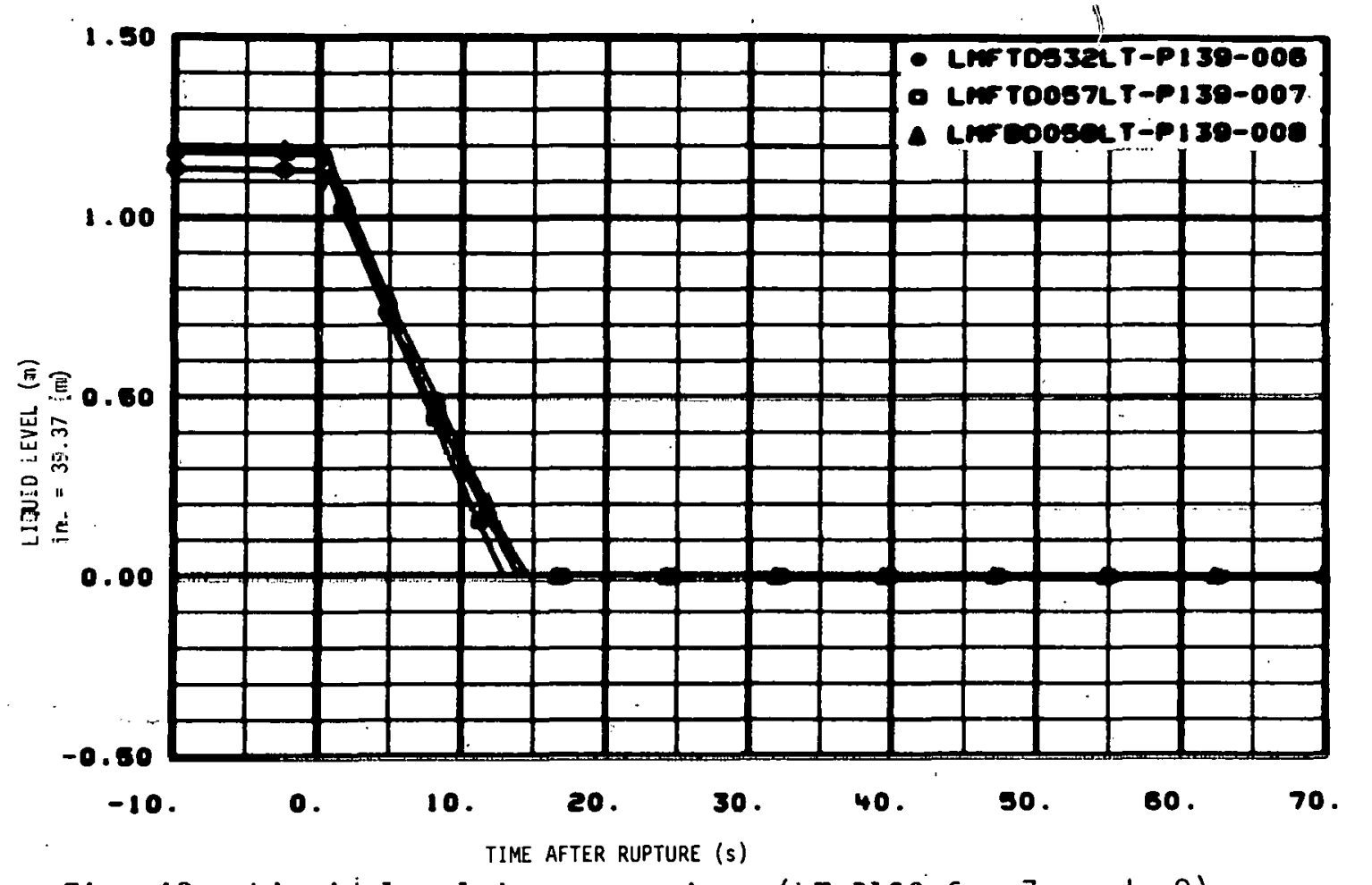

Fig. 48 Liquid level in pressurizer (LT-P139-6, -7, and -8).

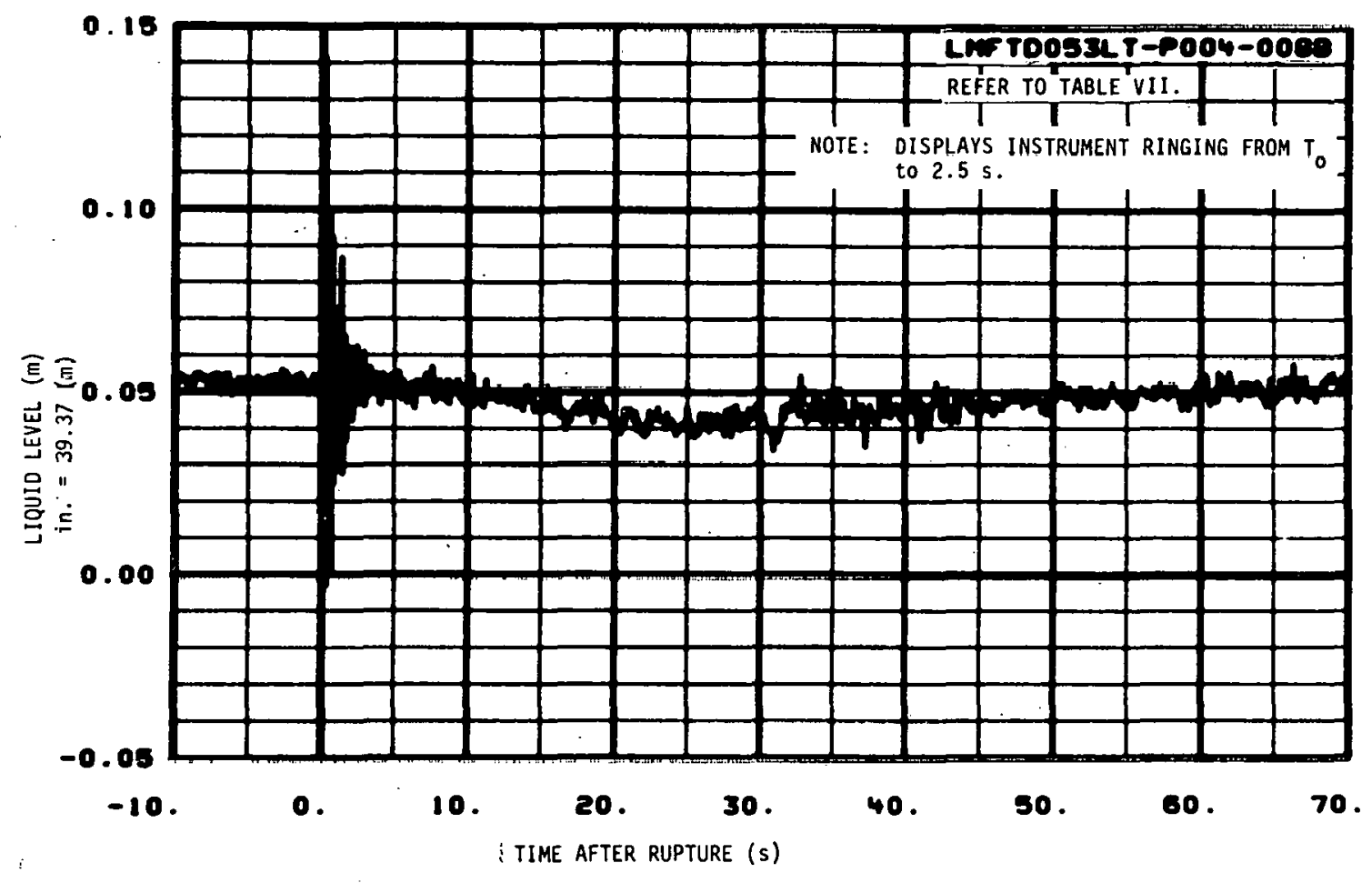

Fig. 49 Liquid level in steam generator secondary side (LT-P4-8B). 


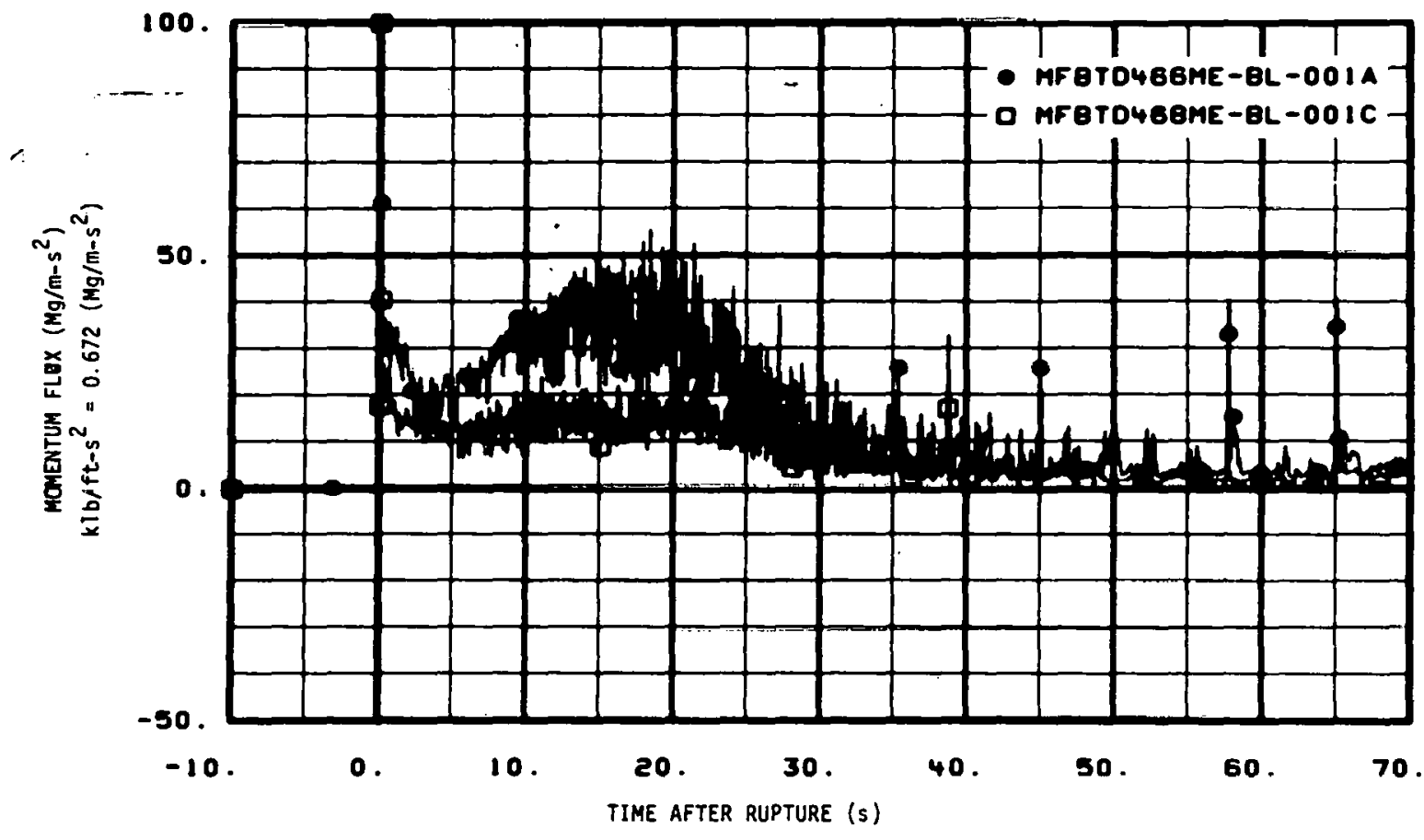

Fig. 50 Momentum flux in broken loop cold leg at DTT flange (ME-BL-IA and -1C) (filtered to $4 \mathrm{~Hz}$ ).

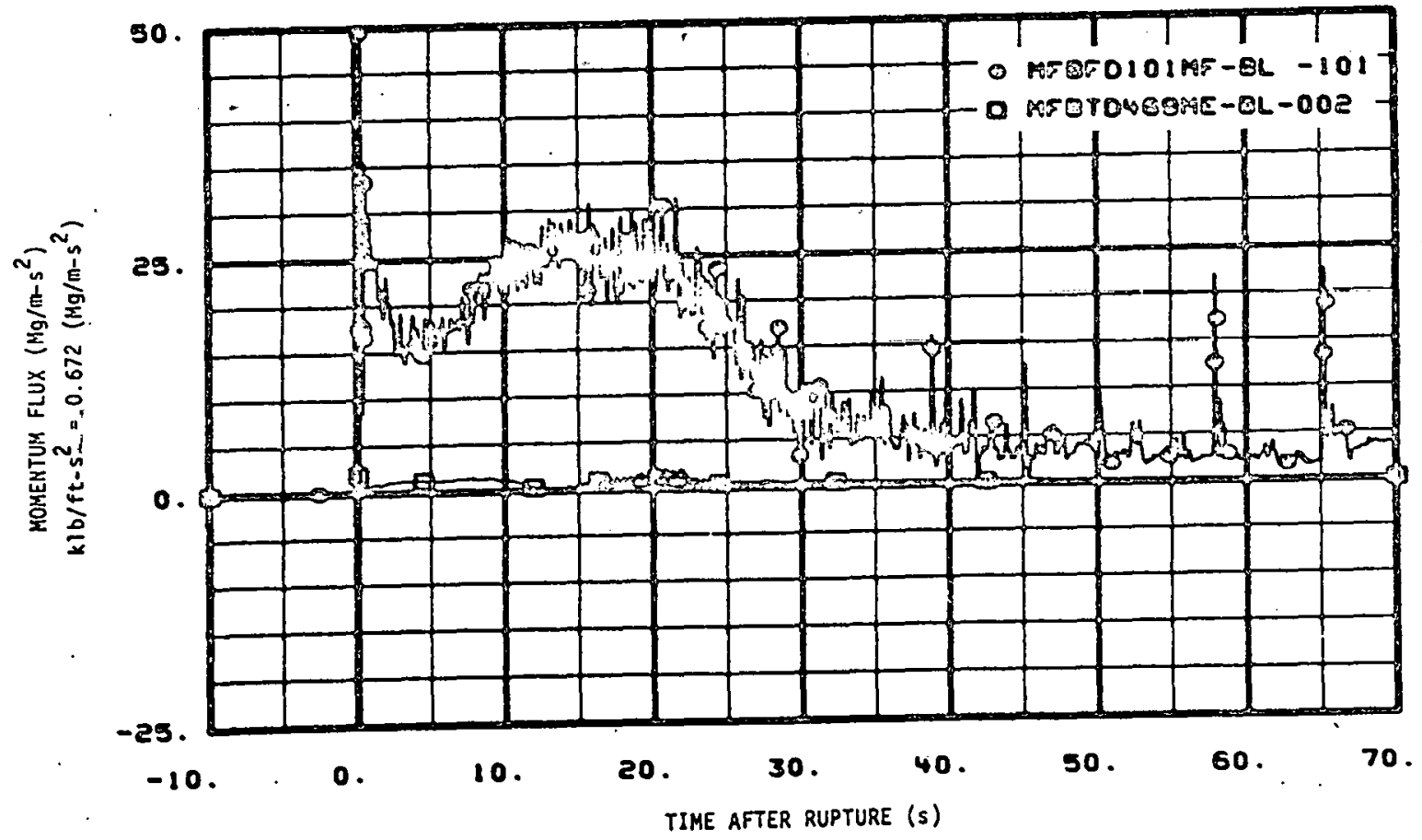

Fig. 51 Momentum flux in broken loop cold and hot legs. (ME-BL-1 and -2) (filtered to $4 \mathrm{~Hz}$ ). 


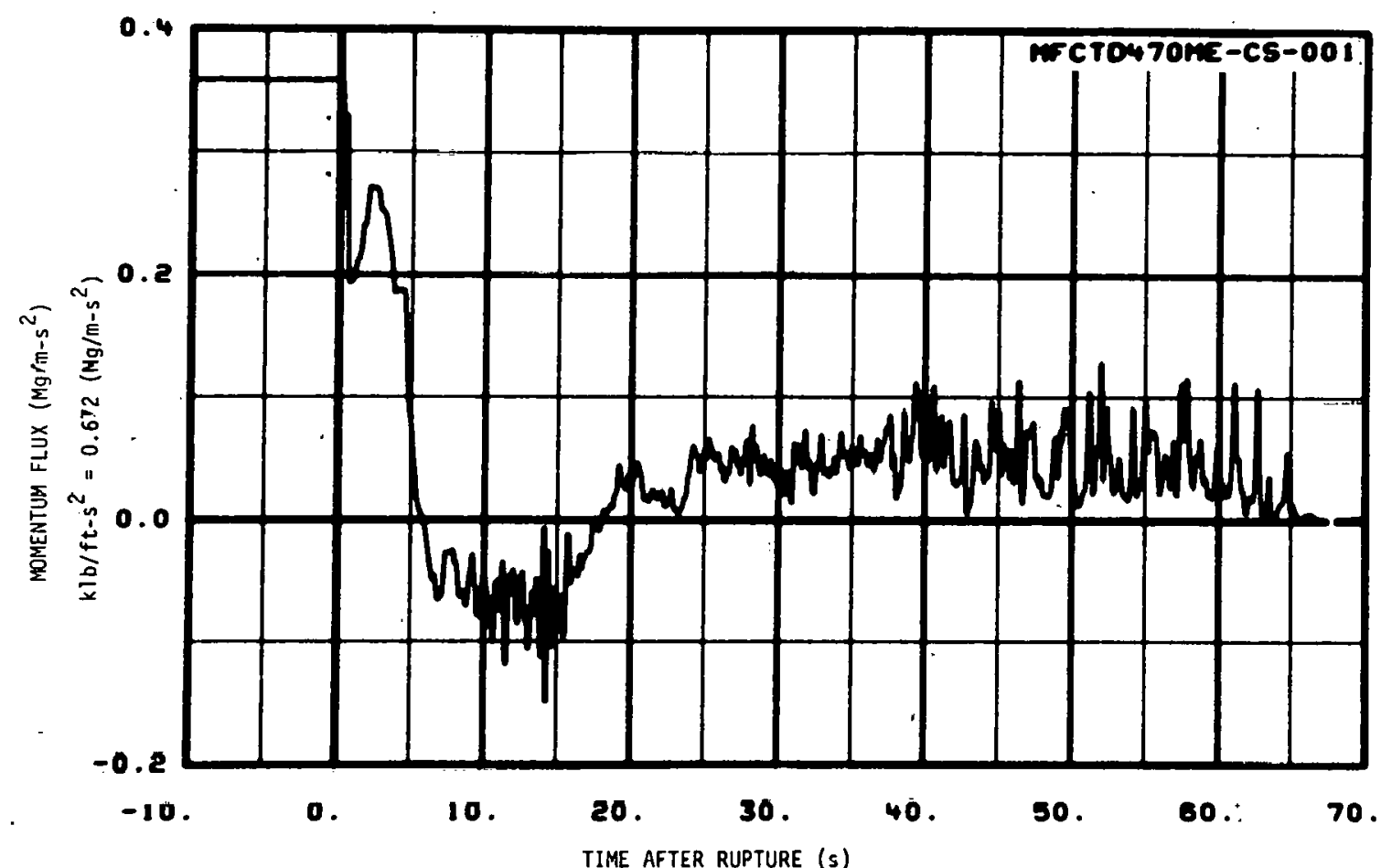

Fig. 52 Momentum 'flux in reactor vessel core simulator stalk (ME-CS-1) (filtered to $4 \mathrm{~Hz}$ ).

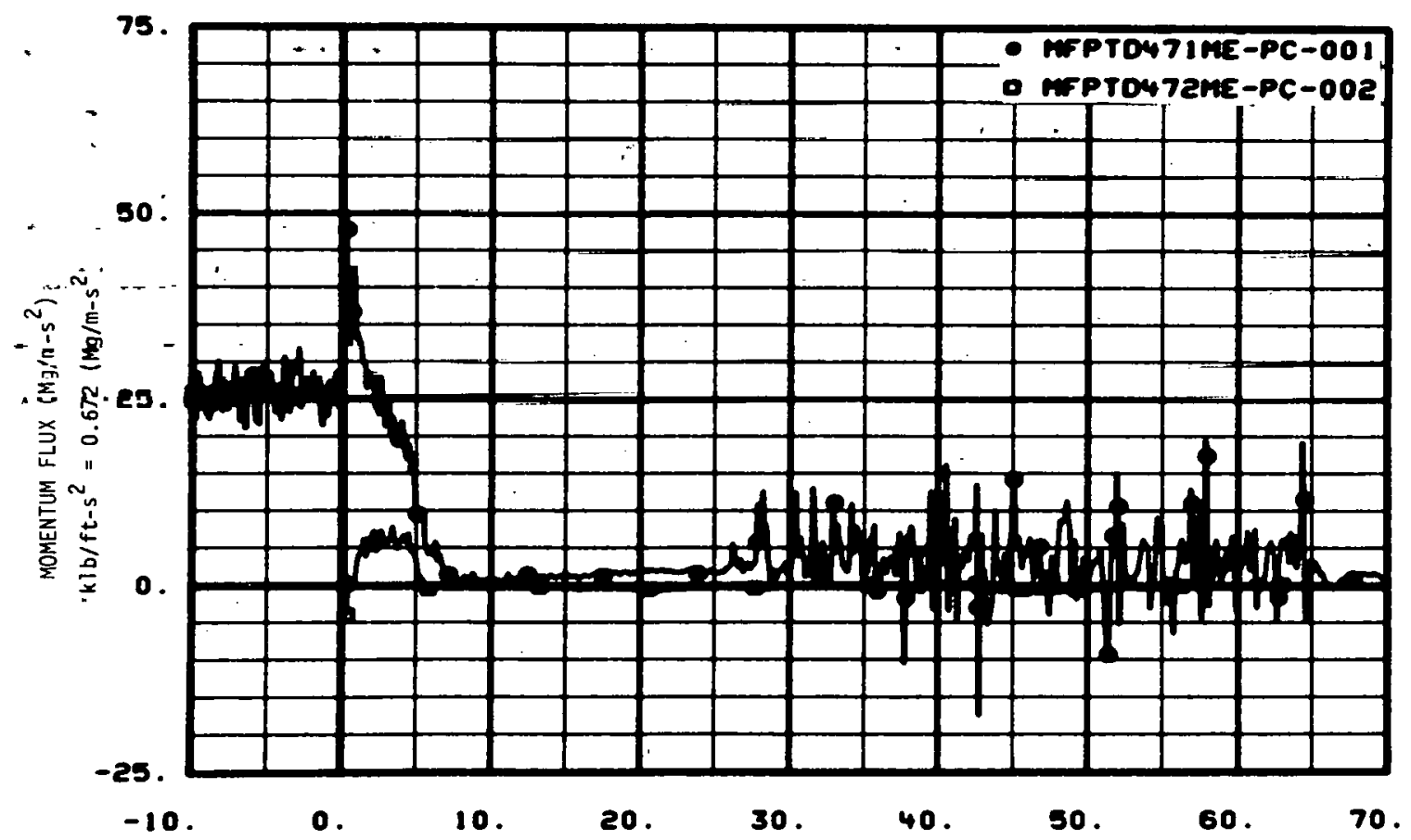

TIME AFTER RUPTURE ( $s$ )

Fig. 53. Momentum flux in intact loop cold leg and hot leg (ME-PC-1 and -2) (filtered to $4 . \mathrm{Hz}$ ). 


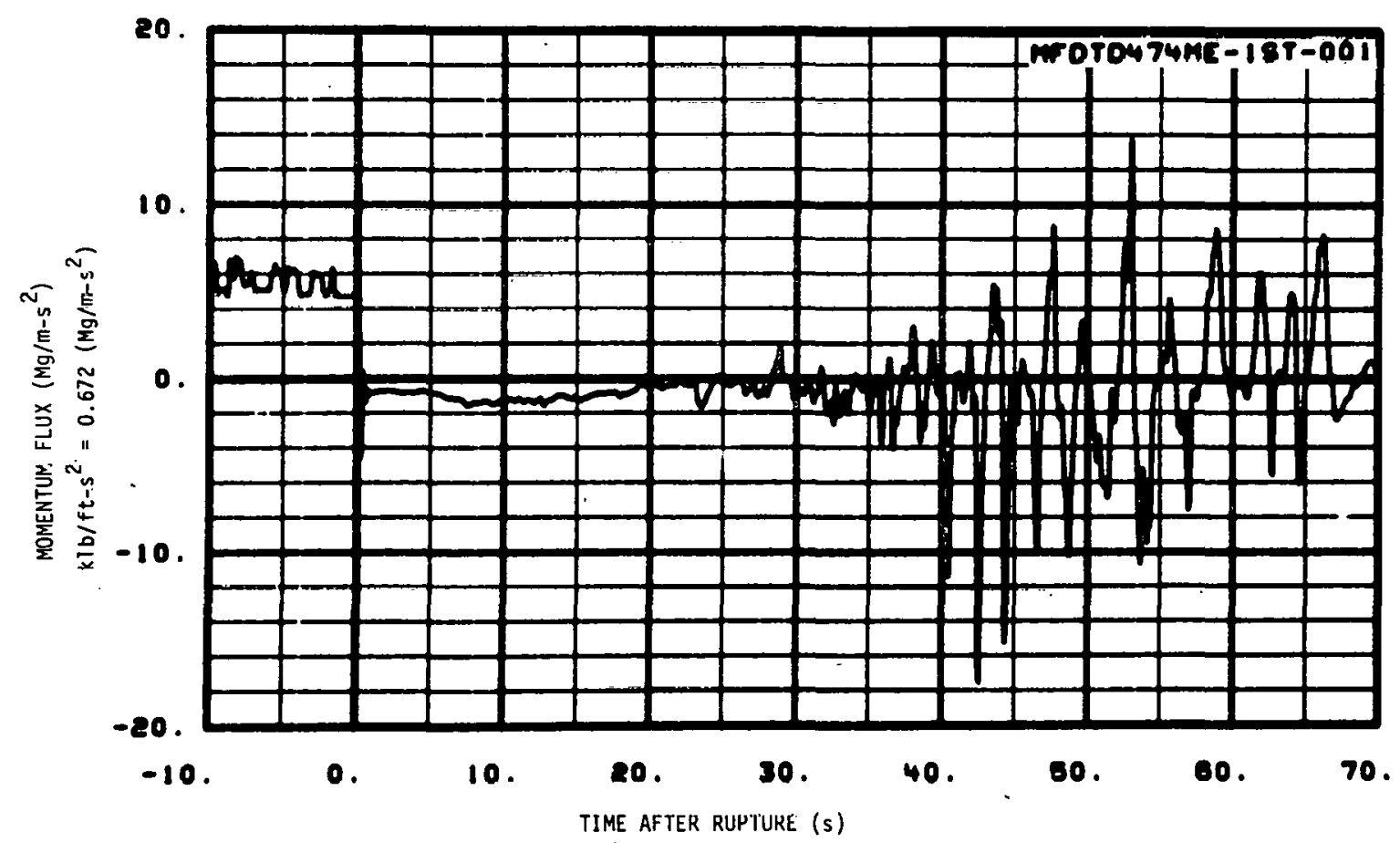

Fig. 54 Momentum flux, in reactor vessel downcomer stalk 1, 1.13 m above reactor vessel bottom ME-1ST-1 (filtered to $4 \mathrm{~Hz}$ ).

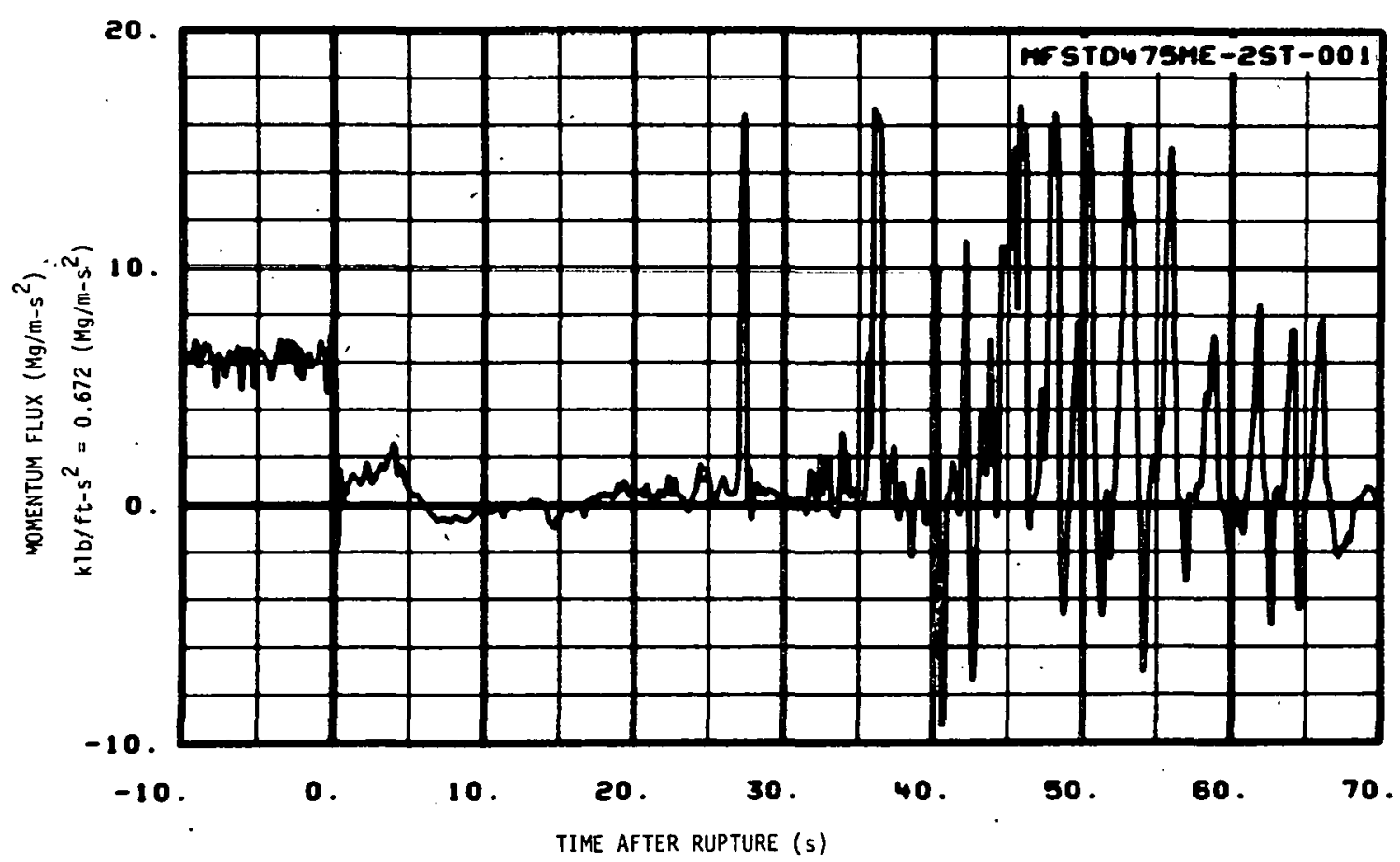

Fig. 55 Momentum flux in reactor vessel downcomer stalk 2, $1.13 \mathrm{~m}$ above reactor vessel bottom (ME-2ST-1) (filtered to $4 \mathrm{~Hz}$ ). 


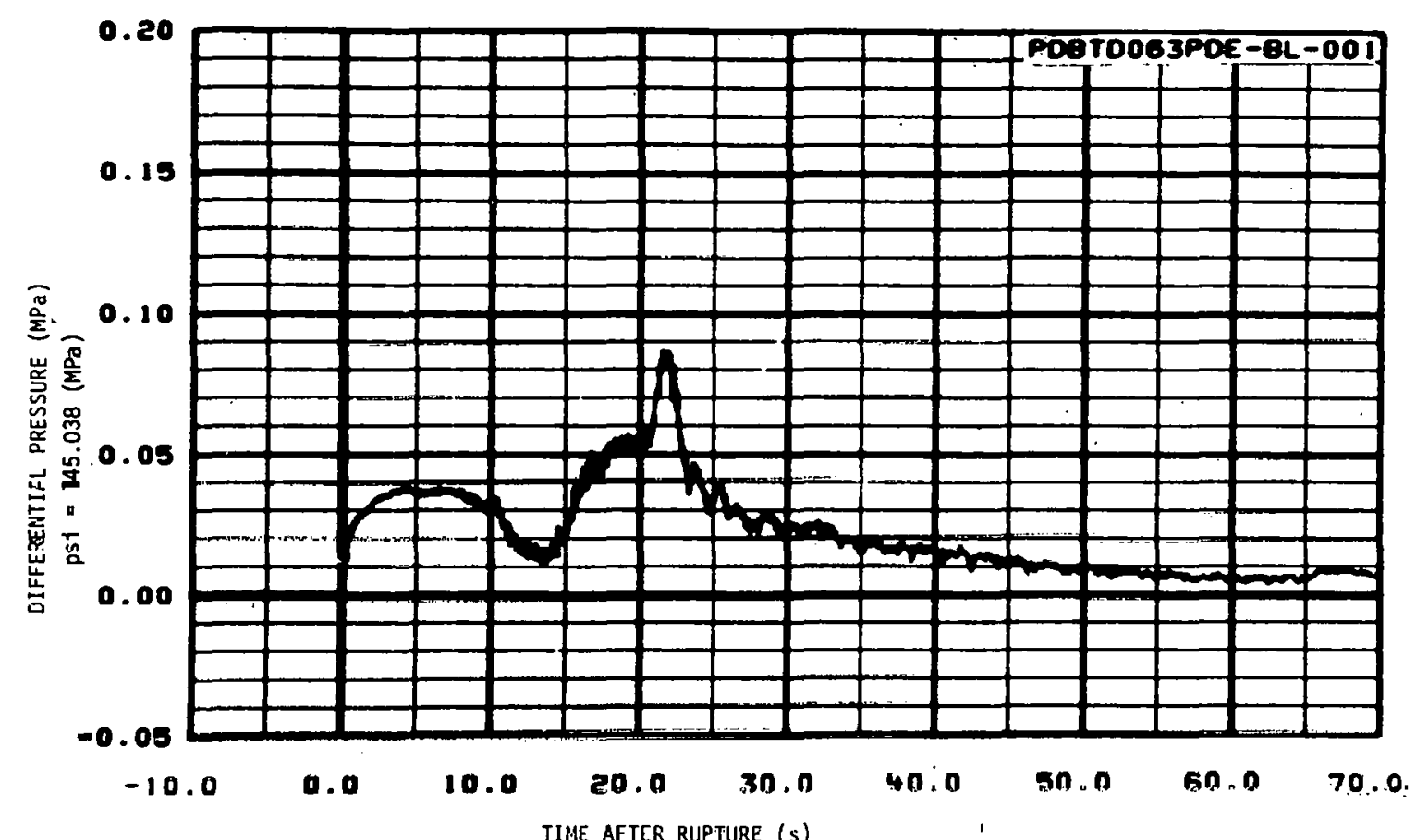

Fig. 56 Differential pressure in broken loop hot 1eg across 14-to-5-in. contraction (PdE-BL-1).

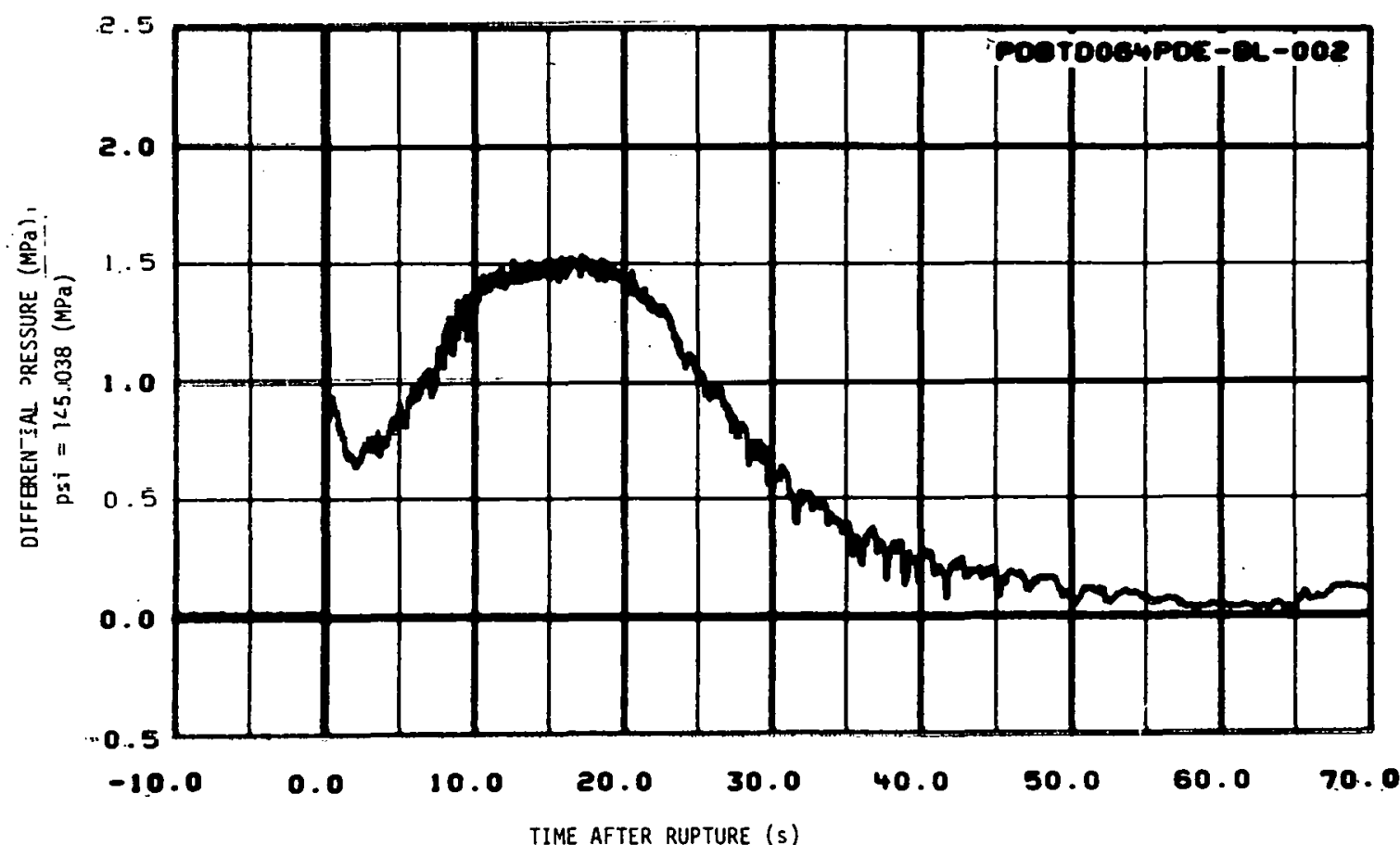

Fig. 57 Differential pressure in broken loop cold leg across 14-to-5-in. contraction (PdE-BL-2). 


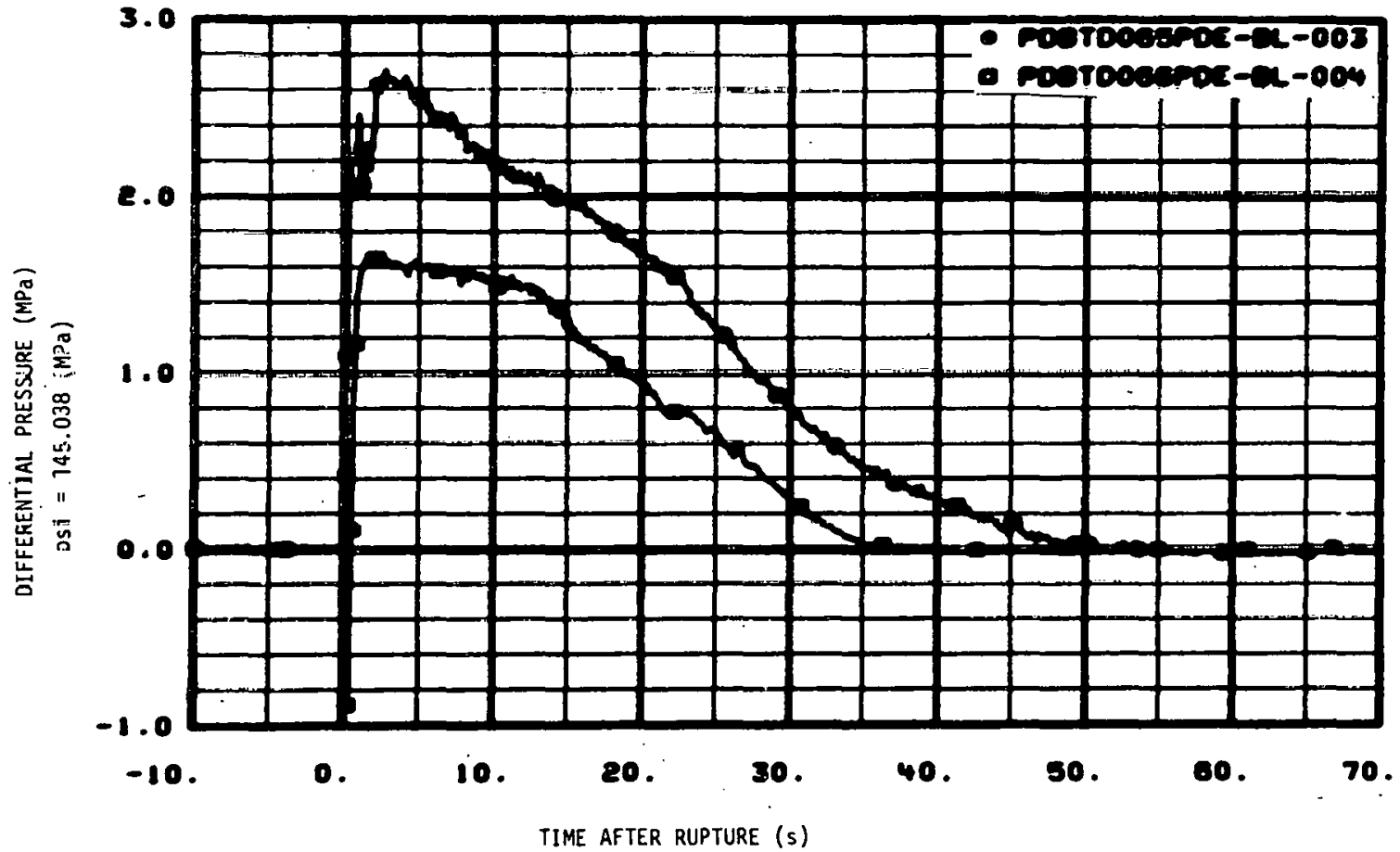

Fig. 58 Differential pressure in broken loop across break planes (PdE-BL-3 and -4).

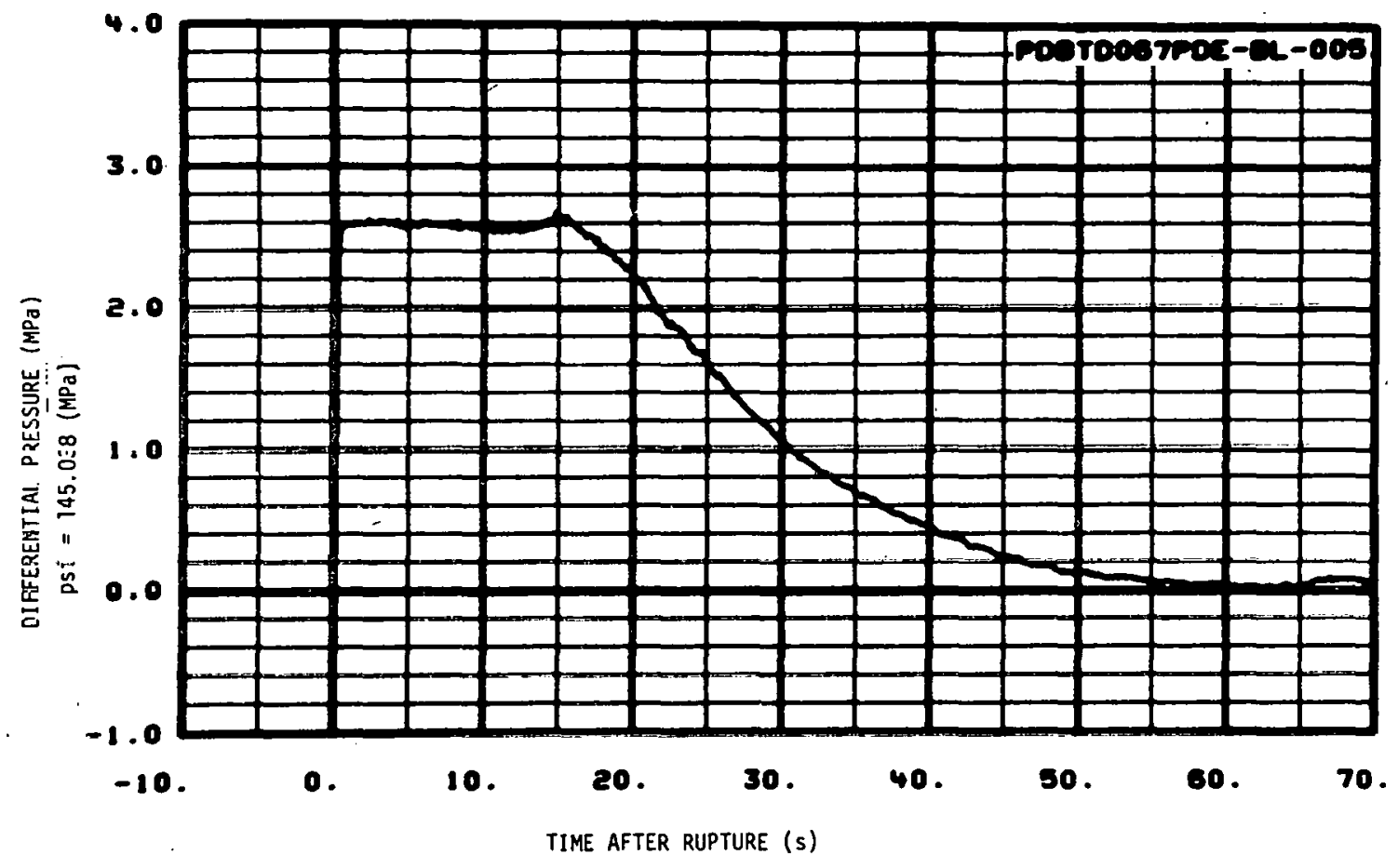

Fig. 59 Differential pressure in broken loop hot leg across pump simulator (PdE-BL-5). 


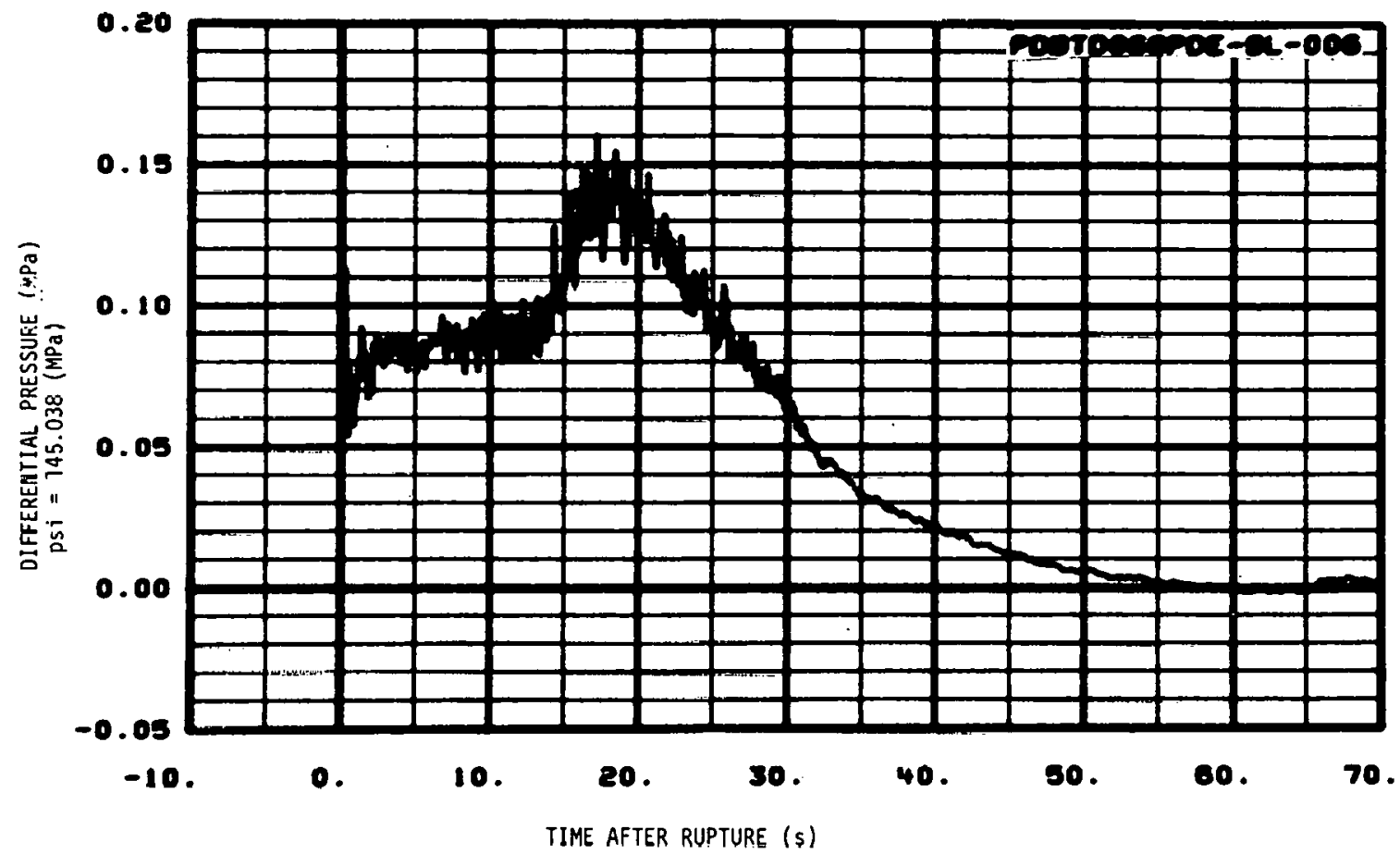

Fig. 60 Differential pressure in broken loop hot leg across steam generator simulator outlet flange (PdE-BL-6).

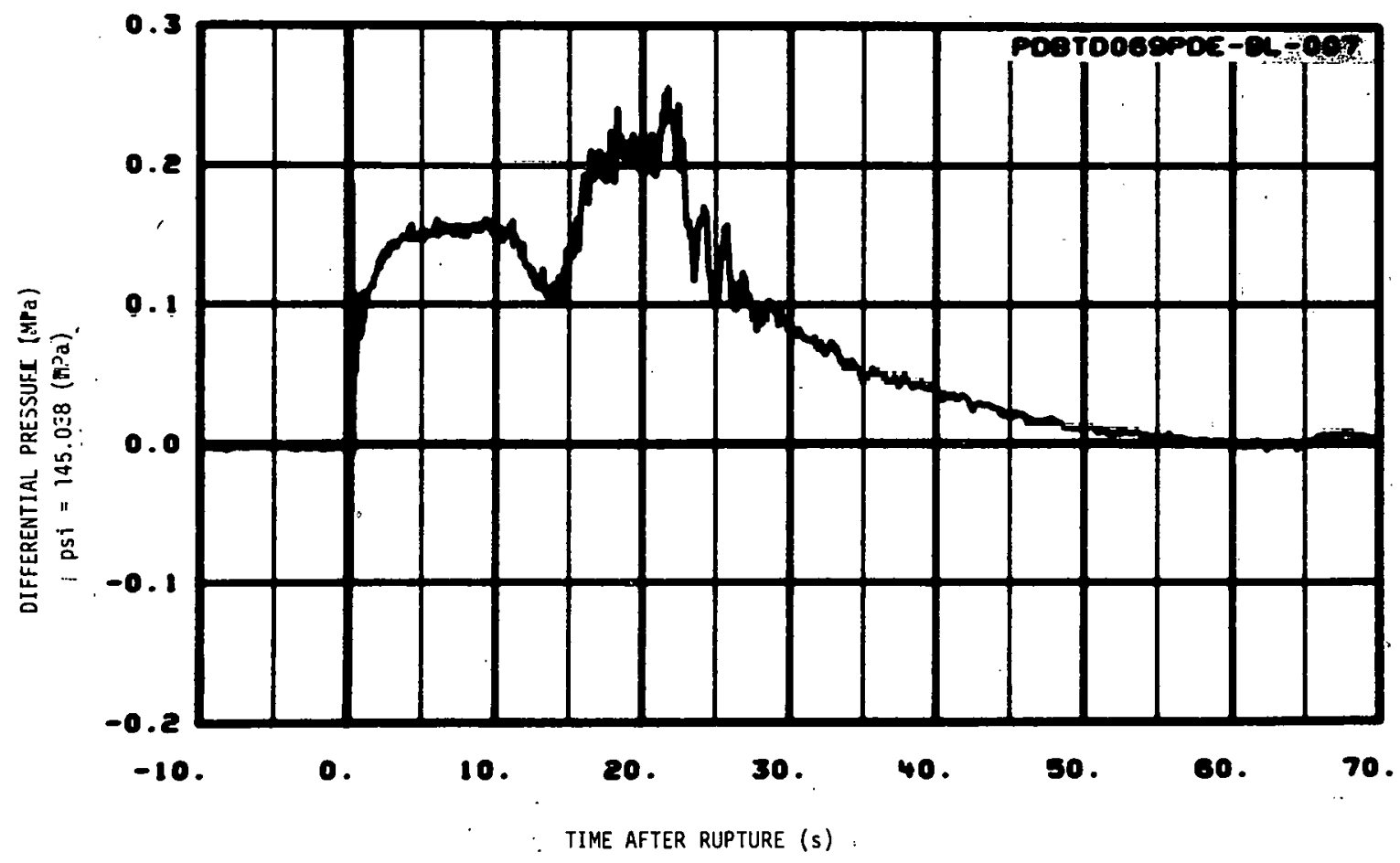

Fig. 61 Differential pressure in broken loop hot leg across the steam generator simulator (PdE-BL-7). 


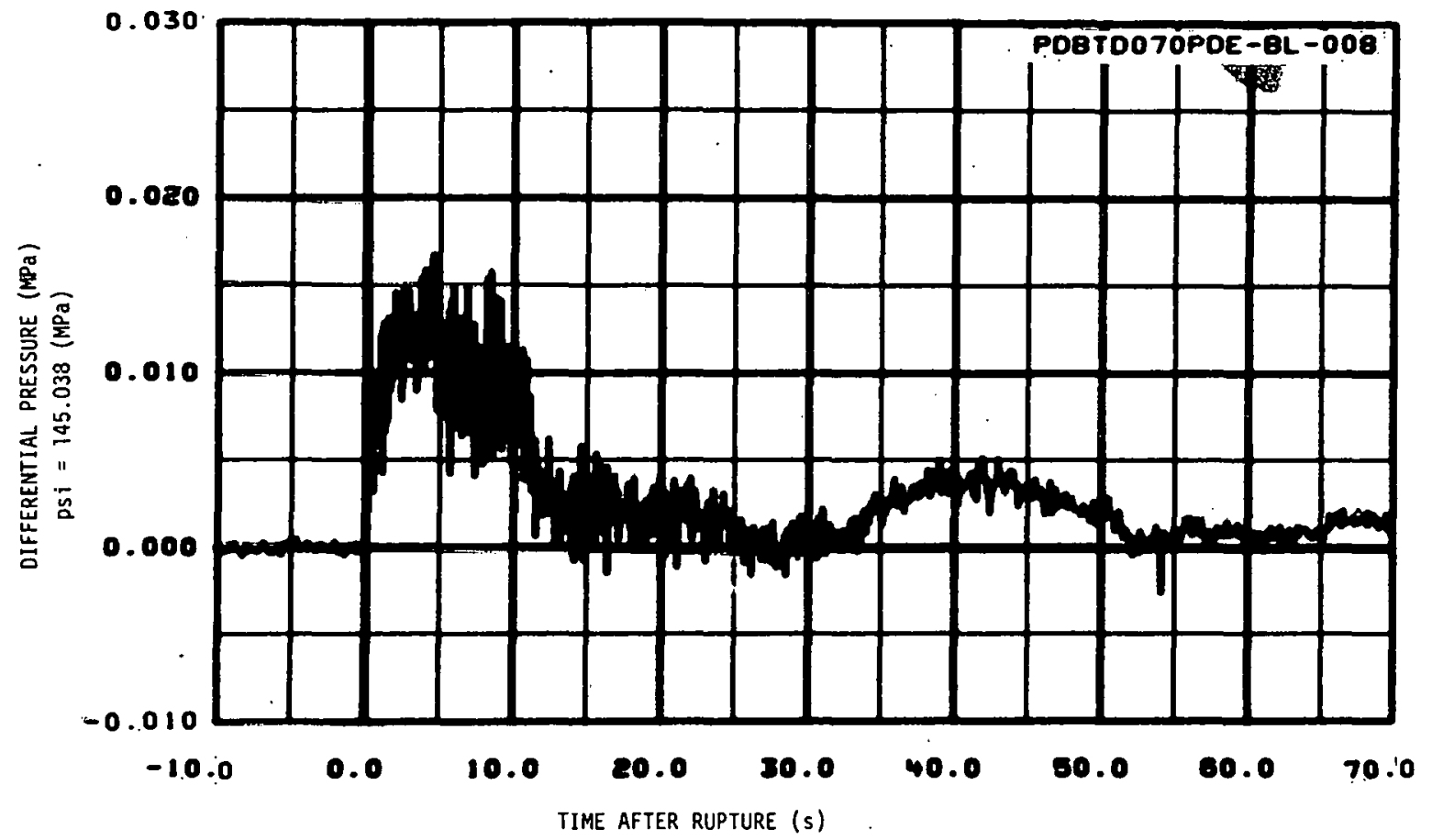

Fig. 62 Differential pressure in broken loop hot leg across steam generator simulator inlet flange (PdE-BL-8) (filtered to $4 \mathrm{~Hz}$ ).

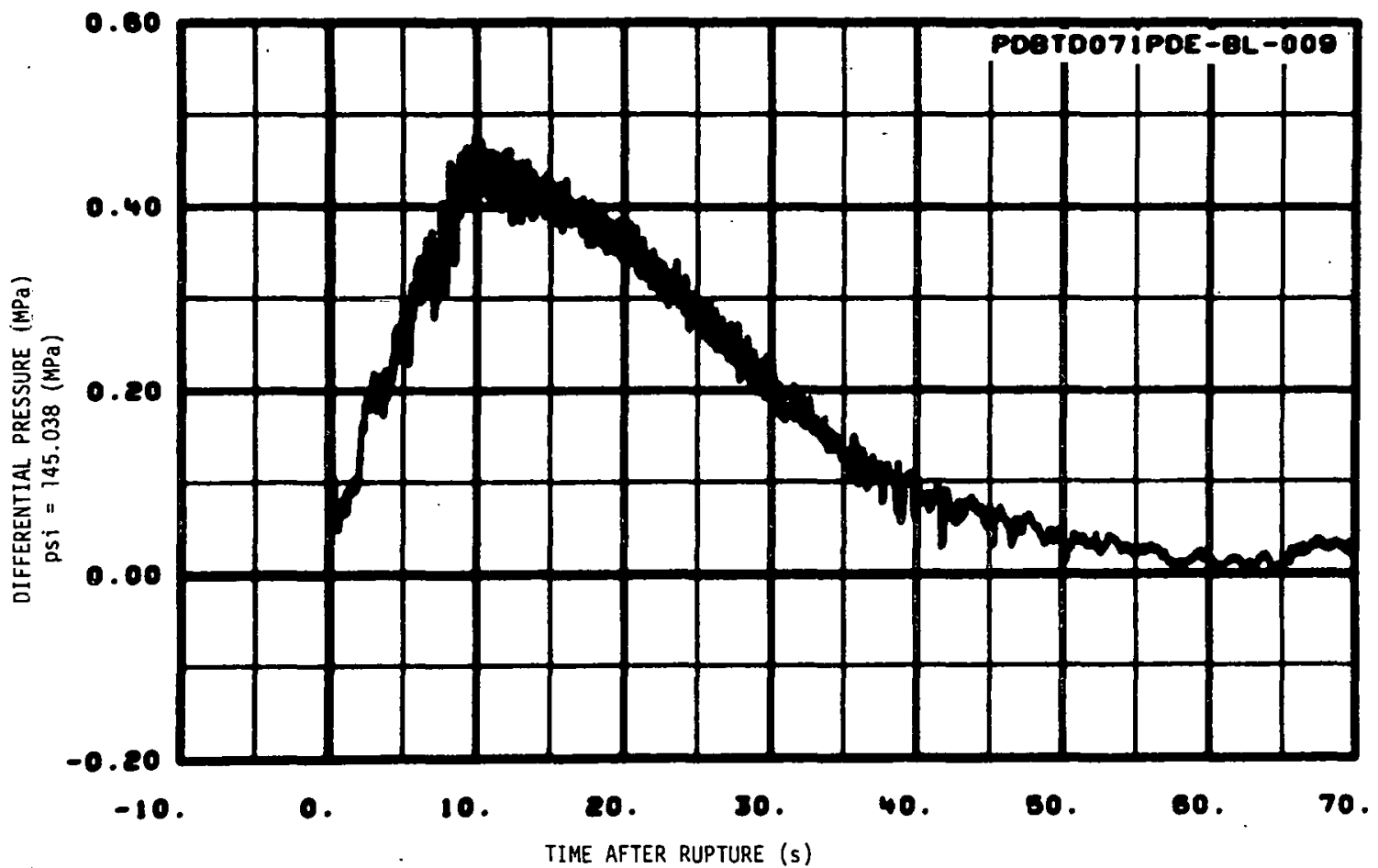

Fig. 63 Differential pressure in broken loop from 14-to-5-in. contraction to first tap (0.127 m downstream) (PdE-BL-9). 


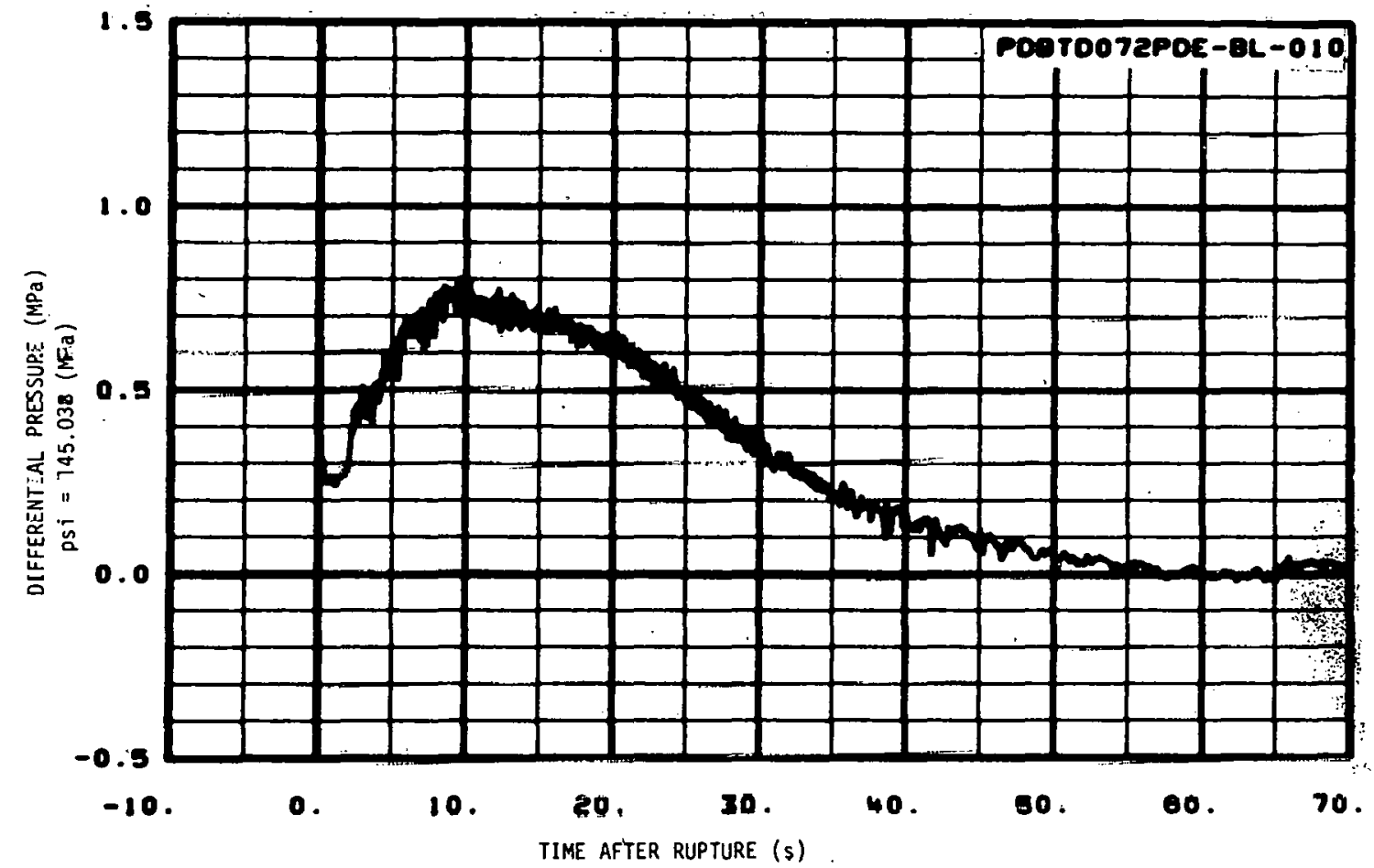

Fig. 64 Differential pressure in broken loop from 14-to-5-in. contraction inlet to break plane (PdE-BL-10).

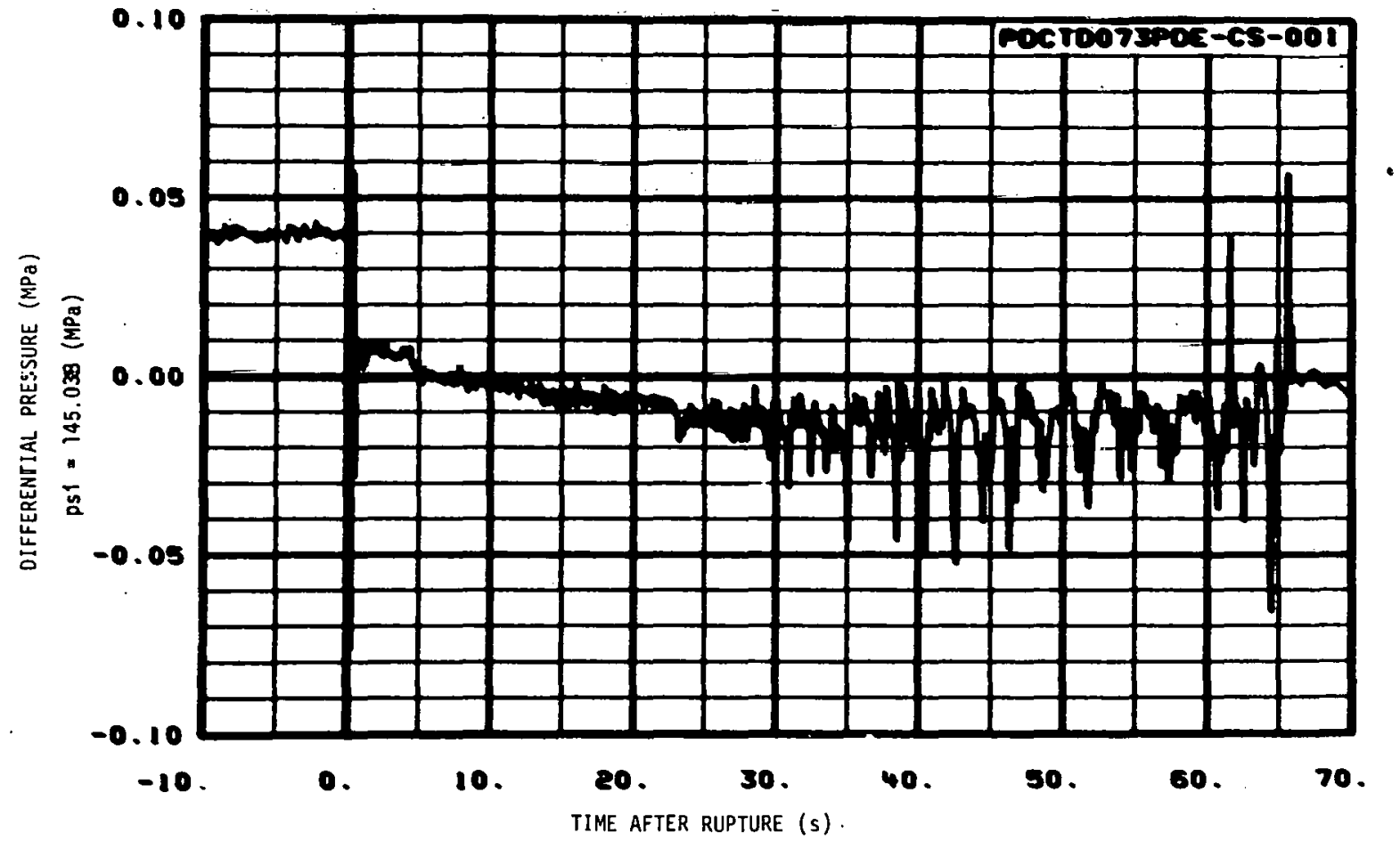

Fig. 65 Differential pressure in reactor vessel core simulator to downcomer instrument stalk $2,0.62 \mathrm{~m}$ from reactor vessel bottom (PdE-CS-1). 


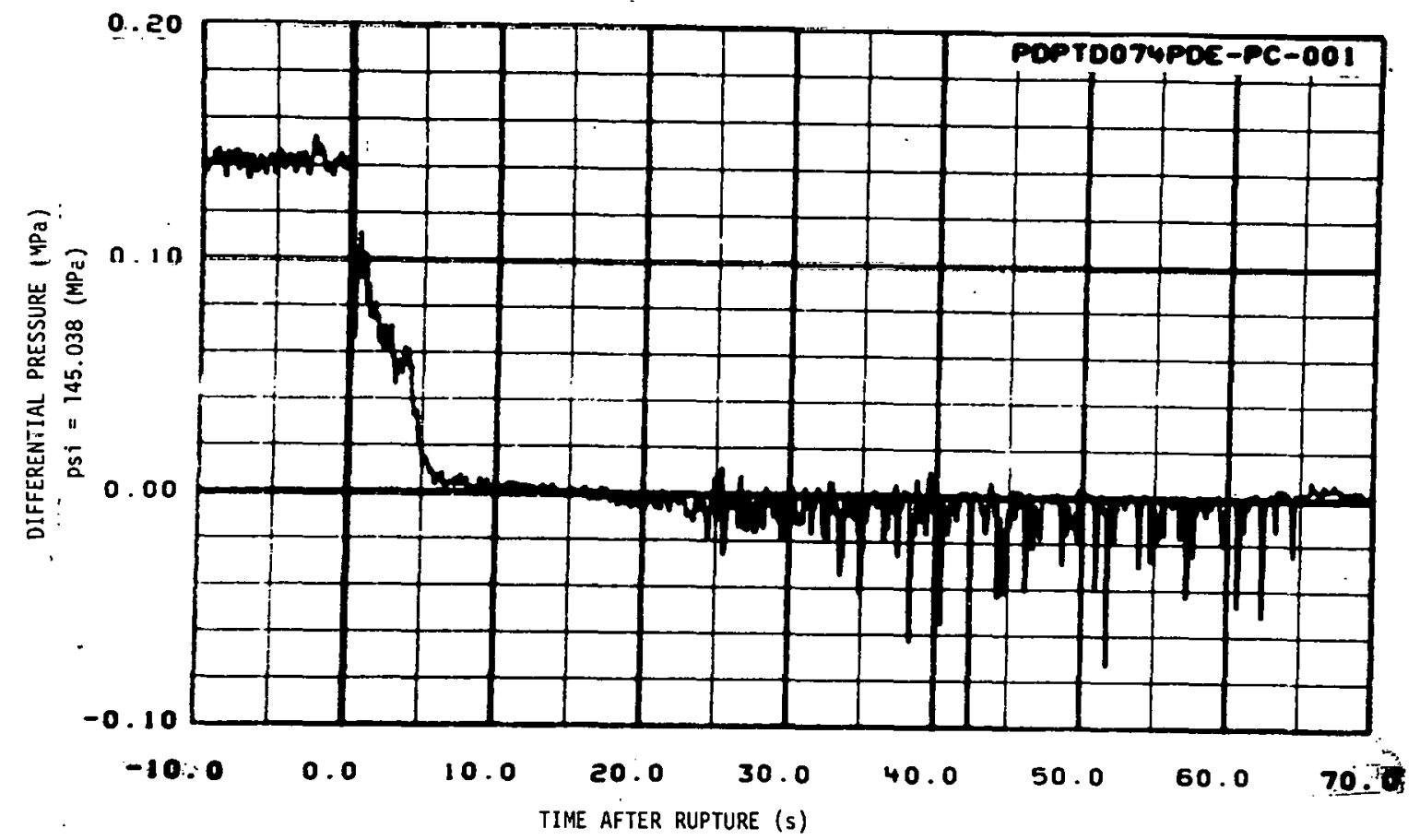

Fig. 66 Differential pressure in intact loop cold leg across primary coolant pumps 1 and 2 (PdE-PC-1).

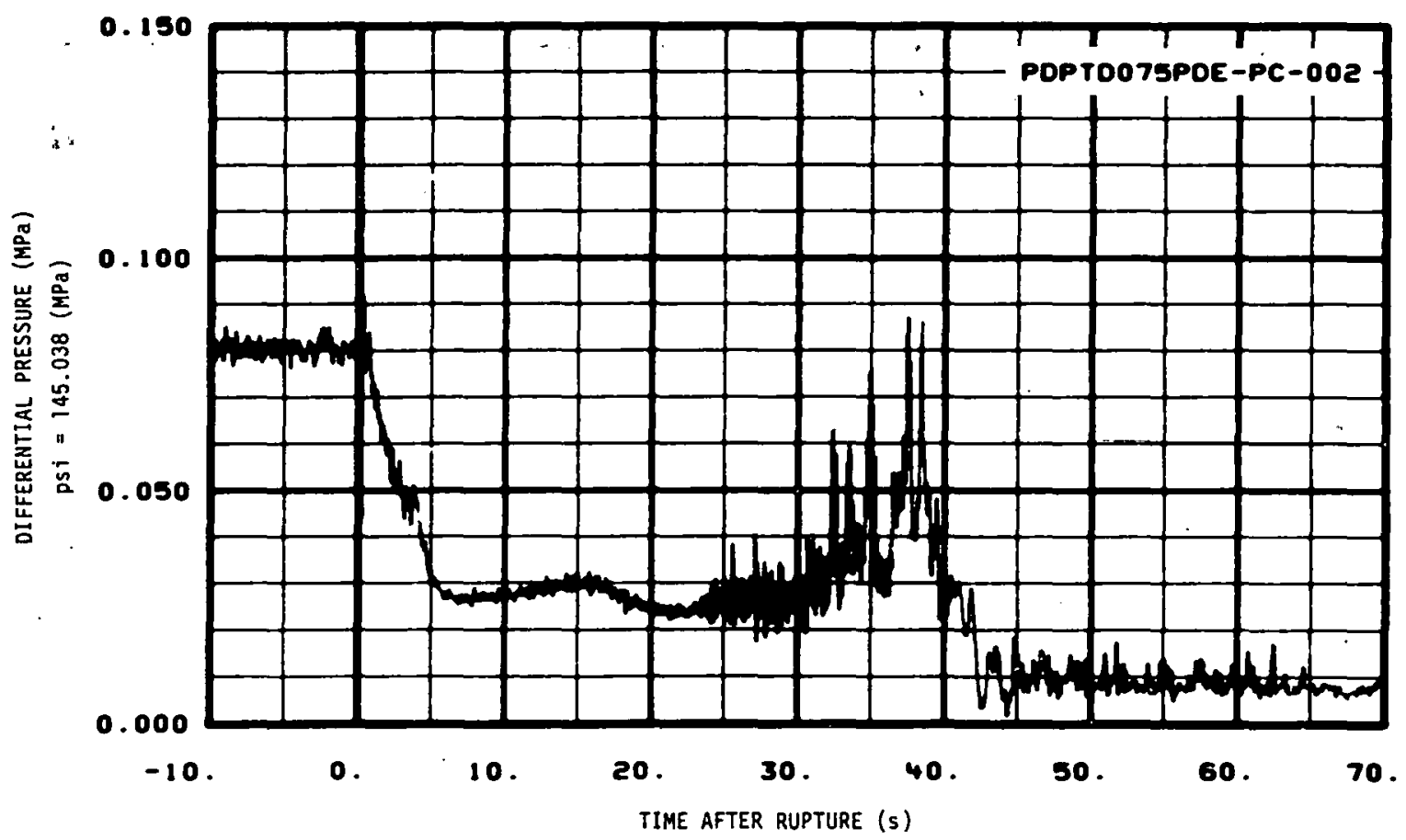

Fig. 67 Differential pressure in jntact loop across the steam generator (PdE-PC-2). 


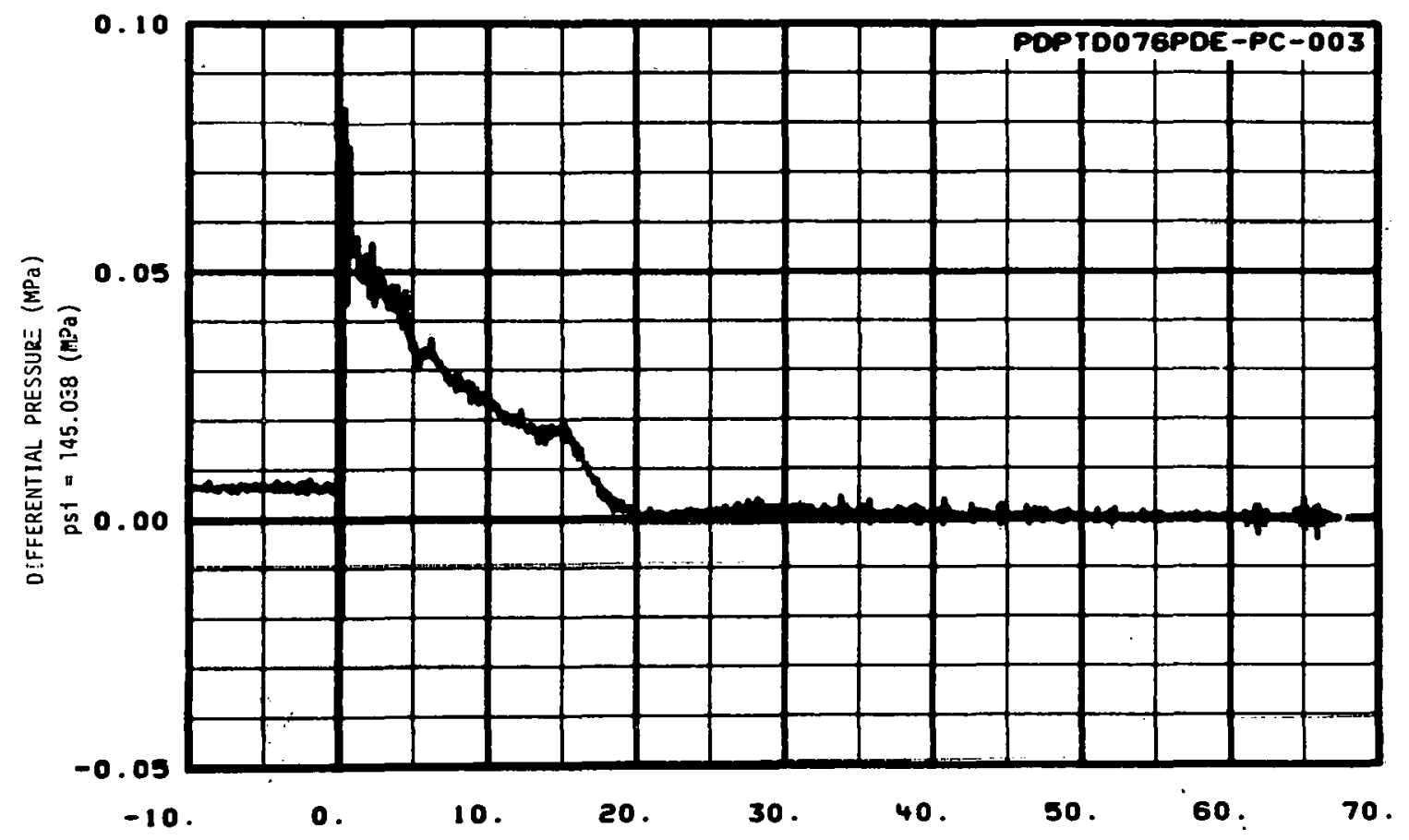

TIME AFTER RUPTURE (s)

Fig. 68 Differential pressure in intact loop hot leg piping from reactor vessel outlet to the flow venturi (PdE-PC-3) (filtered to $4 \mathrm{~Hz}$ ).

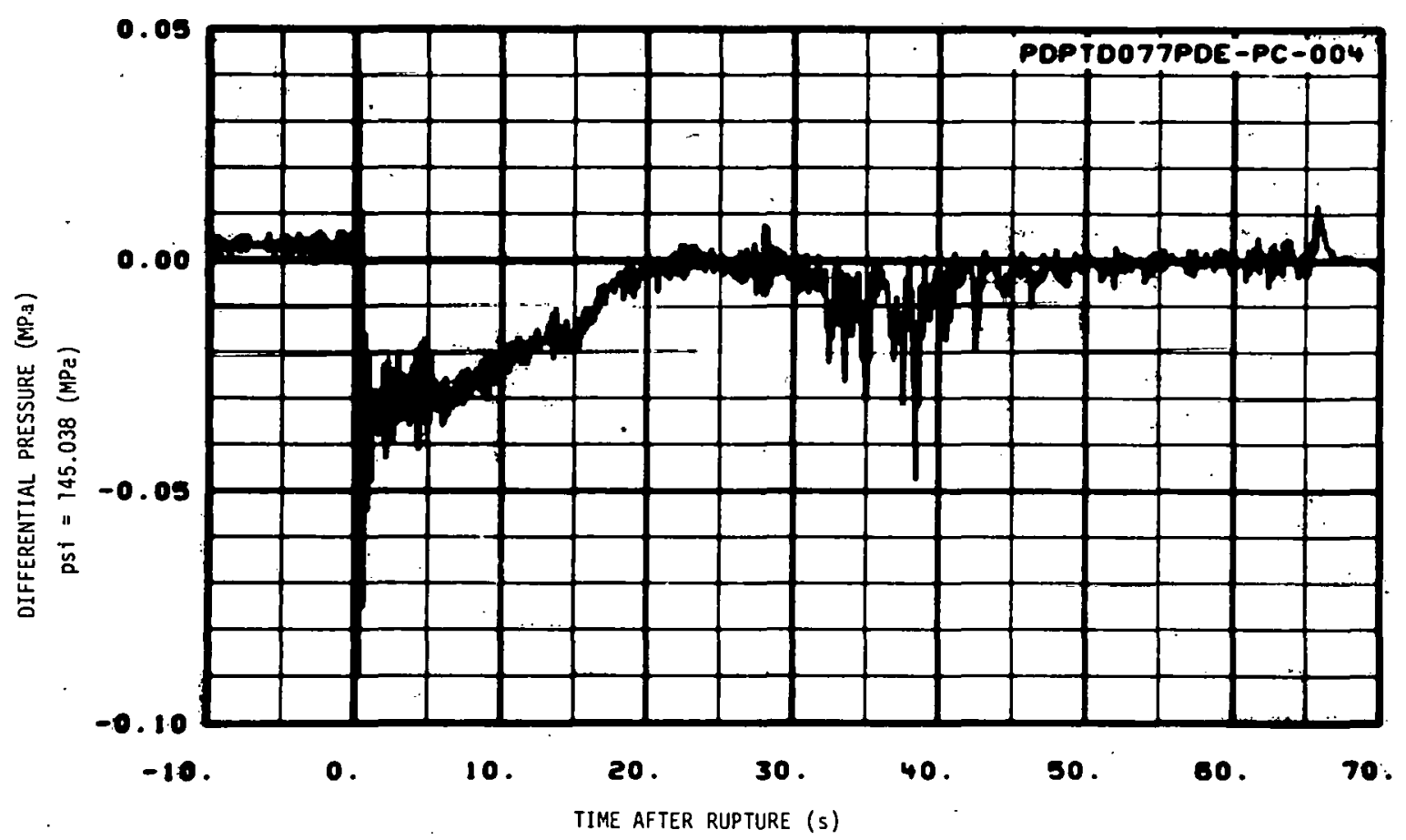

Fig. 69 Differential pressure in intact loop hot leg piping from flow venturi to steam generator inlet. (PdE-PC-4). 


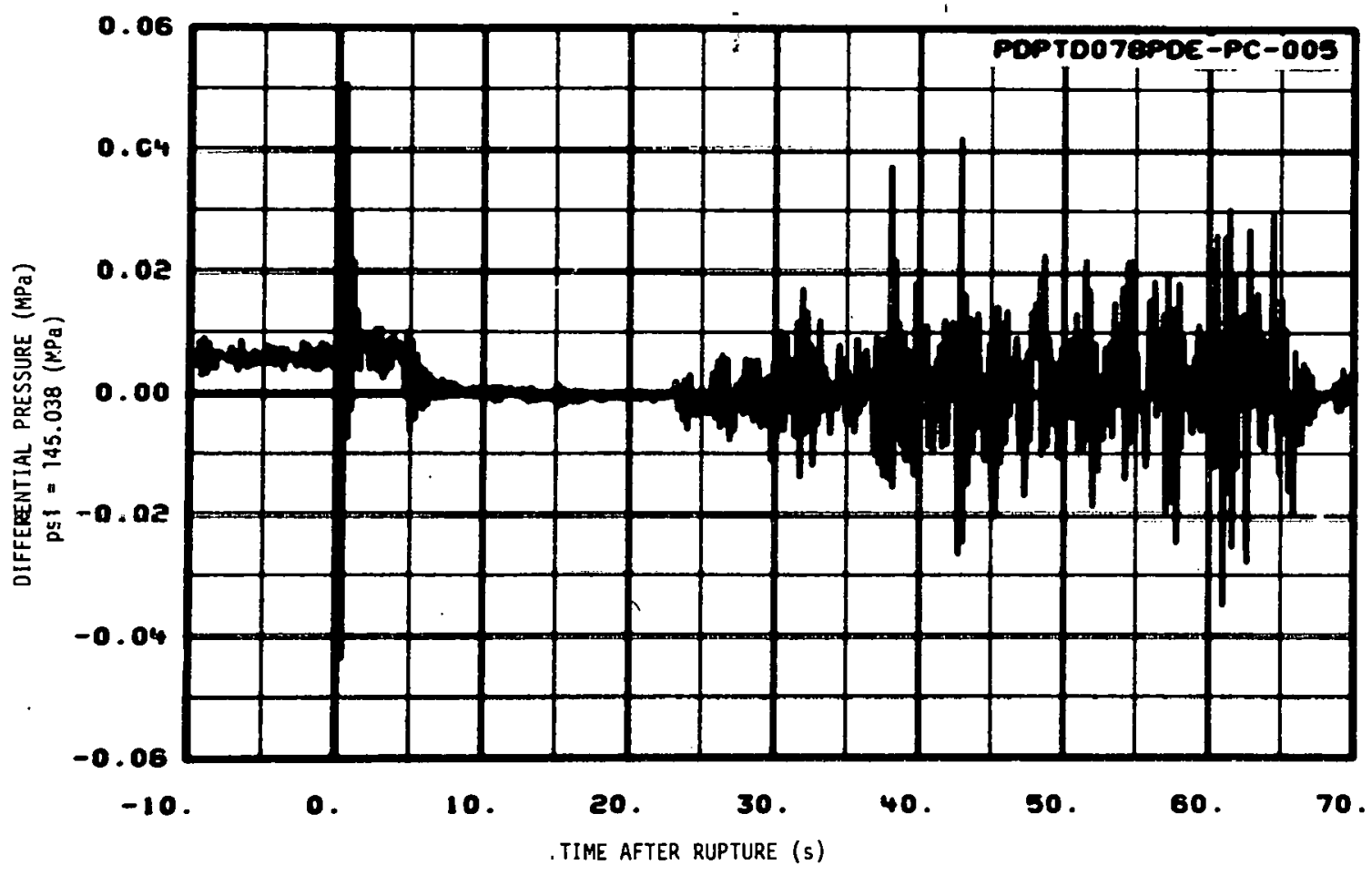

Fig. 70 Differential pressure in intact loop cold leg primary coolant pump discharge to reactor vessel inlet nozzle (PdE-PC-5) (filtered to $4 \mathrm{~Hz}$ ).

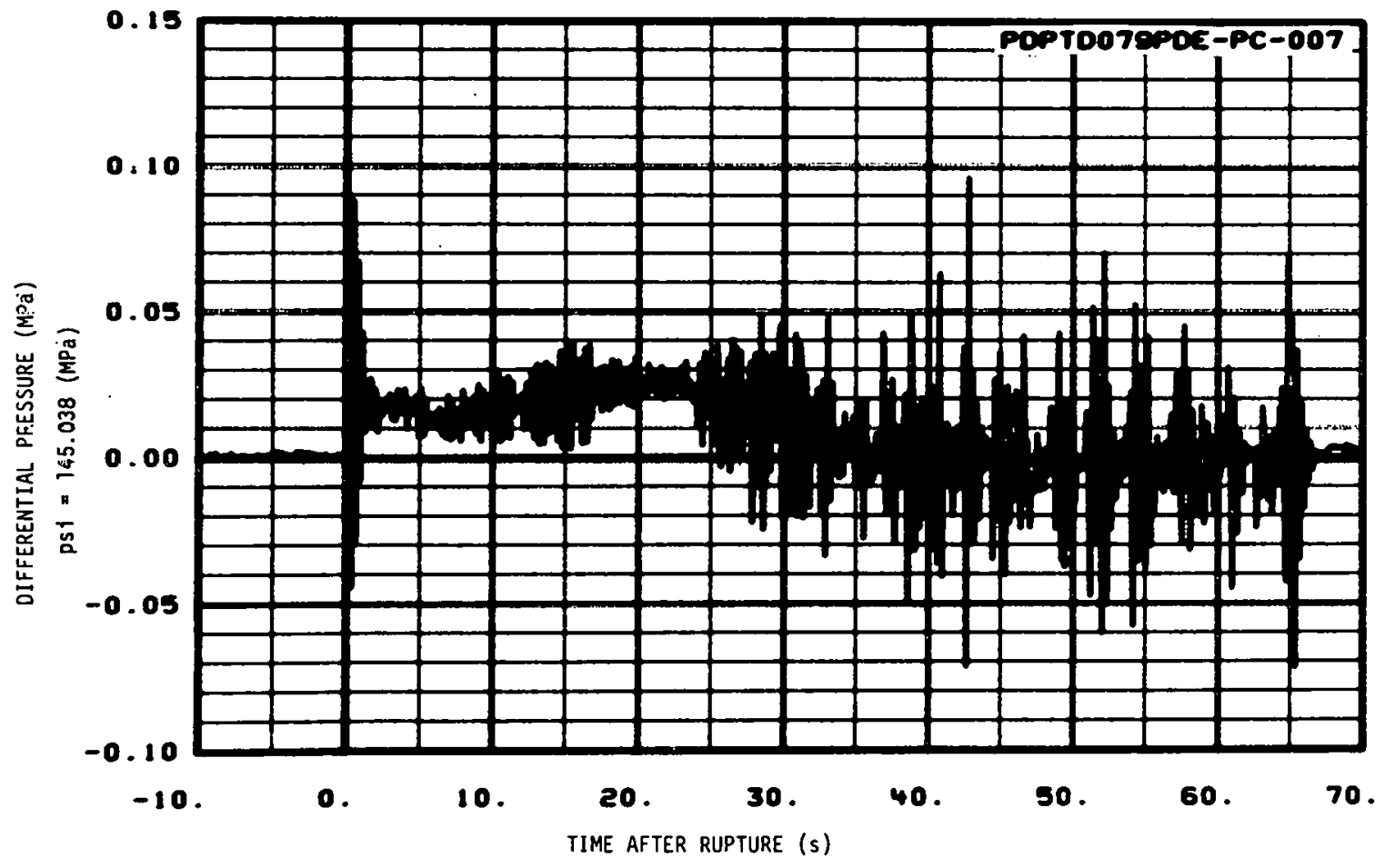

Fig. 71. Differential pressure in intact loop cold leg reactor vessel inlet to broken loop cold leg reactor vessel inlet (PdE-PC-7). (fil tered to $4 \mathrm{~Hz}$ ). 


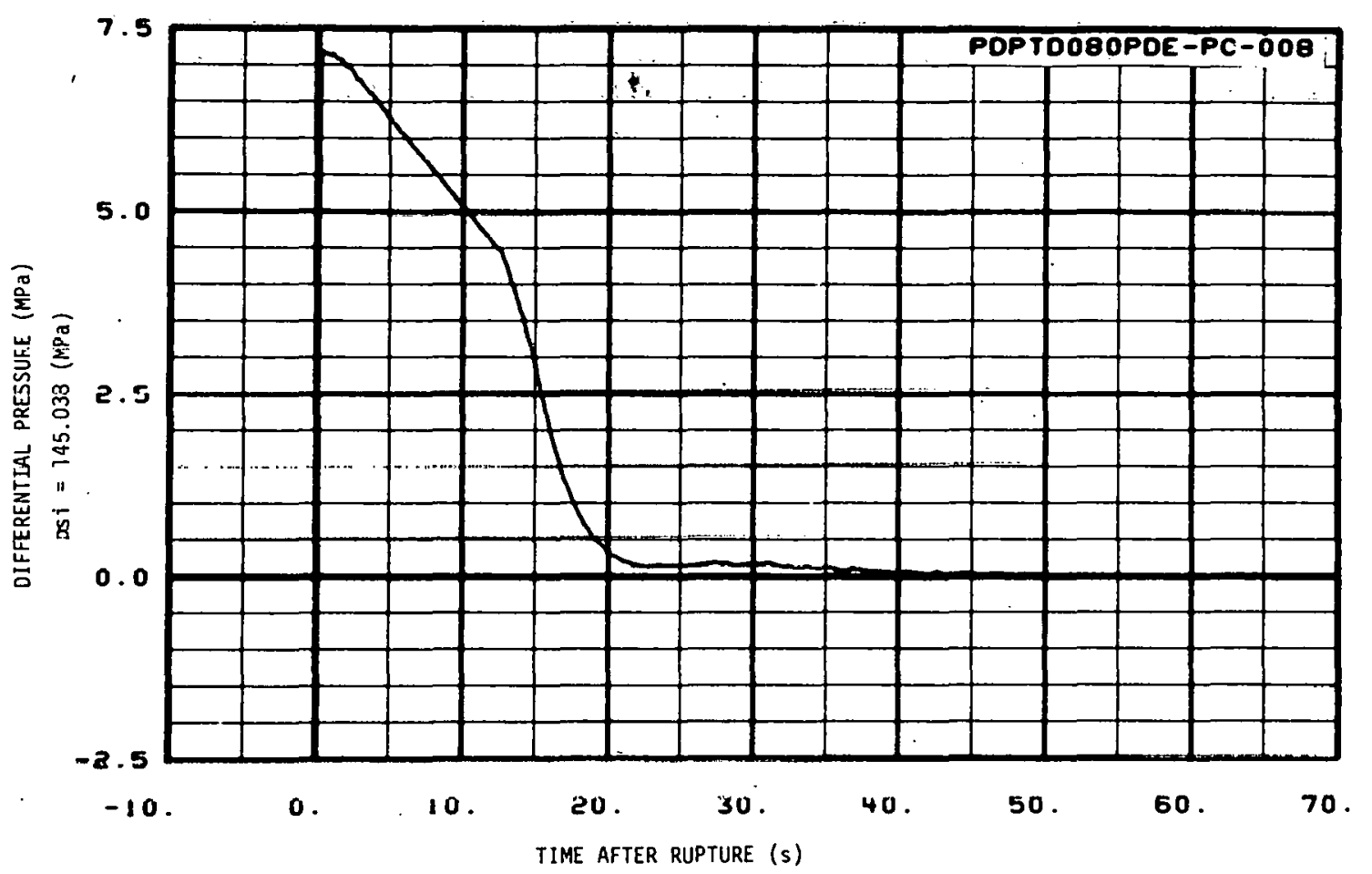

Fig.'72 Differential pressure in intact loop across surge line (PdE-PC-8).

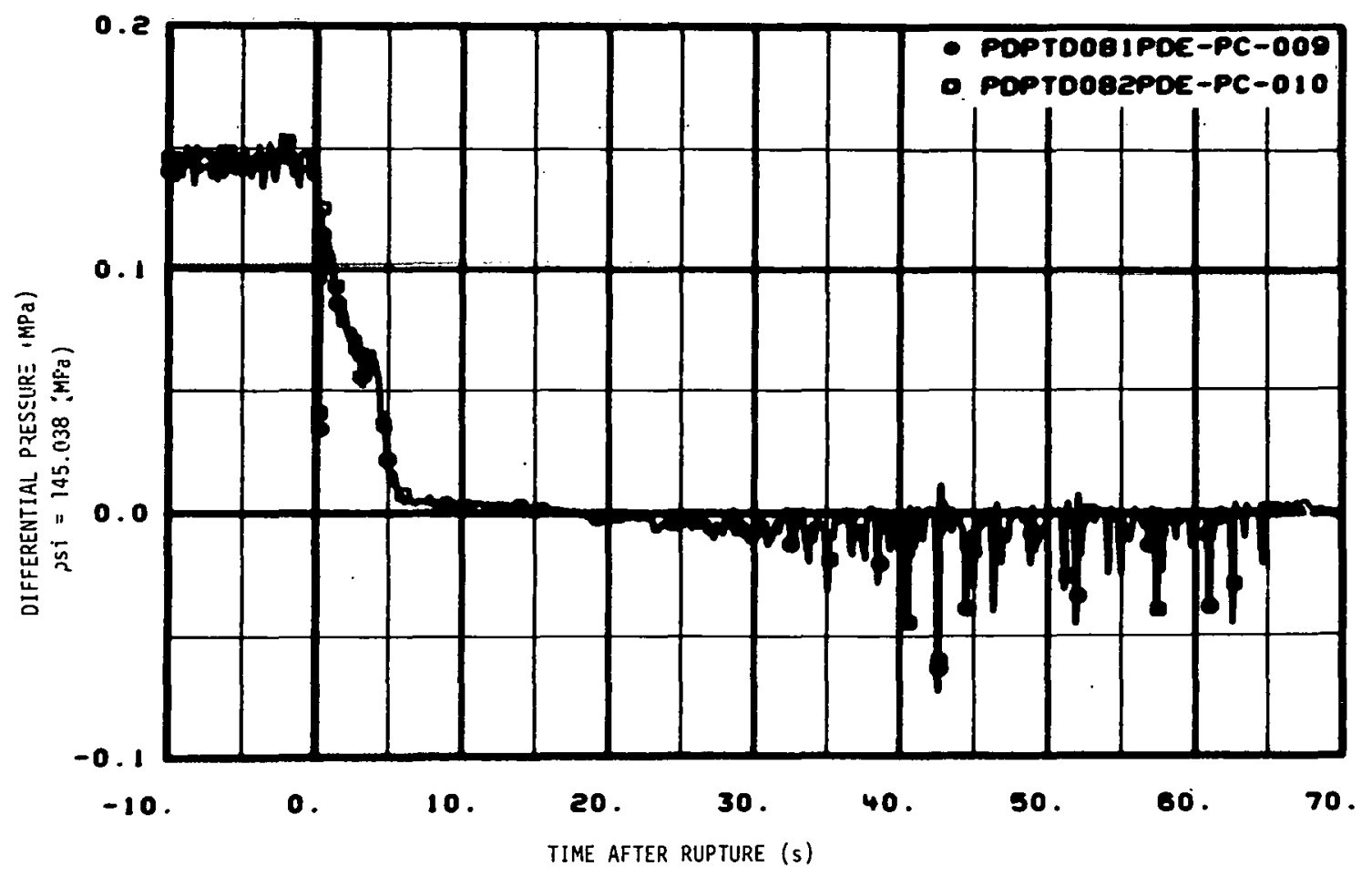

Fig. 73 Differential pressure in intact loop across primary coolant pumps 1 and 2 (PdE-PC-9 and -10$)$. 


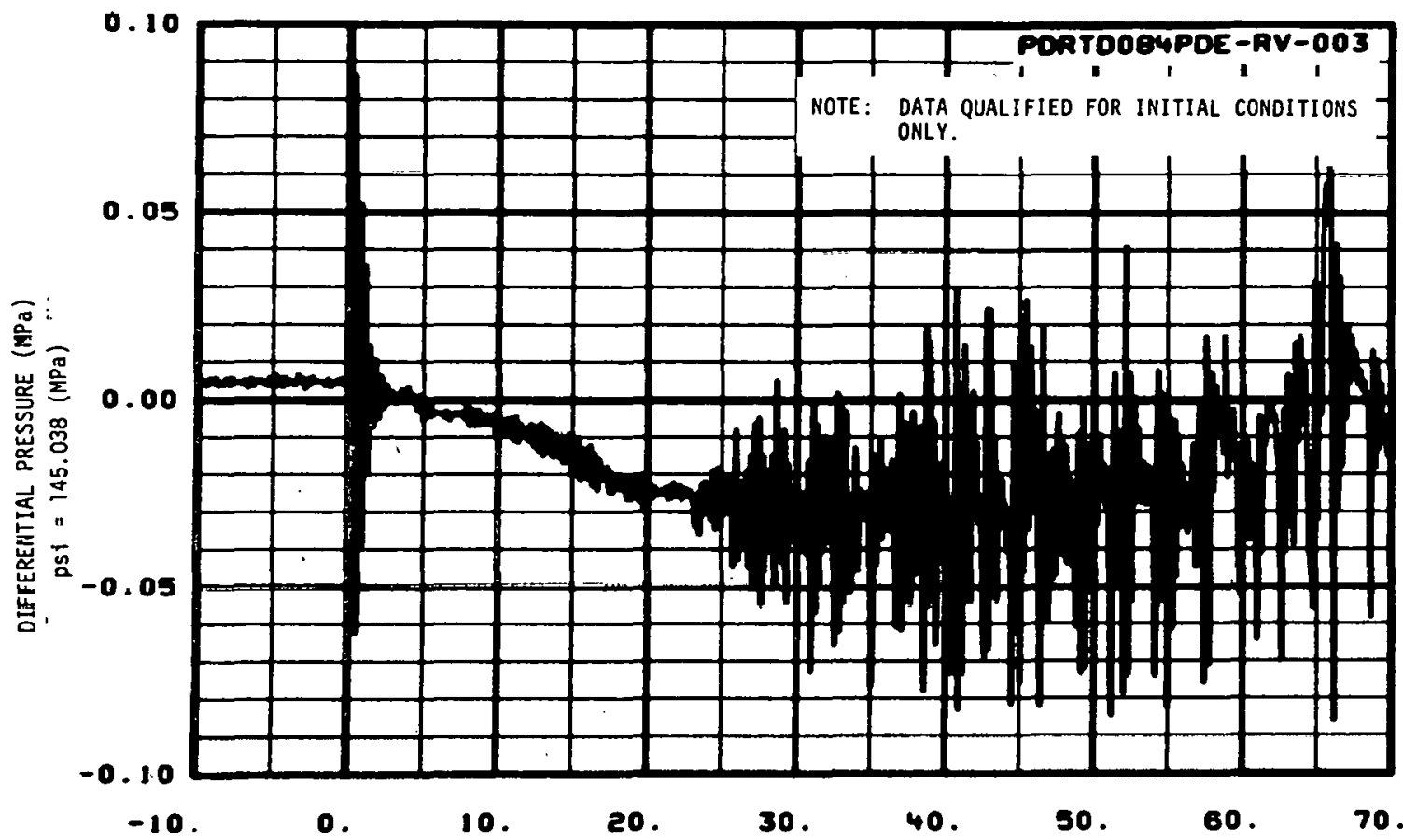

TIME AFTER RUPTURE ( $s$ )

Fig. 74 Differential pressure in reactor vessel intact loop cold leg inlet to downcomer stalk $2(\mathrm{PdE}-\mathrm{RV}-3)$ (filtered to $4 \mathrm{~Hz}$ ).

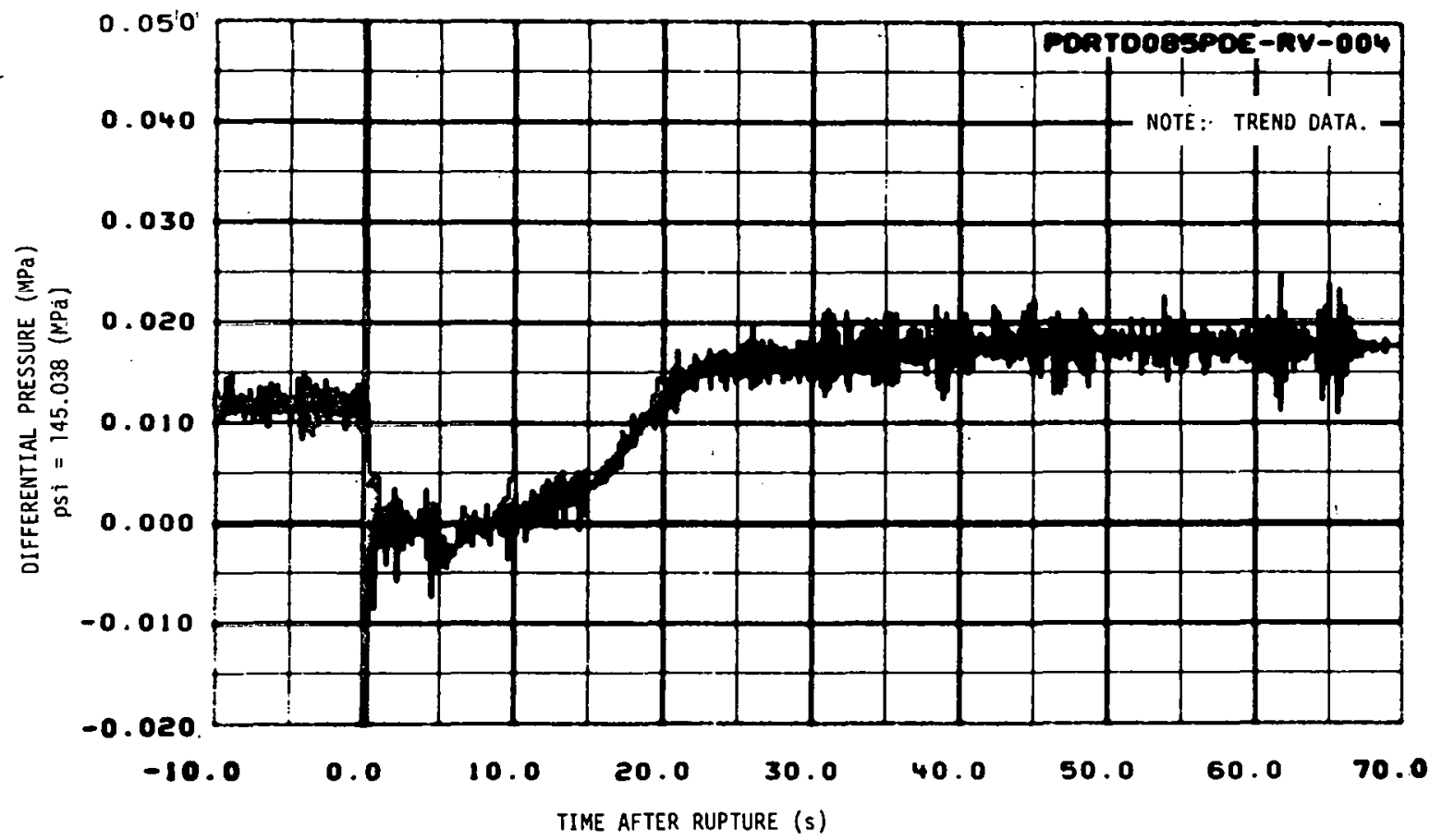

Fig. 75 Differential pressure in reactor vessel upper plenum to intact loop hot leg reactor vessel outlet nozzle (PdE-RV-4). 


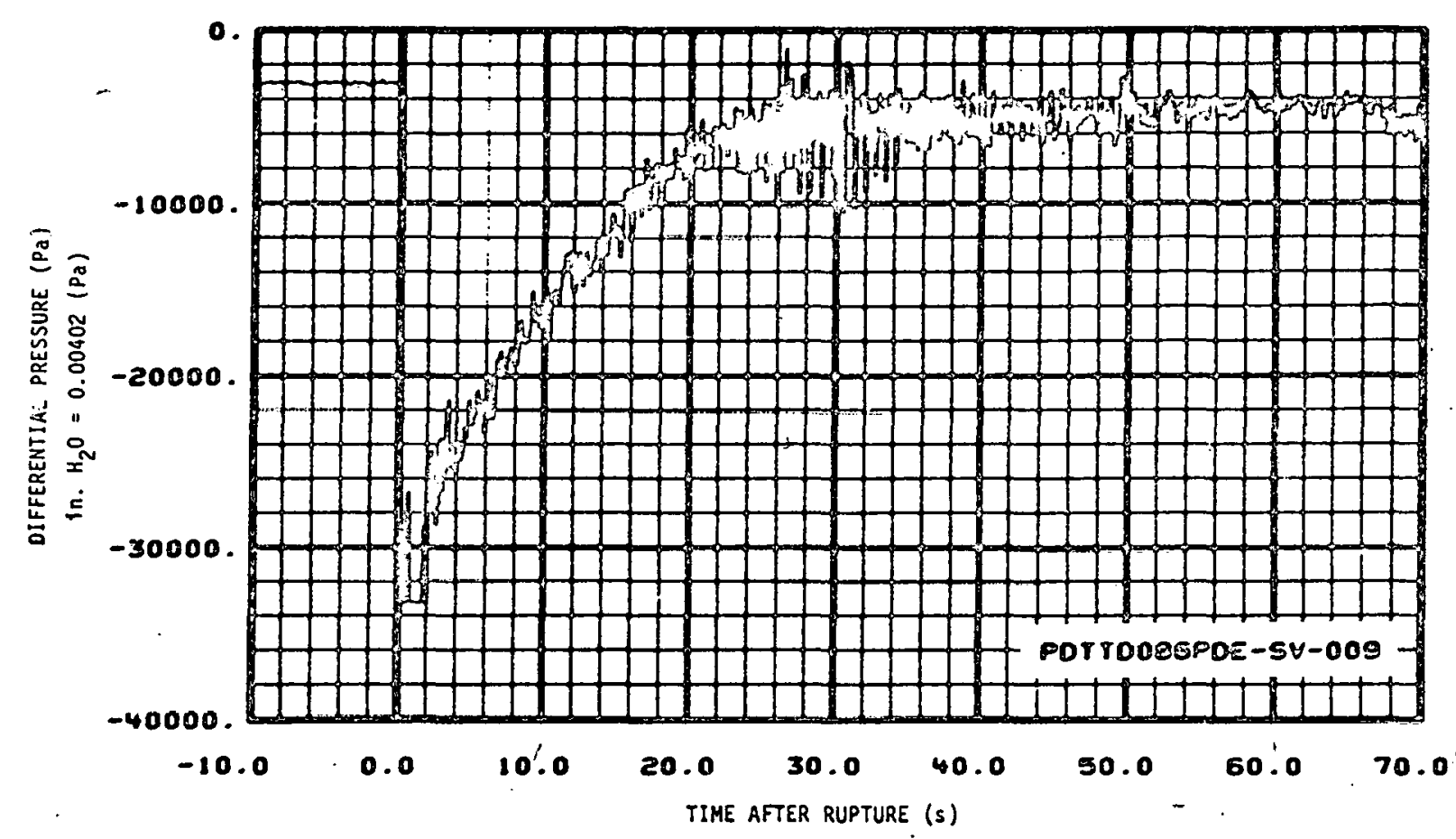

-Fig. 76: Differential-pressure in blowdown suppression tank

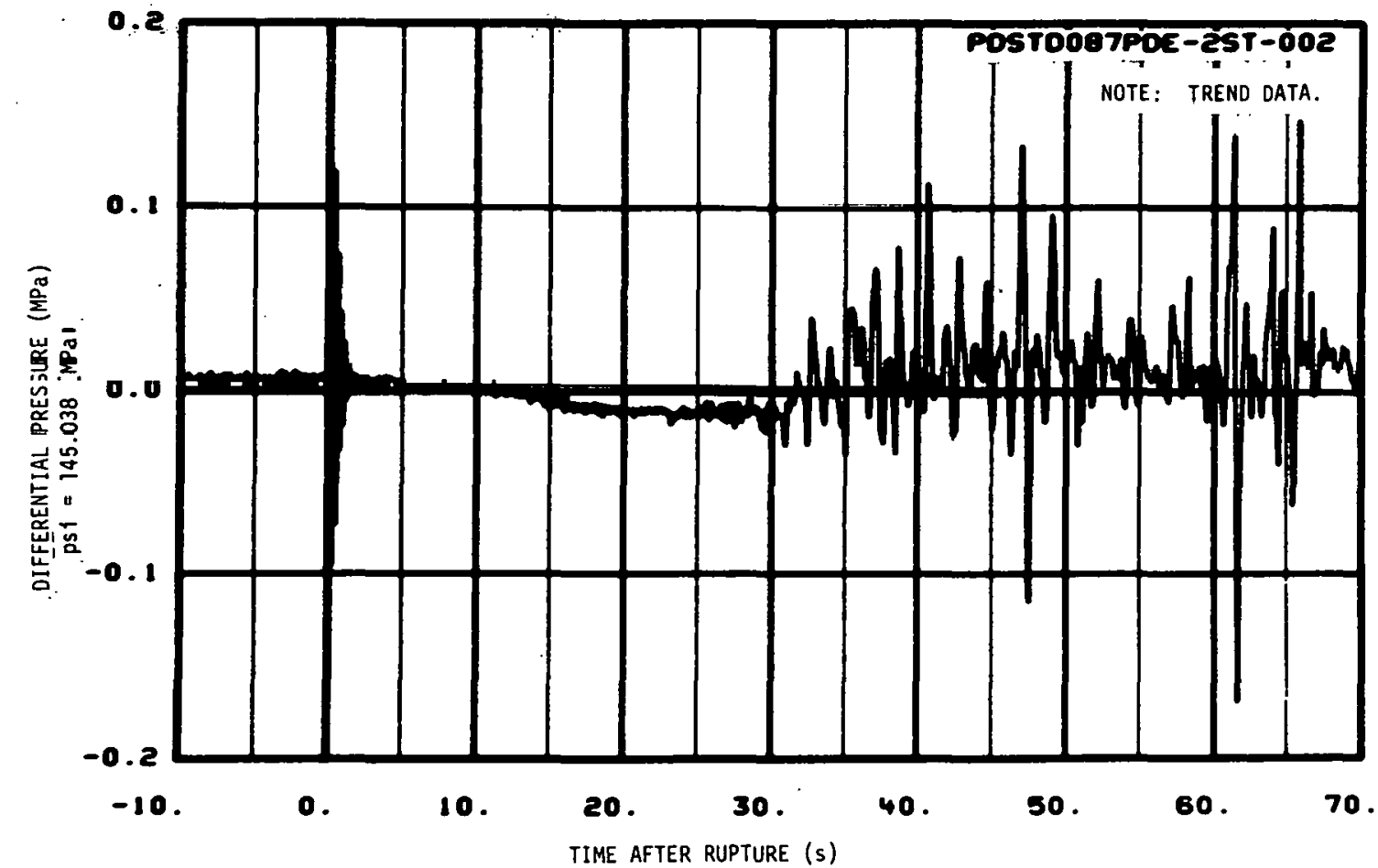

Fig. 77 Differential pressure in reactor vessel downcomer stalk 2 , between 5.32 and $0.62 \mathrm{~m}$ above reactor vessel bottom (PdE-2ST-2) (fil tered to $4 \mathrm{~Hz}$ ). 


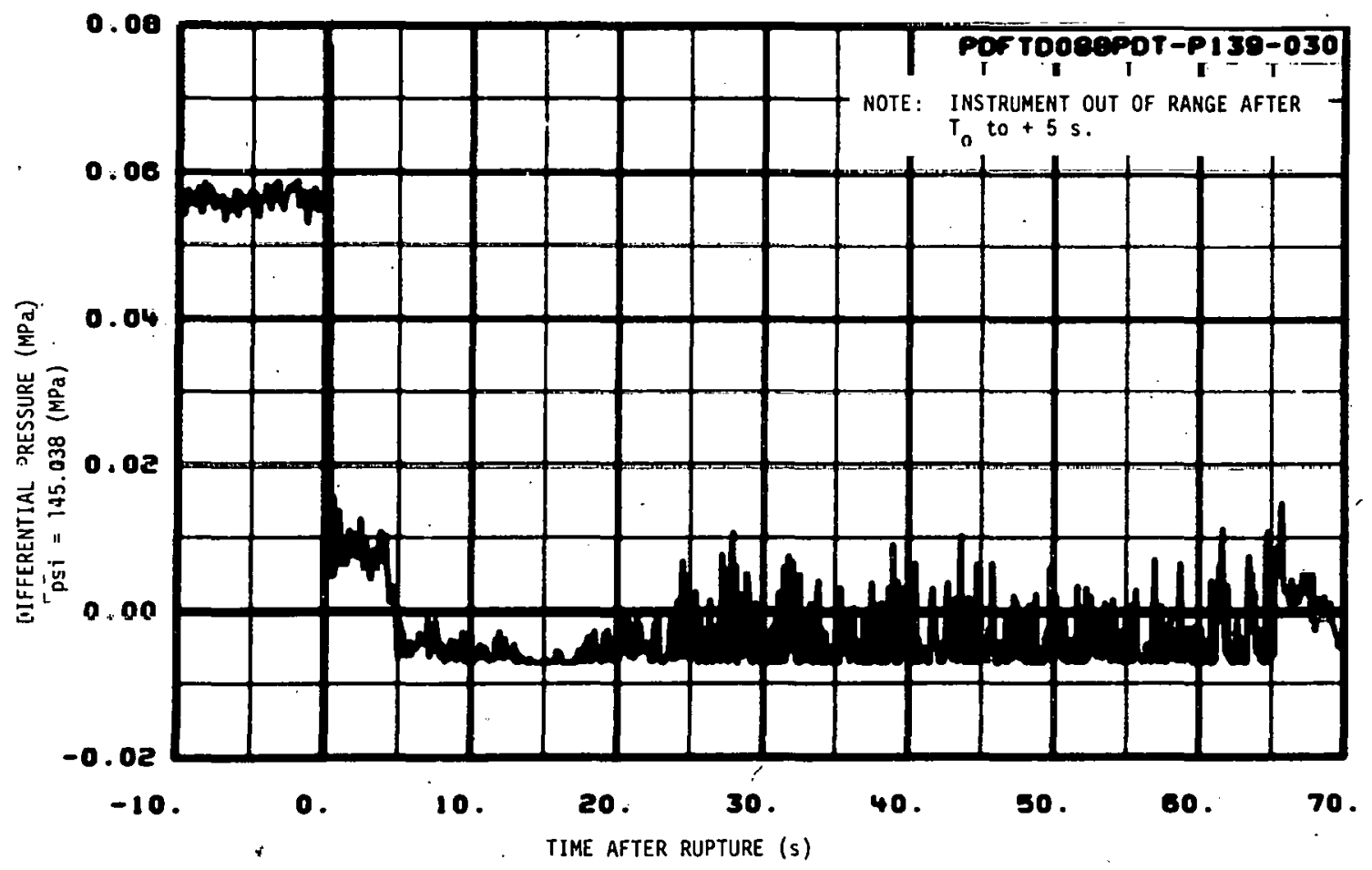

Fig. 78 Differential pressure in intact loop across reactor vessel inlet and outlet nozzles (PdT-P139-30).

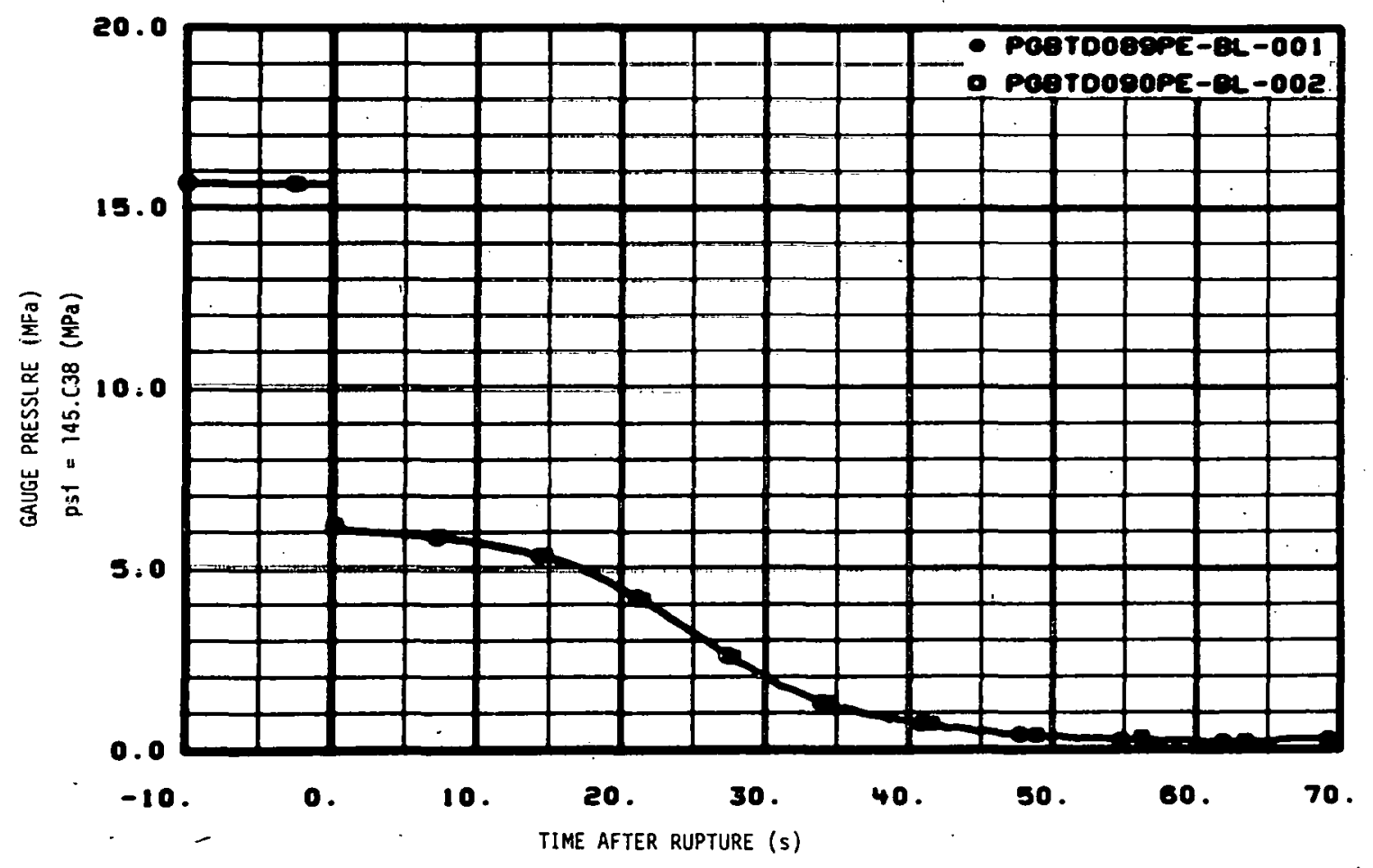

Fig. 79 Pressure in brokèn loop hot and cold legs (PE-BL-1 and -2). 


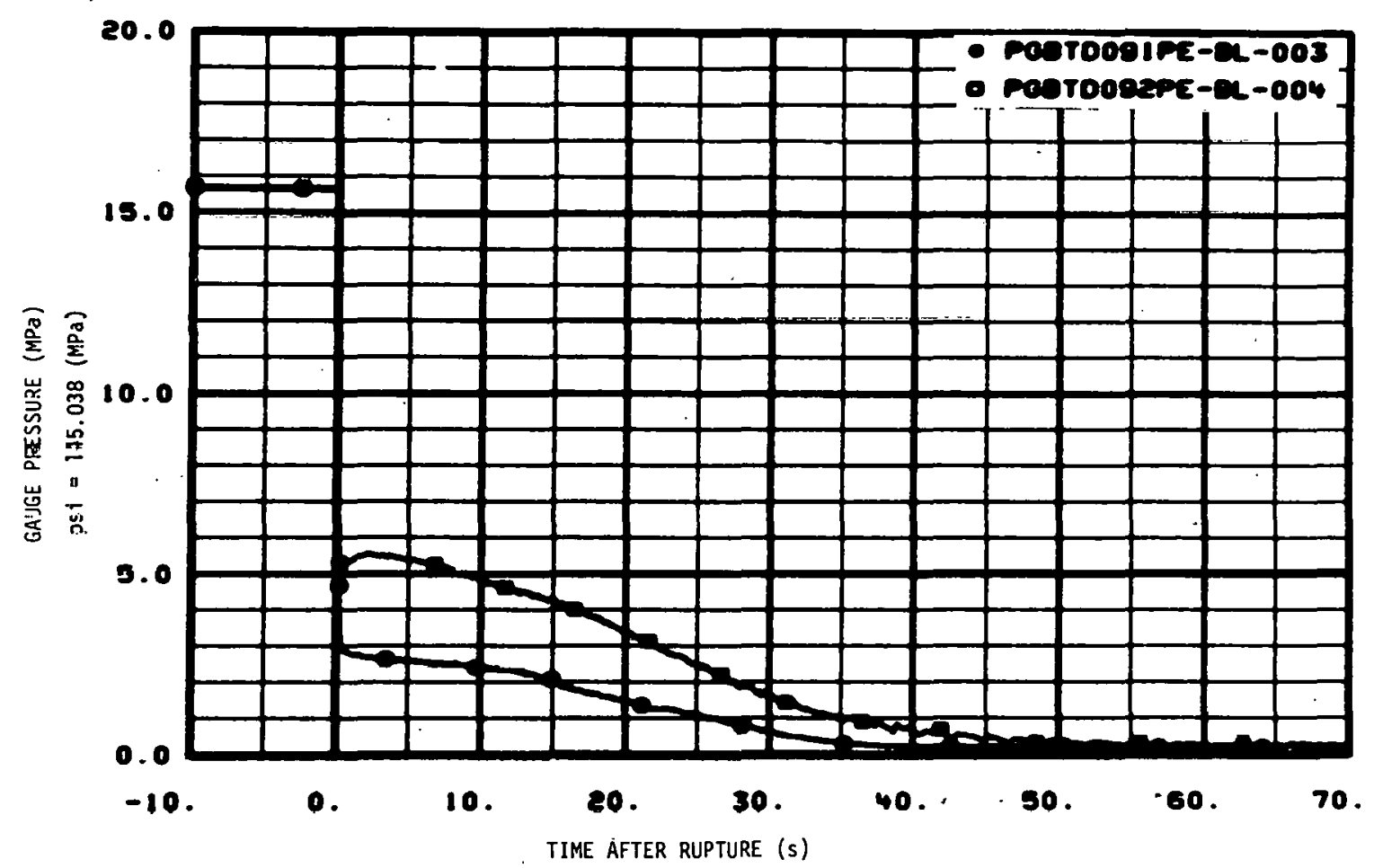

Fig. 80 Pressure in broken loop hot leg downstream of pump simulator and cold leg upstream of break plane (PE-BL-3 and -4$)$.

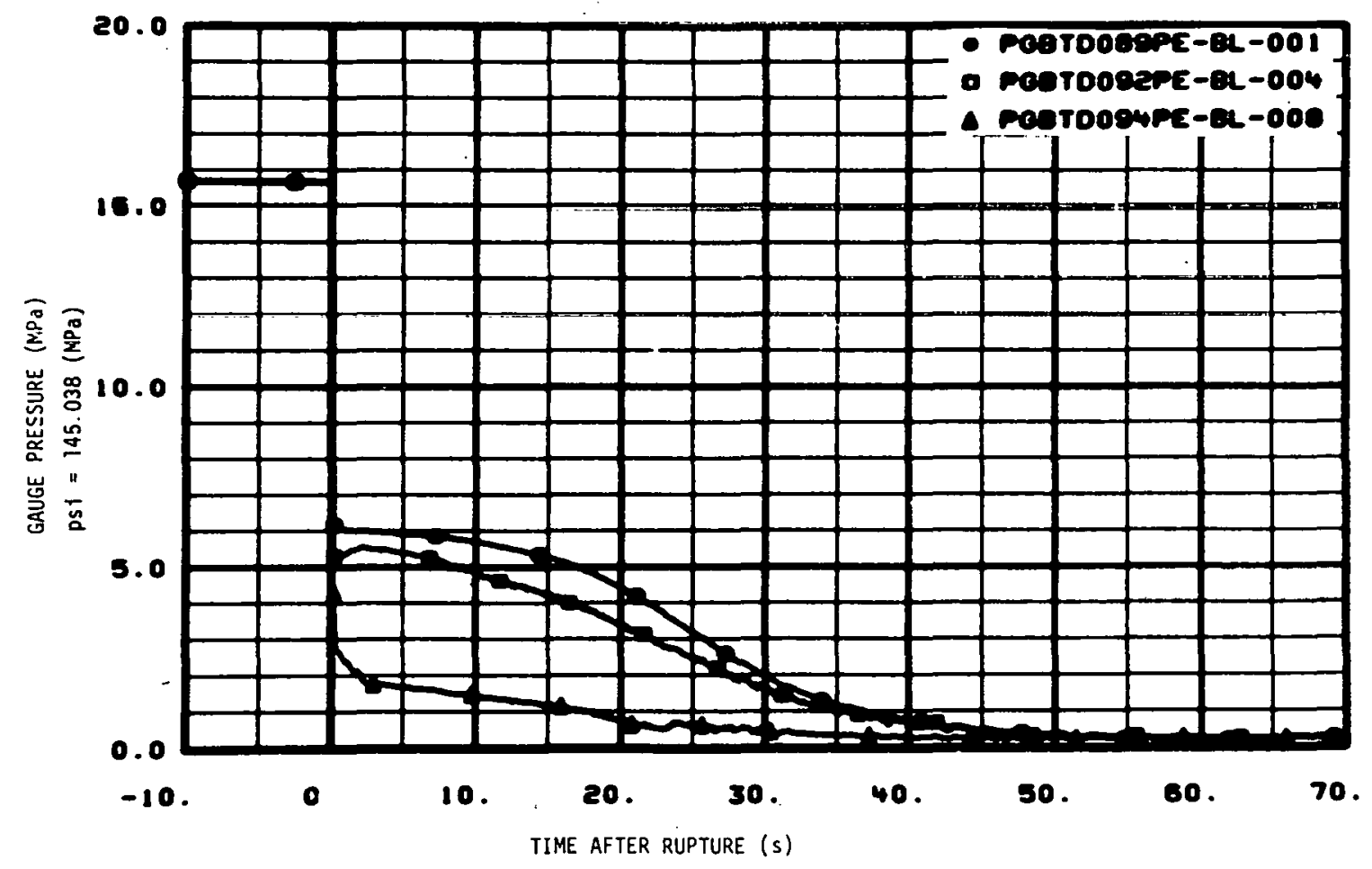

Fig. 81 Pressure in broken loop cold leg (PE-BL-1, -4, and -8). 


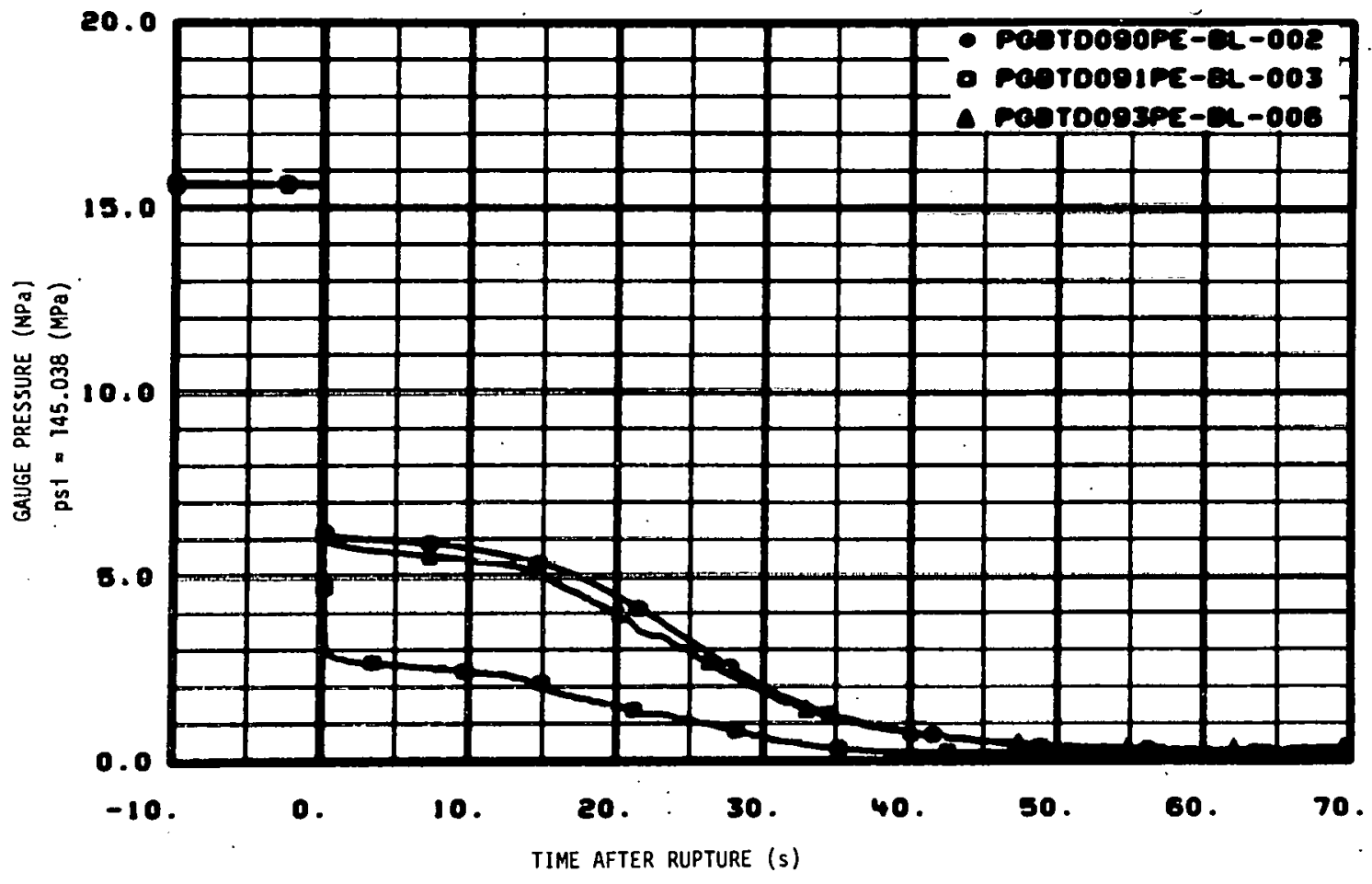

Fig. 82 Pressure in broken loop hot leg (PE-BL-2, -3, and -6).

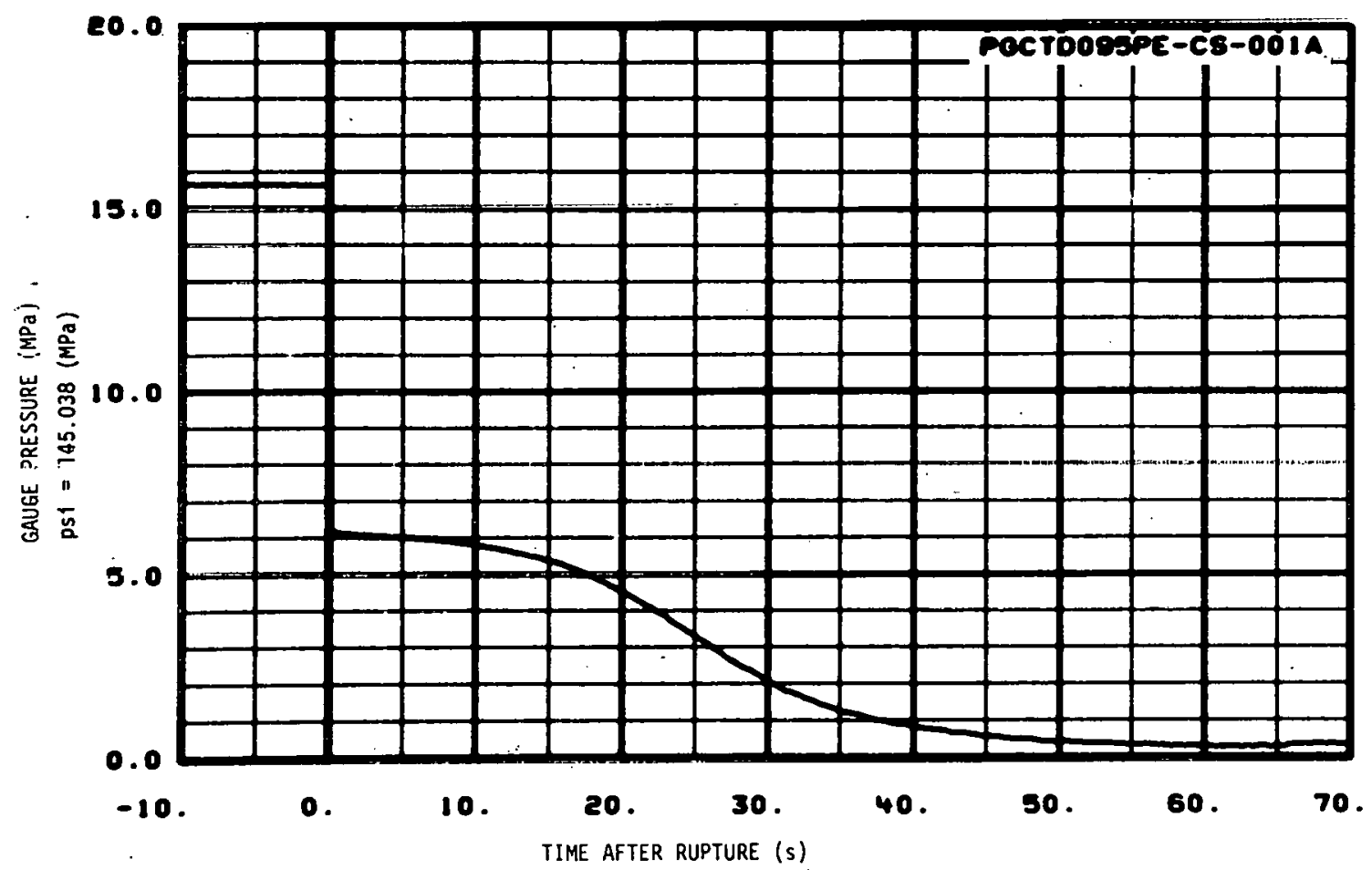

Fig. 83 Pressure in reactor vessel core simulator instrument stalk, wide range (PE-CS- $1 A$ ). 


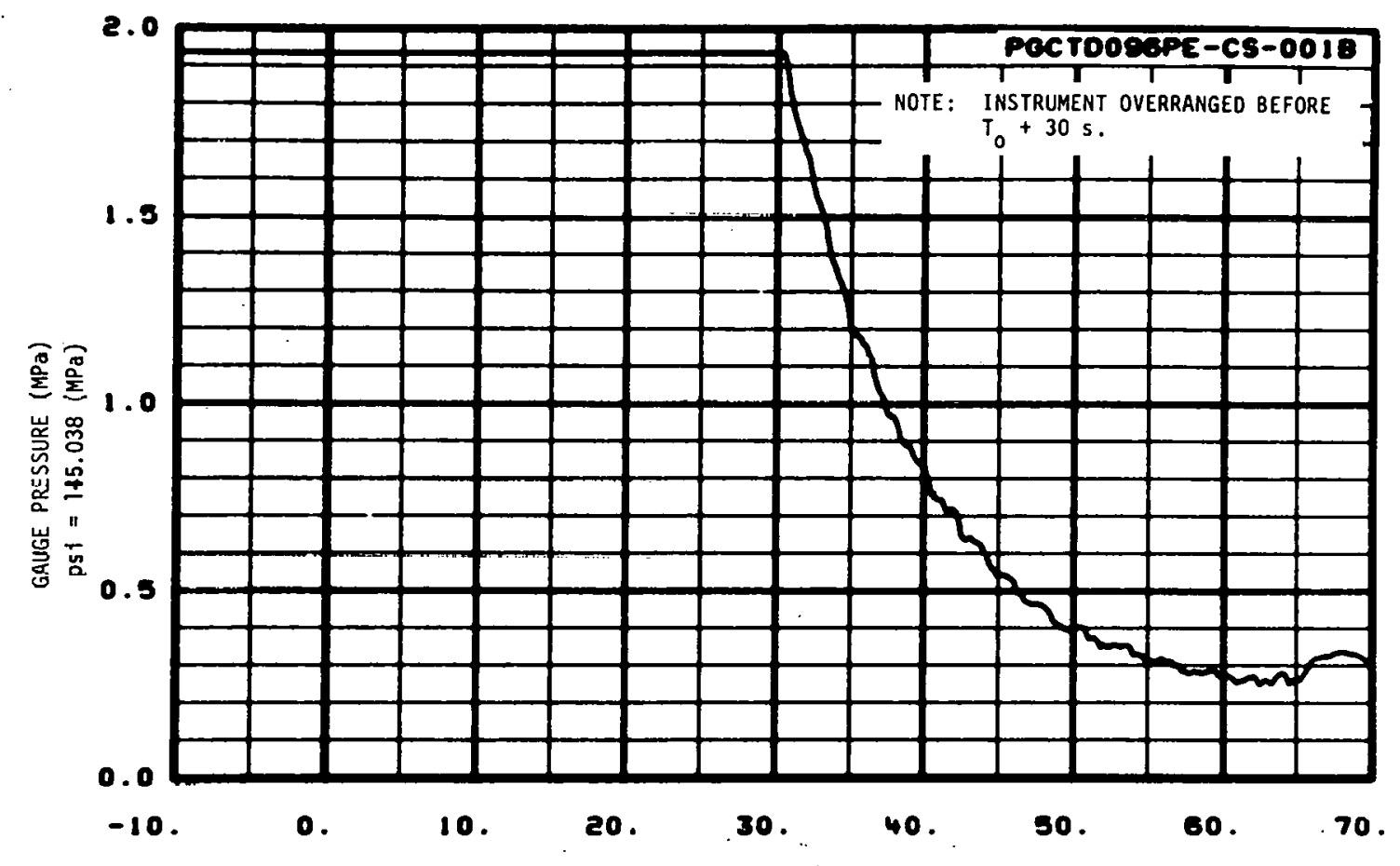

TIME AFTER RUPTURE ( $\mathrm{s}$ )

Fig. 84 Pressure in reactor vessel core simulator instrument stalk, narrow range (PE-CS-1B).

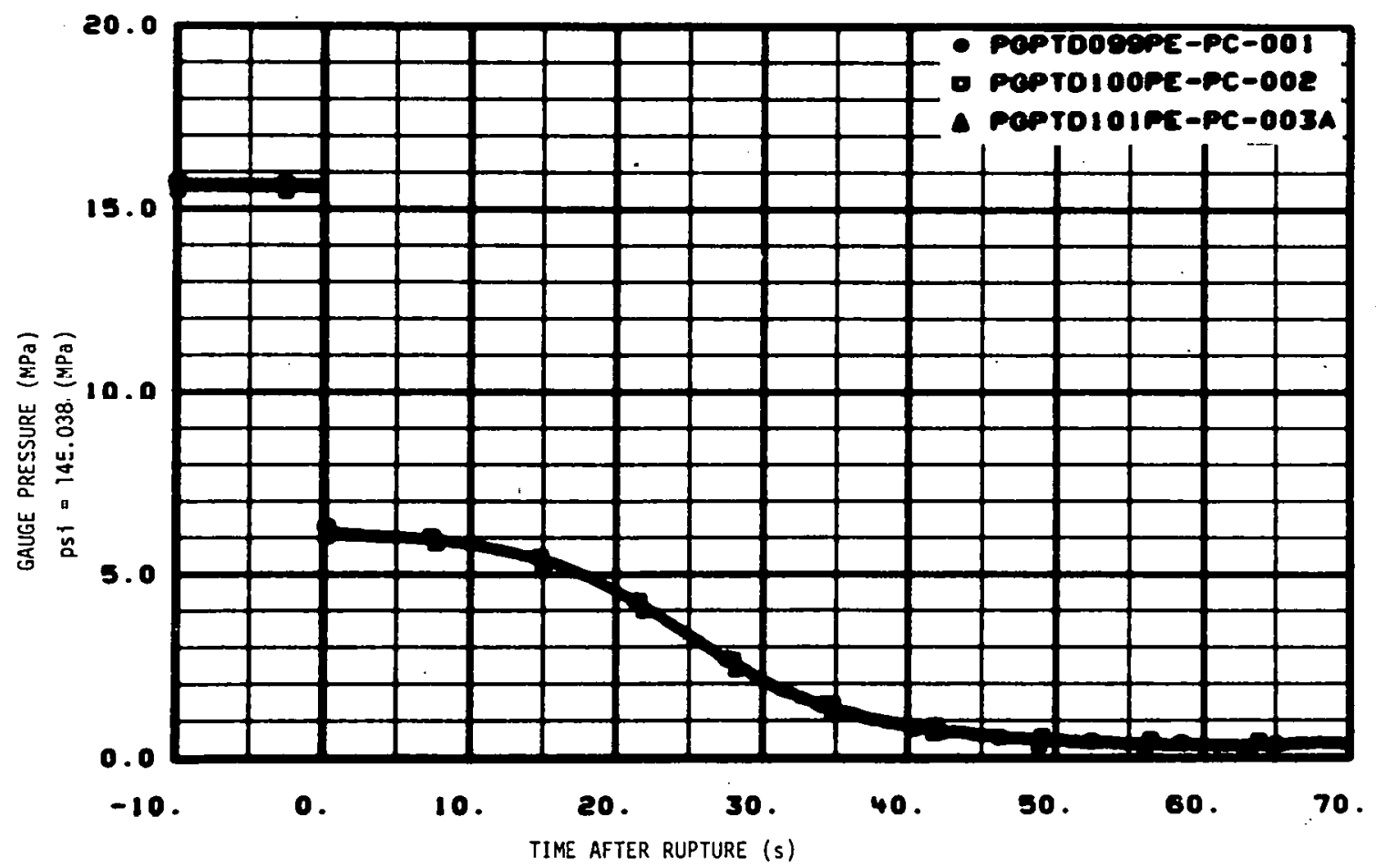

Fig. 85 Pressure in intact loop cold leg, hot leg, and steam generator outlet (PE-PC-1, -2 , and $-3 A$ ). 


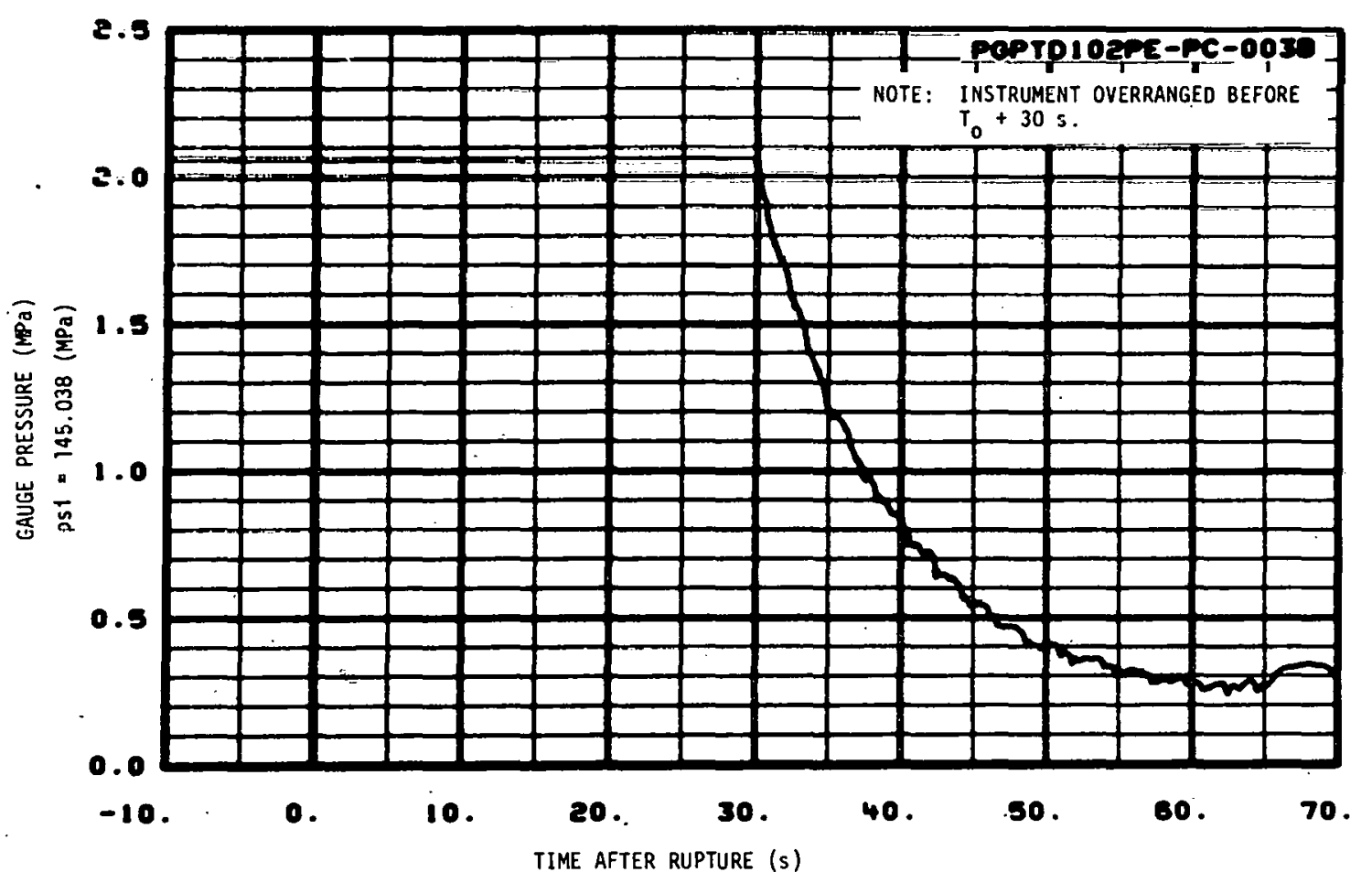

Fig. 86 Pressure in intact loop steam generator outlet, narrow range (PE-PC-3B).

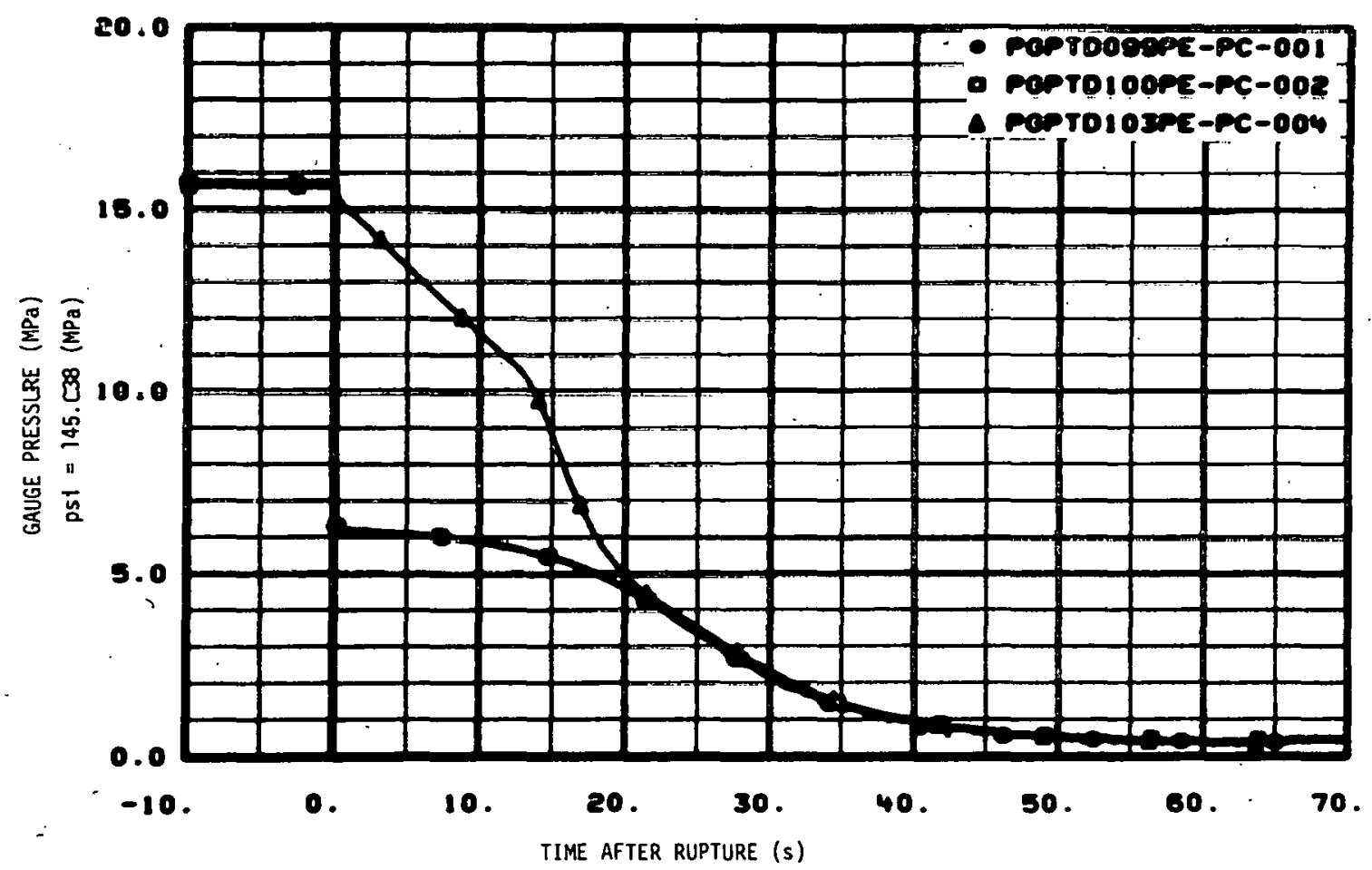

Fig. 87 Pressure in intact loop cold leg, hot leg, and pressurizer $(P E-P C-1,-2$, and -4$)$. 


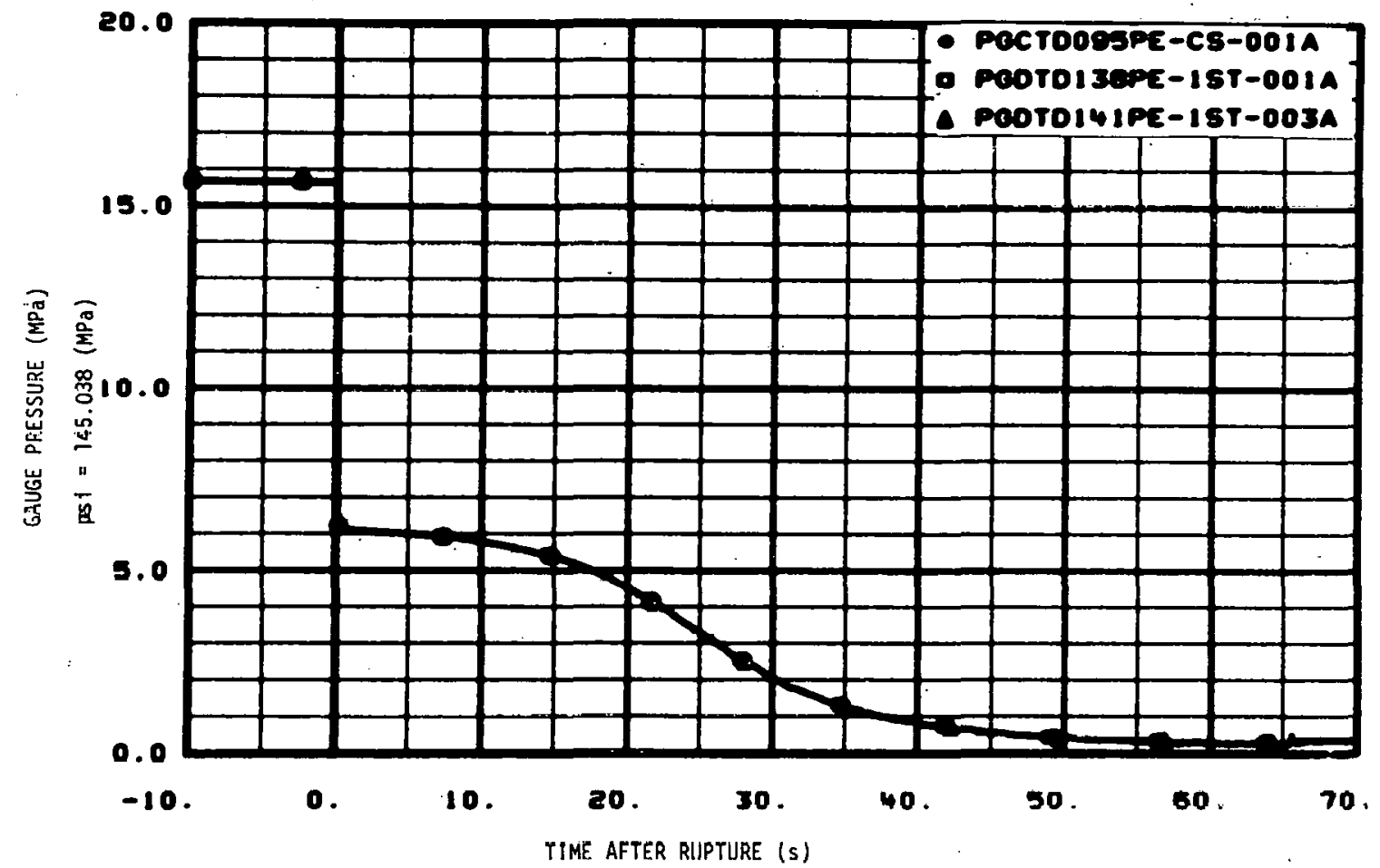

Fig. 88 Pressure in reactor vessel downcomer instrument stalk 1 and core simulator (PE-CS-1A and PE-TST-1A and - 3A).

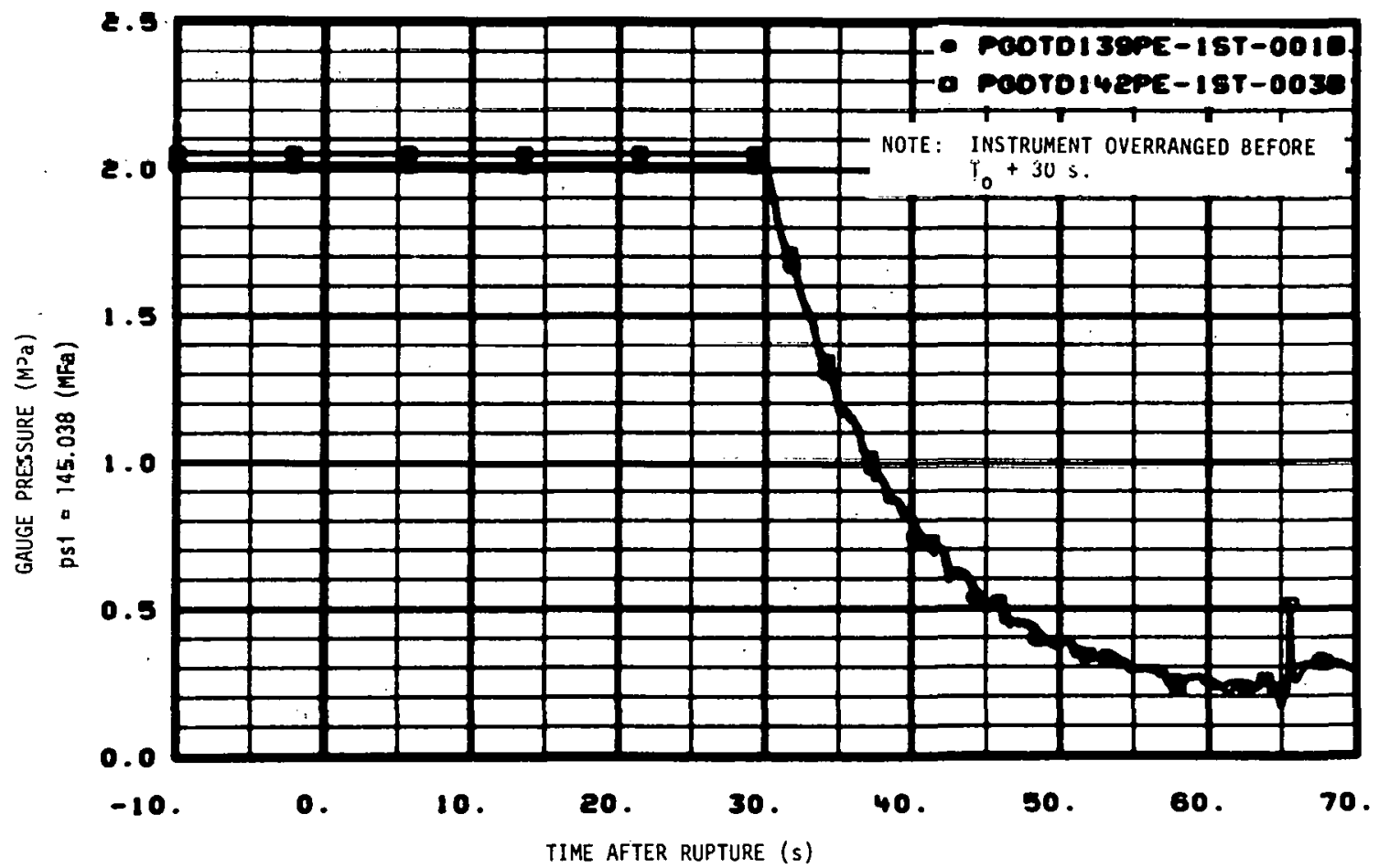

Fig. 89 Pressure in reactor vessel downcomer instrument stalk 1 , 0.62 and $5.32 \mathrm{~m}$ above reactor vessel bottom, narrow range (PE-TST-1B and -3B). 


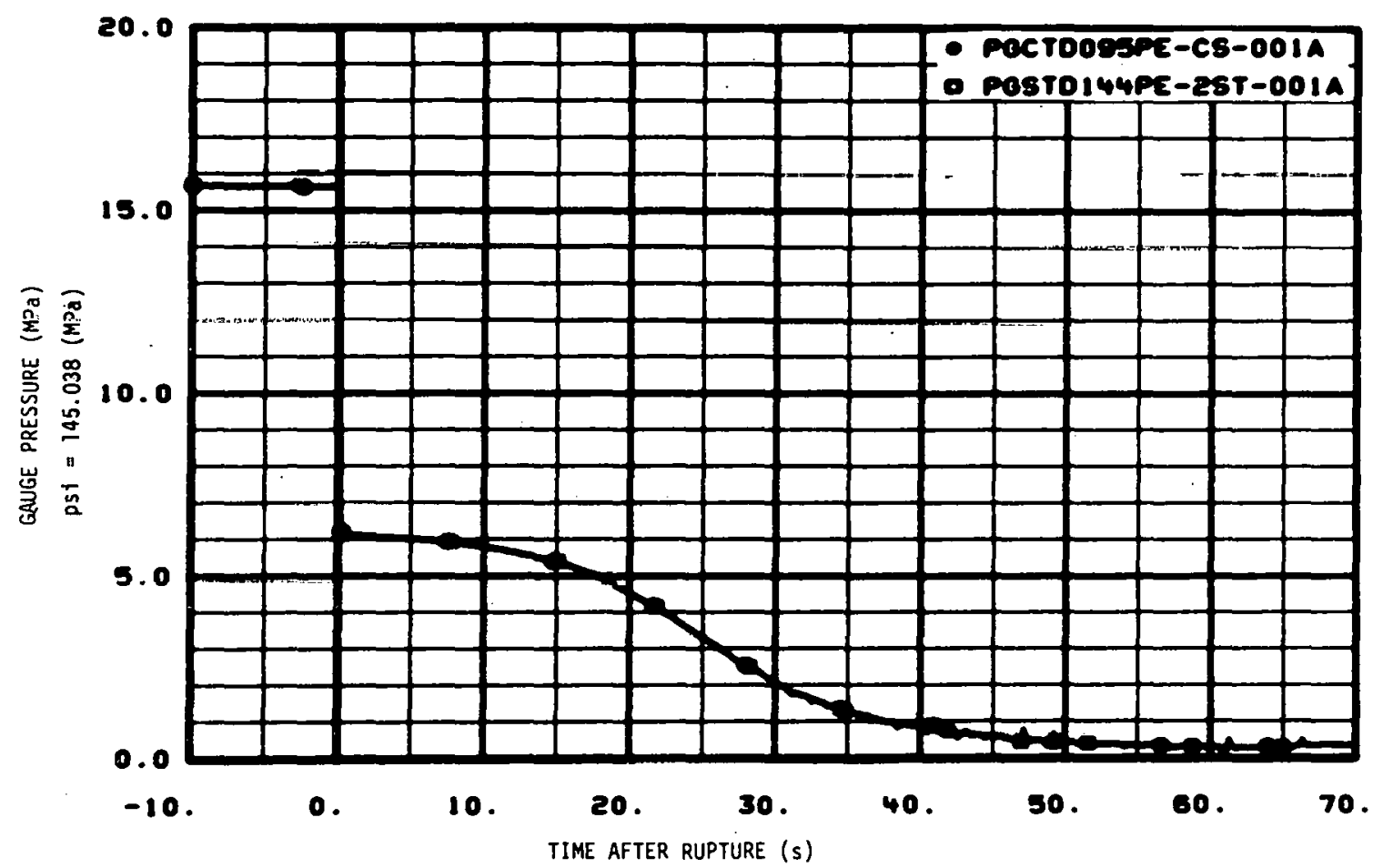

Fig. 90 Pressure in reactor vessel downcomer instrument stalk 2 and core simulator (PE-CS-1A and PE-2ST-1A).

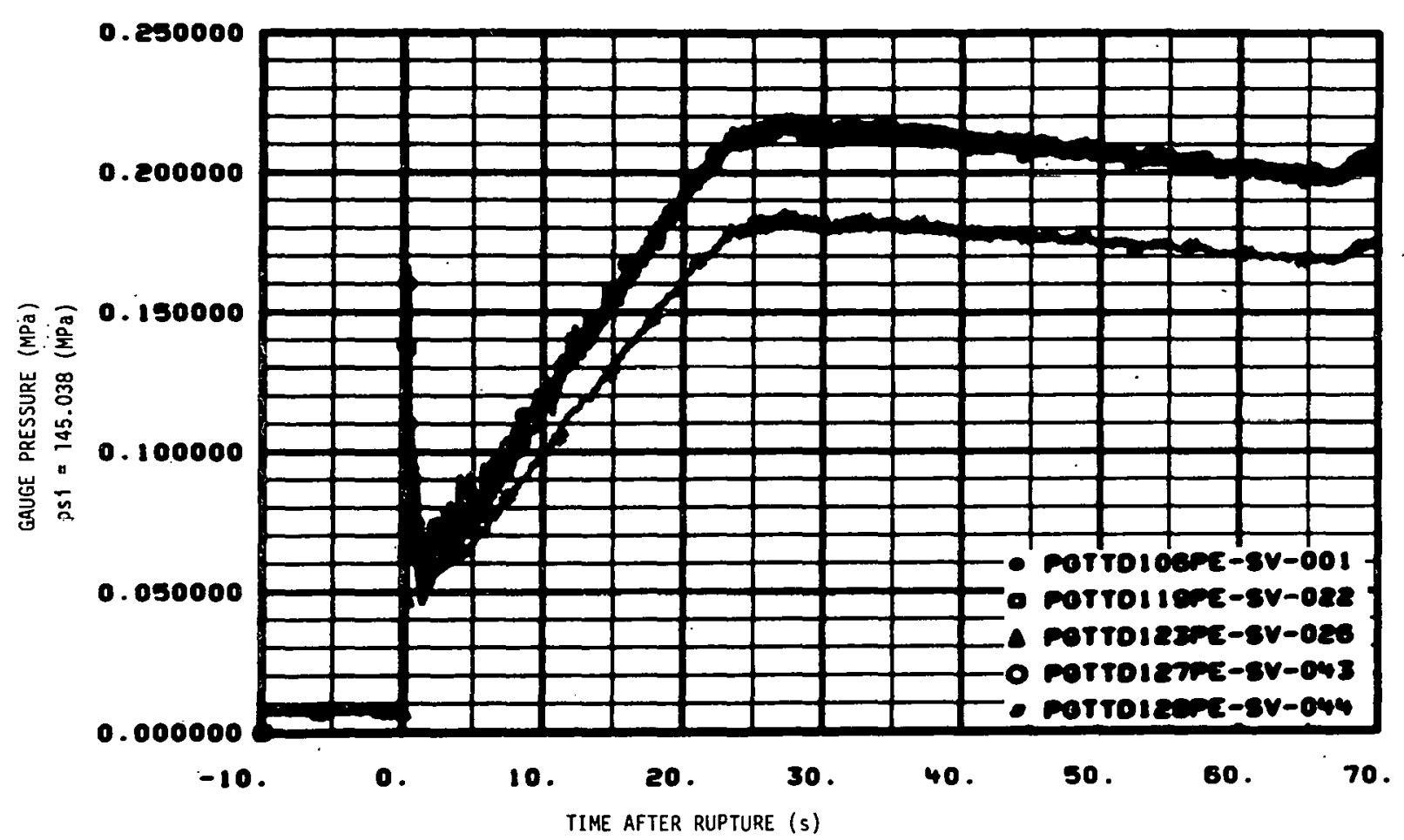

Fig. 91 Pressure in blowdown suppression tank bottom under downcomer 4 , $180^{\circ} ; 1.384 \mathrm{~m}$ north of downcomer $3,180^{\circ}$; under downcomer 3 ; under downcomer $2,180^{\circ}$; and $1.379 \mathrm{~m}$ south of downcomer 2 , $180^{\circ}$ (PE-SV-1, $-22,-26,-43$, and -44 ). 


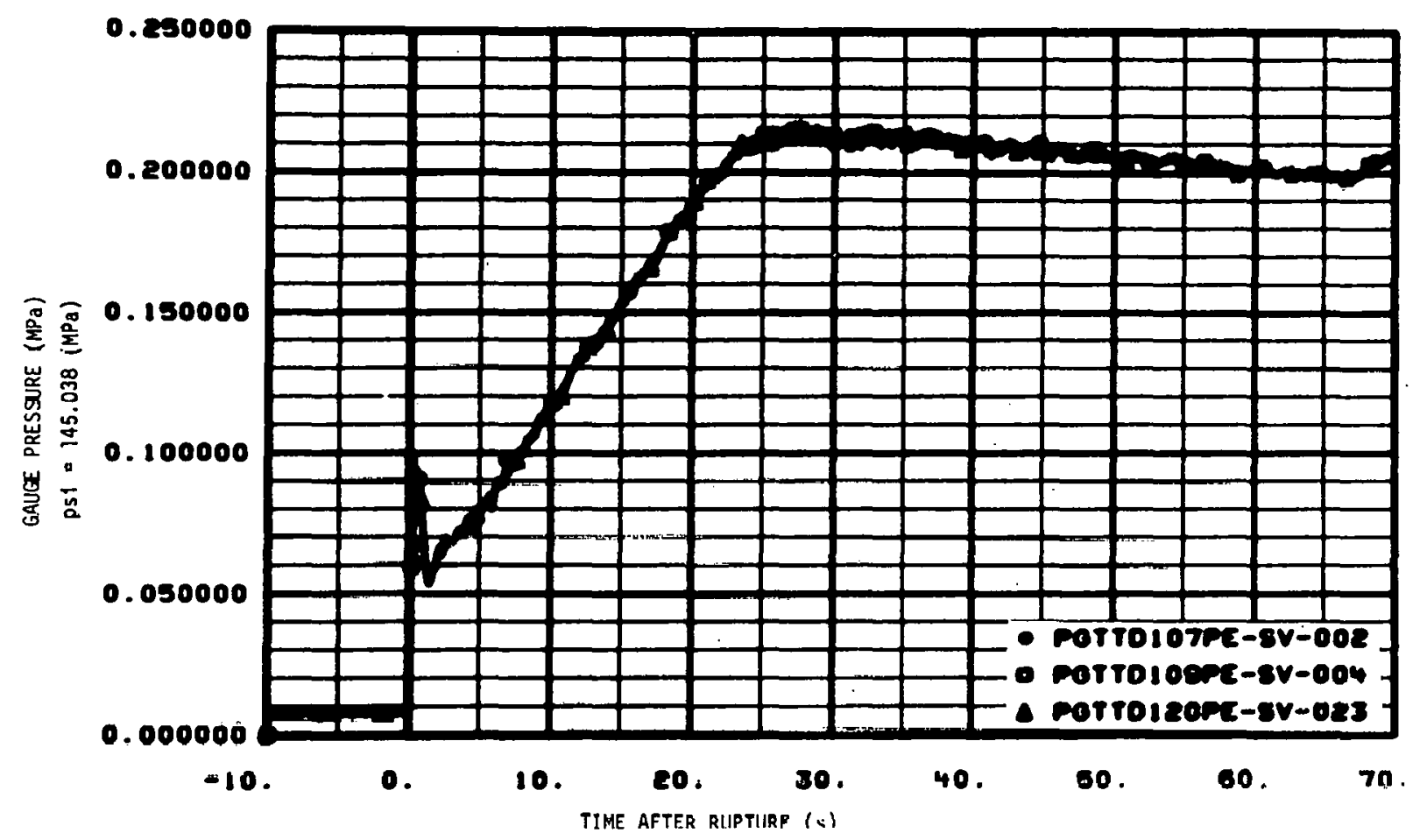

Fig. 92 Pressure in blowdown suppression tank bottom under downcomer 4 , $67.5^{\circ}$; between downcomers 3 and $4,67.5^{\circ}$; and under downcomer 1 , $67.5^{\circ}$ (PE-SV-2, -4 , and -23 ).

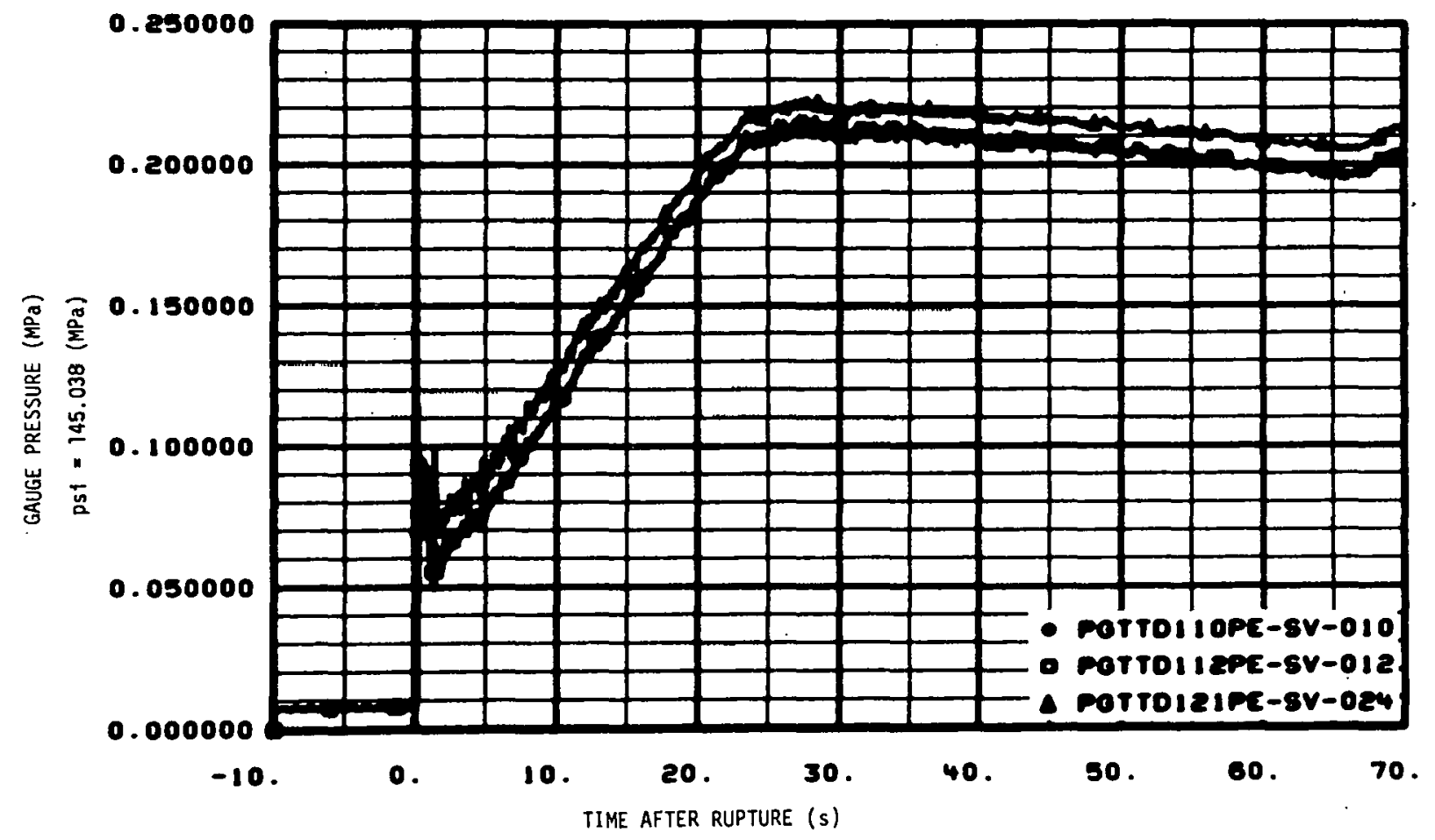

Fig. 93 Pressure in blowdown suppression tank submerged at $A$-end and tank bottom north of downcomer 4 (PE-SV-10, -12, and -24). 


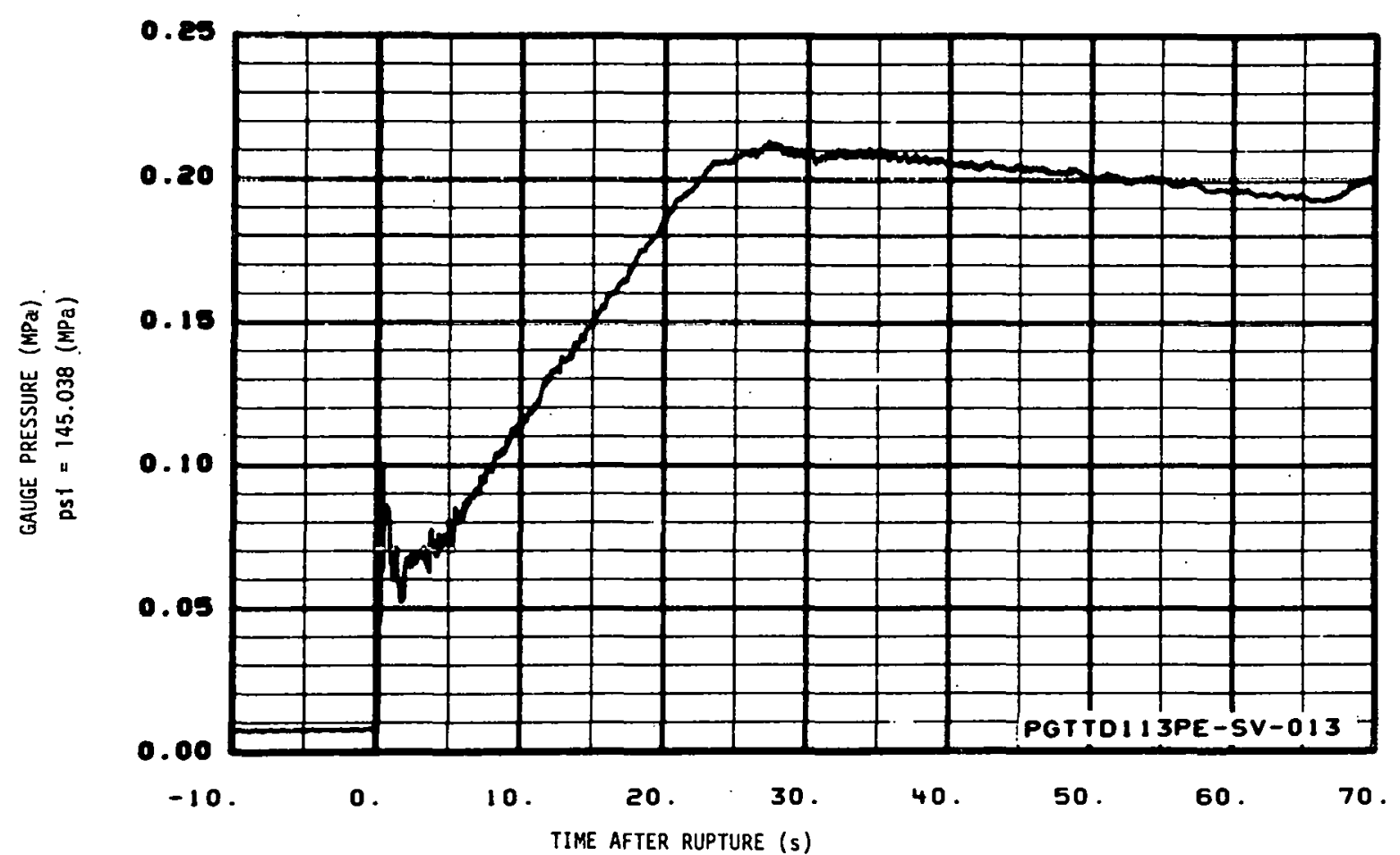

Fig. 94 Pressure in blowdown suppression tank bottom south of downcomer 1 (PE-SV-13).

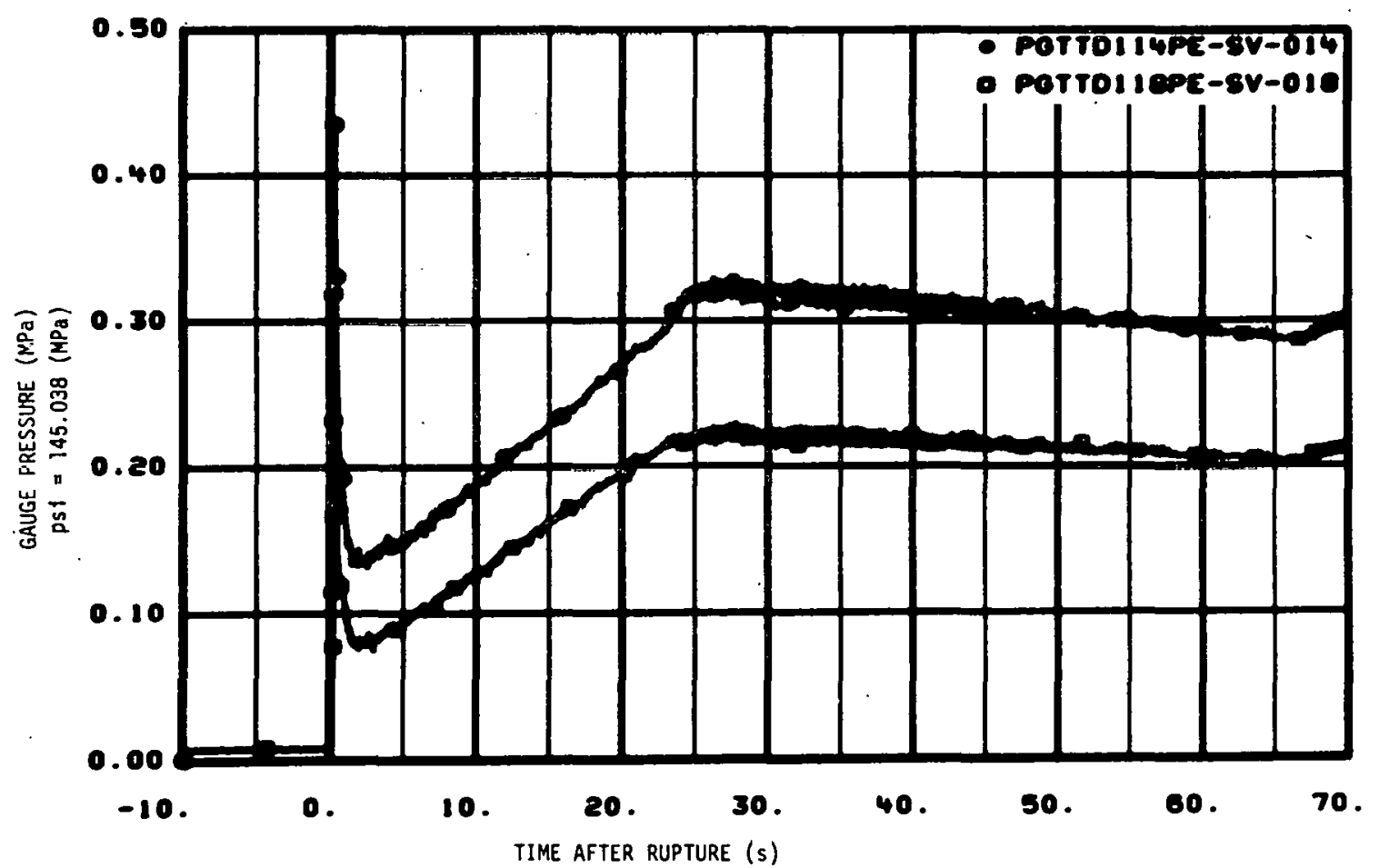

Fig. 95 Pressure in blowdown suppression tank header above downcomer 4 , $321^{\circ}$, and above downcomer 1 (PE-SV-14 and -18 ). 


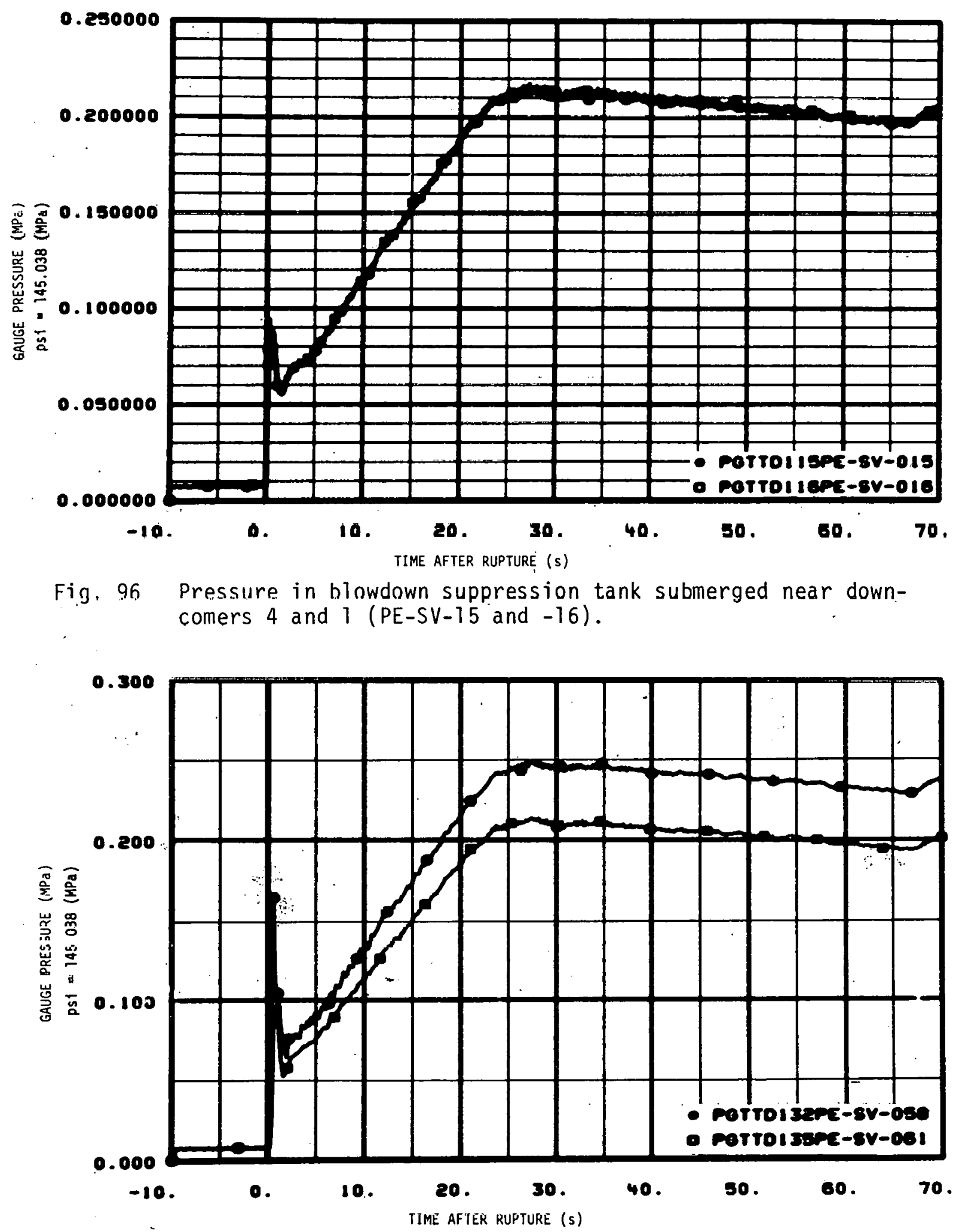

Fig. 97 . Pressure in blowdown suppression tank gas space near downcomers 4 and 1 (P.E-SV-58 and -61 ). 


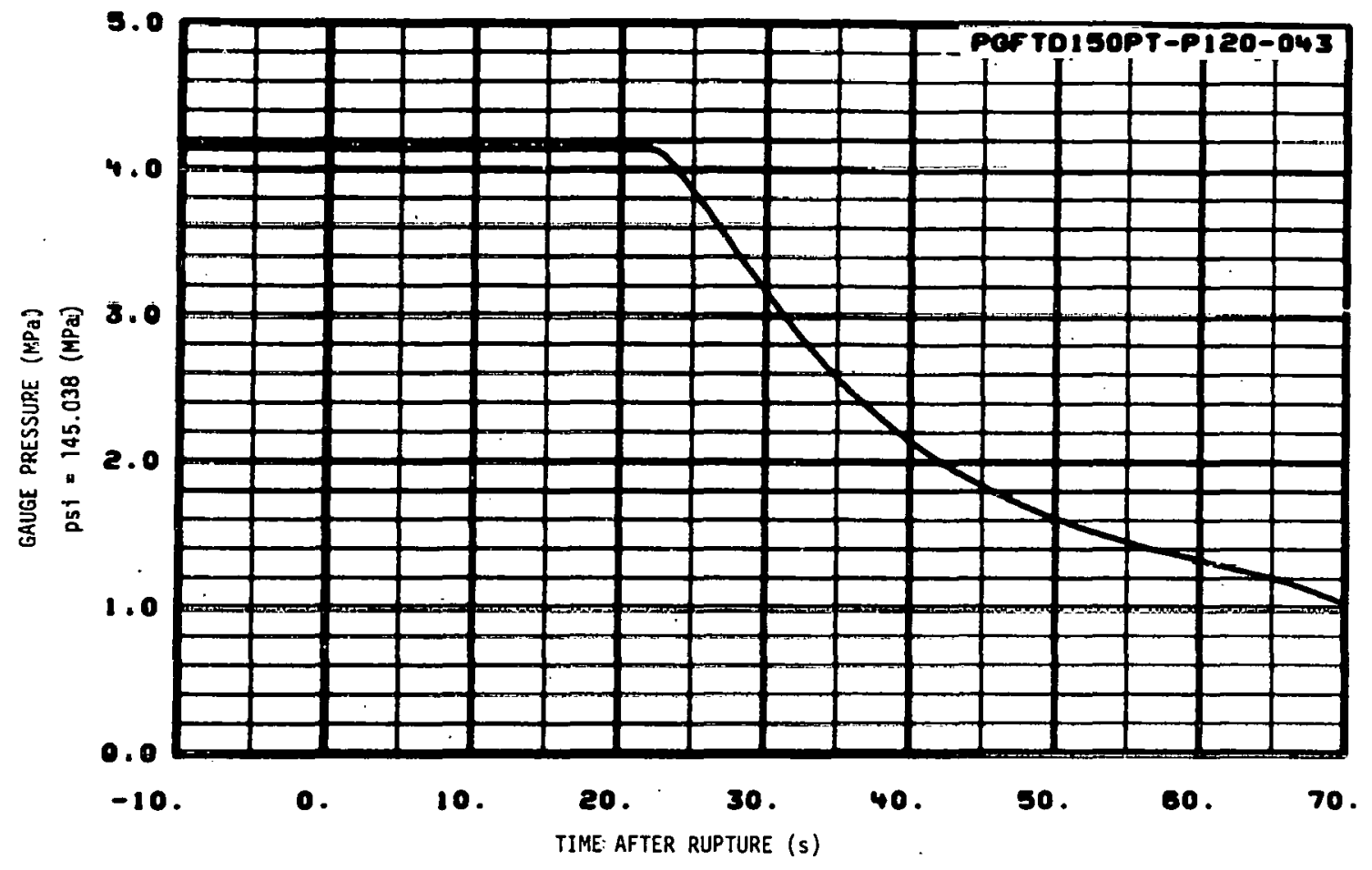

Fig. 98 Pressure in ECCS accumulator A (PT-P120-43).

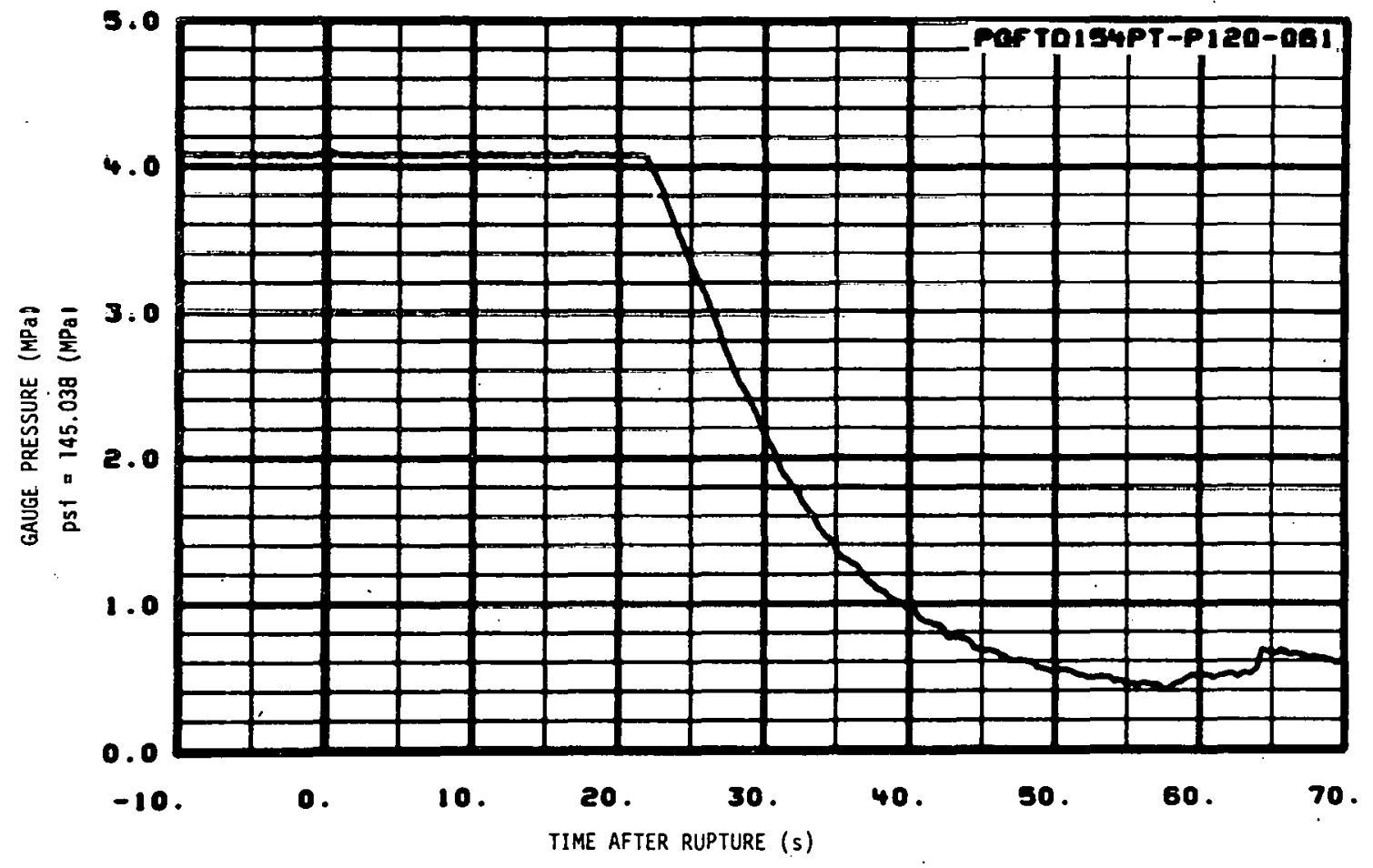

Fig. 99 Pressure in ECCS cold leg injection line (PT-P120-61). 


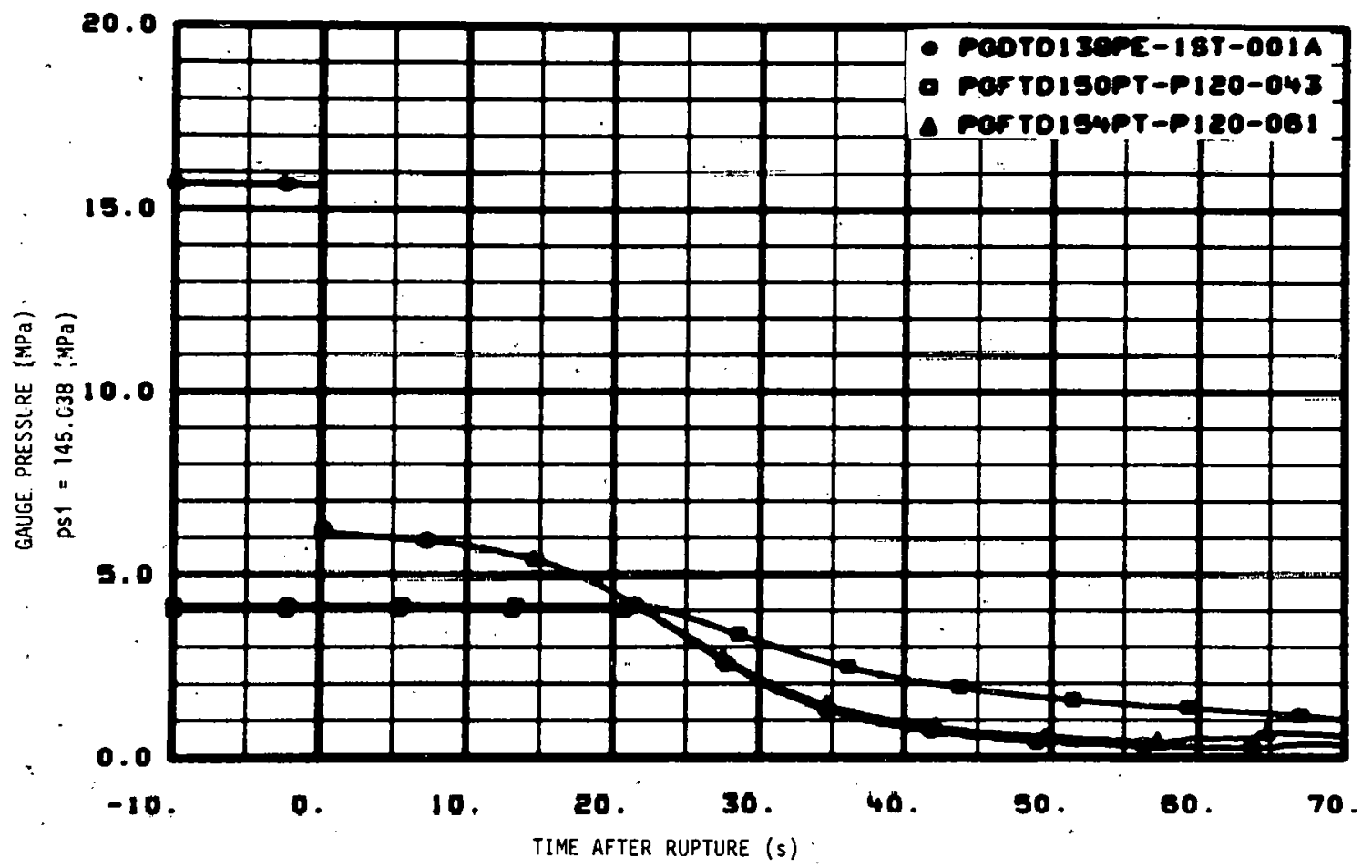

Fig. 100 Pressure in ECCS injection from accumulator $A$ to the cold 1 eg (PE-1ST-1A and PT-P120-43 and -61).

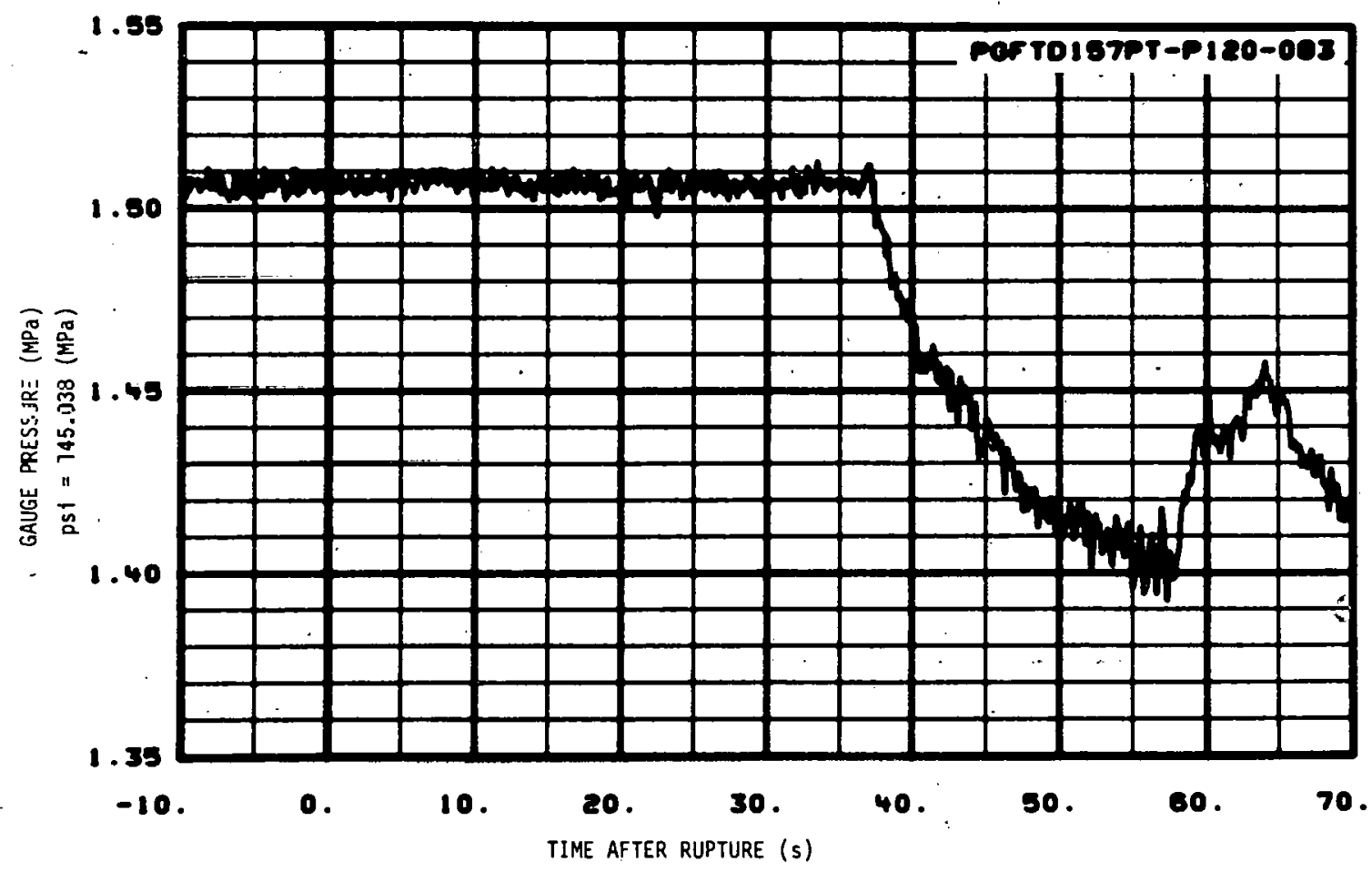

Fig. 101 Pressure in ECCS LPIS pump A dișcharge (PT-P120-83). 


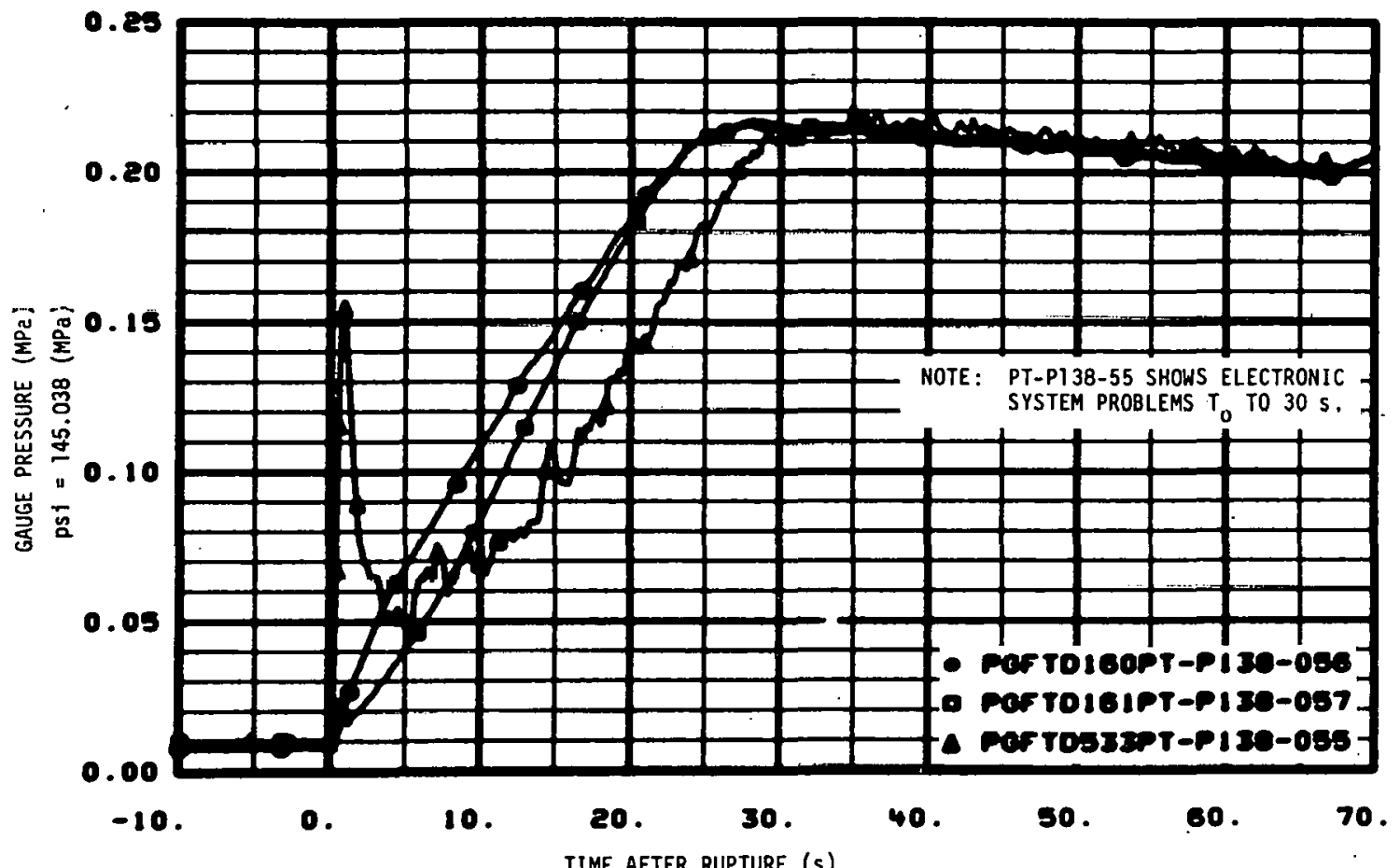

Fig. 102 Pressure in blowdown suppression tank top (PT-P138-55, -56, and -57 ).

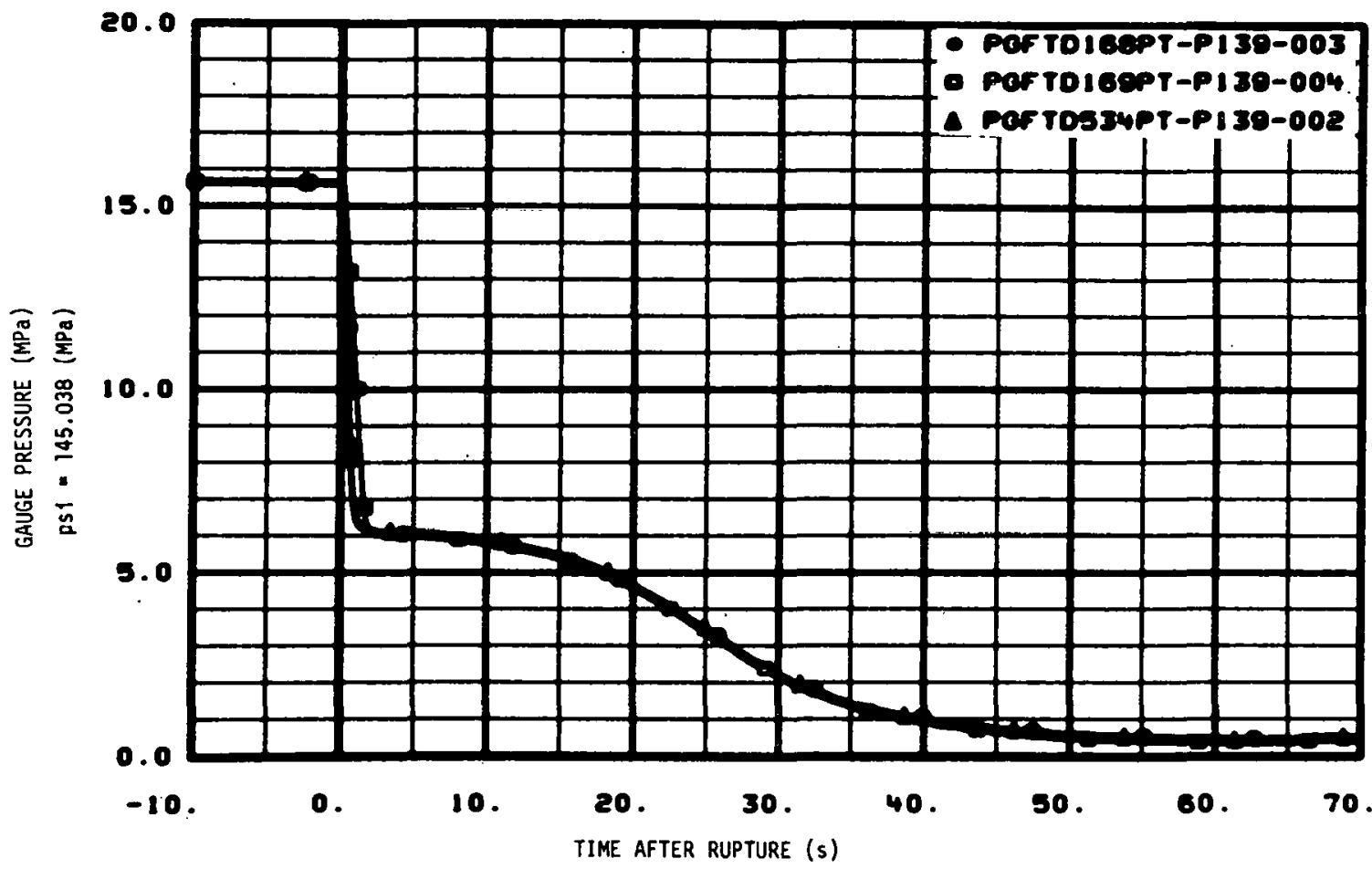

Fig. 103 Pressure in intact loop hot leg venturi (PT-P139-2, -3, and -4). 


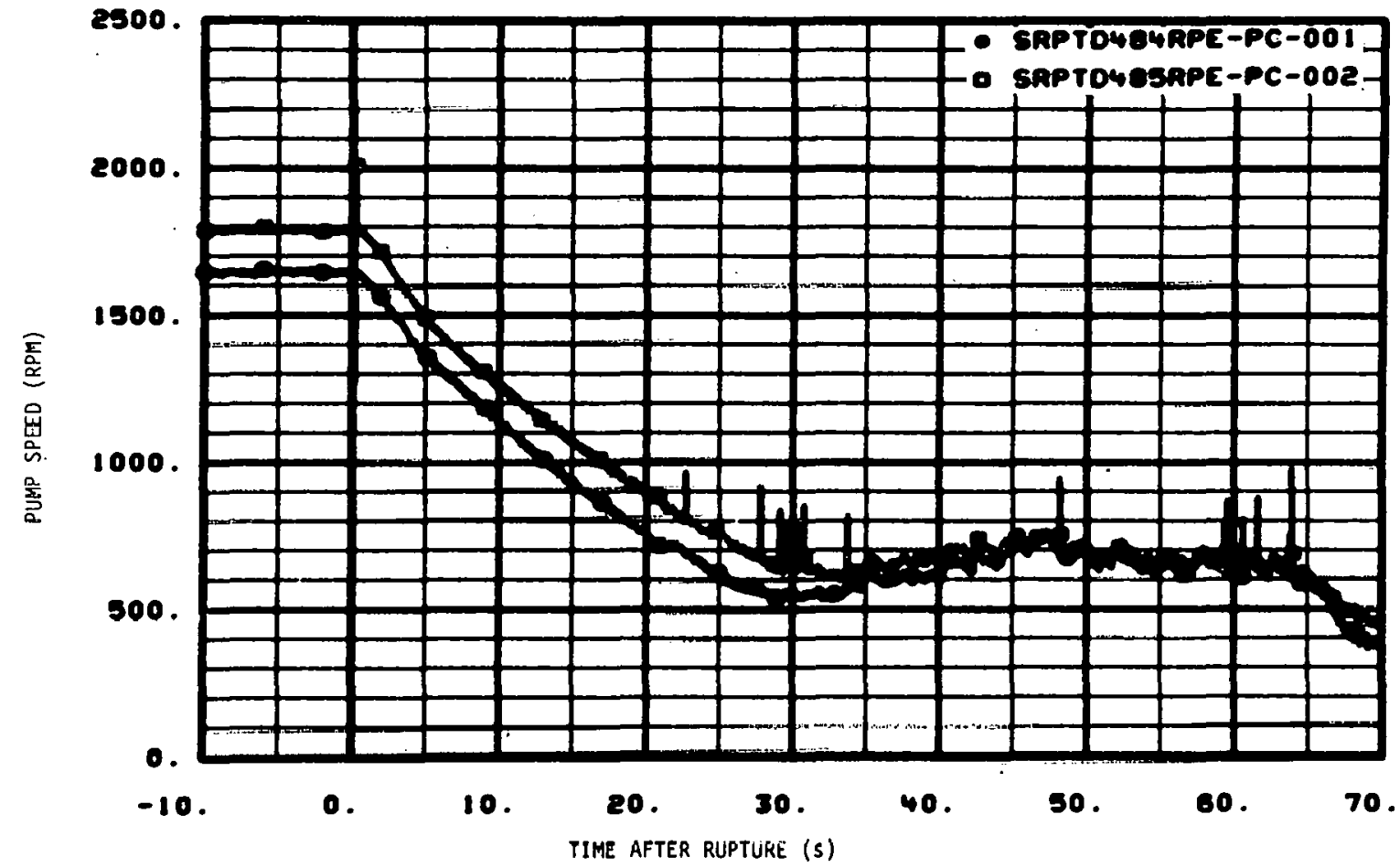

Fig. 104 Pump speed for intact loop pumps 1 and 2 (RPE-PC-1 and -2).

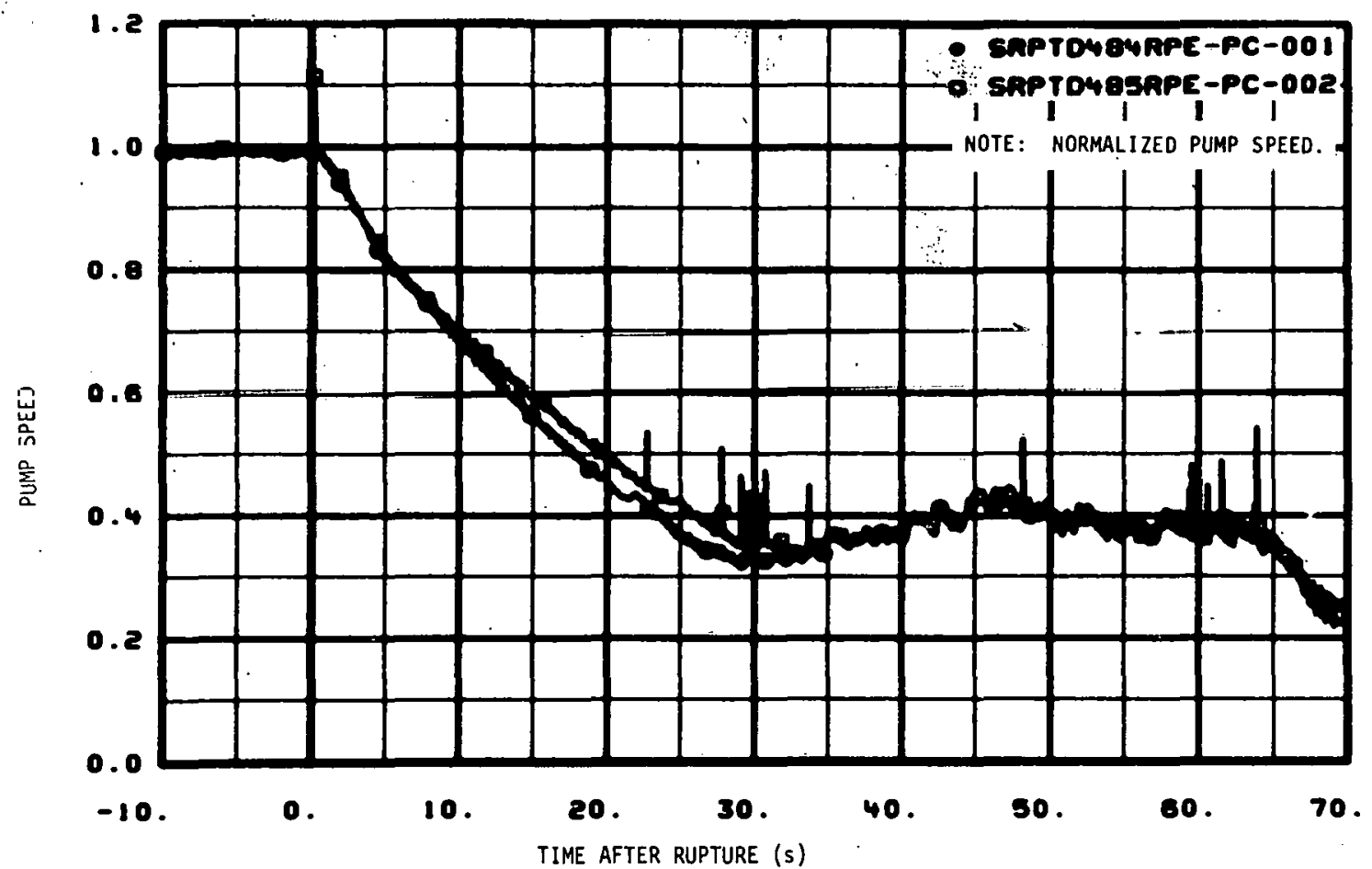

Fig. 105 Pump speed (normalized) for intact loop pumps 1 and 2 (RPE-PC-1 and -2 ). 


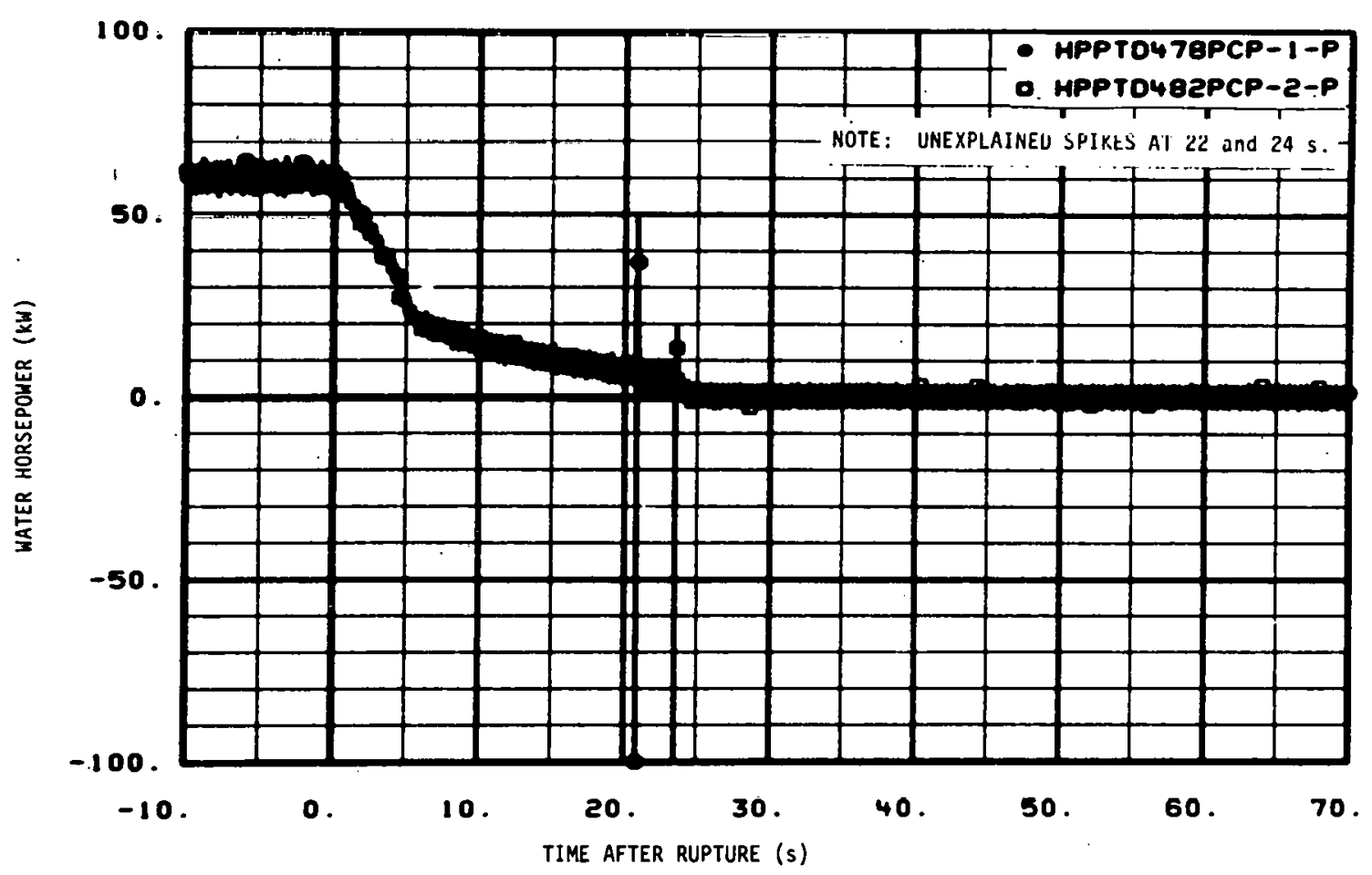

Fig. 106 Pump power for intact loop pumps 1 and 2 (PCP-1-P and PCP-2-P).

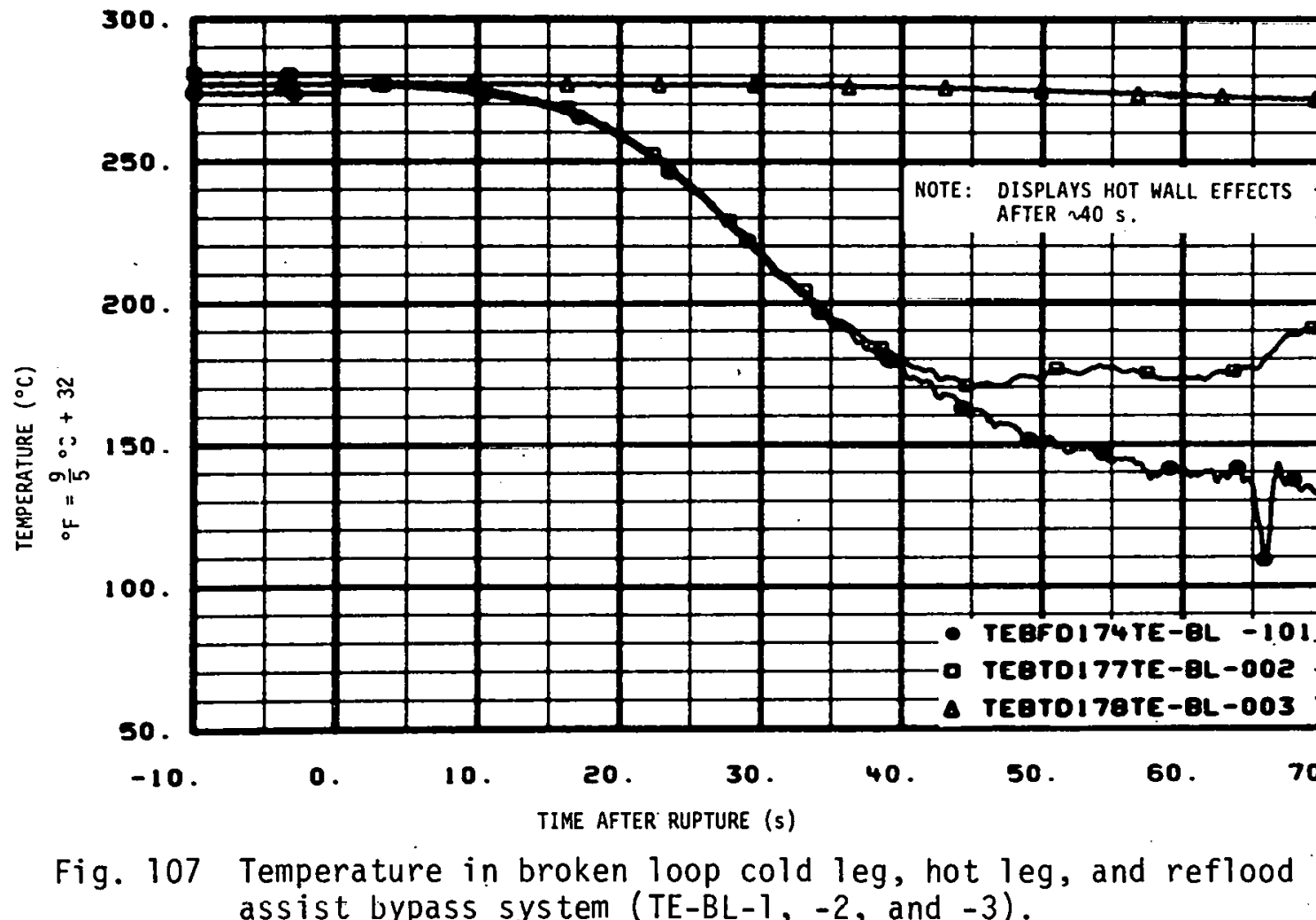




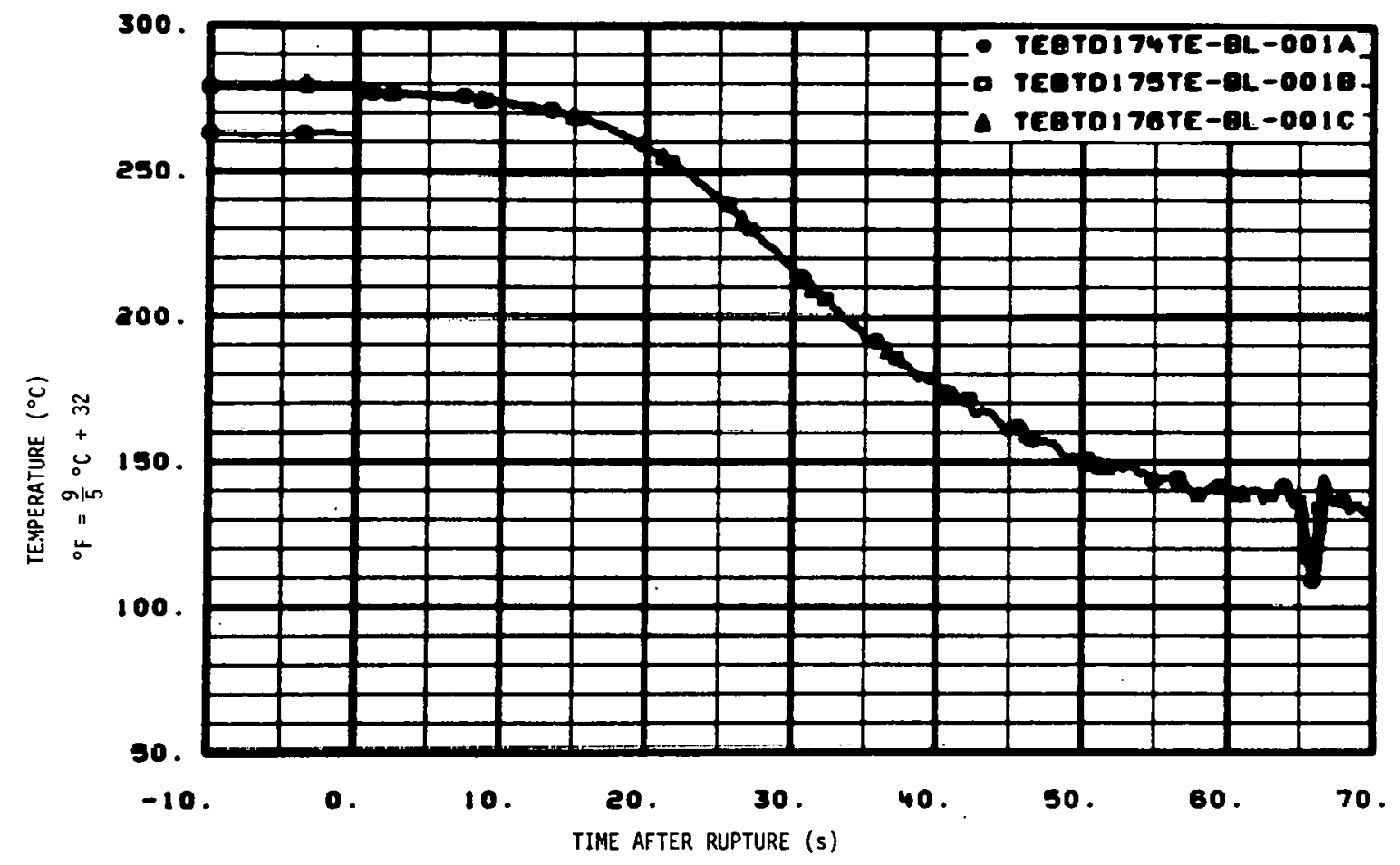

Fig. 108 Temperature in broken loop cold leg bottom, middle, and top at DTT flange (TE-BL-1A, $-1 B$, and $-1 C$ ).

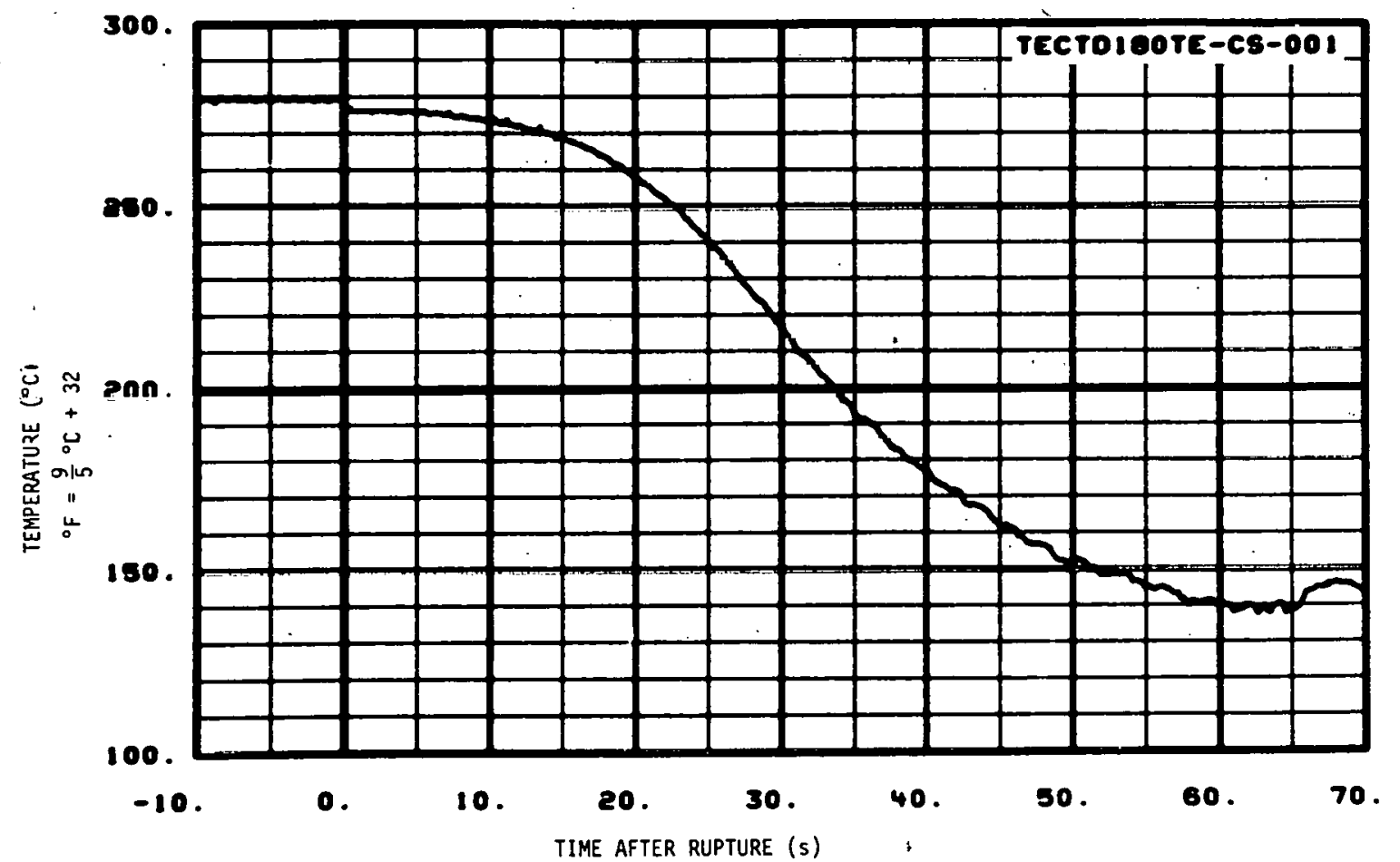

Fig. 109 Temperature in reactor vessel core simulator instrument stalk (TE-CS-1). 


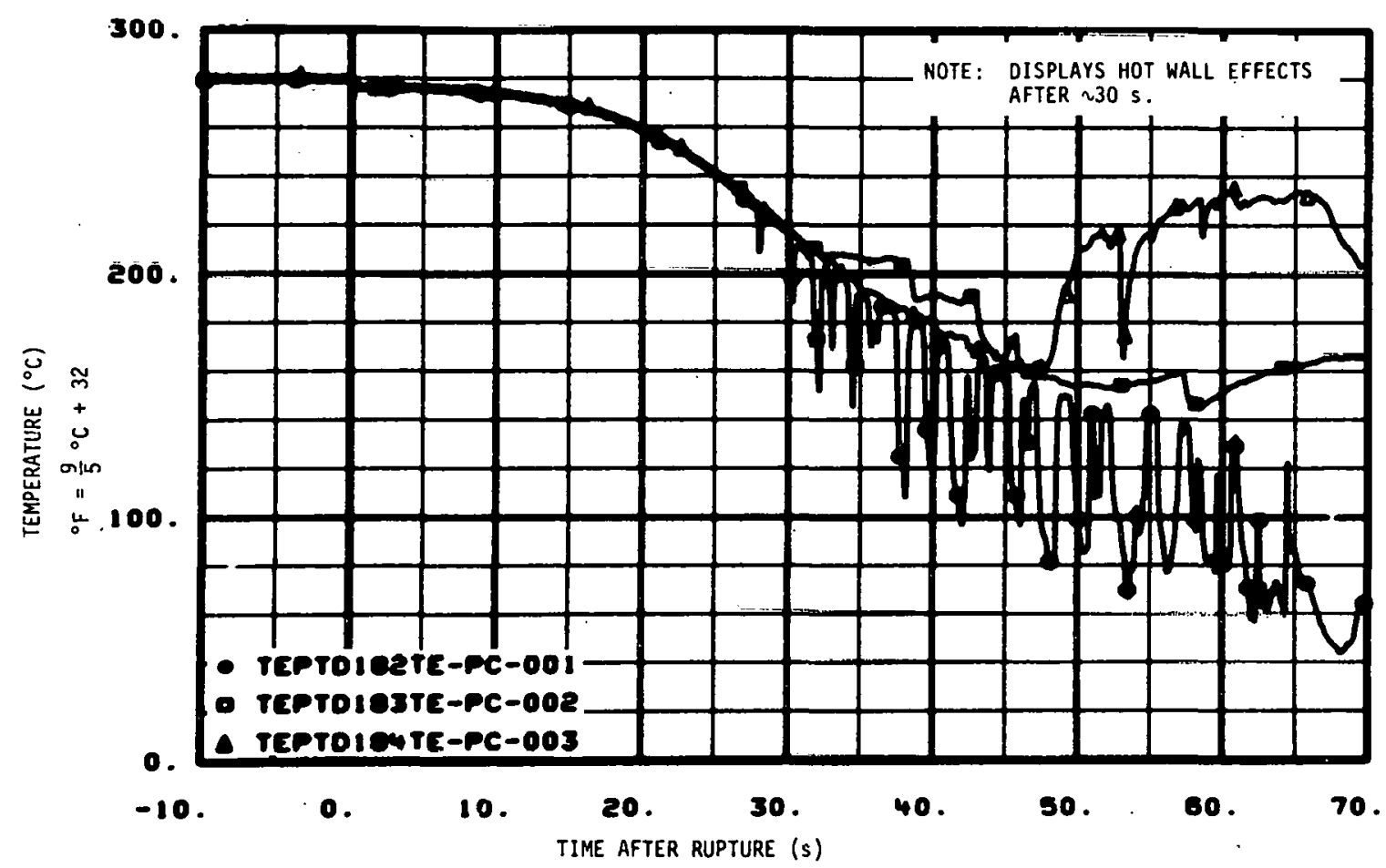

Fig. 110 Temperature in intact loop cold leg, hot leg, and steam genera tor outlet (TE-PC-1, -2 , and -3 ).

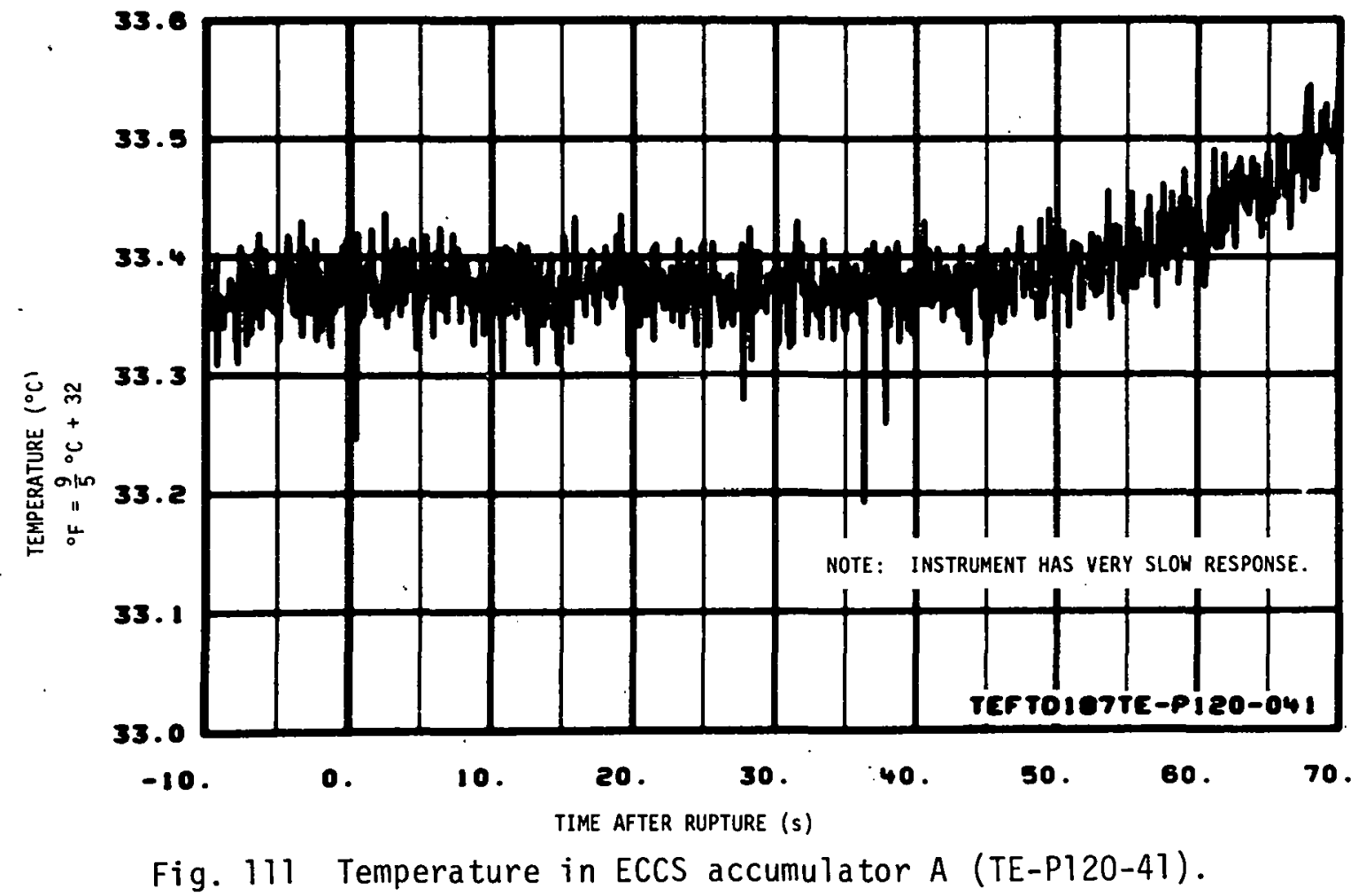




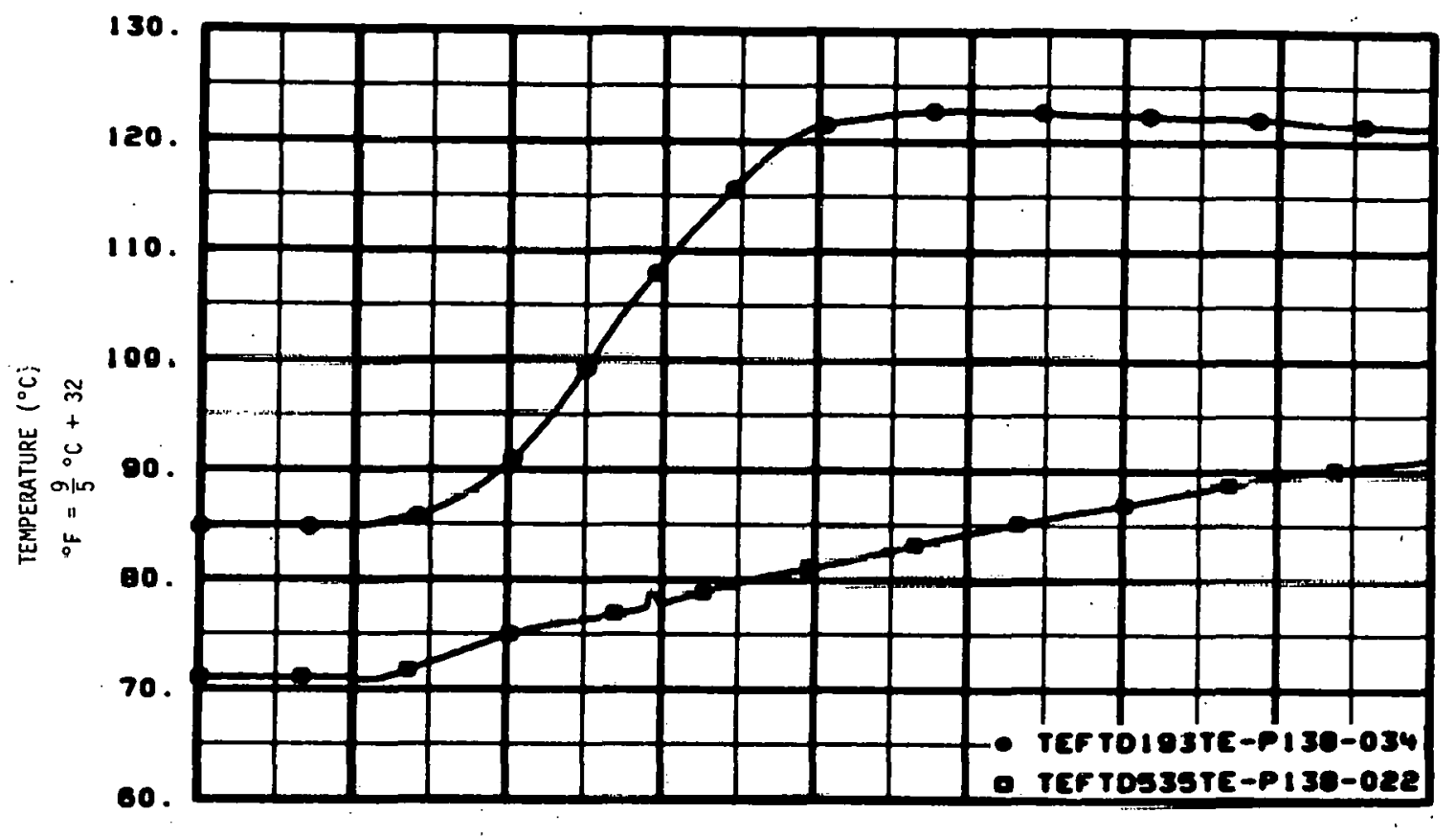

-10 . 0. 10. 20. 30. 40. 80. 60. 70. TIME AFTER RUPTURE ( 5 )

Fig. 112 Temperature in blowdown suppression tank liquid at tank bottom and vapor at tank top (TE-P138-22 and -34).

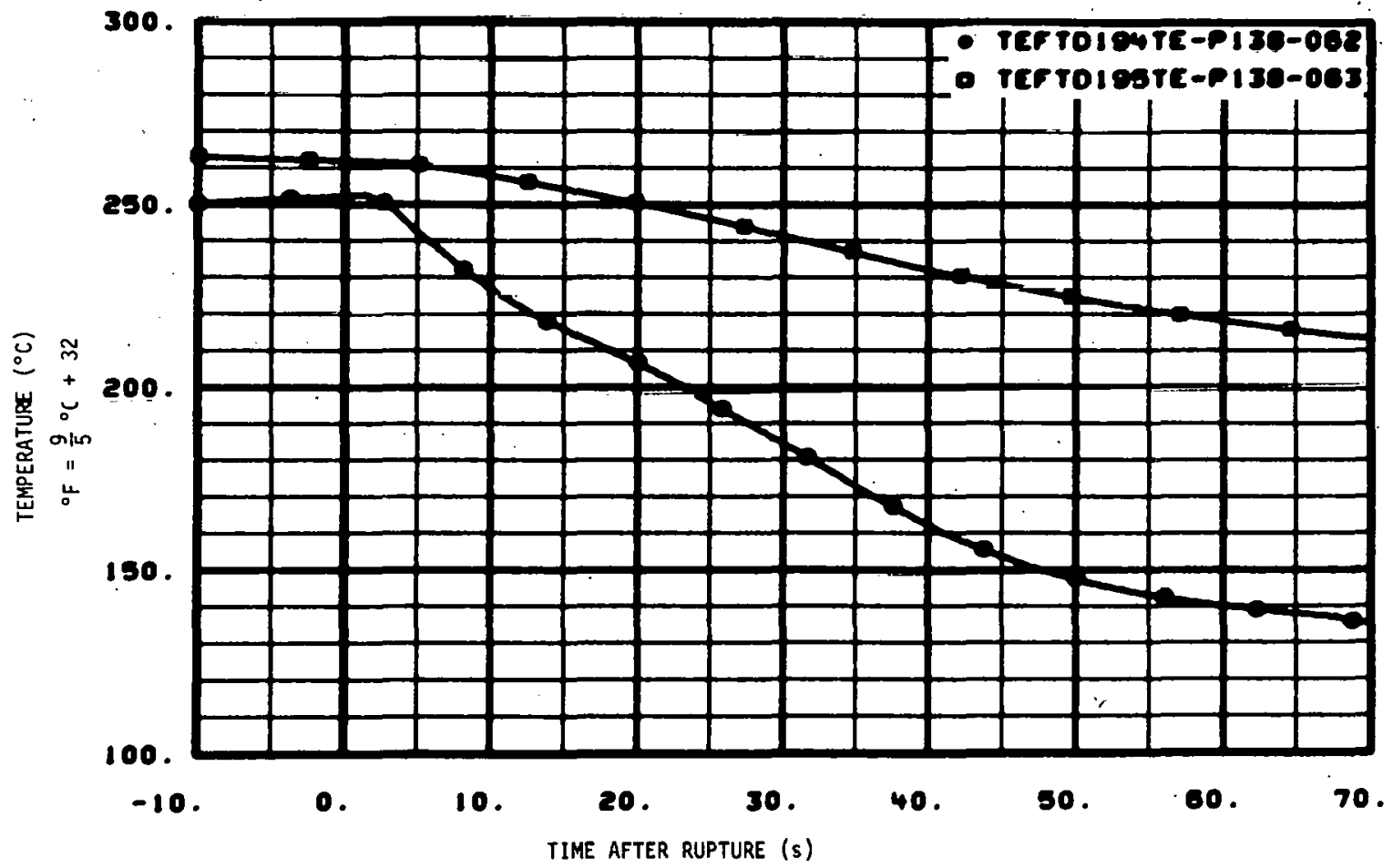

Fig. 113 Temperature in broken loop cold leg Q0BV inlet and isolation valve inlet (TE-P138-62 and -63 ). 


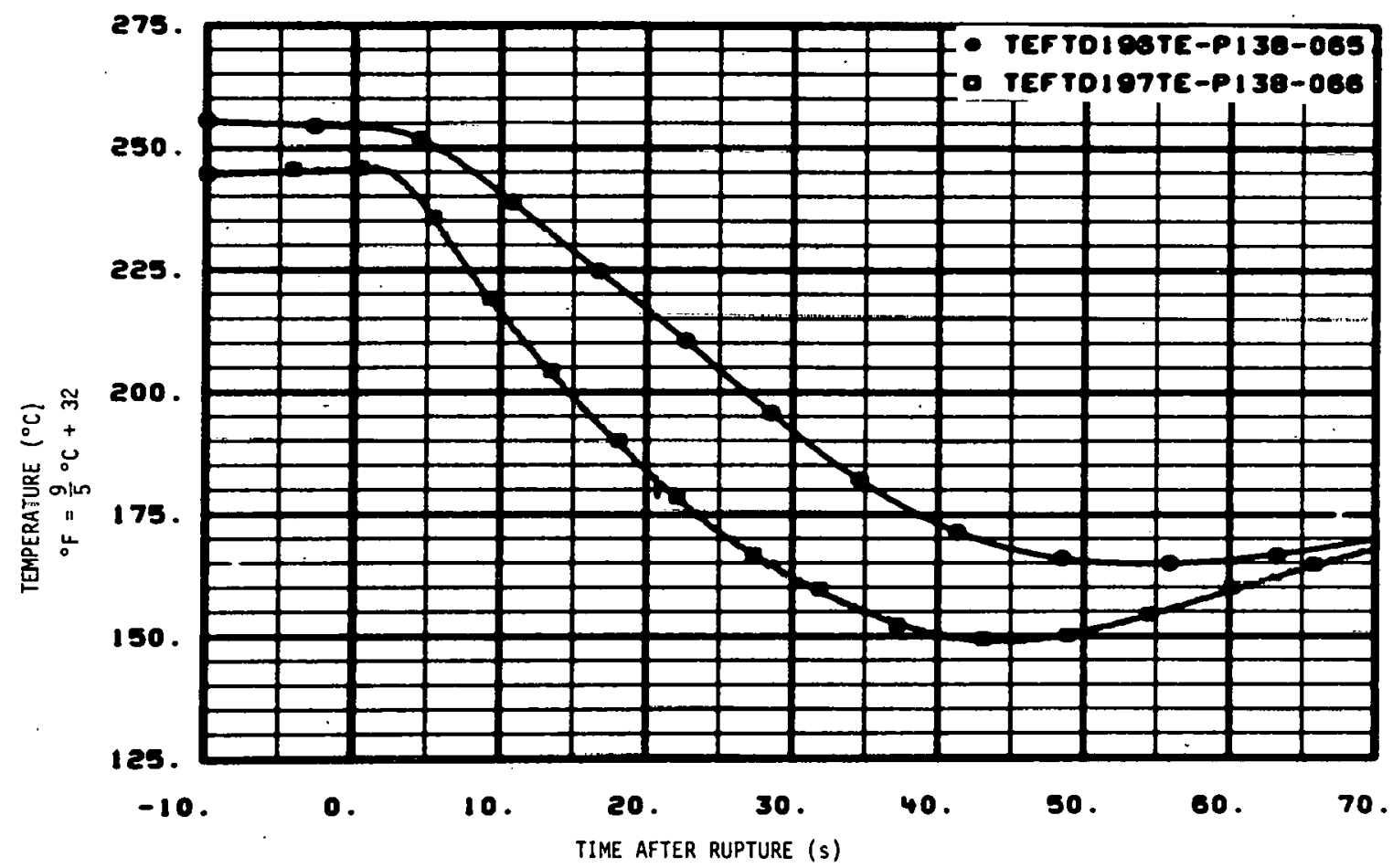

Fig. 114 Temperature in broken loop hot leg QOBV inlet and isolation valve inlet (TE-P138-66 and -65$)$.

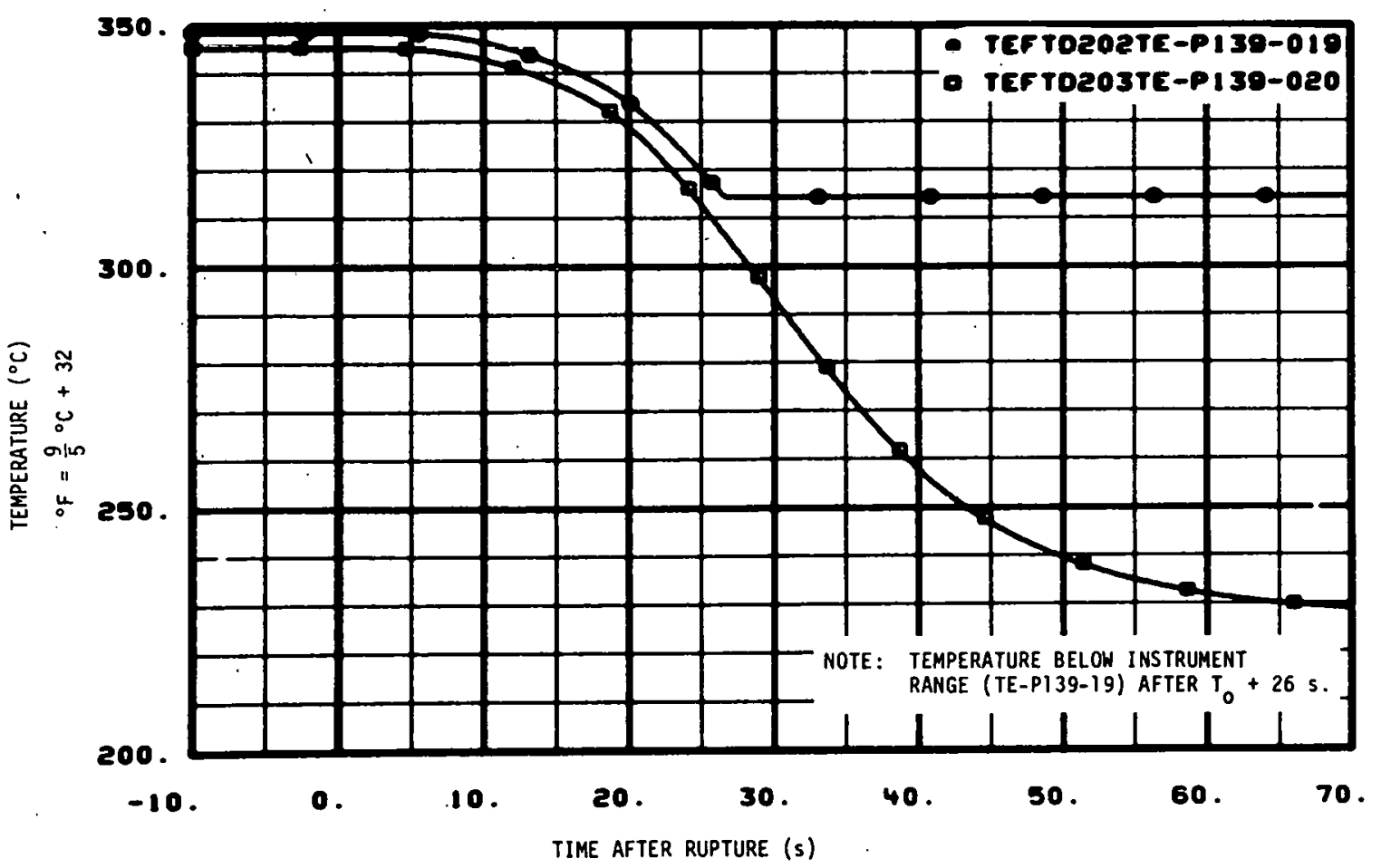

Fig. 115 Temperature in intact loop pressurizer vapor and liquid (TE-PI39-19 and -20 ). 


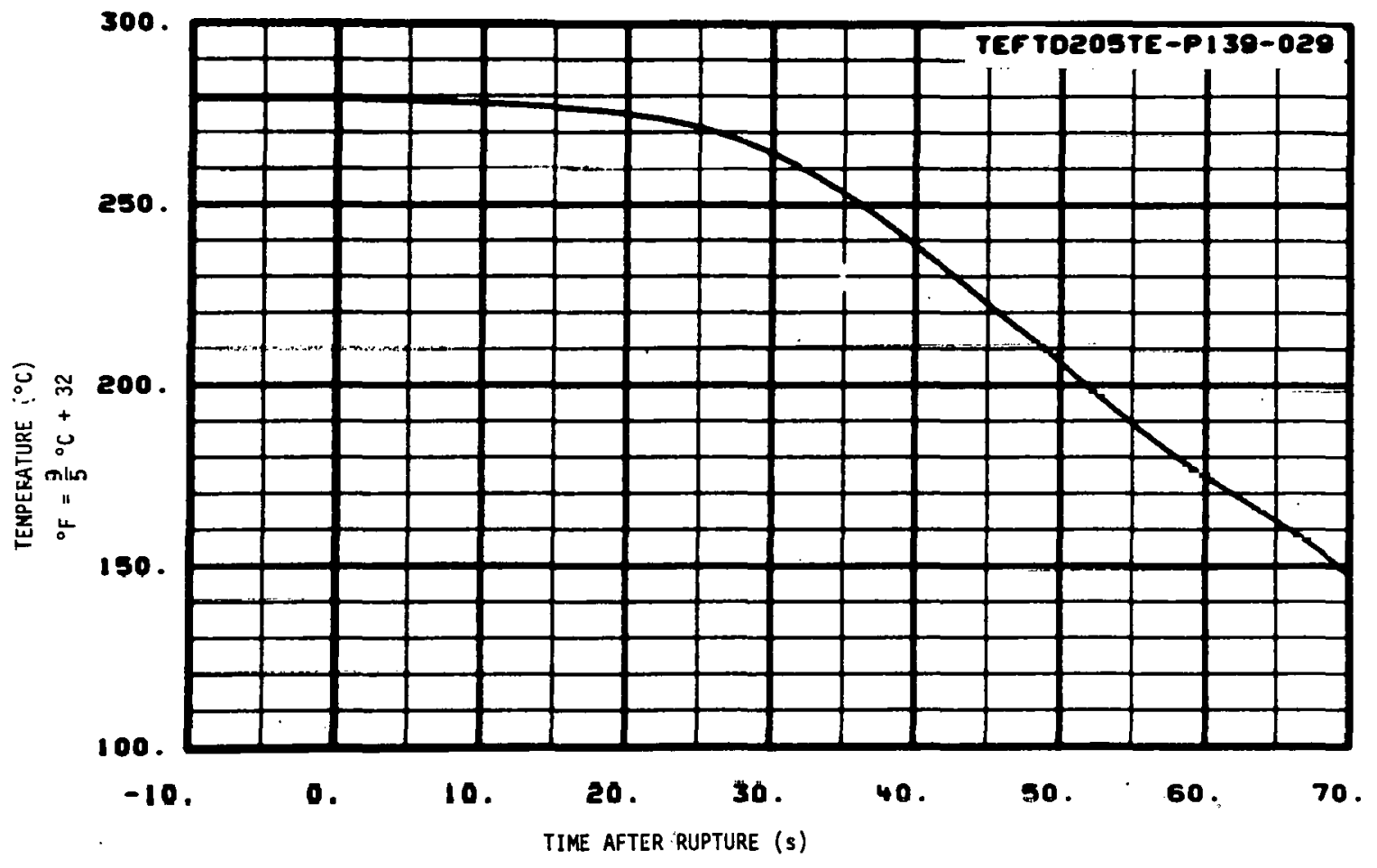

Fig. 116 Temperature in intact loop cold leg upstream of DTT flange (TE-P139-29).

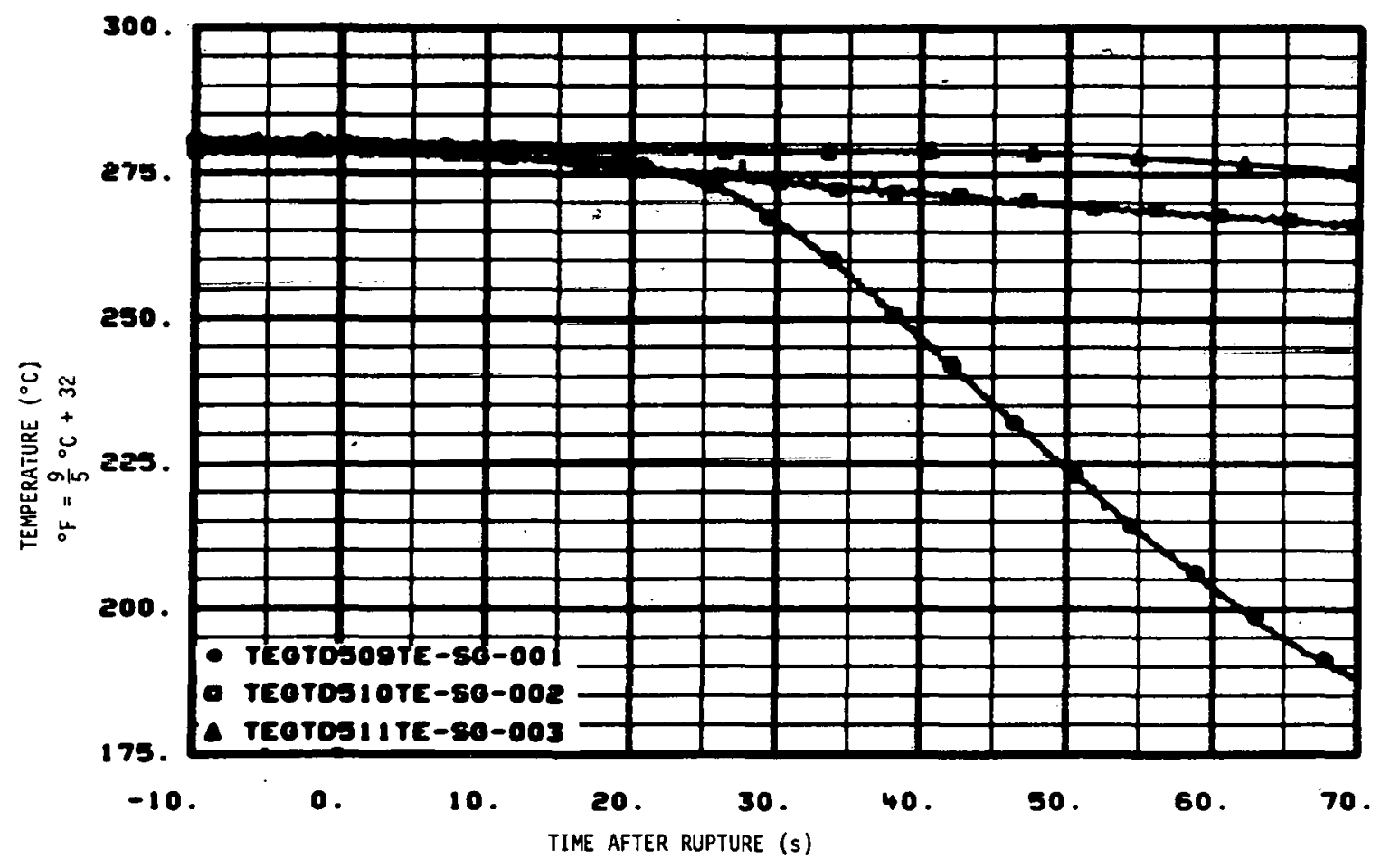

Fig. 117 Temperature in steam generator intact loop cold leg, hot leg, and secondary side (TE-SG-1, -2 , and -3 ). 


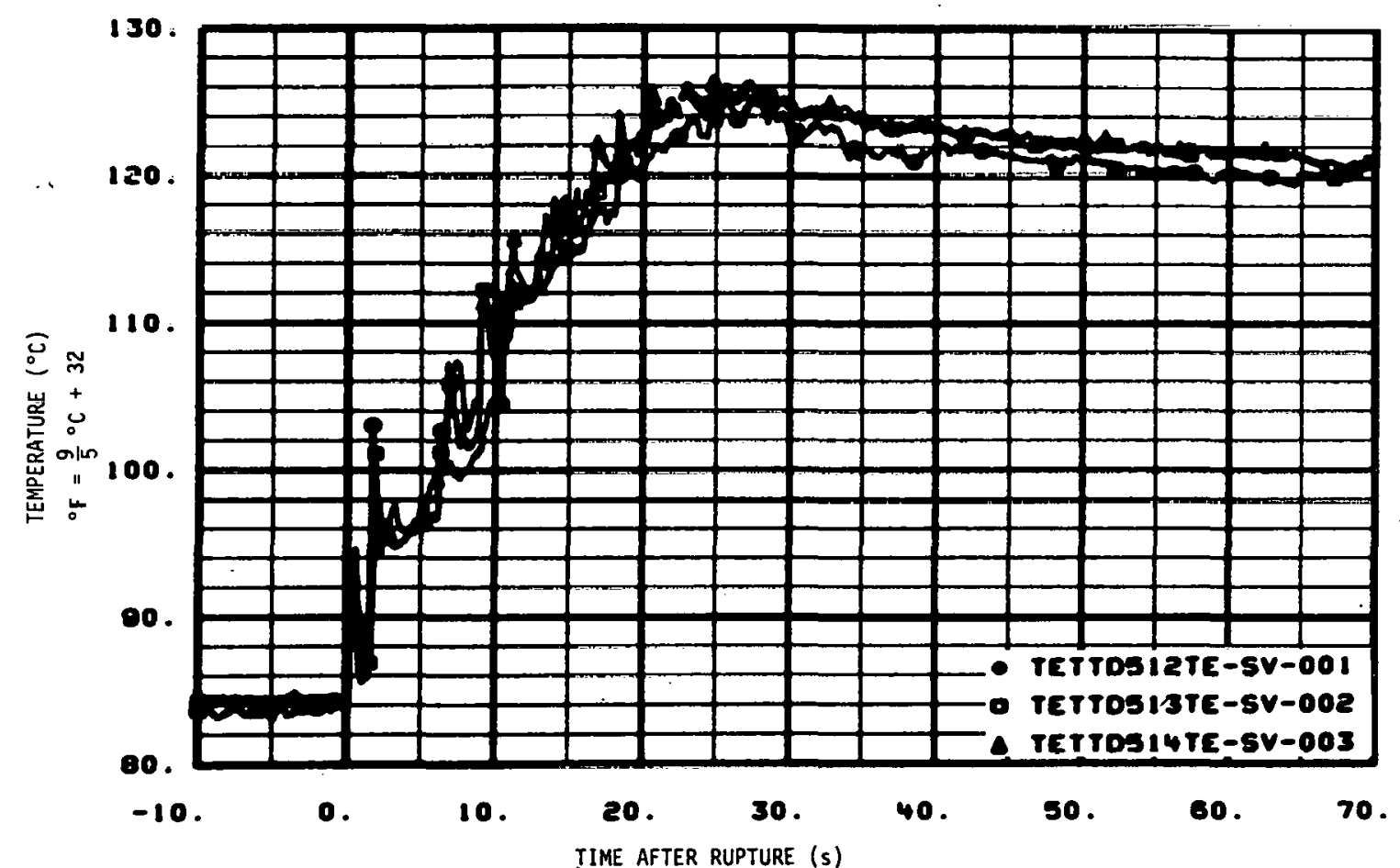

Fig. 118 Temperature in blowdown suppression tank B-end thermocouple stalk (TE-SV-1, -2 , and -3 ).

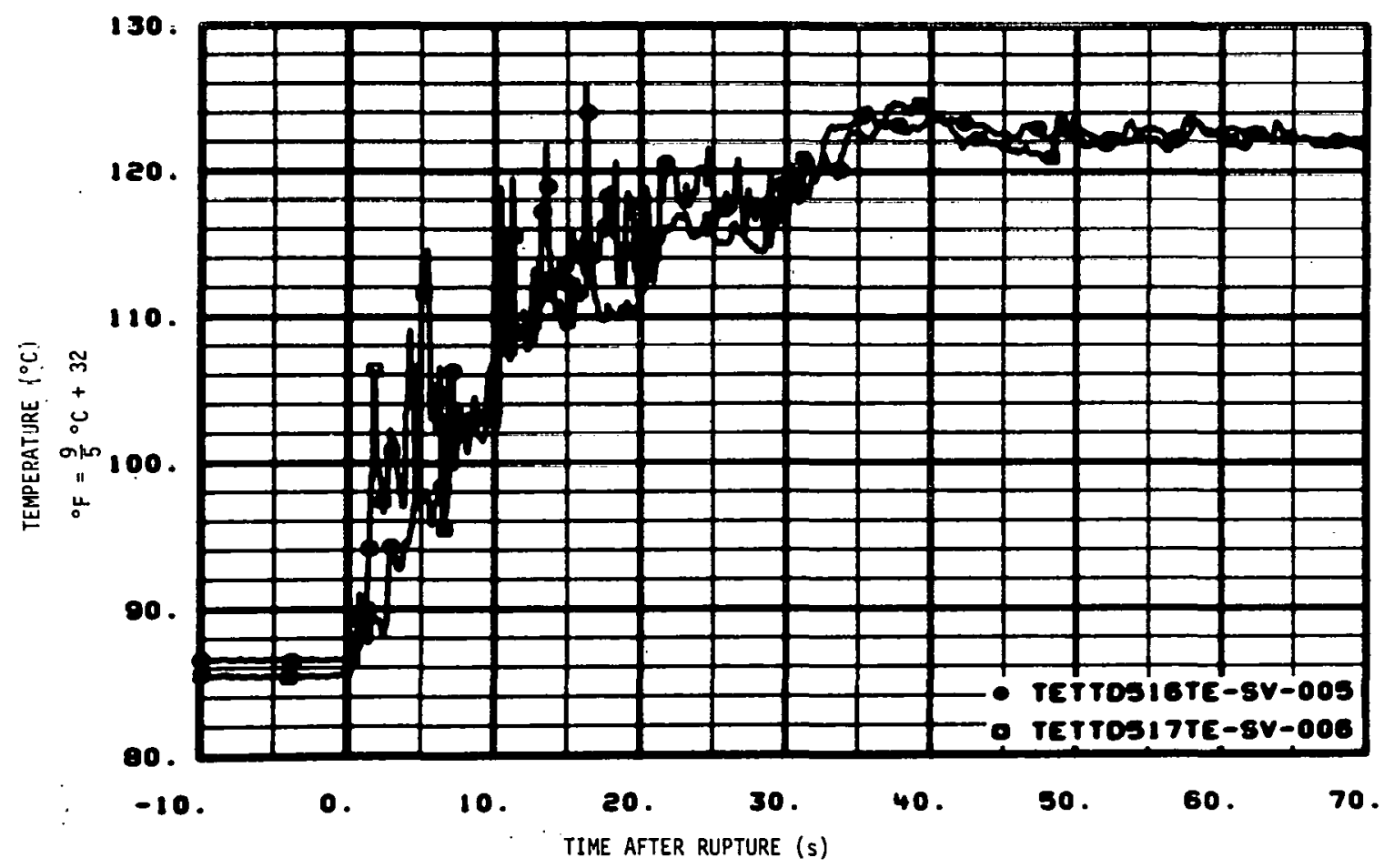

Fig. 119 Temperature in blowdown suppression tank B-end thermocouple staik (TE-SV-5 and -6 ). 


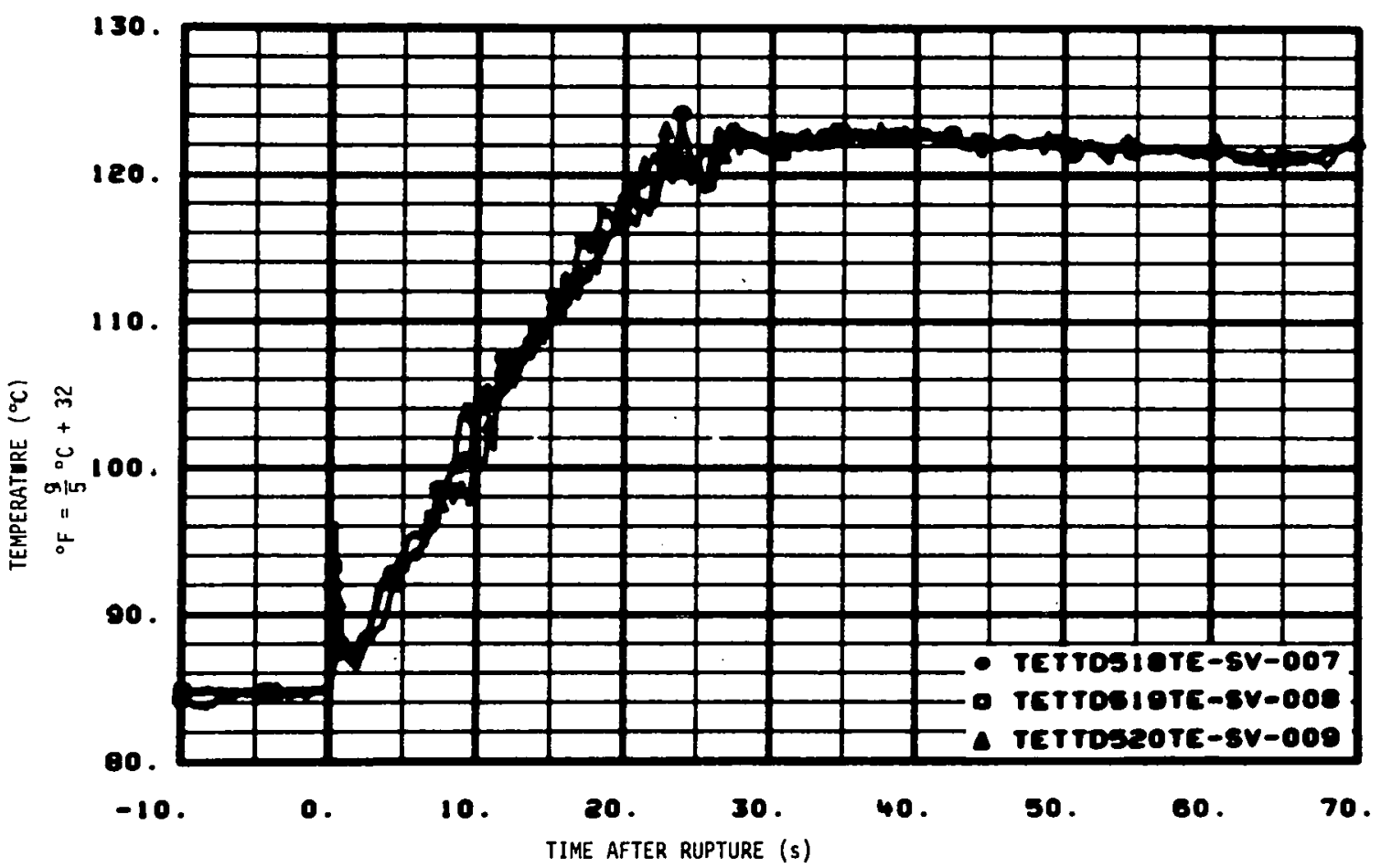

Fig. 120 Temperature in blowdown suppression tank A-end thermocouple stalk (TE-SV-7, -8 , and -9 ).

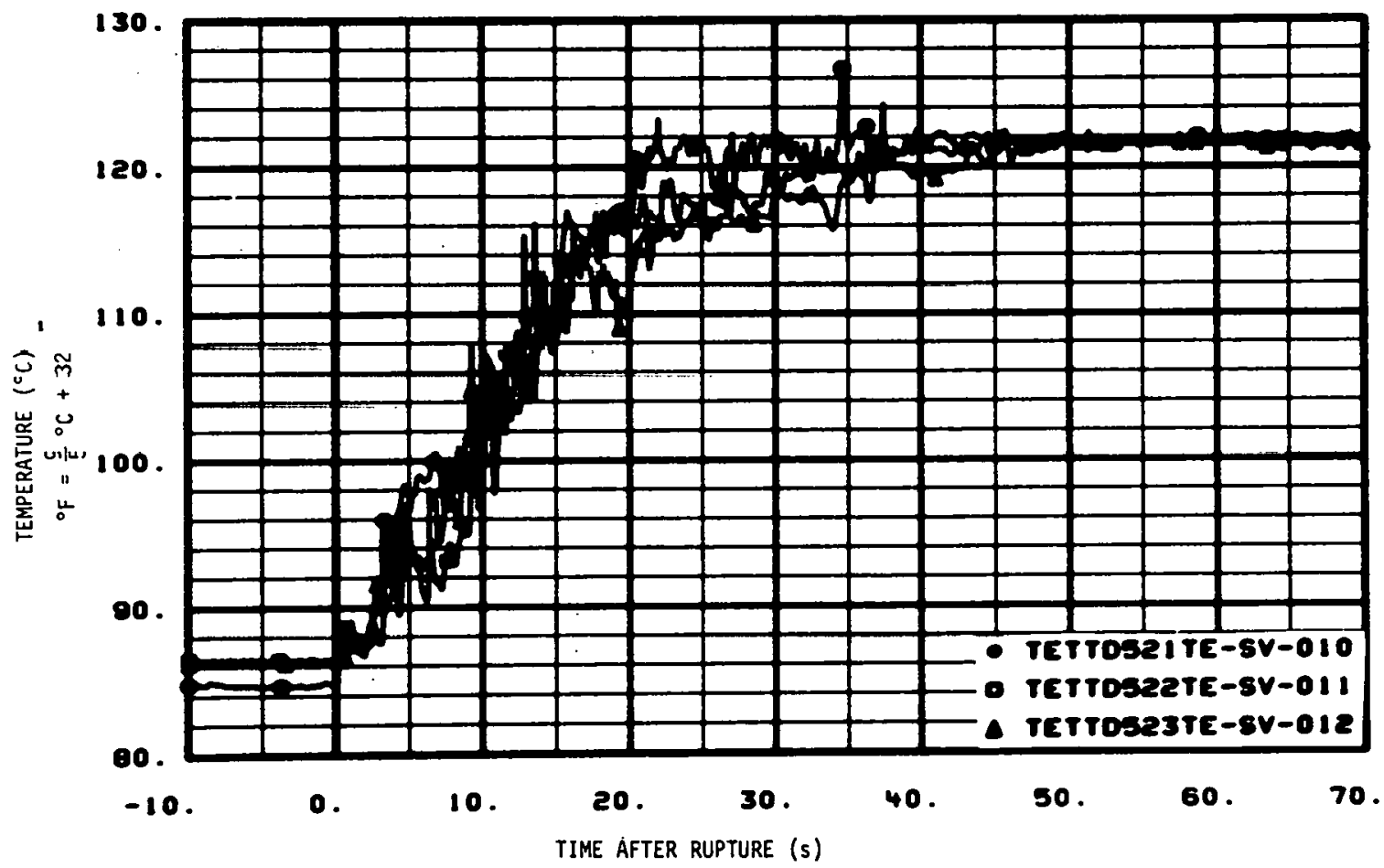

Fig. 121 Temperature in blowdown suppression tank A-end thermocouple stalk (TE-SV-10, -11, and -12). 


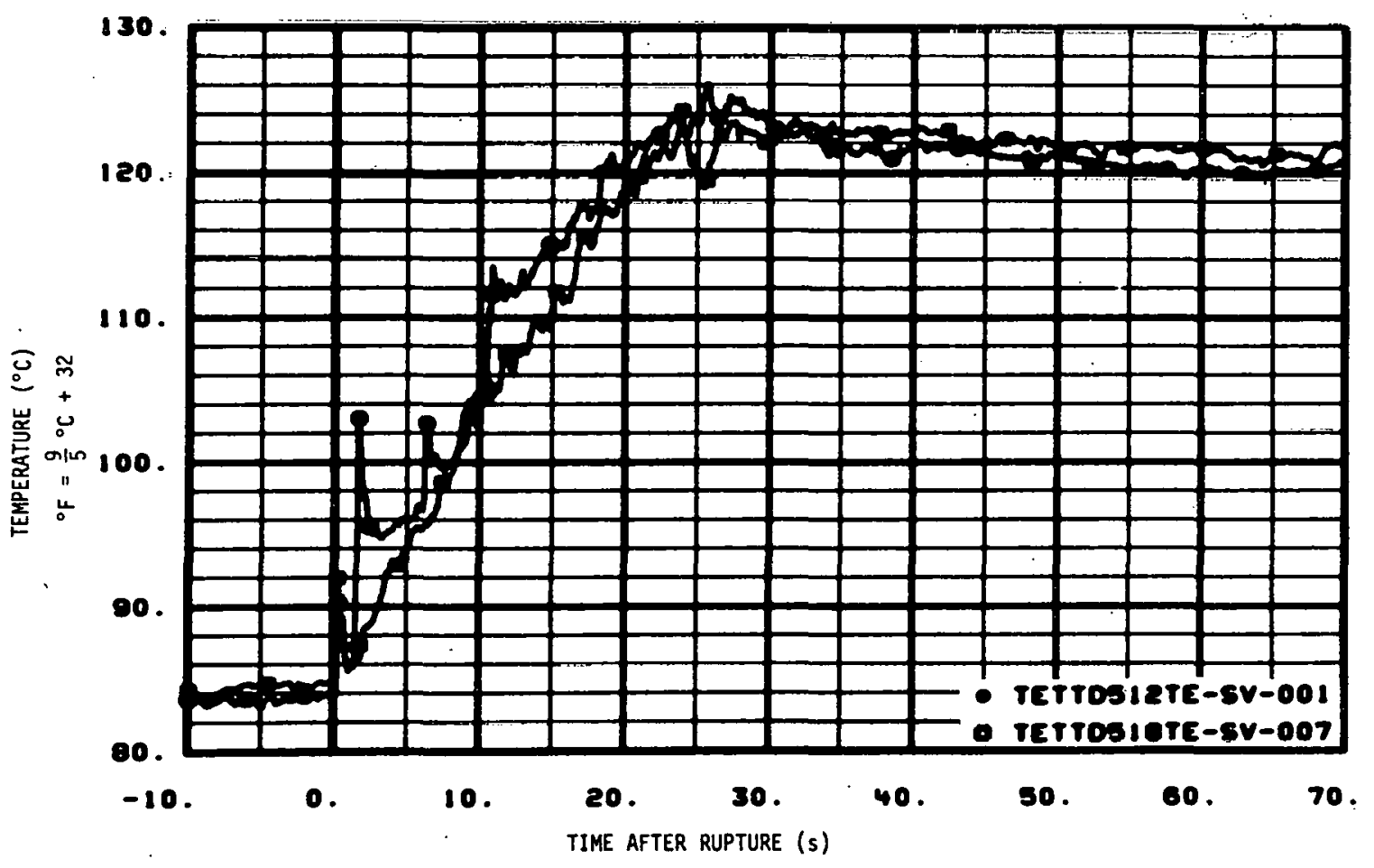

Fig. 122 Temperature in blowdown suppression tank $2.72 \mathrm{~m}$ from tank bottom (TE-SV-1 and -7).

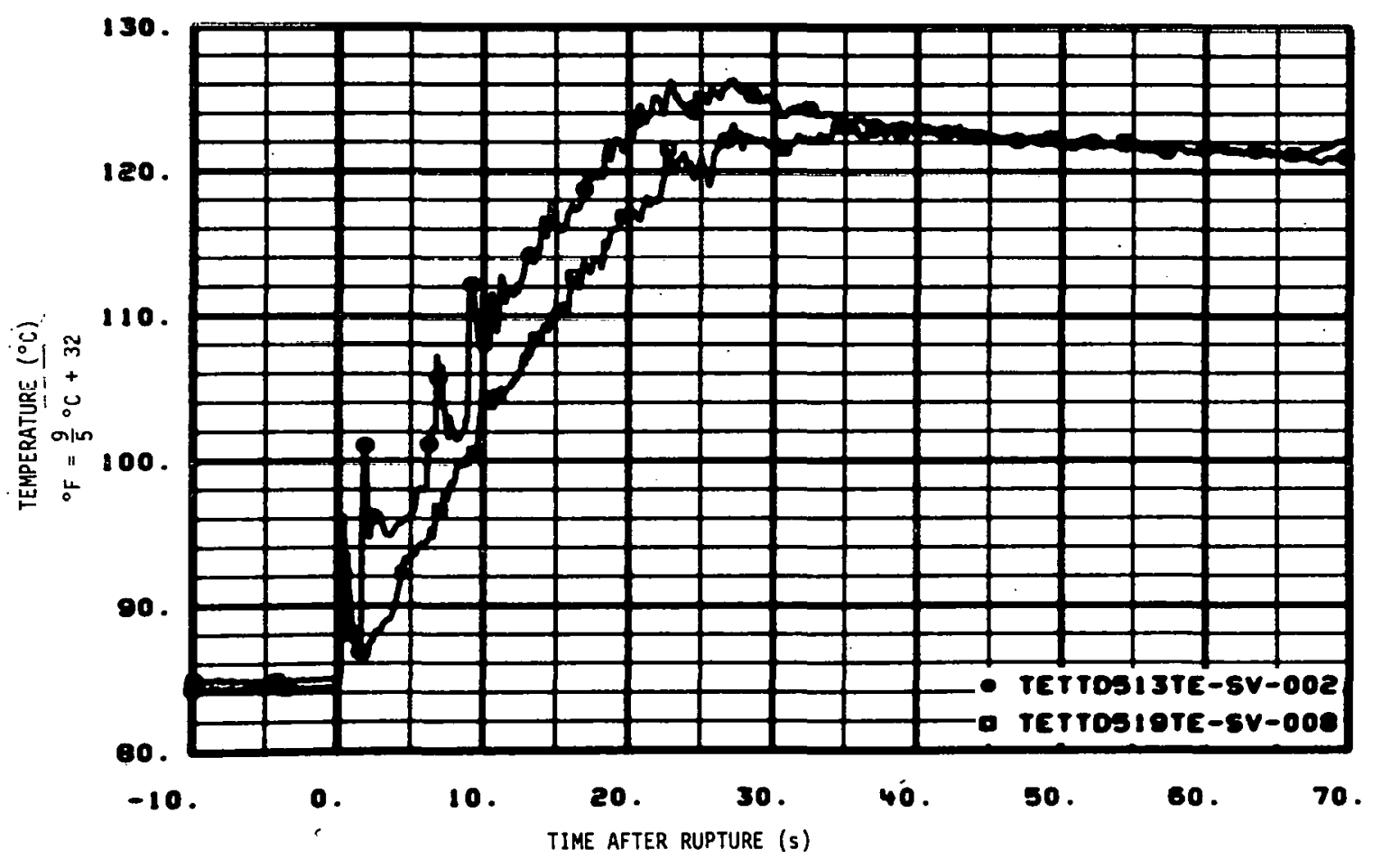

Fig. 123 Temperature in blowdown suppression tank $2.36 \mathrm{~m}$ from tank bottom (TE-SV-2 and -8 ). 


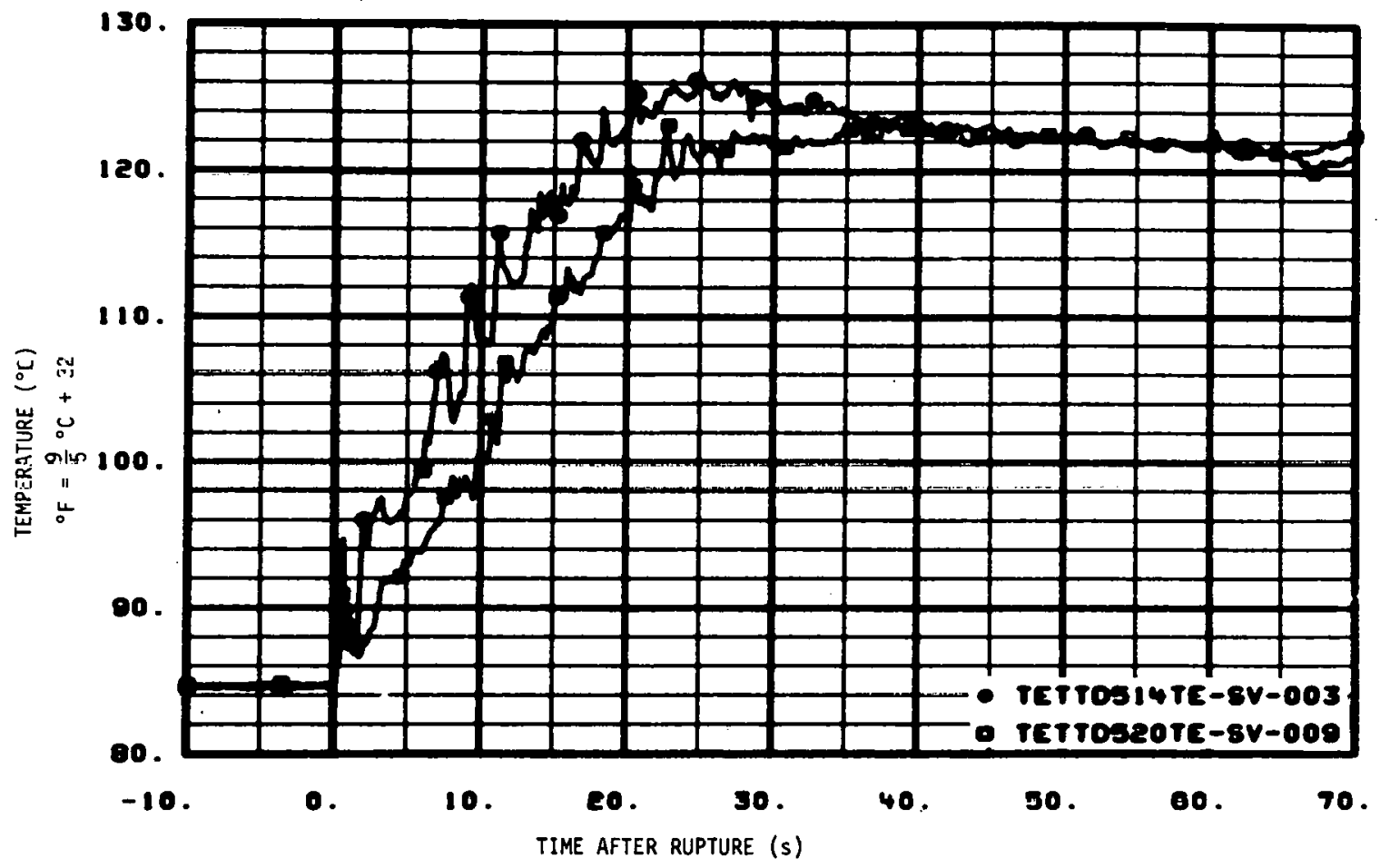

Fig. 124 Temperature in blowdown suppression tank $1.90 \mathrm{~m}$ from tank bottom (TE-SV-3 and -9 ).

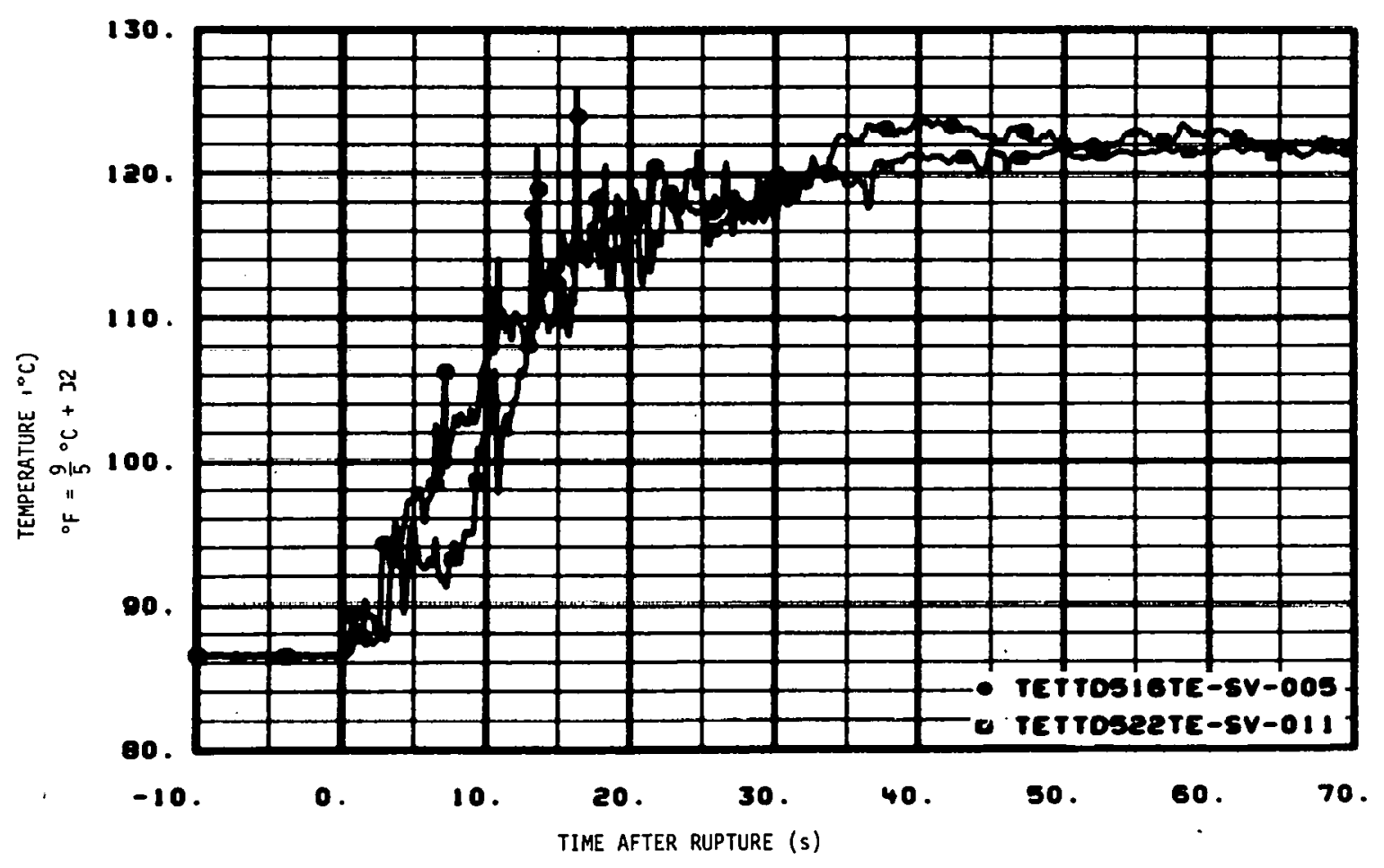

Fig. 125 Temperature in blowdown suppression tank $0.99 \mathrm{~m}$ from tank bottom (TE-SV-5 and -11). 


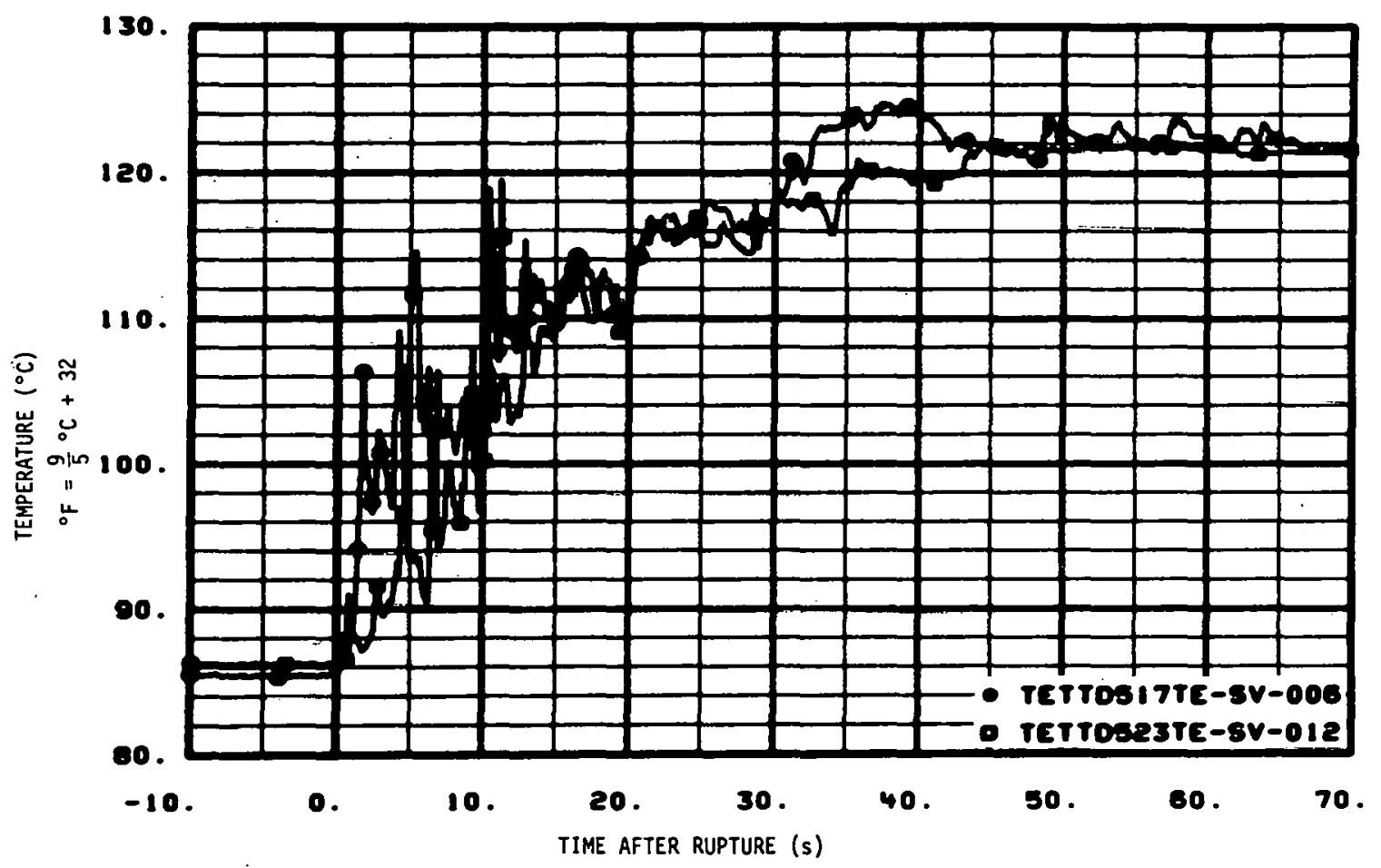

Fig. 126 Temperature in blowdown suppression tank $0.374 \mathrm{~m}$ from tank bottom (TE-SV-6 and -12).

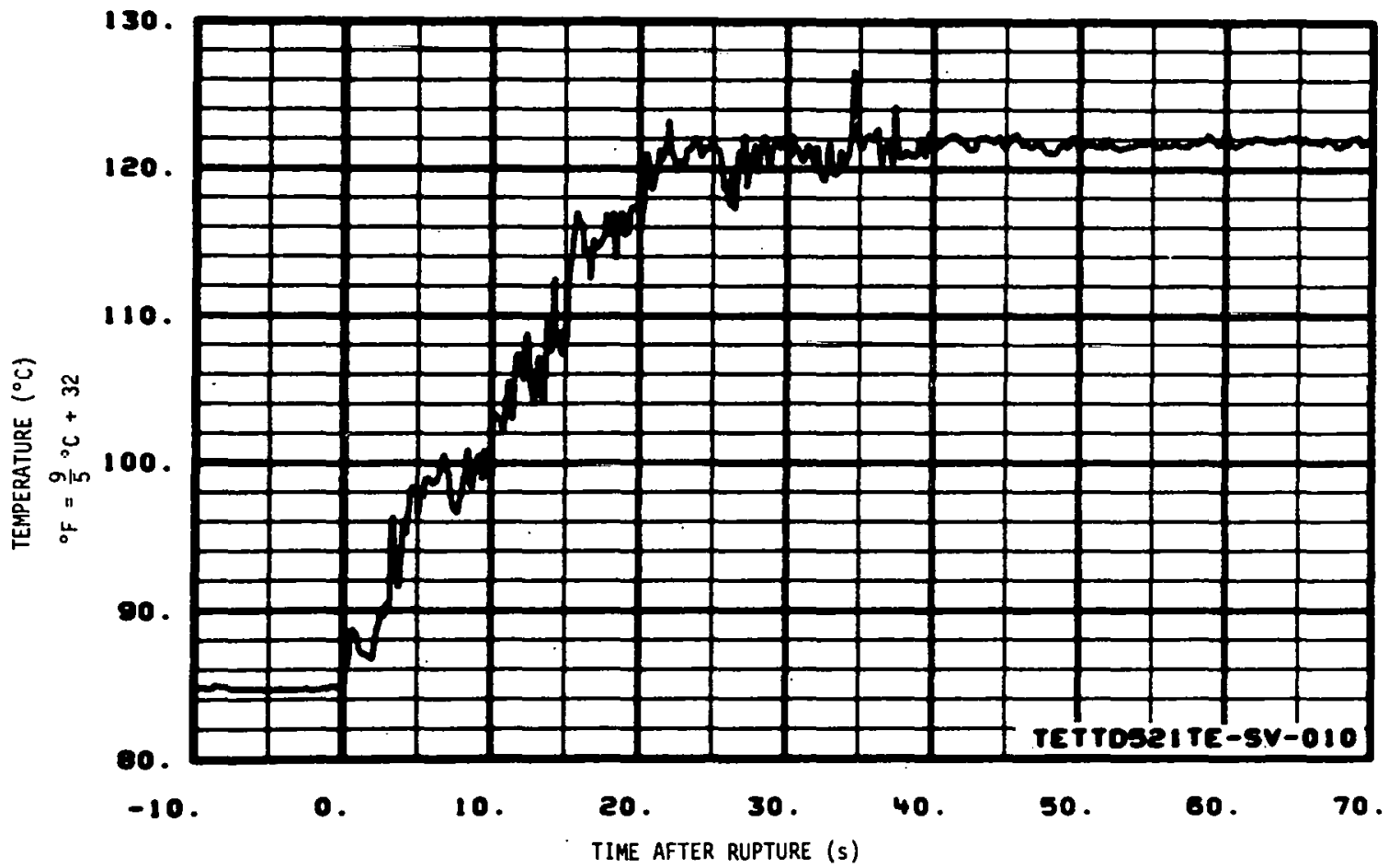

Fig. 127 Temperature in blowdown suppression tank $1.45 \mathrm{~m}$ from tank bottom (TE-SV-10). 


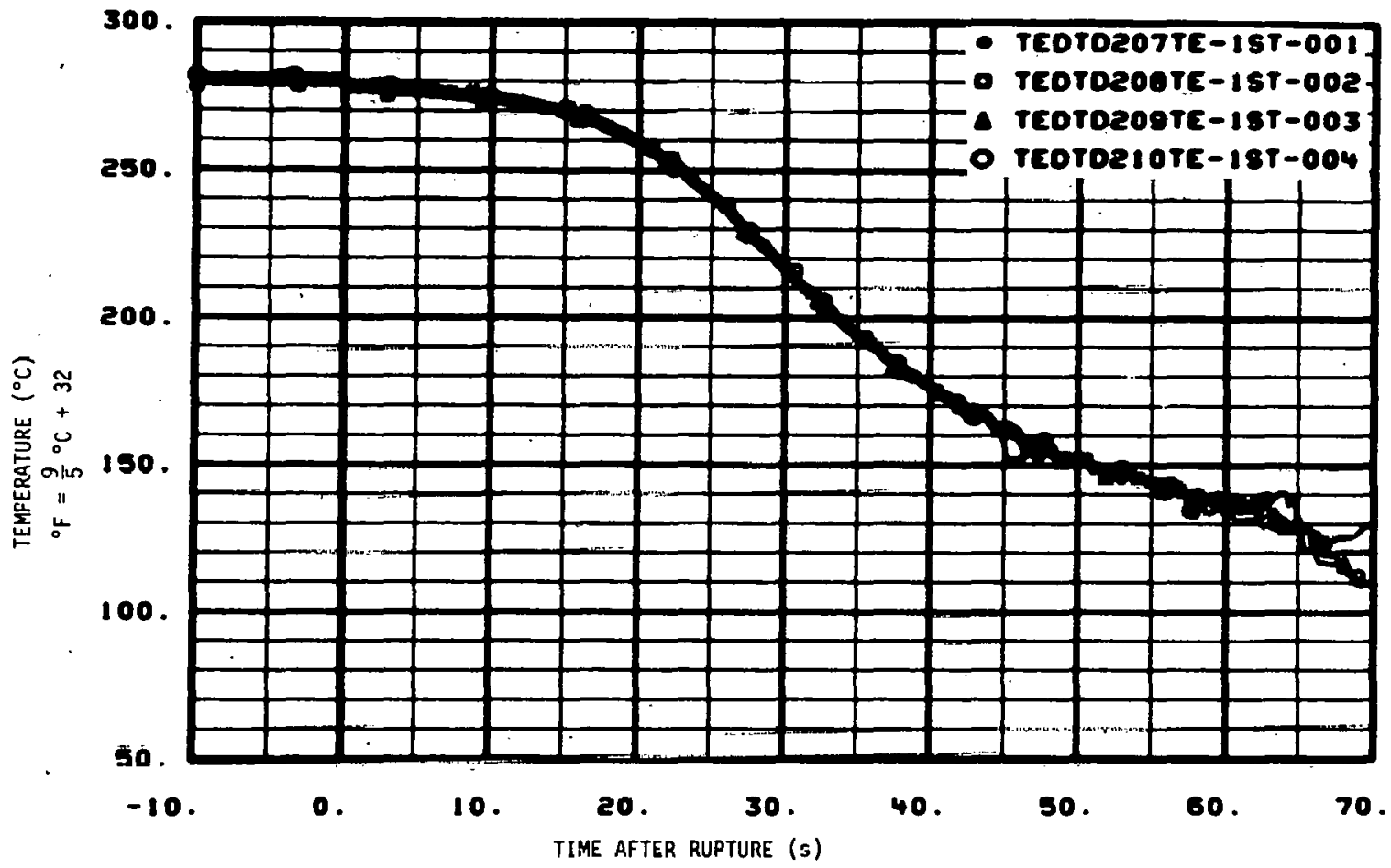

Fig. 128 Temperature in reactor vessel downcomer instrument stalk 1 (TE-IST-1, $-2,-3$, and -4 ).

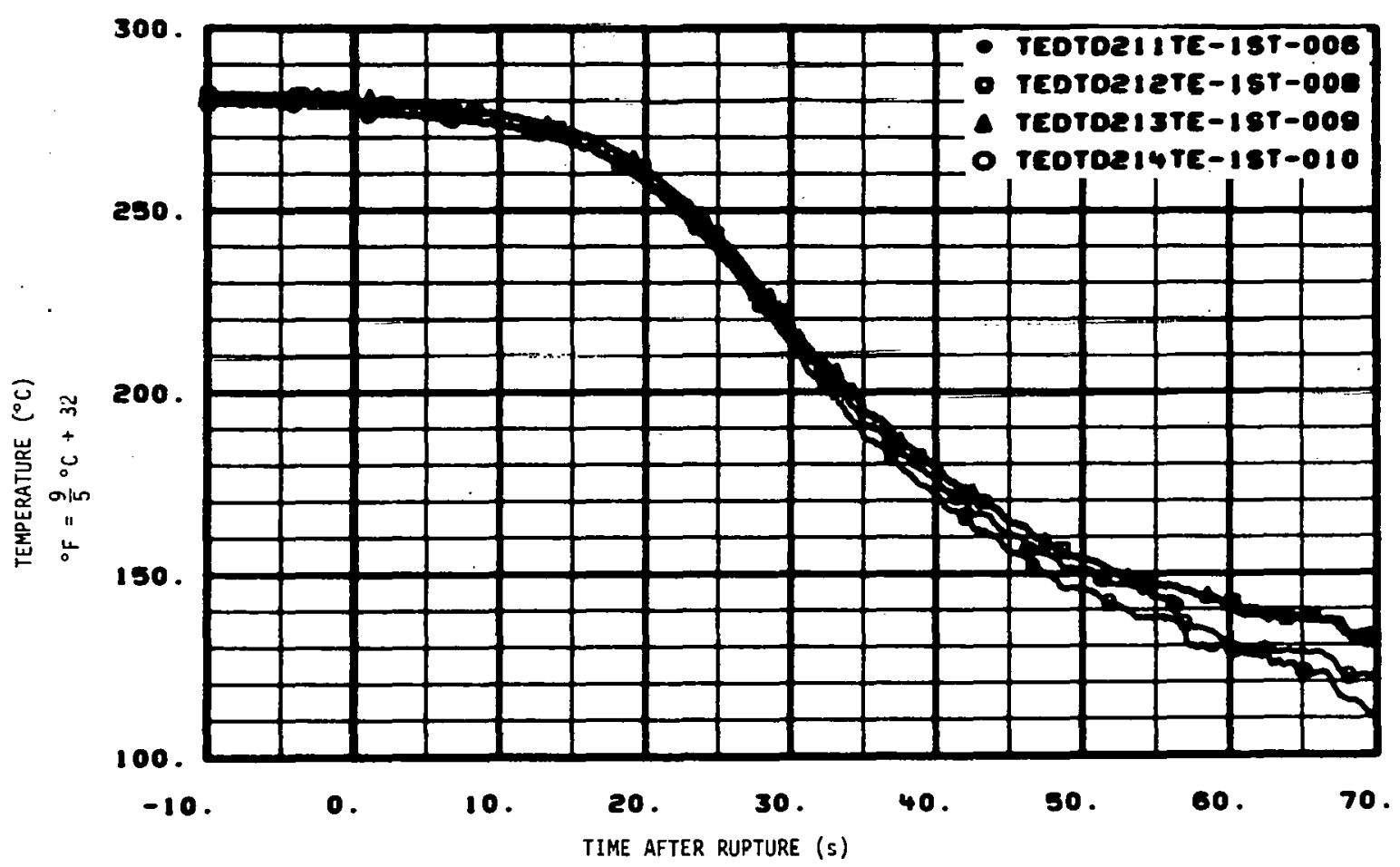

Fig. 129 Temperature in reactor vessel downcomer instrument stalk 1 $(T E-1 S T-6,-8,-9$, and -10$)$. 


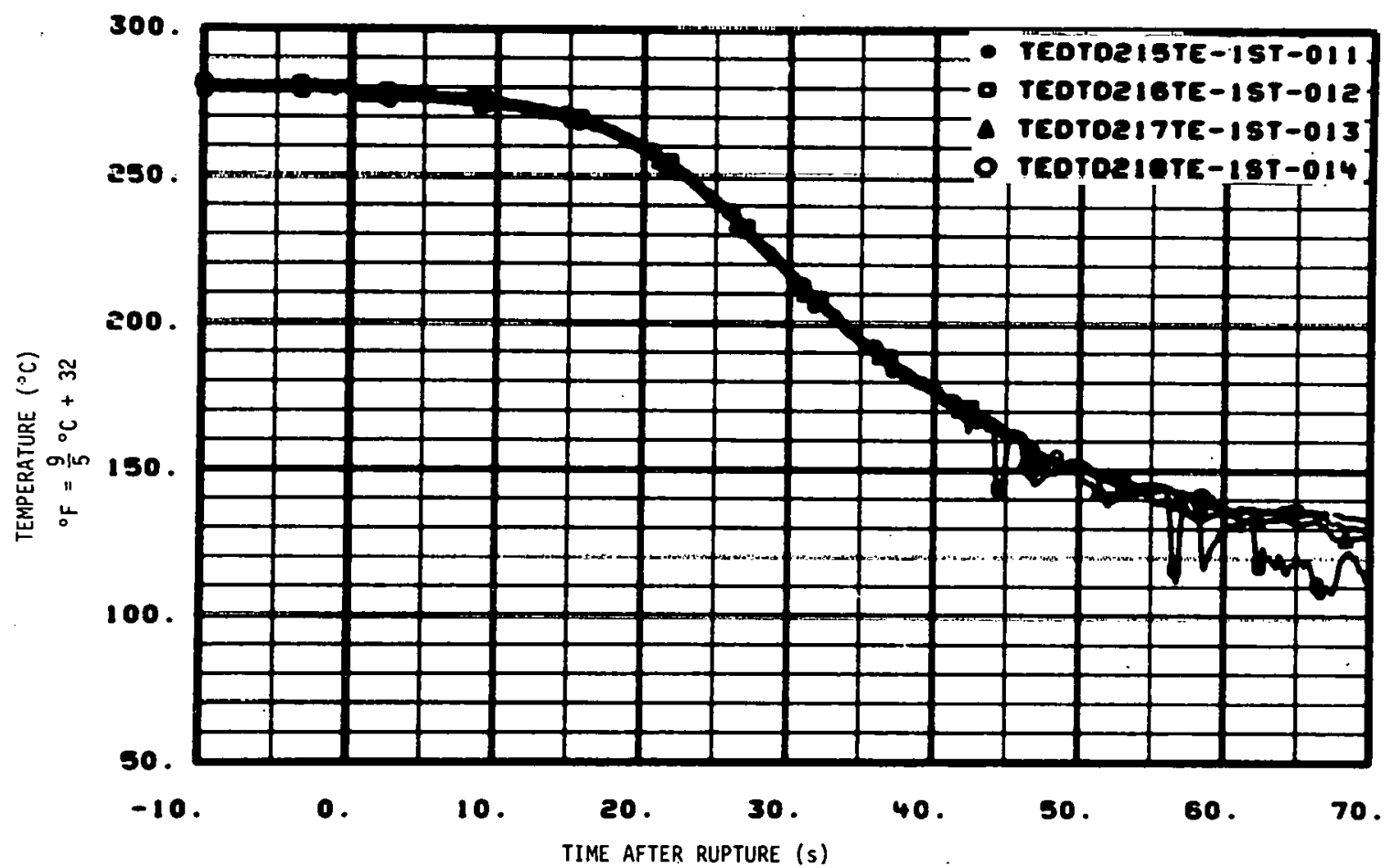

Fig. 130 Temperature in reactor vessel downcomer instrument stalk 1 (TE-1ST-11, -12, -13, and -14).

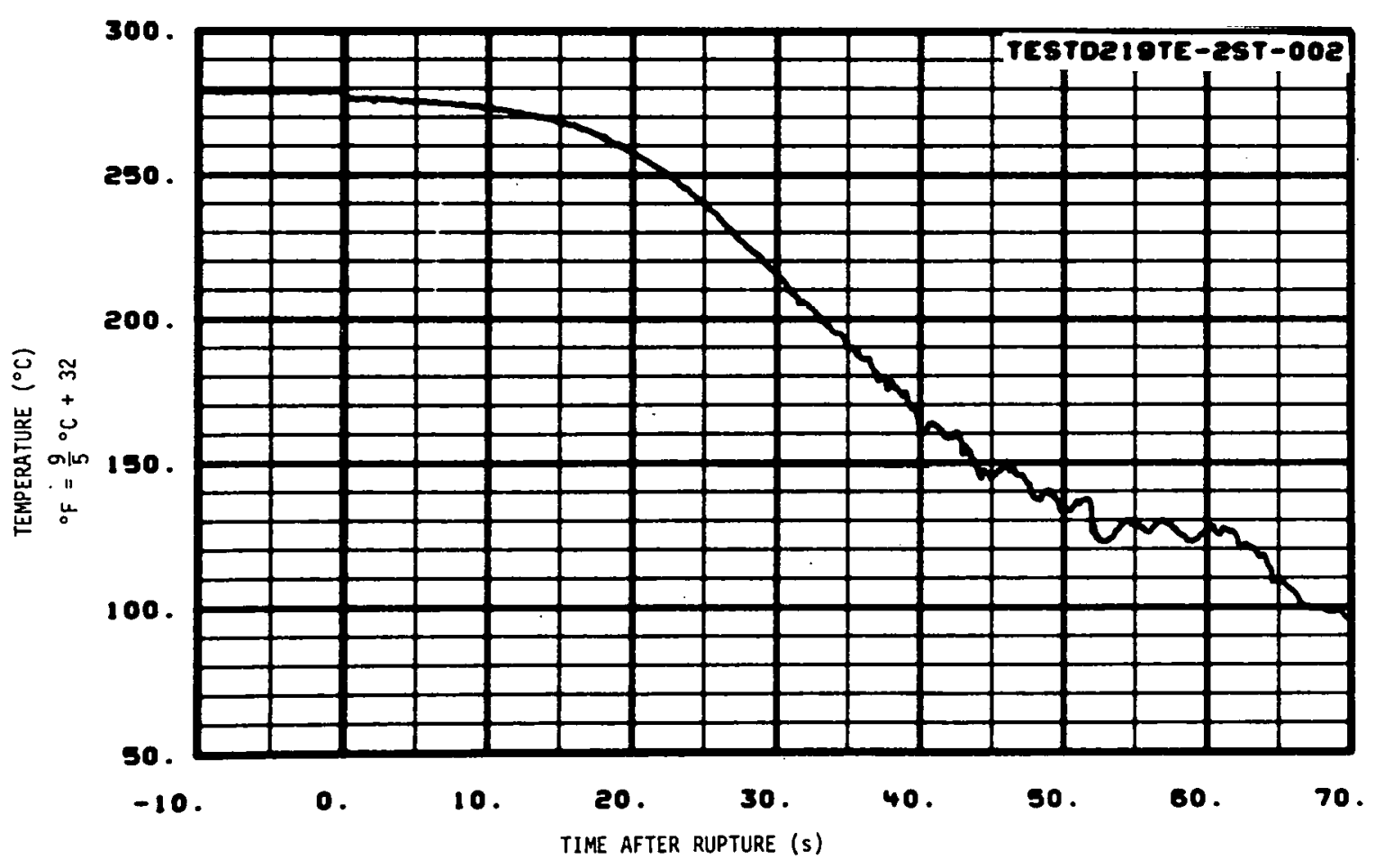

Fig. 131 Temperature in reactor vessel downcomer instrument stalk 2 (TE-2ST-2) . 


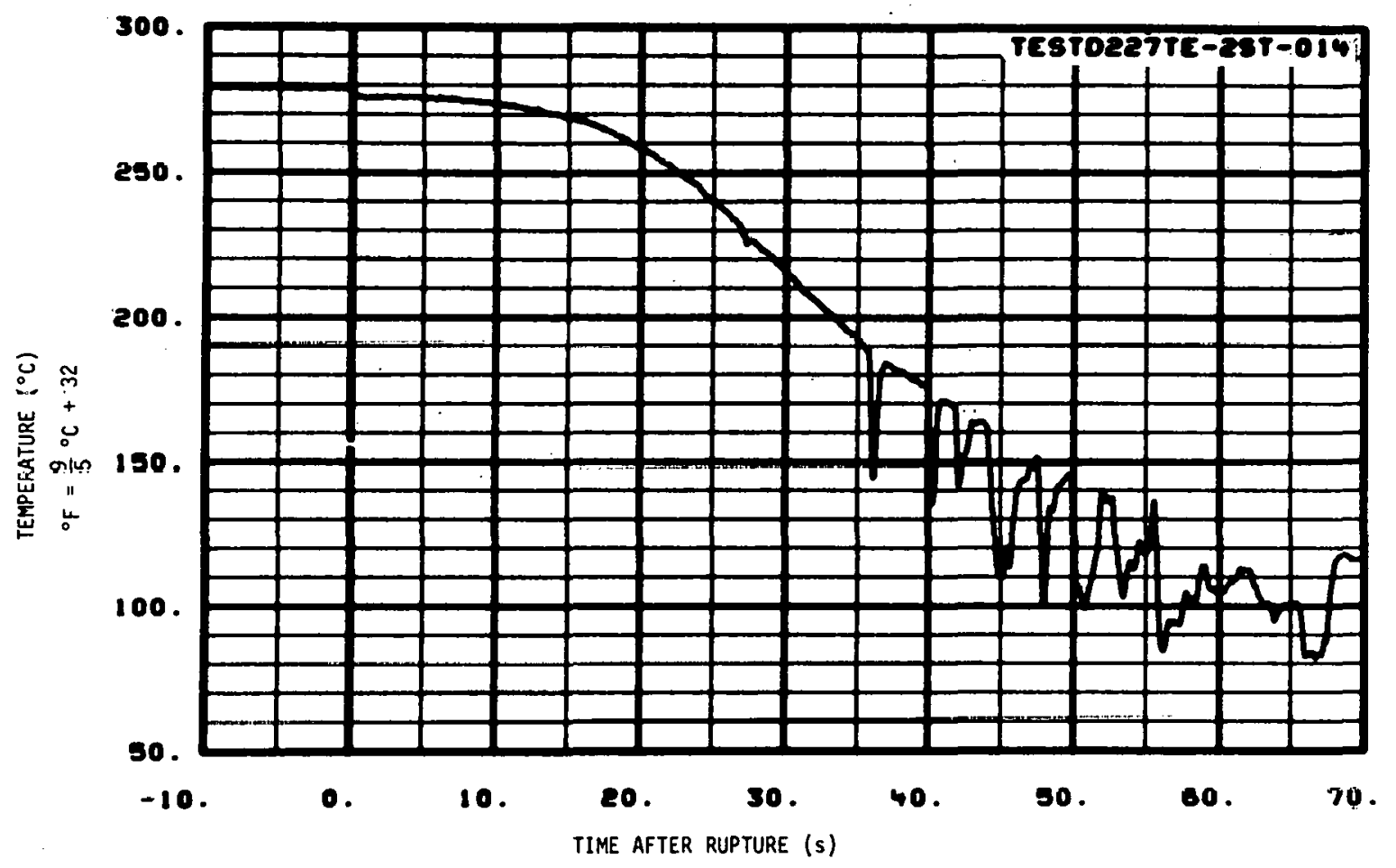

Fig. 132 Temperature in reactor vessel downcomer instrument stalk 2 $(T E-2 S T-14)$.

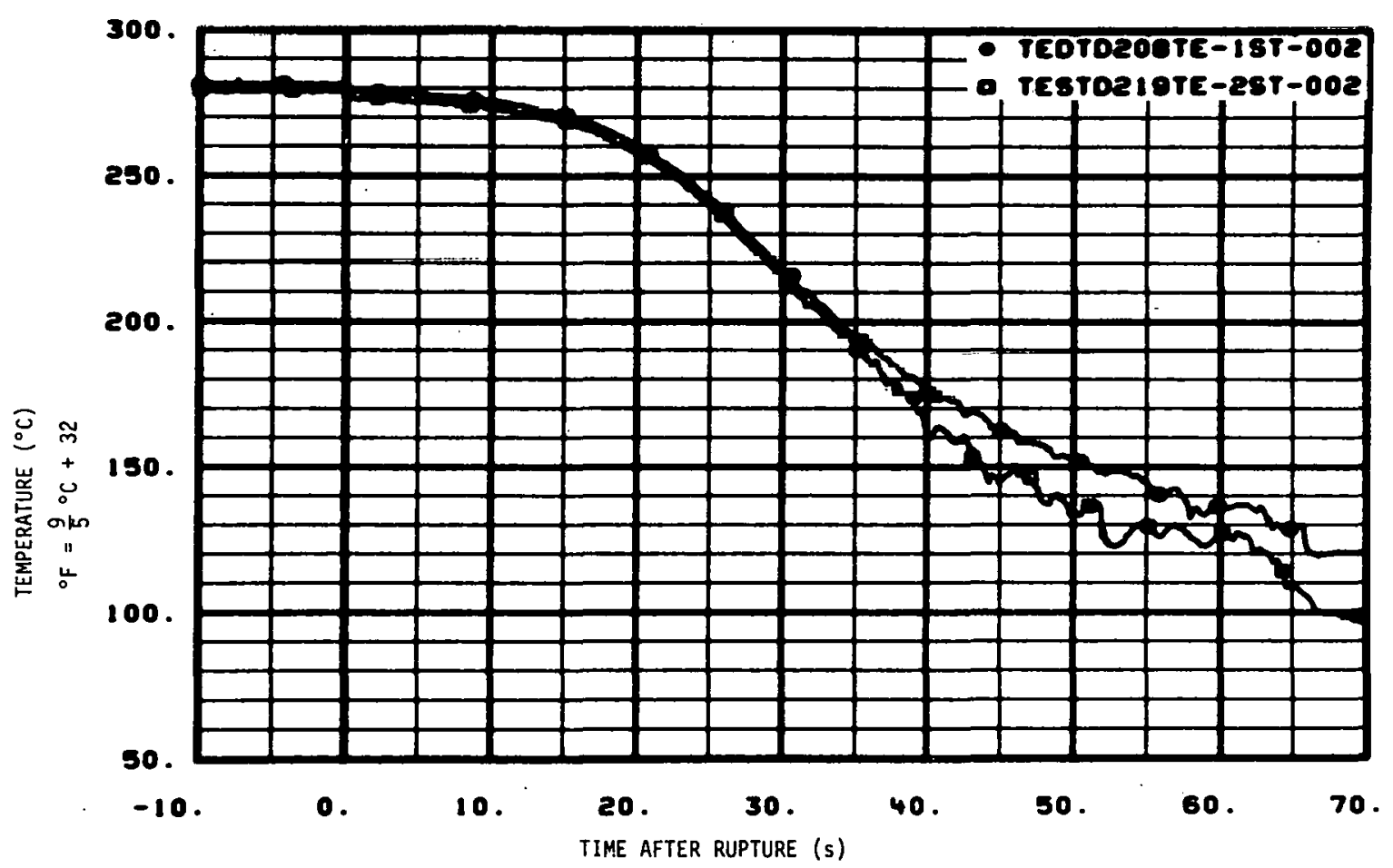

Fig. 133 Temperature in reactor vessel downcomer instrument stalks 1 and $2,4.2 \mathrm{~m}$ above reactor vessel bottom (TE-1ST-2 and TE-2ST-2). 


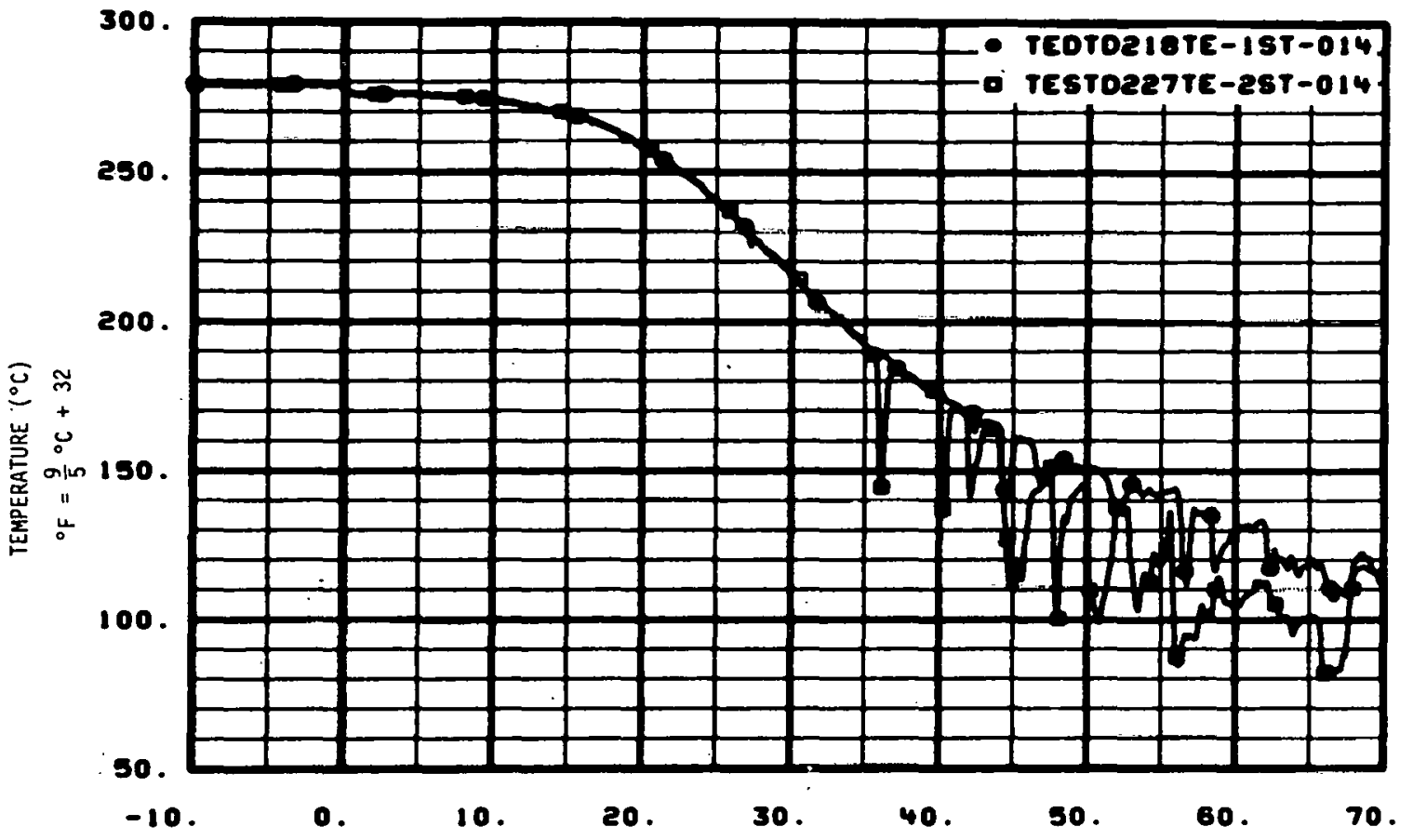

TIME AFTER RUPTURE ( $s$ )

Fig. 134 Temperature in reactor vessel downcomer instrument stalks $i$ and $2,1.17 \mathrm{~m}$ above reactor vessel bottom in DTTs (TE-1ST-14 and TE-2ST-14).

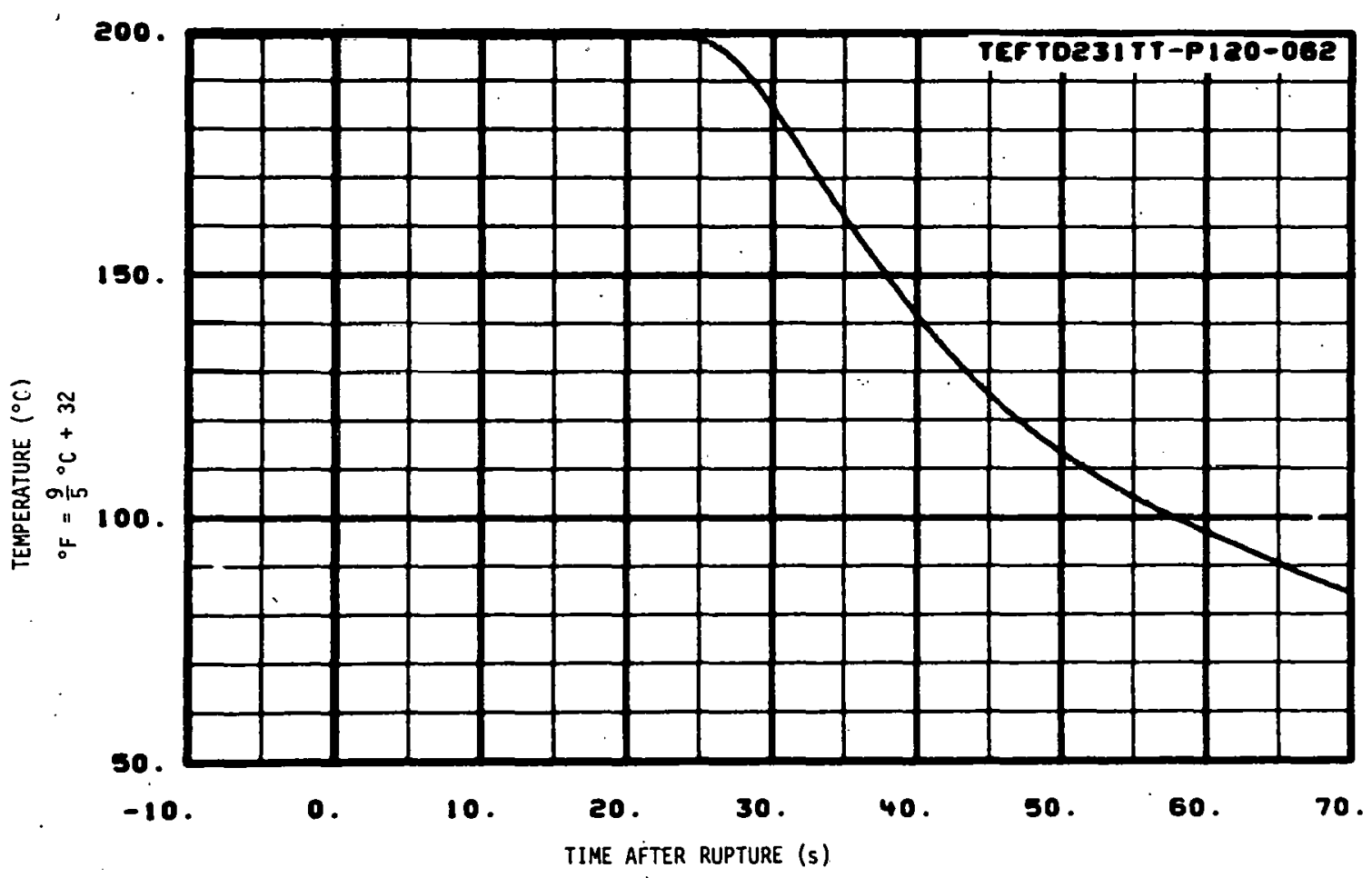

Fig. 135 Temperature in ECCS cold leg injection line (TT-P120-62). 


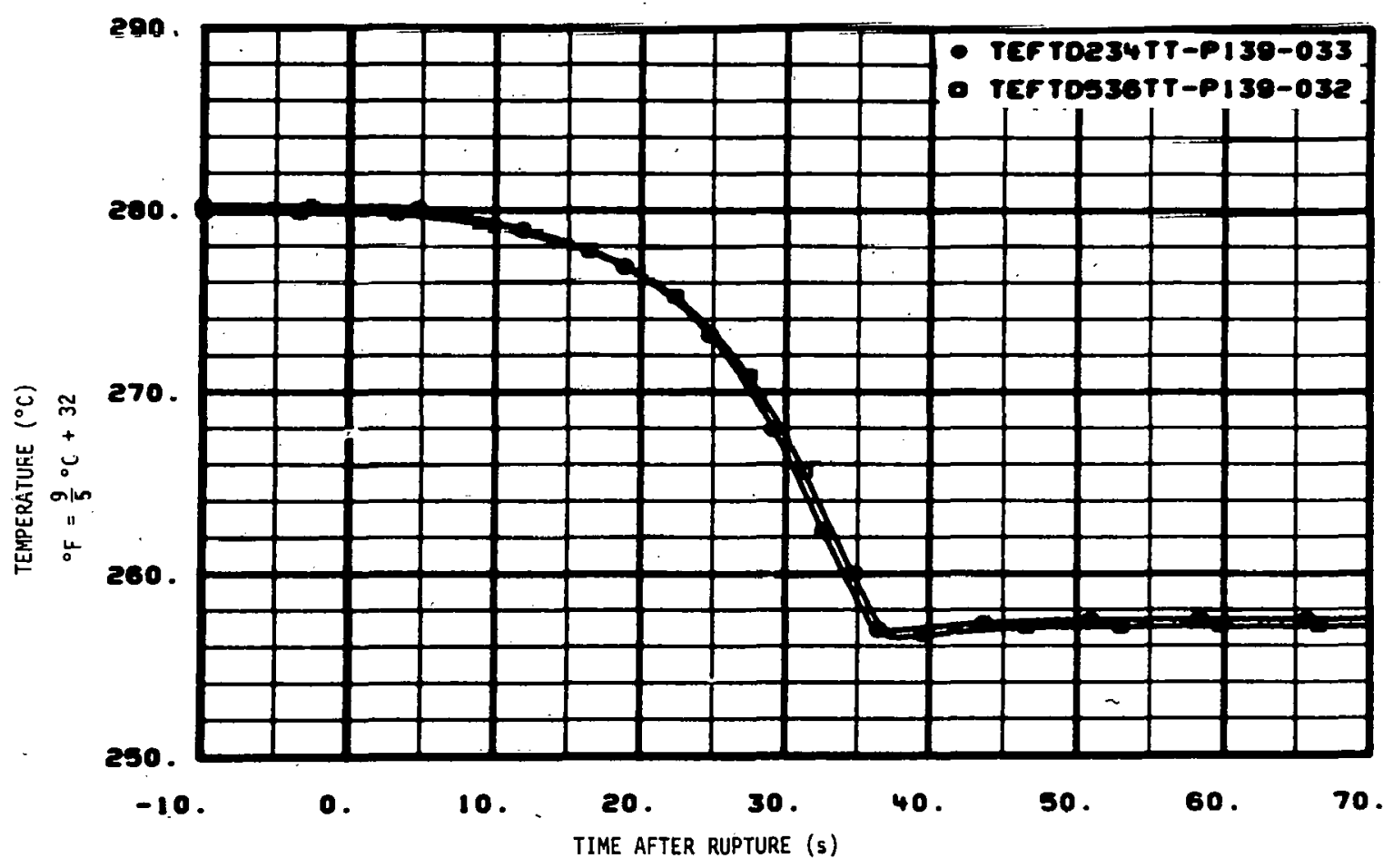

Fig. 136 Temperature in intact loop hot leg in elbow near venturi (TT-P139-32 and -33). 


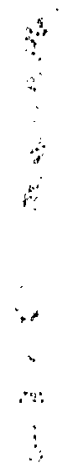

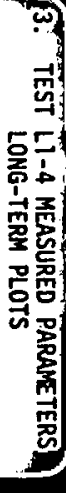

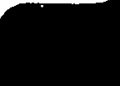




\section{TEST LI-4 MEASURED PARAMETERS -- \\ LONG-TERM PLOTS (190 AND 600 SECONDS)}

This section of presented data consists of Figures 137 through 174 . 


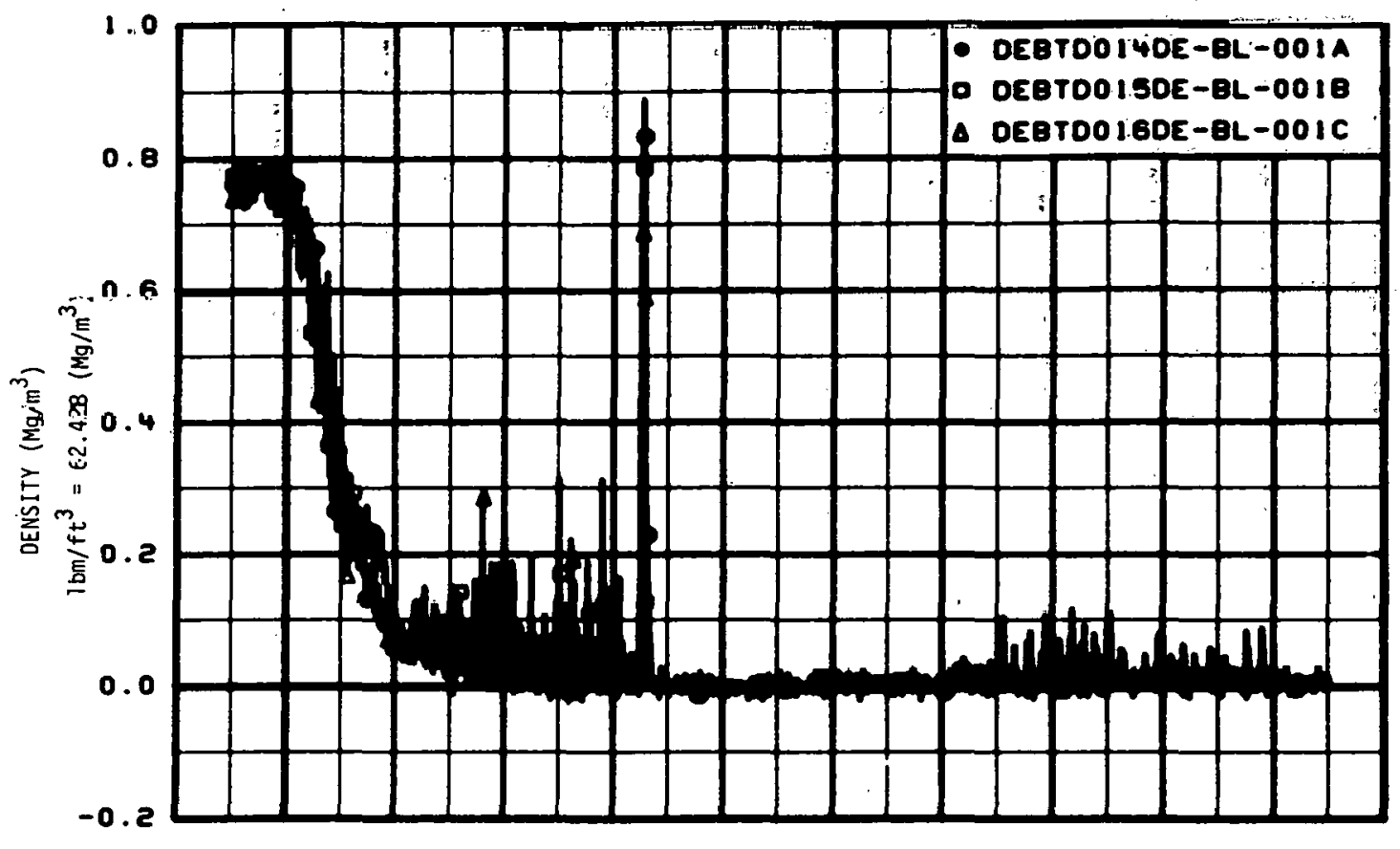

-20 . 0. 20. 40. 80. 80. 100. 180. 140. 180. 180. 200. TIME AFTER RUPTURE ( $s$ )

Fig. 137 Density in broken loop cold leg, chordal density (DE-BL-1A, $-1 B$, and $-1 C$ ).

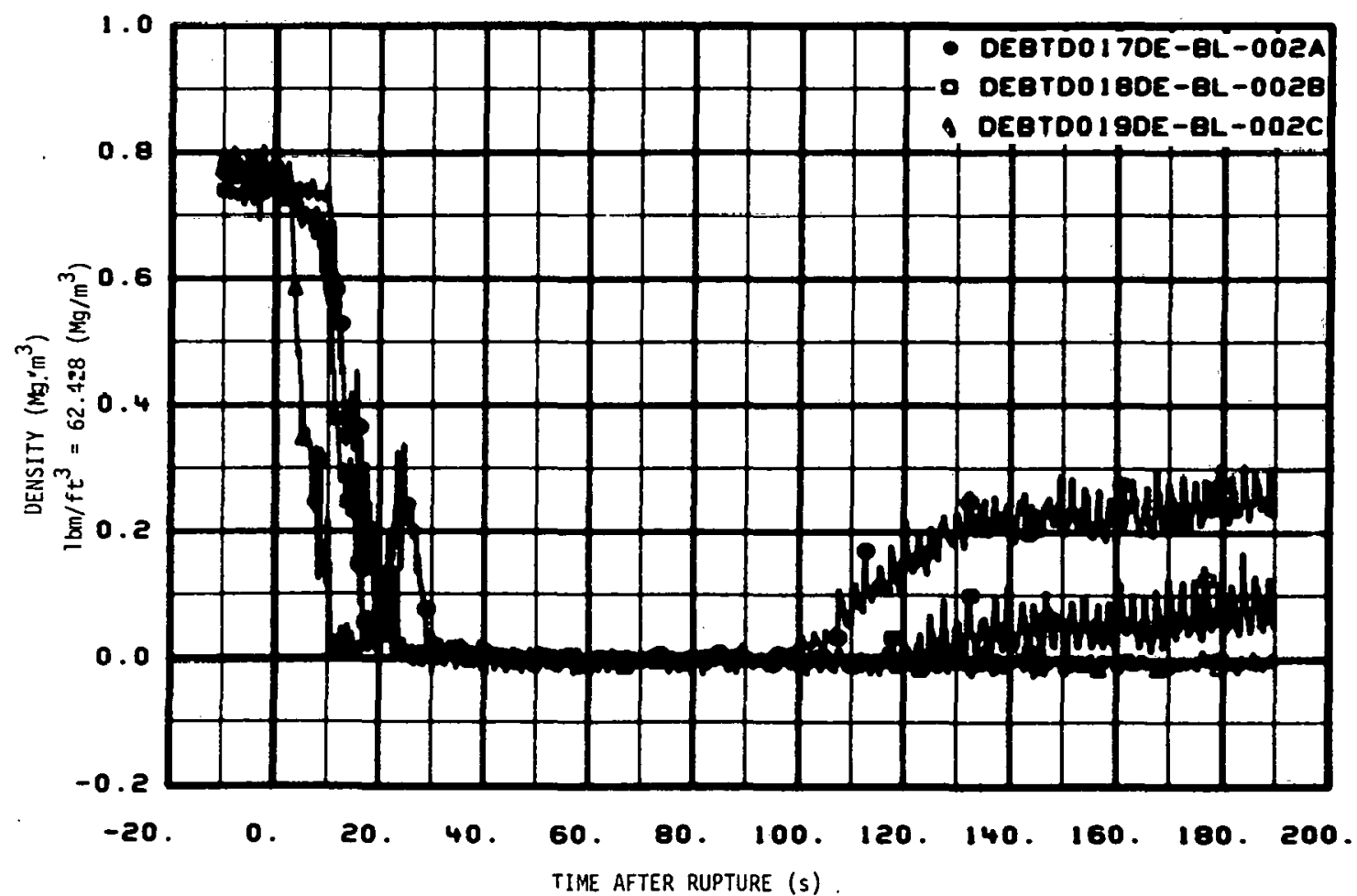

Fig. 138 Density in broken loop hot leg, chordal density (DE-BL-2A, -2B, and -2 C). 


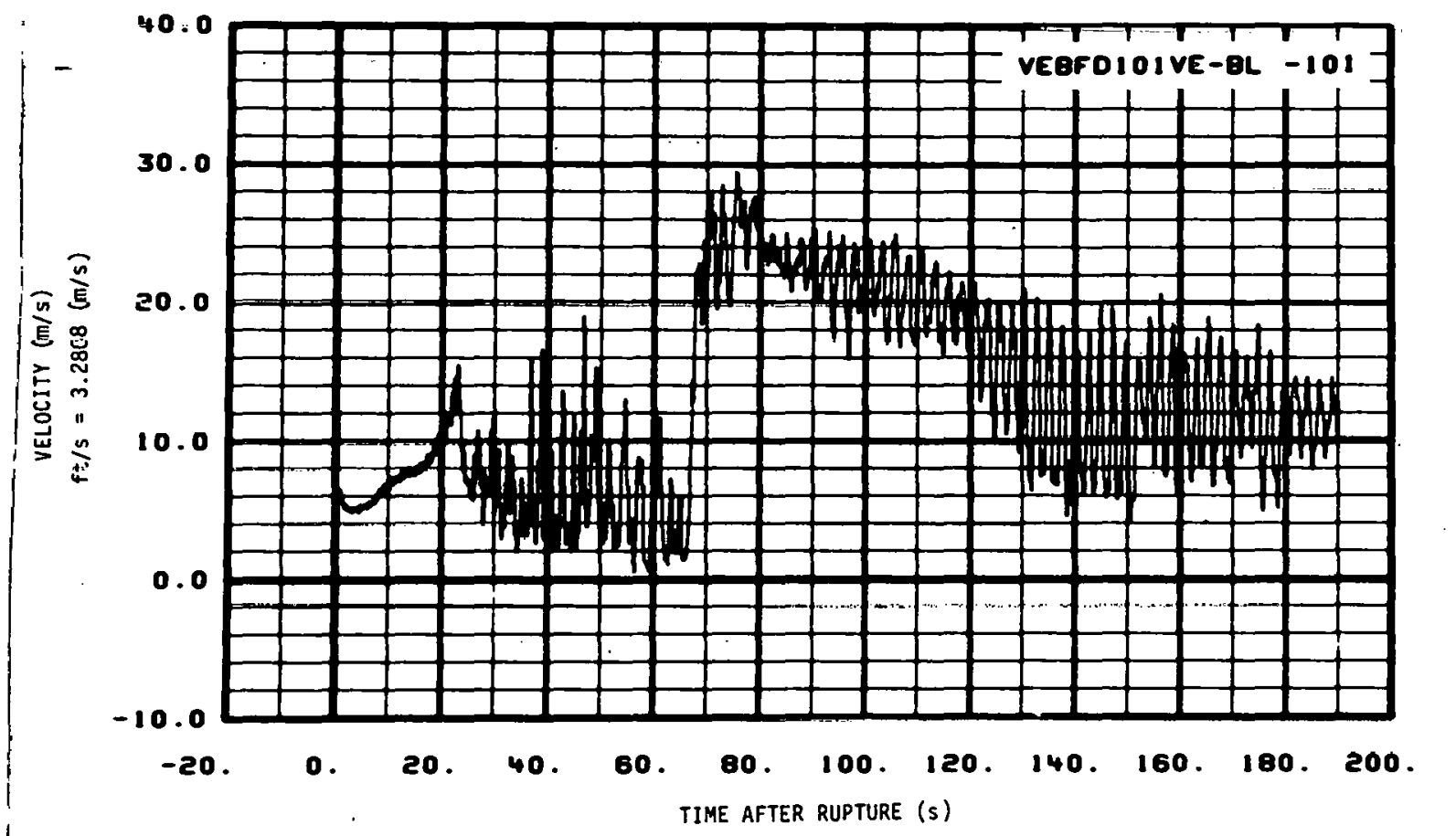

Fig. 139 Fluid velocity in broken loop cold leg àt DTT flanges $(\mathrm{FE}-\mathrm{BL}-1)$.

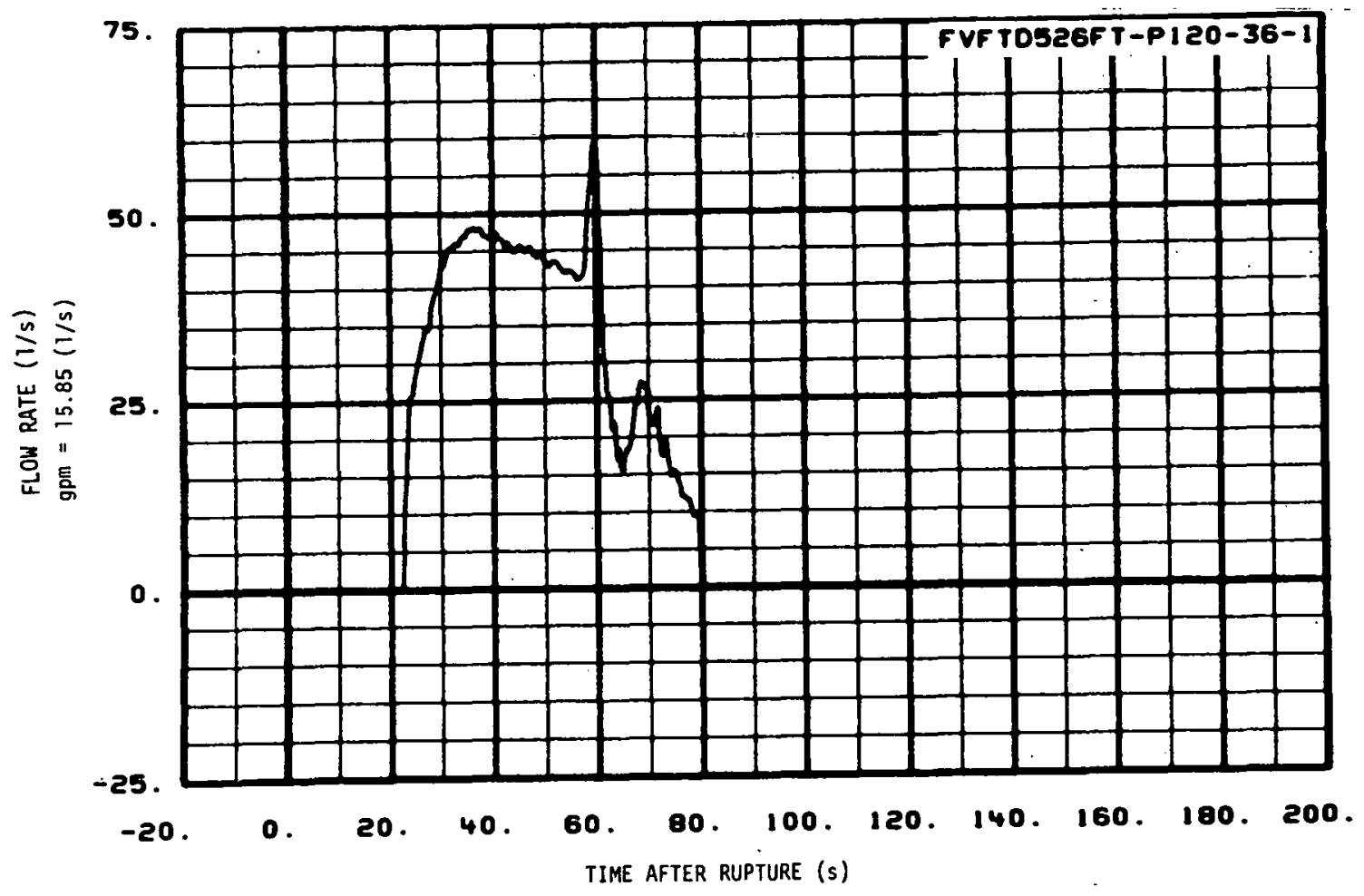

Fig. 140 Flow rate in ECCS accumulator $A$ discharge, high range (FT-P120-36-1). 


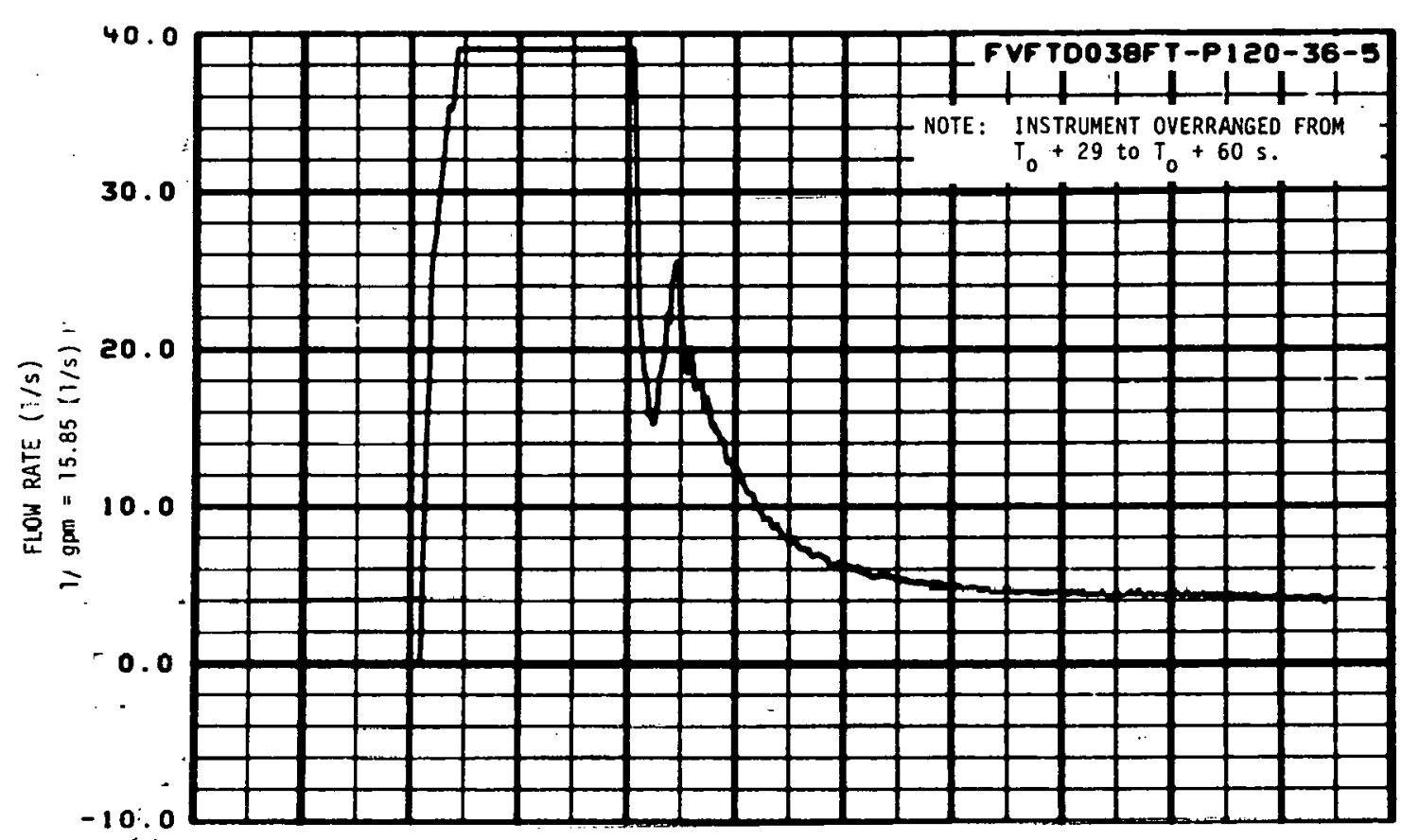

$\therefore-20$. 0. 20. 40. 60. 80. 100. 120. 140. 160. 180. 200 . TIME AFTER RUPTURE ( $s$ )

s Fig. 141 . Flow rate in ECCS accumulator $A$ discharge, low range (FT-P120-36-5).

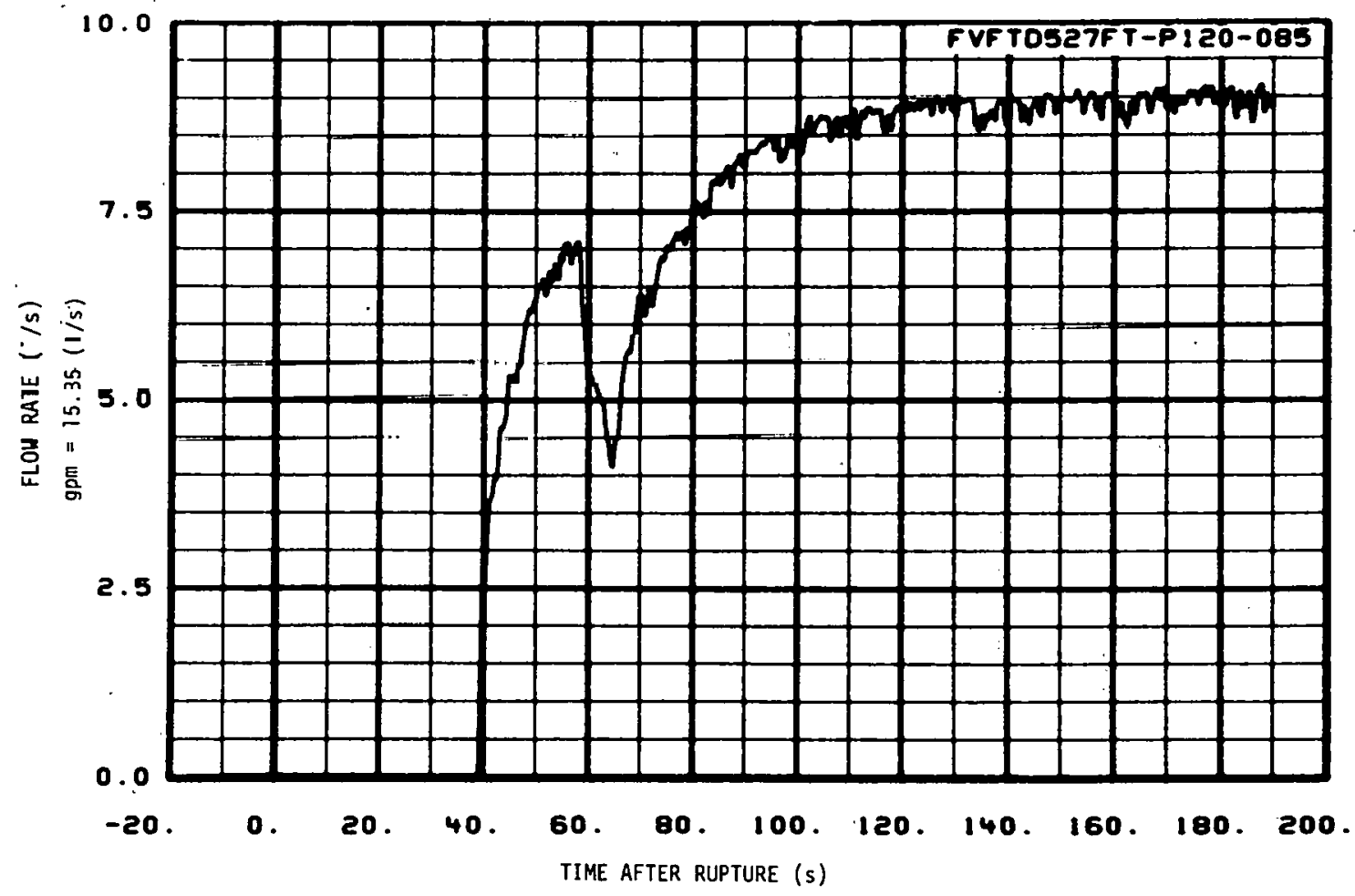

Fig. 142 Flow rate in ECCS LPIS pump A discharge (FT-P120-85). 


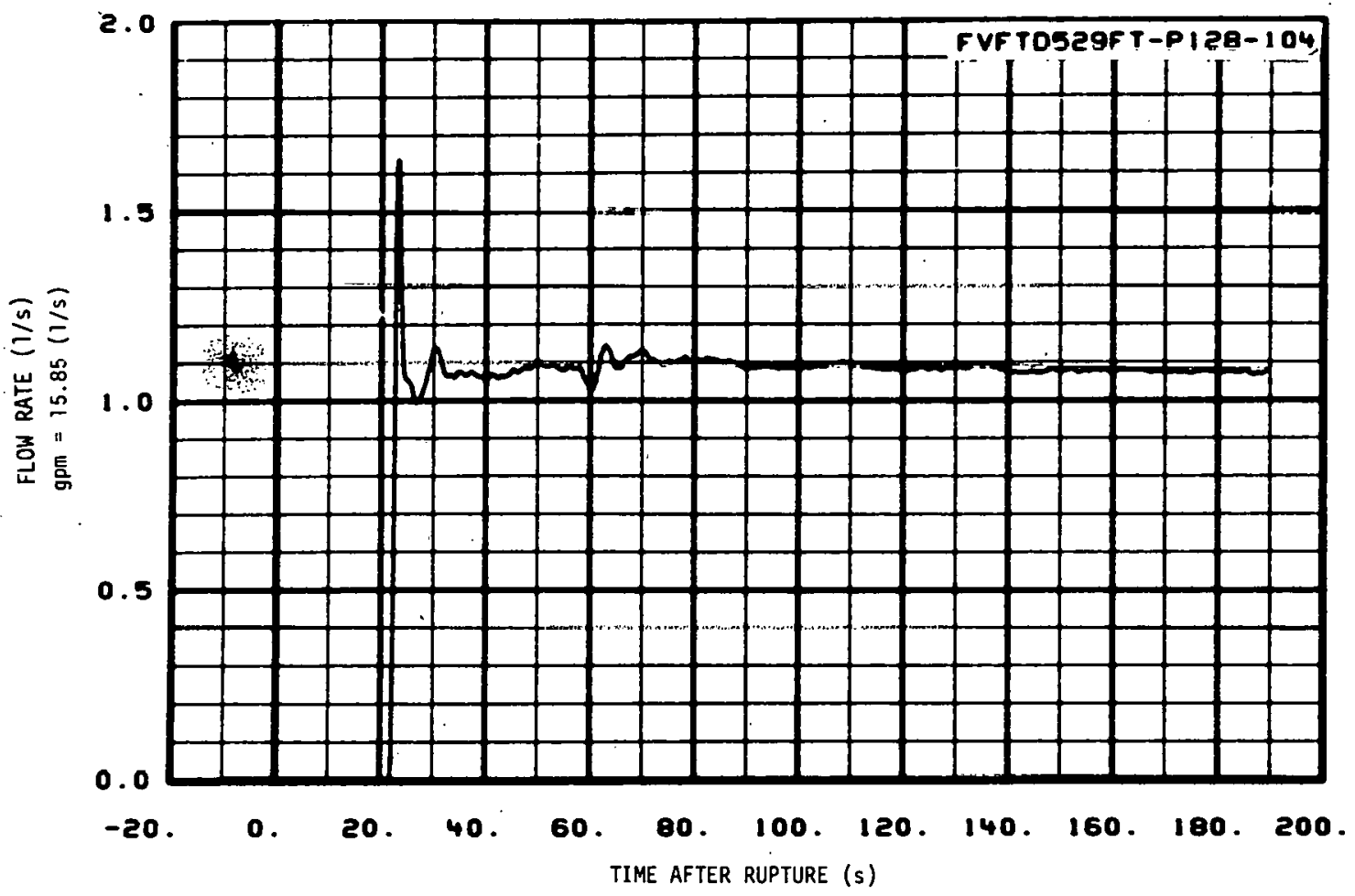

Fig. 143 Flow rate in ECCS HPIS pump A discharge (FT-P128-104).

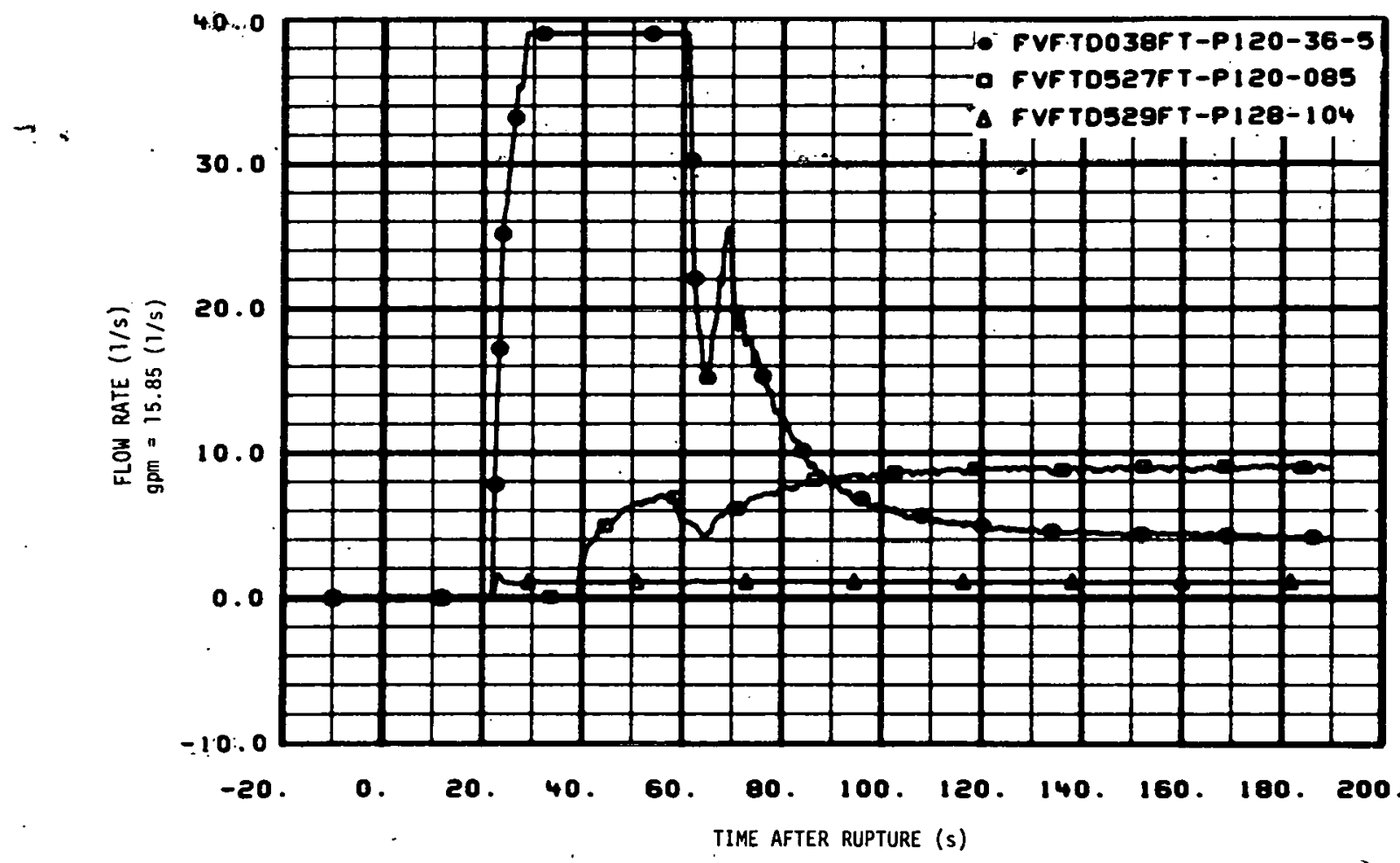

Fig. 144 Flow rate in ECCCS lines to intact loop cold leg (FT-P128-104, FT-P120-36-5, and FT-P120-85). 


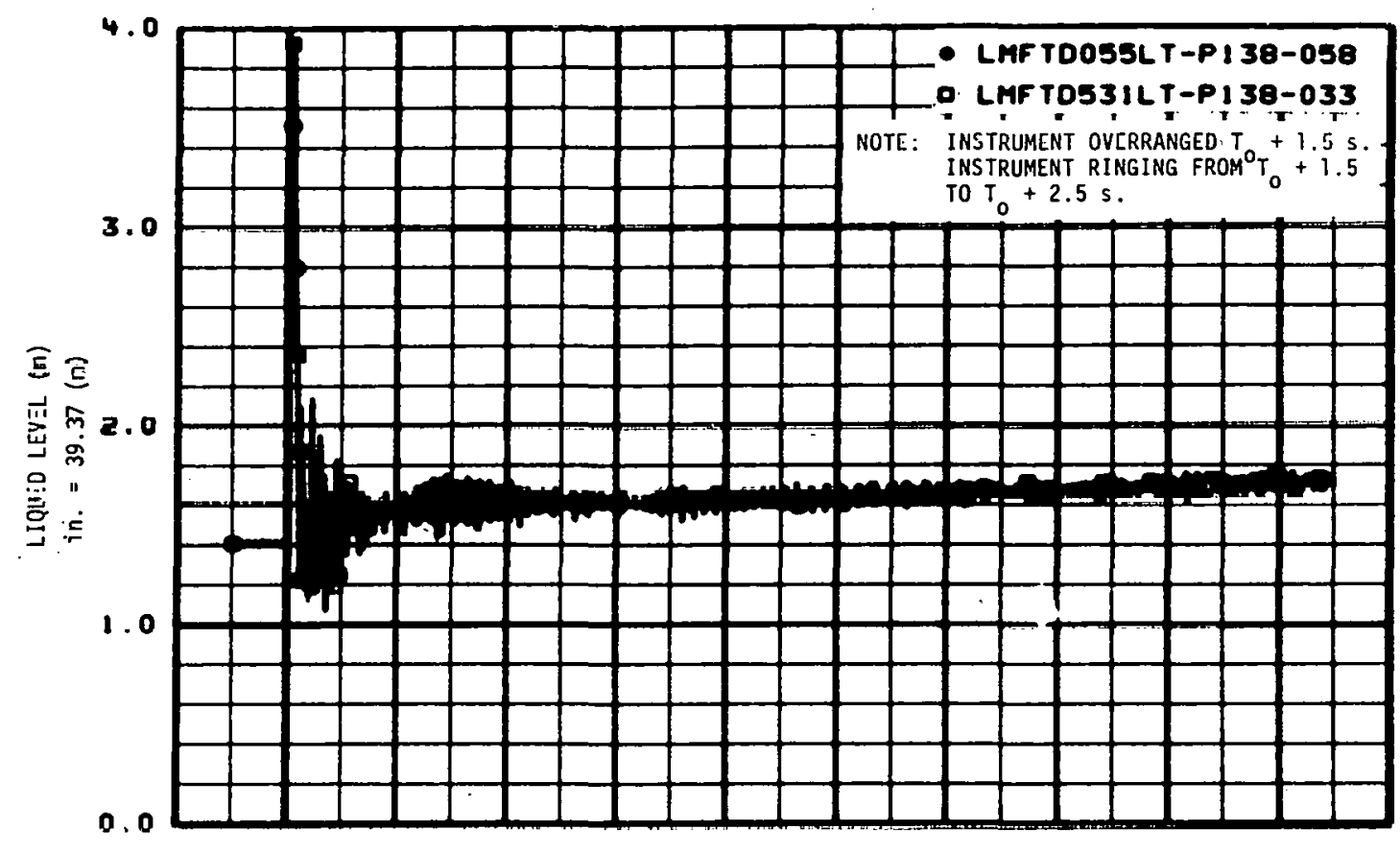

-20 . 0. 20. 40. 60. 80. 100. 120. 140. 160, 180. 200. TIME ÁFTER RUPTURE ( $s$ )

Fig. 145 Liquid level in blowdown suppression tank (LT-P138-33 and -58).

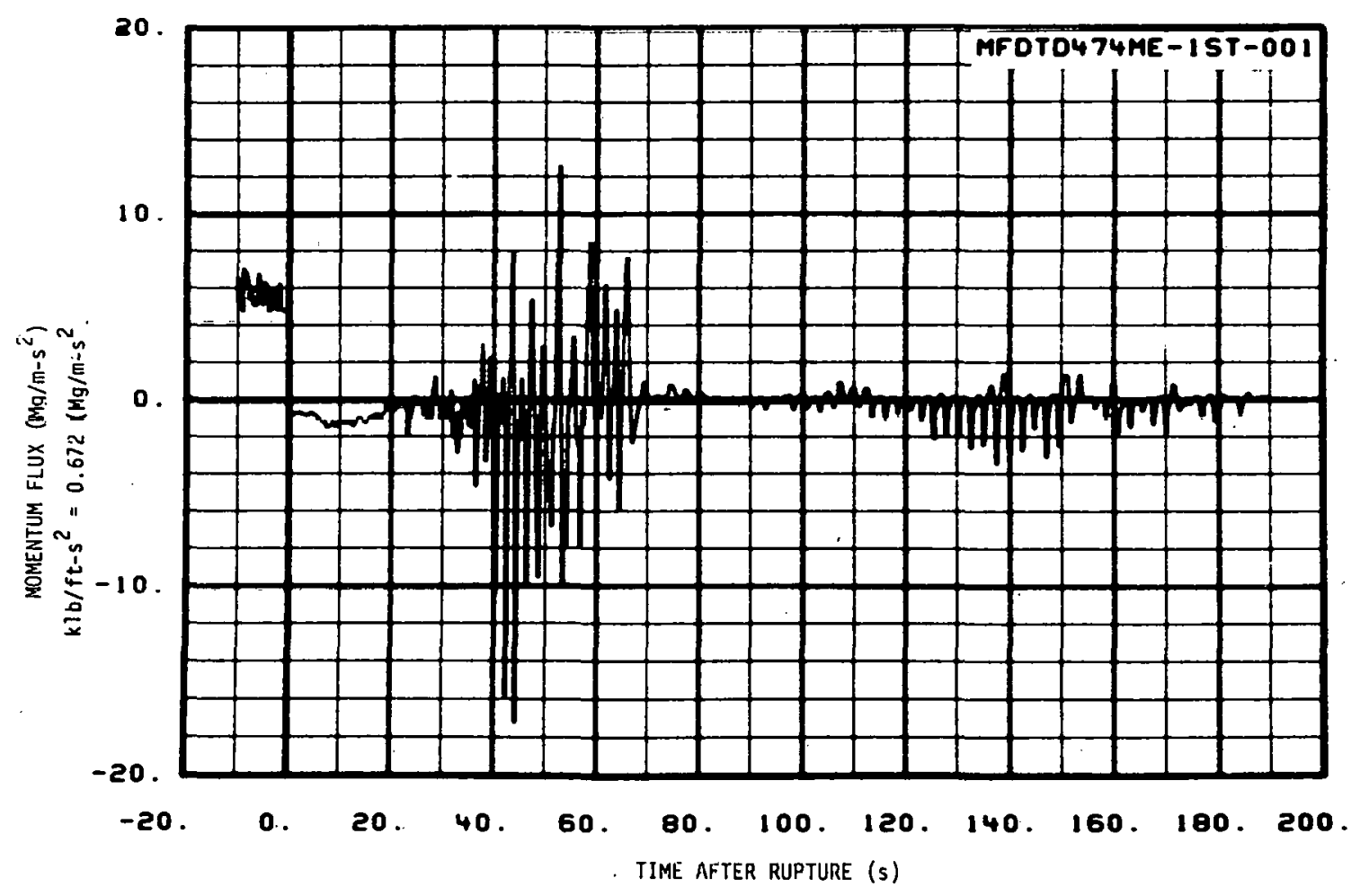

Fig. 146 Momentum flux in reactor vessel downcomer instrument stalk 1 , $1.13 \mathrm{~m}$ above reactor vessel bottom (ME-1ST-1). 


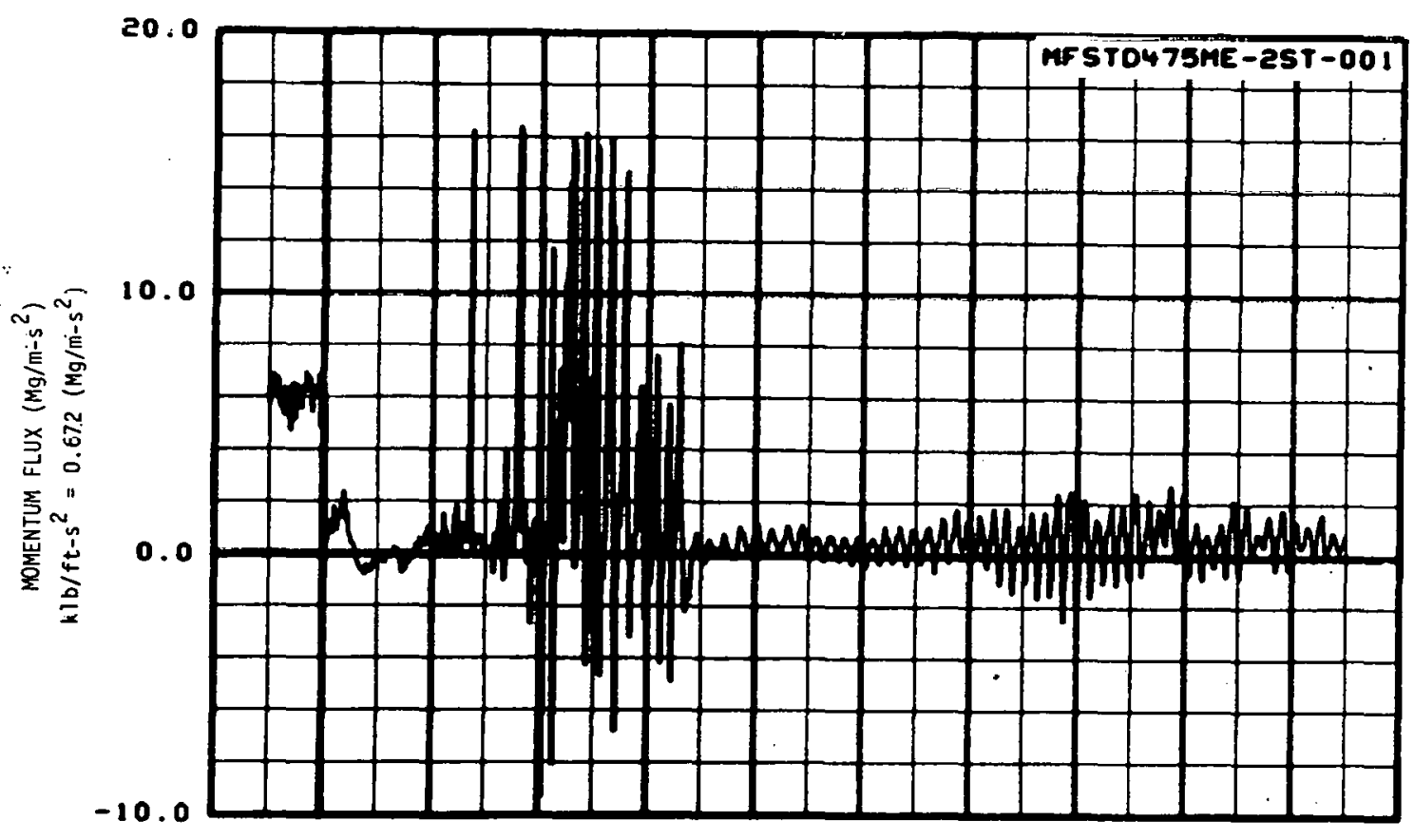

-20. 0. 20. 40. 80. 80. 100. 120.140. 160. 180. 200 . TIME AFTER RUPTURE ( $s$ )

Fig. 147 Momentum flux in reactor vessel downcomer instrumen $i$ stalk 2, $1.13 \mathrm{~m}$ above reactor vessel bottom (ME-2ST-1).

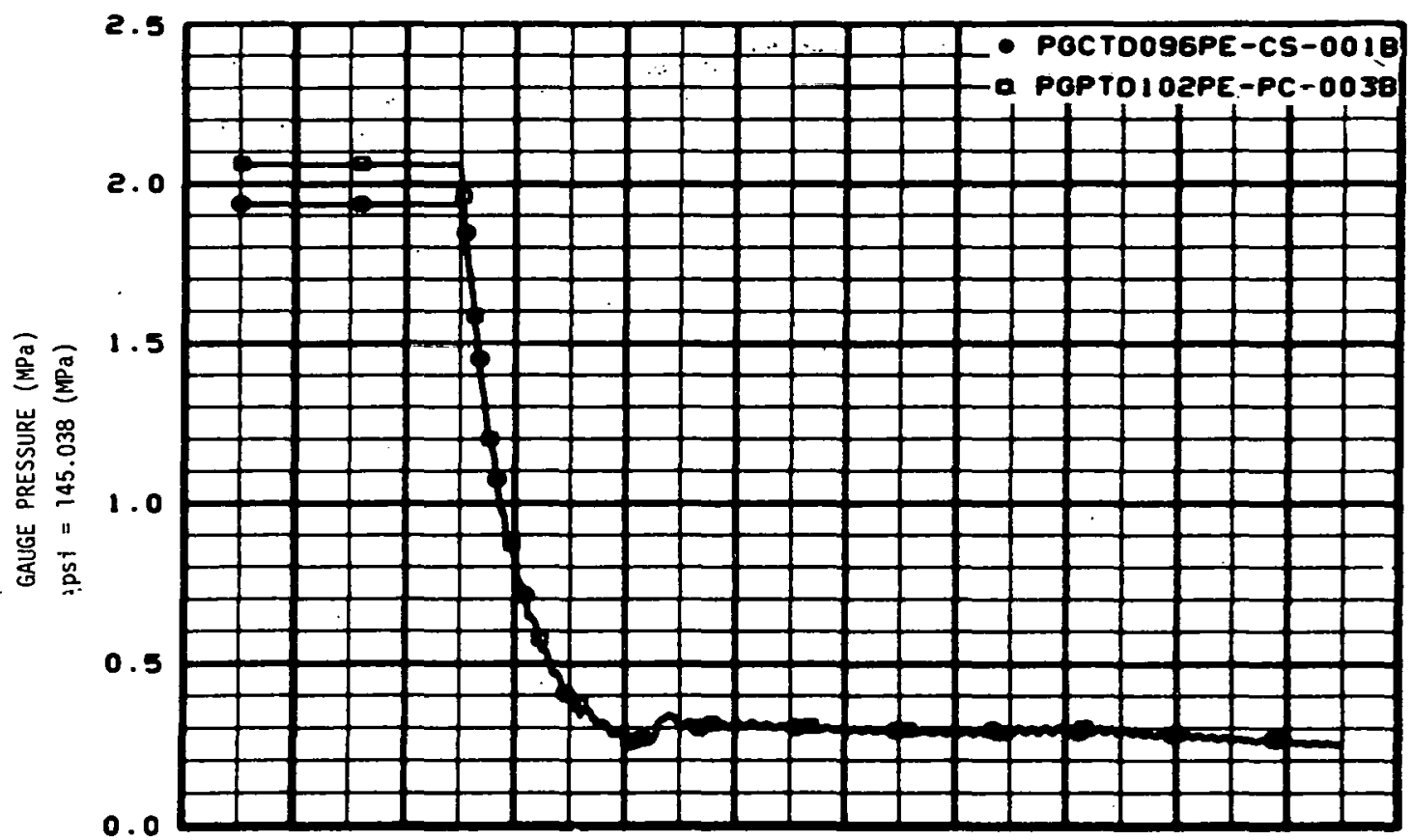

-20 . 0. 20. 40. 60. 80. 100. 120. 140.160. 180. 200. TIME AFTER RUPTURE (s)

Fig. 148 Pressure in reactor vessel core simulator instrument stalk, narrow range, and intact loop steam generator outlet (PE-CS-1B and $P E-P(-3 B)$. 


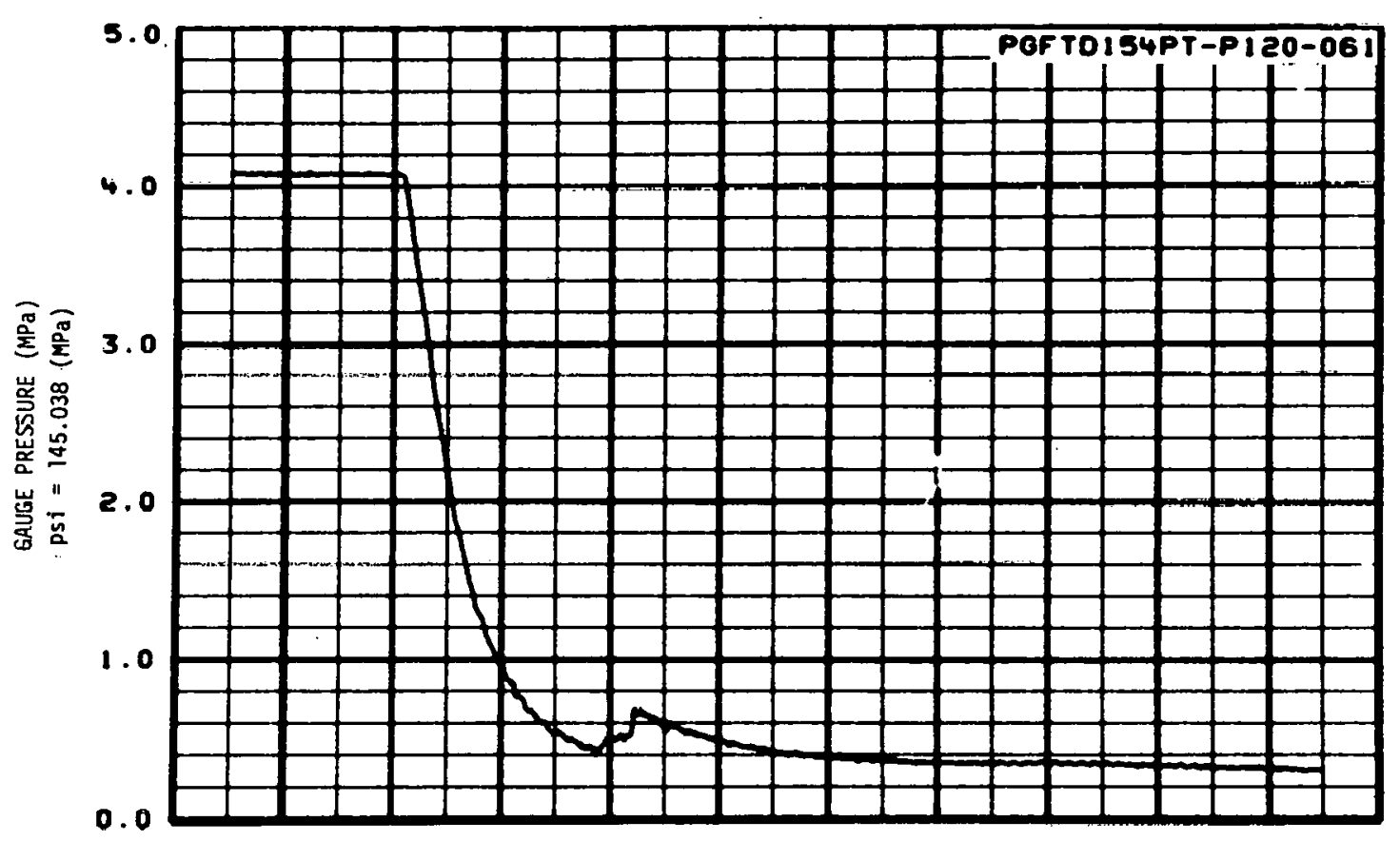

-20. 0. 20. 40. 60. 80. 100. 120. 140. 160. 180. 200. TIME AFTER RUPTURE ( $s$ )

Fig. 149 Pressure in ECCS cold leg injection line (PT-P120-61).

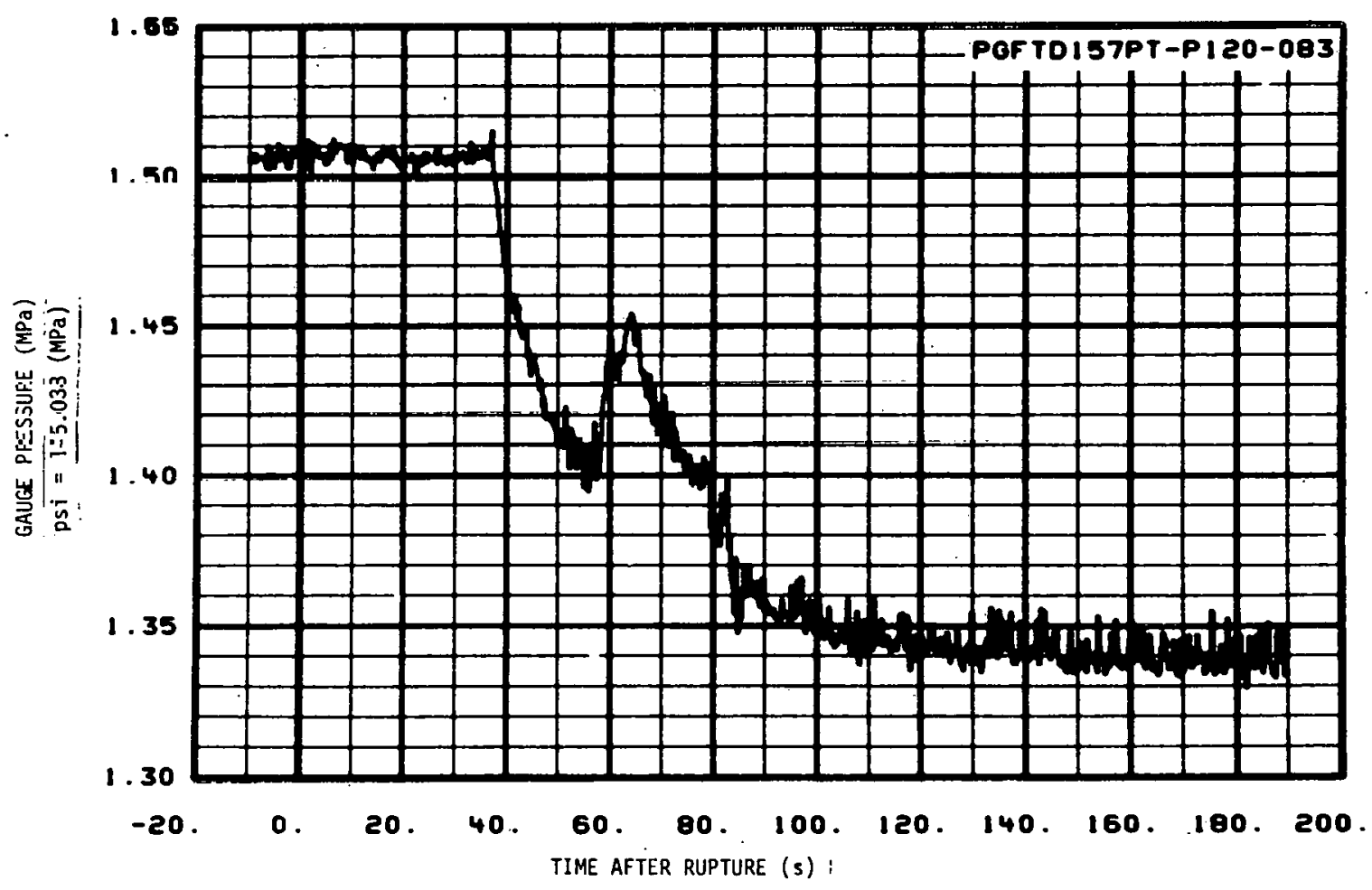

Fig. 150 Pressure in ECCS LPIS pump A discharge (PT-P120-83). 


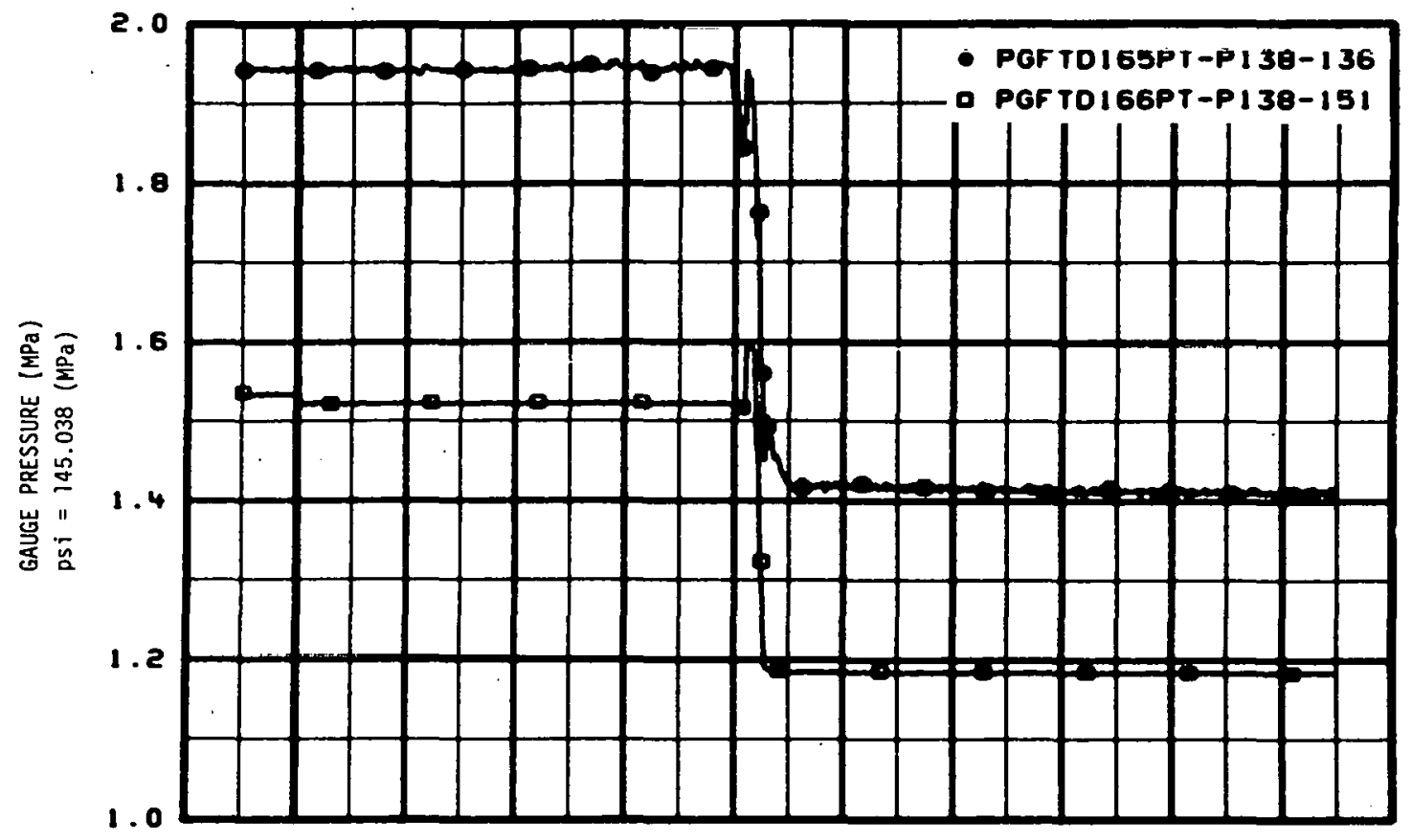

-20. 0. 20. 40. 60. 80. 100. 120. 140. 160. 180. 200 TIME AFTER RUPTURE $(s)$

Fig. 151 Pressure in blowdown suppression tank spray system pump discharge and cooldown heat exchanger outlet (PT-P138-136 and -151).

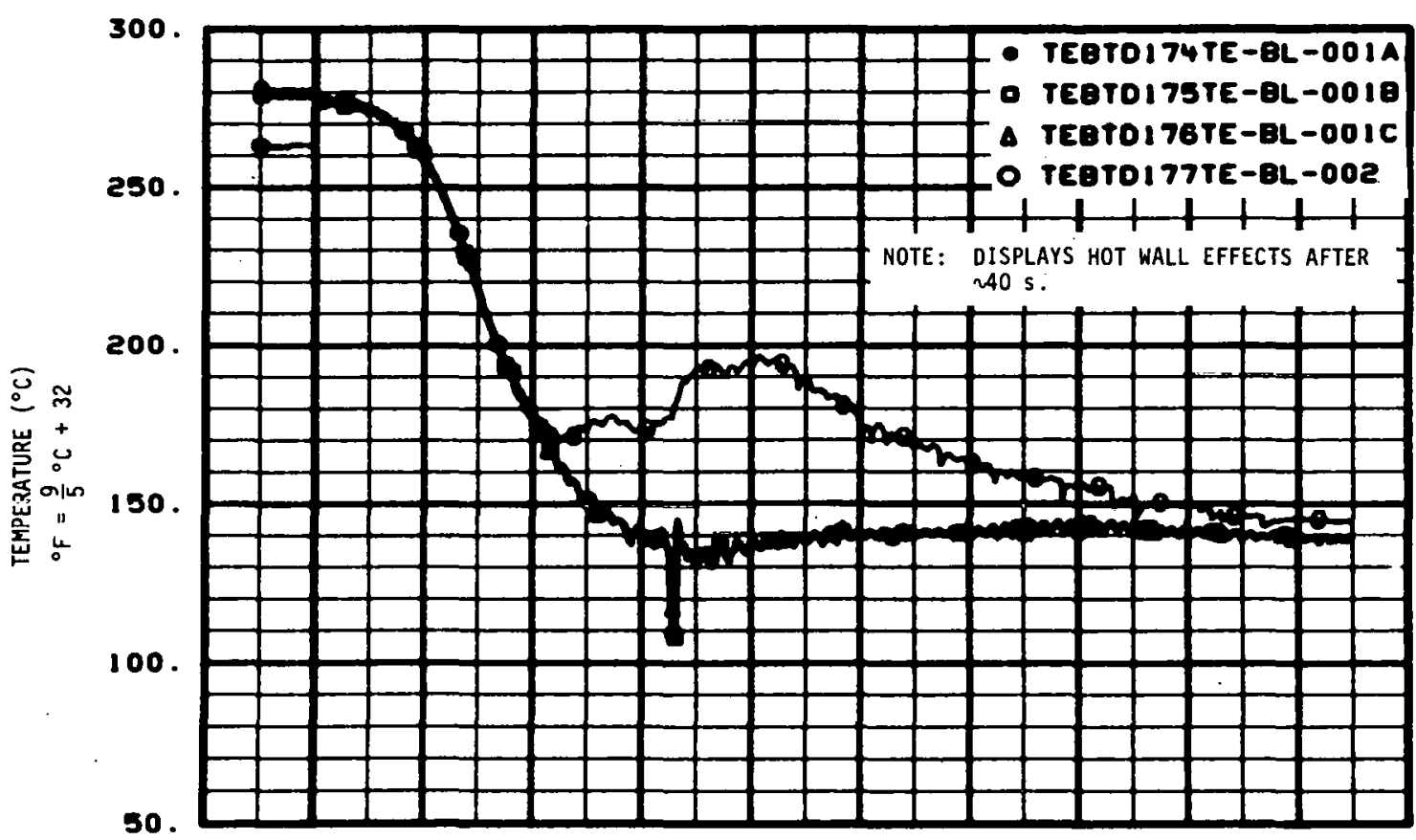

-20 . 0. 20. 40. 60. 80. 100.120. 140. 160. 180. 200. TIME AFTER RUPTURE $(s)$

Fig. 152 Temperature in broken loop cold leg and hot leg (TE-BL-1 and -2 ). 


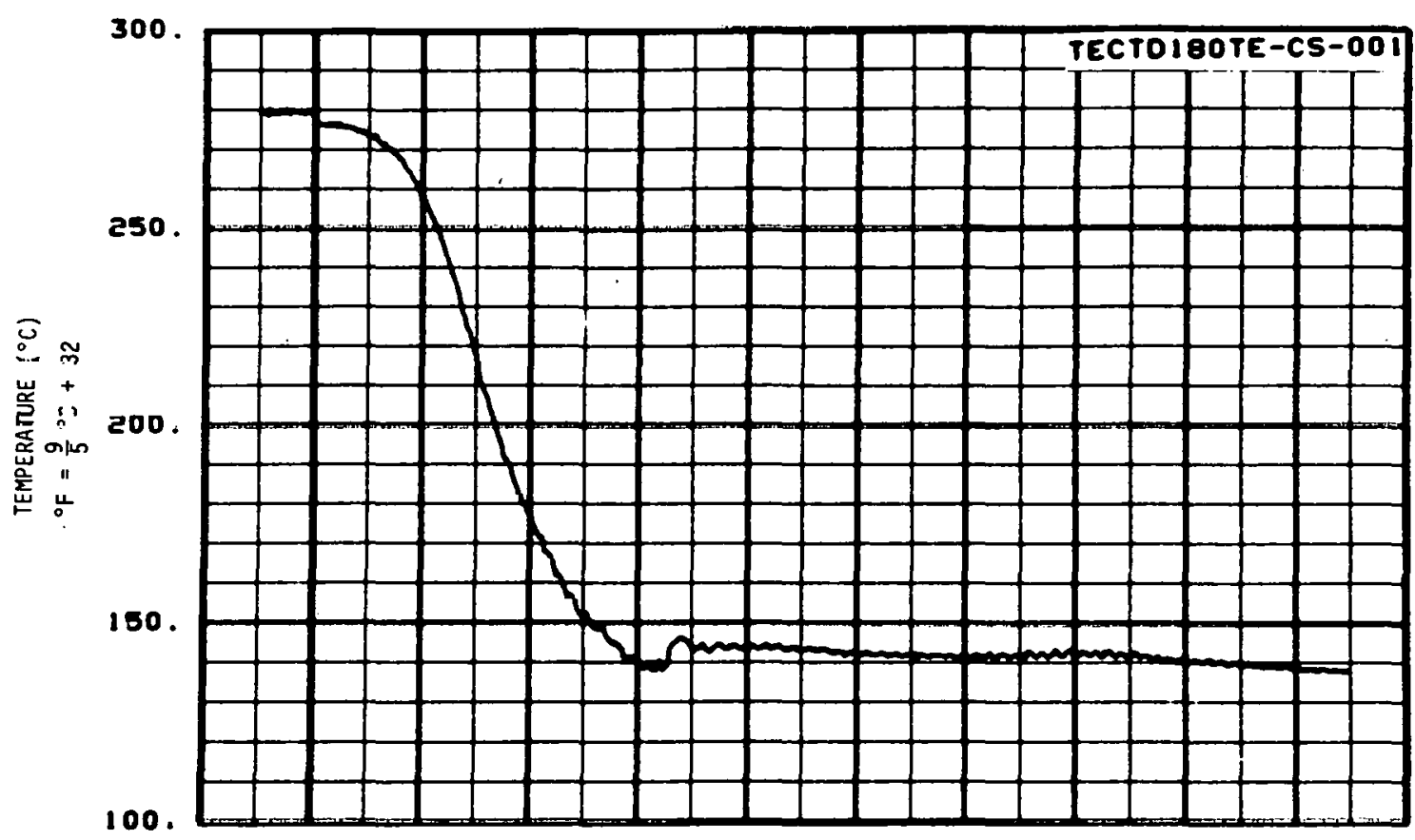

-20. 0. 20. 40. 60. 80. 100.120. 140. 160. 180. 200. TIME AFTER R̂LPTURE (s)

Fig. 153 Temperature in reactor vessel core simulator instrument stalk (TE-CS-1).

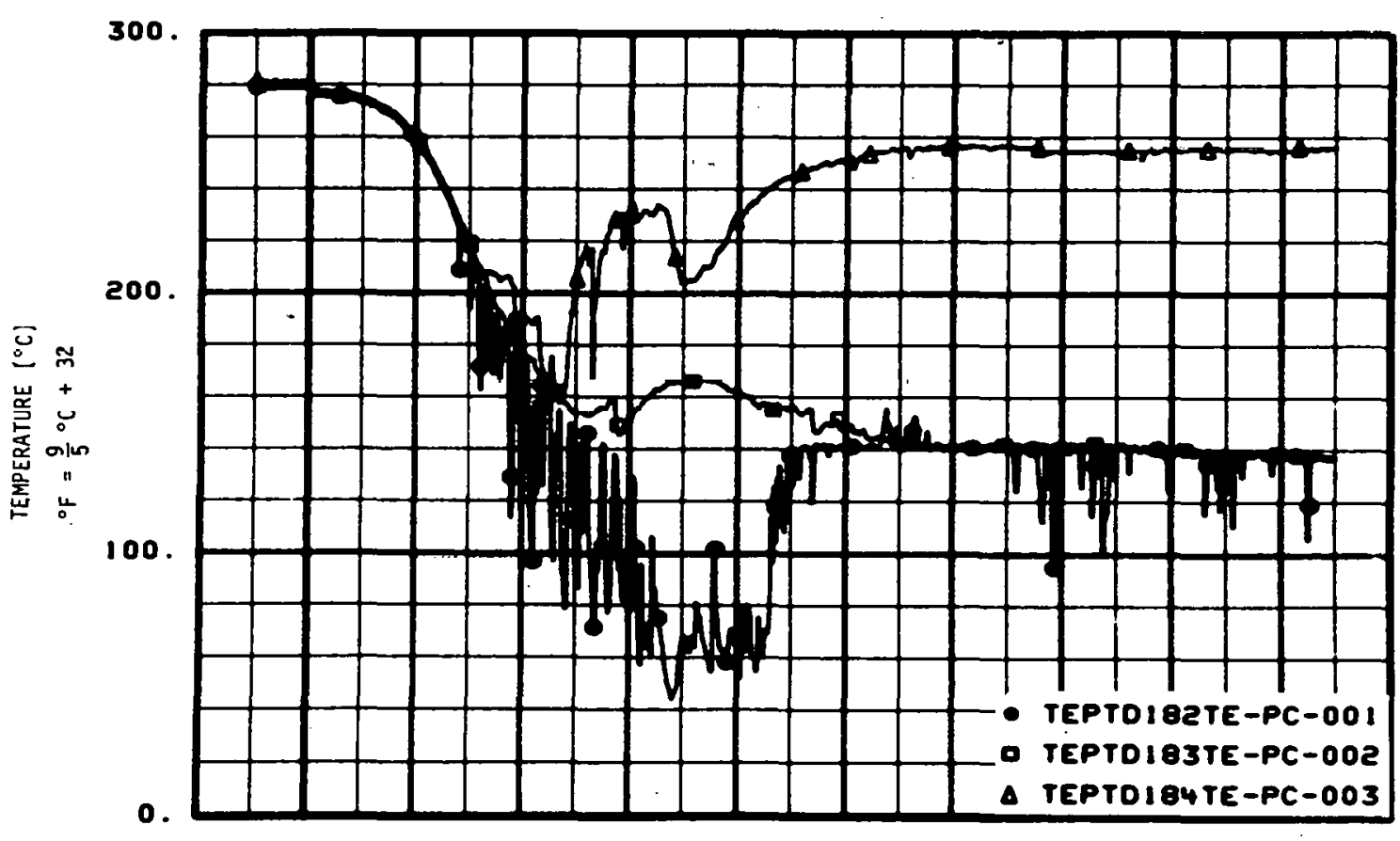

-20. 0. 20. 40. 60. 80. 100.120. 140. 160. 180. 200. TIME AFTER RUPTURE ( $s$ )

Fig. 154 Temperature in intact loop cold leg, hot leg, and steam generator outlet (TE-PC-1, -2 , and -3 ). 


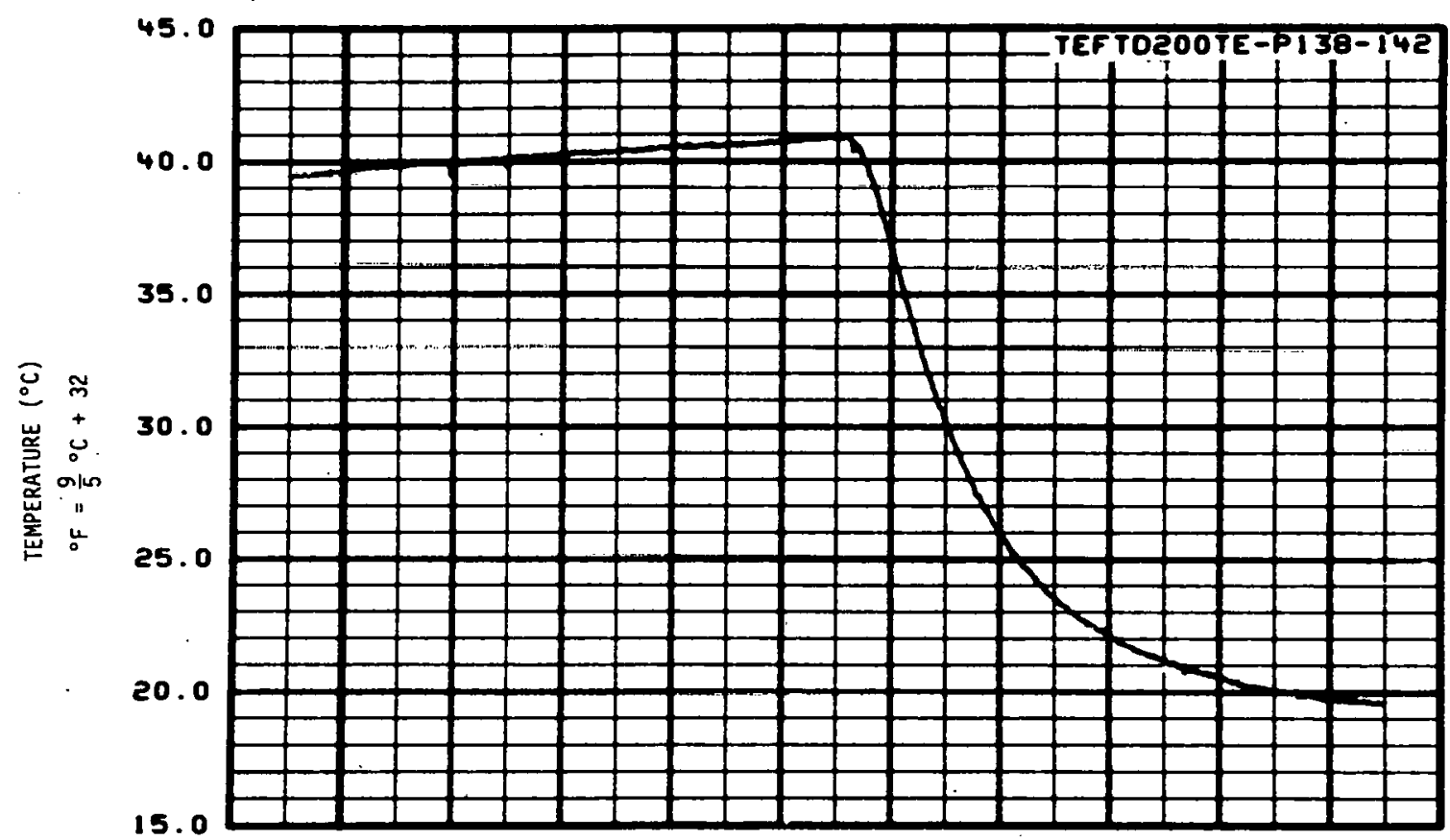

-20. 0. 20. 40. 60. 80. 100.120.140.160. 180. 200. TIME AFTER RUPTURE $(s)$

Fig. 155 Temperature in blowdown suppression tank spray system pump discharge (TE-P138-142).

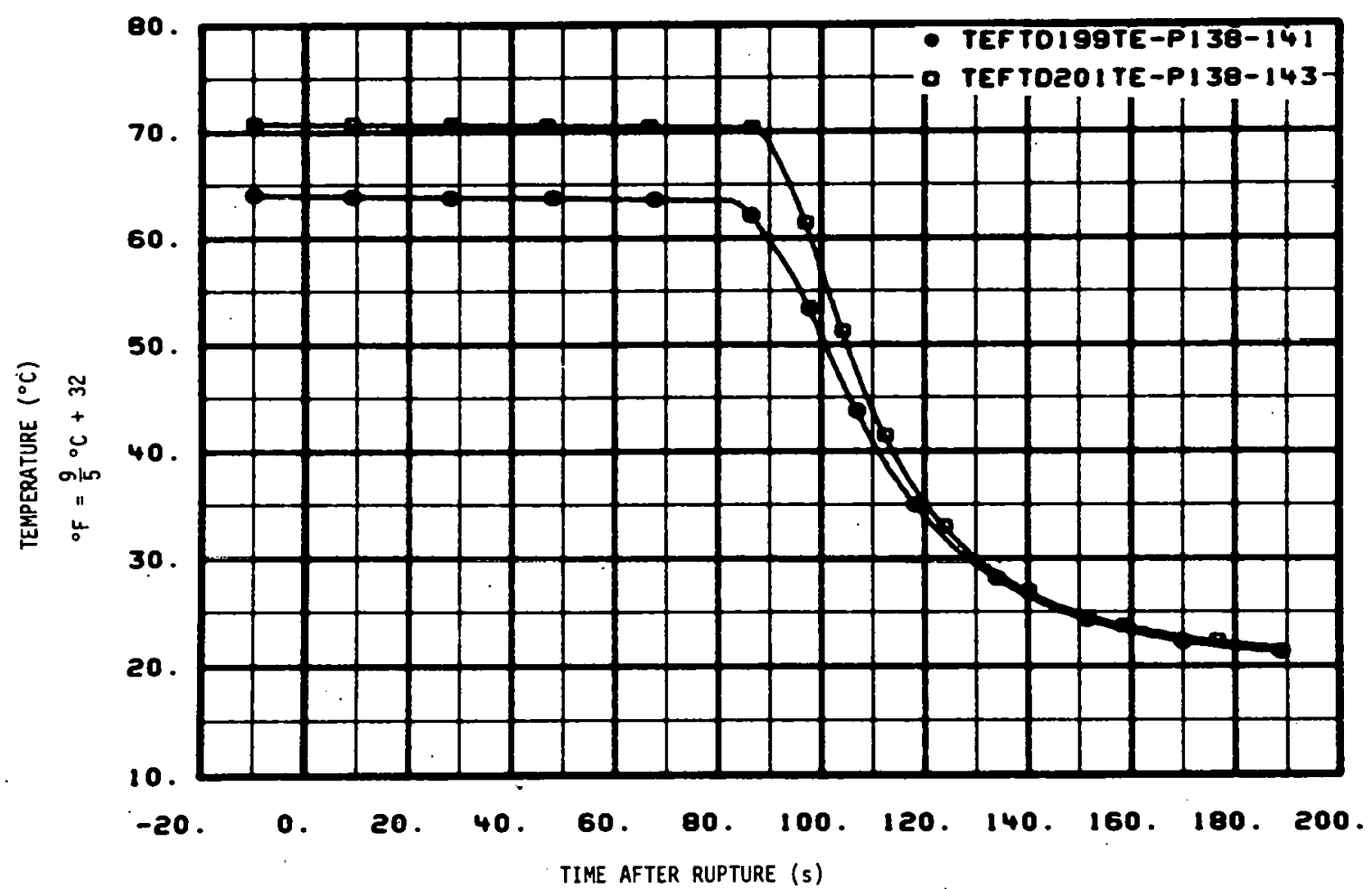

Fig. 156 Temperature in blowdown suppression tank spray system 3.79-1/s header and 13.88-1/s spray header (TE-P138-141 and -143). 


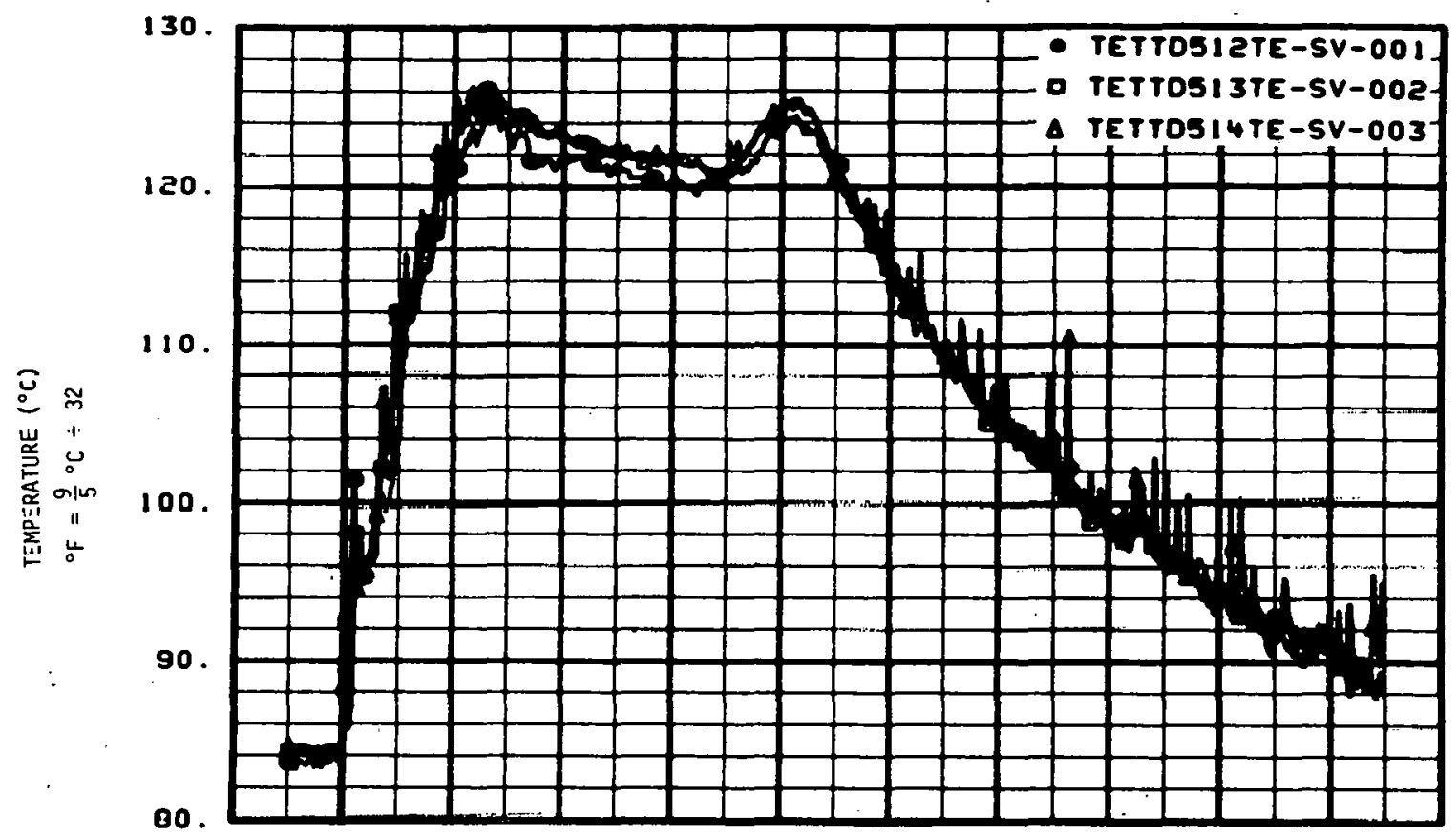

-20. 0. 20. 40. 60. 80. 100. 120. 140. 160. 180. 200. TIME AFTER RUPTURE $(s)$

Fig. 157 Temperature in blowdown suppression tank B-end thermocouple stalk (TE-SV-1, -2 , and -3 ).

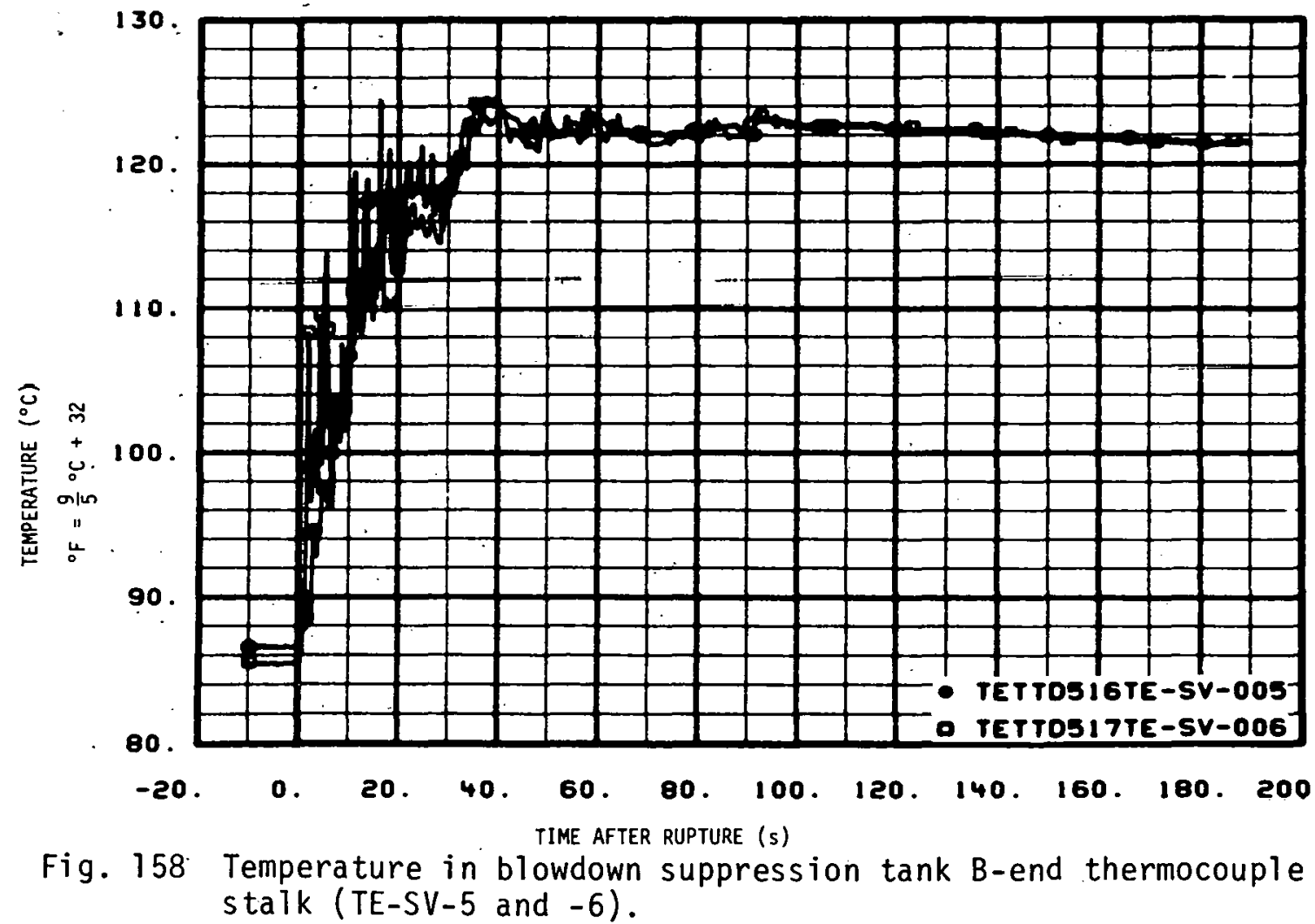




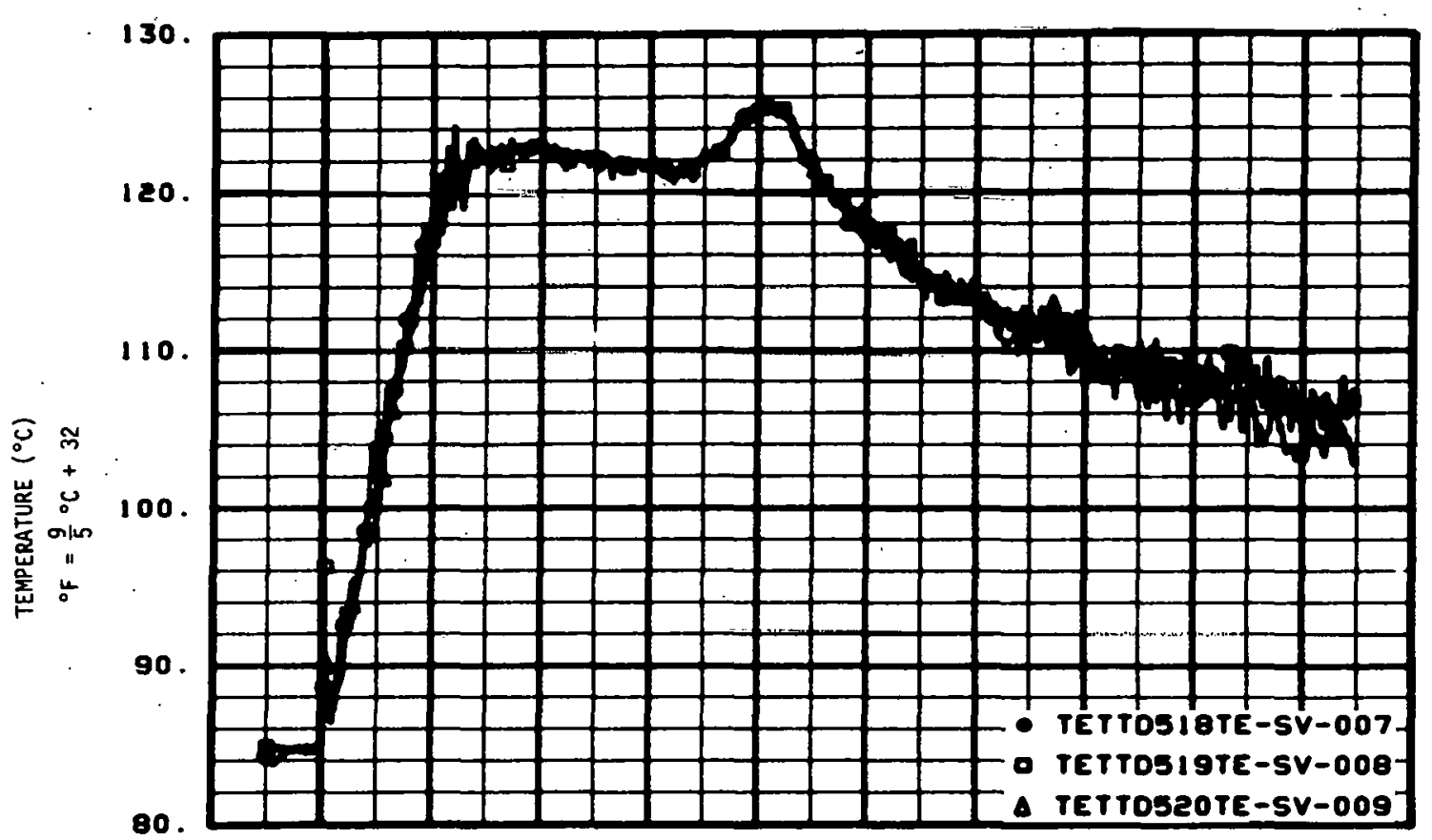

-20. 0. 20. 40. 60. 80. 100. 120. 140. 160. 180. 200. TIME AFTER RUPTURE (s)

Fig. 159 Temperature in blowdown suppression tank A-end thermocouple stalk (TE-SV-7, -8 , and -9).

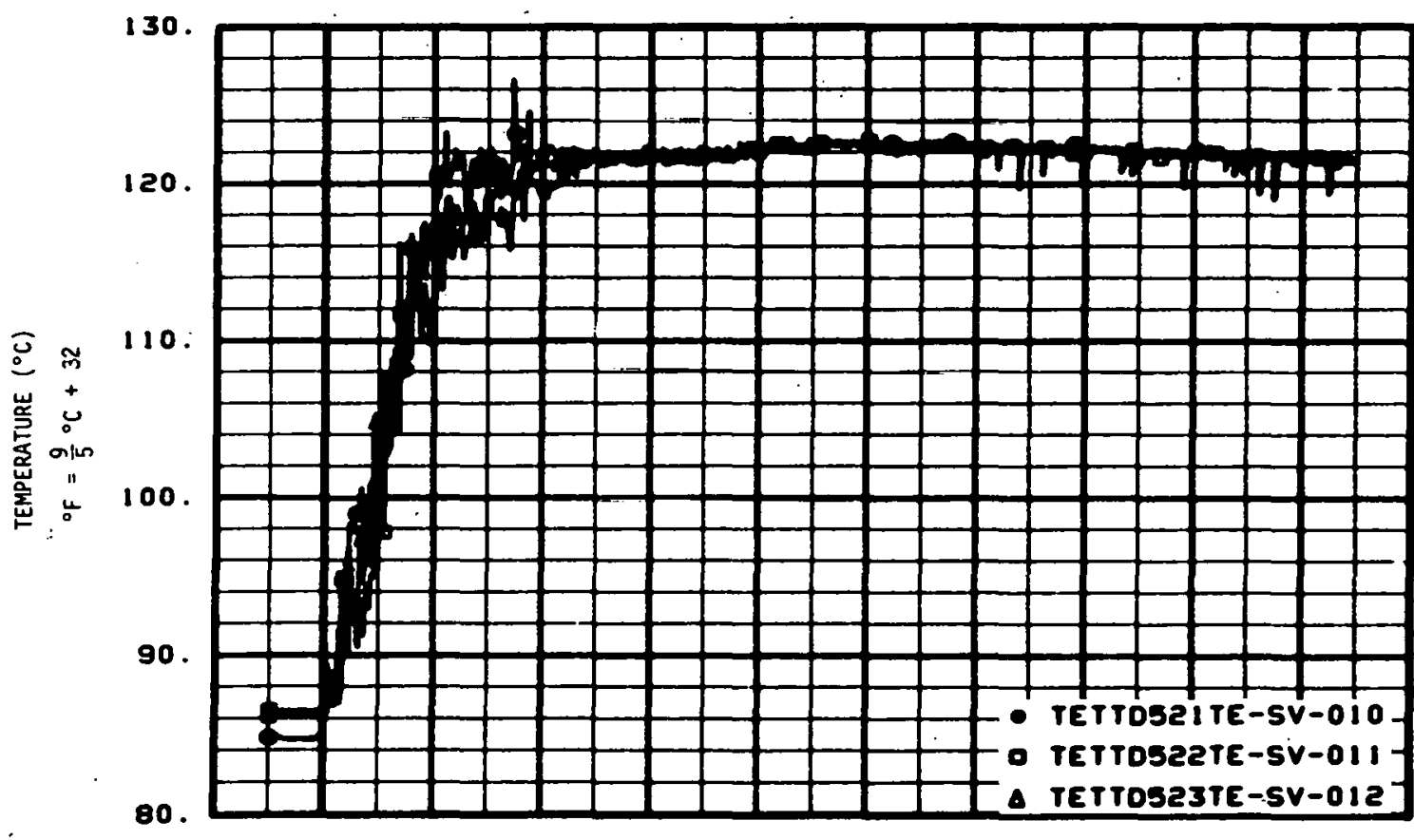

-20. 0. 20. 40. 60. 80. 100. 120. 140. 160. 180. 200. TIME AFTER RUPTURE (s)

Fig. 160 Temperature in blowdown suppression tank A-end thermocouple stalk (TE-SV-10, -11, and -12). 


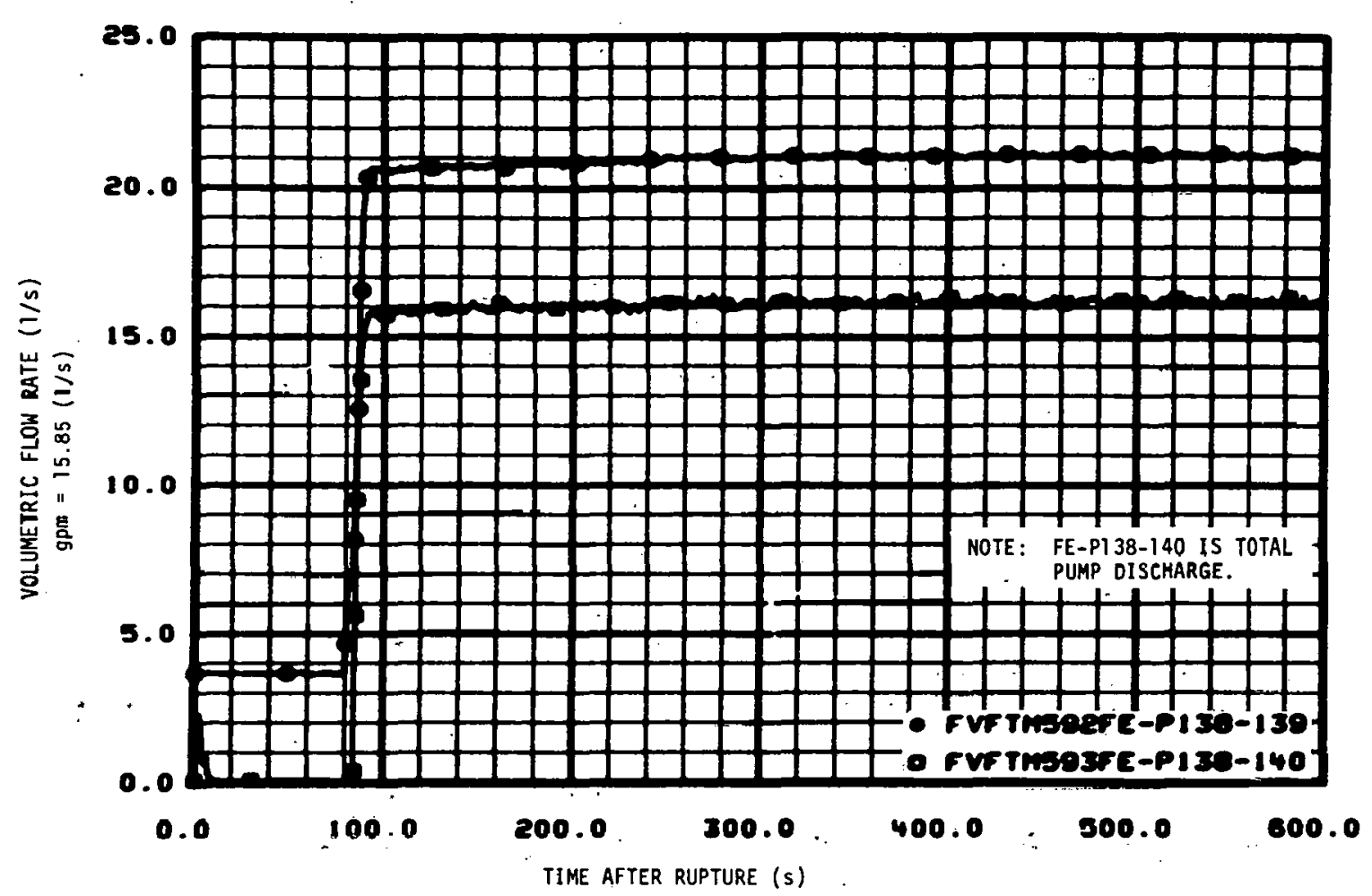

Fig. 161 Flow rate in blowdown suppression tank system pump discharge (FE-P138-139 and-140).

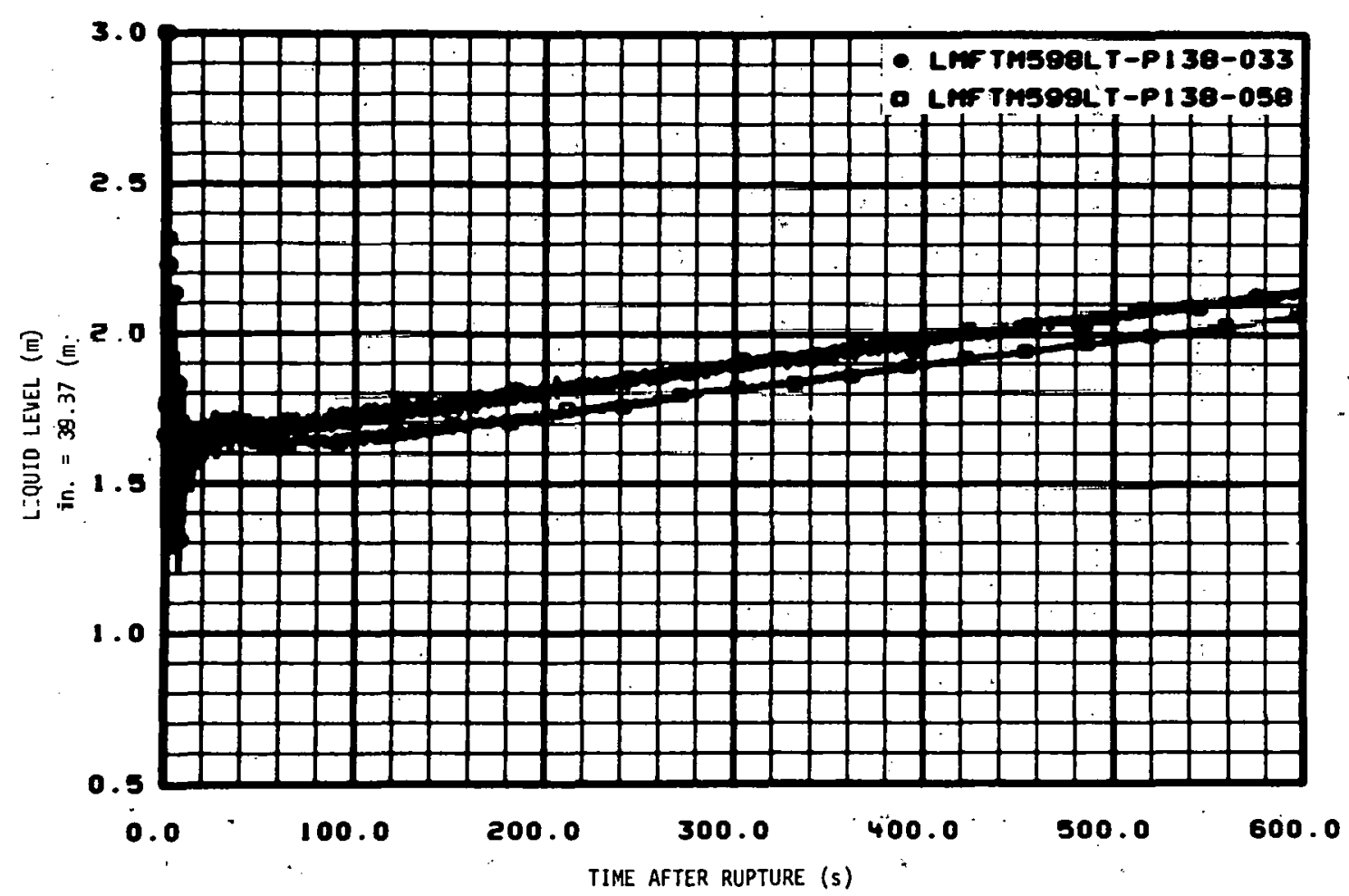

Fig. 162 Liquid level in blowdown suppression tank north and south ends (LT-P138-33 and -58). 


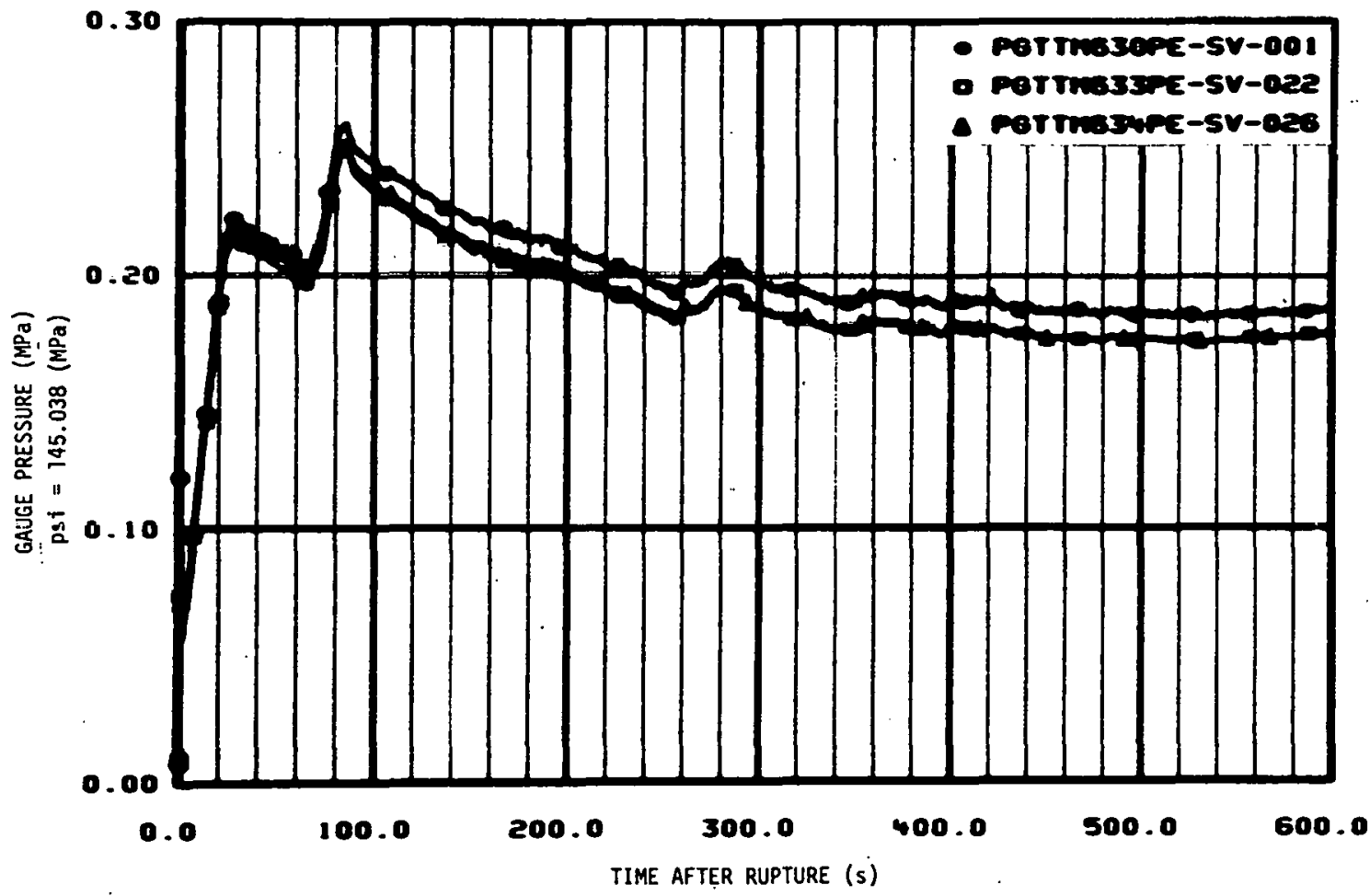

Fig. 163 Pressure in blowdown suppression tank bottom under downcomers 4 , 3 , and 2 (PE-SV-1, -22 , and -26$)$.

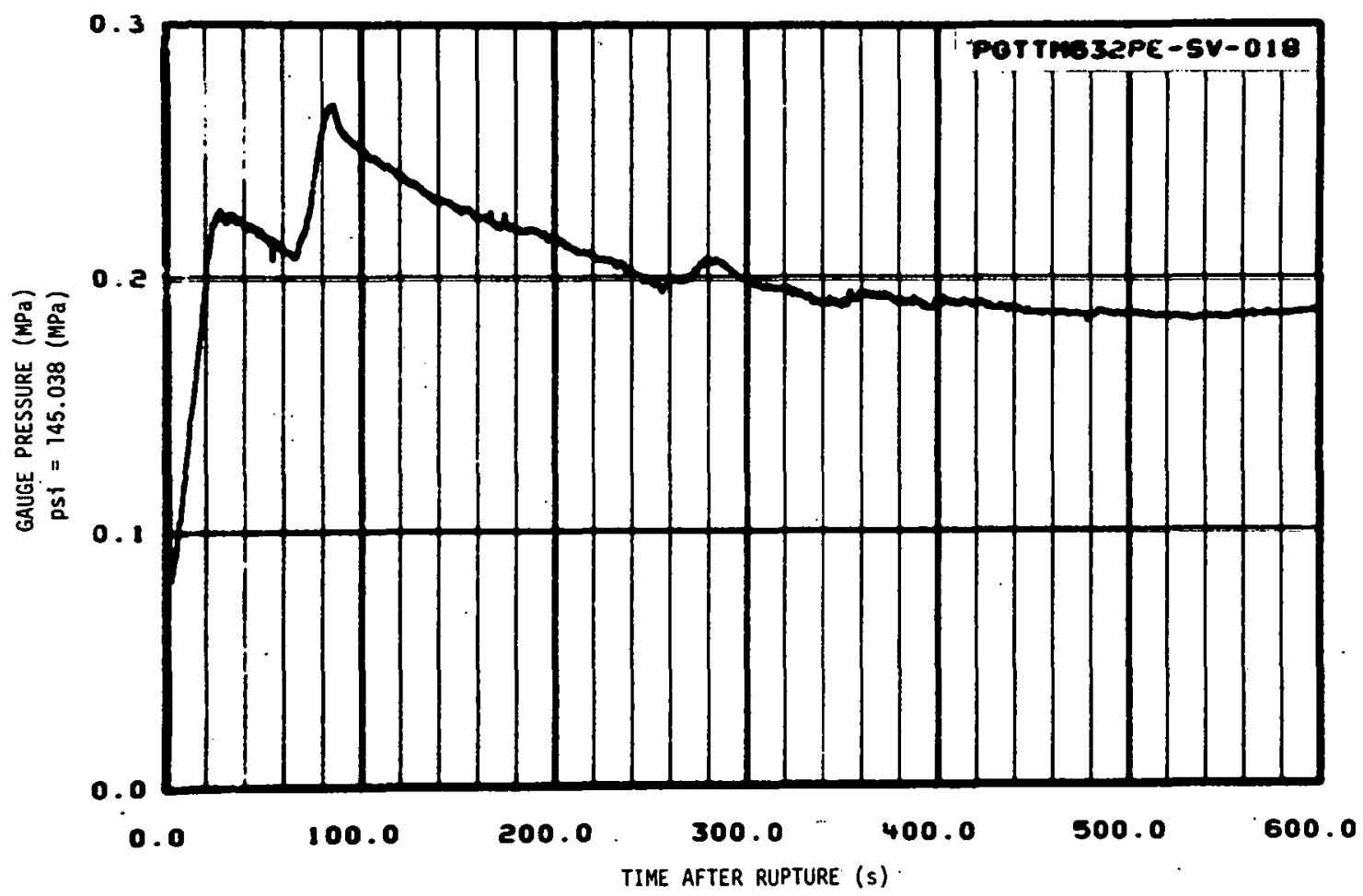

Fig. 164 Pressure in blowdown suppression tank header above downcomer 1 (PE-SV-18). 


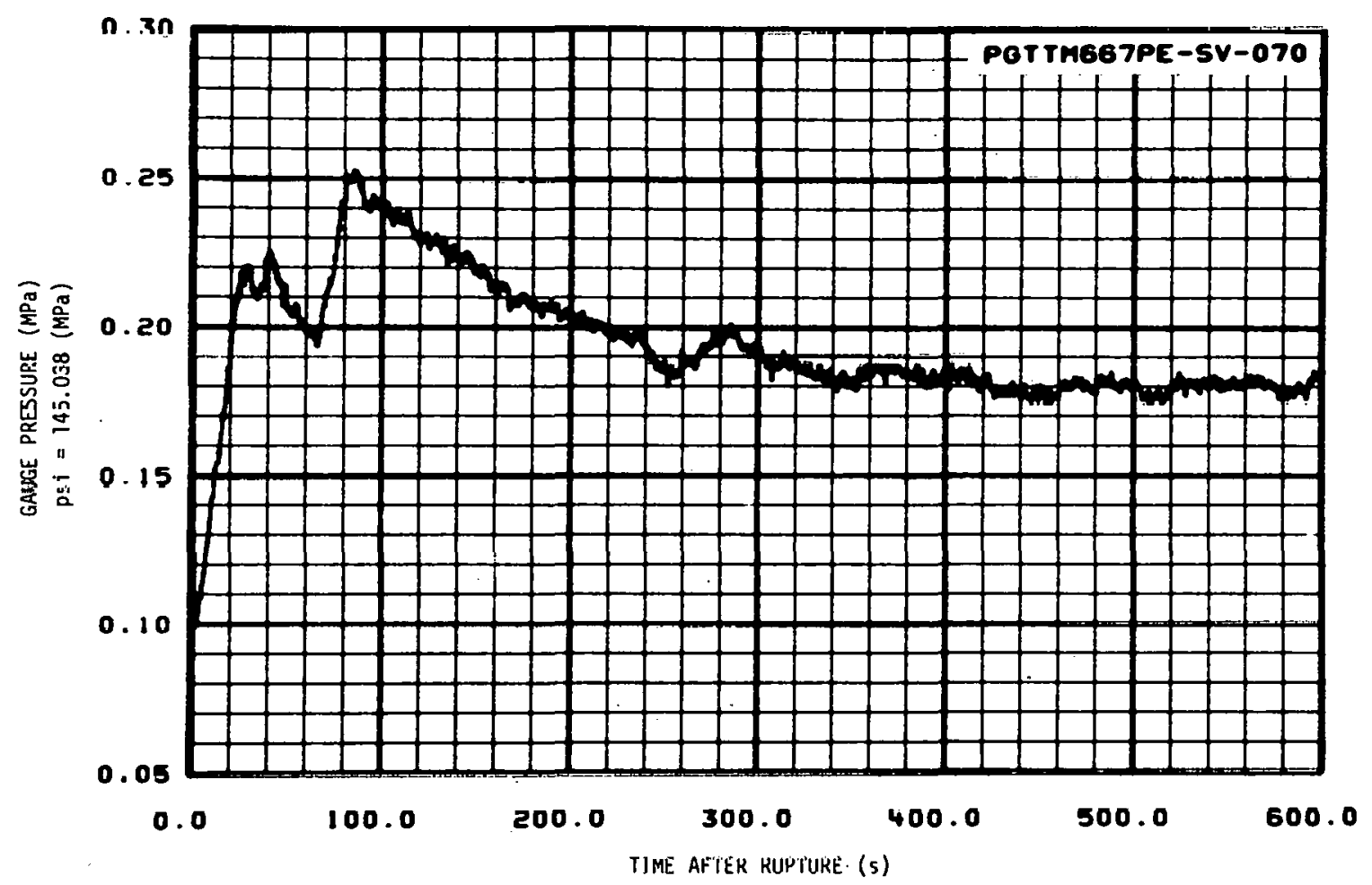

Fig. 165 Pressure in blowdown suppression tank bellows at header to test assembly (PE-SV-70).

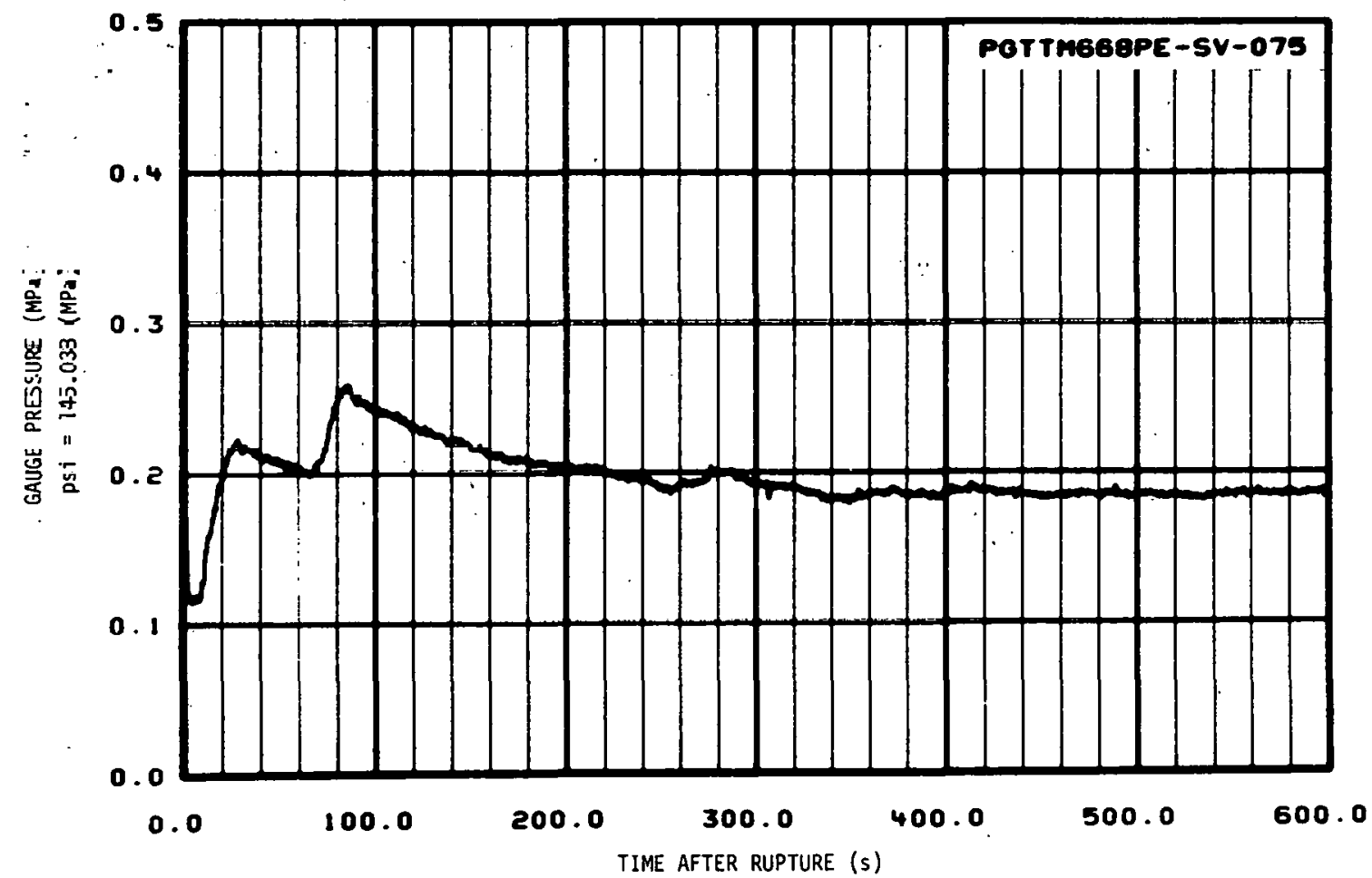

Fig. 166 Pressure in blowdown suppression tank header (PE-SV-75). 


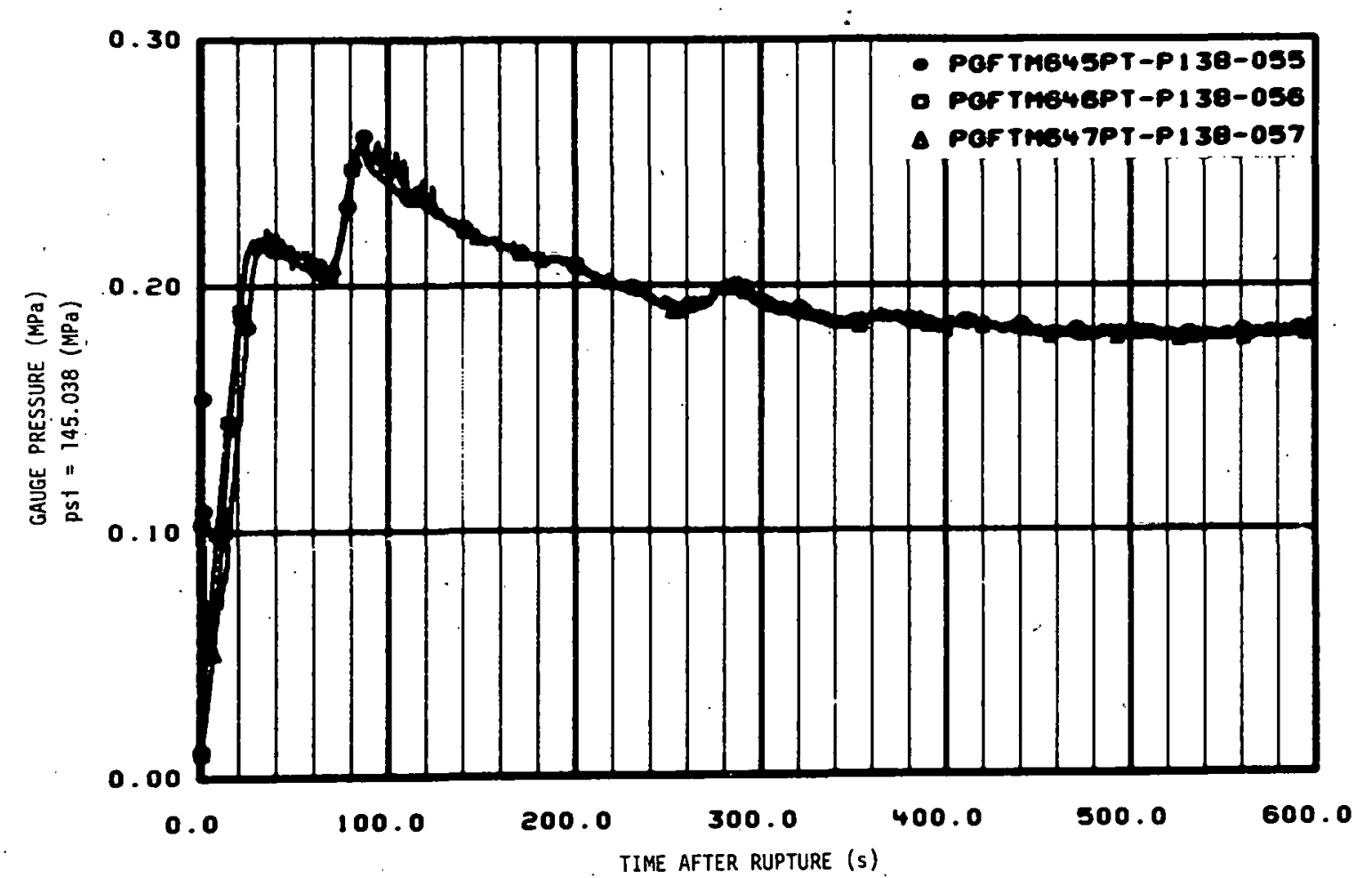

Fig. 167 Pressure in blowdown suppression tank top (PT-P138-55, -56, and -57$)$.

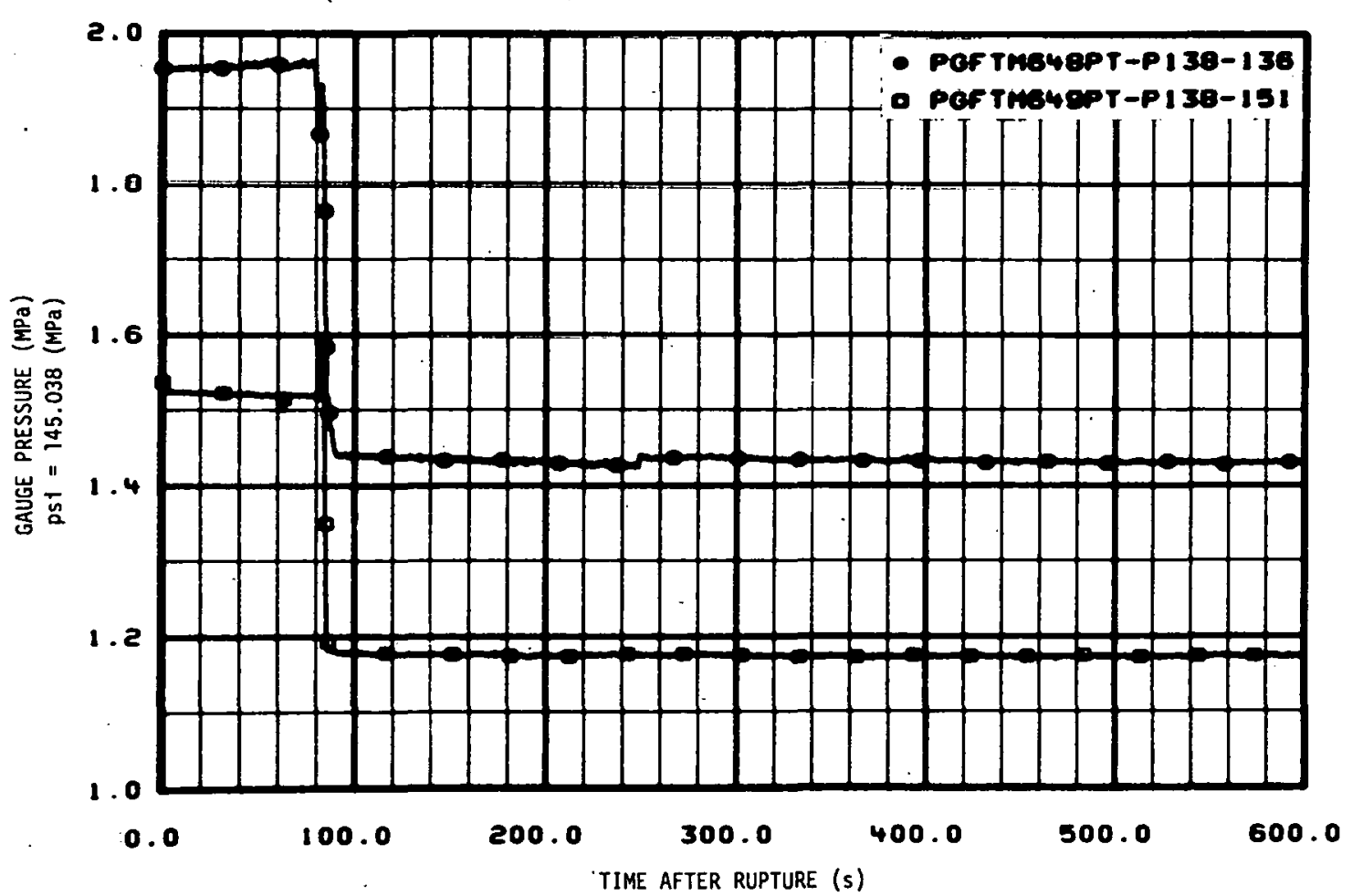

Fig. 168 Pressure in blowdown suppression tank spray pump BS-P-83 discharge and at heat exchanger BS-H-32 tube side (PT-P138-136. and -151$)$. 


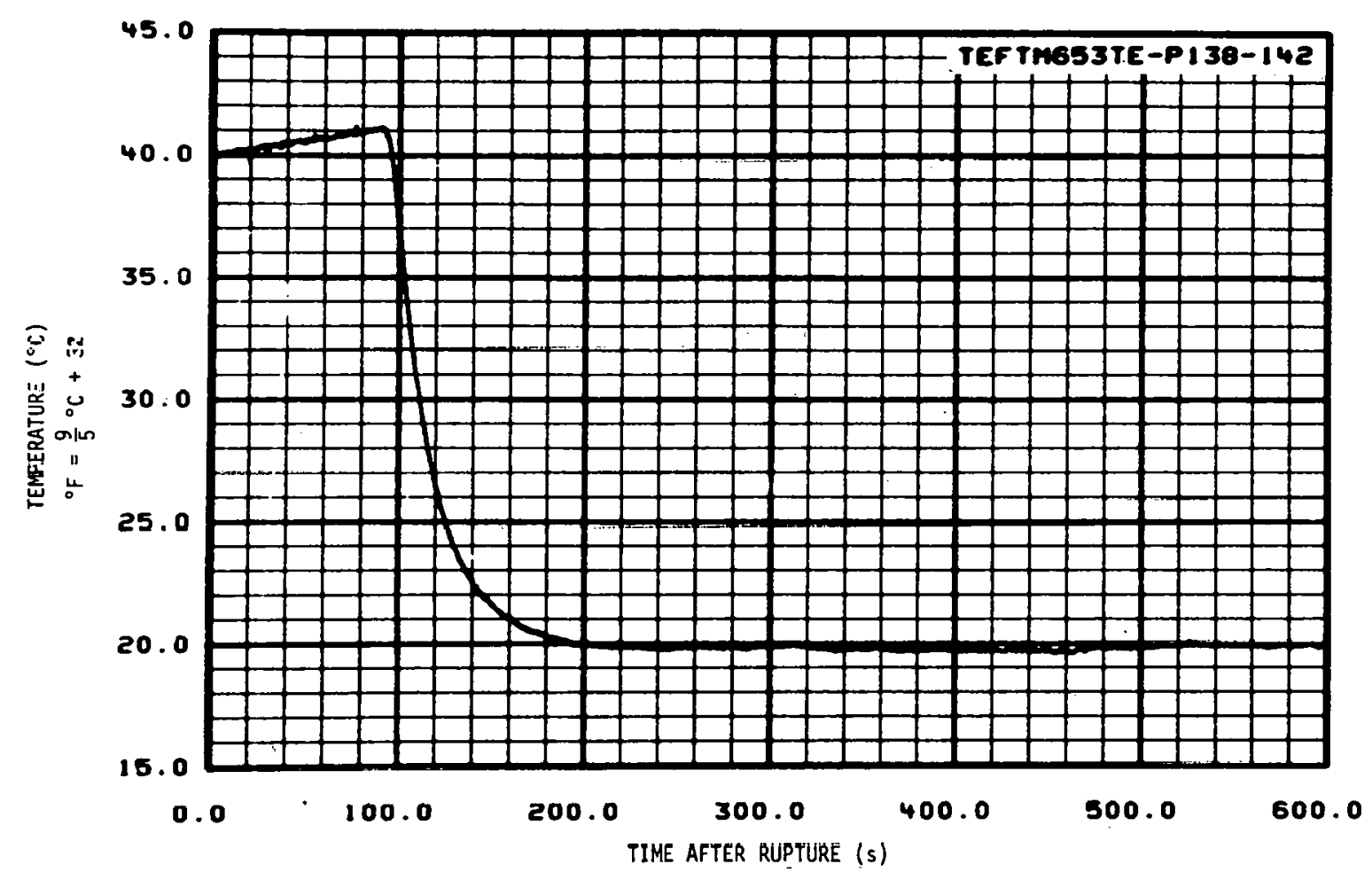

Fig. 169 Temperature in blowdown suppression tank spray pump discharge (TE-P138-142).

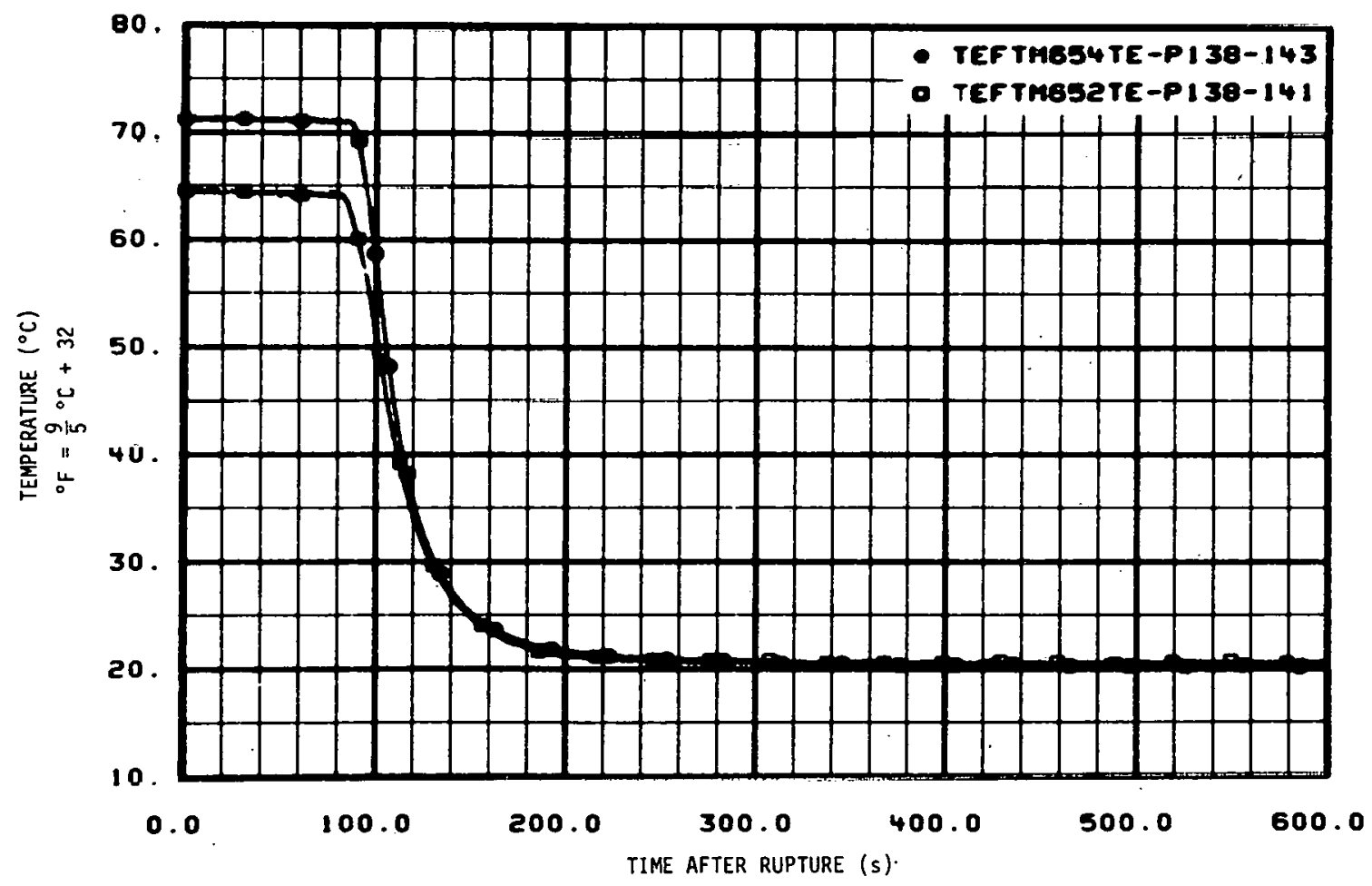

Fig. 170 Temperature of 1 iquid at $3.79 \mathrm{l} / \mathrm{s}$ and $13.881 / \mathrm{s}$ spray headers (TE-P138-141 and -143). 


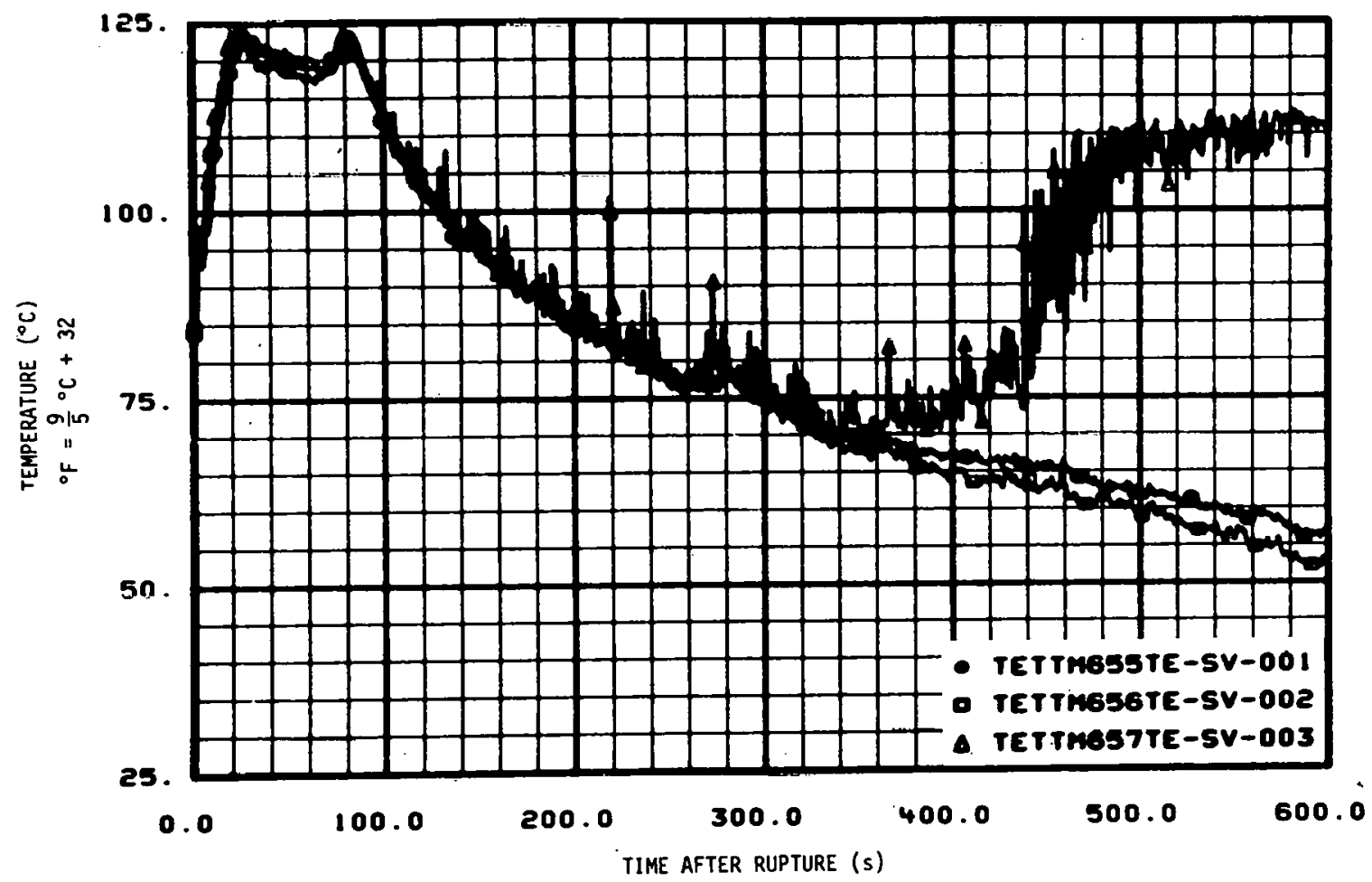

Fig. 171 Temperature in blowdown suppression tank $B$-end thermocouple stalk 1 (TE-SV-1, -2 , and -3).

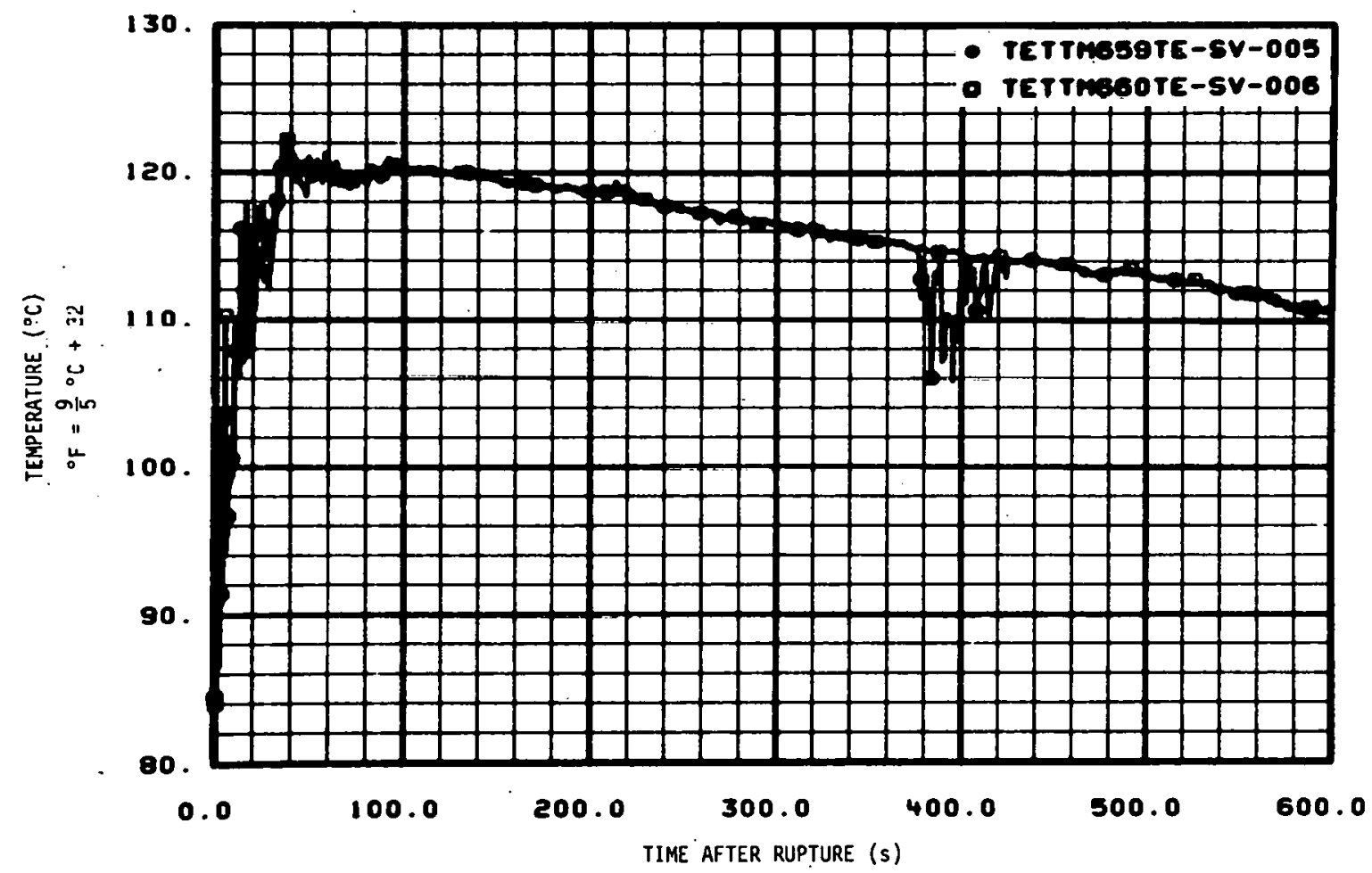

Fig. 172 Temperature in blowdown suppression tank B-end thermocouple stalk 1 (TE-SV-5 and -6). 


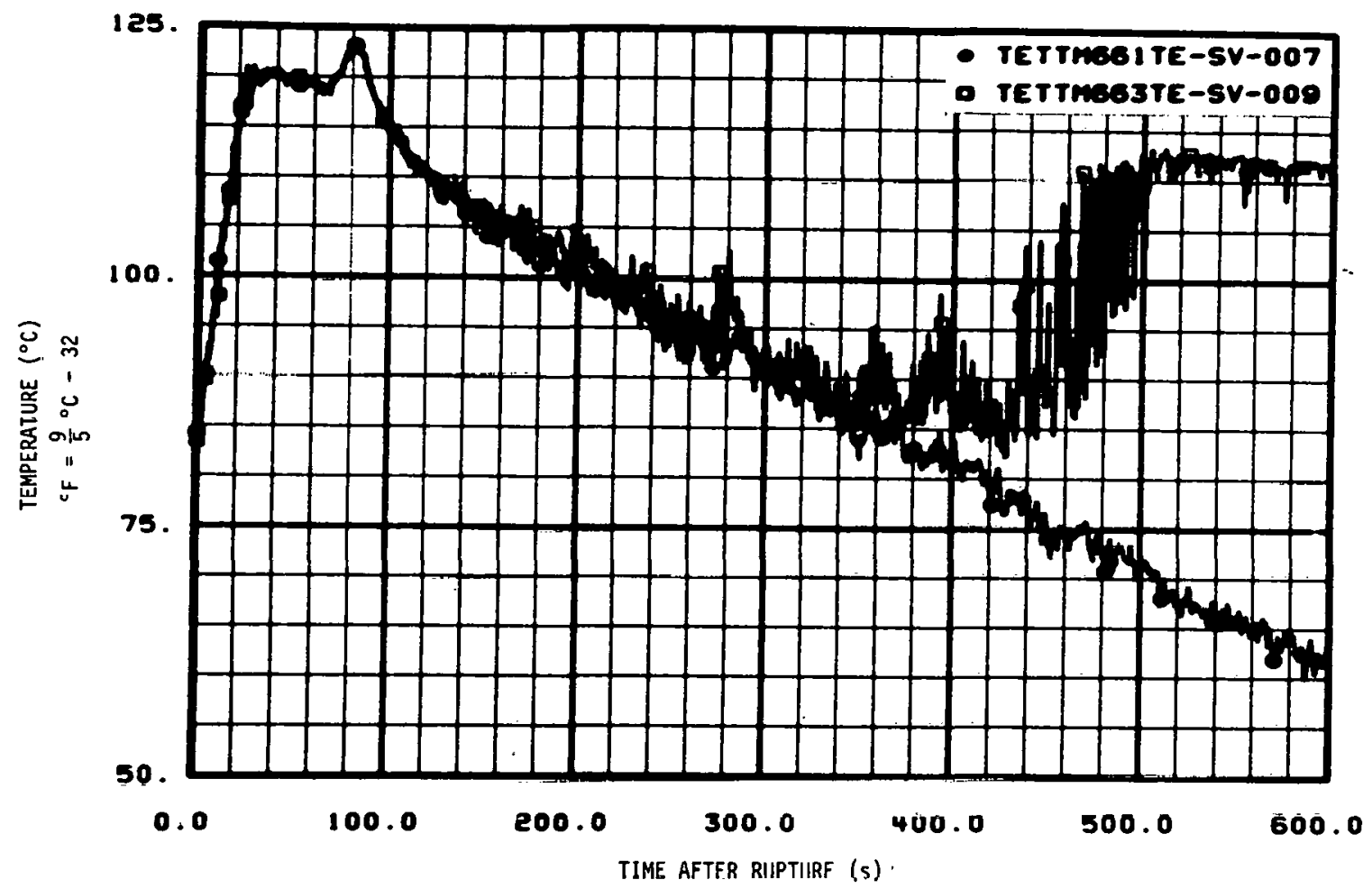

rig. 173 Teilperature in blowdown suppression tank A-end thermocouple stalk 2 (TE-SV-7 and -9).

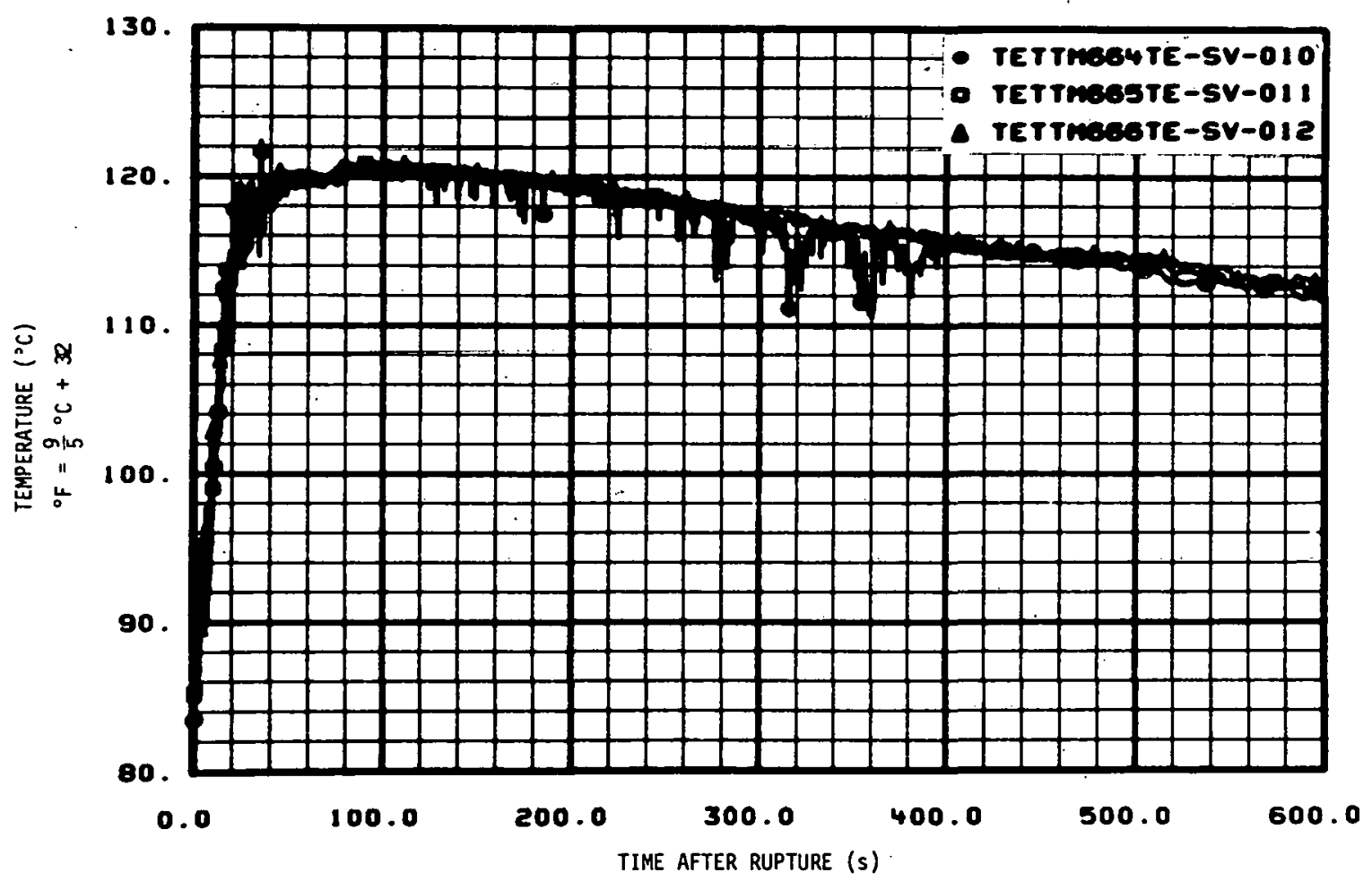

Fig. 174 Temperature in blowdown suppression tank A-end thermocouple stalk 2 (TE-SV-10, -11, and -12). 


\section{TEST L $1-4$ COMPUTED PARAMETERS}

This section of presented data consists of Figures 175 through 2.31. 


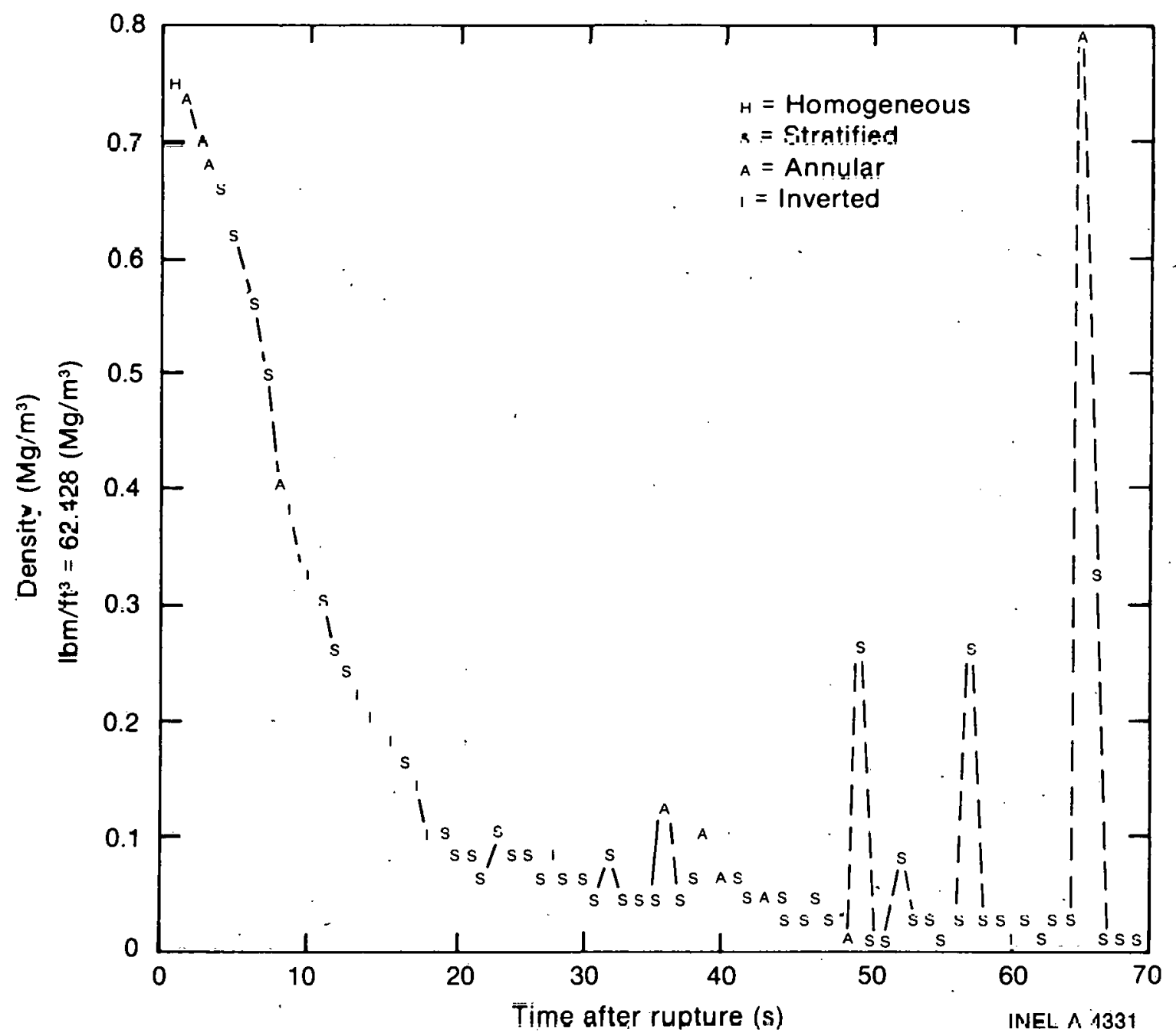

Fig. 175 Flow regime and average density in broken loop cold leg. 


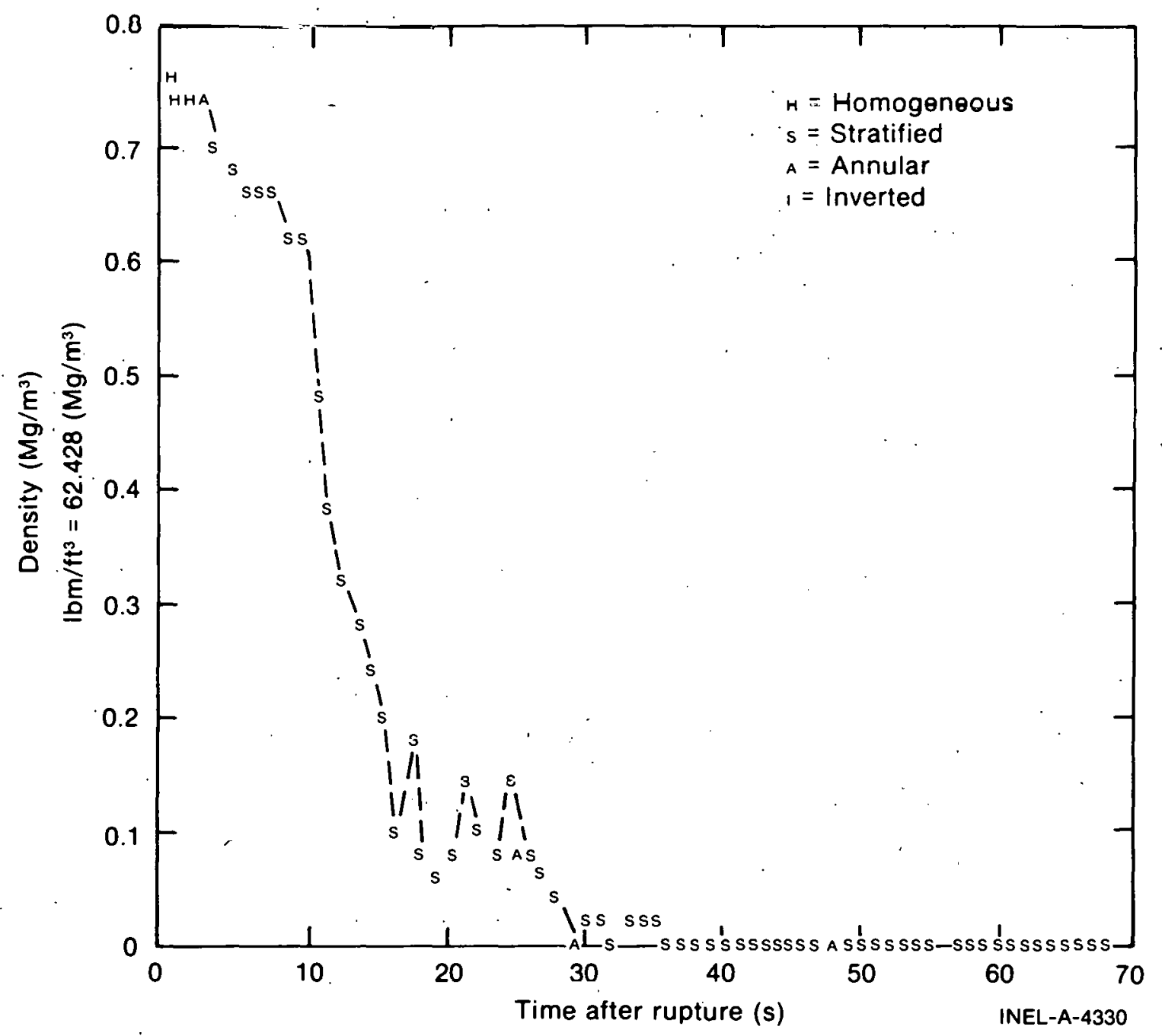

Fig. 176 Flow regime and average density in broken loop hot leg. 


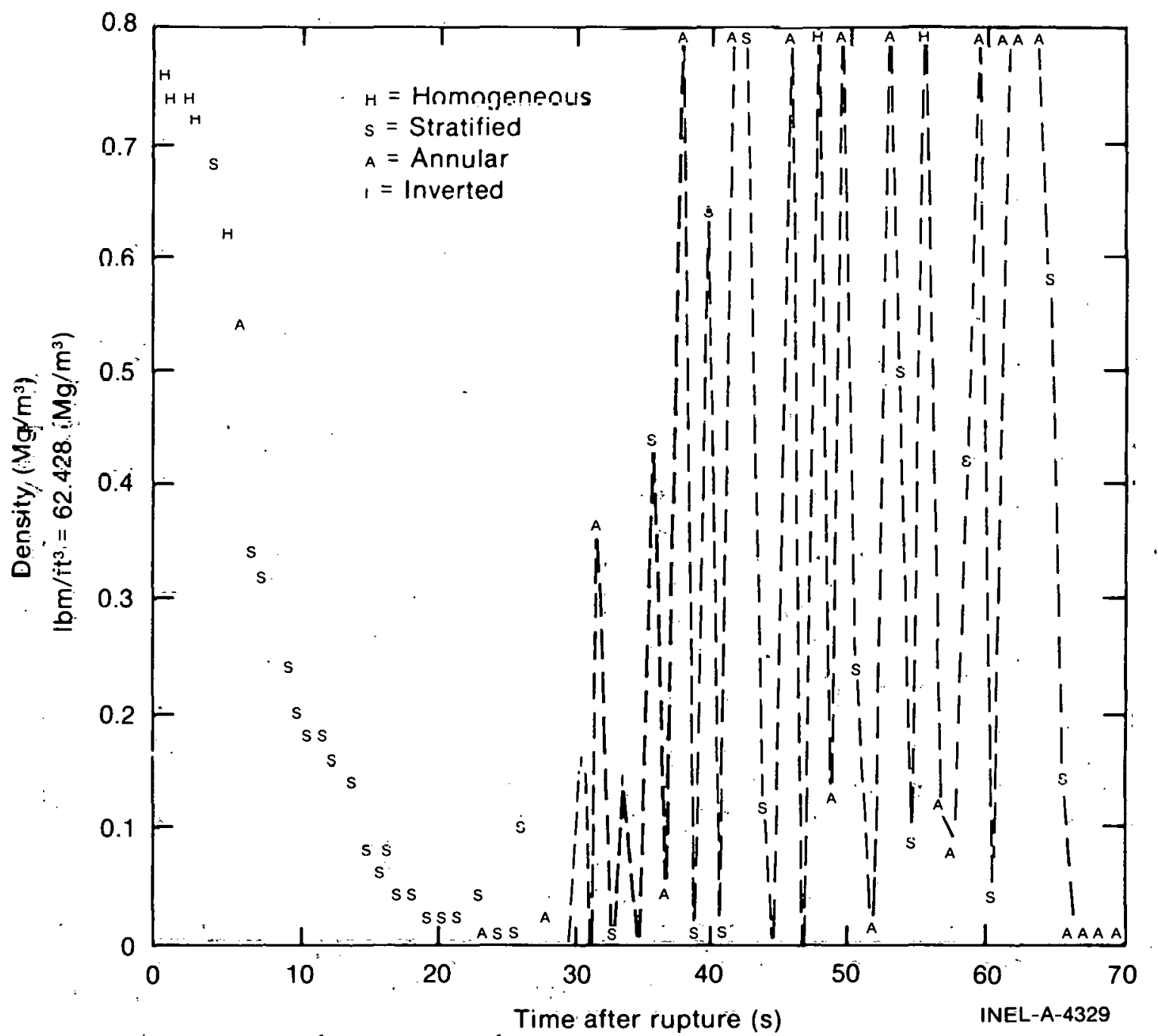

Fig. 177 Flow régime and average density in intact loop cold leg. 


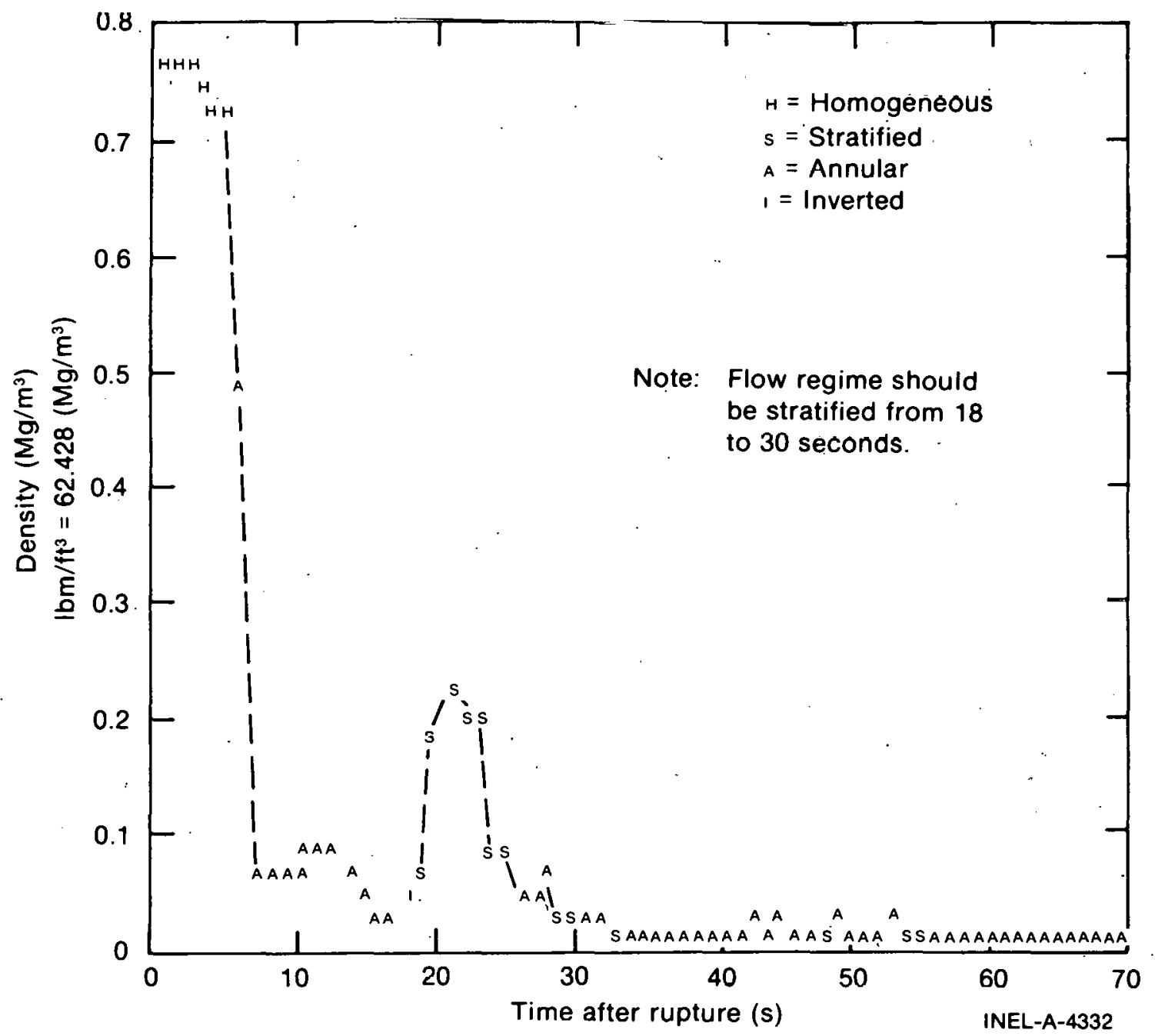

Fig. 178 Flow regime and average density in intact loop hot leg. 


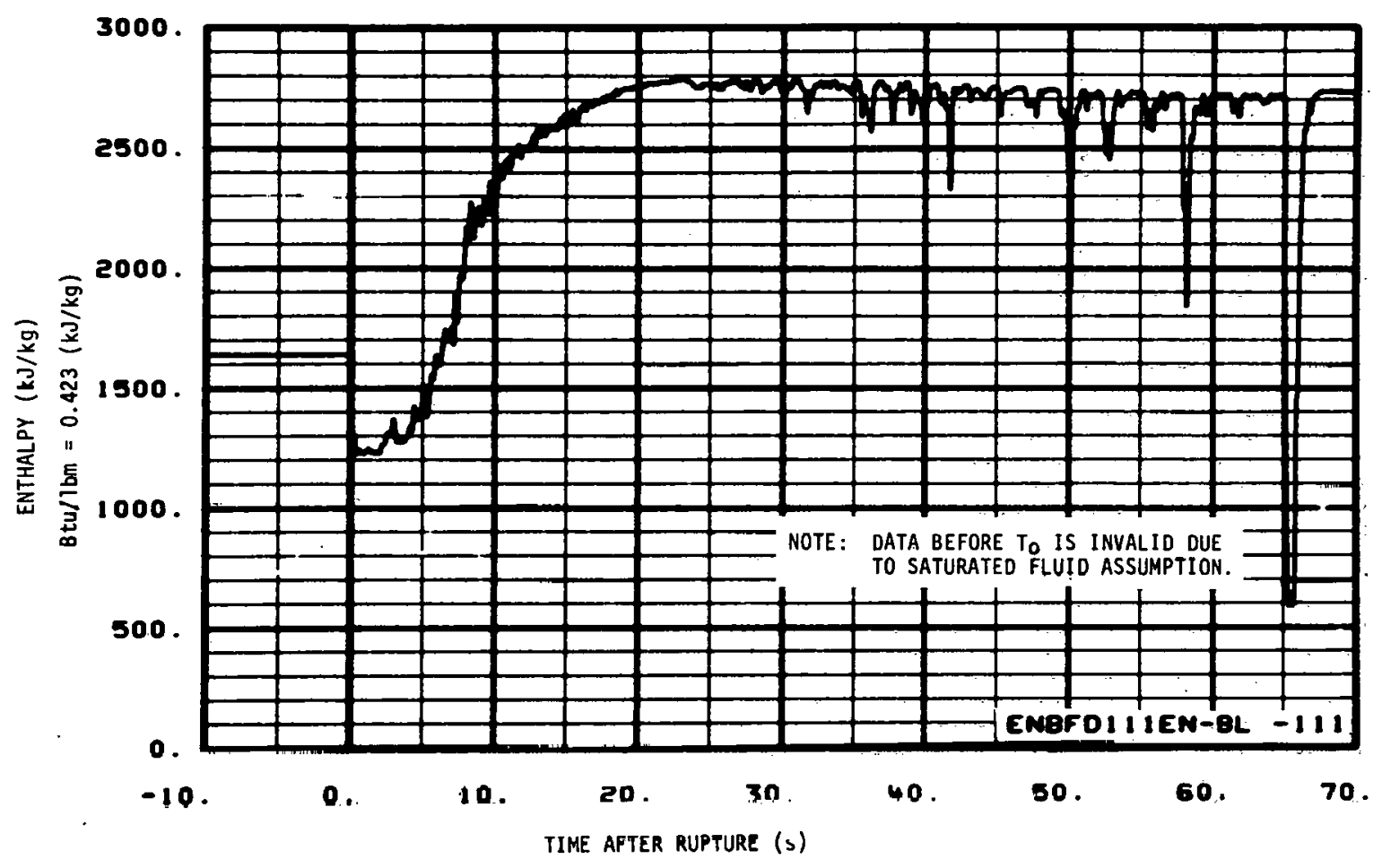

Fig. 179 Enthalpy in broken loop cold leg.

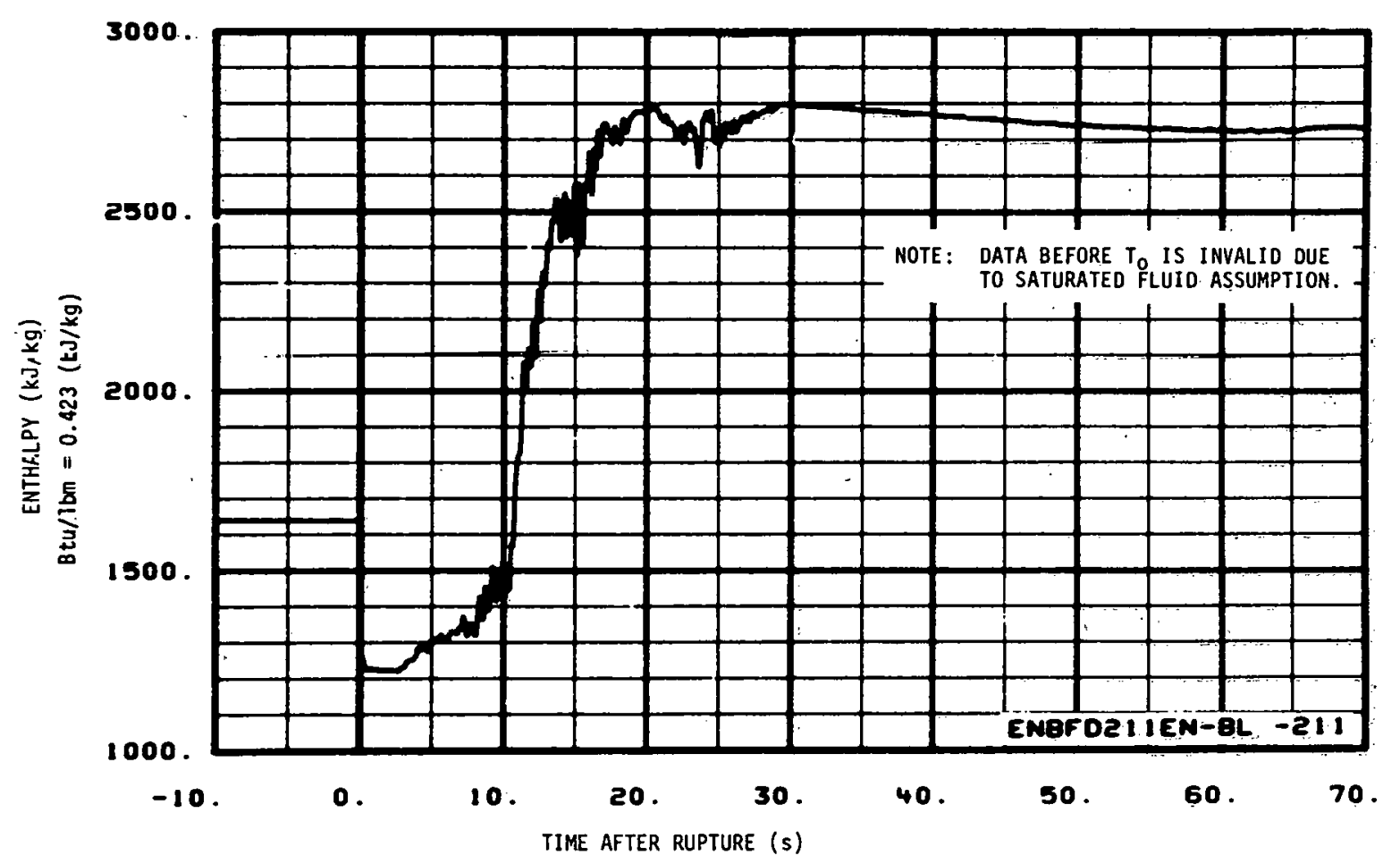

Fig. 180 Enthalpy in broken loop hot leg. 


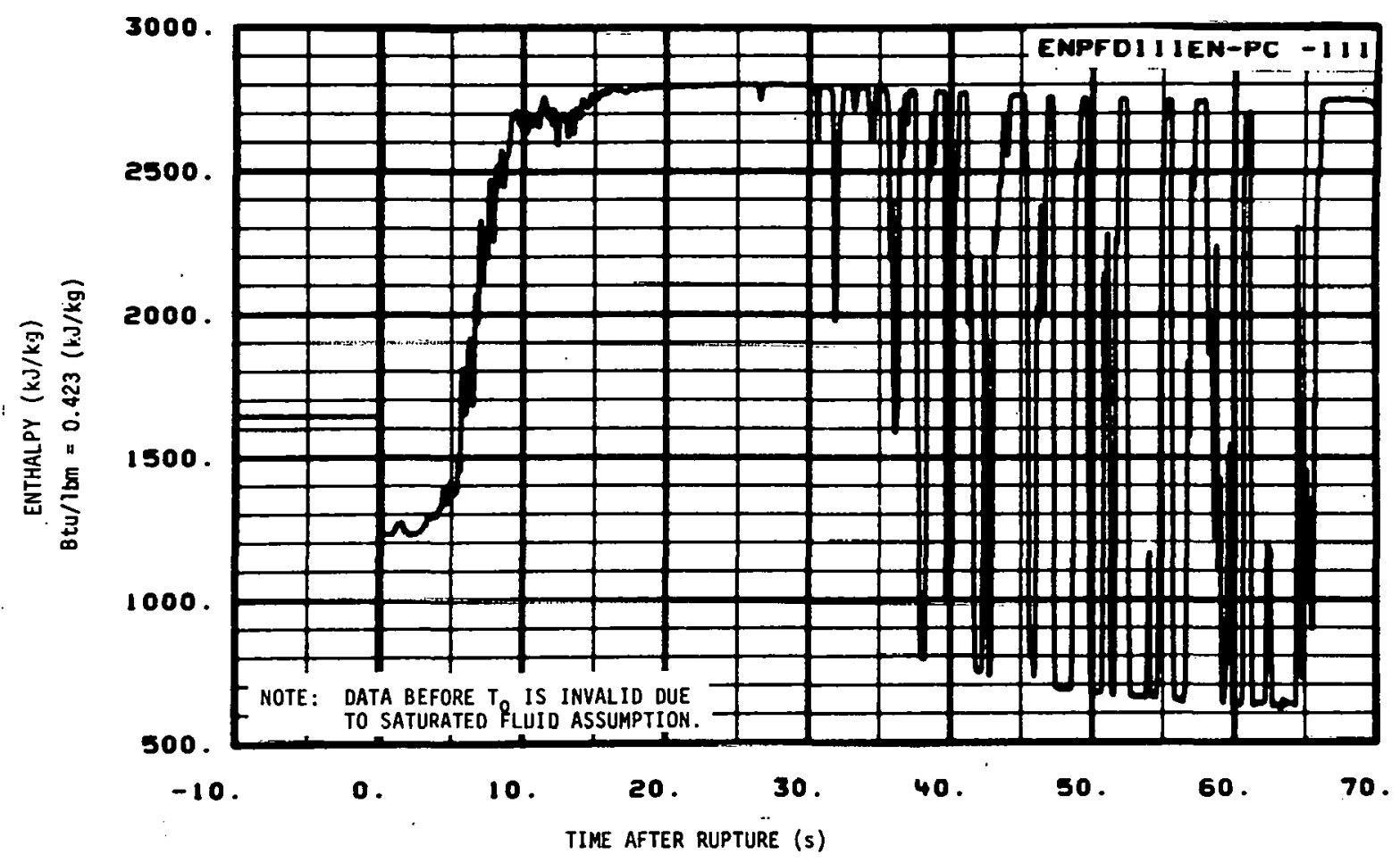

Fig. 181 Enthalpy in intact loop cold leg.

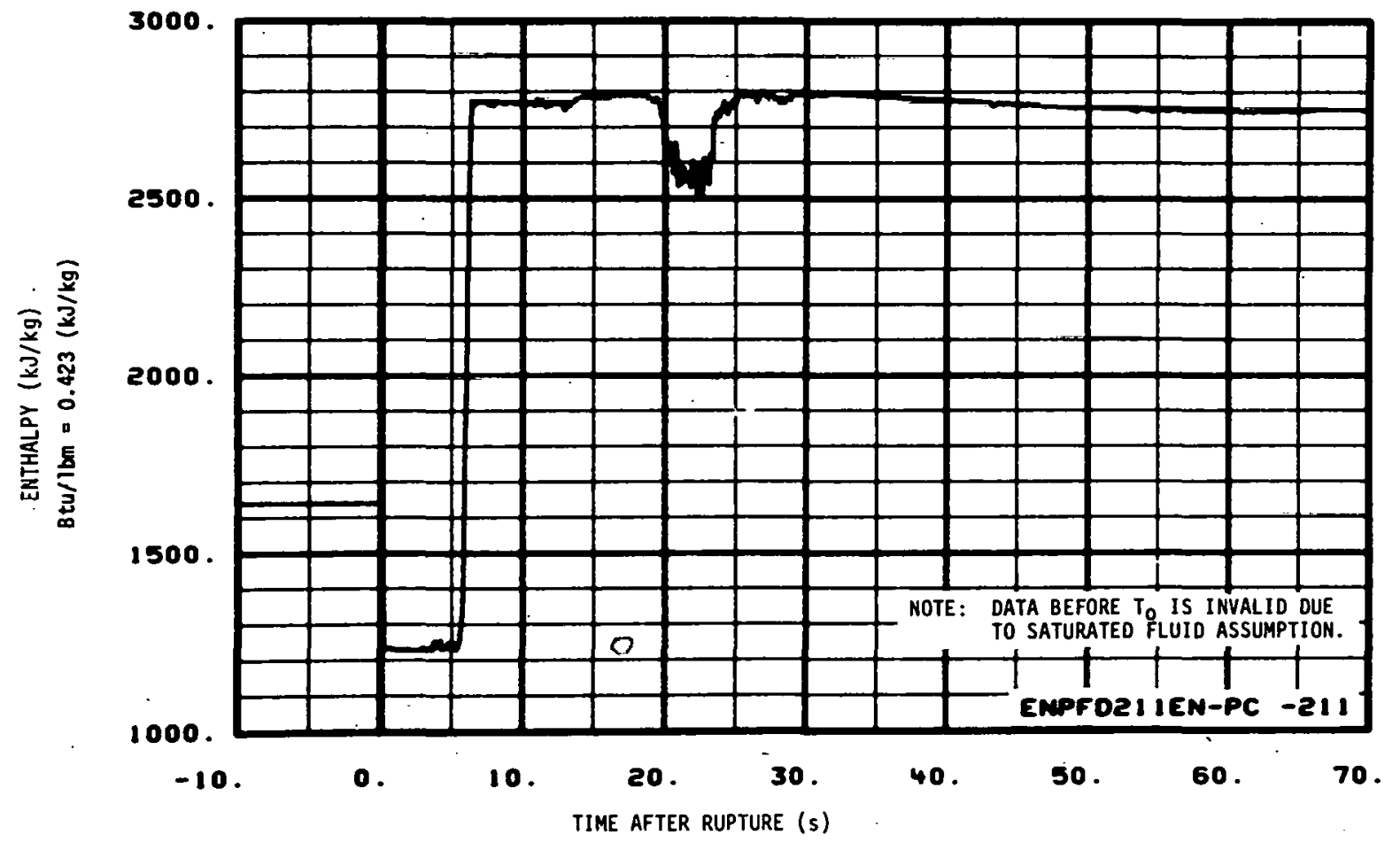

Fig. 182 Enthalpy in intact loop hot leg. 


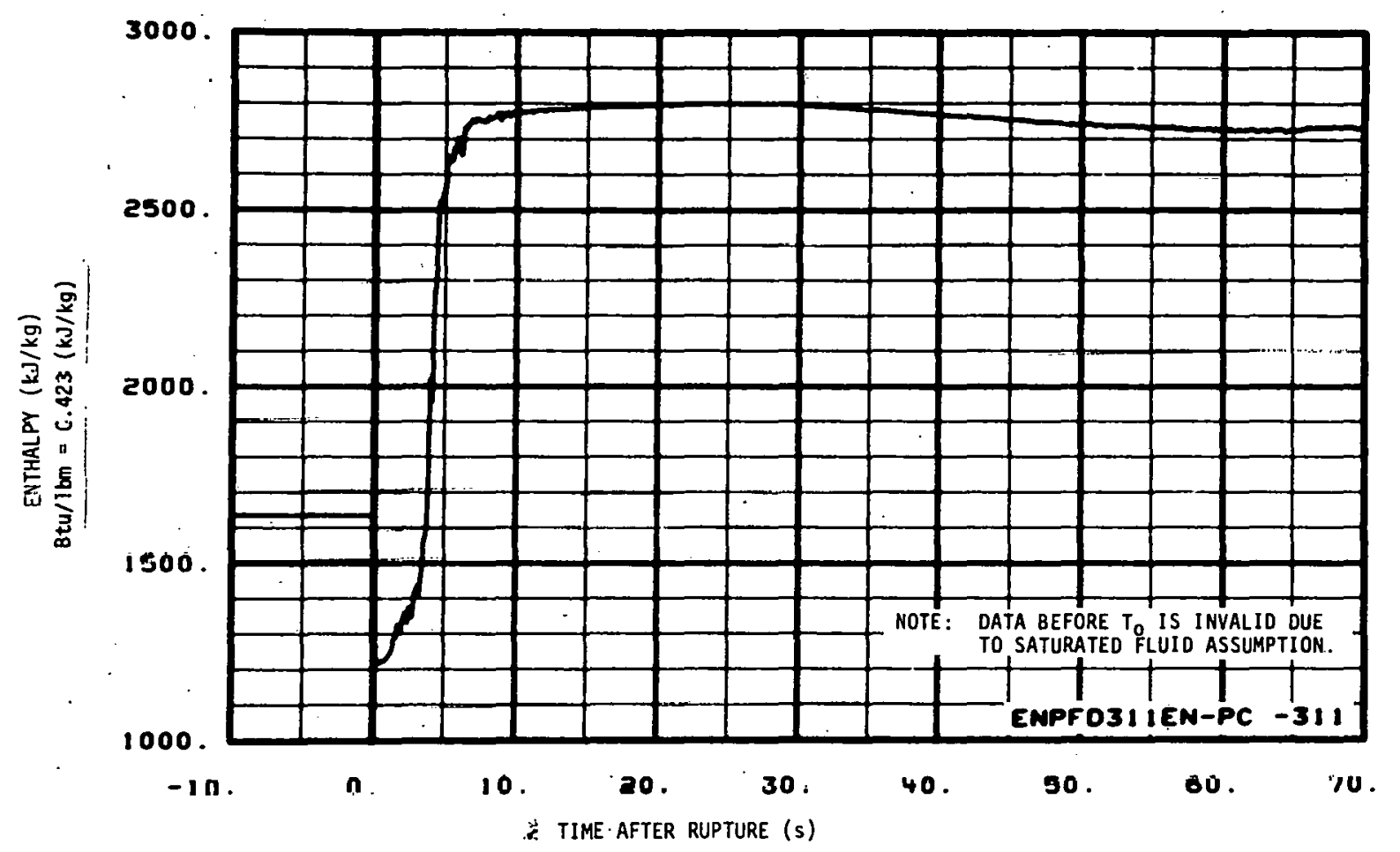

FIg. 183 Enthaipy in intact loop at steam generator nutlet.

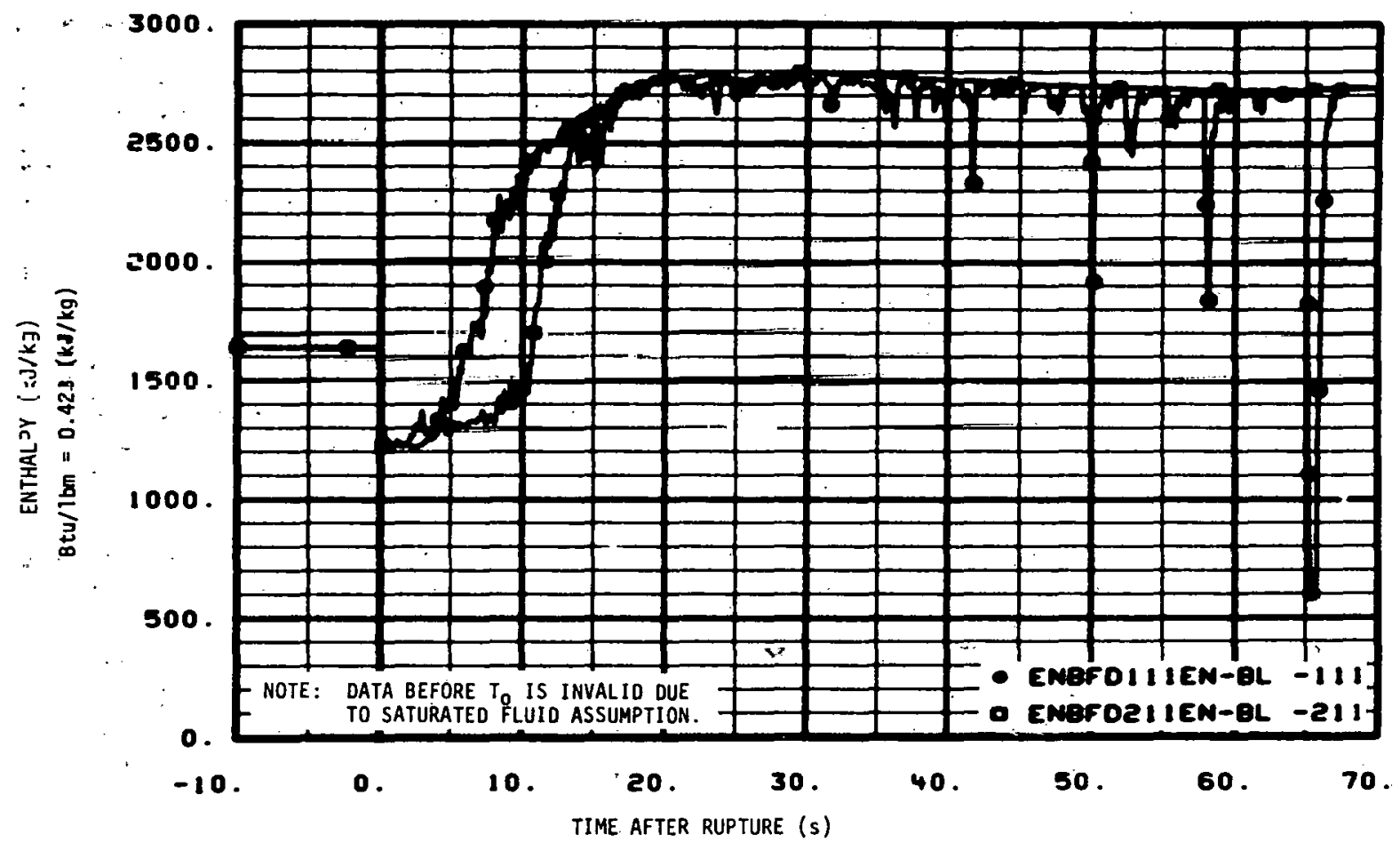

Fig. 184 Enthalpy in broken loop cold and hot legs. 


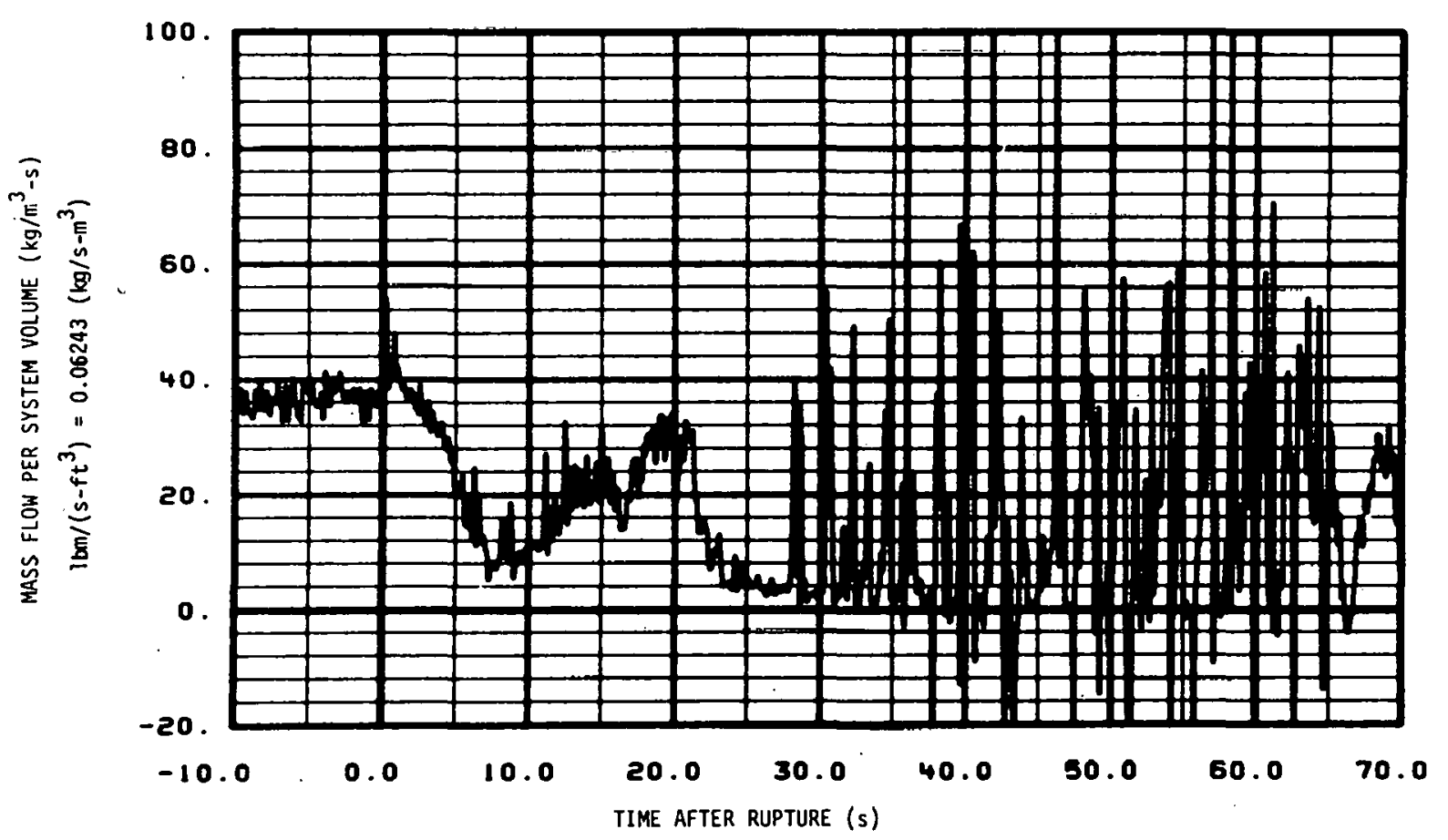

Fig. 185 Mass flow rate per system volume in intact loop cold leg calculated from FE-PC-1 and ME-PC- 1 .

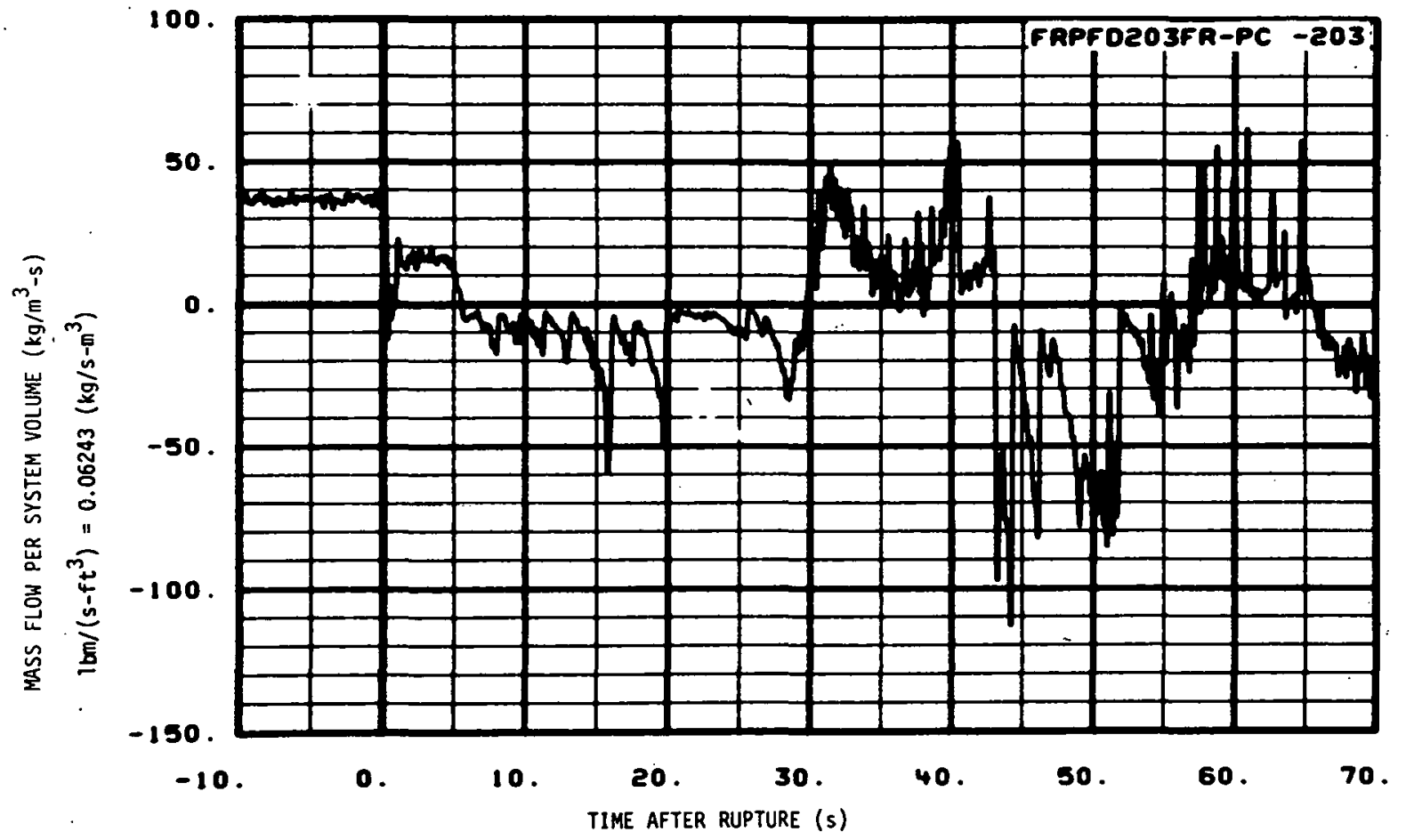

Fig. 186 Mass flow rate per system volume in intact loop hot leg calculated from FE-PC-2 and ME-PC-2. 


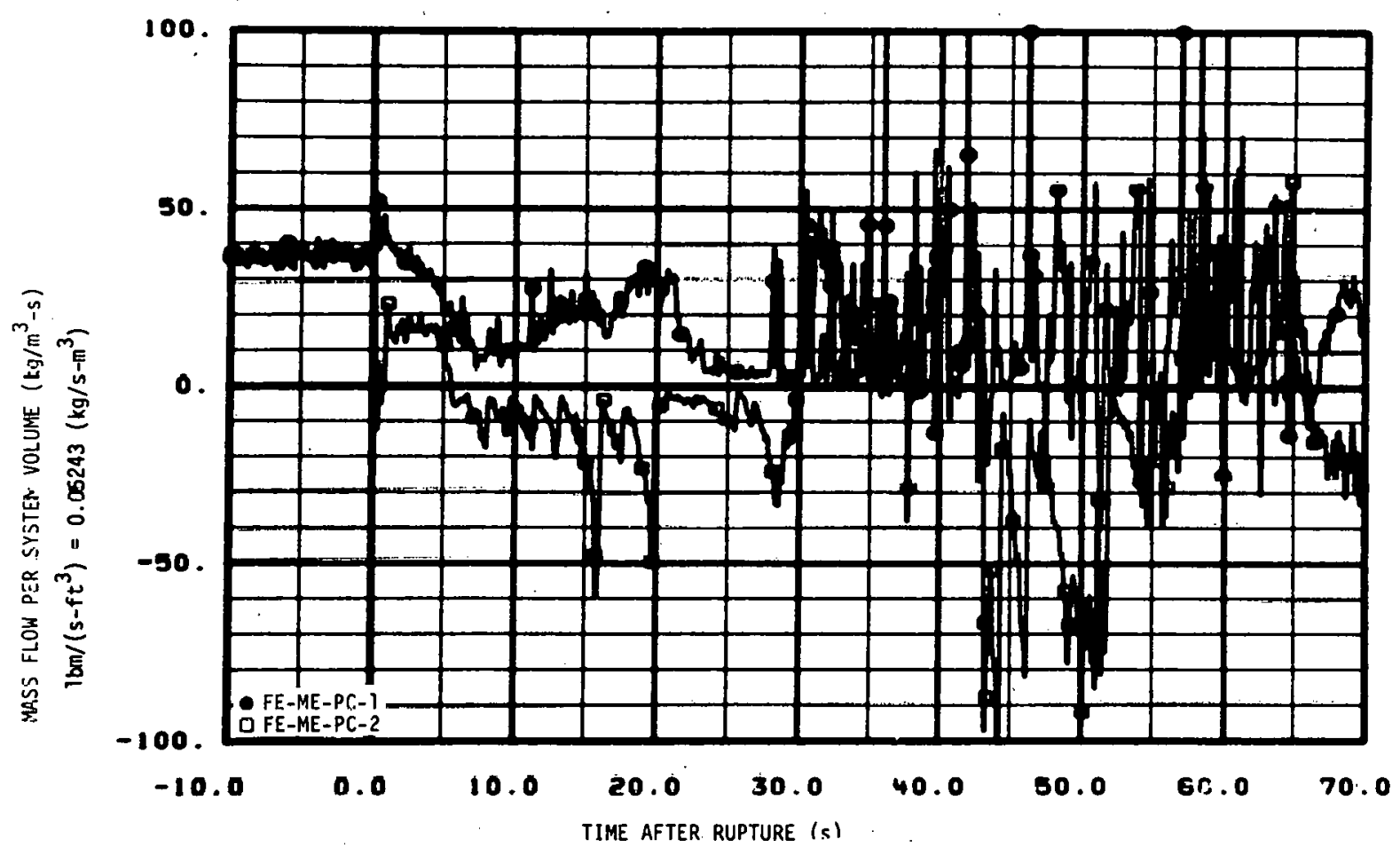

Fig. 187 Mass flow rate per system volume in intact loop cold and hot legs calculated from $\mathrm{FE}$ and ME.

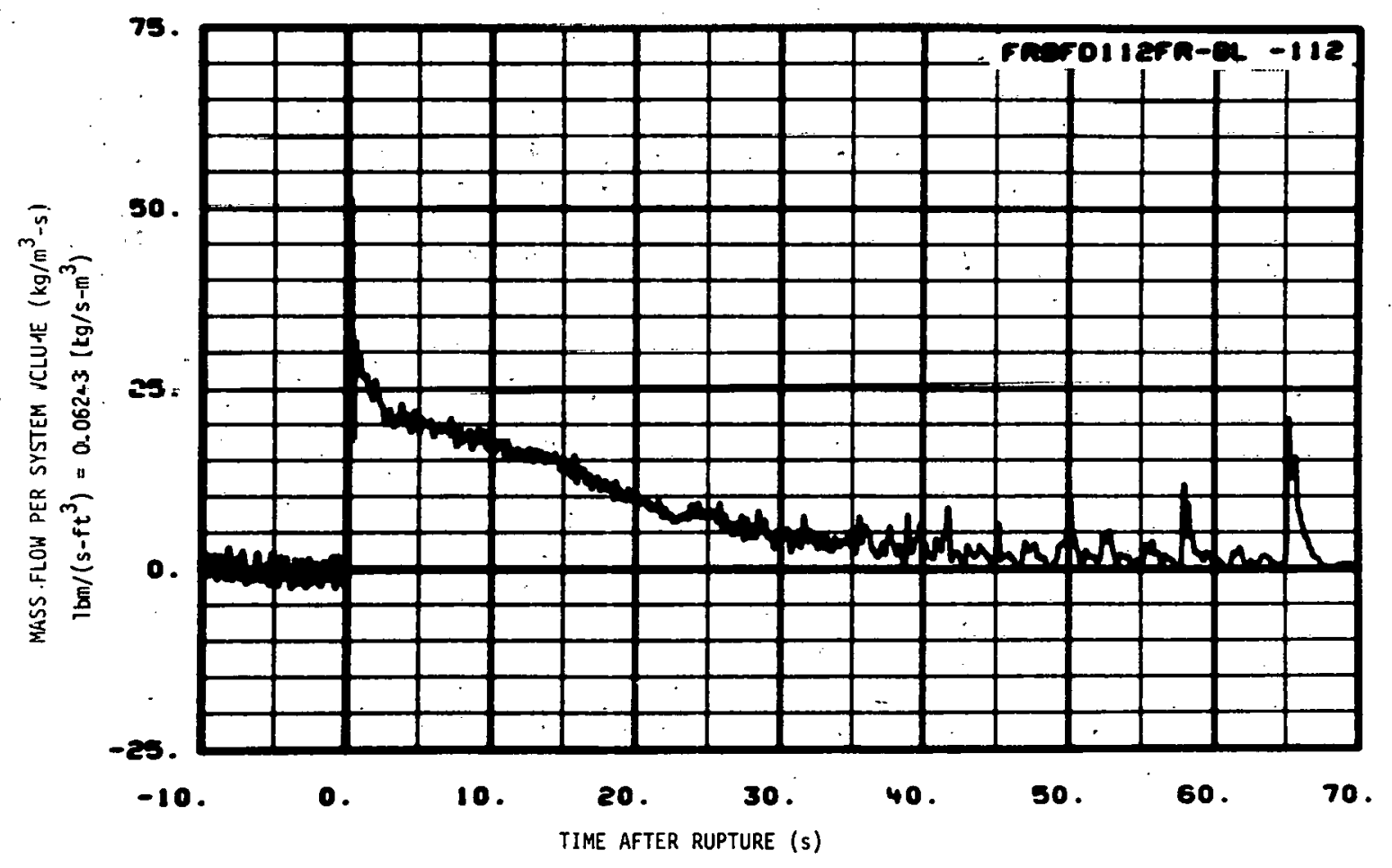

Fig. 188 Mass flow rate per system volume in. broken loop cold leg calculated from $D E-B L-1$ and $M E-B L-1$. 


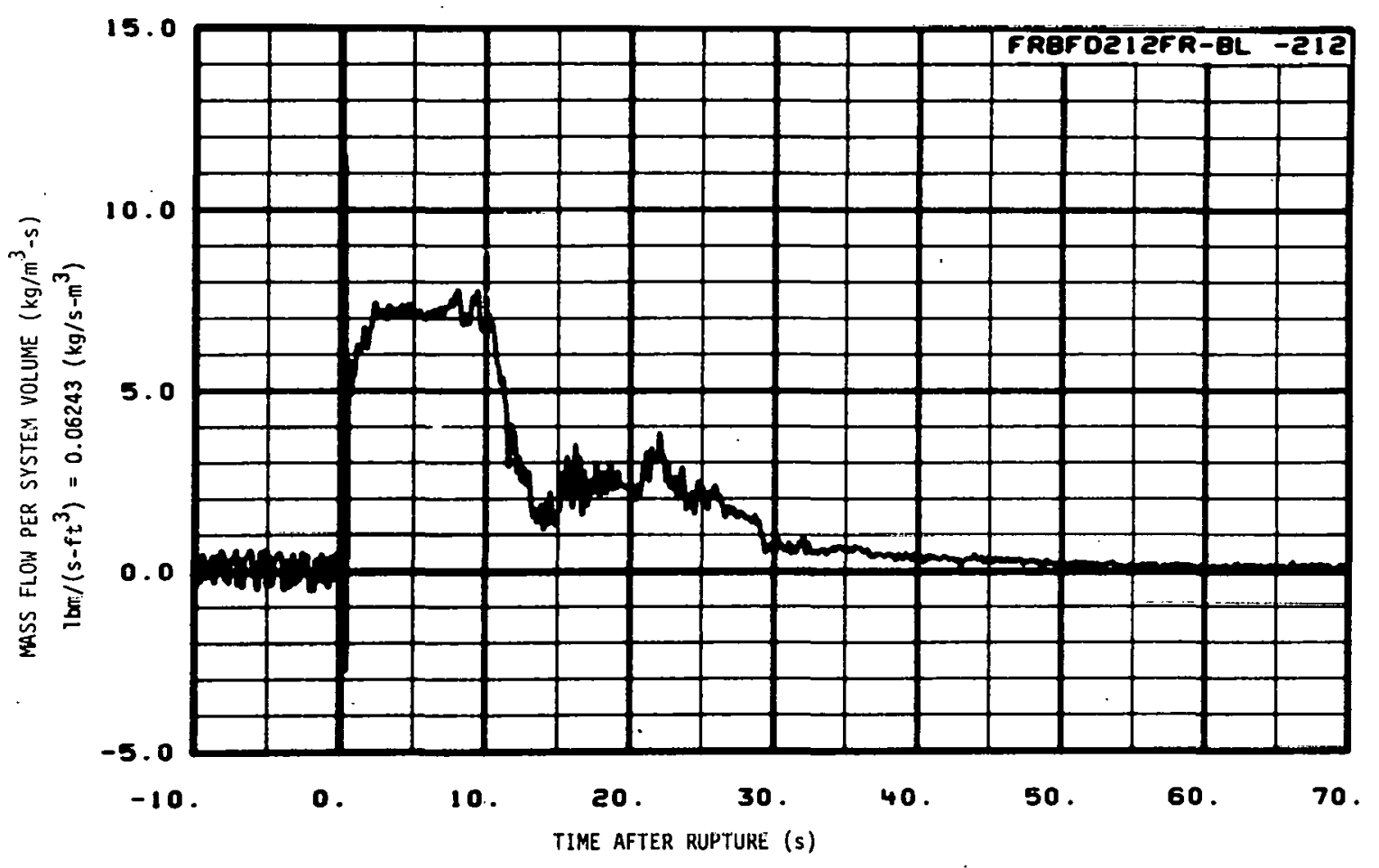

Fig. 189 Mass flow rate per system volume in broken loop hot leg calculated from DE-BL-2 and ME-BL-2.

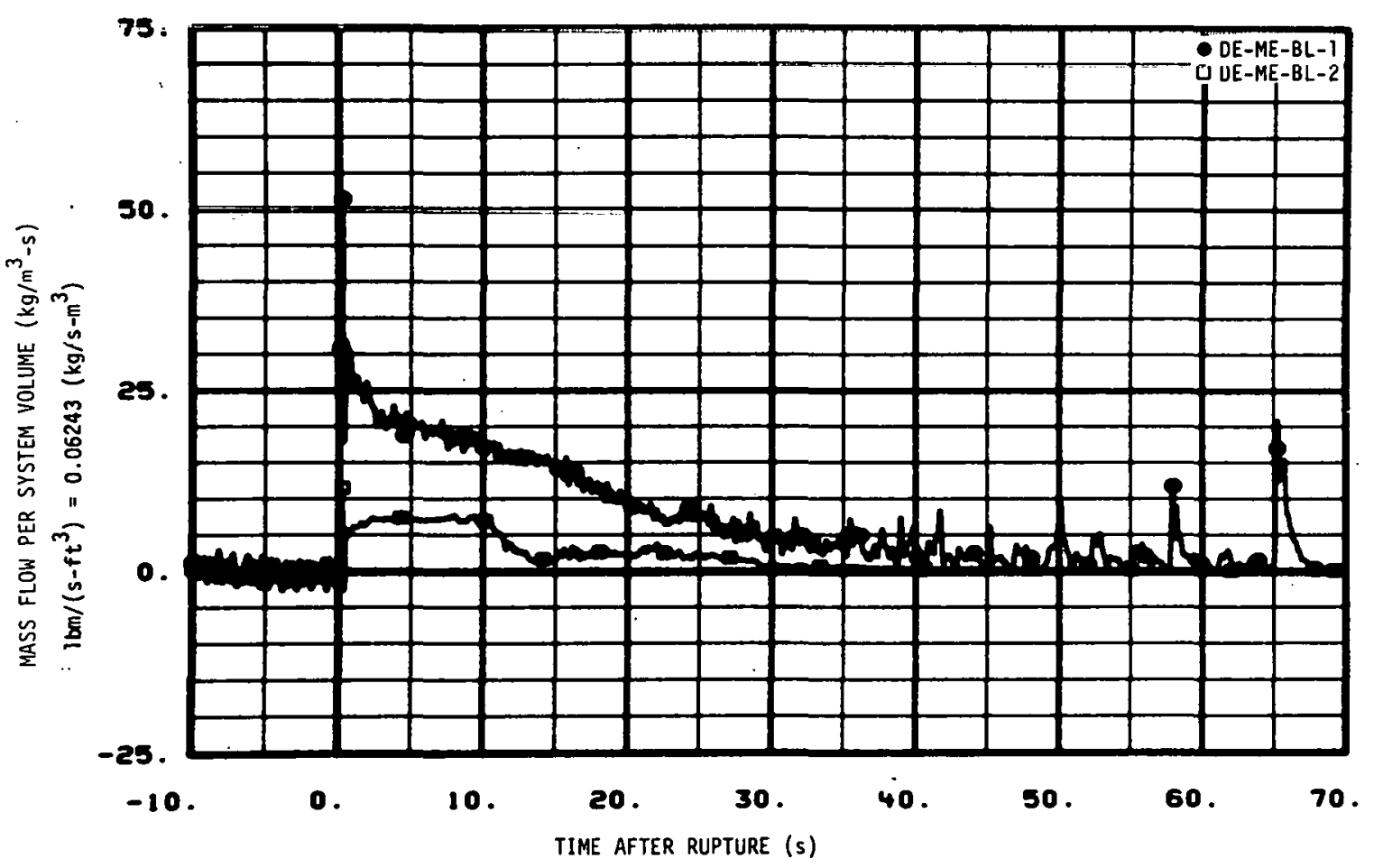

Fig. 190 Mass flow rate per system volume in broken loop hot and cold legs calculated from DE and ME. 


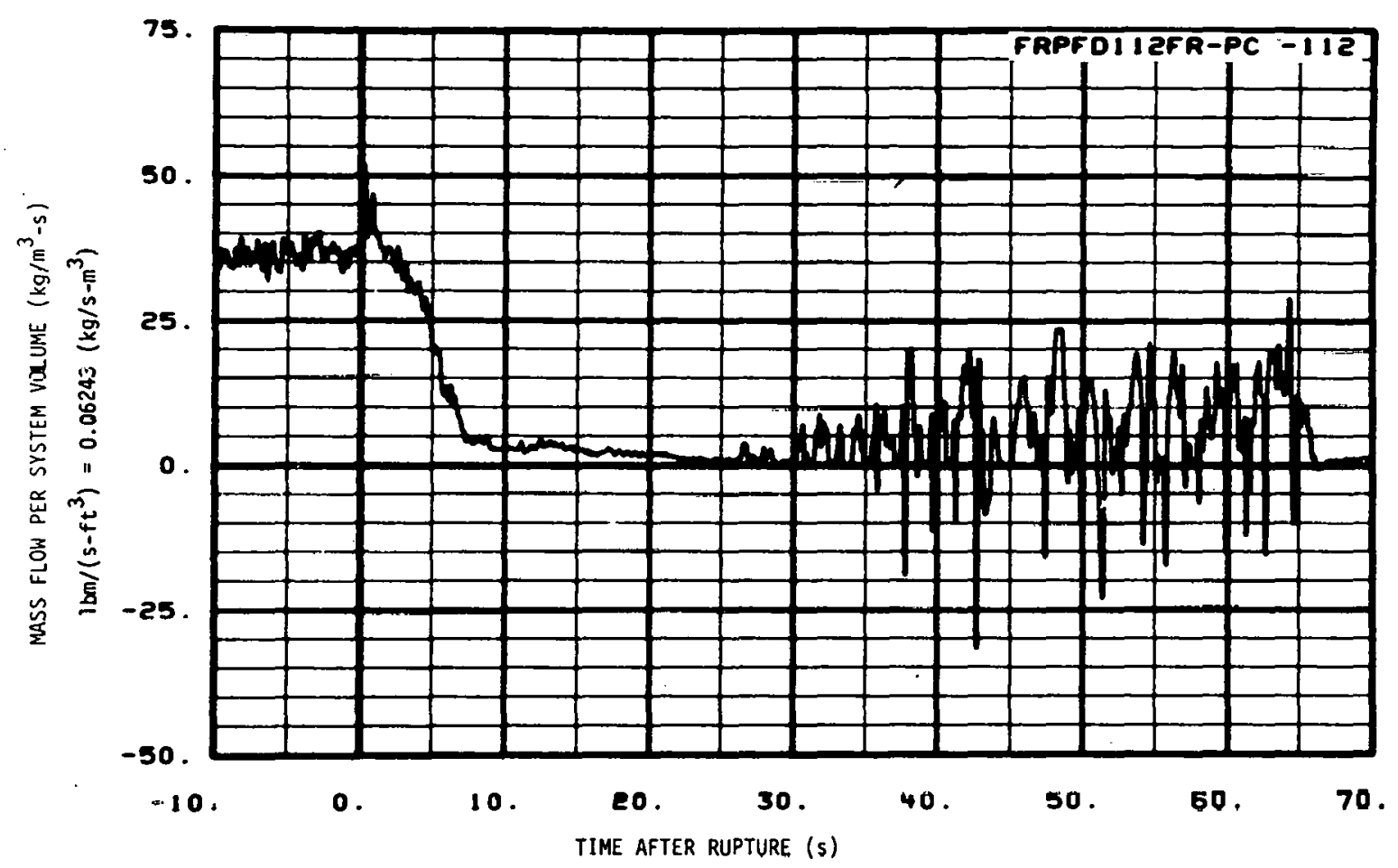

Fig. 191 Mass flow rate per system volume in intact loop cold leg calculated from DE-PC- 1 and ME-PC- 1 .

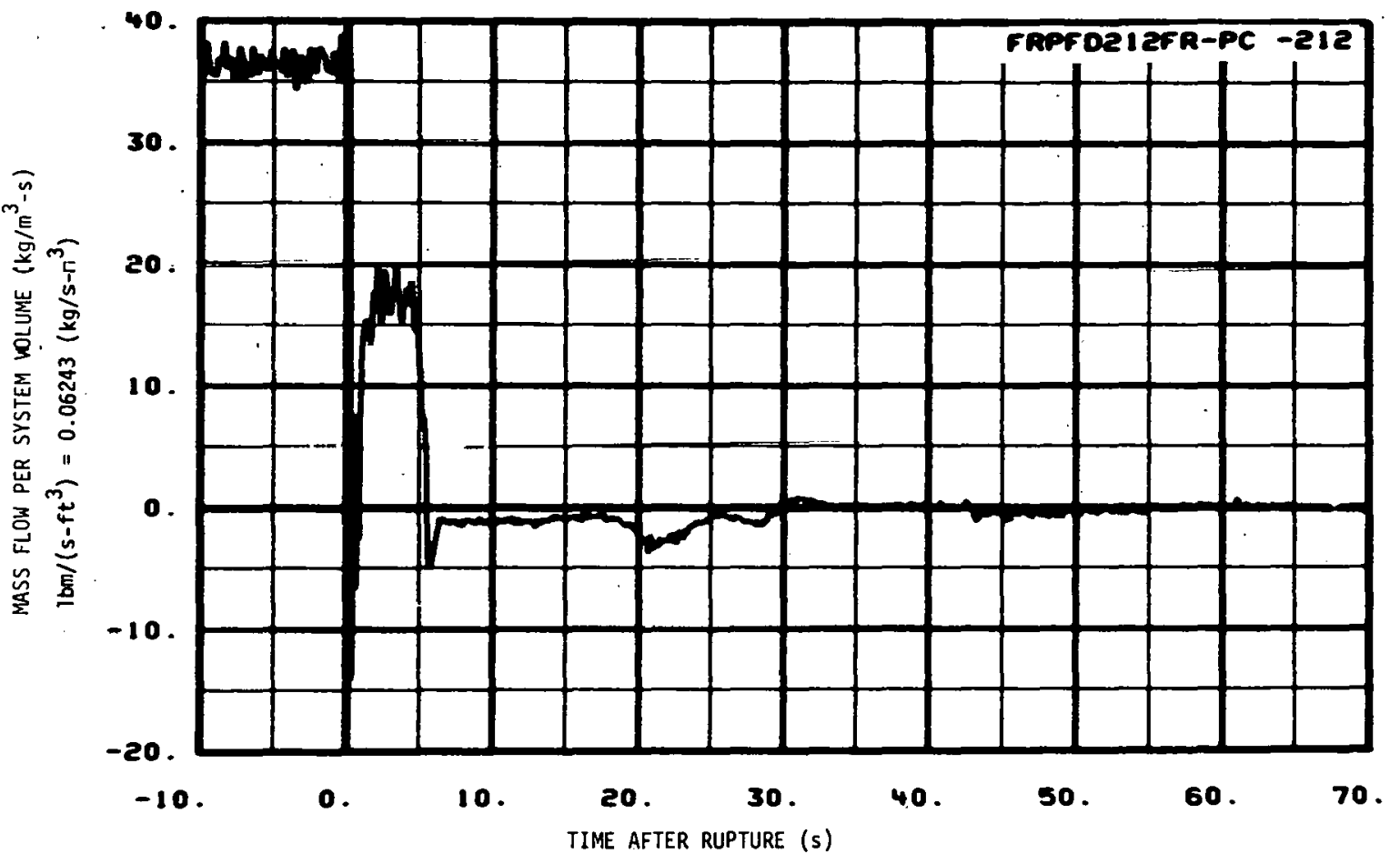

Fig. 192 Mass flow rate per system volume in intact loop hot leg calculated from DE-PC-2 and ME-PC-2. 


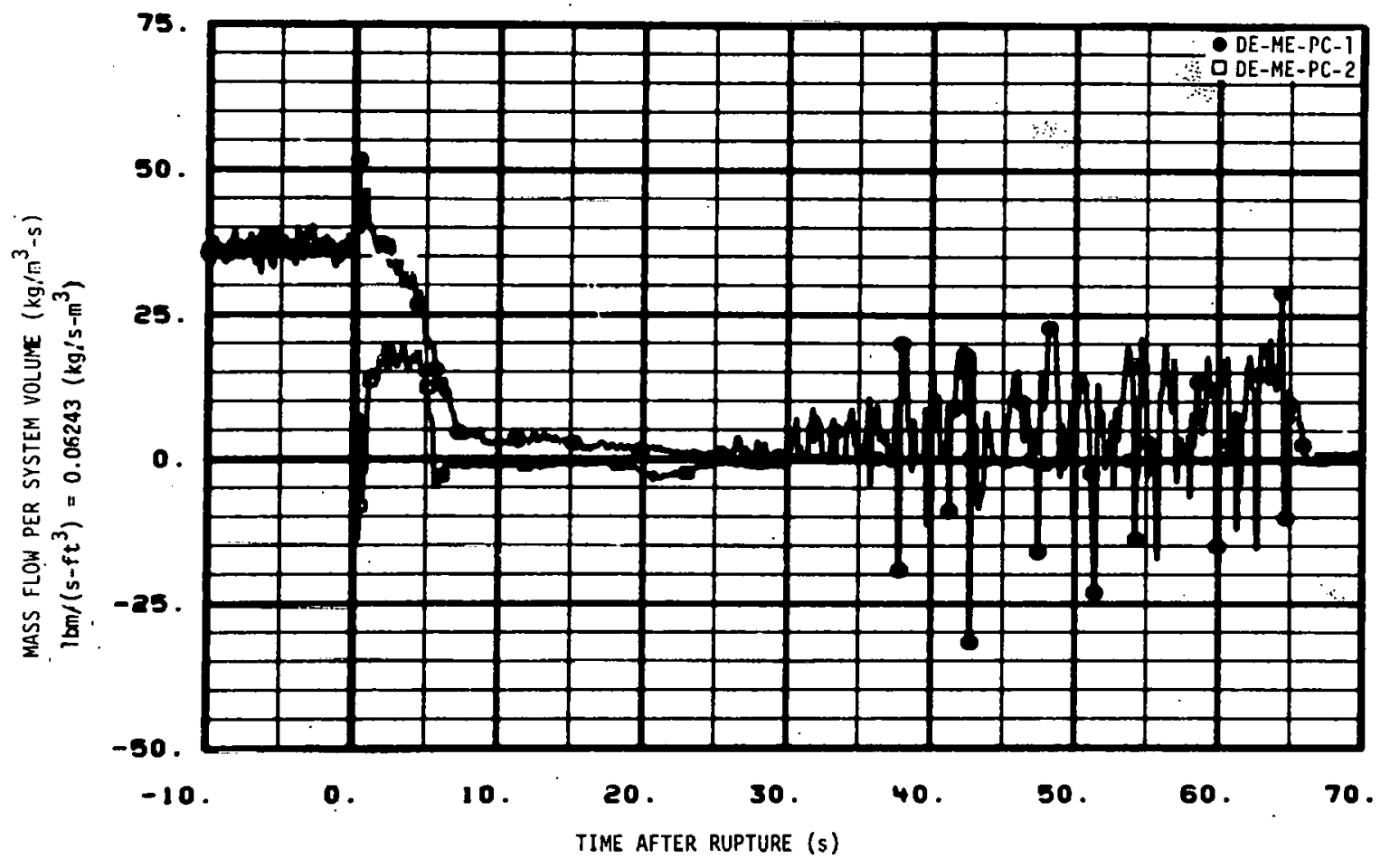

Fig. 193 Mass flow rate per system volume in intact loop cold and hot legs calculated from DE and ME.

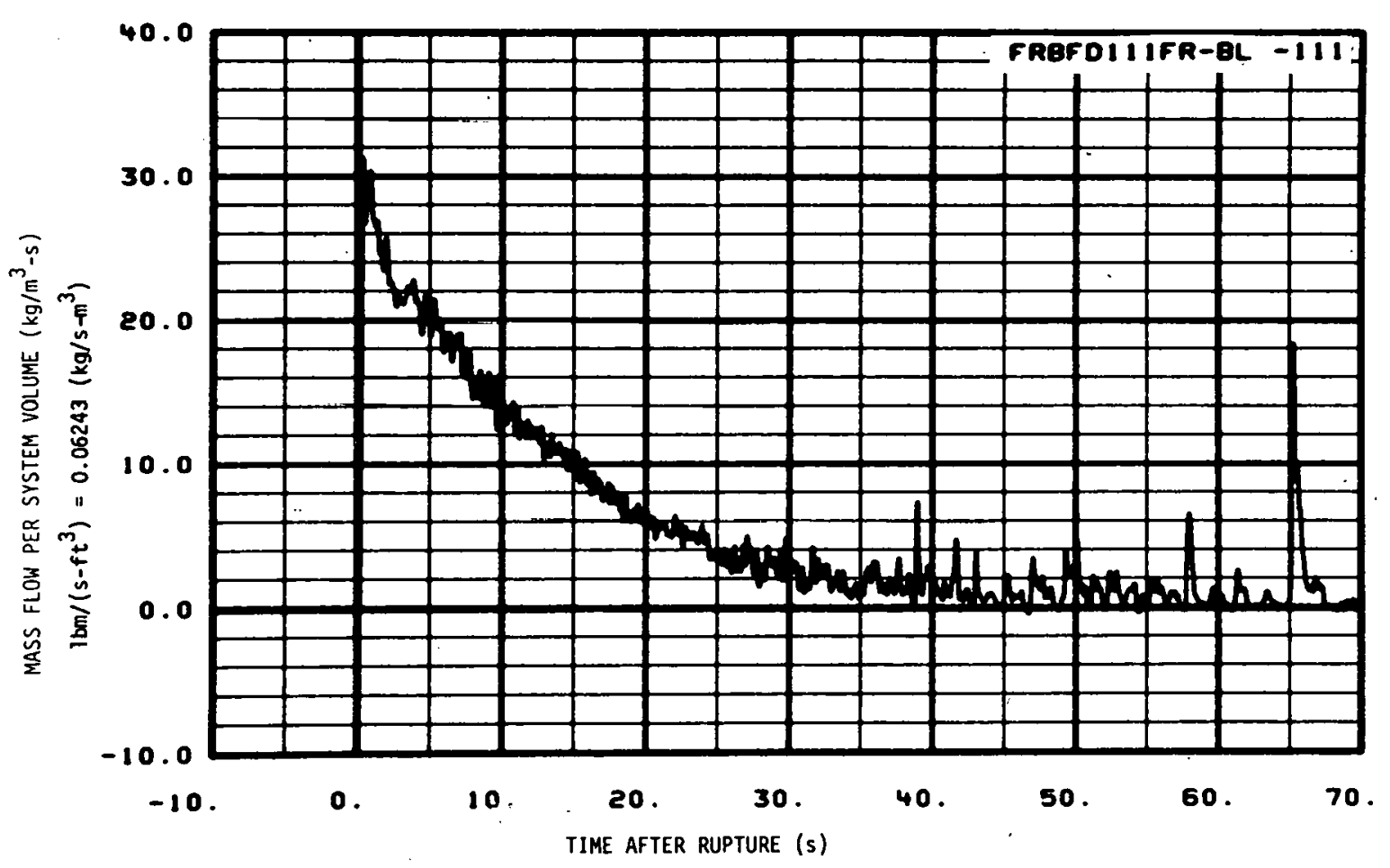

Fig. 194 Mass flow rate per system volume in broken loop cold leg calculated from FE-BL-1 and DE-BL-1. 


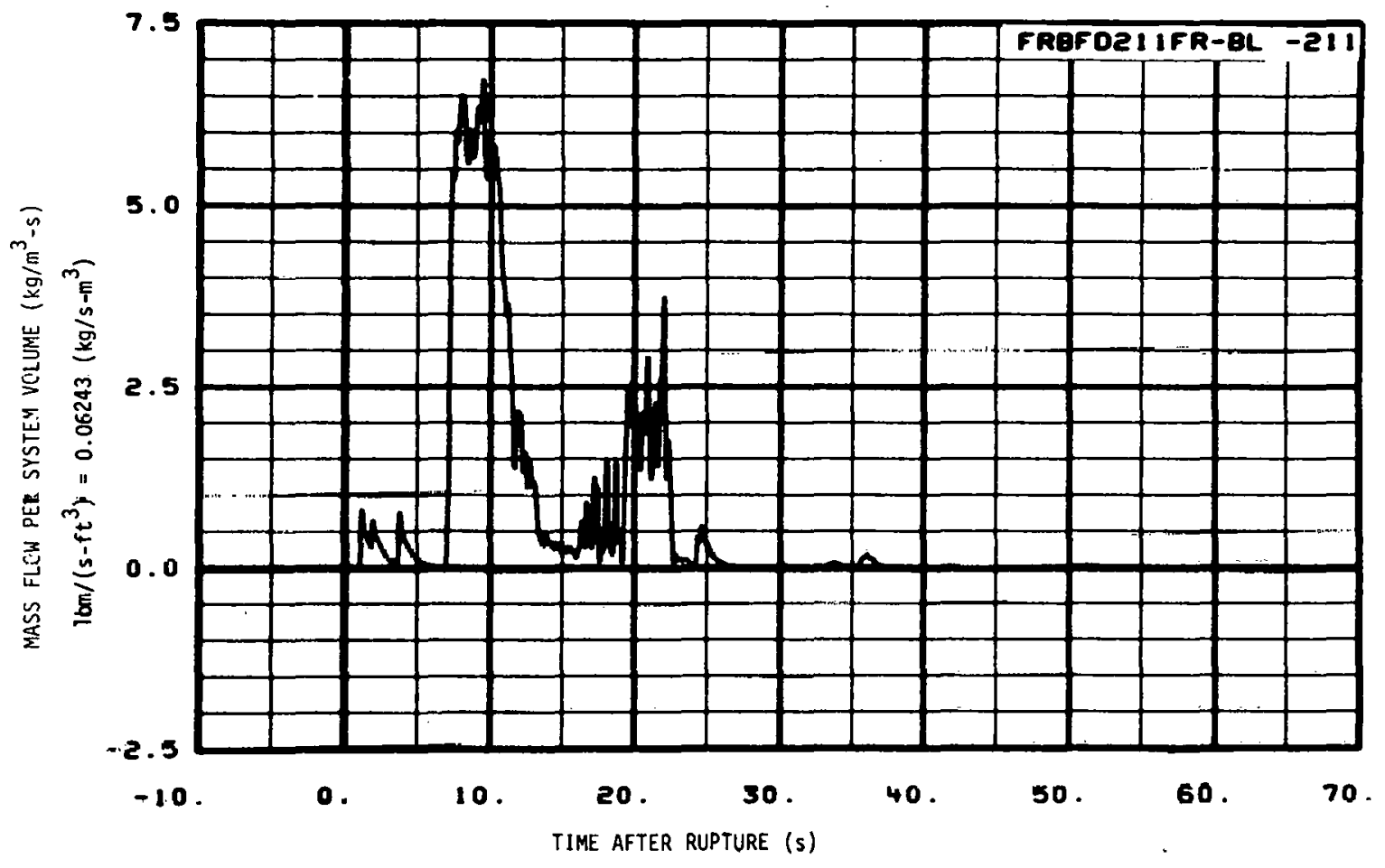

Fig. 195 Mass flow rate per system. volume in broken loop hot leg calculated from FE-BL-2 and DE-BL-2.

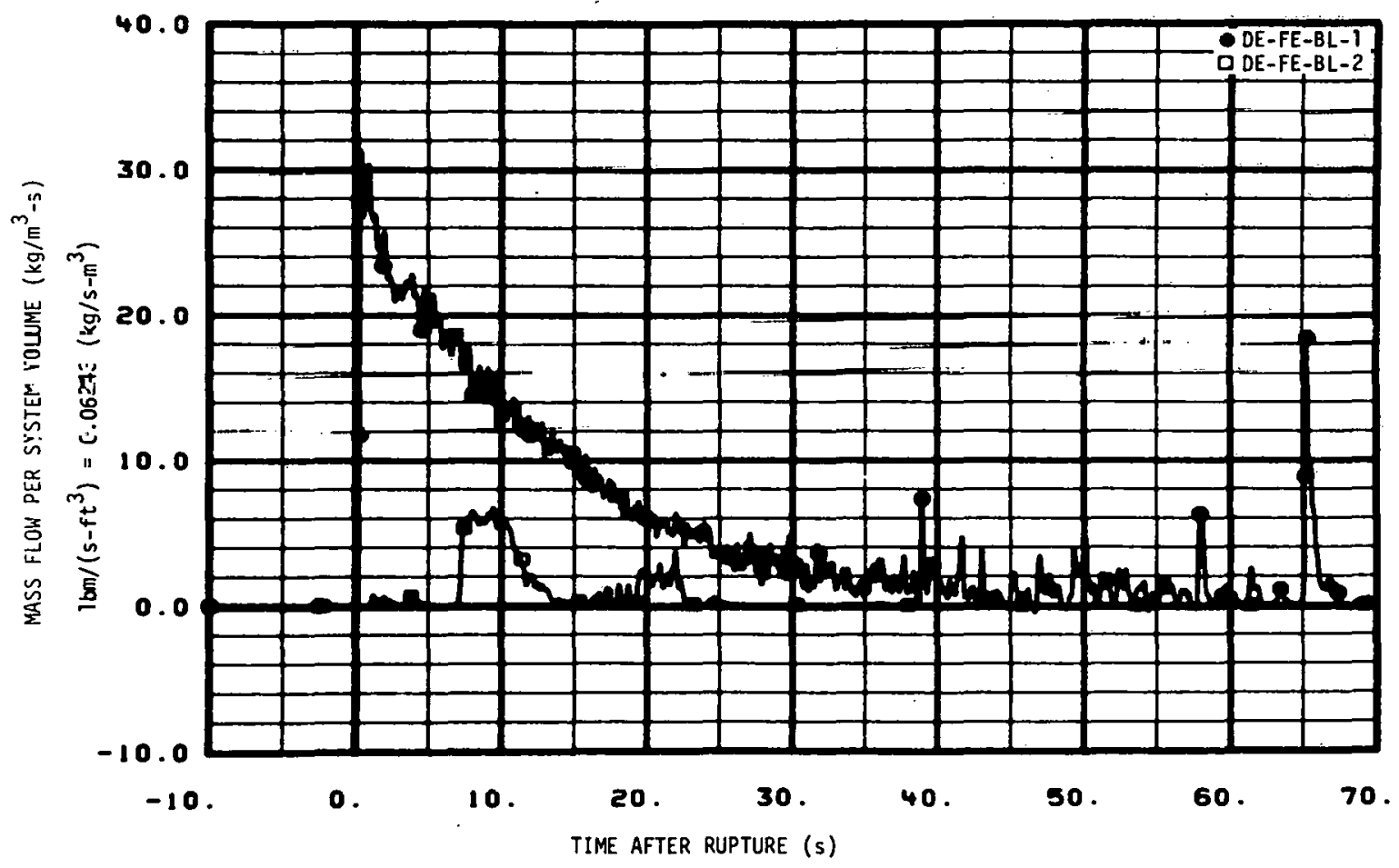

Fig. 196 Mass flow rate per system volume in broken loop hot and cold legs calculated from FE and DE. 


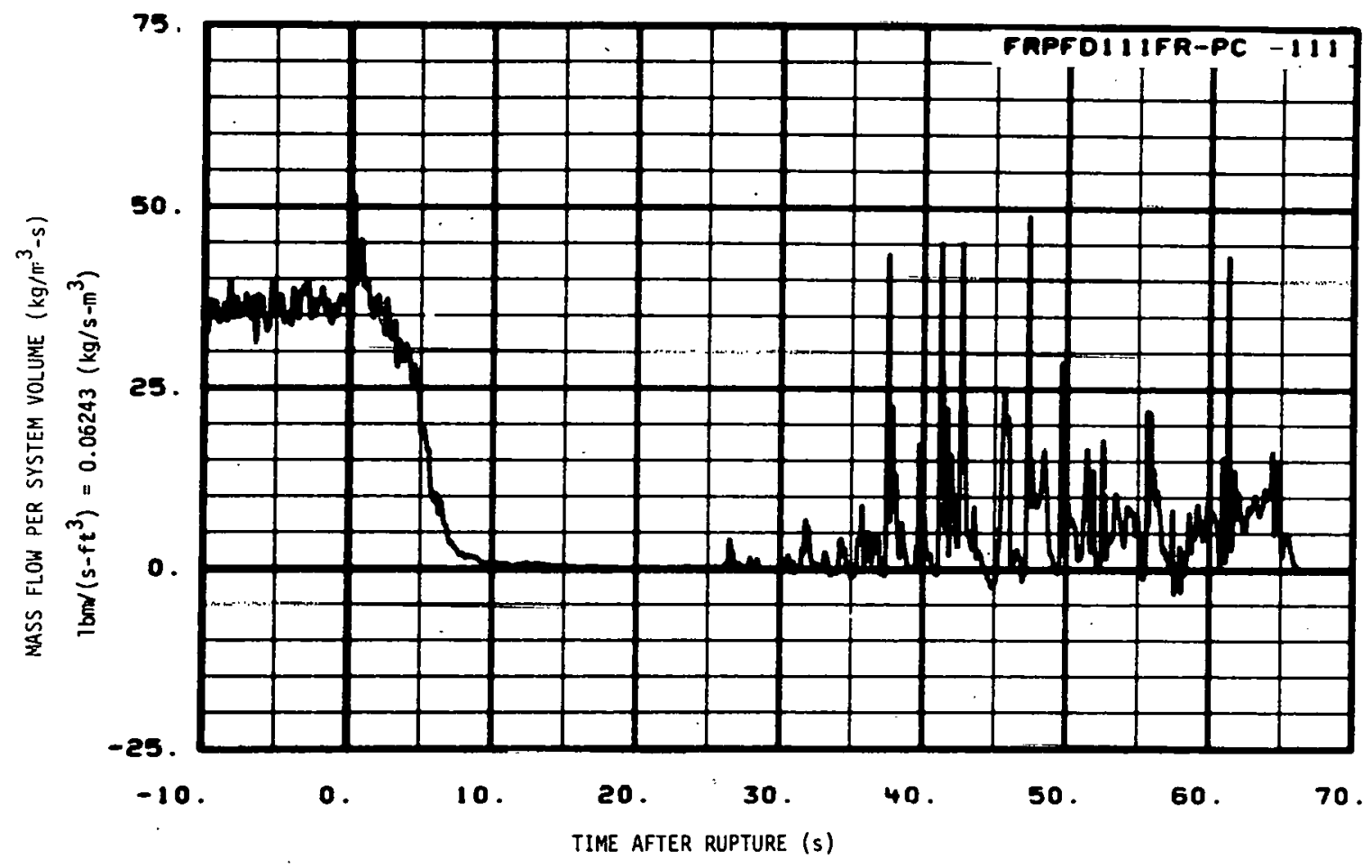

Fig. 197 Mass flow rate per system volume in intact loop cold leg calculated from FE-PC-1 and DE-PC-1.

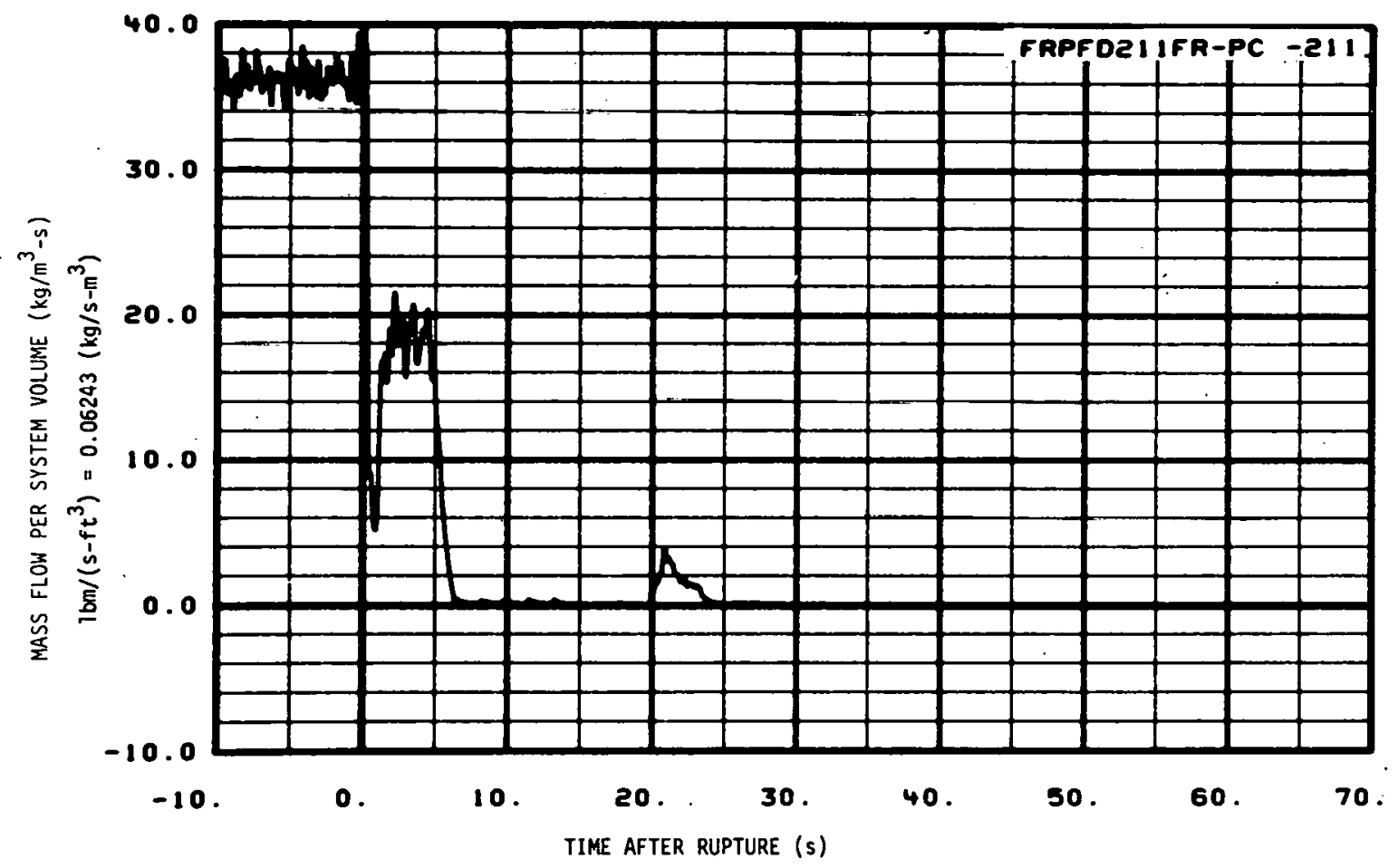

Fig. 198 Mass flow rate per system volume in intact loop hot leg calculated from FE-PC-2 and DE-PC-2. 


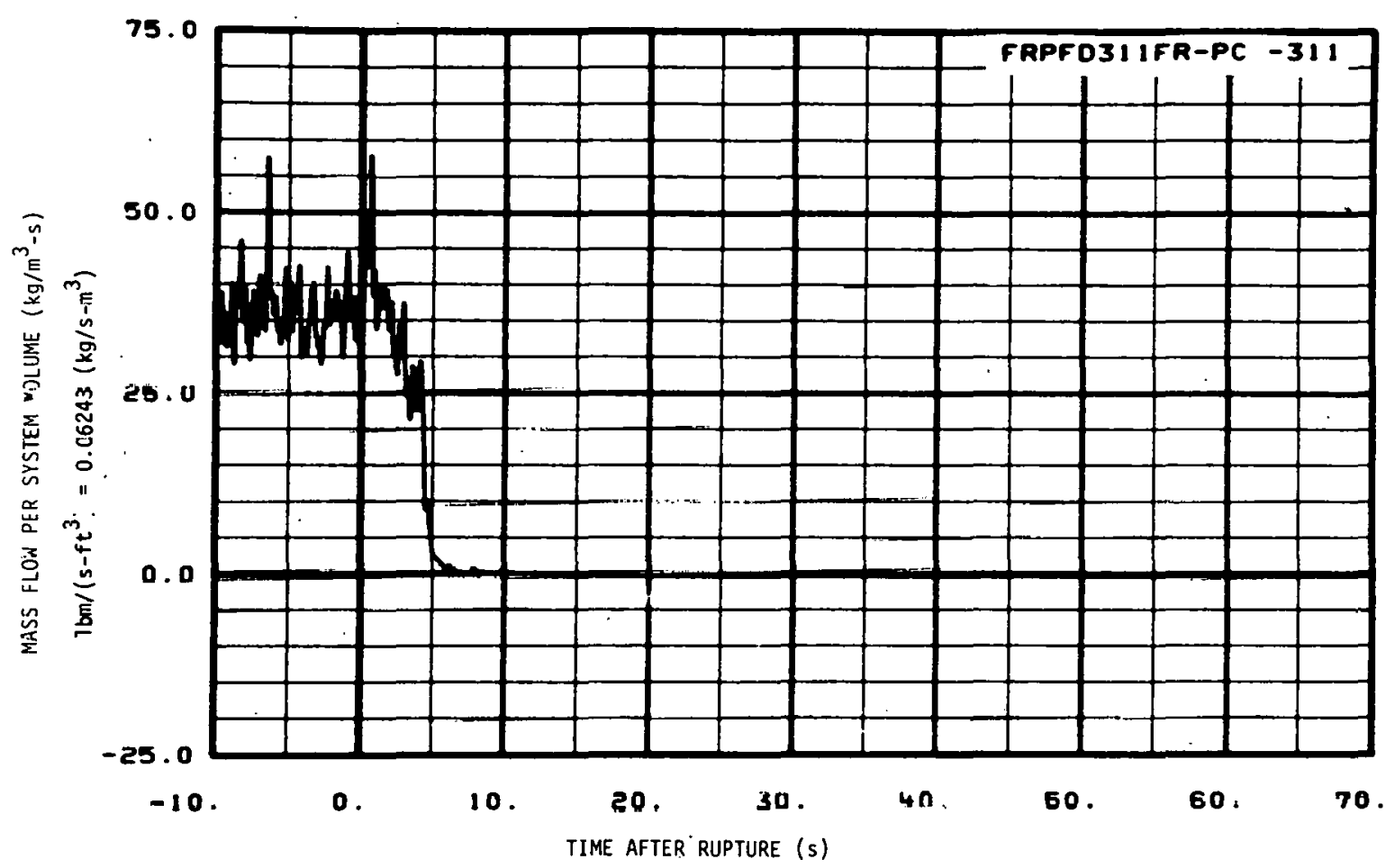

Fig. 199 Mass flow race per system volume in intact loop steam generator outlet calculated from FE-PC-3 and DE-PC-3.

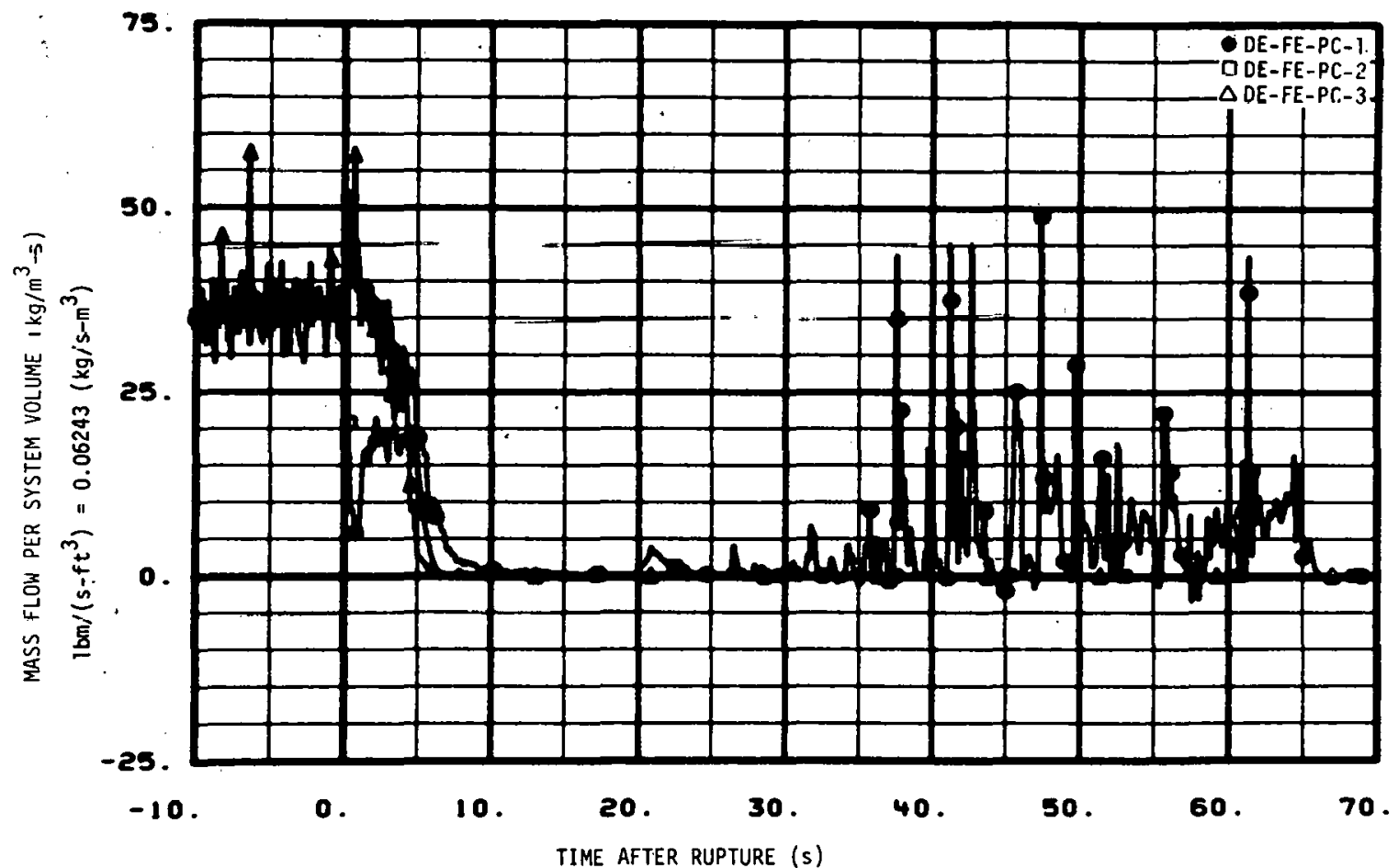

Fig. 200 Mass flow rate per system volume in intact loop cold leg, hot leg, and steam generator outlet calculated from FE and DE. 


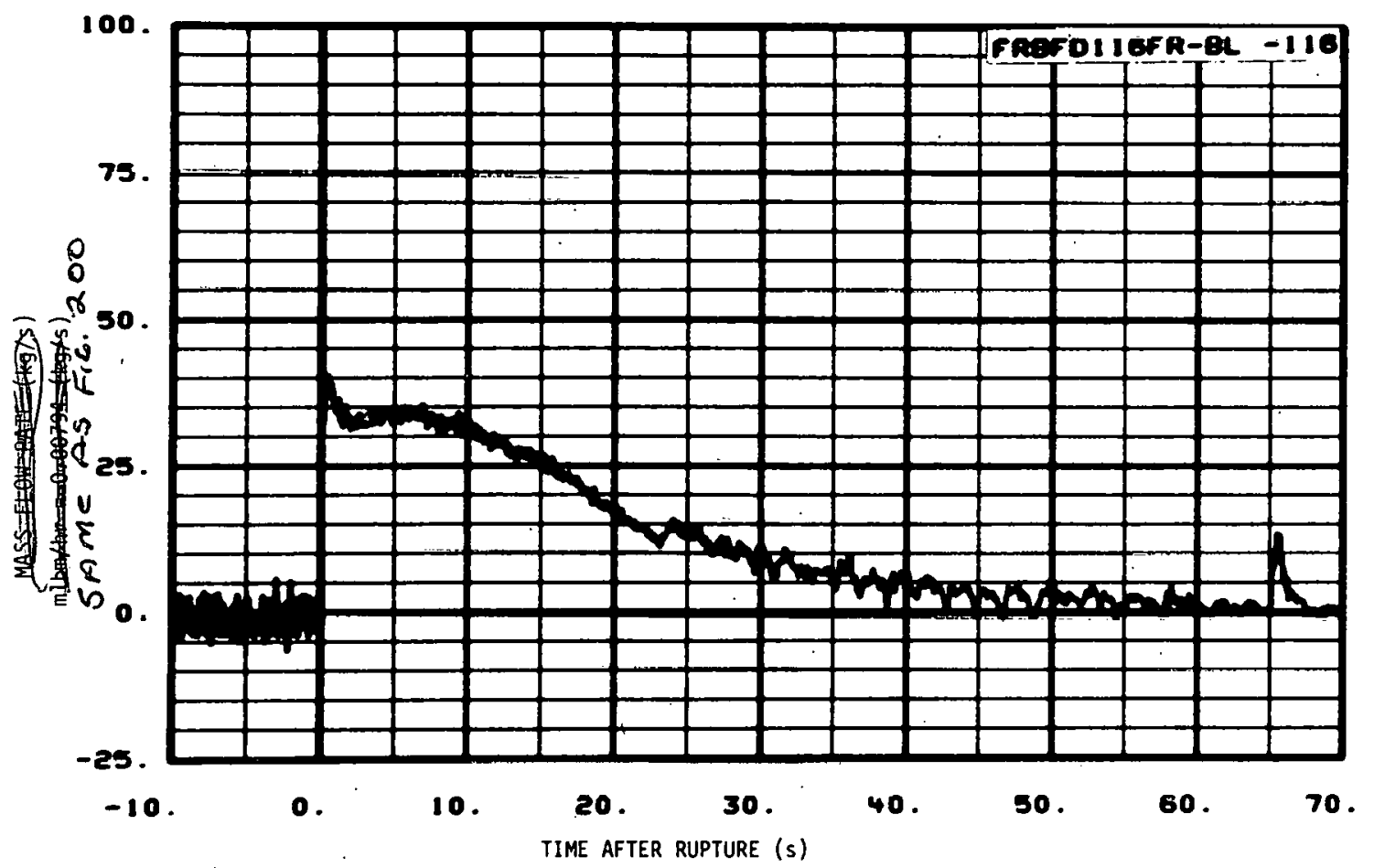

Fig. 201 Mass flow rate per system volume in broken loop cold leg calculated from PdE-BL-2 and DE-BL- 1 .

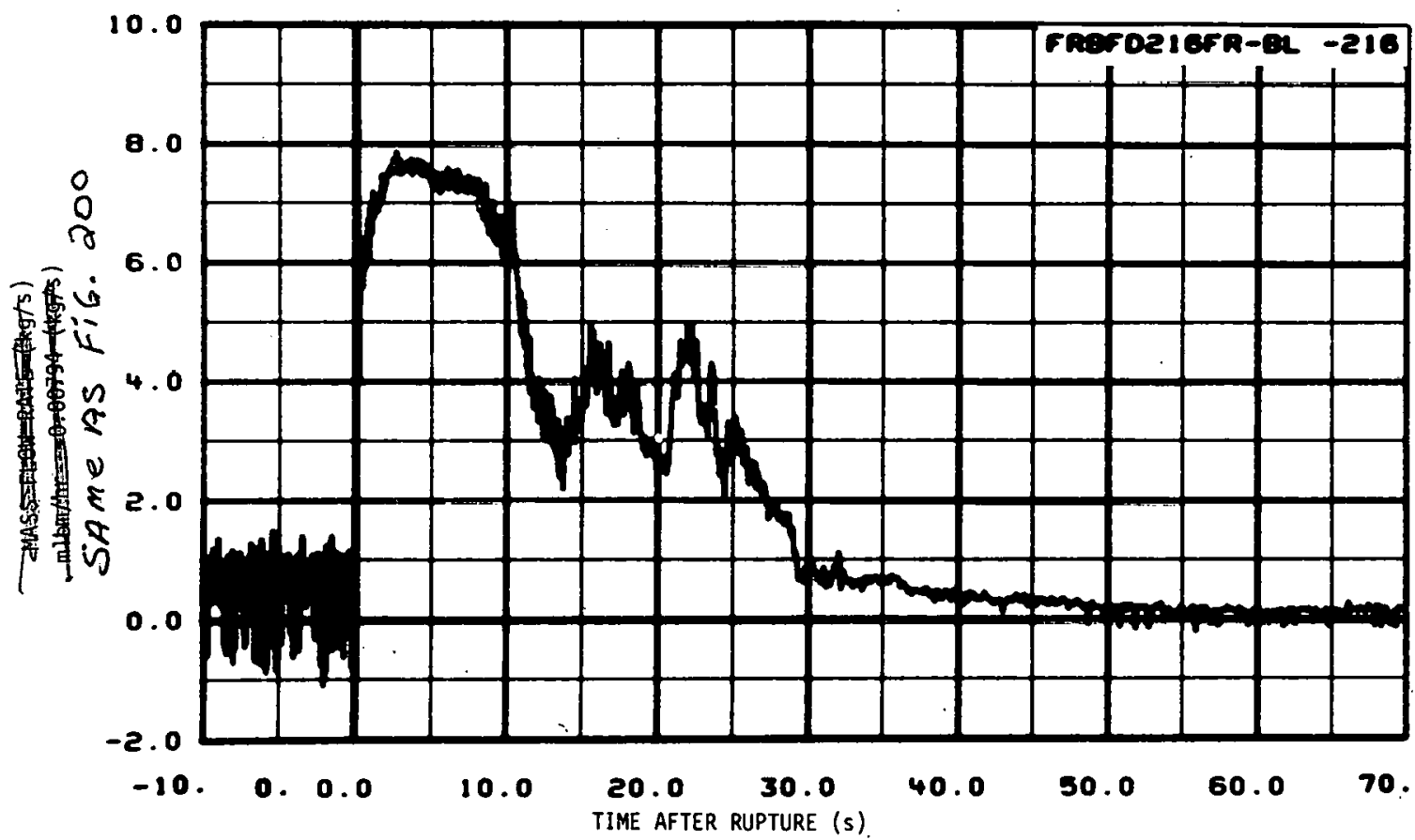

Fig. 202 Mass flow rate per system volume in broken loop hot leg calculated from PdE-BL-1 and DE-BL-2. 


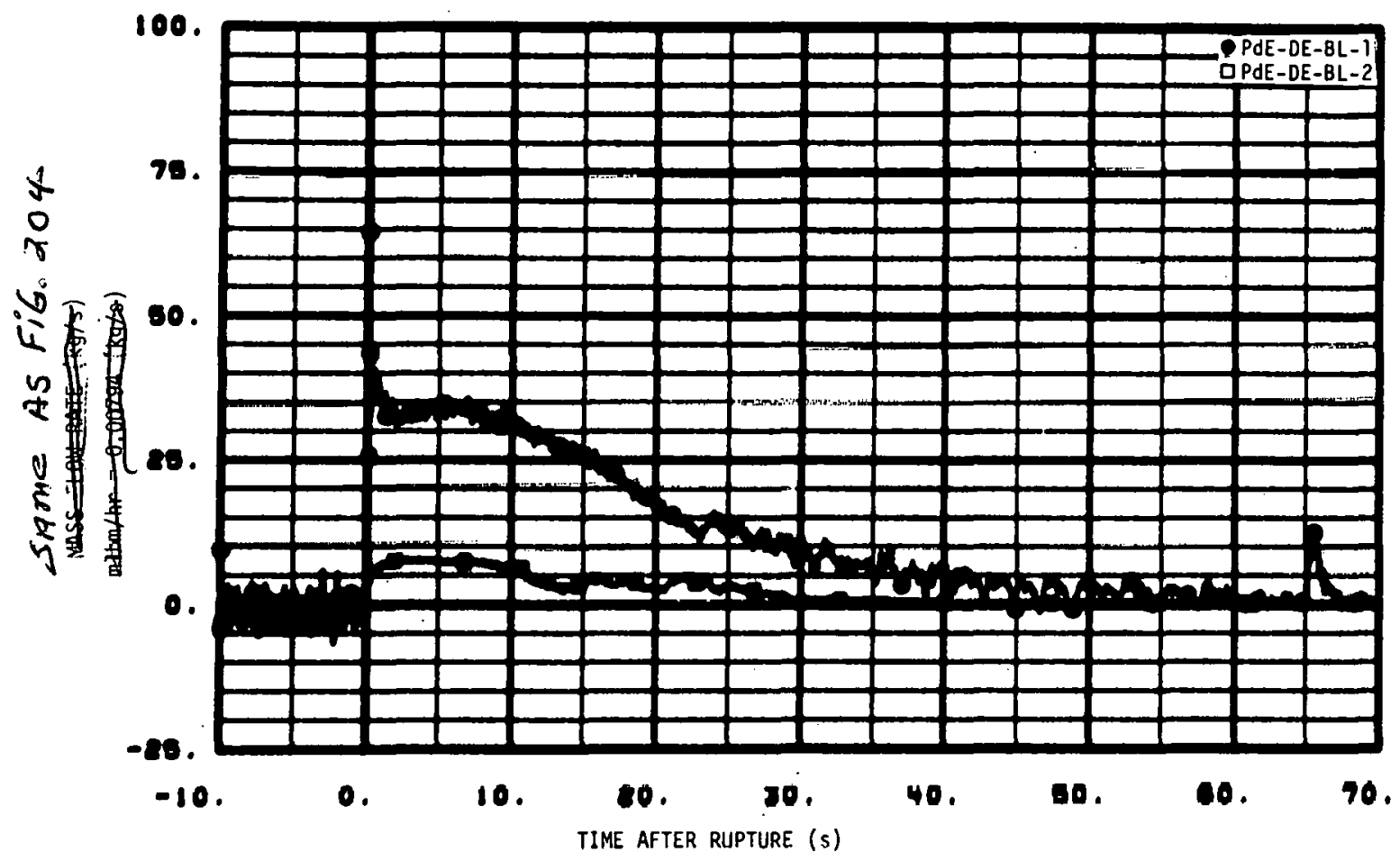

Fig. 203 Mass flow rate per system volume in broken loop hot and cold legs calculated from PdE and DE.

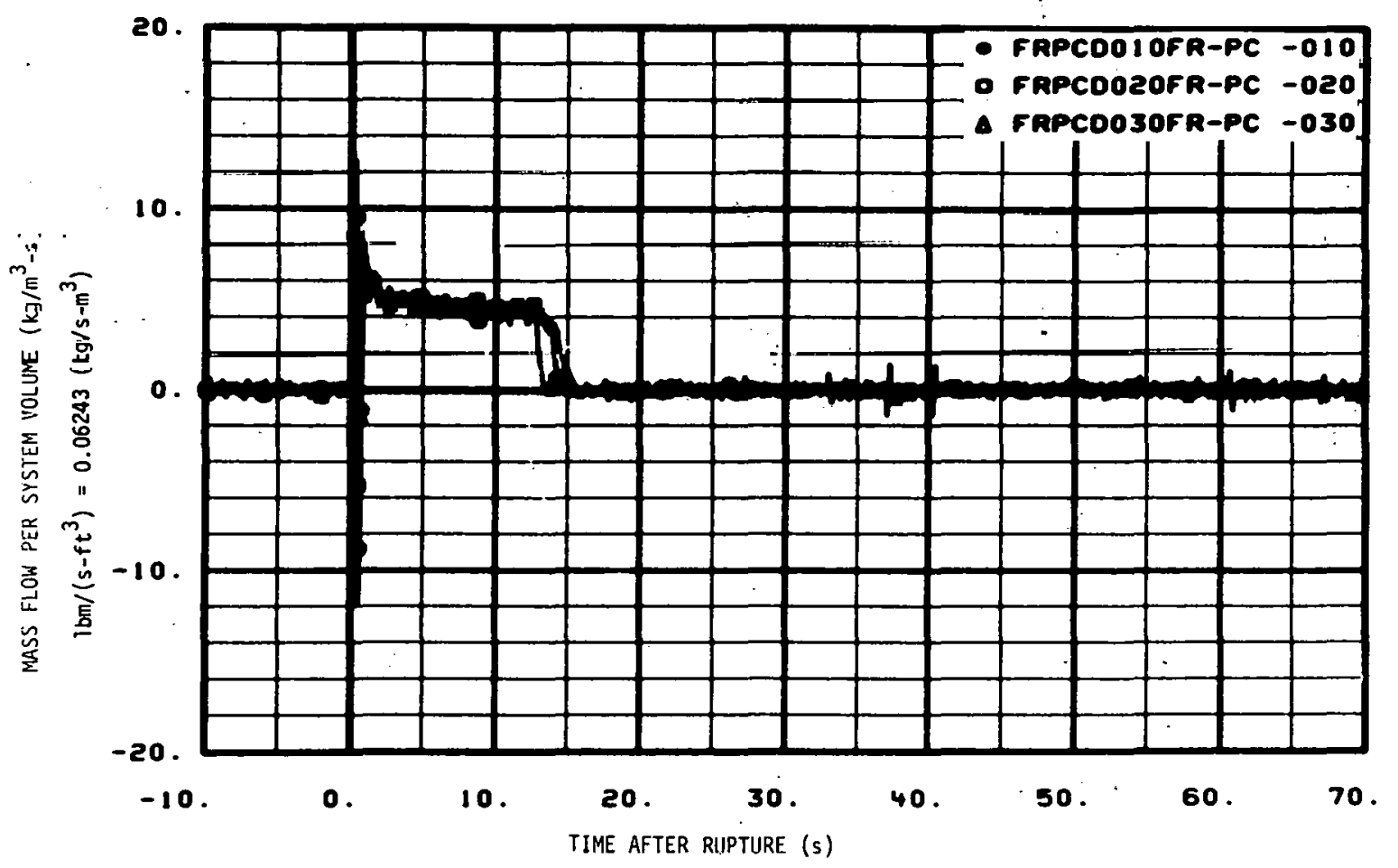

Fig. 204 Mass flow rate per system volume in pressurizer calculated from LT-P139-6, -7 , and -8 and PE-PC-4. 


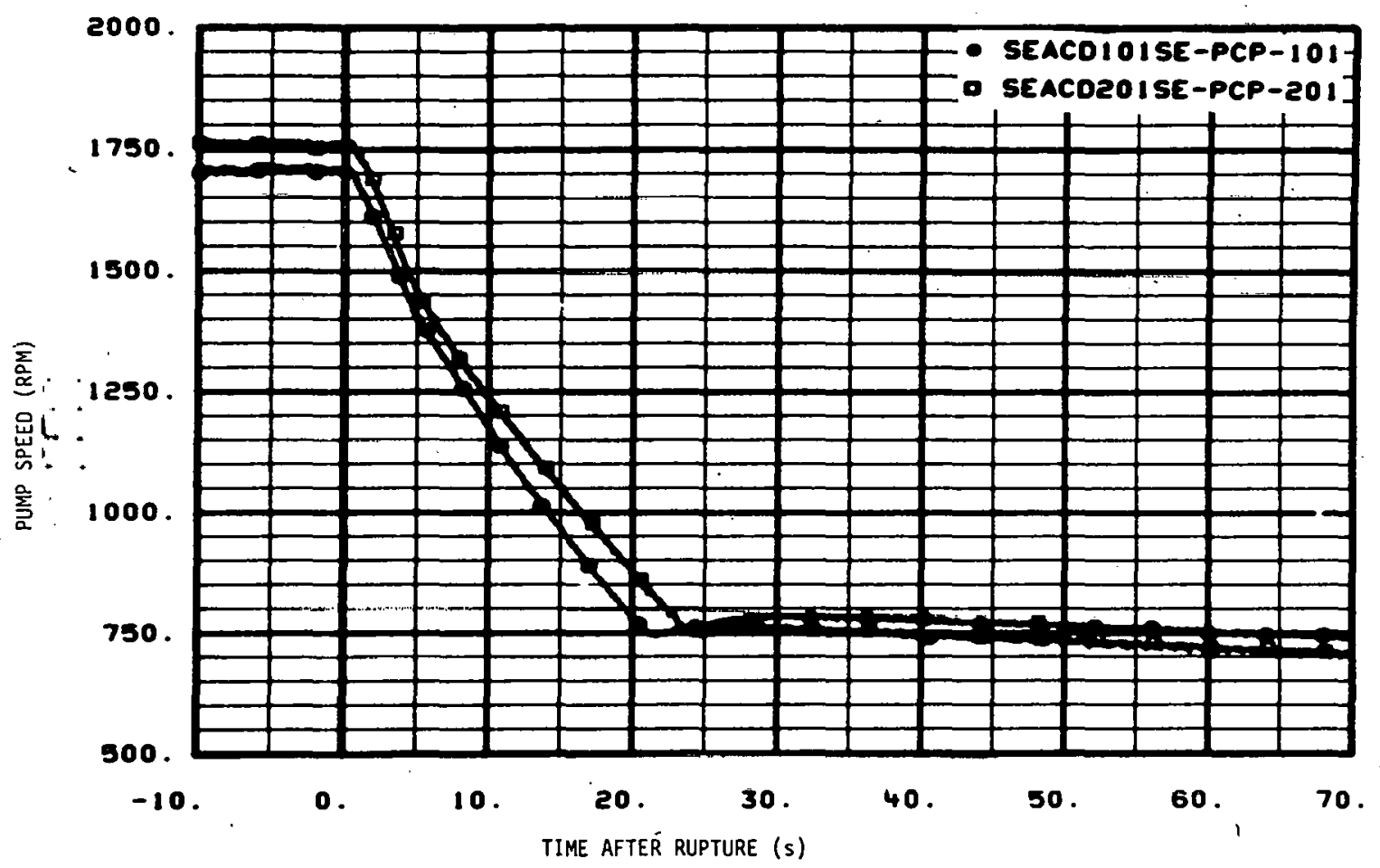

Fig. 205 Pump speed, electrical, in intact loop primary coolant pumps 1 and 2 .

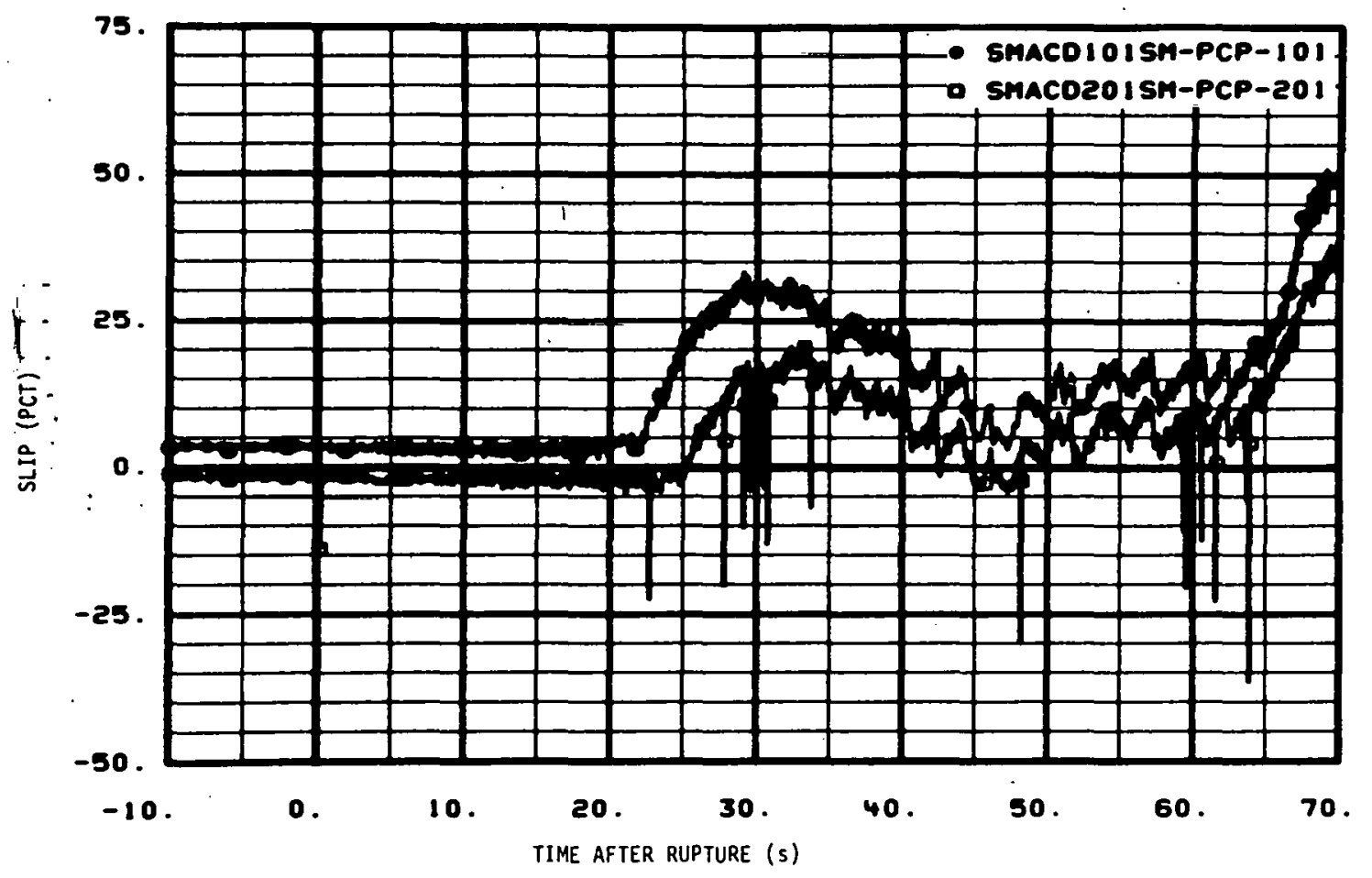

Fig. 206 Pump motor slip in intact loop primary coolant pumps 1 and 2 . 


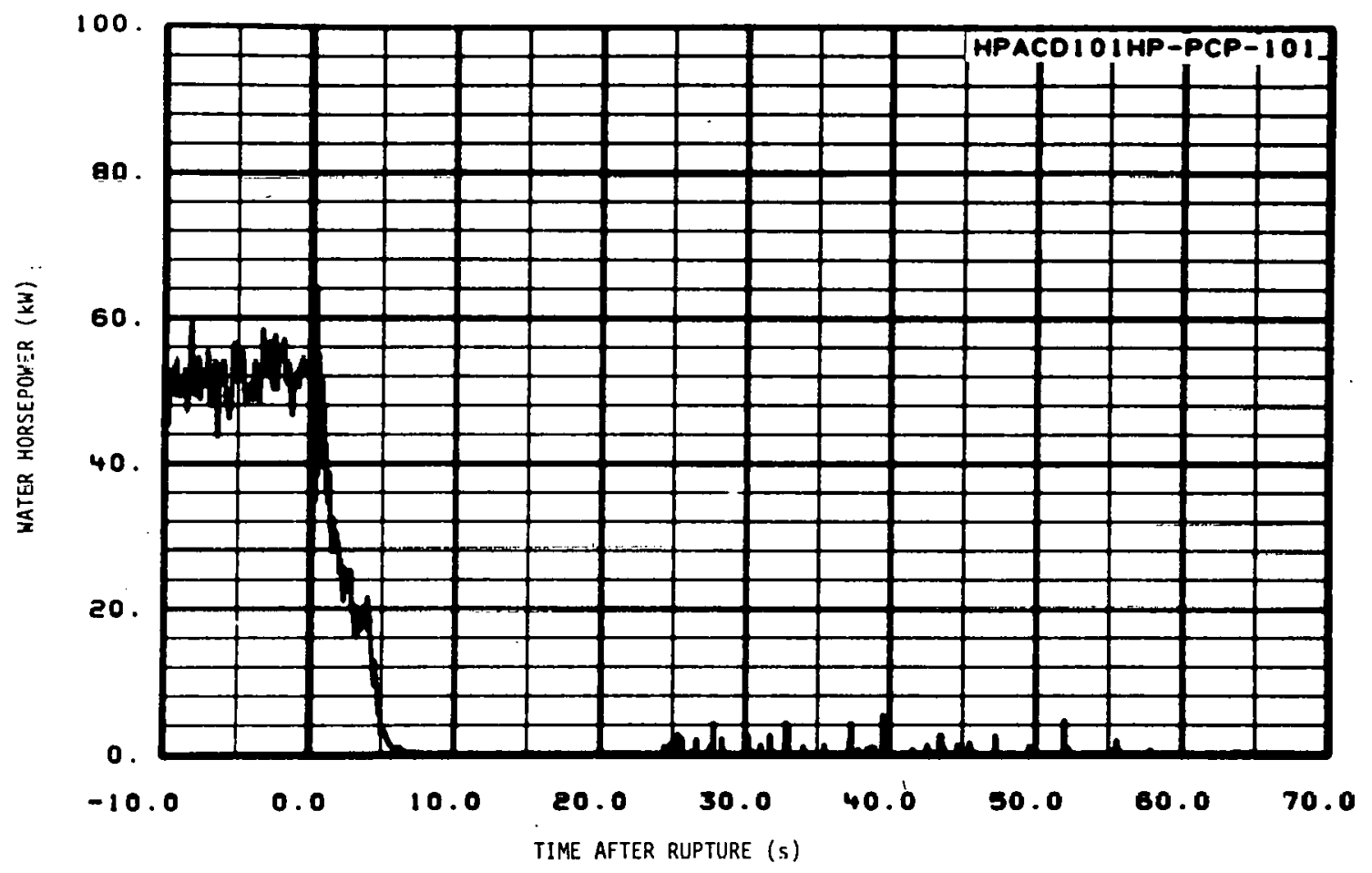

Fig. 207 Pump water horsepower (normalized for PCP-1 and PCP-2).

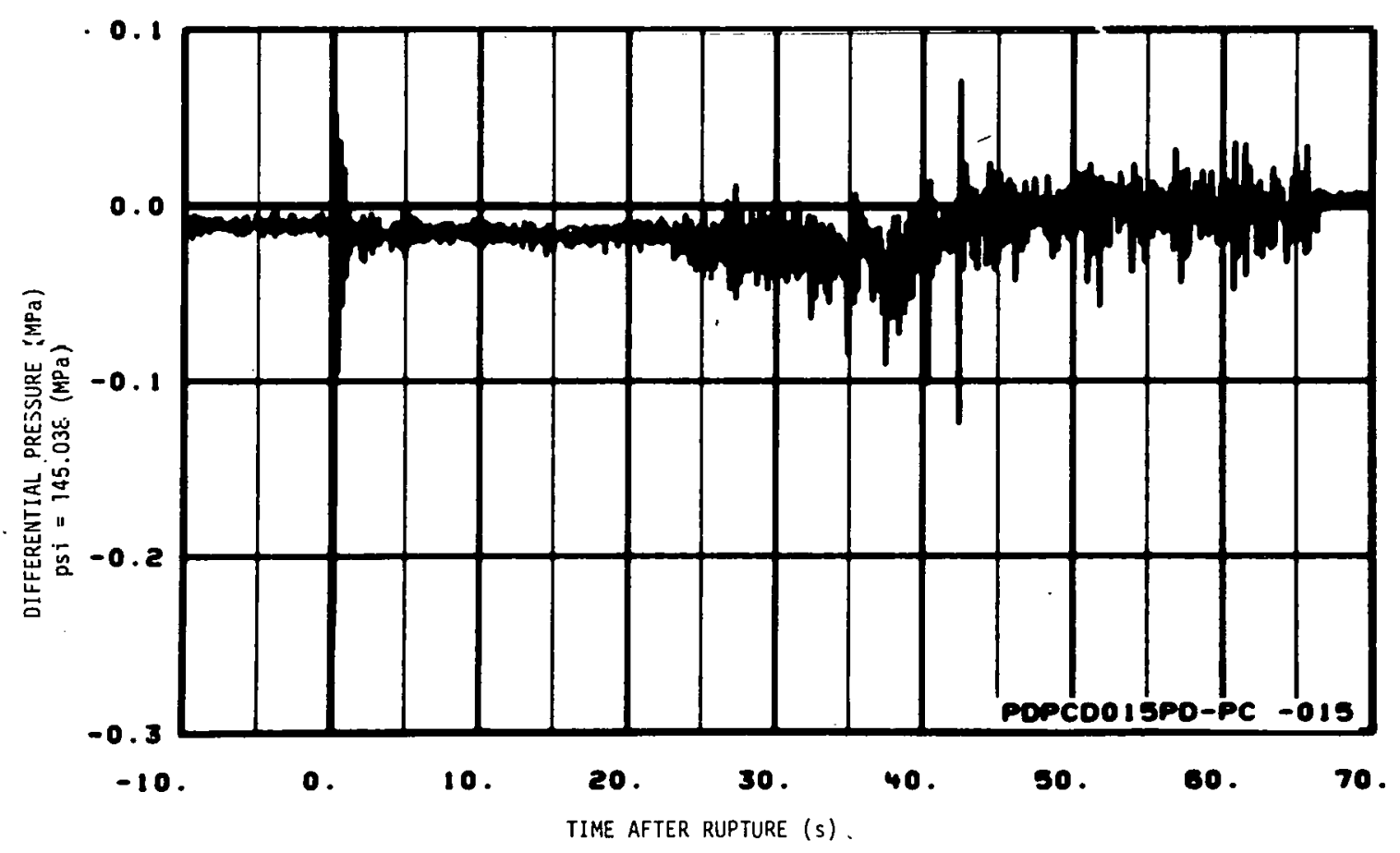

Fig. 208 Pressure, closure, in intact loop. 


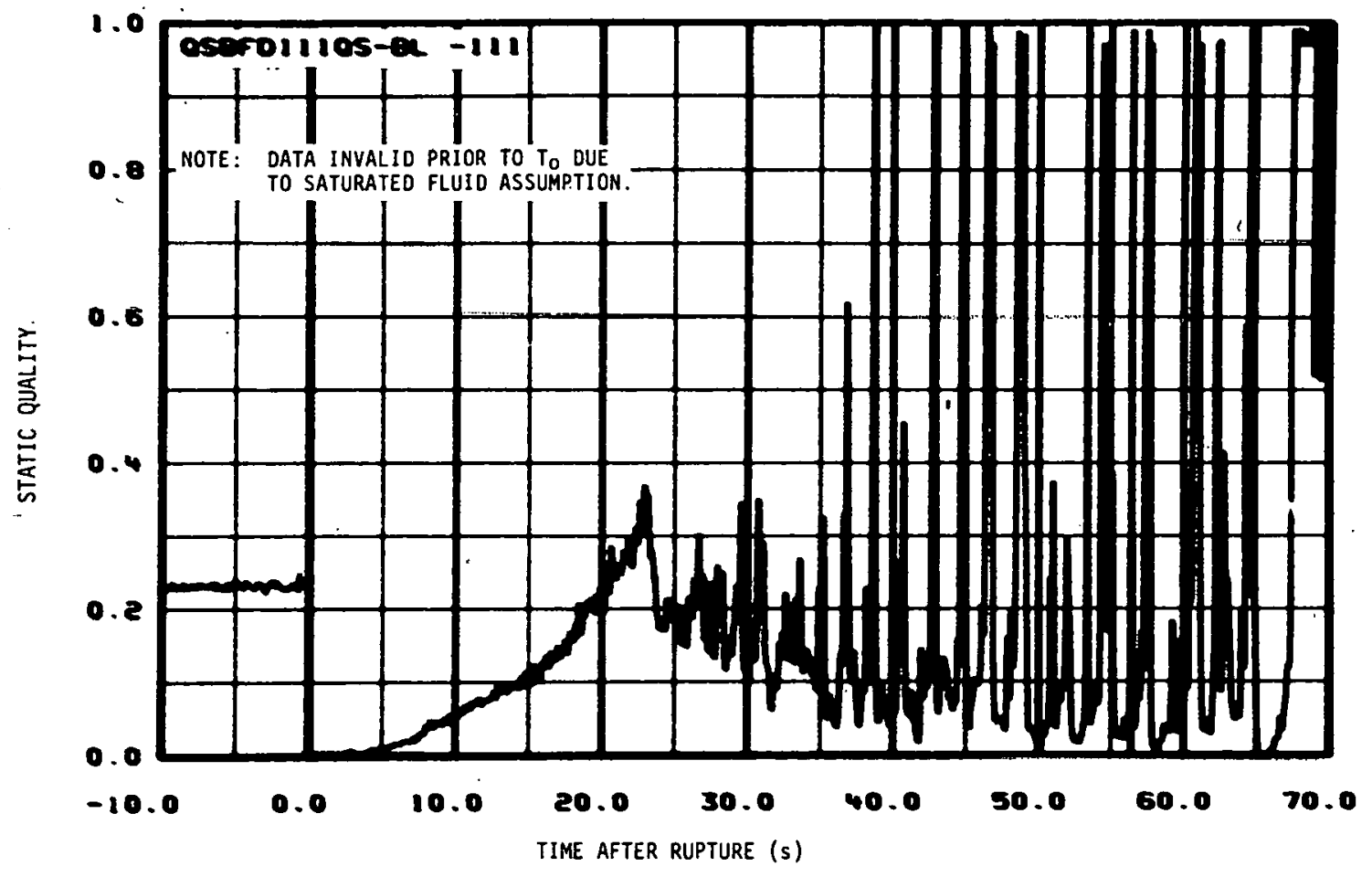

Fig. 209 Static quality in broken loop cold leg.

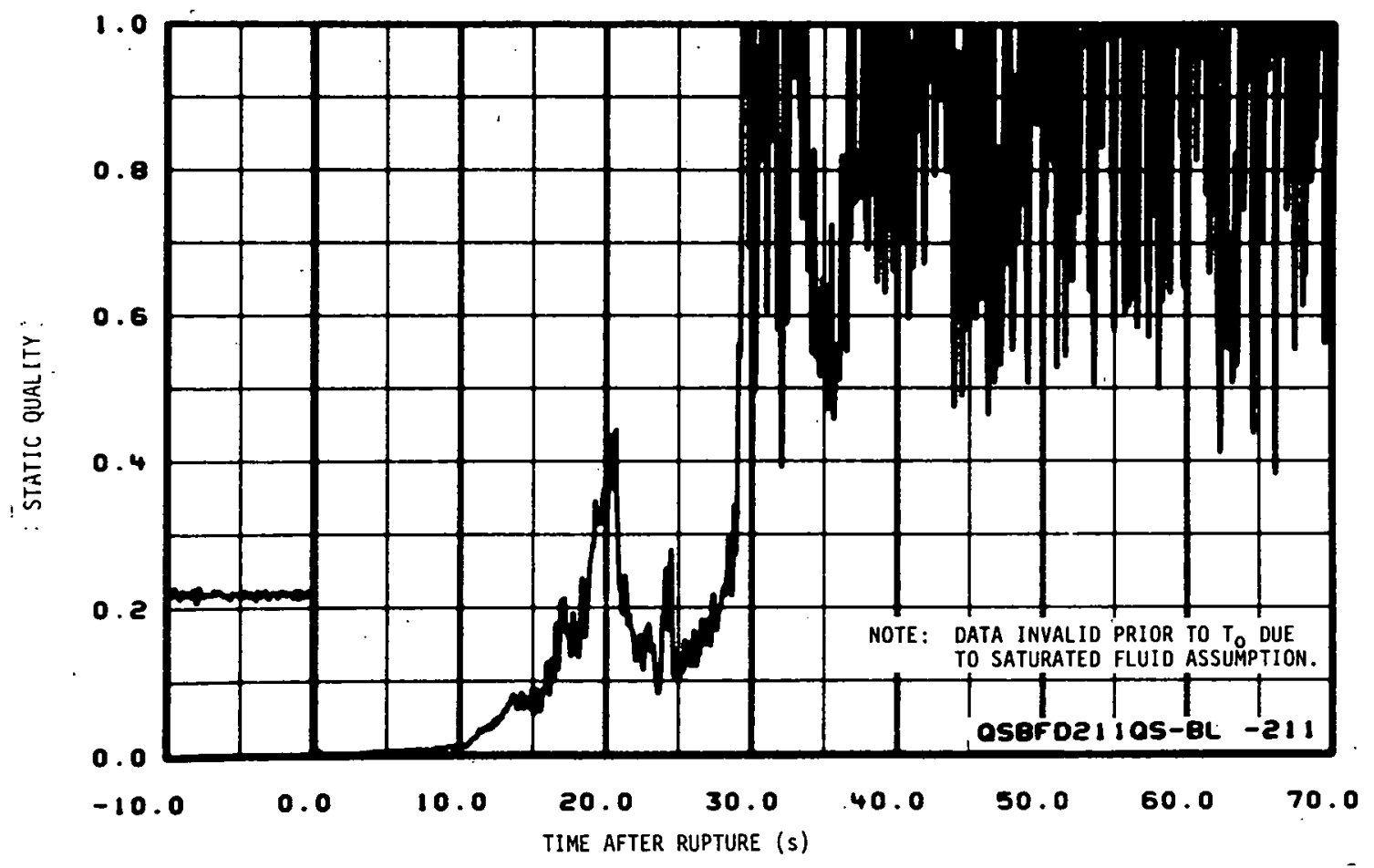

Fig. $210^{\circ}$ Static quality in broken loop hot leg. 


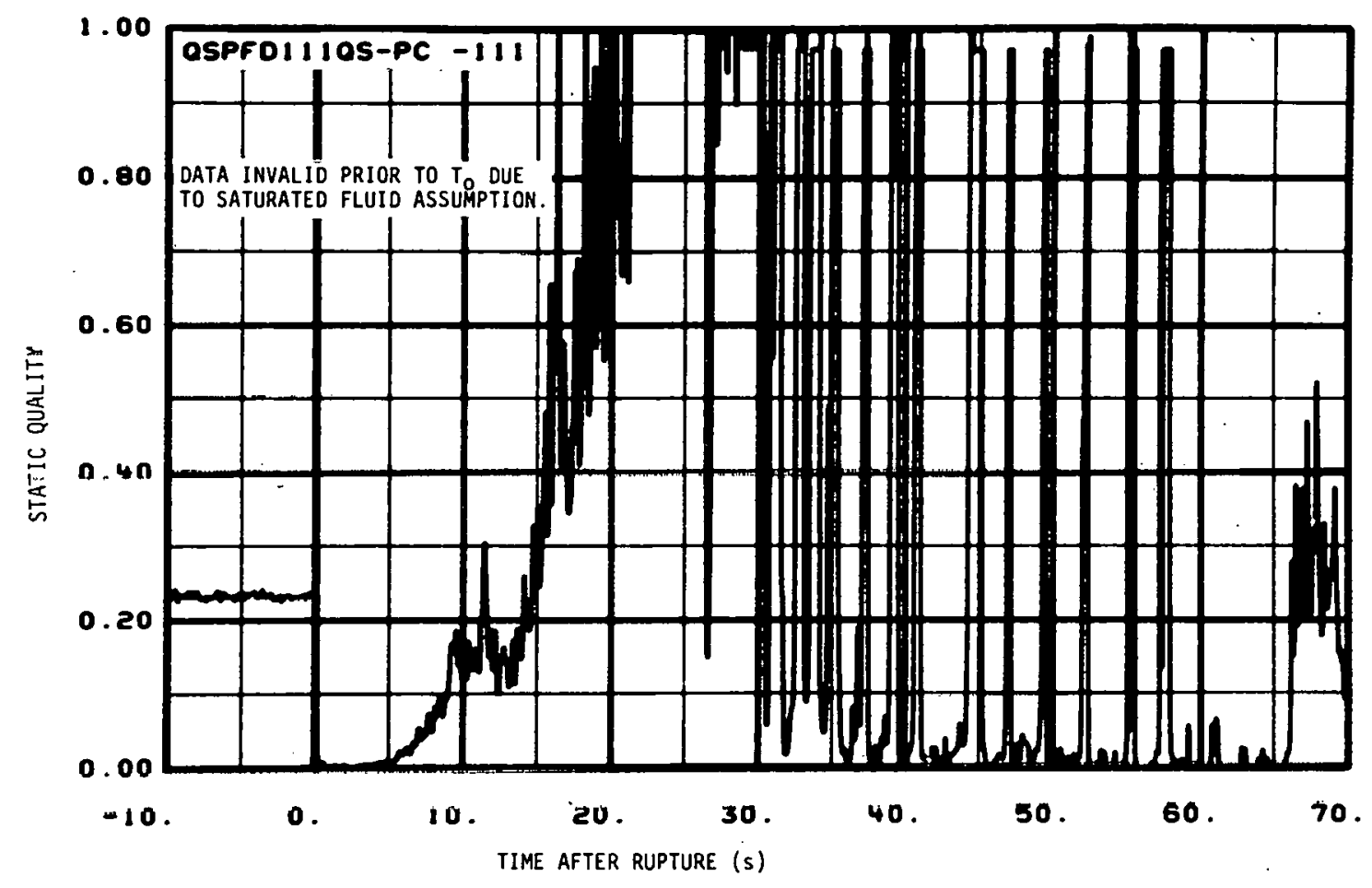

Fig. 211 Static quality in intact loop cold leg.

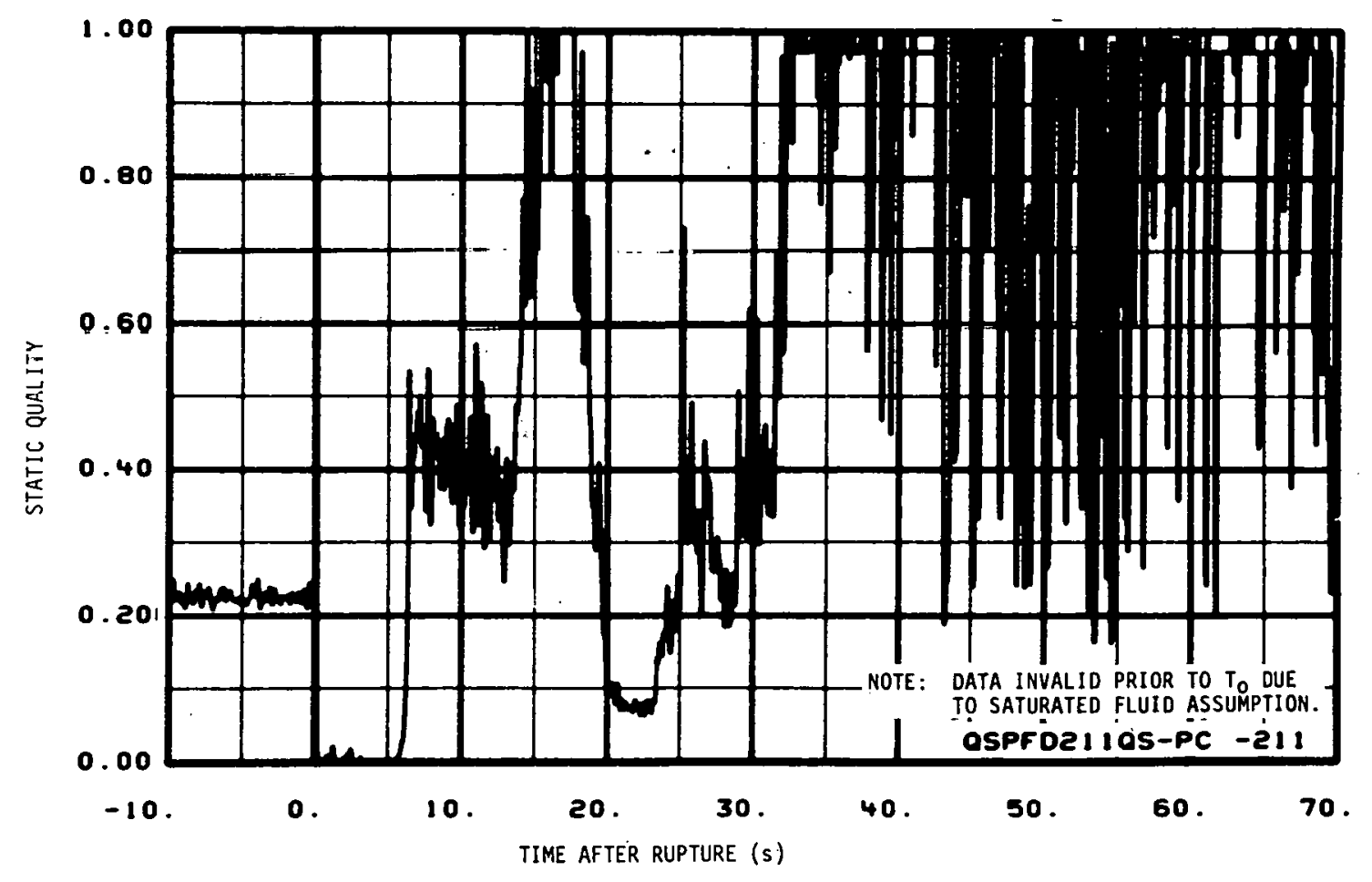

Fig. 212 Static quality in intact loop hot leg. 


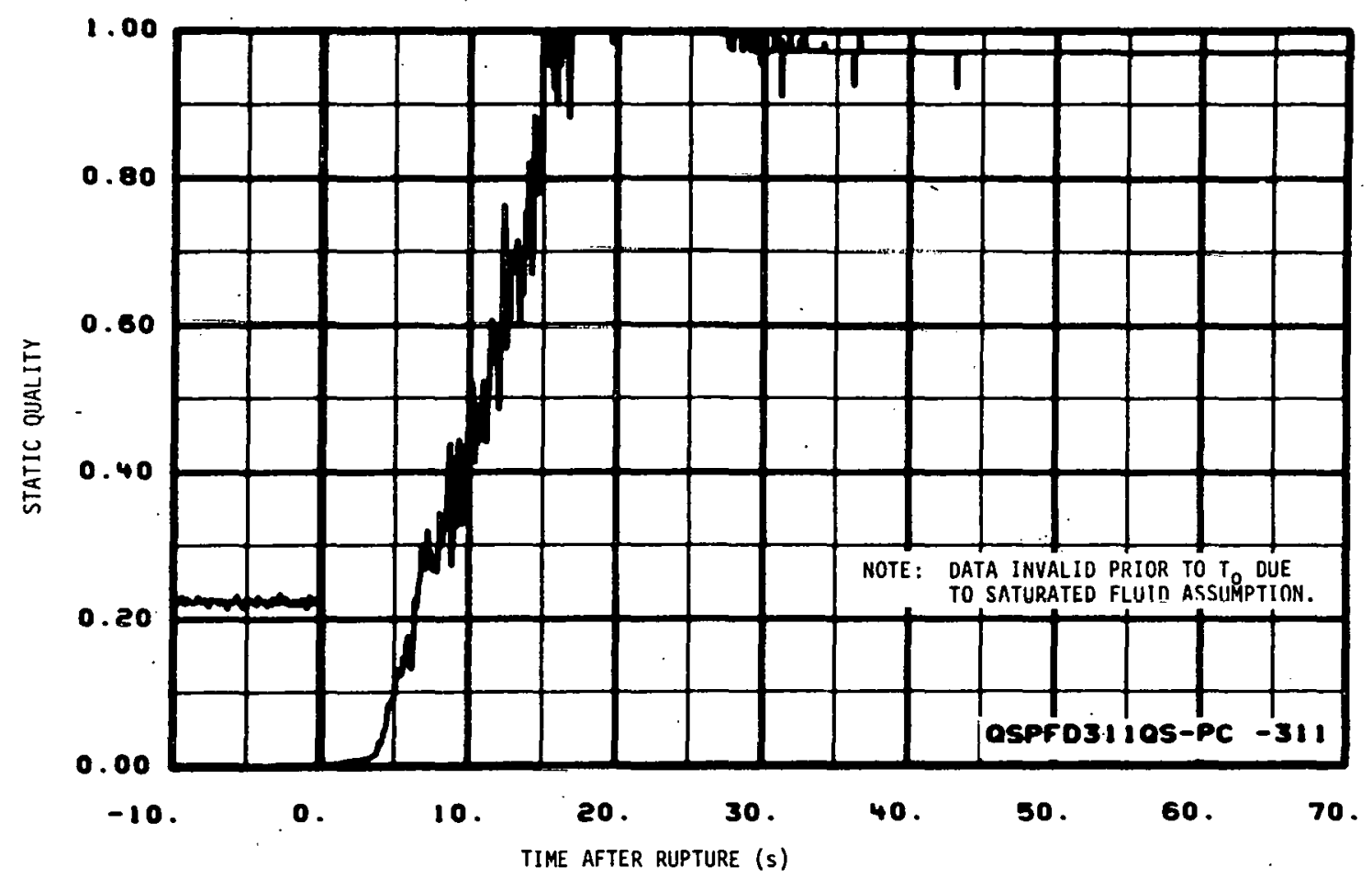

Fig. 213 Static quality in intact loop at steam generator outlet.

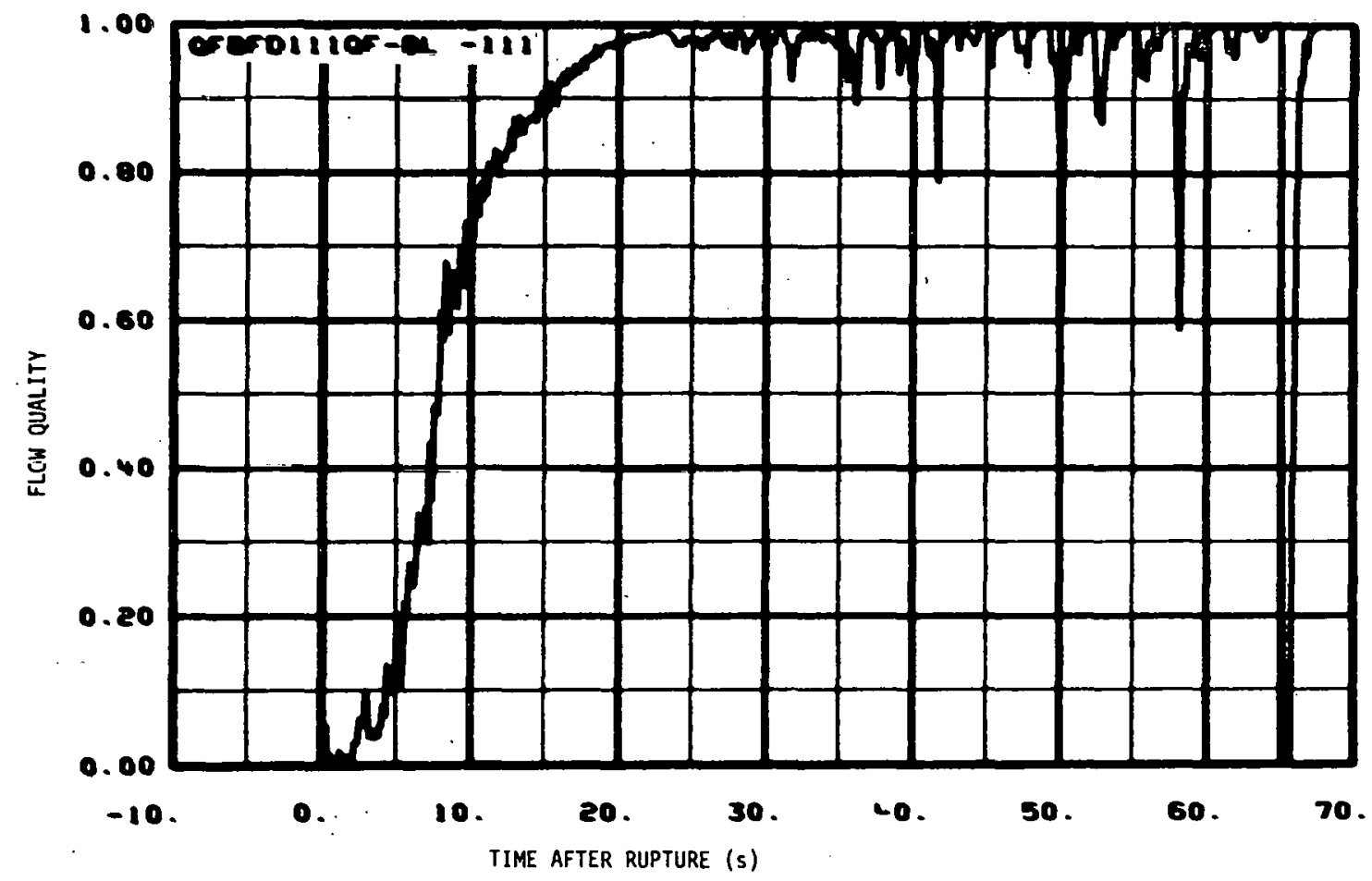

Fig. 214 Flow quality in broken loop cold leg. 


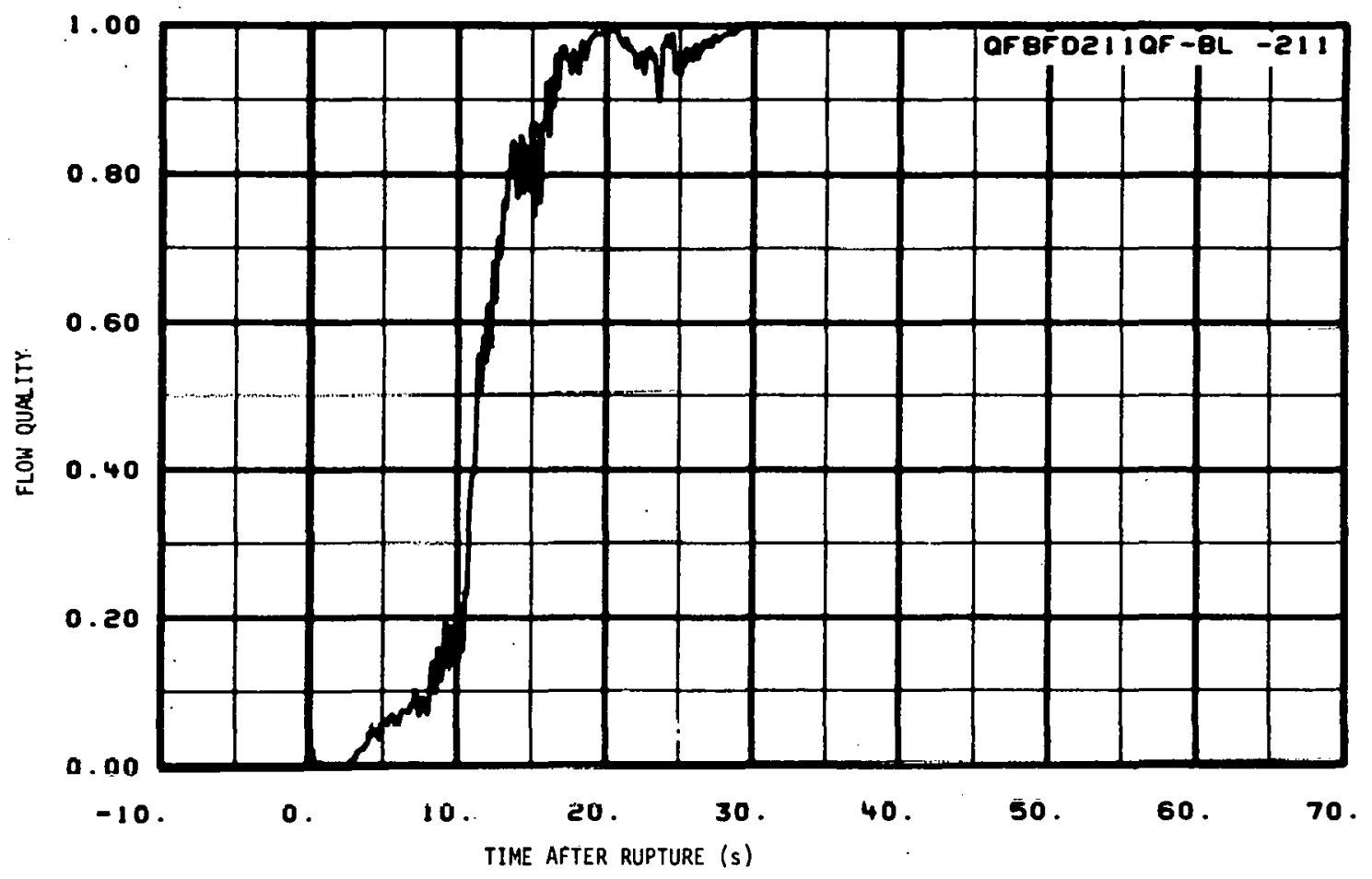

Fig. 215 Flow quality in broken loop hot leg.

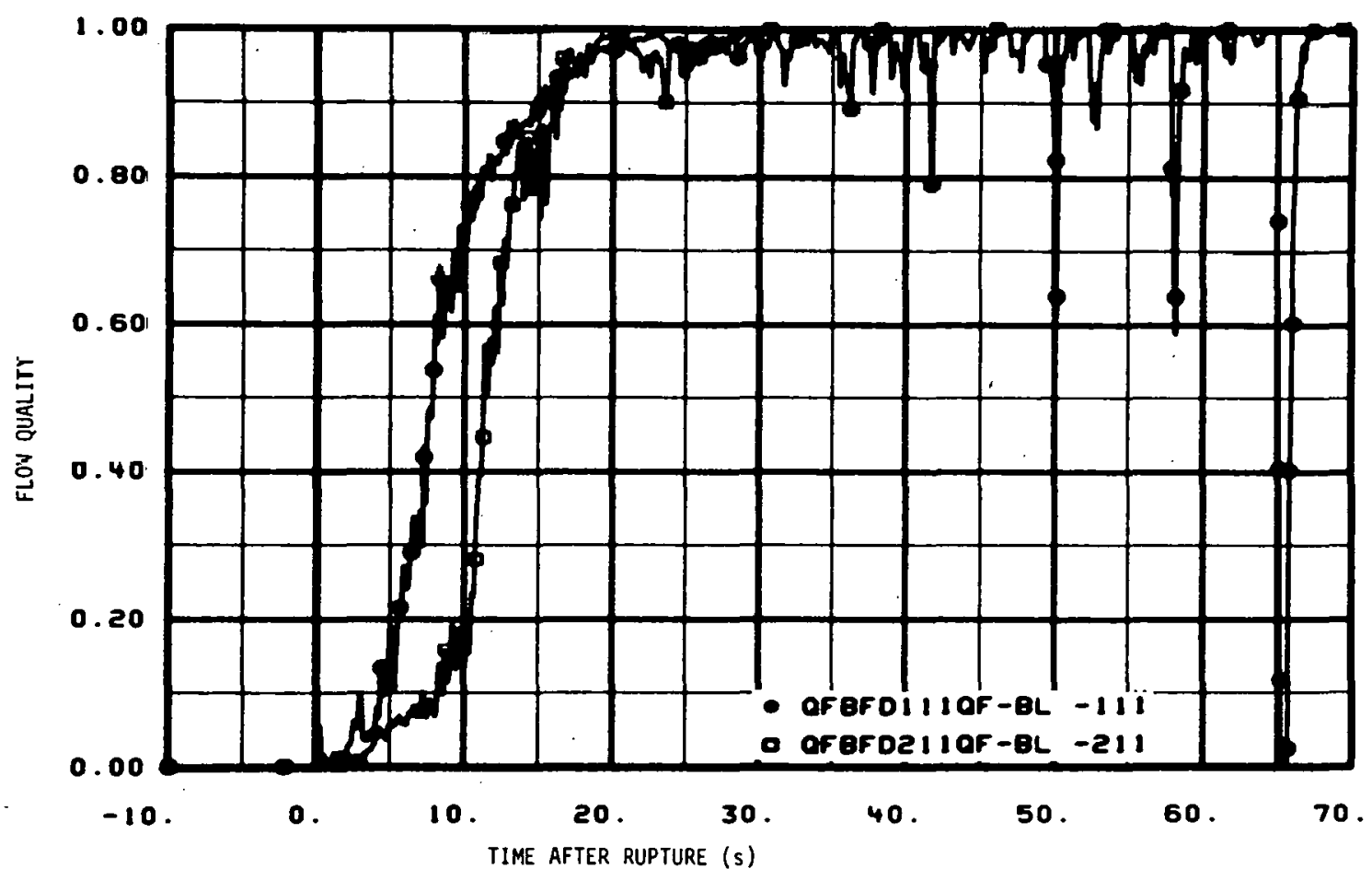

Fig. 216 Flow quality in broken loop cold and hot legs. 


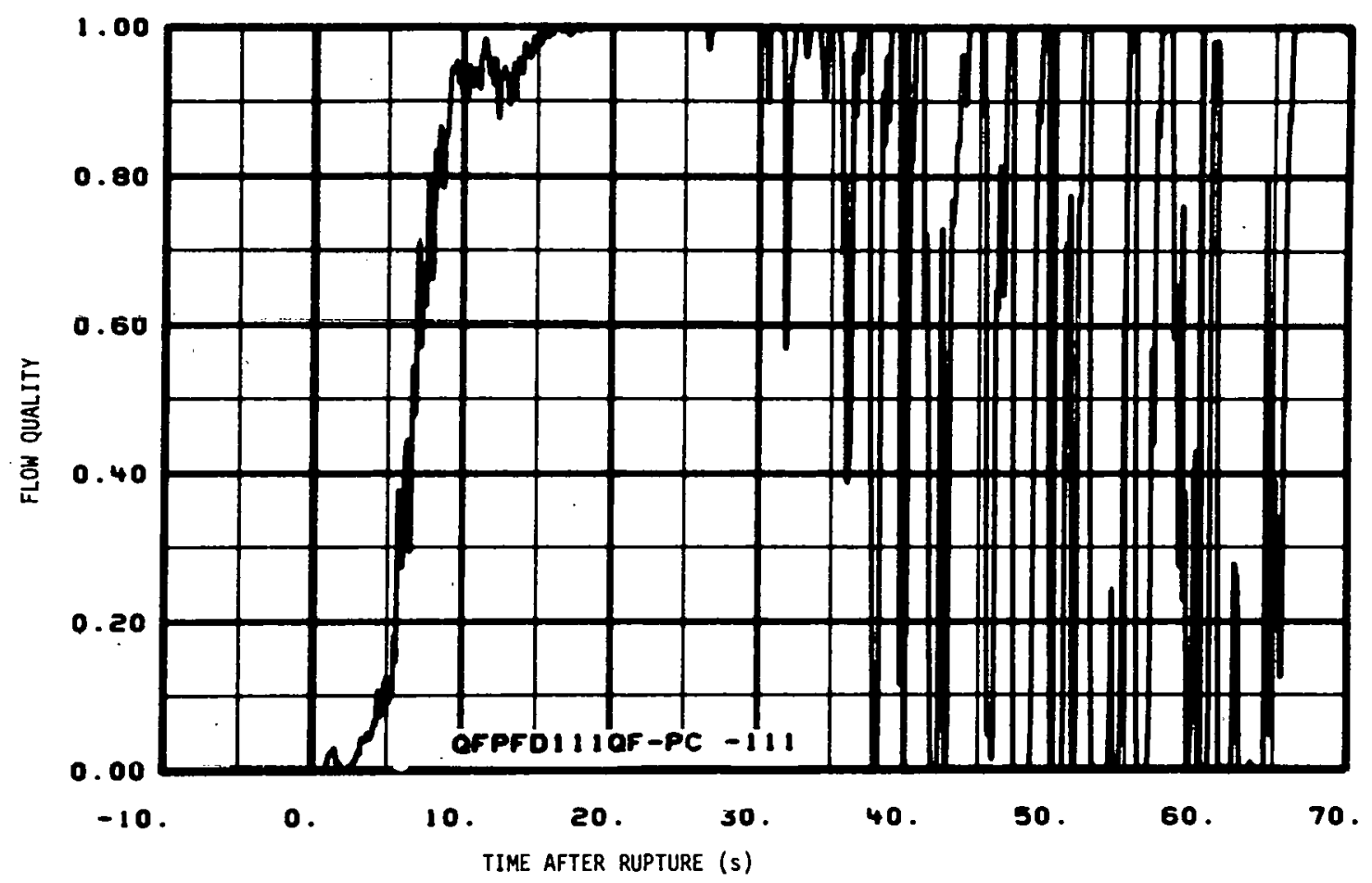

Fig. 217 Flow quality in intact loop cold leg.

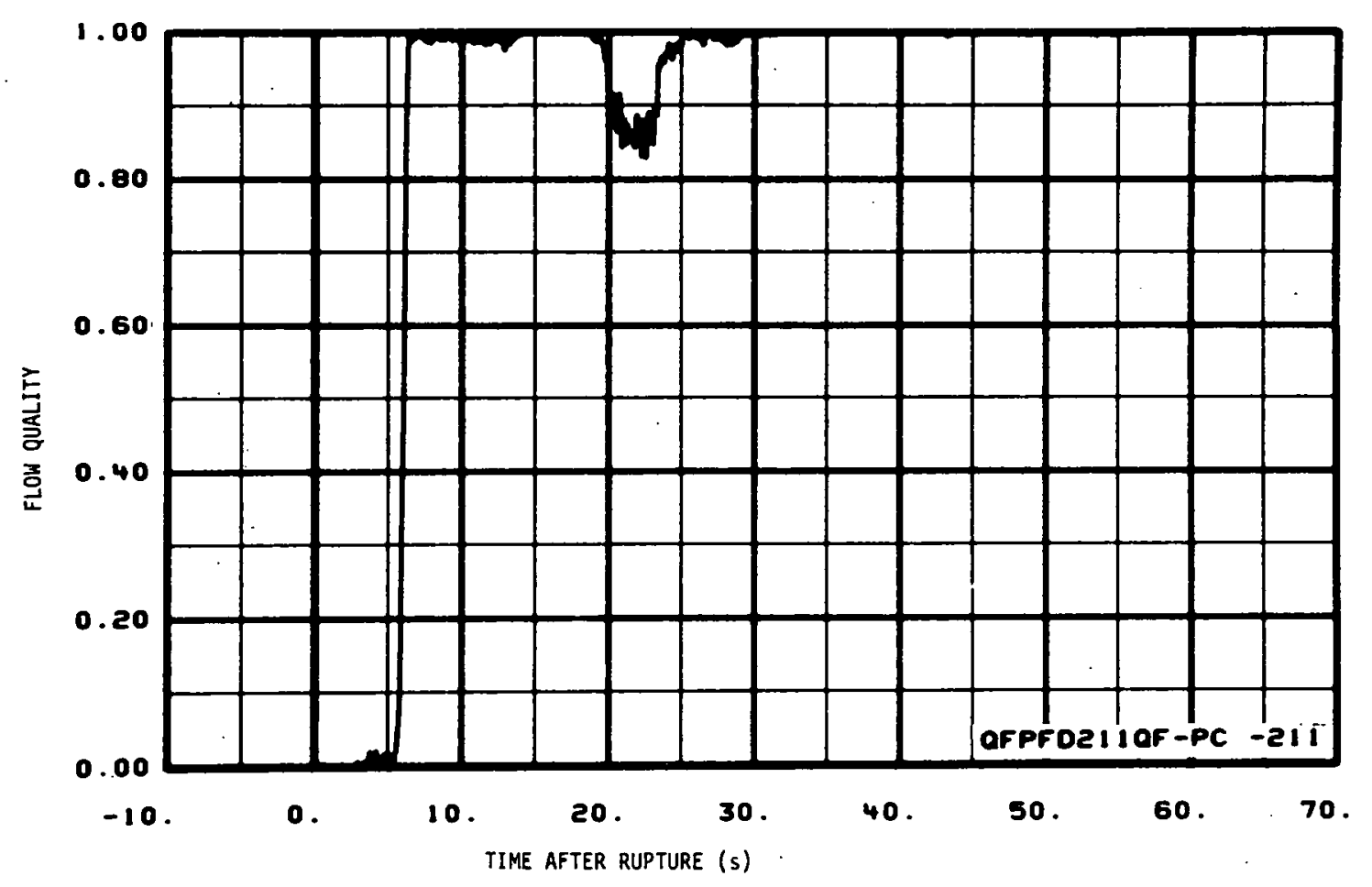

Fig. 218 Flow quality in intact loop hot leg. 


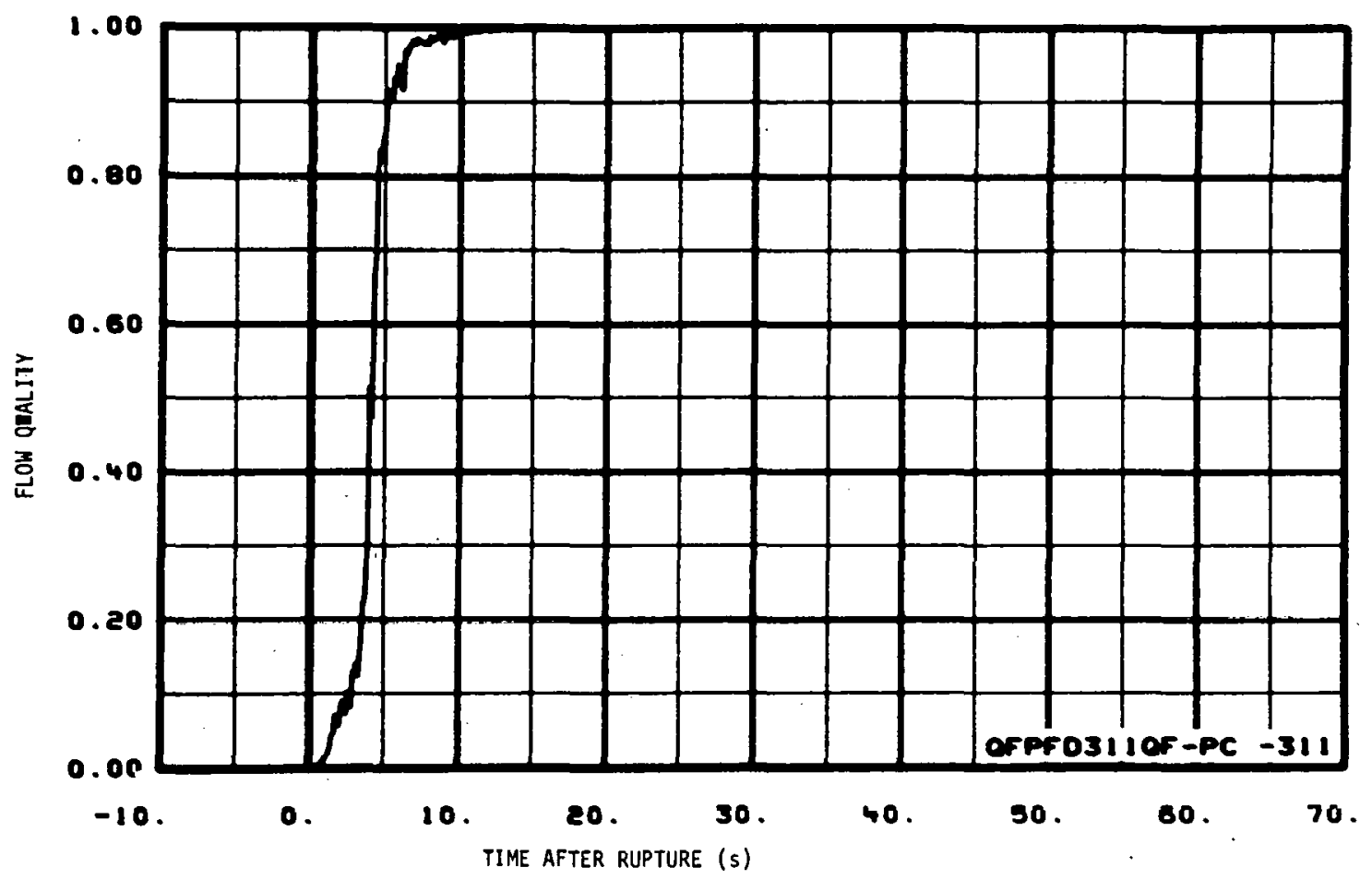

Fig. 219 Flow quality in intact loop at steam generator outlet.

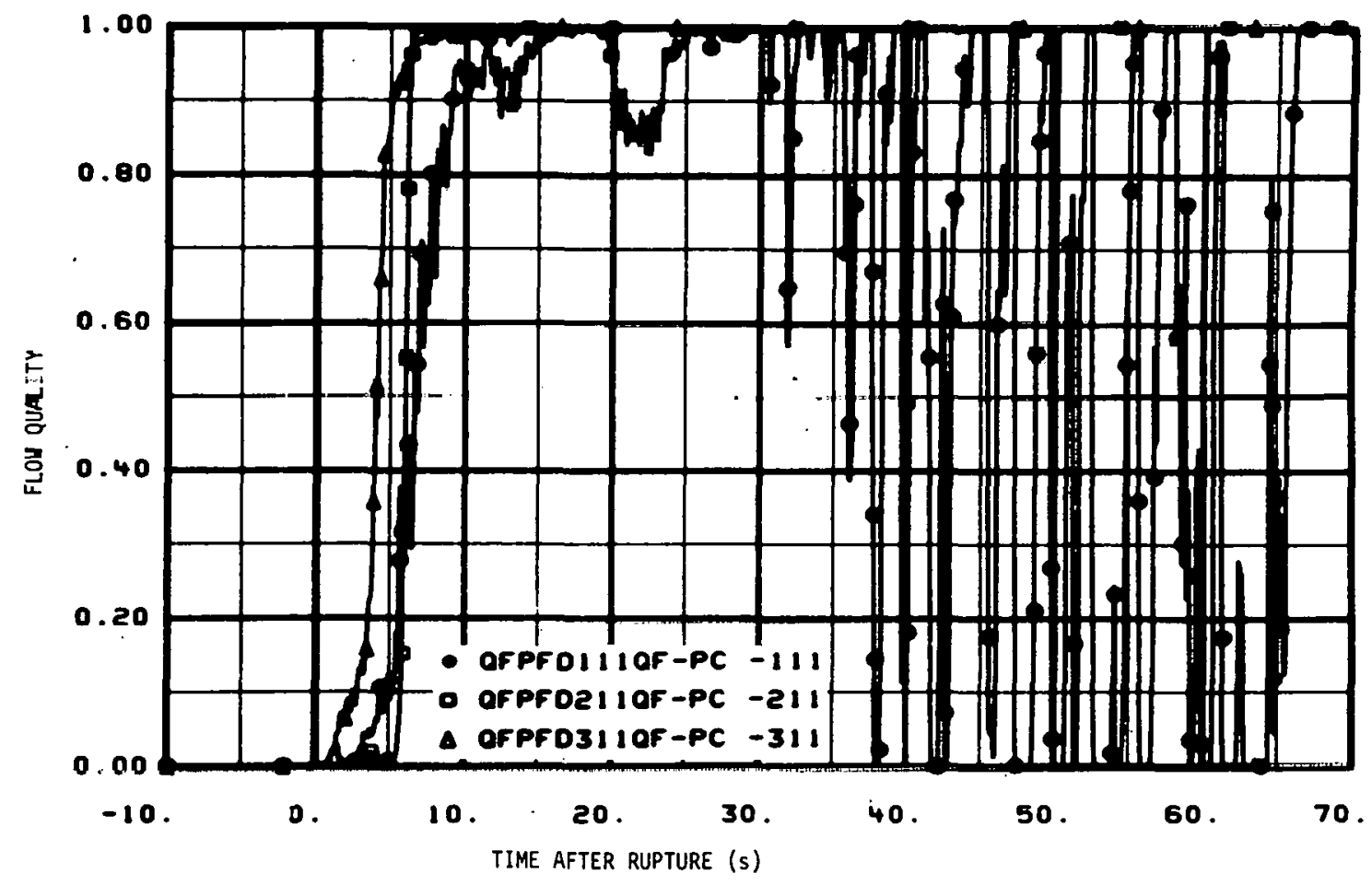

Fig. 220 Flow quality in intact loop cold leg, hot leg, and steam generator outlet. 


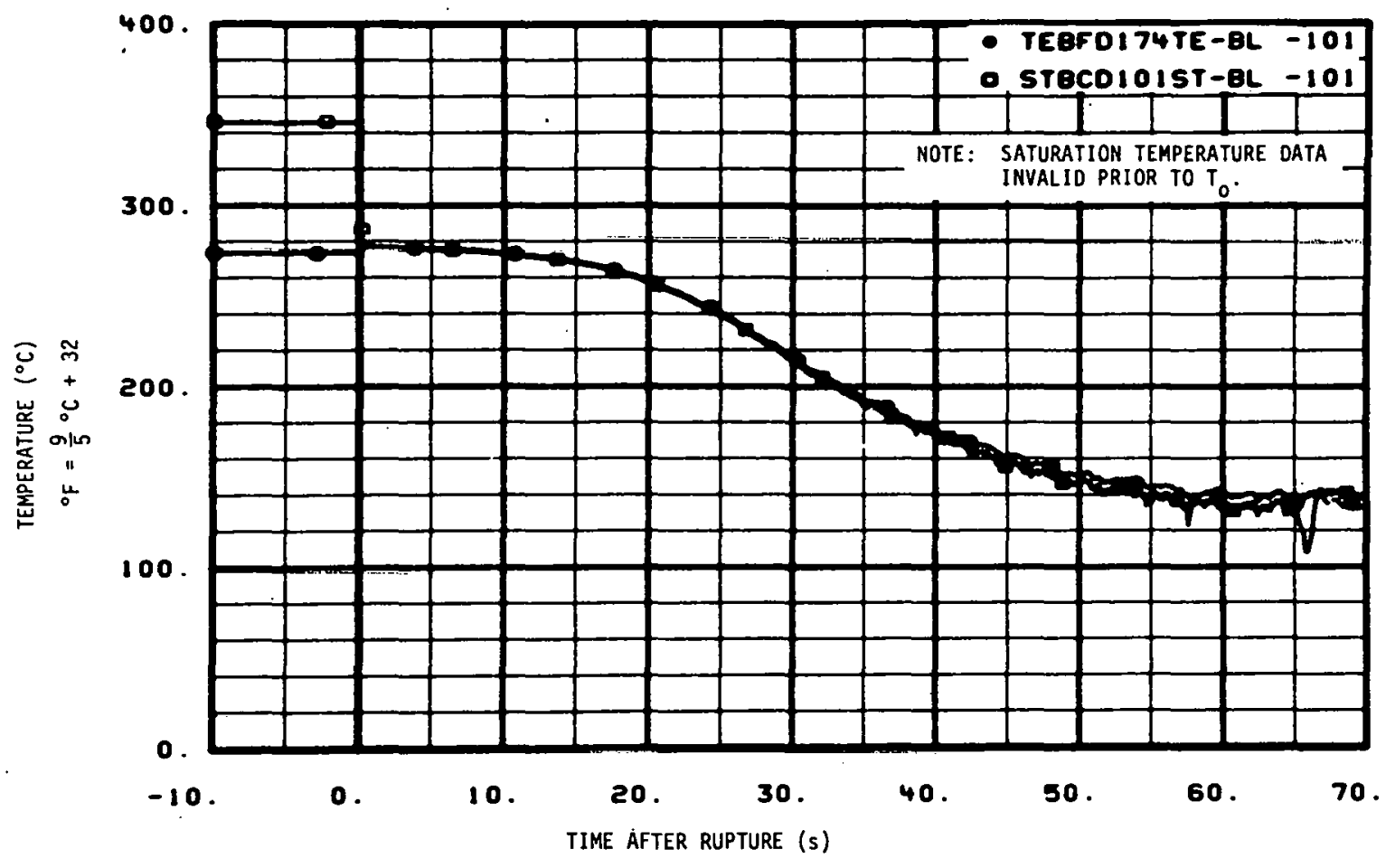

Fig. 221 Saturation temperature in broken loop cold leg overlaid with TE-BL-1.

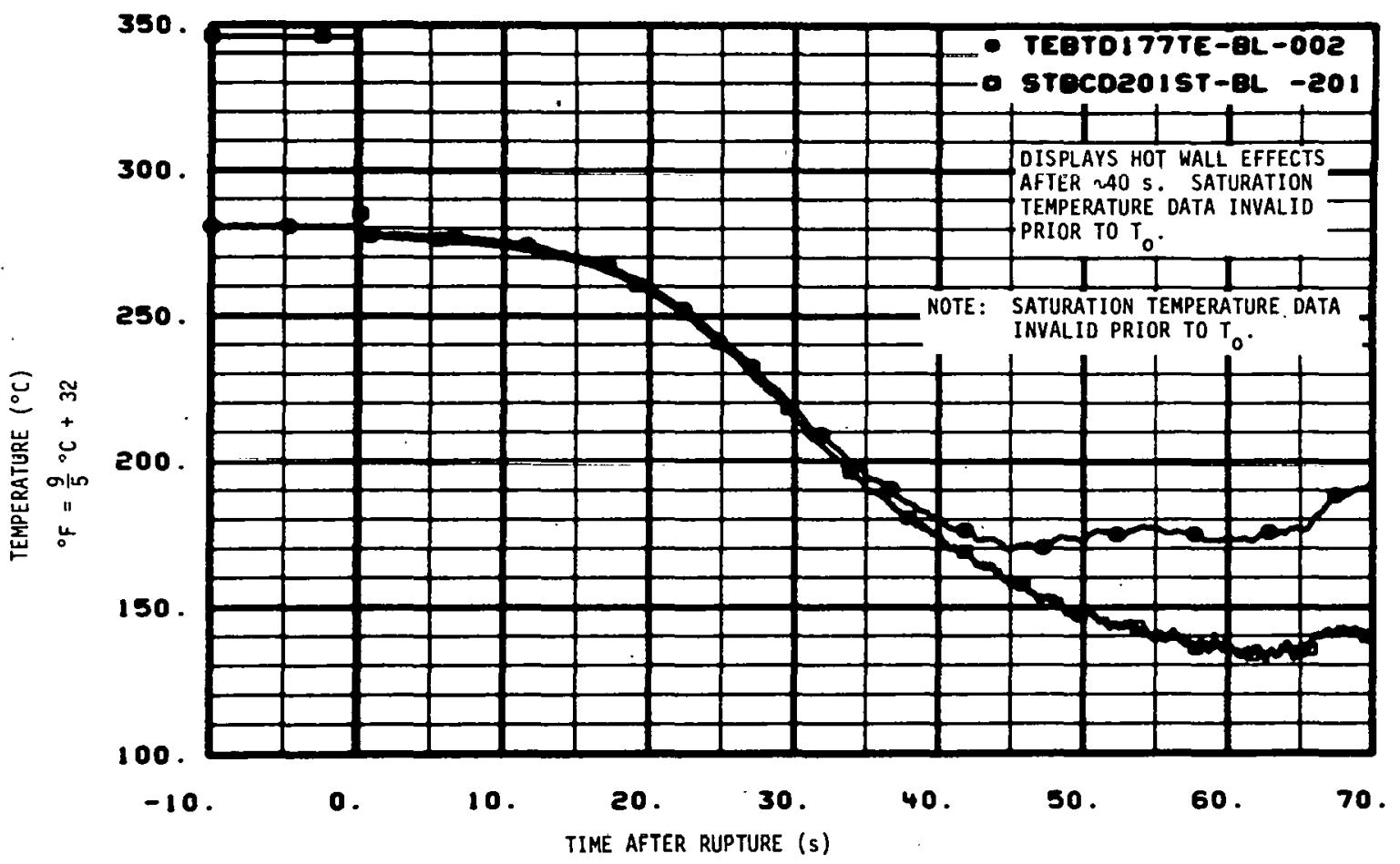

Fig. 222 Saturation temperature in broken loop hot leg overlaid with TE-BL-2. 


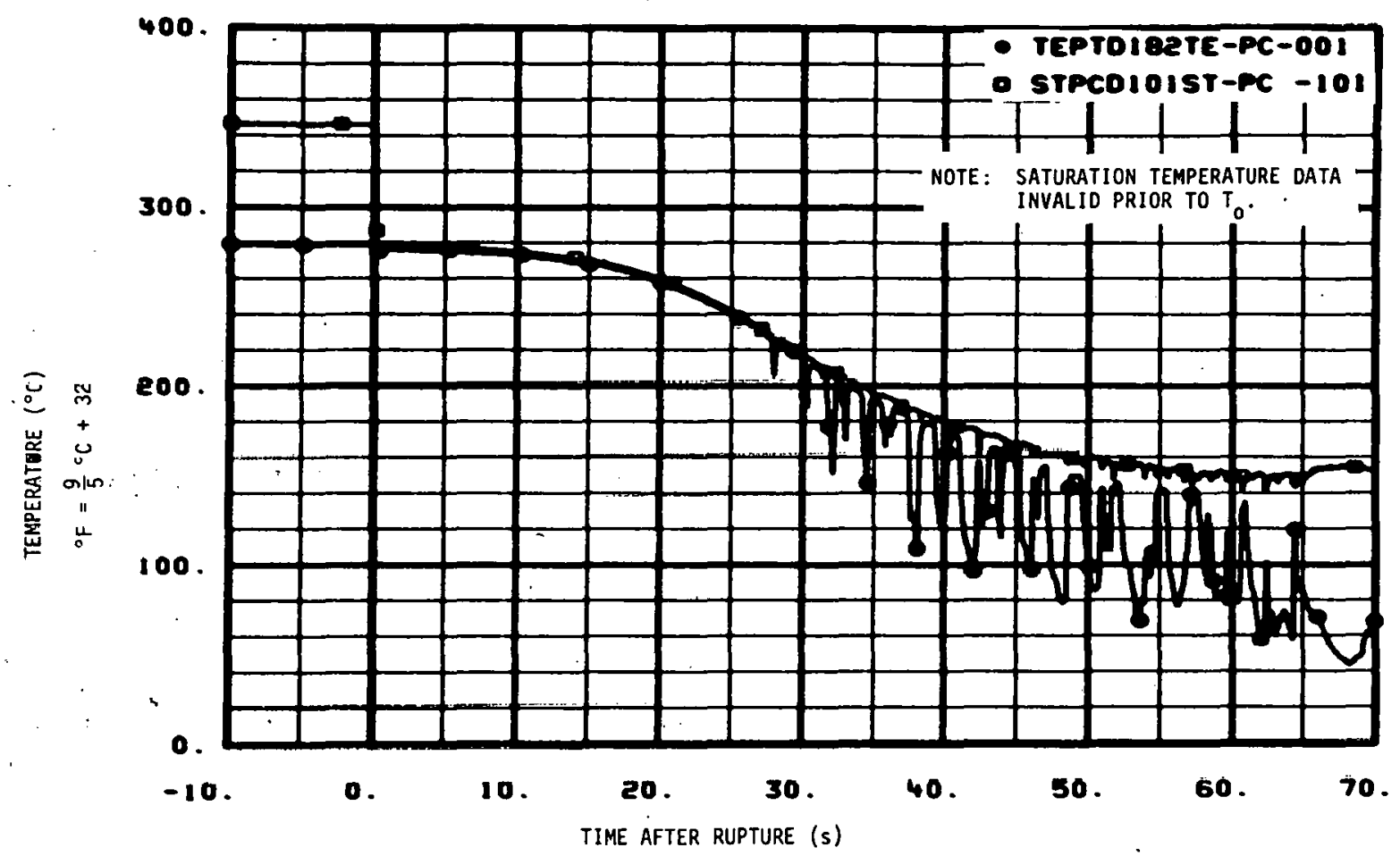

Fig. 223 Saturation temperature in intact loop cold leg overlaid with TE-PC-1.

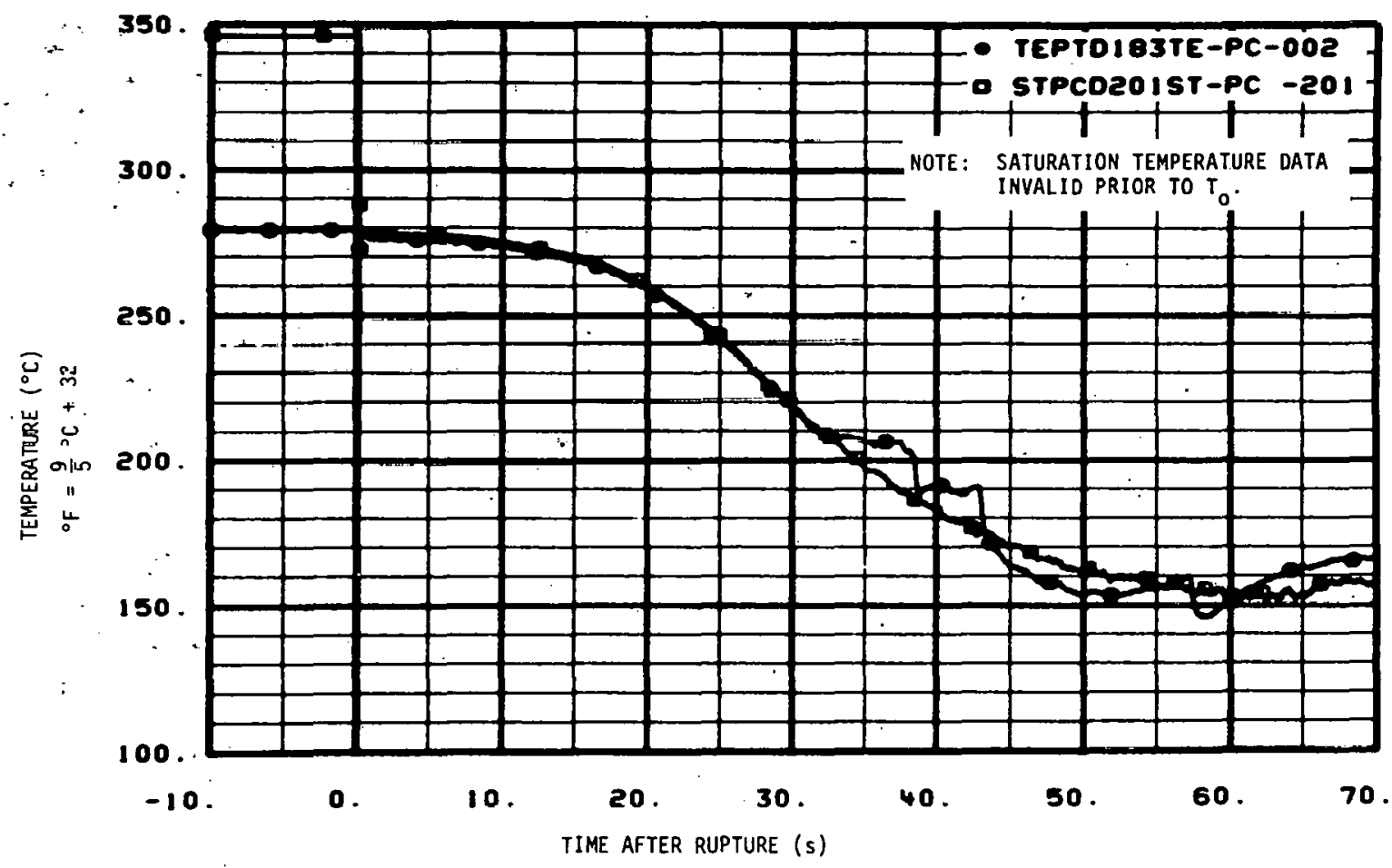

Fig. 224. Saturation temperature in intact loop hot leg overlaid wi th TE-PC-2. 


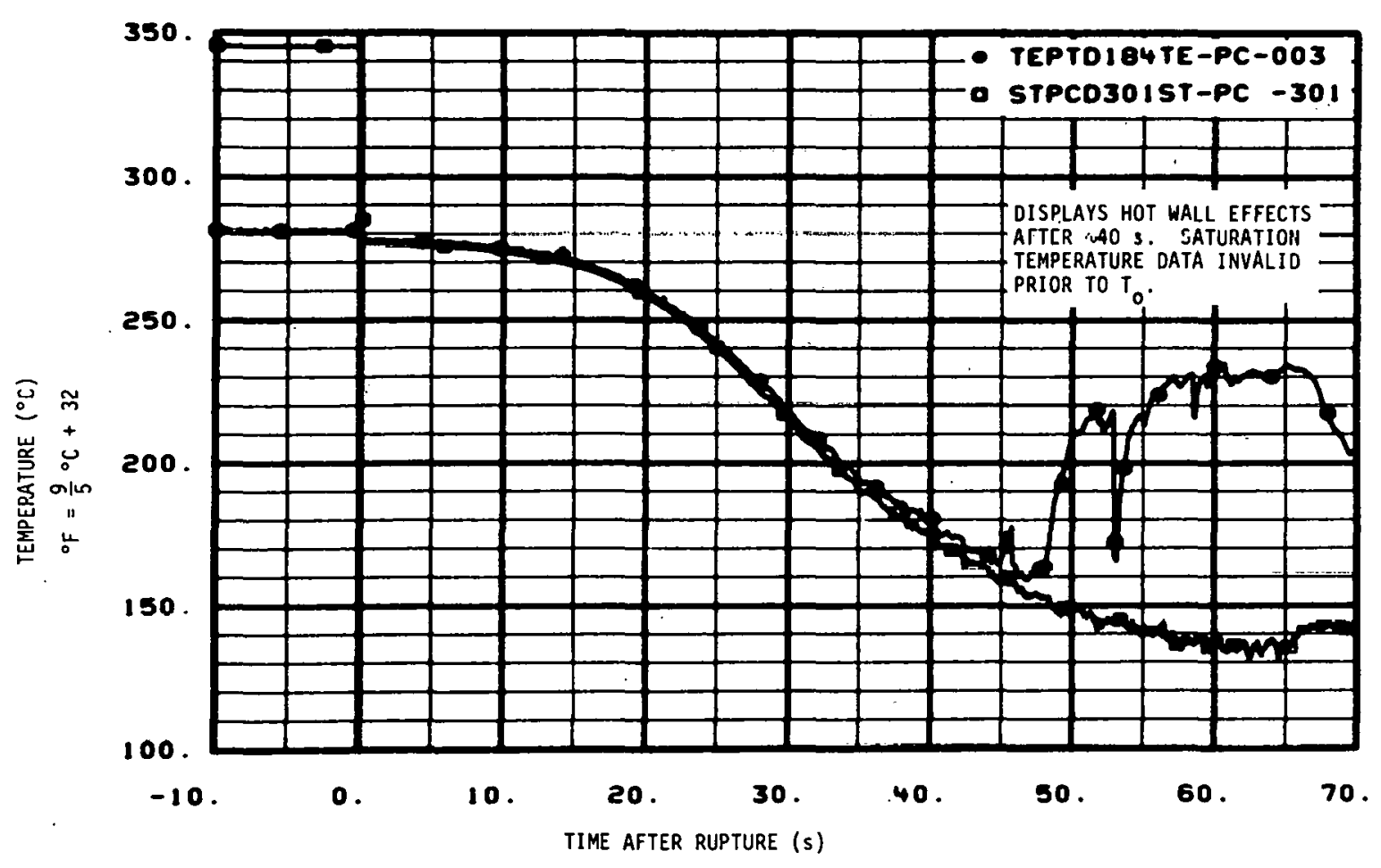

Fig. 225 Saturation temperature in intact loop steam generator outlet overlaid with TE-PC-3.

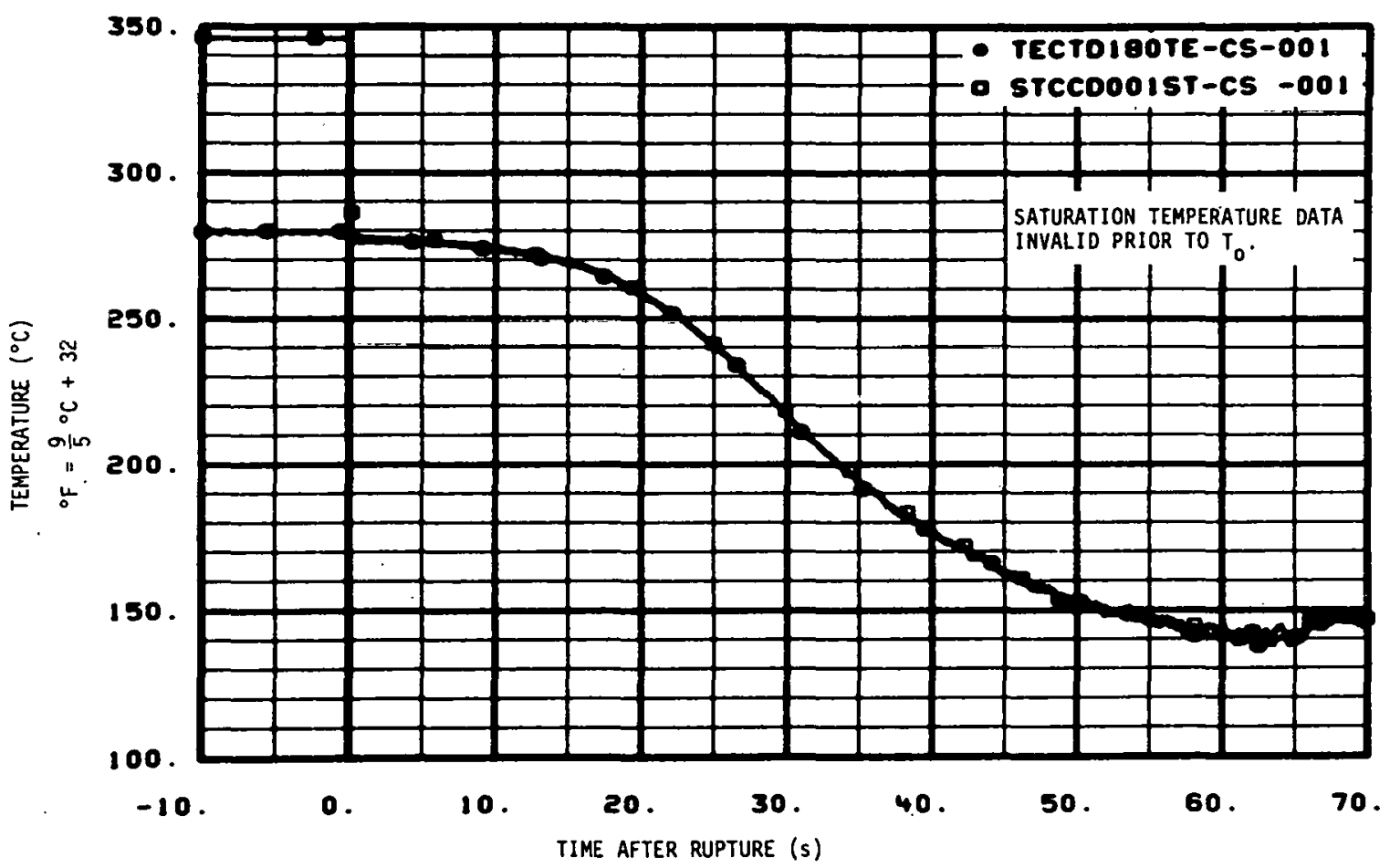

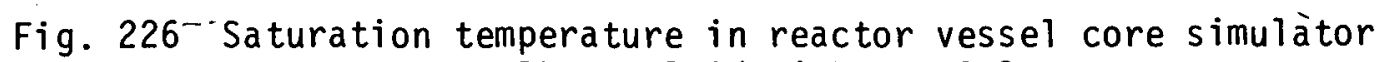
instrument stalk overlaid with TE-CS-1. 


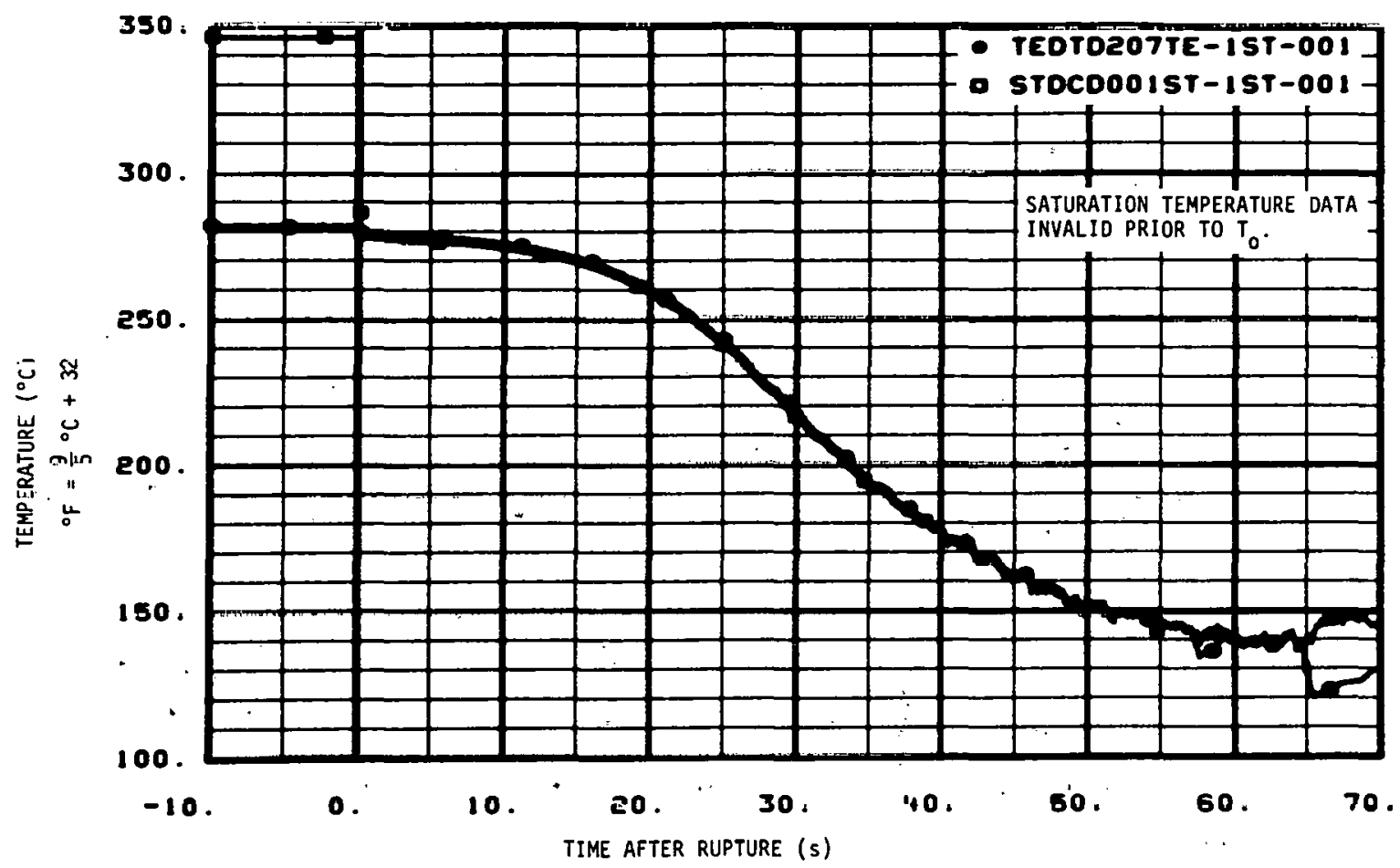

Fig. 227 Saturation temperature in reactor vessel downcomer instrument stalk. 1 overlaid with TE-1ST-1A.

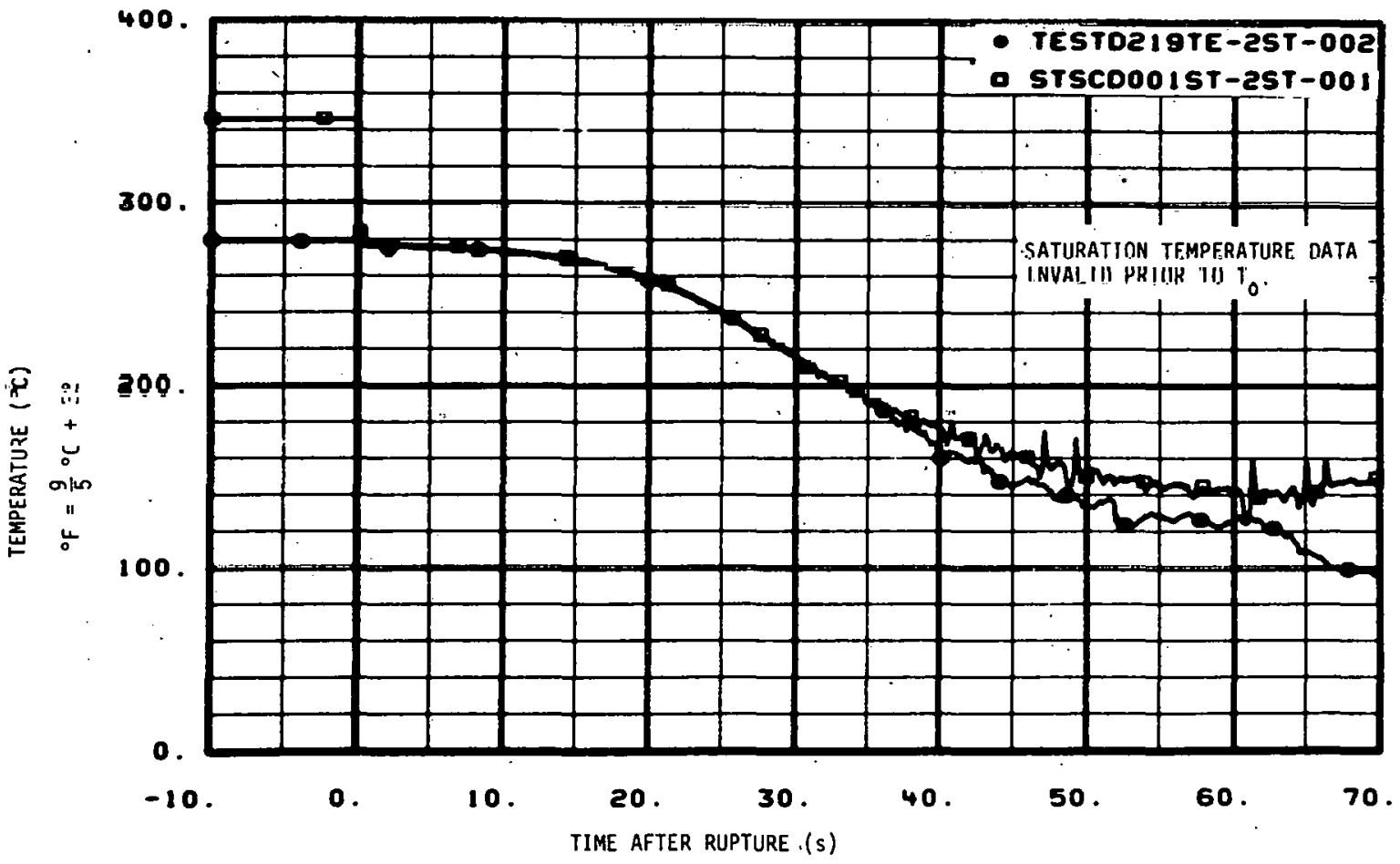

Fig. 228 Saturation temperature in reactor vessel downcomer instrument stalk 2 overlaid with TE-2ST-1A. 



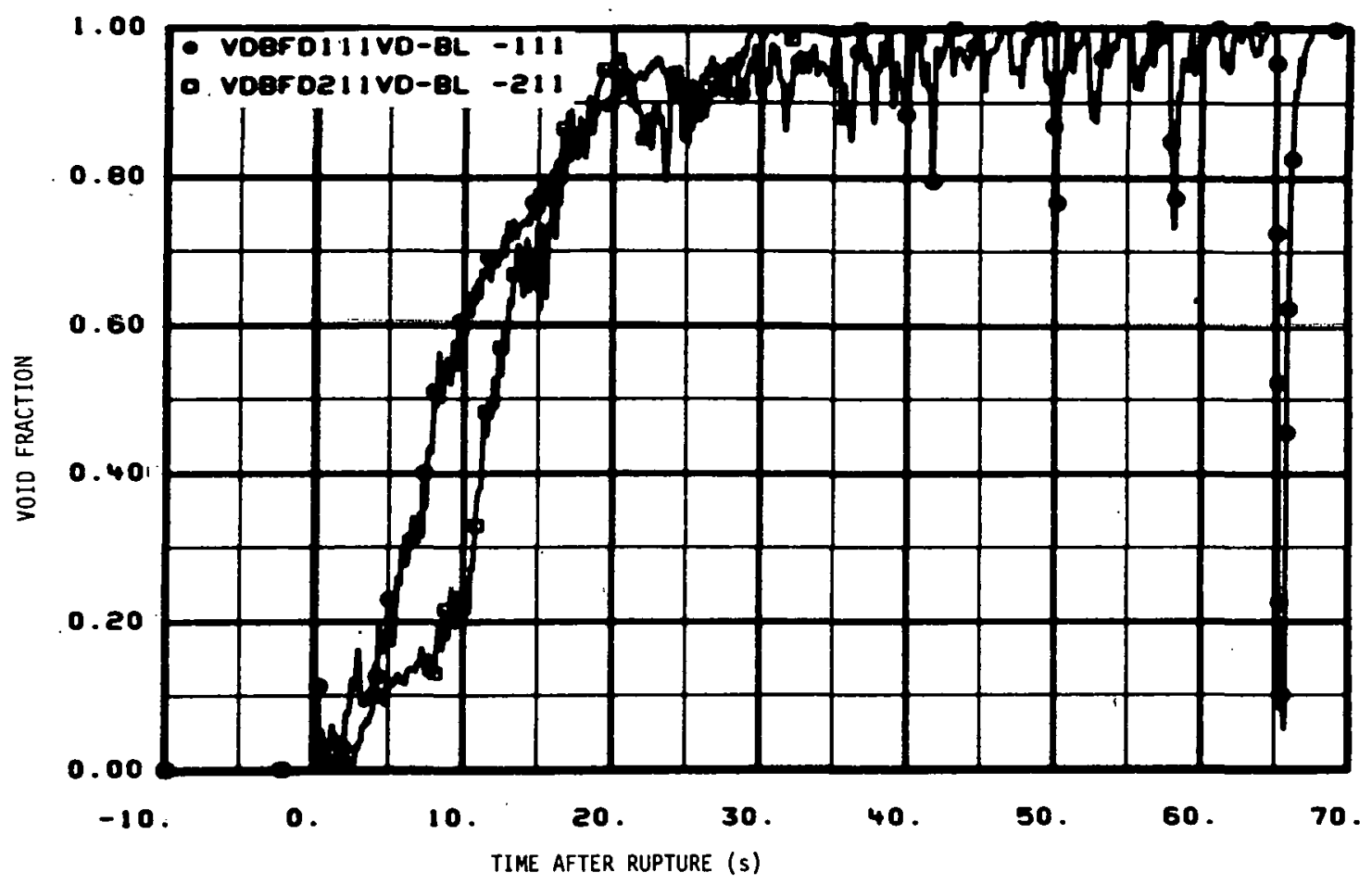

Fig. 229 Void fraction in broken loop cold and hot legs.

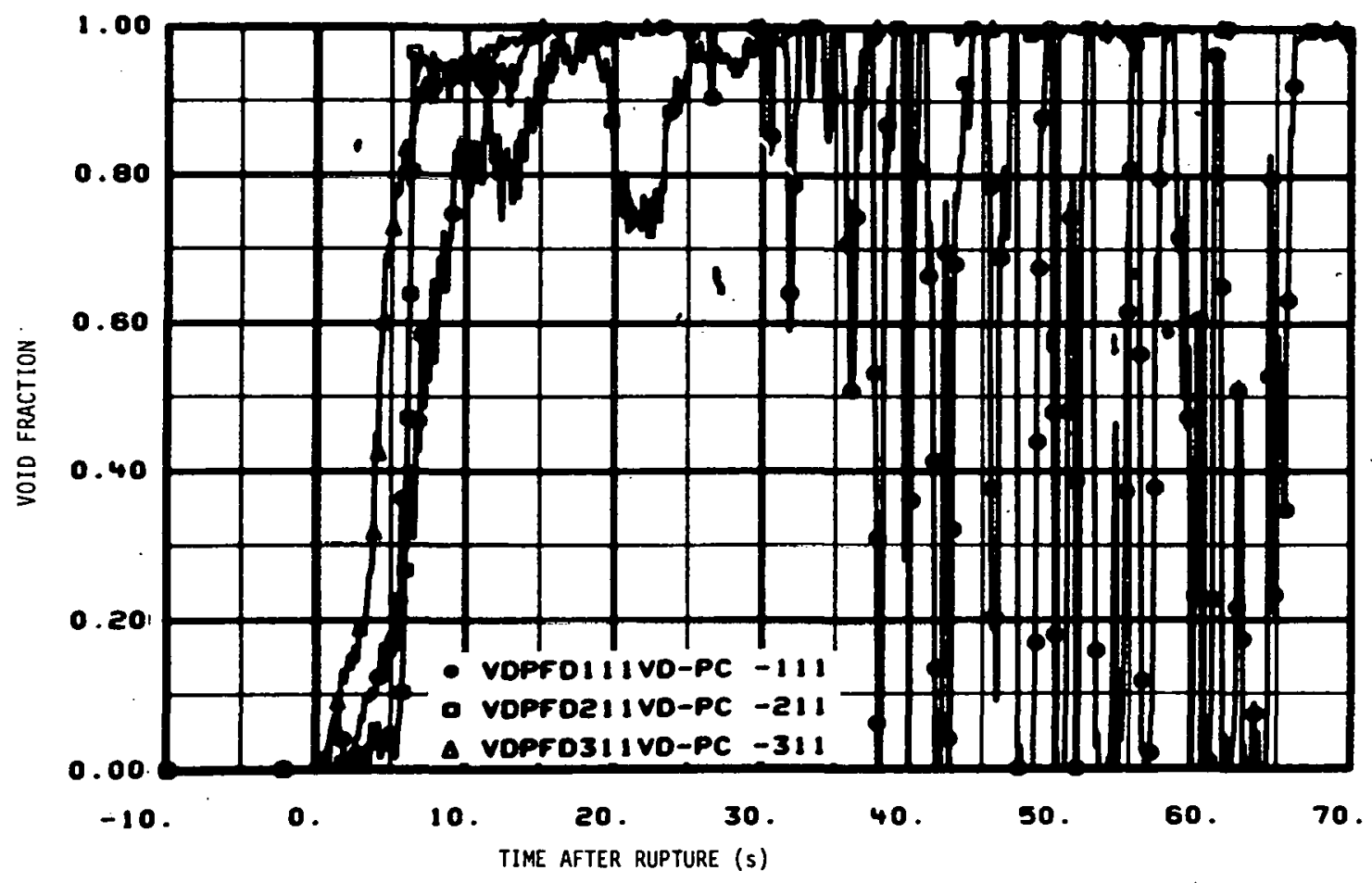

Fig. 230 Void fraction in intact loop cold leg, hot leg, and steam generator outlet. 


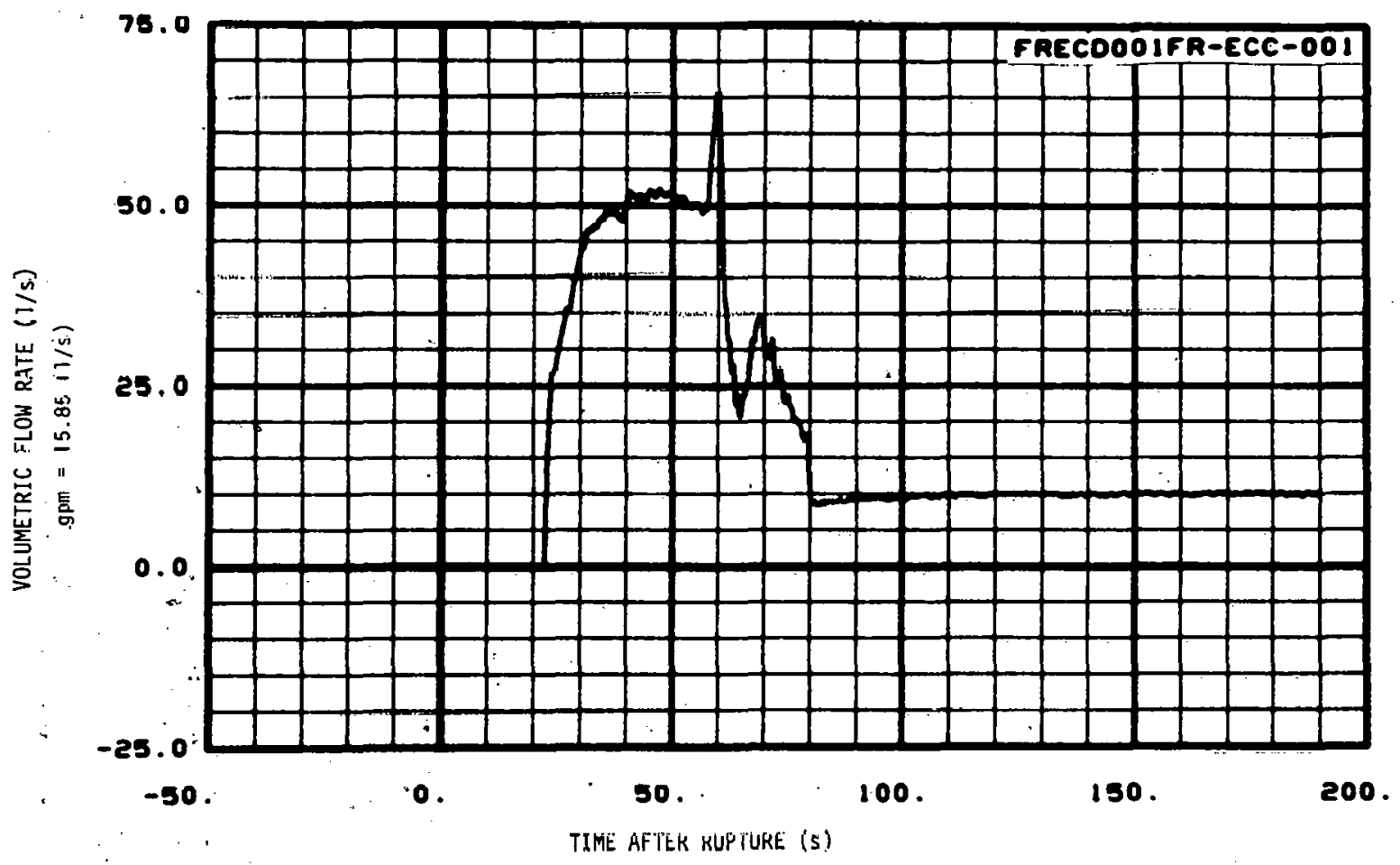

Fig. 231 Volumetric flow rate of ECC into cold leg injection line calculated from FT-P120-36-1, FT-P120-85, and FT-P128-104. 


\section{ERROR BAND PLOTS}

This section of presented data consists of Figures 232 through 256.

The uncertainty for various instruments used only to establish steady state conditions are presented in Table IX. A complete list of the instrument uncertainties is contained in Reference 11.

TABLE IX

TYPICAL ERROR BANDS

Typical Instrument

FE-P138-139

FT-P120-85

FT-P 739-27-3

PdE-PC-2

PdE-RV-1

PE-CS-2FF

PT-P1 20-64

PT-P120-83

PT-P138-55

PT-P.138-111

PT-P138-1.36

TE-P138-22

TE-P138-34

TE-P138-62

TE-P138-63

TE-P138-141

TE-P139-020

TE-SG-001
Uncertainty

$$
\begin{aligned}
& +0.331 / \mathrm{s} \\
& \mp 0.18 \mathrm{l} / \mathrm{s} \\
& \pm 0.007 \mathrm{~m} \\
& \mp 0.007 \mathrm{MPa} \\
& \mp 0.24 \mathrm{MPa} \\
& \mp 0.14 \mathrm{MPa} \\
& \mp 0.15 \mathrm{MPa} \\
& \mp 0.05 \mathrm{MPa} \\
& \mp 0.005 \mathrm{MPa} \\
& \begin{array}{r}
+0.09+0.0022 \mathrm{RD}(\mathrm{MPa})[\mathrm{a}] \\
\pm 0.69+0.02 \mathrm{RD}(\mathrm{MPa})
\end{array} \\
& +1.28^{\circ} \mathrm{C} \\
& \mp 1.69^{\circ} \mathrm{C} \\
& \mp 3.4^{\circ} \mathrm{C} \\
& \mp 3.0^{\circ} \mathrm{C} \\
& \mp 2.67^{\circ} \mathrm{C} \\
& \mp 4.0^{\circ} \mathrm{C} \\
& \mp 4.3 \% \text { reading }
\end{aligned}
$$

[a] To apply uncertainty values, use the root mean square method (i.e. $\sqrt{\left.[0.09 \text { (range) }]^{2}+[0.0022(\text { reading })]^{2}\right)}$. 


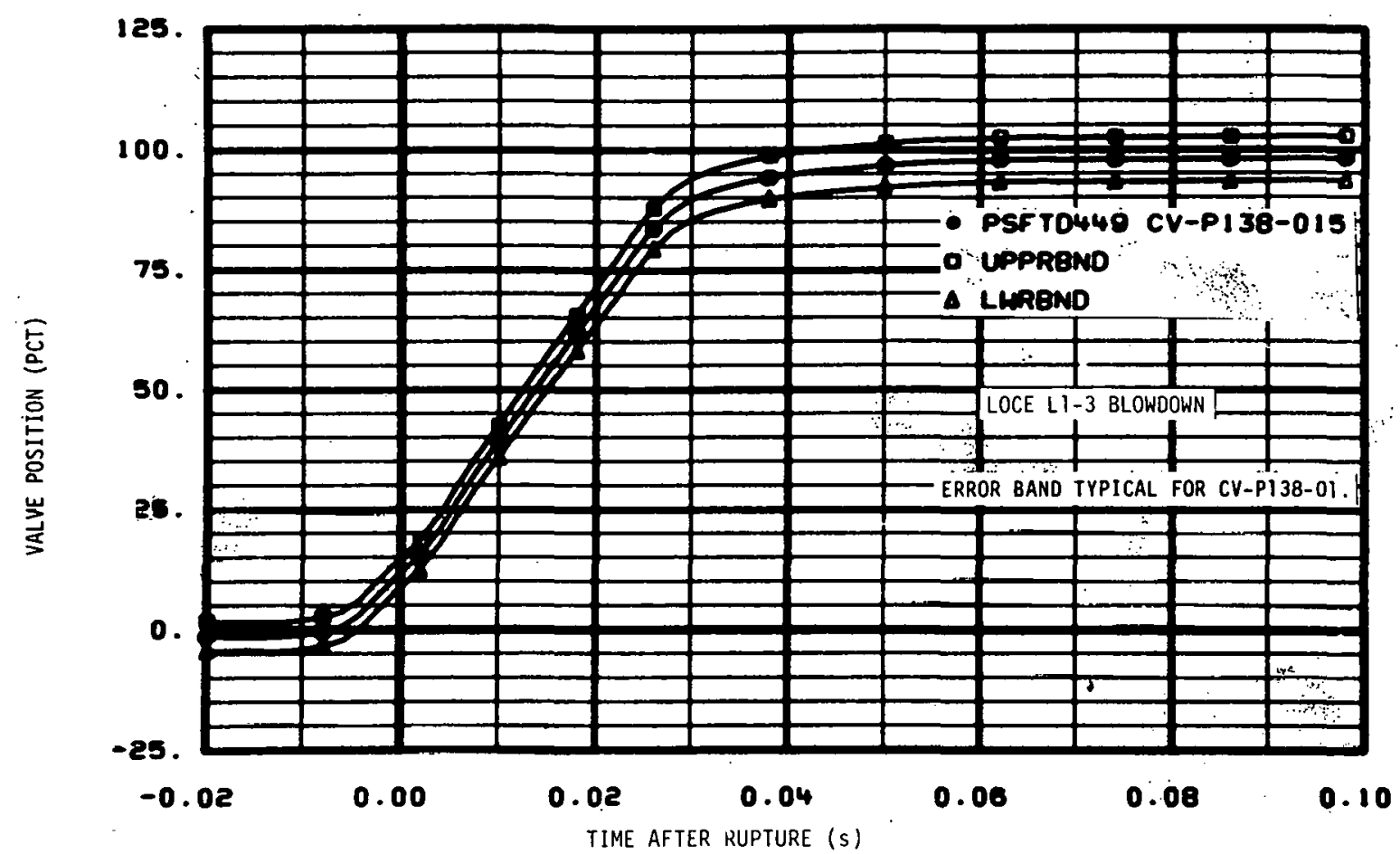

Fig. 232 Valve opening (\%) in broken loop hot leg QOBV with error bands (CV-PT38-15).

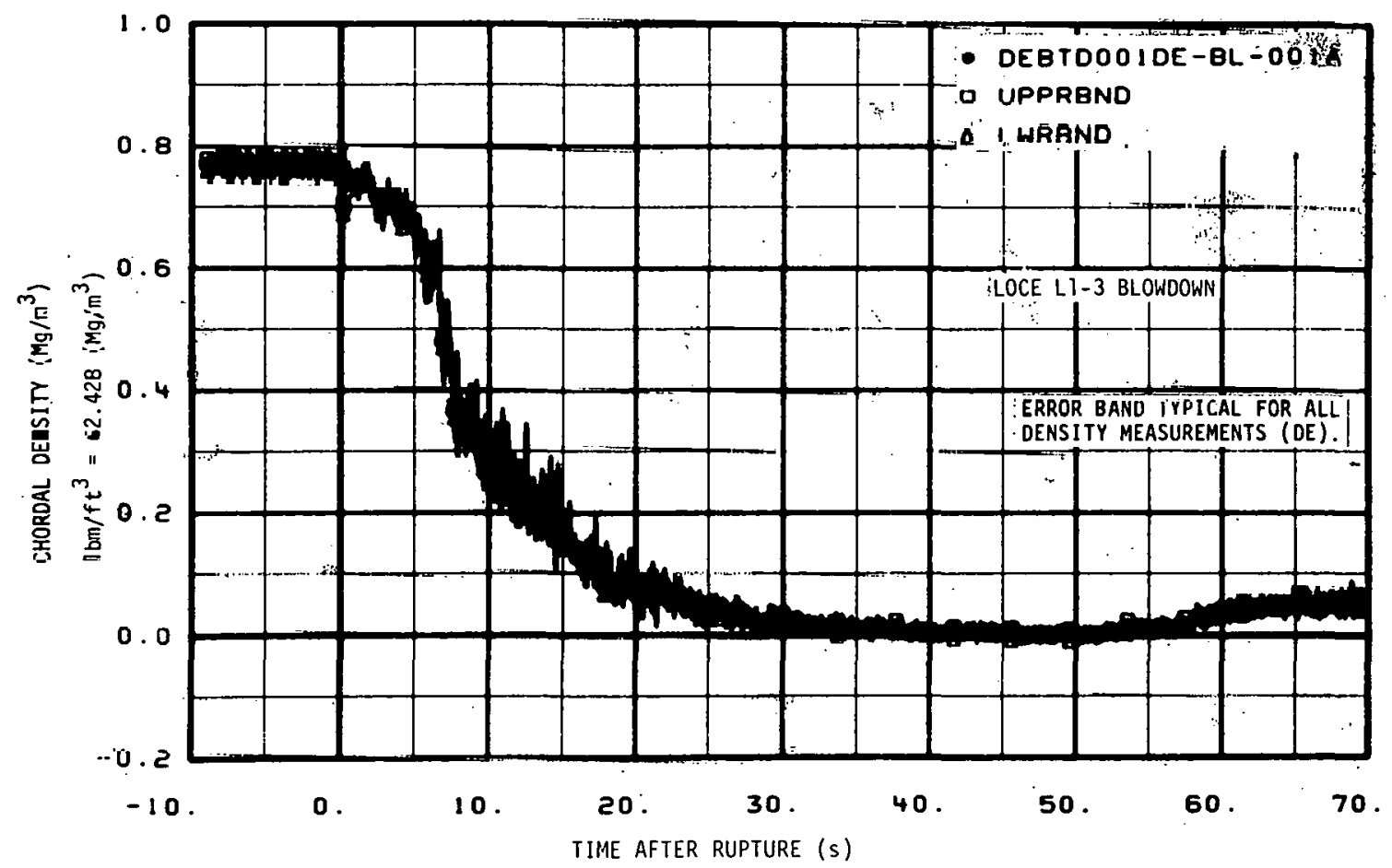

Fig. 233 Chordal density in broken loop cold leg with error bands $(D E-B L-1 A)$ (filtered to $4 \mathrm{~Hz}$ ). 


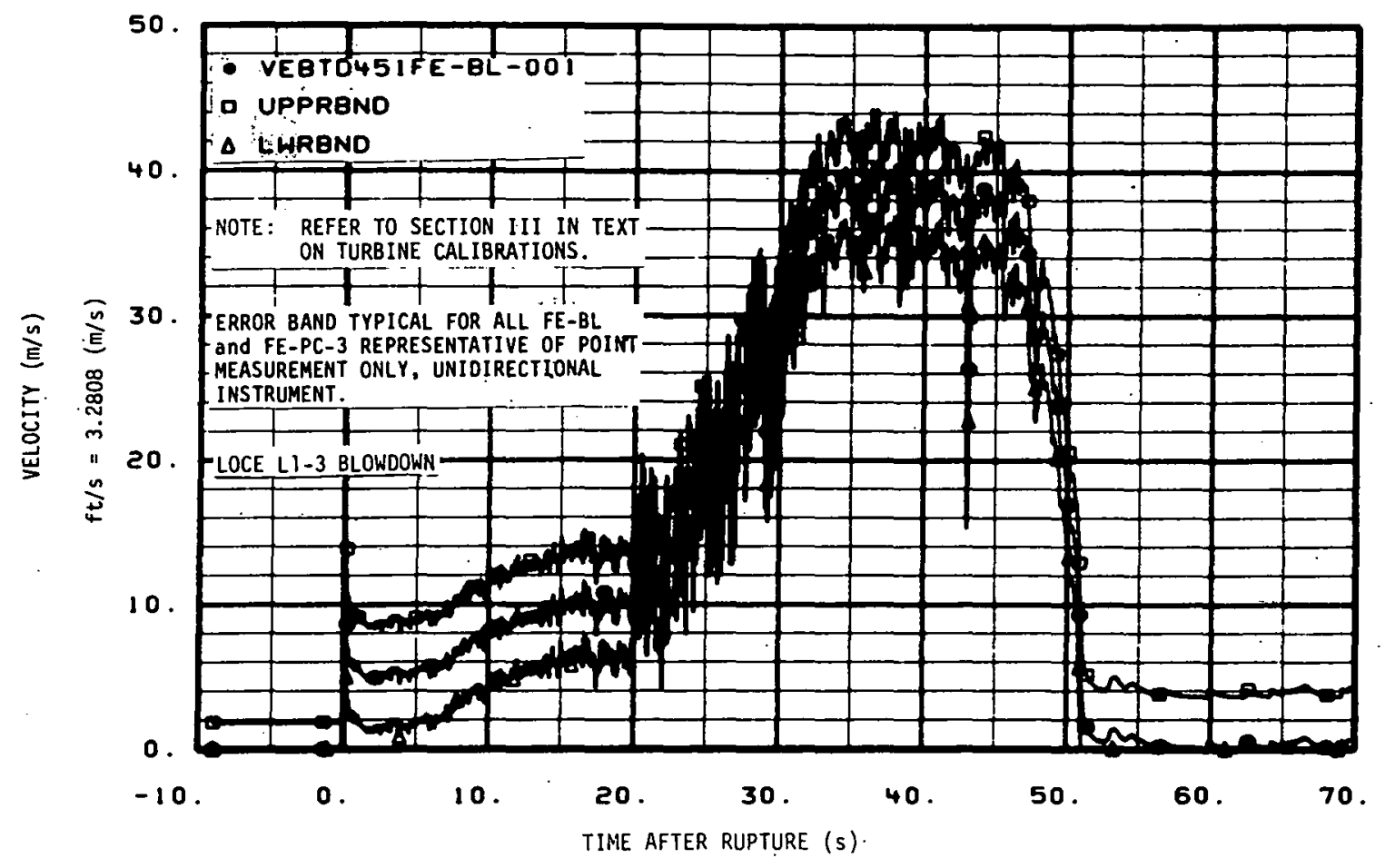

Fig. 234 Average velocity in broken loop cold leg at DTT flange with error bands (FE-BL-1) (filtered to $4 \mathrm{~Hz}$ ).

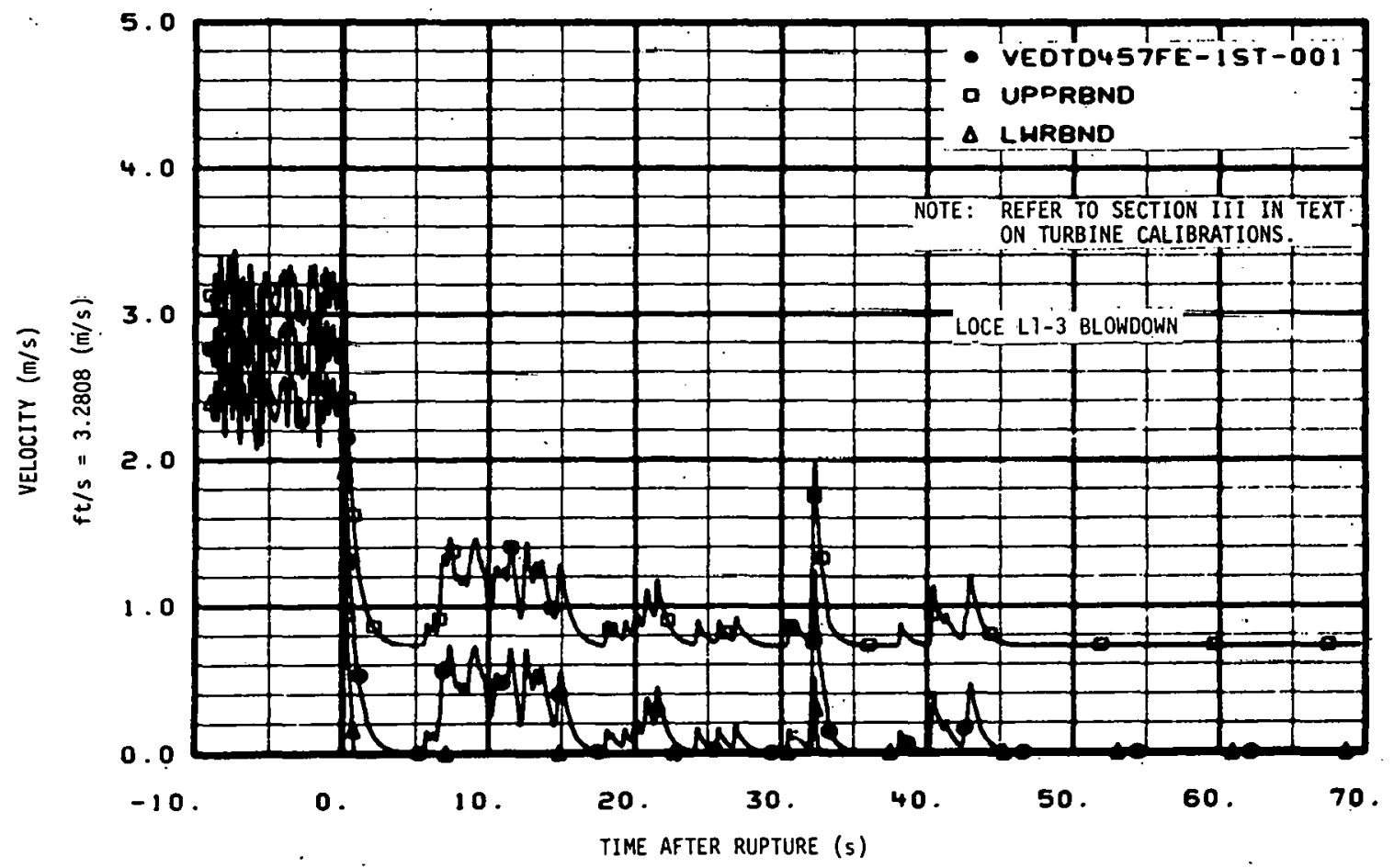

Fig. 235 Average velocity in reactor vessel downcomer instrument. stalk 1 with error bands (FE-1ST-1) (filtered to $4 \mathrm{~Hz}$ ). 


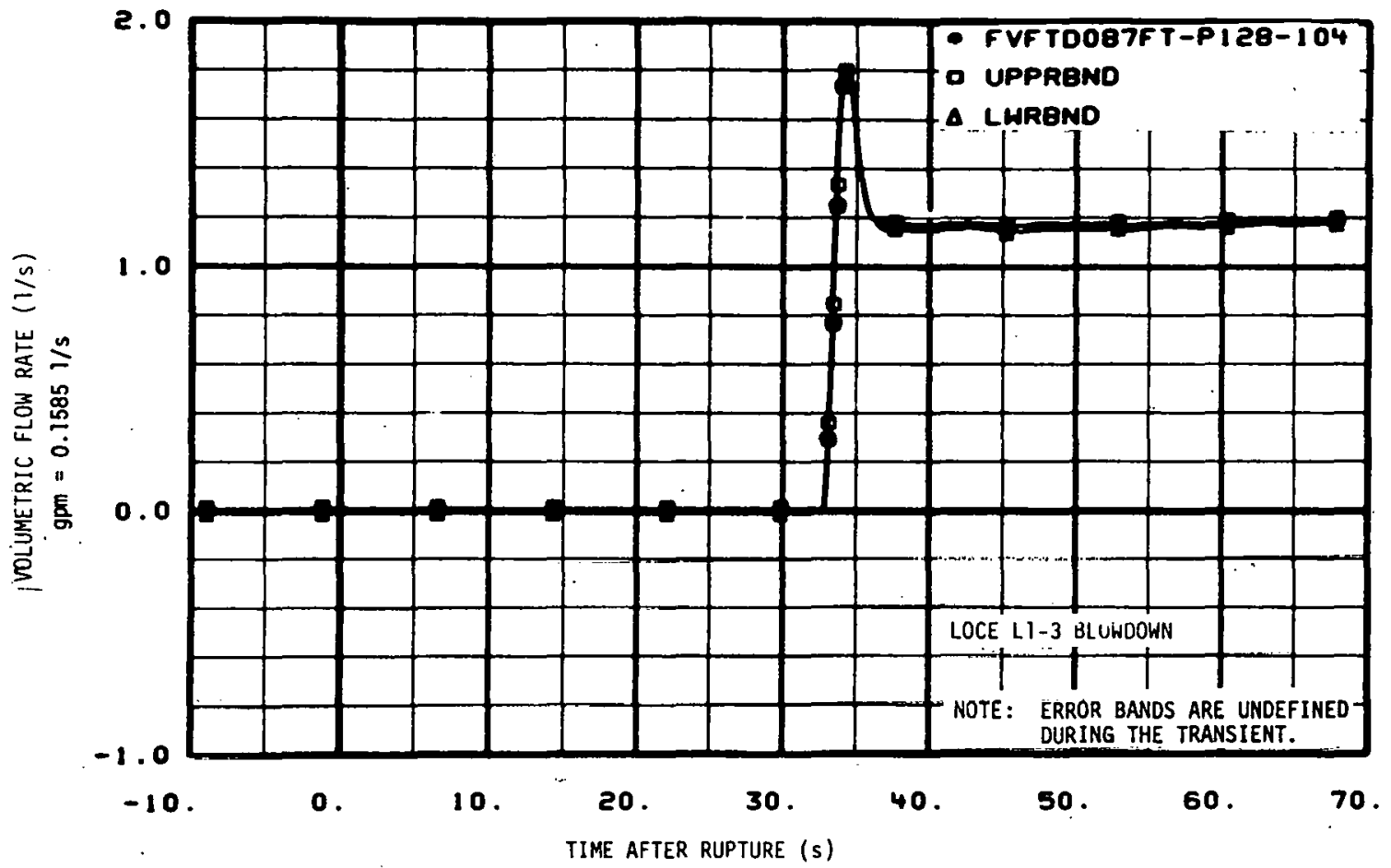

Fig. 236 Flow rate in ECCS HPIS pump A discharge with error bands (FT-P128-104).

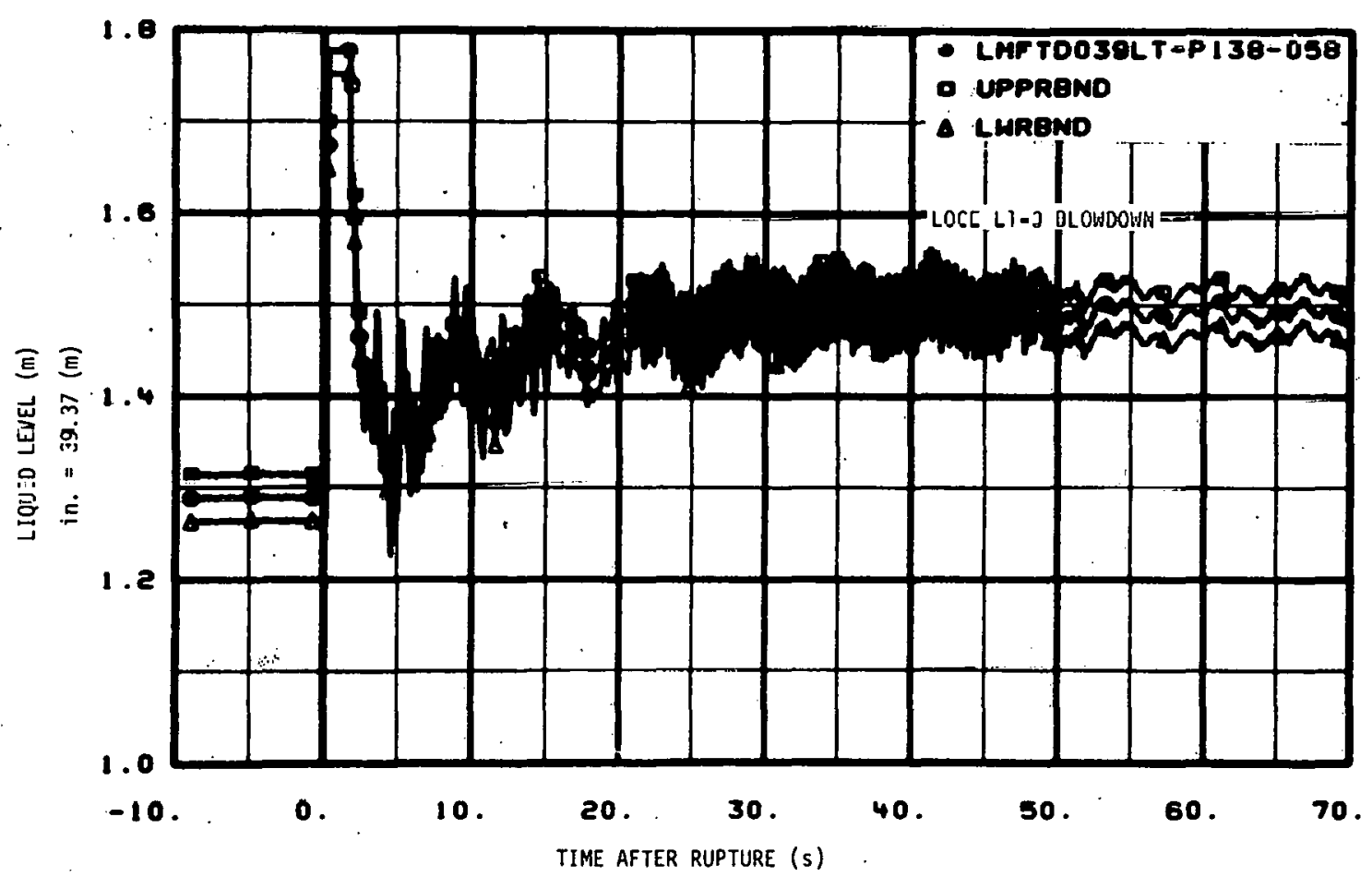

Fig. 237 Liquid level in blowdown suppression tank south end with error bands (LT-P138-58). 


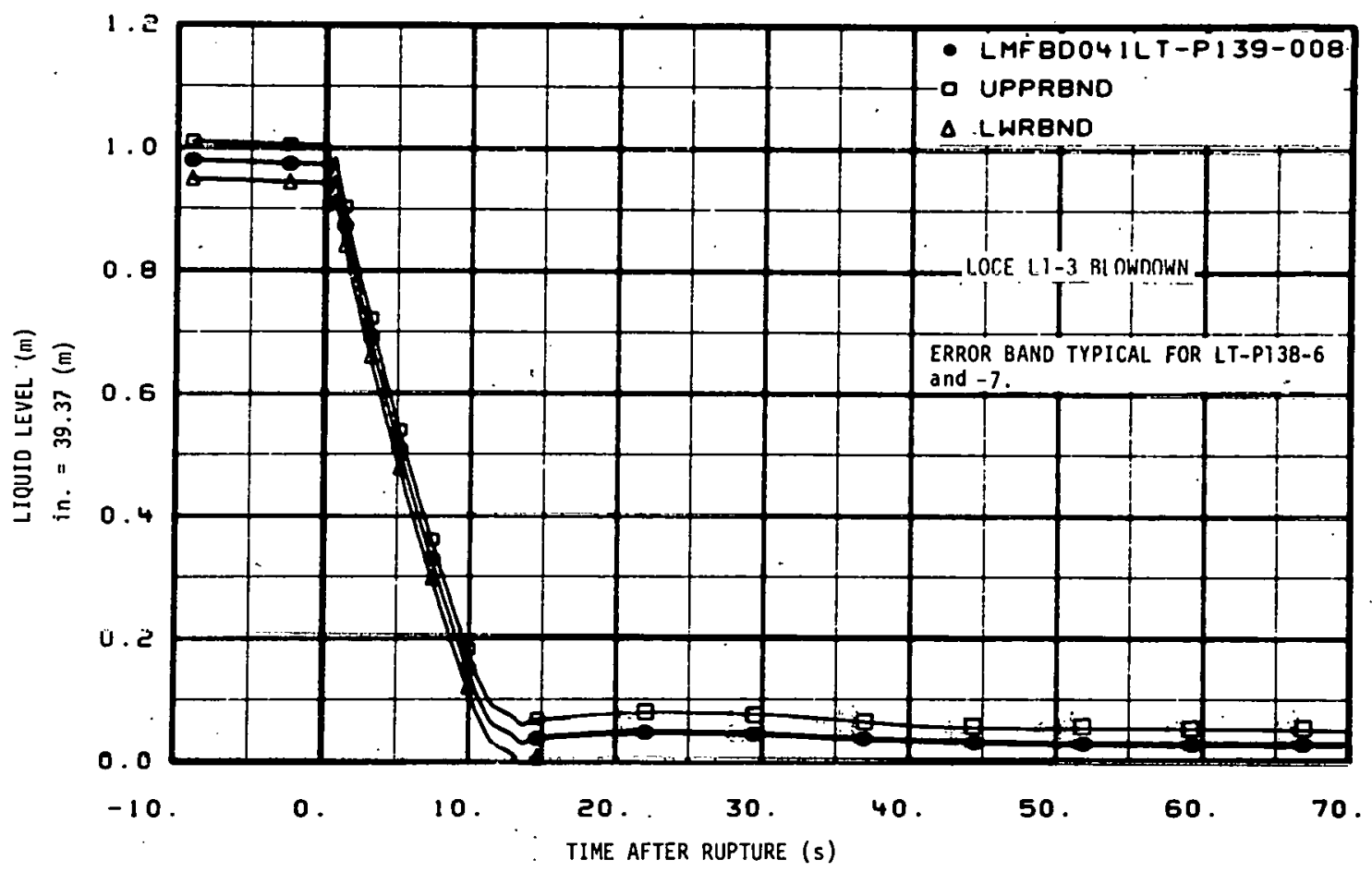

Fig. 238 Liquid level in pressurizer north side with error bands (LT-P139-8).

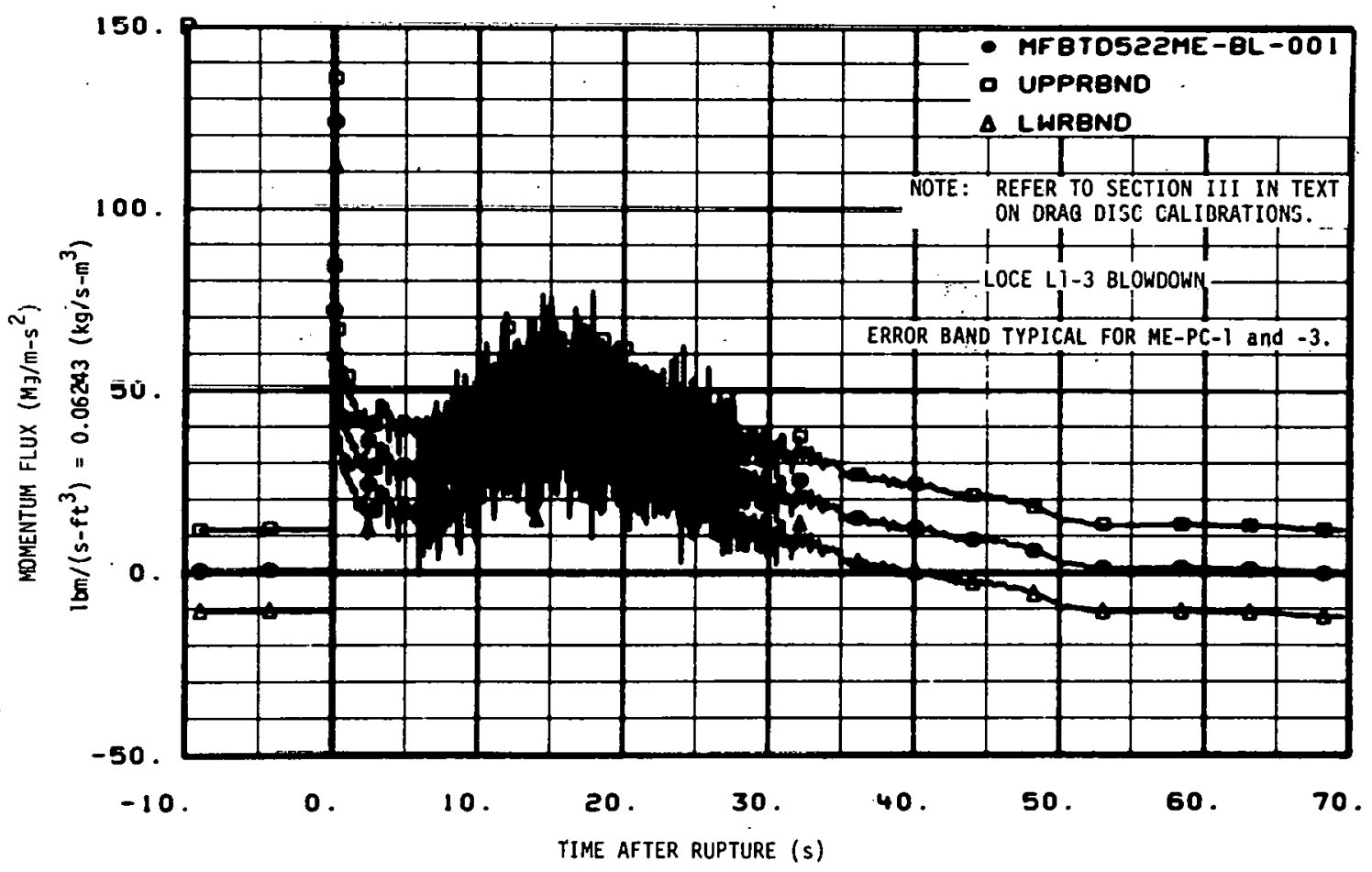

Fig. 239 Momentum flux in broken loop cold leg at DTT flange with error bands (ME-BL- 1 ) (filtered to $4 \mathrm{~Hz}$ ). 


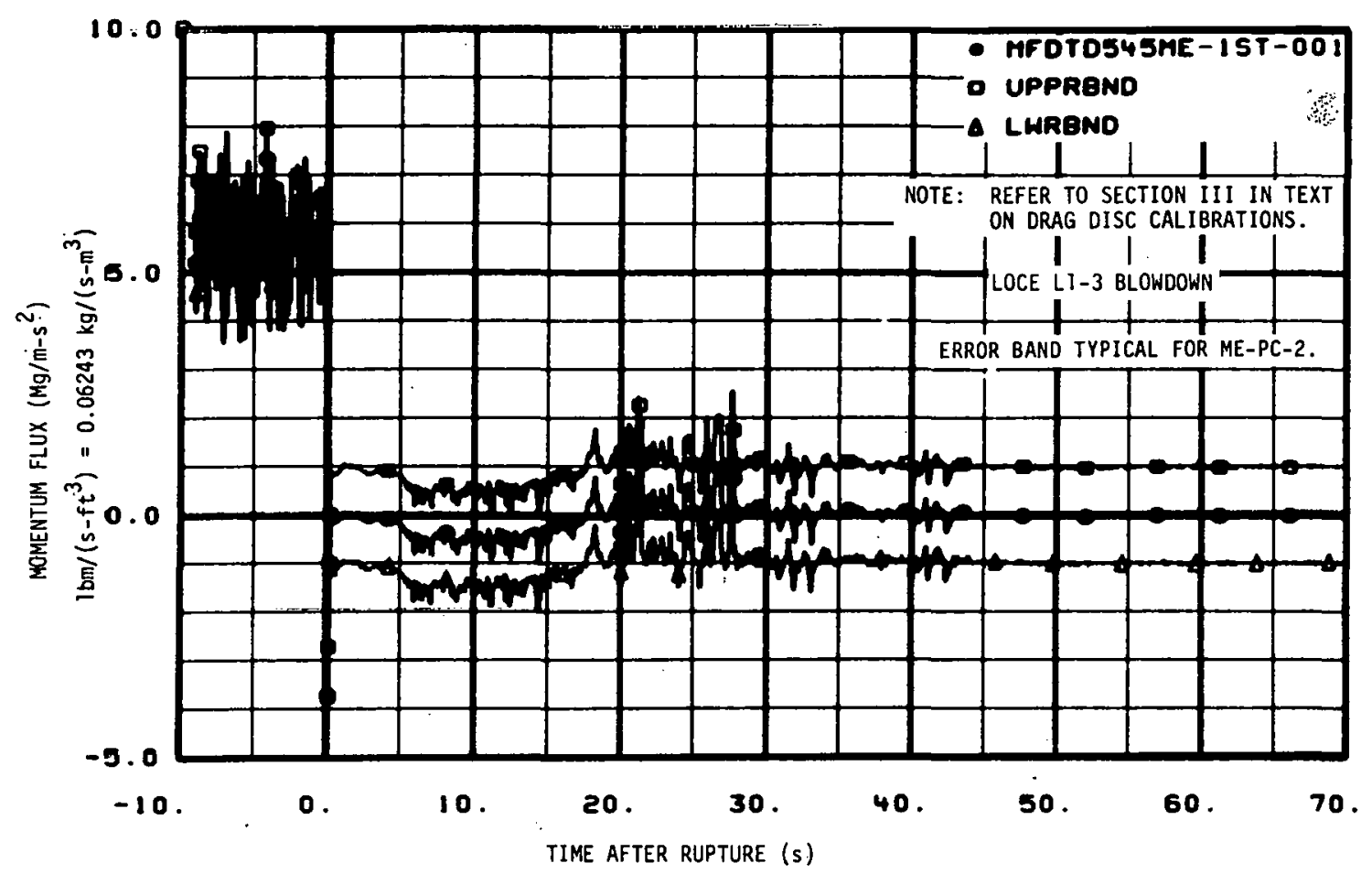

Fig. 240 Momentum flux in reactor vessel downcomer instrument stalk 1 with error bands (ME-1ST-1) (filtered to $4 \mathrm{~Hz}$ ).

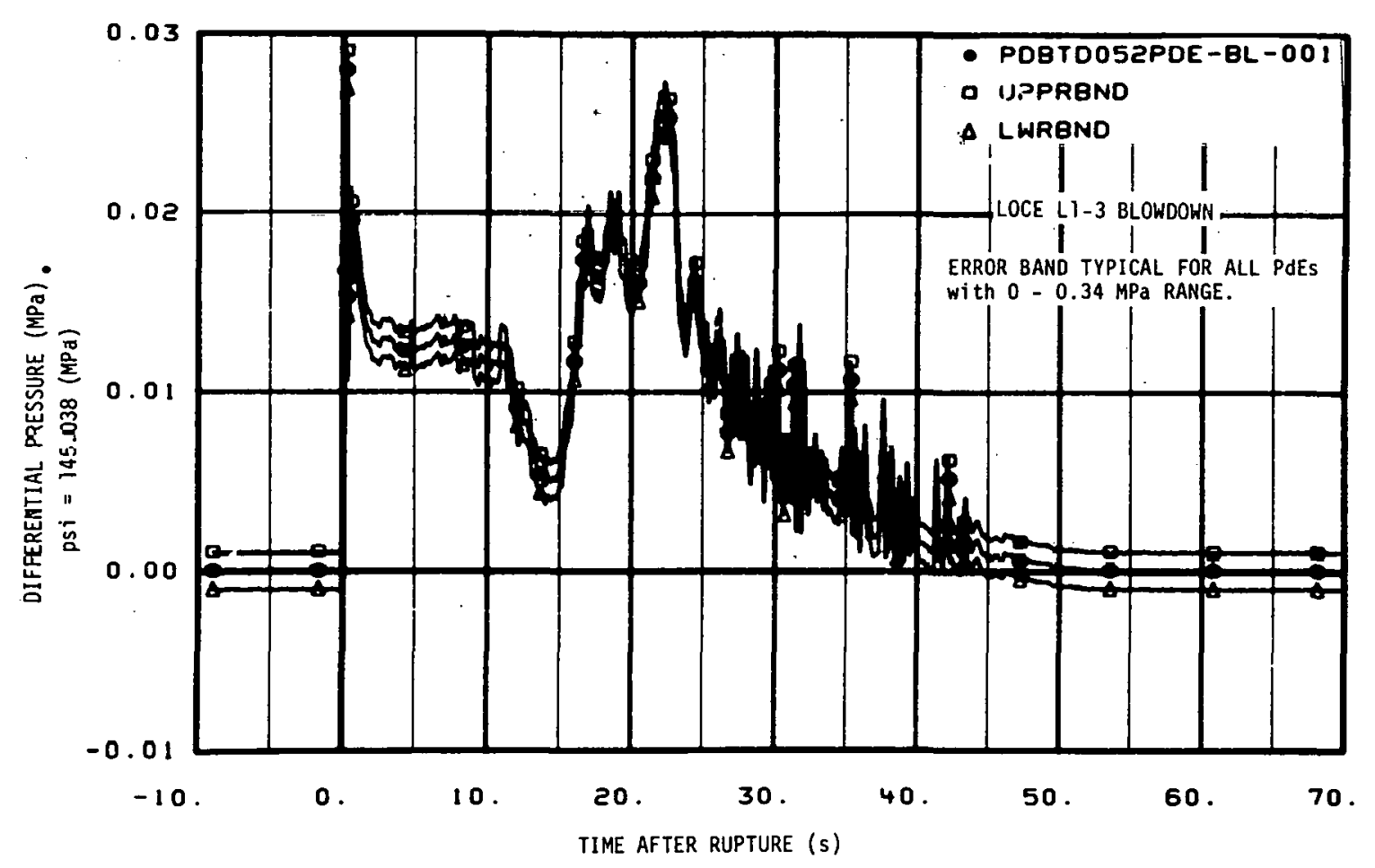

Fig. 241 Differential pressure in broken loop hot leg at 14-to-5-in. reduction with error bands ( $P d E-B L-1)$ ( filtered to $4 \mathrm{~Hz}$ ). 


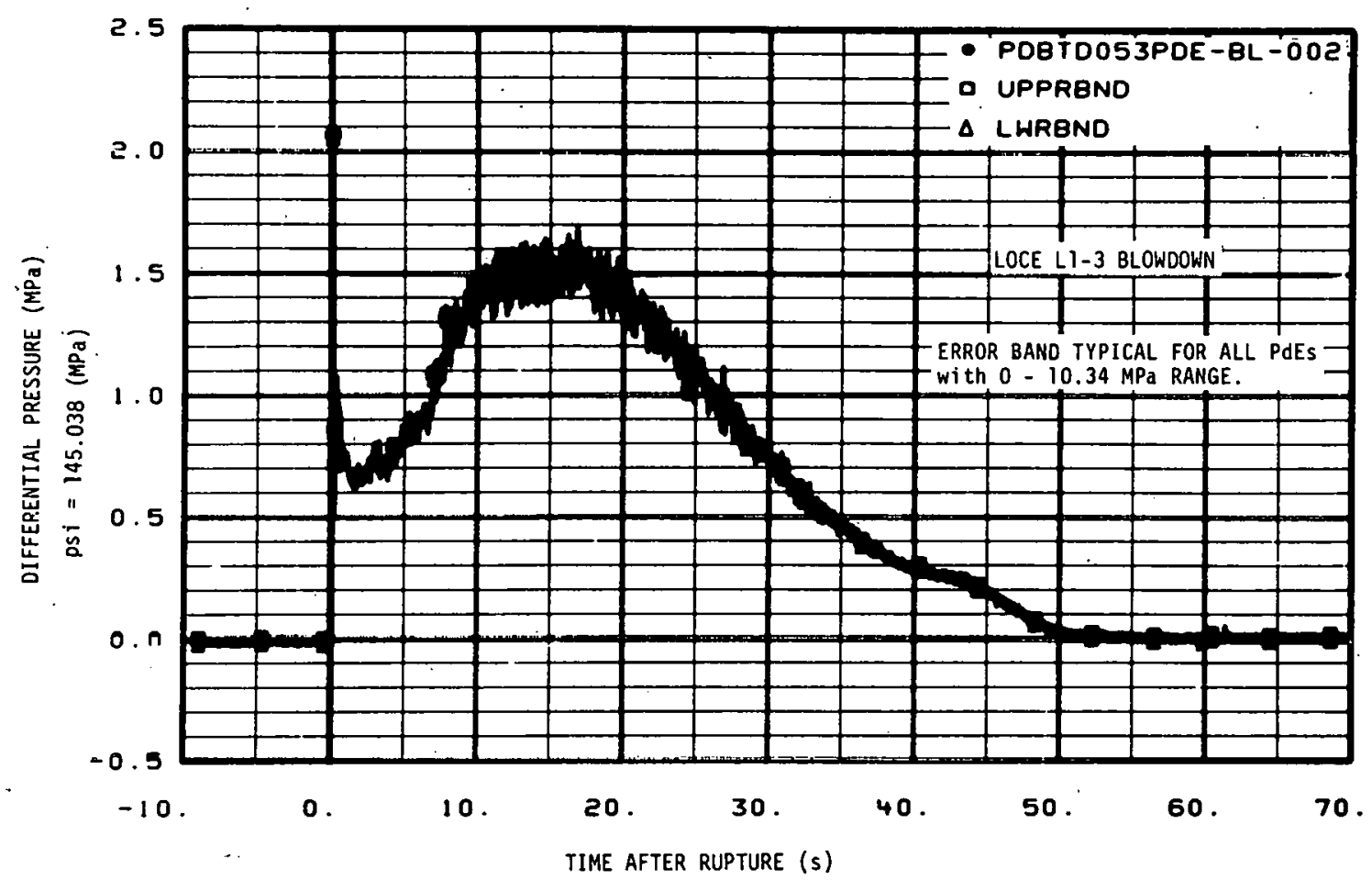

Fig. 242 Differential pressure in broken loop cold leg at 14-to-5-in. reduction with error bands (PdE-BL-2) (filtered to $4 \mathrm{~Hz}$ ).

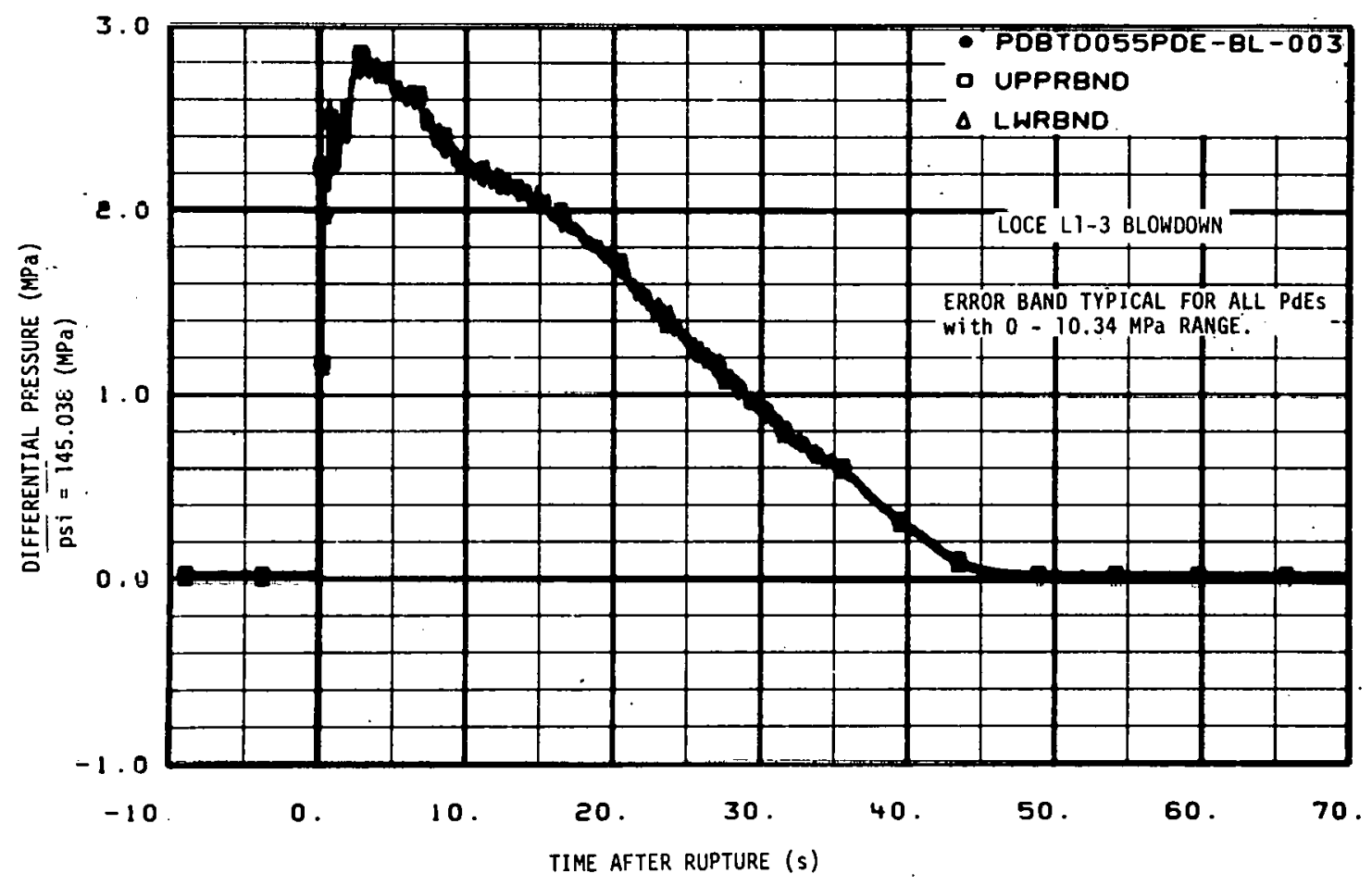

Fig. 243 Differential pressure in broken loop cold leg across break plane with error bands (PdE-BL-3). 


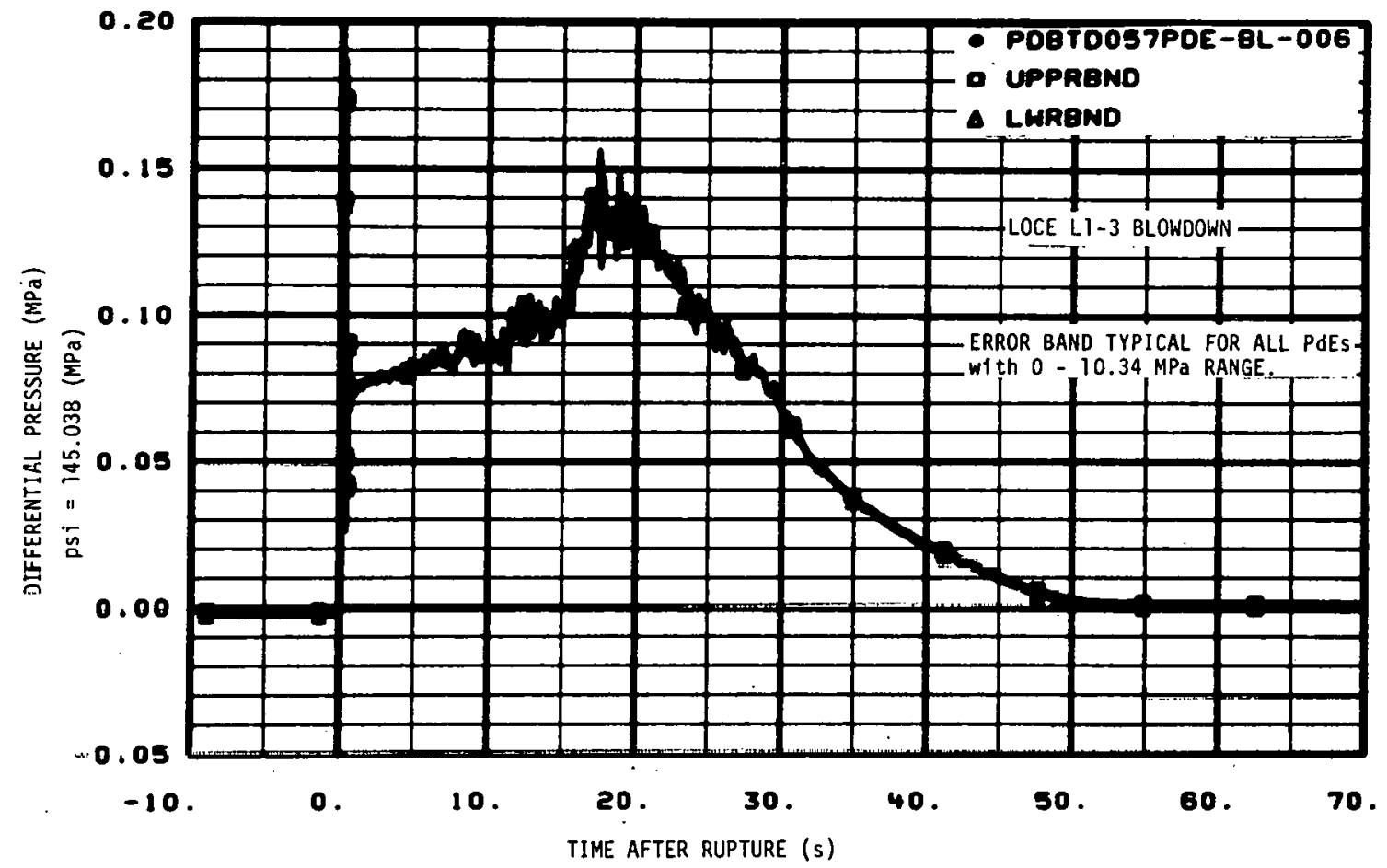

Fig. 244 Differential pressure in broken loop hot leg across steam generator simulator outlet flange with error bands (PdE-BL-6) (filtered to $4 \mathrm{~Hz}$ ).

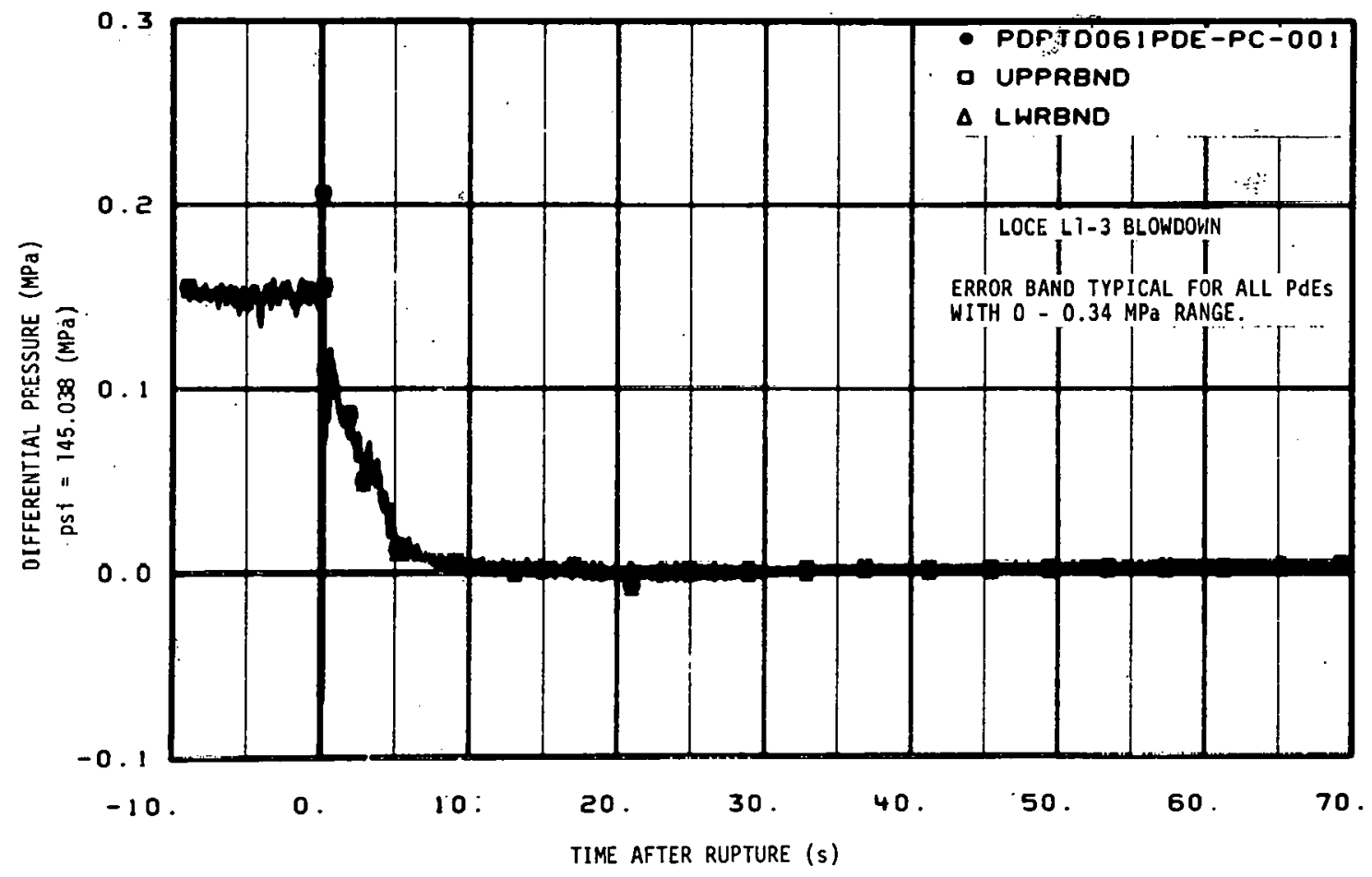

Fig. 245 Differential pressure in intact loop cold leg across primary coolant pumps 1 and 2 with error bands ( $P d E-P C-1)$. 


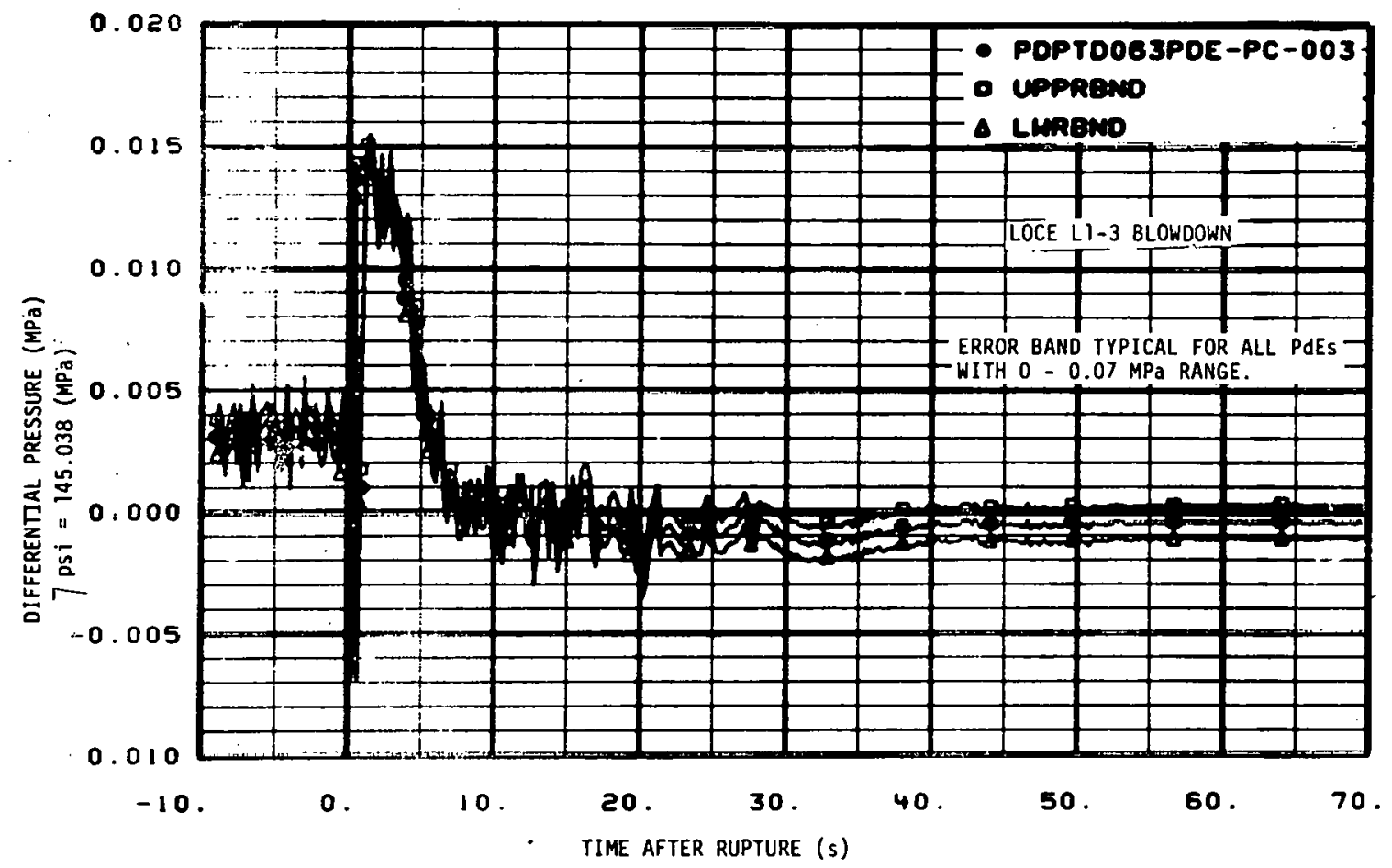

Fig. 246 Differential pressure in intact loop hot leg reactor vessel outlet to flow venturi with error bands (PdE-PC-3).

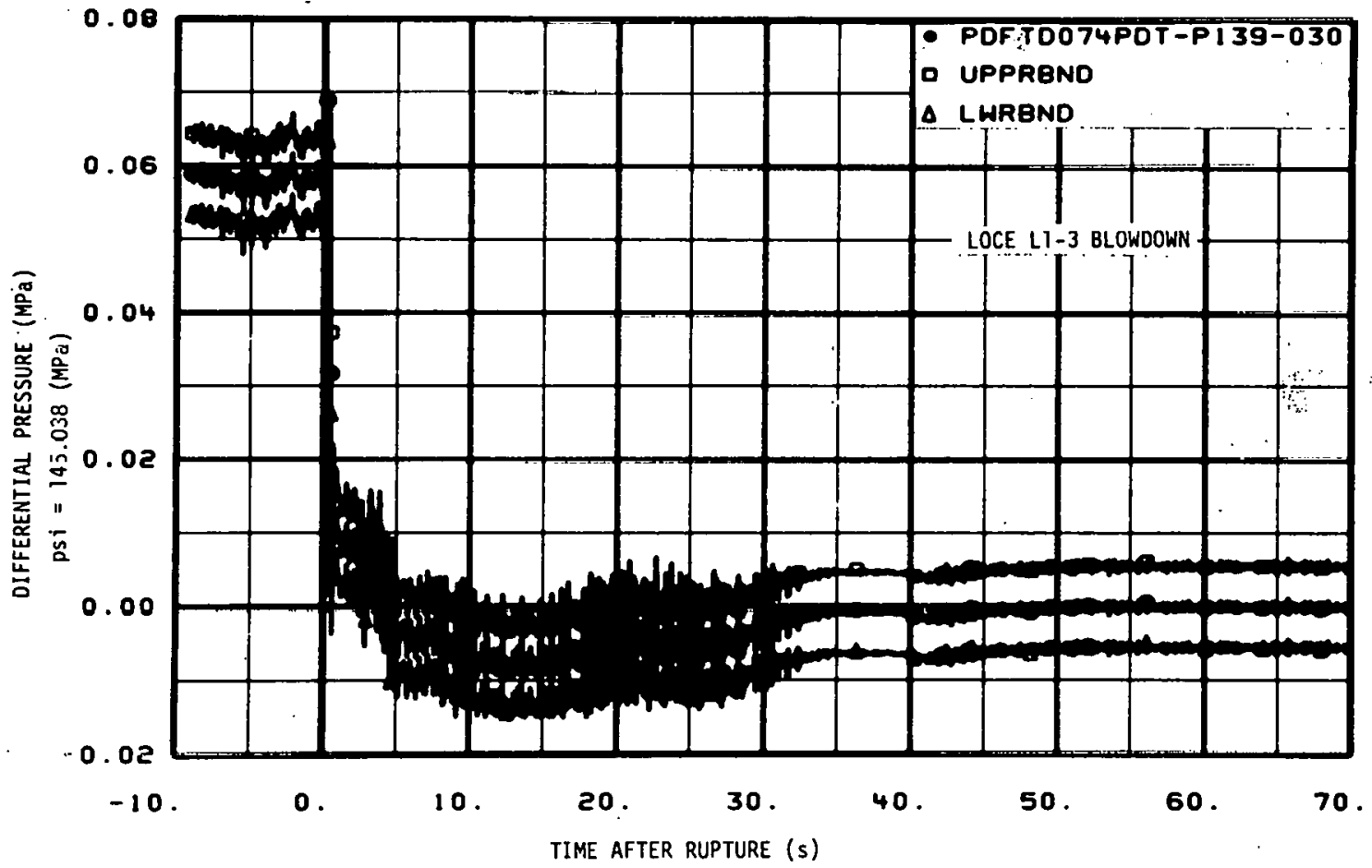

Fig. 247 Differential pressure in intact loop across the reactor vessel inlet and outlet nozzles with error bands (PdT-P139-30). 


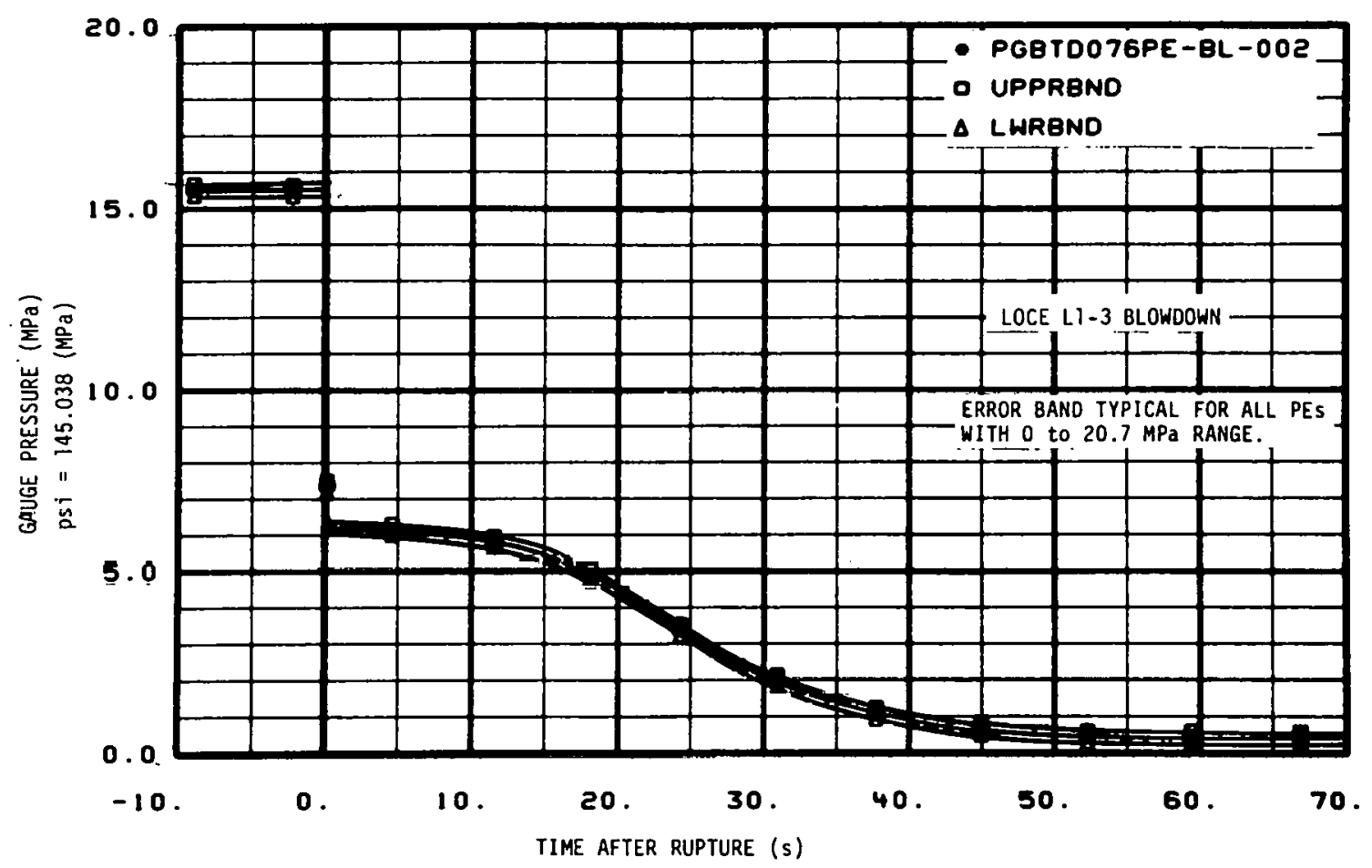

Fig. 248 Pressure in broken loop hot leg with error bands (PE-BL-2).

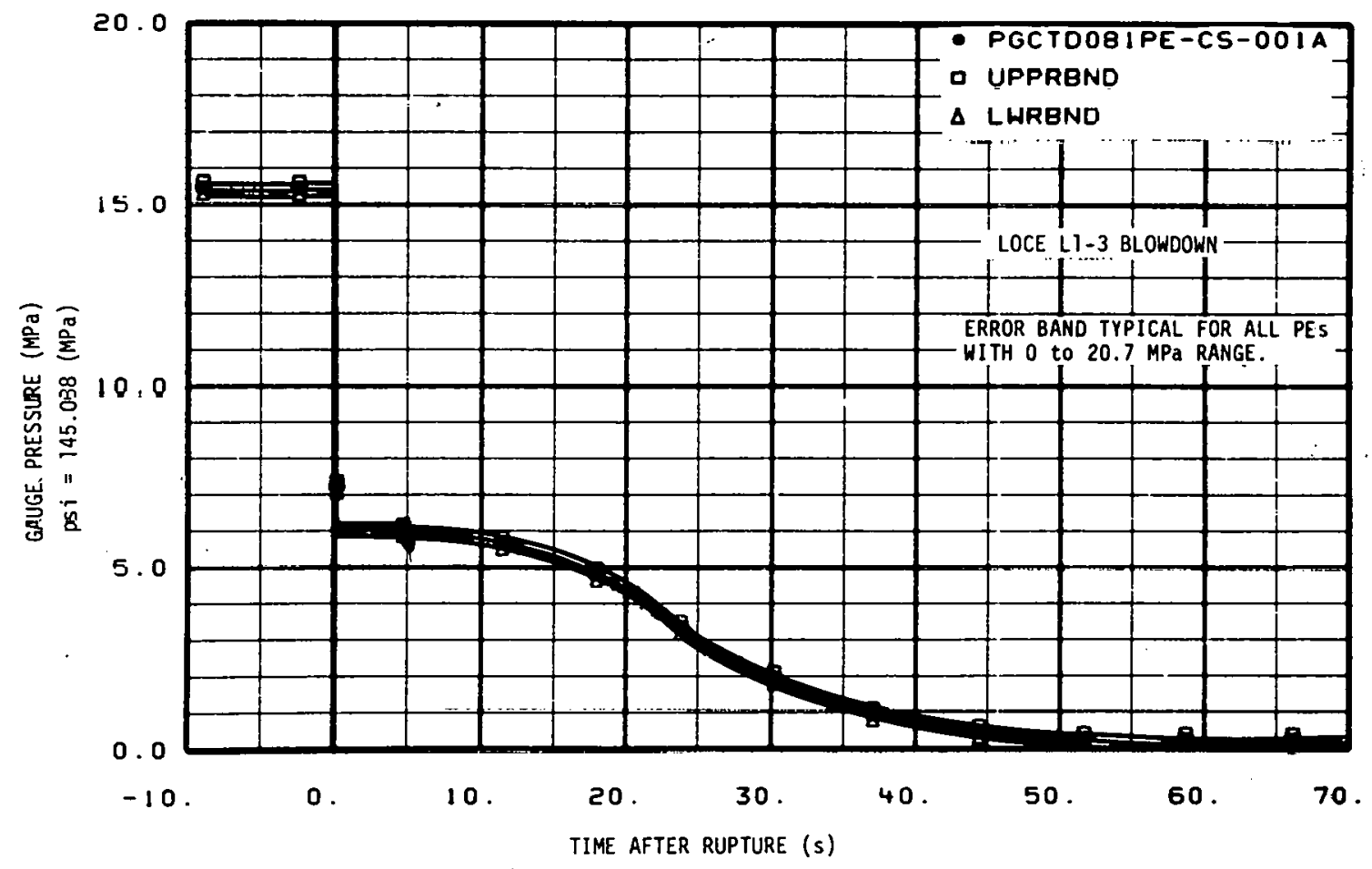

Fig. 249 Pressure in reactor vessel core simulator instrument stalk, wide range, with error bands (PE-CS-1A). 


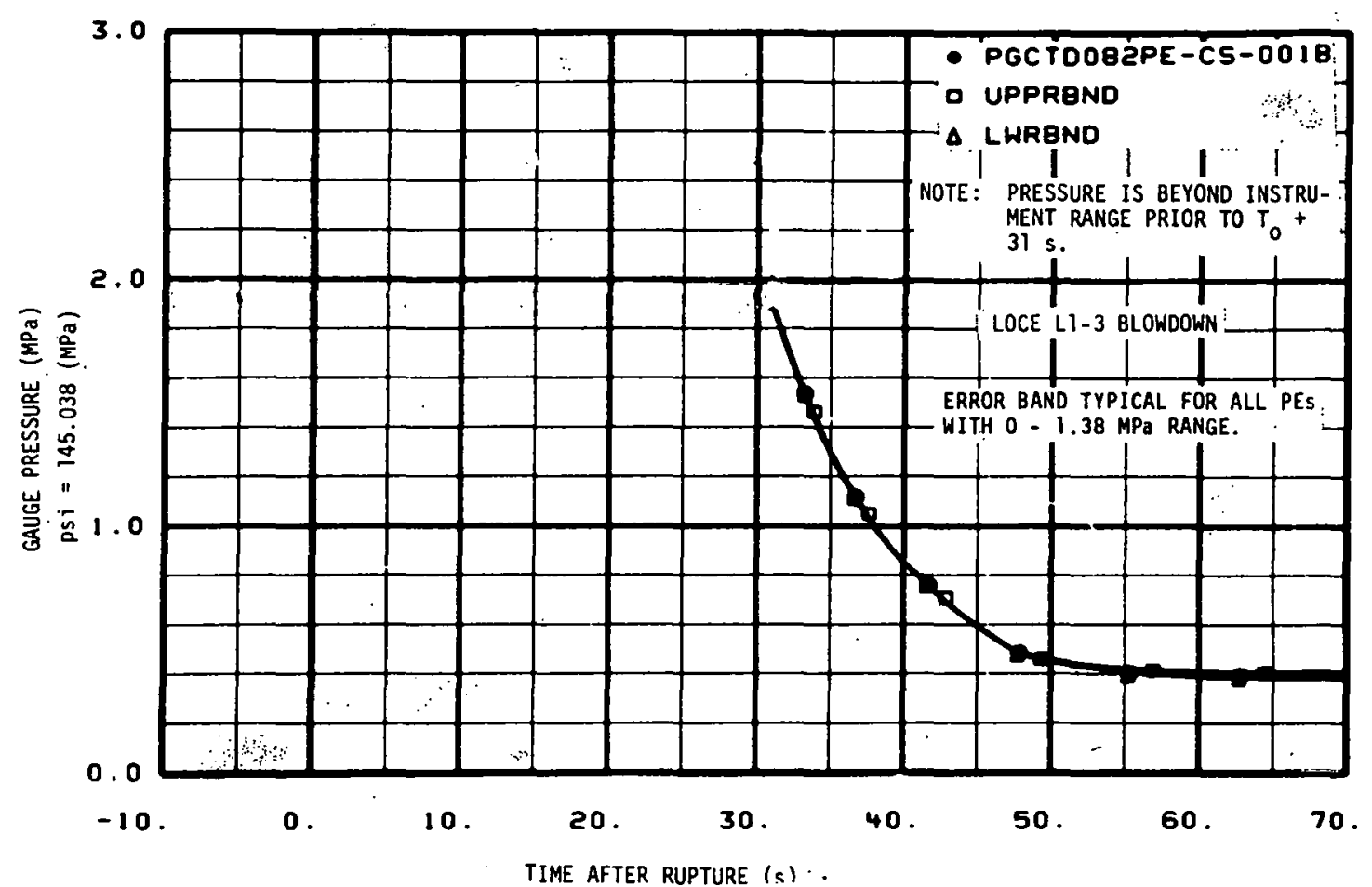

Fig. 250 Pressure in reactor vessel core simulator instrument stalk, narrow range, with error bands (PE-CS-1B).

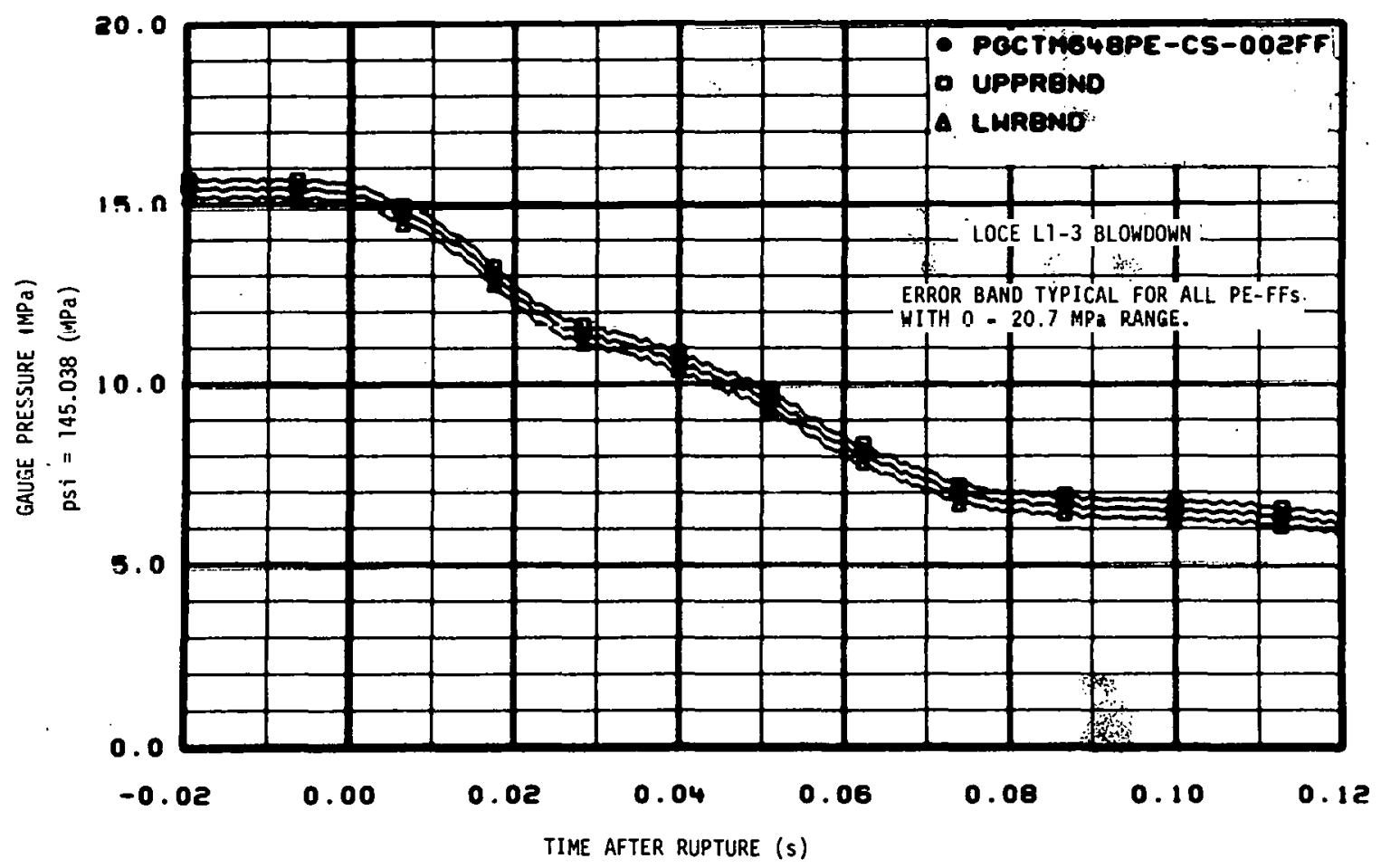

Fig. 251 Pressure in reactor vessel core simulator instrument stalk, short-term plot, with error bands (PE-CS-2FF). 


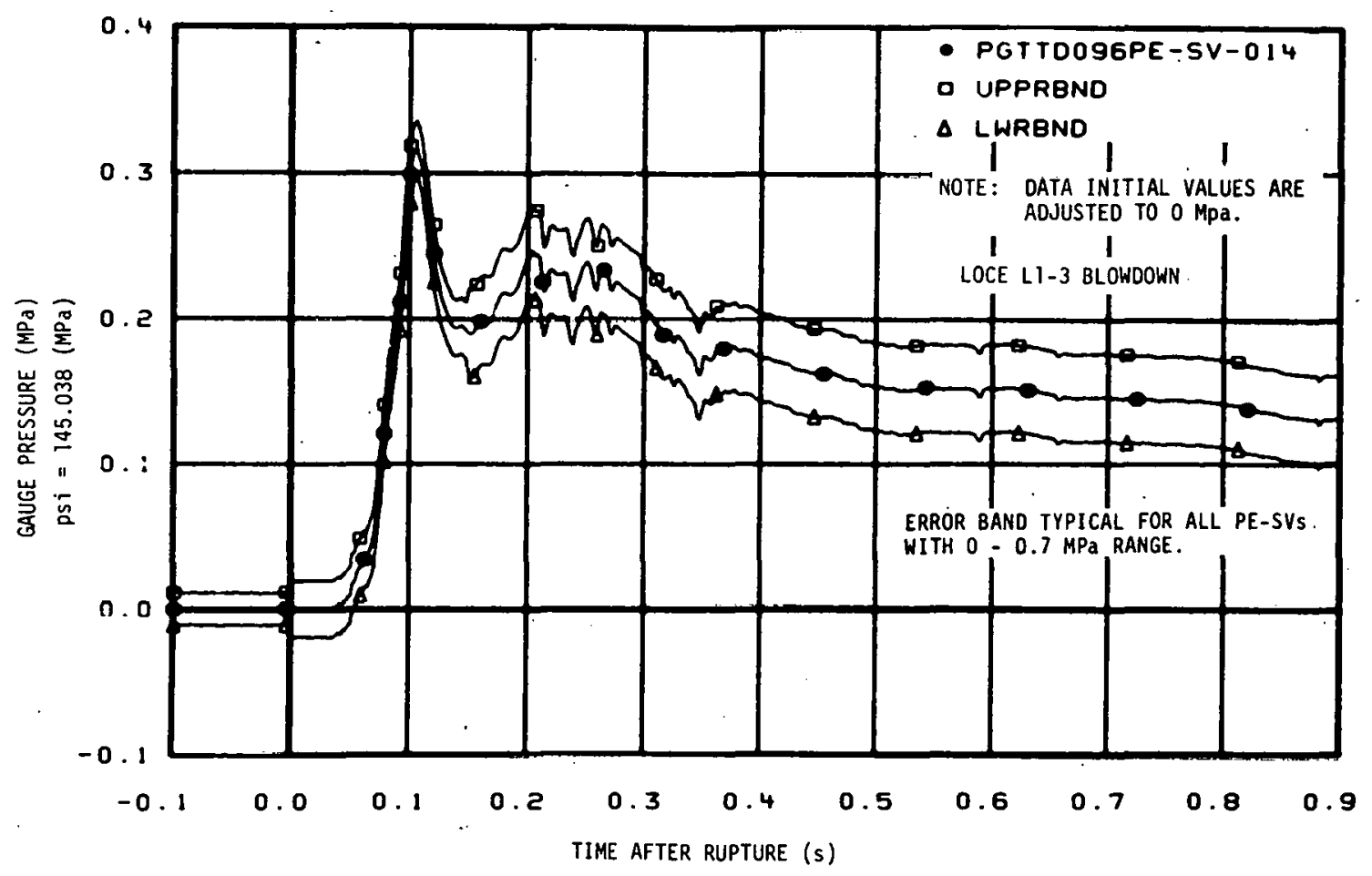

Fig. 252 Pressure in blowdown suppression tank header above downcomer 4 , short-term plot, with error bands (PE-SV-14).

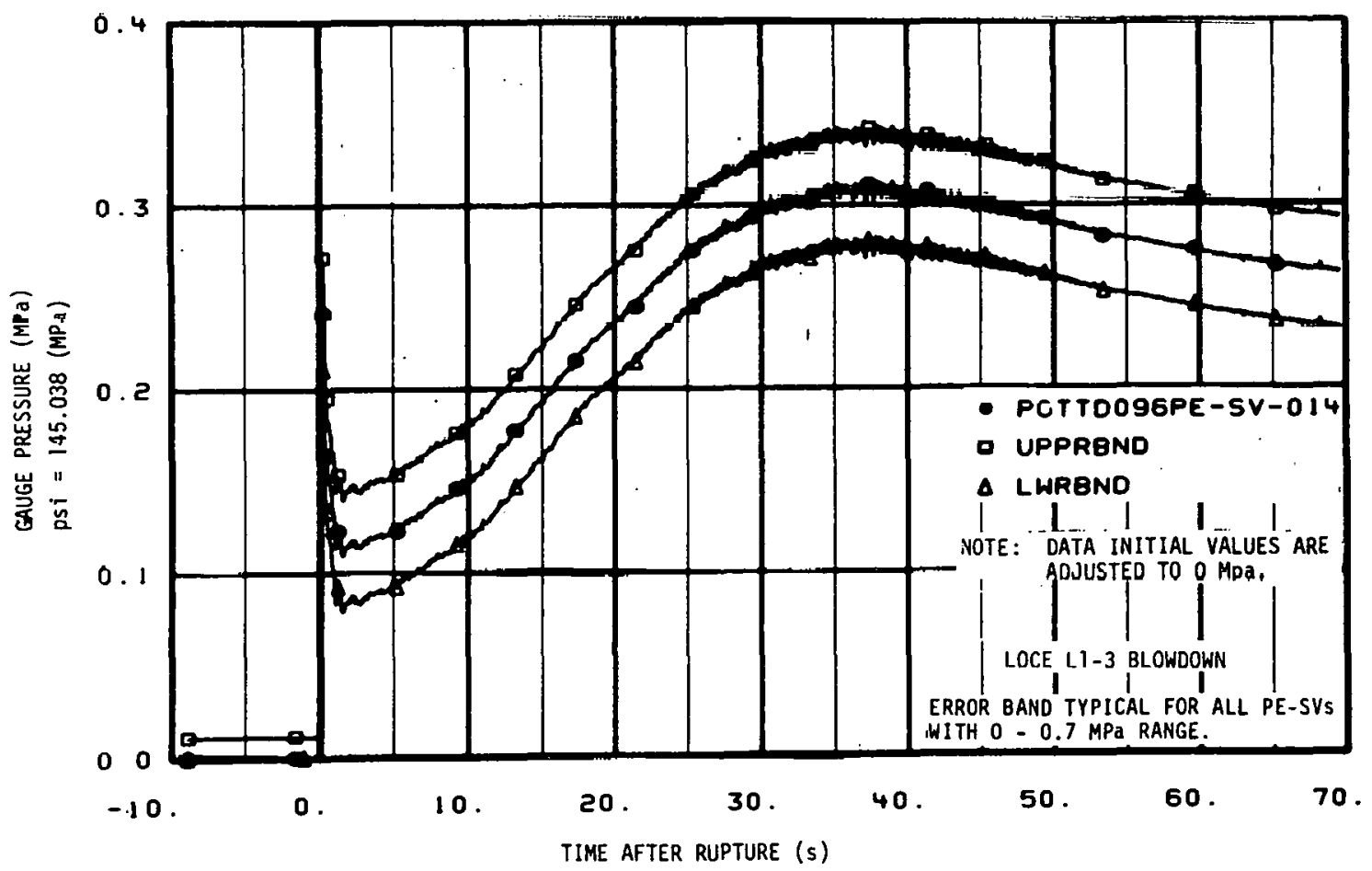

Fig. 253 Pressure in blowdown suppression tank header above downcomer 4 , 70-second plot, with error bands (PE-SV-14). 


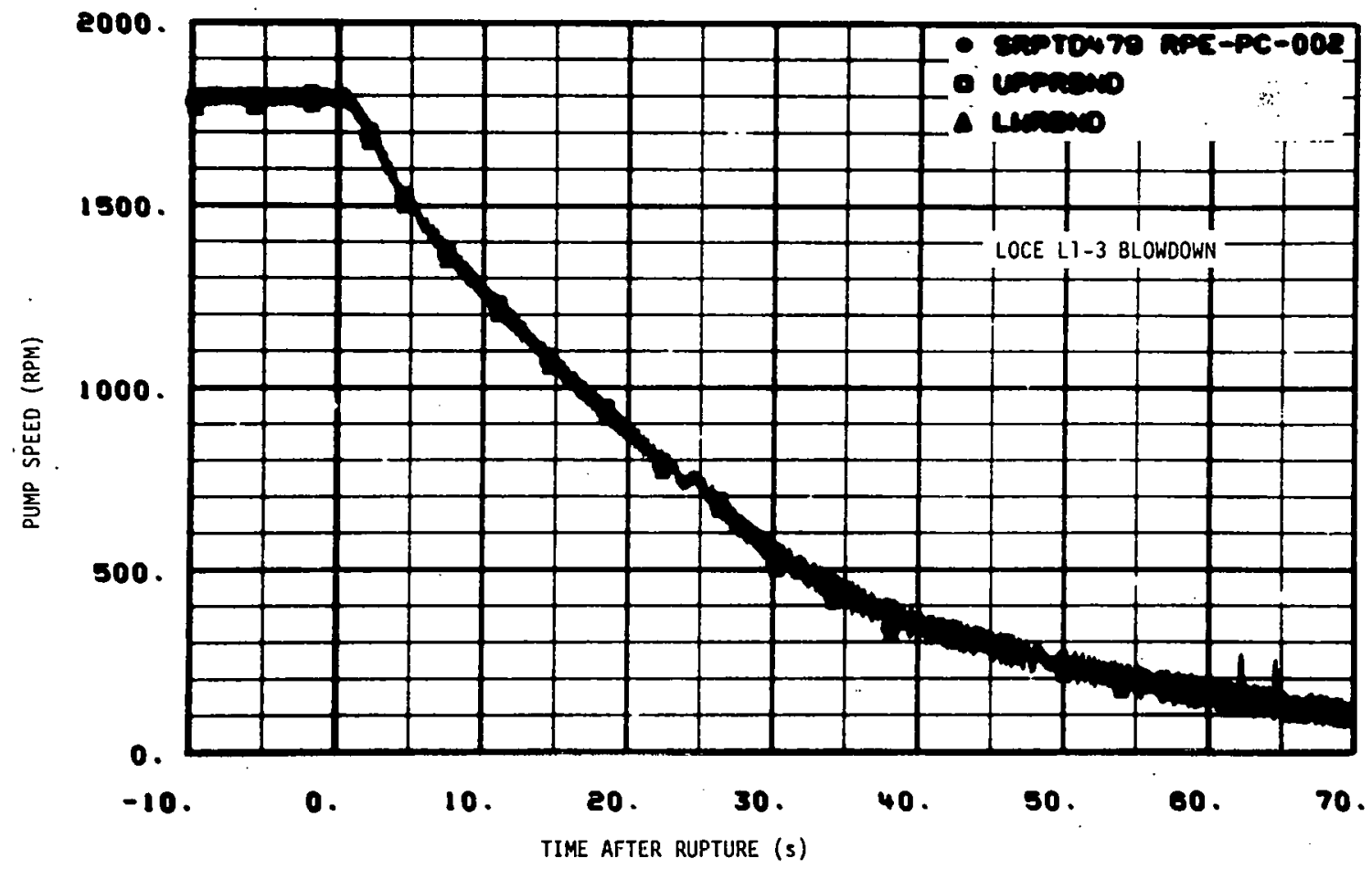

Fig. 254 Pump speed in intact loop operating pump 2 with error bands (RPE-PC-2).

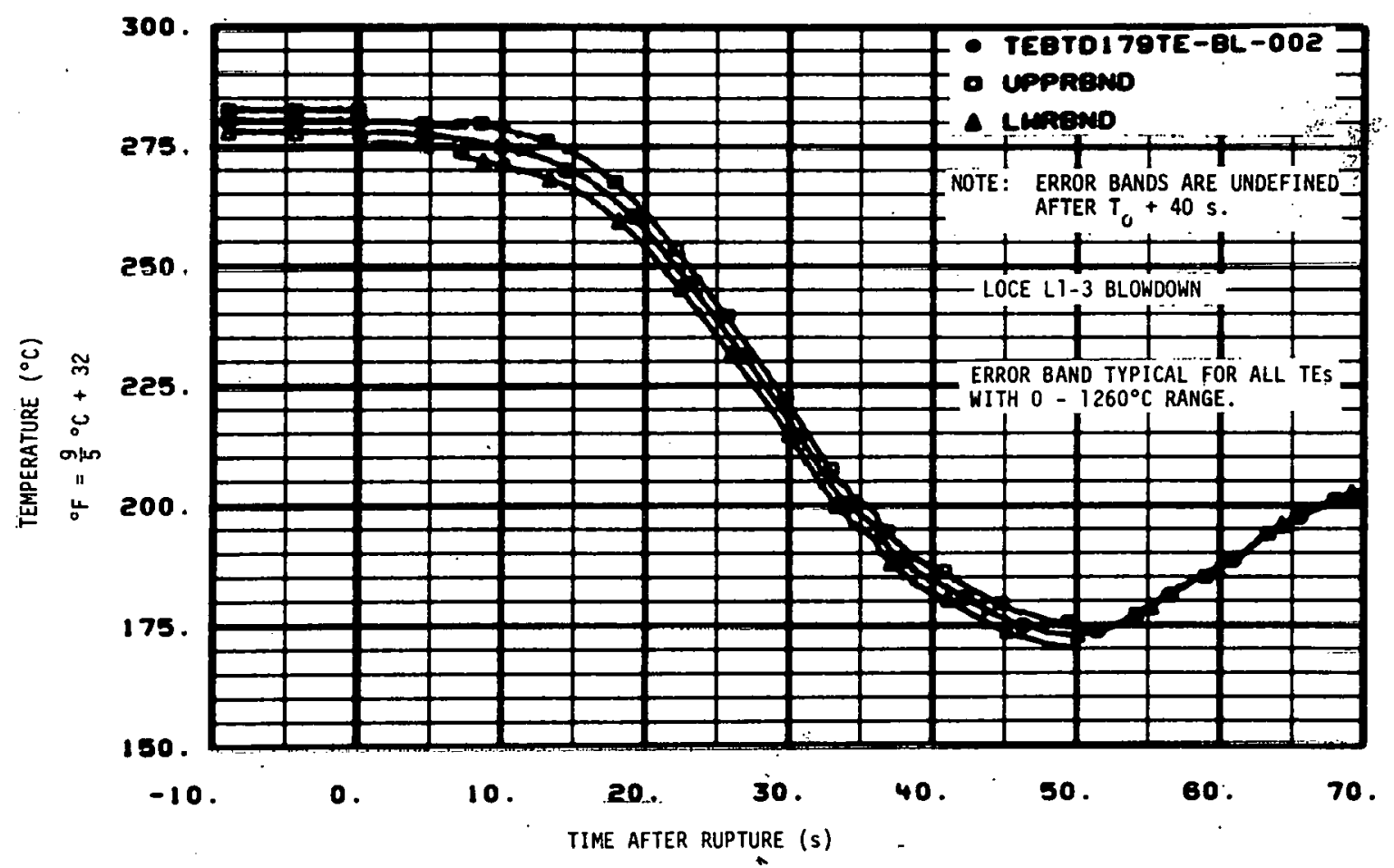

Fig. 255 Temperature in broken loop hot leg with error bands (TE-BL-2). 


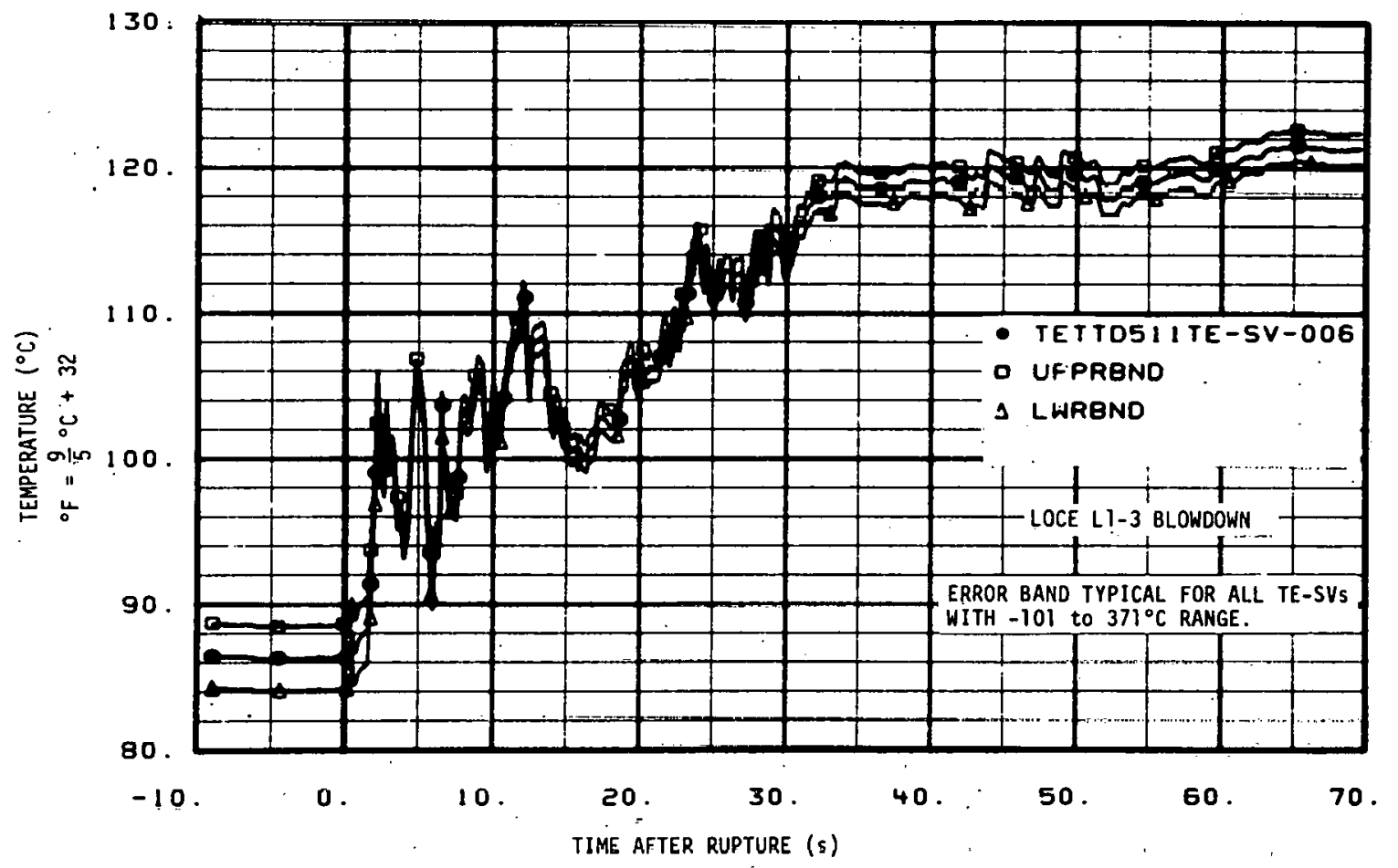

Fig. 256 Temperature in blowdown suppression tank B-end thermocouple stalk with error bands (TE-SV-6). 


\section{REFERENCES}

1. P. A. Harris and T. K. Samuels, LOFT Experiment Operating Specification, Volume 2, Nonnuclear Test Series, Experiment 4, NNE L1-4, Revision 2 (January 1977).

2. J. R. White et al, Experiment Prediction for LOFT Nonnuclear Experiment L1-4, TREE-NUREG-1086 (Apri1 1977).

3. H. C. Robinson, Quick-Look Report on LOFT Nonnuclear Experiment Li-4, QLR-LI-4 (June 1977).

4. H. C. Robinson, LOFT System and Test Description (Loss-of-Coolant Experiments Using a Core Simulator), TREE-NUREG-10.19 (November 1976).

5. J. R. Chappel1, Experiment Data Report for LOFT Nonnuclear Test LI-1, TREE-NUREG-1025 (December 1976).

6. H. C. Robinson, Experiment Data Report for LOFT Nonnuclear Test LI-2, TREE-NUREG-1026 (December 1976).

7. G. M. Millar, Experiment Data Report for LOFT Nonnuclear Test L7-3, TREE-NUREG-1065 (April 1977).

8. G. M. Millar, Experiment Data Report for LOFT Nonnuclear Test Li-3A, TREE-NUREG-1027 (December 1976).

9. F. S. Miyasaki, Digital Data Acquisition Program, ANCR-1250 (August 1975).

10. N. L. Norman, LOFT Data Reduction, ANCR-1251 (August 1975). 
11. G. L. Biladeau et al, LOFT Experimental Measurements Uncertainty Analysis, LTR 141-39 (September 1975).

12. Internal document.

13. S. N. Zender et al, Experiment Data Report for Semiscale Mod-1 Tests S-01-4 and S-01-4A (Isothermal Blowdown with Core Resistance Simulator); ANCR-1196 (March 1975).

14. D. Butterworth, "A Comparison of Some Void-Fraction Relationships for Co-Current 'Gas-Liquid Flow"., International Journal of Multiphase Flow, Vol. 1, Pergamon/Elsevier, printed in Great Britain (1975) .pp 845-850. 


\section{LIST OF ABREVIATIONS AND ACRONYMS}

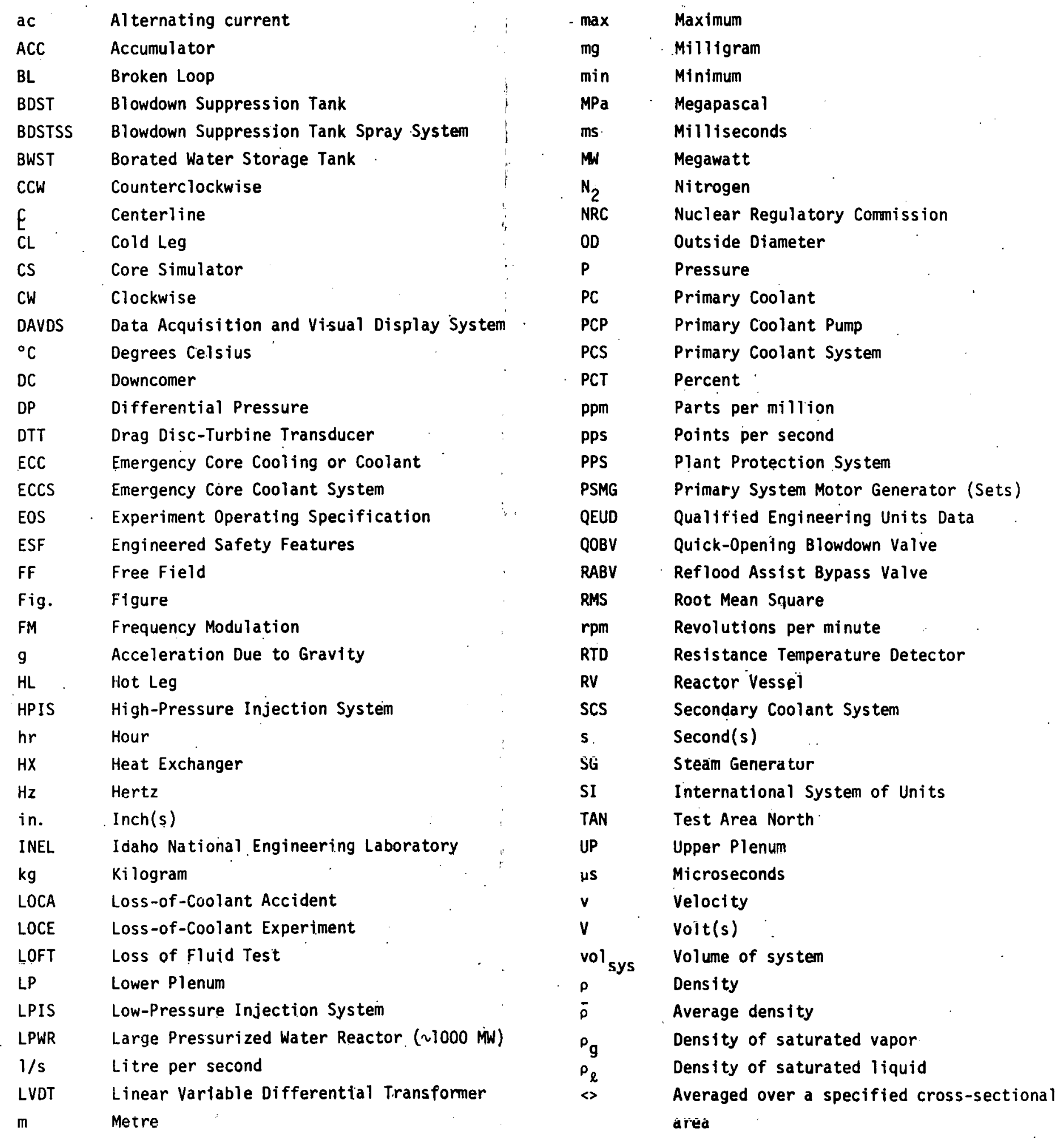


DISTRIBUTION RECORD FOR TREE-NUREG-1084

\section{Internal Distribution}

$$
\begin{aligned}
& 1 \text { - } \text { Chicago Patent Group - ERDA } \\
& 9800 \text { South Cass Avenue } \\
& \text { Argonne, Illinois } 60439 \\
& \text { 2 - C. A. Benson } \text { Idaho Operations 0ffice - ERDA } \\
& \text { Idaho Falls, ID } 83407 \\
& 3 \text { - R. J. Beers, ID } \\
& 4 \text { - P. E. Litteneker, ID } \\
& 5 \text { - R. E. Tiller, ID } \\
& 6 \text { - R. E. Wood, ID } \\
& 7 \text { - H. P. Pearson, Supervisor } \\
& \text { Technical Information } \\
& 8-17 \text { - INEL Technical Library } \\
& 18=147 \text { - Special Intcrnal } \\
& 148-382 \text { - Authors }
\end{aligned}
$$

\section{External Distribution}

383-384 - Sall1 I.evine, Director Office of Nuclear Regulatory Research, NRC Washington, DC 20555

$385-4 \overline{3} 9$ - Special External

440-744 - Distribution under NRC-2, Water Reactor Safety Research Systems Engineering 
Errata to TREE-NUREG-1084, "Experiment Data Report For LOFT Nonnuclear Test L1-4", JuTy 1977, D. L. Batt.

1. On page 69, TABLE VII, under "Measurement Comments" for PE-SV-59, change "Not presented." to "Channel failed.".

2. On page 109, replace Figure 34 with the attached Figure 34 .

3. On page 110 , replace Figure 35 with the attached Figure 35.

4. On page 115, Figure 44, change ordinate labeled "LIQUID LEVEL (m), in. $=39.37(\mathrm{~m})$ " to "LIQUID LEVEL $(\mathrm{cm})$, in. $=0.3937(\mathrm{~cm})$ ".

5. On page 116, Figure 45, change ordinate labeled "LIQUID LEVEL (m), in. $=39.37(\mathrm{~m})$ " to "LIQUID LEVEL $(\mathrm{cm})$, in. $=0.3937(\mathrm{~cm})$ ".

6. On page 119 , replace Figures 50 and 51 with the attached Figures 50 and 51 .

7. On page 127, replace Figure 67 with the attached Figure 67 .

8. On page 132 , replace Figure 76 with the attached Figure 76 .

9. On page 165, replace Figure 139 with the attached Figure 139.

10. On pages 199 and 200, Figures 201, 202, and 203, change ordinates labeled "MASS FLOW RATE $(\mathrm{kg} / \mathrm{s}), \mathrm{mlbm} / \mathrm{hr}=0.00794(\mathrm{~kg} / \mathrm{s})$ " to "MASS FLOW PER SYSTEM VOLUME $\left(\mathrm{kg} / \mathrm{m}^{3}-\mathrm{s}\right), 1 \mathrm{bm} /\left(\mathrm{s}-\mathrm{ft}^{3}\right)=0.06243\left(\mathrm{~kg} / \mathrm{s}-\mathrm{m}^{3}\right) . "$ 
Errata to TREE-NUREG-1084, "Experiment Data Report for LOFT Nonnuclear Test L1-4", Ju1y 1977, D. L. Batt.

On page 109, replace Figure 34 with the one below.

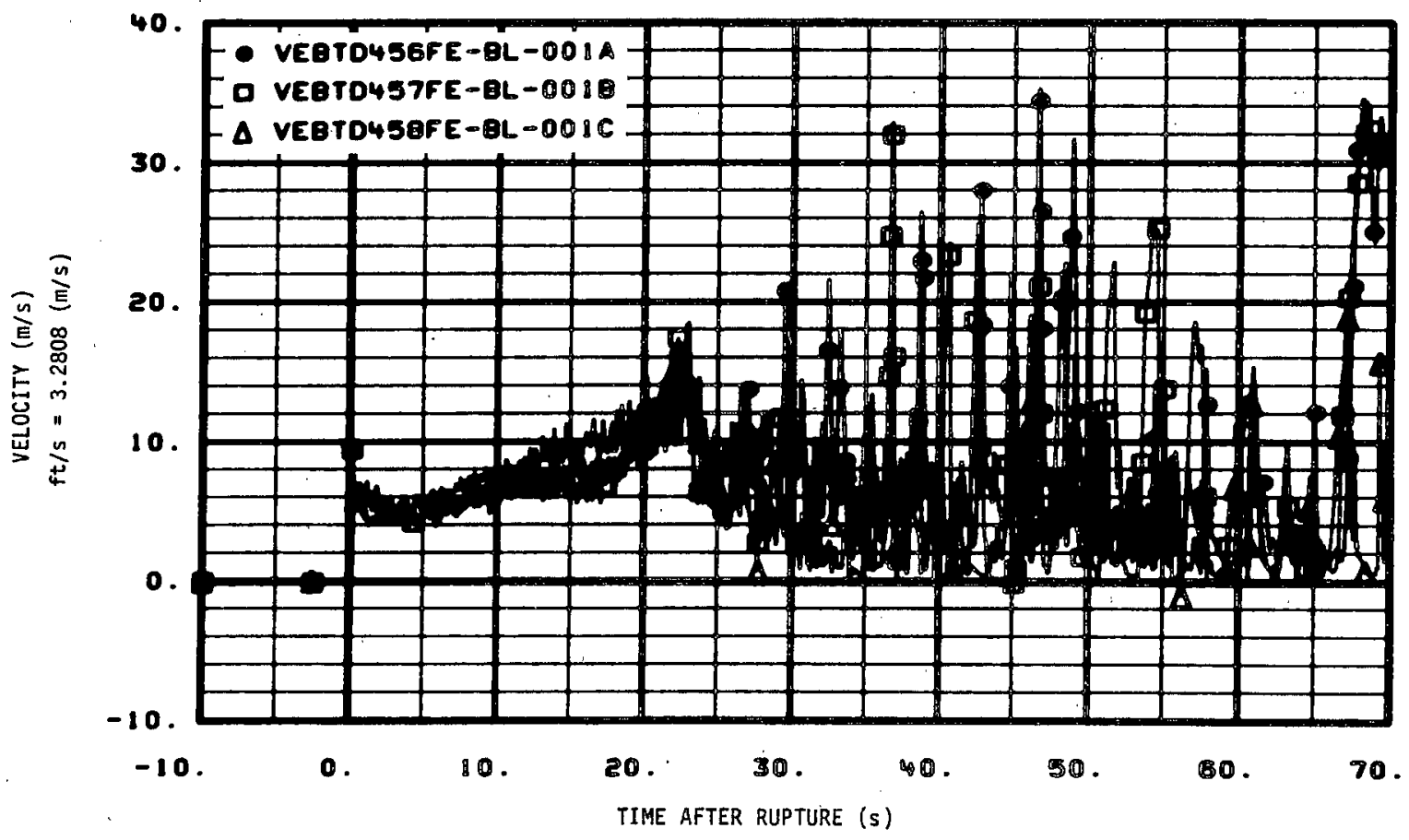

Fig. 34 Fluid velocity in broken loop cold leg at DTT flange (FE-BL-1A, -1B, and -1C) (filtered to $4 \mathrm{~Hz}$ ). 


\section{ERRA TA}

Errata to TREE-NUREG-1084, "Experiment Data Report for LOFT Nonnúclear Test L1-4", Ju1y 1977, D. L. Batt.

On page 110 , replace Figure 35 with the one below.

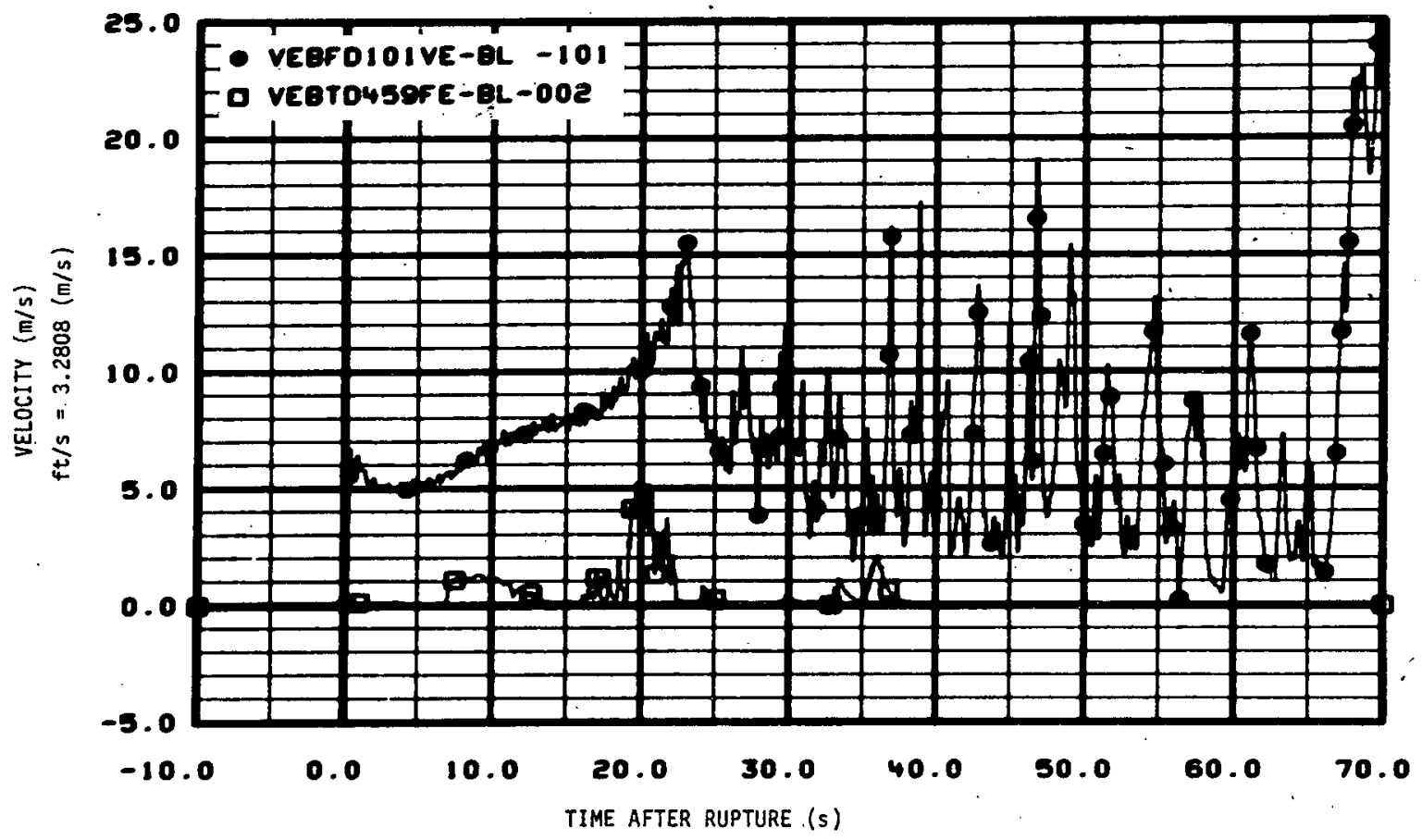

Fig. 35 Fluid velocity in broken loop hot and cold legs at DTT flanges (FE-BL-1 and -2 ). 
Errata to TREE-NUREG-1084, "Experiment Data Report for LOFT Nonnuclear Test L1-4", July 1977, D. L. Batt.

On page 119 , replace Figure 50 with the one below.

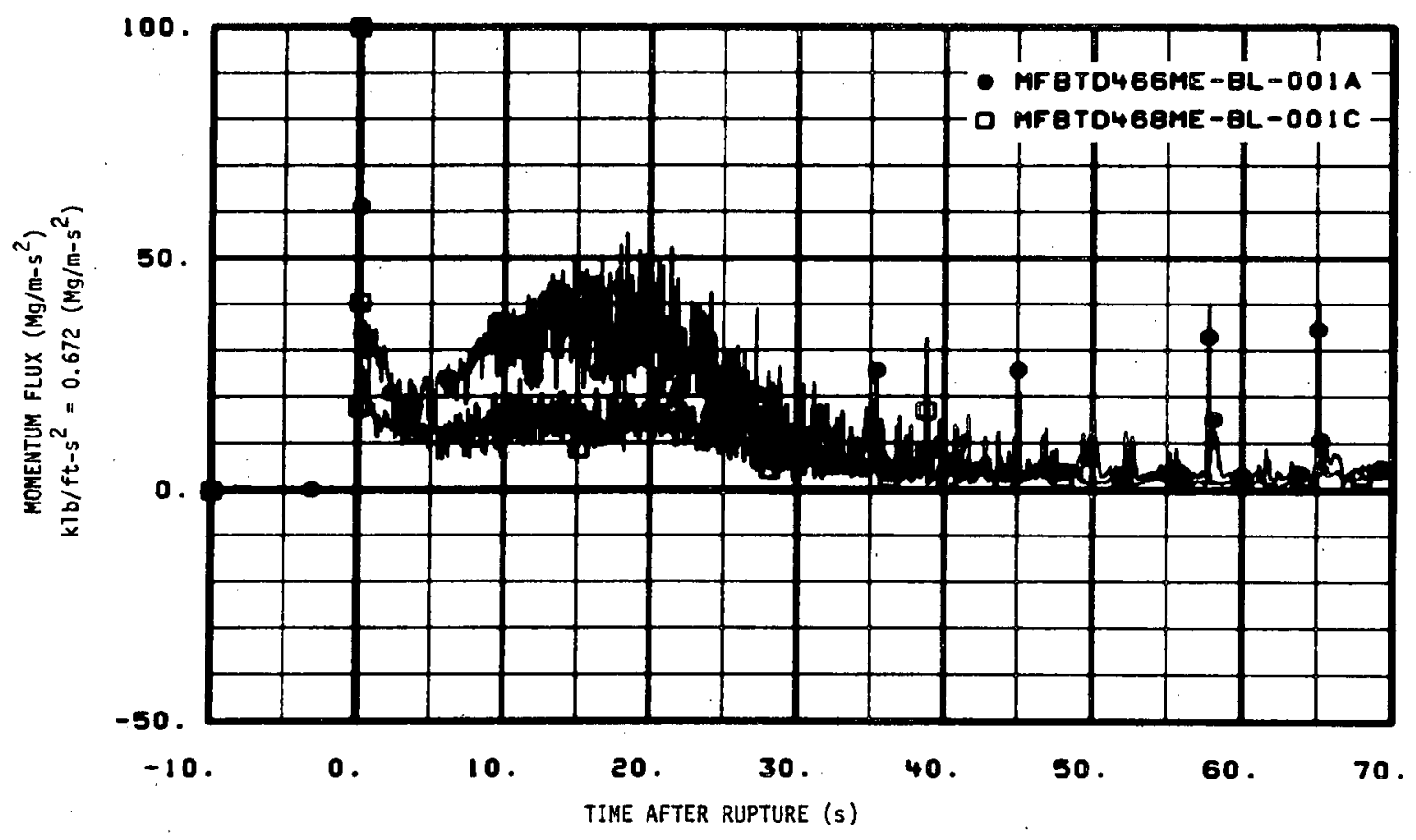

Fig. 50 Momentum flux in broken loop cold leg at DTT flange (ME-BL-1A and -1C) (filtered to $4 \mathrm{~Hz}$ ). 
Errata to TREE-NUREG-1084, "Experiment Data Report for LOFT Nonnuclear Test L1-4", July 1977, D. L. Batt.

On page 119 , replace Figure 51 with the one below.

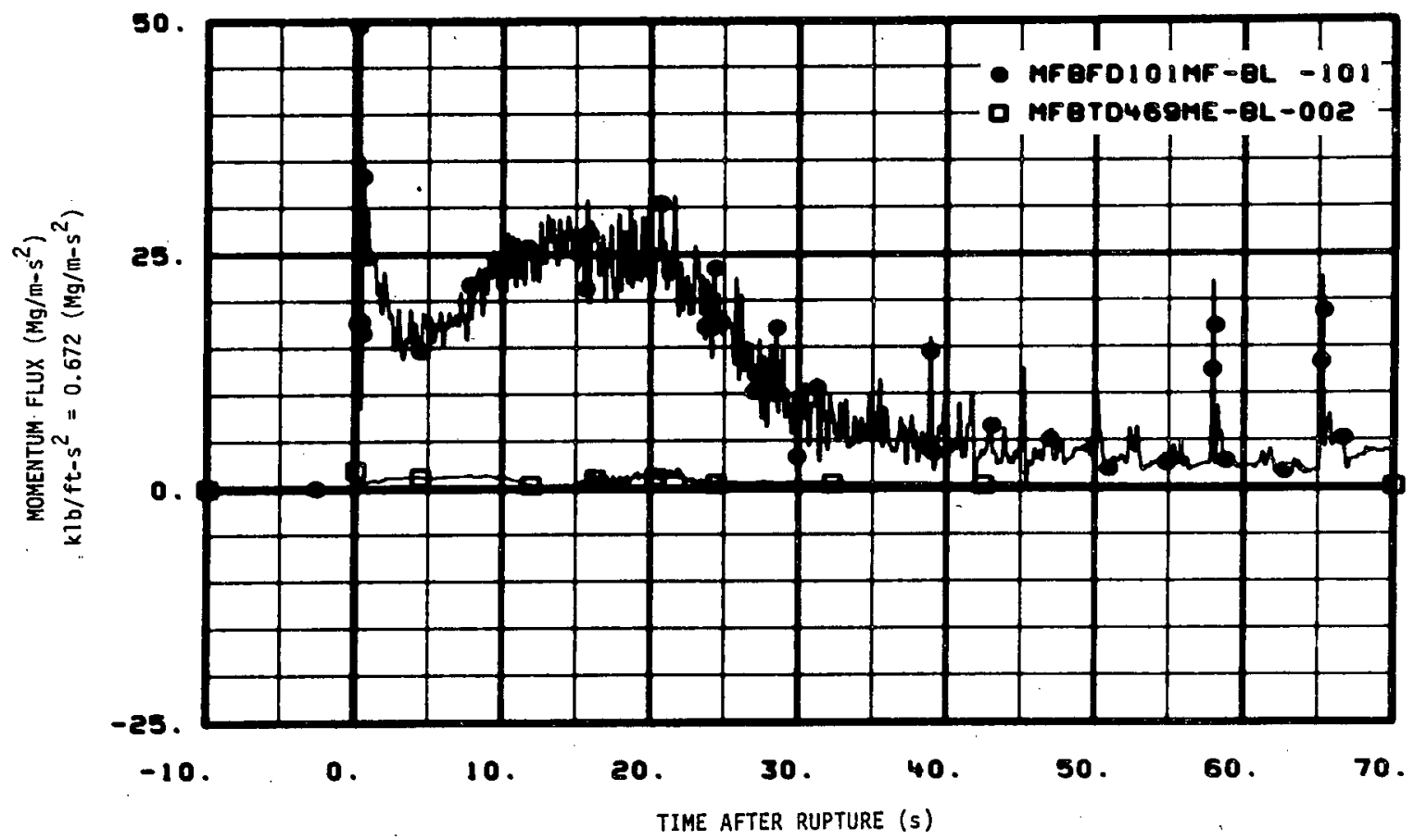

Fig. 51 Momentum flux in broken loop cold and hot legs (ME-BL-1 and -2) (filtered to $4 \mathrm{~Hz}$ ). 


\section{ERRA T A}

Errata to TREE-NUREG-1084, "Experiment Data Report for LOFT Nonnuclear Test L1-4", July 1977, D. L. Batt.

On page 127 , replace Figure 67 with the one below.

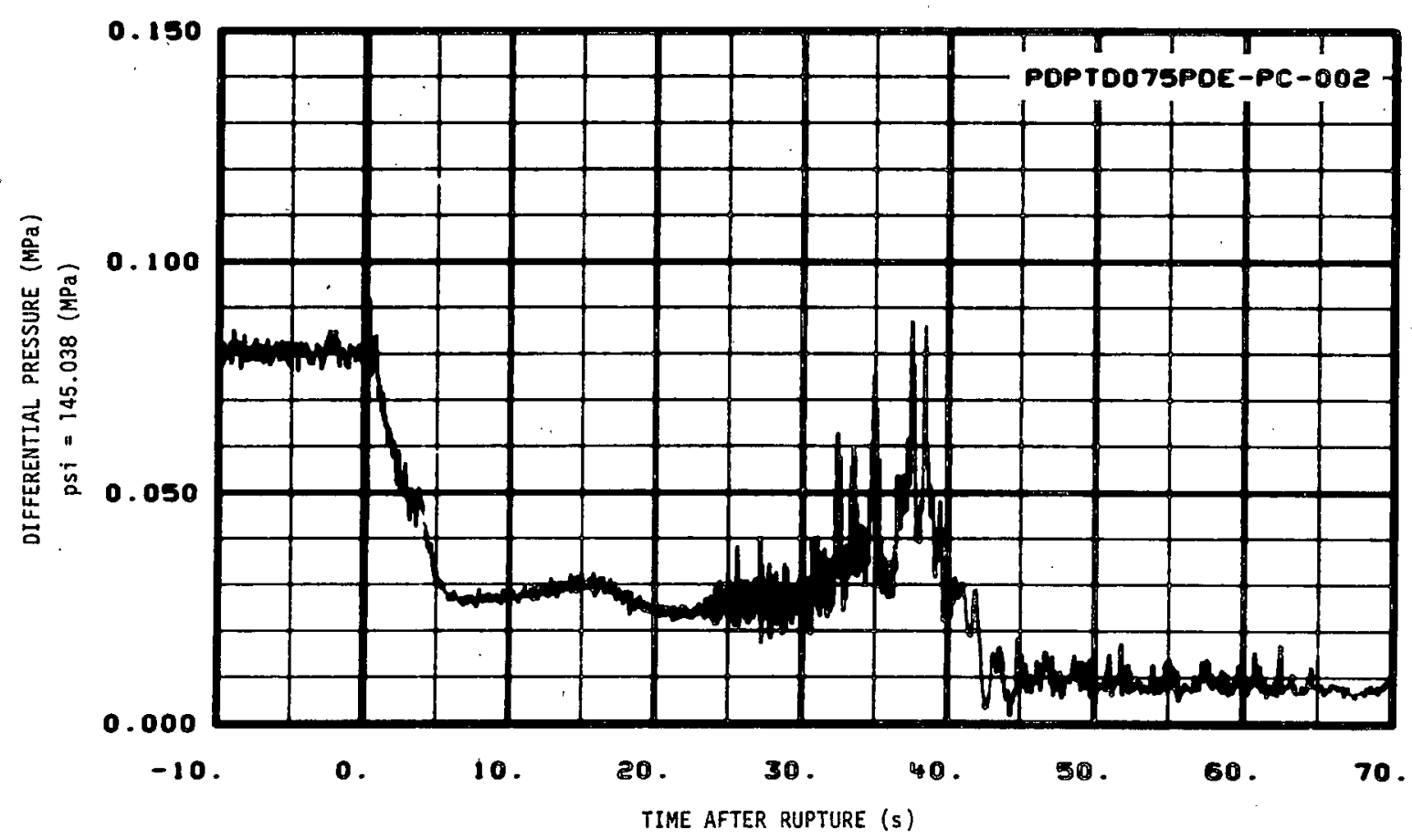

Fig. 67 Differential pressure in intact loop across the steam generator (PdE-PC-2). 
Errata to TREE-NUREG-1084, "Experiment Data Report for LOFT Nonnuclear. Test L1-4", July 1977, D. L. Batt.

On page 132, replace Figure 76 with the one below.

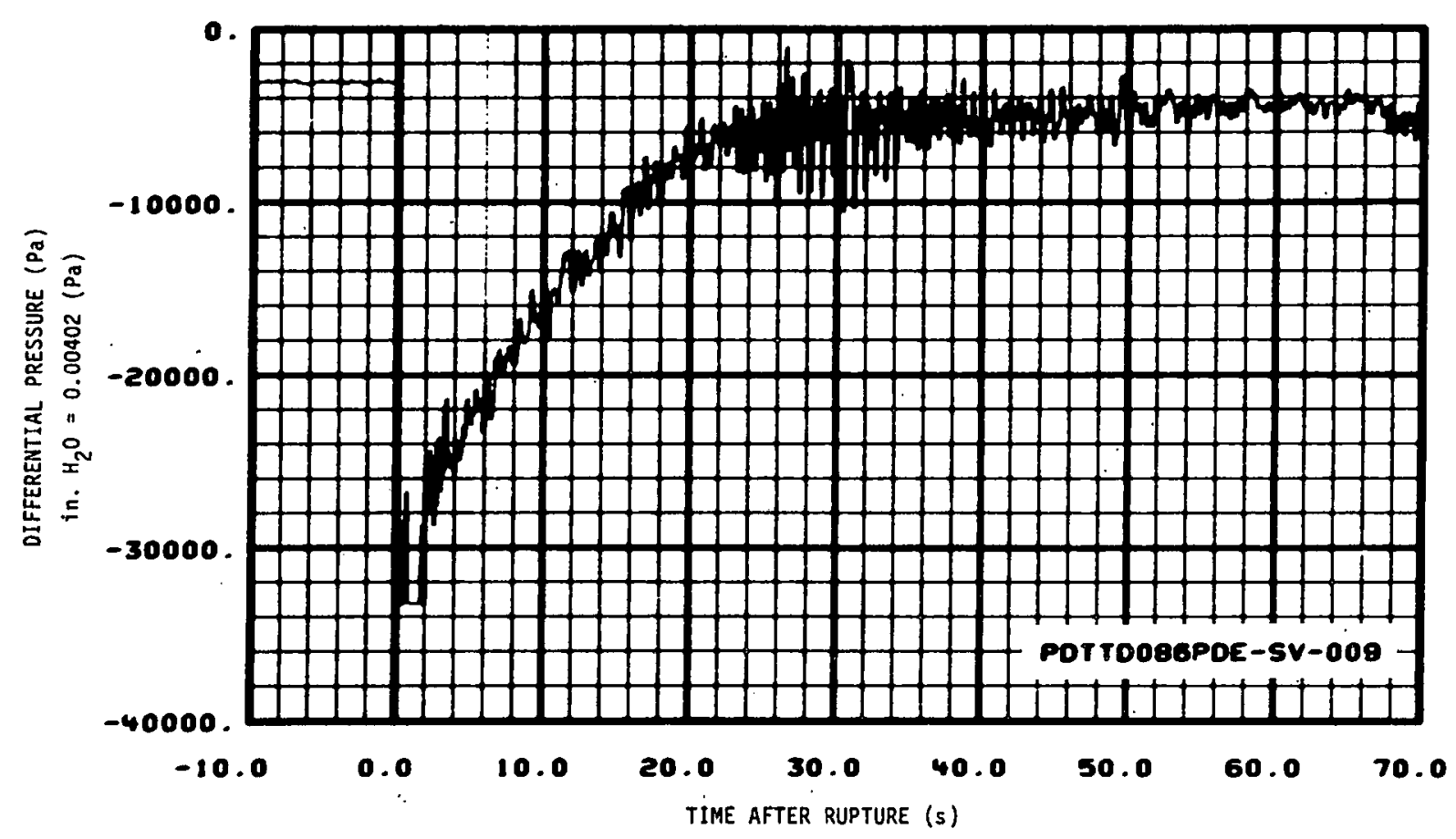

Fig. 76 Differential pressure in blowdown suppression tank across vacuum breaker line (PdE-SV-9). 


\section{ERRA T A}

Errata to TREE-NUREG-1084, "Experiment Data Report for LOFT Nonnuclear Test LI-4", July 1977, D. L. Batt.

On page 165, replace Figure 139 with the one below.

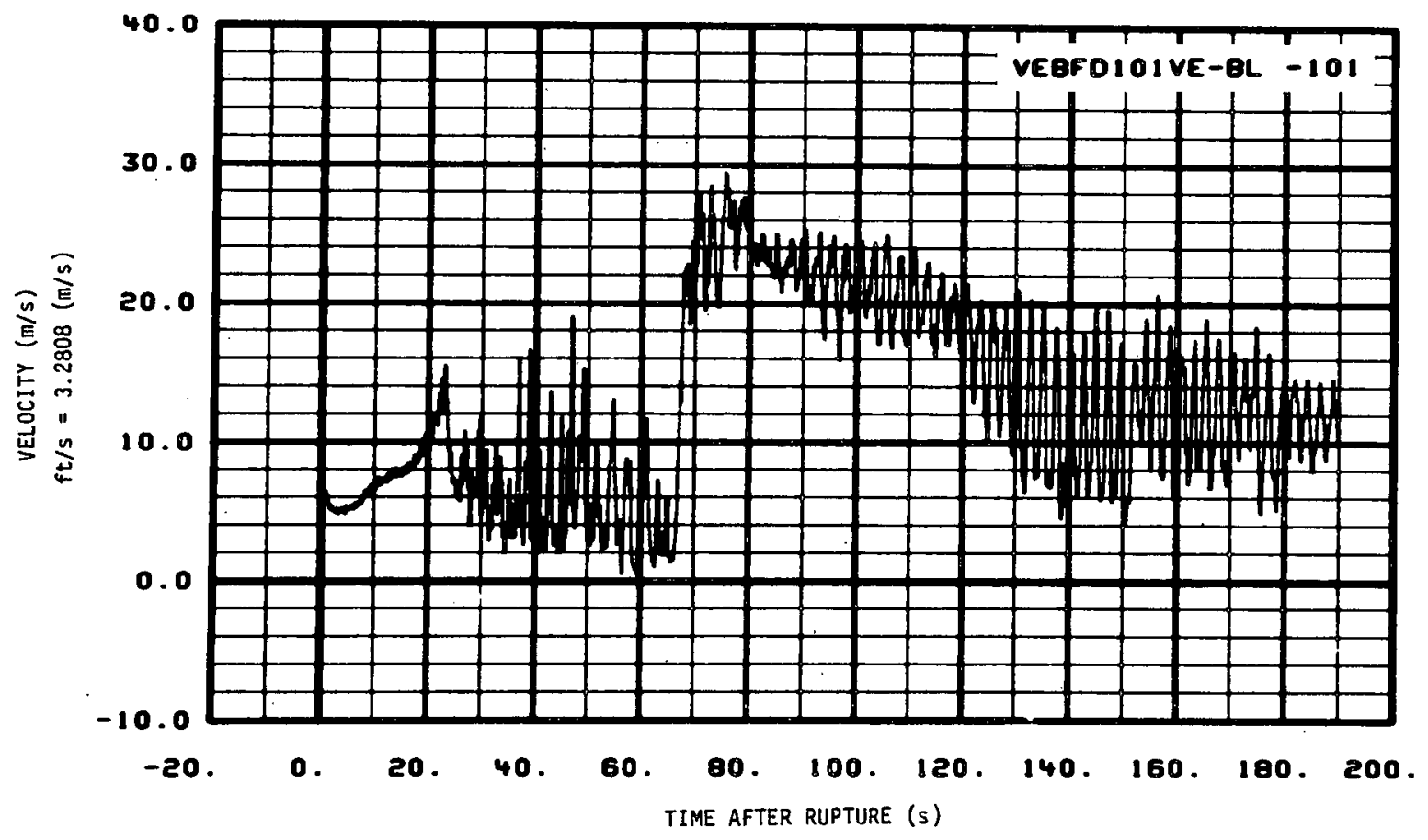

Fig. 139 Fluid velocity in broken loop cold leg at DTT flanges (FE-BL-1). 